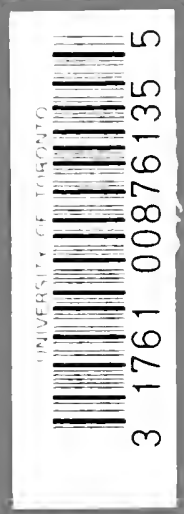



i 
Digitized by the Internet Archive in 2008 with funding from Microsoft Corporation 
THE WOMEN OF THE RENAISSANCE A STUDY OF FEMINISM 


\section{OPINIONS OF THE PRESS.}

"WE have only admiration to bestow upon this most intricate and masterly analysis of the great feminine Revolution or Renaissance of the sixteenth century. . . . It is the storyof the struggles of the woman's soul under the golden robe to emerge into the sunshine of a more spiritual realisation of the rite which, at its worst, still meant the best lot earth held for her. There are chapters which we find ourselves wishing that everybody might read, the admirable essay, for instance, on 'The Embroidery of Life,' and that other chapter discussing the inflnence of Platonism on conversation, especially the passages touching on the indiscriminate reading of the ladies who made it their business to refine the taste of men. It is a book to be much pressed upon every young woman who thinks she knows life, but perhaps to be kept back from the one who modestly confesses she would rather not know."-The Spectator.

"These studies of the woman of the sixteenth century, in all her social relations and in all her activities, are illustrated with an unceasing flow of anecdote and citation, never more apt than when employed to characterise that remarkable group who were imbued with the so-called 'idées platoniciennes.' The book will attract a wide circle of readers." -Athenceum.

"A fascinating volume. In these days of new women, the Renaissance women preach from the grave. Behind the bars of marriage they played handsomely at the game of life. Their colouring was not all rouge, nor their laughter but the tinkling of cymbals. They had grace, and gave grace; they were royally sentimental; they were women of the cult of youth."-A cademy.

"Everything is so brightly, so captivatingly important in this volume; the search into the past has been so well rewarded, the conclusions are so shrewd and clever, the subject is so limitless, yet curiously limited, that as history or psychology it should gain a large public."-Bookman.

"The translator has done his work well, and has rendered good service in bringing before English readers a notable work, which is by no means without its bearing upon the problems suggested by the somewhat assertive 'feminism' of our own day." - World.

" The importance of M. de Maulde's book to the literature of feminism is difficult to exaggerate. It is not only an exhaustive study of the life, occupation, aims, and character of the woman of the sixteenth century, but it is also a fascinating portrait of the eternal feminine, written with an extraordinary sympathy, a sensibility and an innate comprehension of women's strength and weakness, of their ideals and their impracticability." -Daily T'elegraph.

"A singularly close and scholarly picture of the position of women in an age of subjection. as well as in a subsequent epoch under less fettered and healthier conditions."-Standard.

"The fascination of the book is such as baffles complete analysis, just as its style, its play of delicate irony, its almost indefinable grace and piquaney must needs cloud the skill of the translator. It presents one of the happiest conjunctions of artist and scholar. Many-sided and pevetrative, this historical study is equally uotable for its exquisite lightness of touch and its brilliancy of execution."-St.'James's Garette.

"A thoroughly noteworthy work, written by one who is a master of his subject. It is difficult in modern literature to find auything with which to compare it."-Notes and Queries. 


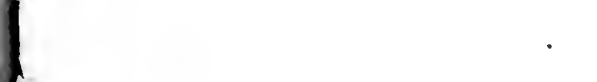

$f^{\prime}$

$-$

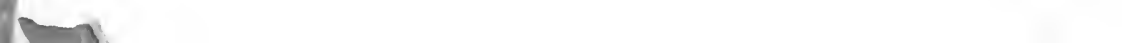




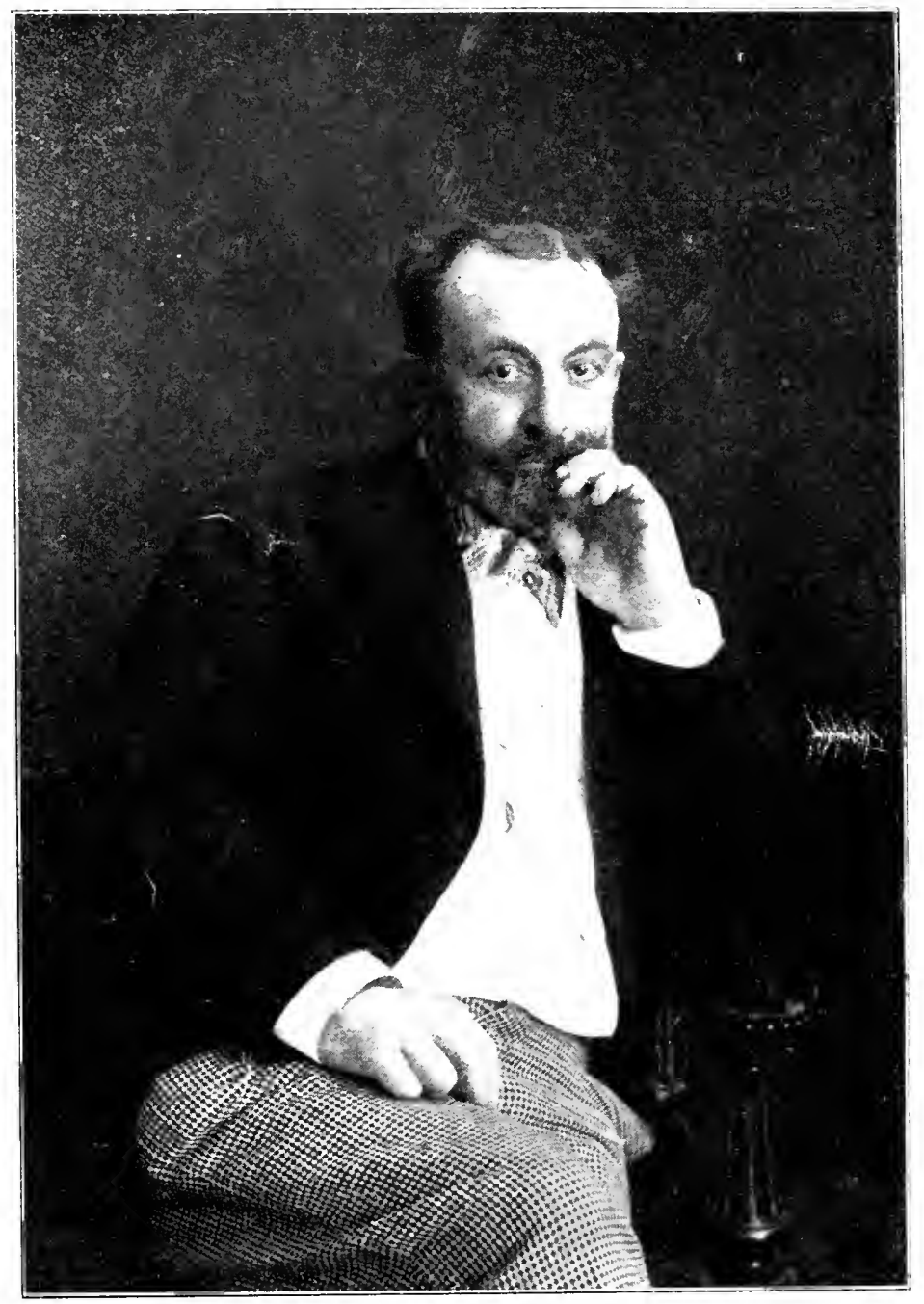

$$
\begin{aligned}
& \text { vothe the gixceirms dertani' } \\
& \text { Plle manlly }
\end{aligned}
$$


Ee

\title{
The Women of
}

\section{the Renaissance}

A Siudy of Feminism

\author{
By \\ R. de Maulde la Clavière \\ Translated by
}

George Herbert Ely

"The path of a good woman is indeed strewn with flowers, but they rise bebind her steps, not before them."-Ruskin.

With a Portrait of the Author

London

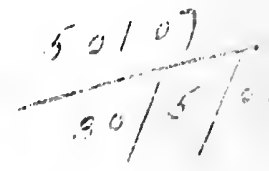

Swan Sonnenschein \& Co., Limited

New York: G. Putnam's Sons

1901 


\section{HQ}

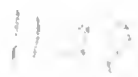

First Edition, October, I900; Reprinted (and revised) December, 1900.

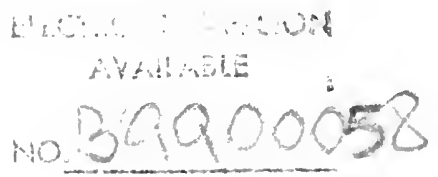




\section{『0}

\section{WILLIAM ERNEST HENLEY}

EDITOR OF TUDOR TRANSLATIONS

THIS VERSION IS

INSCRIBED 
Vers le bonheur! 


\section{TRANSLATOR'S PREFACE}

No mere translator can hope to preserve the style of his original, and herein M. de Maulde is bound to suffer more than most writers. There is no one to whom Buffon's phrase, Le style est l'homme même, may be more justly applied. His work is absolutely himself; it derives from his original personality and his wide and sure learning an historical value and a literary charm almost unique. $\mathrm{He}$ is a wit with the curiosity and patience of the scholar, and a scholar with the temperament of the artist. The sparkle and humour of his conversation are crystallised in his letters, the charming expression of a large and generous nature.

Trained at the École des Chartes, M. de Maulde held for a few years an appointment in the prefectoral administration. But his tastes drew him rather to history than to politics. In 1886 he founded the Société d'Histoire diplomatique, of which he has been the life and soul, and which owes its success mainly to his activity and enthusiasm. He is the founder also of the Congrès internationaux d'histoire, of which the first was held at the Hague in the summer of 1898, when official delegates from all the great countries of the world met amicably to discuss international relations in the cold light of scientific history. For many years he has been a member of our Royal Society.

But it is above all as a student of the Renaissance that M. de Maulde takes high rank among contemporary 
scholars. He has made a close study of that great movement, in regard both to the internal politics of France and the origins of modern diplomacy, and to the general march of ideas and the evolution of manners. The results of his studies are embodied in a remarkable series of works, the earliest being a book entitled Les Origines de la Révolution française au commencement du xvi siècle -a brilliant picture of French Society at that critical epoch. This was succeeded by the first part, in three volumes, of an Histoire de Louis XII., and this by the three volumes entitled La diplomatie au temps de Machiavel. Other works in the same series are two volumes on Jeanne de France, duchesse d'Orléans and Louise de Savoie et François I ${ }^{\text {r. }}$ In all these M. de Maulde shows the profound erudition and the just critical sense to be expected in an historian of the school of Fustel de Coulanges, together with a literary grace and a lightness of touch with which the scientific historian is too rarely endowed. His brief experience of official politics seems to have left him with an urbane scepticism, a benerolent irony, which serve only to set off his radical enthusiasm for great ideas and for the great conceptions of art. At bottom an idealist, he has interpreted with insight and humour the aesthetic and spiritualist revolution of the Renaissance, nowhere more characteristically than in the present volume.

With M. de Maulde's consent the greater part of his footnotes are omitted-mainly references to authorities unknown or inaccessible to the English reader, and useless without the complete bibliography omitted by desire of the French publishers, MM. Perrin et Cie. A few notes are added within brackets: for these and for the Index the translator is responsible.

The translator is under great obligations to the Baronne 
Louise Dupont-Delporte, who, at M. de Maulde's request, has compared the proofs of this book with the original text, and to whose watchfulness and friendly care heartiest acknowledgments are due. The same task of collation was undertaken by Mr. David Frew, whose frank, tonic, kindly criticism has been of the highest value. Thanks are also tendered to all who in various ways and with constant kindness have given their assistance in the course of this work, among whom M. de Maulde himself has laid the translator under a large debt of gratitude.

August, 1900.

\section{NOTE TO THE SECOND EDITION}

THE early demand for a reprint has enabled the translator to do no more than to correct a few misprints and oversights and to remove a blunder. To all those critics who have so generously received a sincere effort he cannot be too grateful.

December, 1900. 



\section{CONTENTS}

\section{PREAMBLE}

Masculinism of Anglo-Saxon countries-Feminism of Latin countries.

Pages 1-5

\section{INTRODUCTION}

Italian origin of the Renaissance feminist movement-Protests against war, force, the materialisation of the religious spirit and the hollowness of learning-Recourse to the affections-Quest of true happiness-Idealism: woman chooses the method-"Love and faith"-Crusade of love-Worship of life and hatred of deathWomen the motive-force of life-Active and tranquillising rôle of Italian women in the 16th century-Conquest of France by the new spirit-General sentiment of the new society. Pages 6-20

\section{BOOK I. F'AMILY LIFE}

\section{CHAPTER I}

\section{MARRIAGE}

Marriage, its realist character and its difficulties--The aim of marriage not personal satisfaction-The girl married blindfold-The father - Marriageable age-Interviews-Reflections of the father-Ideas of the bridegroom elect-His physical and moral criterion -His uneasiness-Final crisis-Ideas of Michelangelo and 
Raphael-Marriage ceremonies and festivities-Weddings at Naples, Florence, and Venice-Behind the scenes-Weddings in France-Brides' journey-s-Moral aspects.

Pages 21-44

\section{CHAPTER II}

\section{THE MARRIED WOMAN}

The genius of motherhood-Marriage a physical science-Domestic difficulties-Platonism in marriage-Semi-wives-Wives in name only-Vocation of women for medicine-Women as sick-nursesas doctors-Enfranchisement of women as regards medicineIntimacies between women and doctors-Women's medical collections-Hygienic rules-Neurasthenia-Woman as home-rulerThe chatelaine-Her management of retainers-The science of charity-Principles of great houses.

Pages 45-69

\section{CHAPTER III}

\section{THE CHILDREN}

1. Maternity.-Tendency to small families, its various causes-Marital misfortunes-How new arrivals were received-Unpopularity of feeding by the mothers-Children educated by the mother till the age of seven-Old system of hardening-New system based on reason. 2. The Boys.-Necessity of developing individualism among them-Paternal education-Growing influence of the motherCollege life-Greatness and decadence of tutors-Understanding between tutors and mothers-Excessive production of young men of fashion-Influence of the new ideas-Decline of the spirit of toil and discipline.

Pages 70-85

\section{CHAPTER IV}

\section{THE EDUCATION OF GIRLS}

Girls brought up solely by their mothers-Old theory of early marriage -Education, especially physical and nroral-Opinion of moralists and physicians: counsels of Anne of France-Utilitarian system of Germany-The intensive school: Vives; St. Theresa; the Spanish system-The aesthetic school : Dolce; the Italian systemLouise of Savoy-New theory of late marriage-Protests against 
the realism of elucation-Tutors of girls-Moral freedom of girls - Protests against what they read-The story for girls, after Anne of France-The flirt-The hunt for a husband-Various ideas on that matter-Coquetry, intrigue, chambermaids-Jean Raulin's sermon-Open-air life.

Pages 86-108

\section{CHAPTER V}

\section{THE HUSBAND, AND THE VARIOUS WAYS OF SLIPPING HIS YOKE}

The husband lord and master: his absolute authority-The stick-The wife's insignificance-The husband's grievances against marriage -The wife's grievances-Beware love!-Modus vivendi-Women dowered or not: growth of women's influence on the dowry system - Practical philosophy-Unsatisfied affections-Wives separated or divorced-Widows-Sentimental finery-The wife of a dead husband-Classical widows: their spirit of order and piety-Gay widows-Widows' virtue-Advantages and disadvantages of widowhood-Re-marriage-Sincerity of women's praise of marriage.

Pages 109-135

\section{BOOK II. SOCIAL LIFE}

\section{CHAPTER I \\ PHILOSOPHY OF LIFE}

Individualistic and anti-philosophic spirit of France-Flourishing of the salons-Reign of money: legitimated in Italy-The Roman programme-Freuch society-Proposed remedies against Christian socialism-Anne of France-School of Cardinal d'AmboisePrinciples of sentimental sociology-Social raison d'être of platonism-Its Florentine origin-Development of the doctrine-Intellectual aristocracy-I'latonism a fashionable craze-Discussions on the real character of love-Cataneo-Eloquent Bembo-Petrarchism-Elevation of sentiments by platonism - MichelangeloFrench opposition to platonism-Triumph of platonism through Italianism and feminism-Anne of France-Margaret of France and her general philosophy.

Pages 137-176 


\section{CHAPTER II}

\section{THE SCIENCE OF PLATONISM}

Is platonism dangerous for women?-Double system for catching men : passion and sensibility-To spread love the end of life and the secret of happiness-Platonic virtue-Criticism of this virtue in practice-School of Anne of France-Vittoria Colonna and Michelangelo-Philosophic school-Multiplication and withdrawal of favours-Love through duty-Love of princesses-The veil of mystery-Practical recruiting of platonism-Sources of love or second love.

Pages 17\%-193

\section{CHAPTER III}

\section{THE MISSION OE BEAUTY}

Science consists in extracting the element of happiness from everything, first of all from oneself-Beanty a social duty-Charm has no physical rules-Women slight or the reverse; blondes; the skin, the eyes-Corporeal beauty-Michelangelo and DirerPortraits of women as Veluus-Prudence of women-Artists and their fancies-Joan of Aragon-Margaret of France-Receptions in the morning-The 'Innocents'-Art of retaining youth, or of restoring youthfulness -A lady's toilette-Eashion-Spiritual significance of colours-Luxury-Architecture-Taste for fine furniture.

Pages 194-227

\section{CHAPTER IV}

\section{THE EMBROIDERY OF LIFE}

The science of dining-Table-talk-Balls and lancing: custom of kissing-Protests of the Reformers-Church-PilgrinagesGardens and country life-Flowers-Pugs and parrots-The horse-Hunting, Roman and platonist-Hunting philosophised; Budé and Blondo-Park animals-Nature-Life at wateringplaces; pure water; gravity and fun.

Pages 228-260 


\section{CONTENTS}

xV

\section{CHAPTER V \\ INTELLECTUAL RESOURCES}

The library-Curiosity divided and dilettante in character-Taste for tales, jest-books, romances - The old poets-Music-Instruments, the human voice-Intellectual music-Harmony-Sacred music-Chamber music-The orchestra-Discussion on the abuse of music-The theatre-'Phaedra,' Bibbiena-The CalandraOpposition to the theatre-French ideas.

Pages 261-283

\section{CHAPTER VI}

\section{CONVERSATION}

Art of conversation: its supreme rôle-Women's triumph-Tone of conversation-Philosophical spirit-Variety of form-Subjects of conversation-French conversation-Quips and cranks-Conversational dallyings-Stories-Dissertations-Gaieties-Correspondence, its revival-Family letters-Letters in the grand styleTone of letters-Some Italian letters.

Pages 284-310

\section{BOOK III. THE INFLUENCE OF WOMEN}

\section{CHAPTER I \\ POLITICAL INFLUENCE}

Women remain strangers to the keener activities: war, justiceWomen, political in spite of themselves-Isabella of AragonJcan of Aragon-Anne of France-Return from ambition to love-Restless women-Renée of France-Purely defensive heroism of women-Ladies of Sienna and Pisa-Isabella the Catholic-Catherine Sforza-Woman according to Michelangelo.

Pages 311-324

\section{CHAPTER II \\ MORAL INFLUENCE}

The good old times-Moral degeneration-Ambition, money-Evil, to be cured homoopathically as in Italy, or allopathically as in Gerniany? - Virtue, must it necessarily be tiresome ?-Raphael's 
embarrassment-The antiplatonists-Louise of Savoy, RabelaisThe work of amelioration by two methods. (i) The softening of virtue-Different systems in regard to marriage; free union; system of contract; the double marriage-Firenzuola-Marriages of affection-Secondary platonism, a compromise-Alms without significance, to lure the human animal-Sipping at love, by way of Italian dilettantism-The attack-Love a dream-Prayer. (ii) The ennoblement of vice-Attempt at purification of carnal love-The Italian courtesans, and their moral influence-Tullia d'Aragona-Imperia-Venice-Francis I.-French system of the double household-Diana of Poitiers-Bembo in tears-Infatuation-The feminising of men-The question of the beard.

Pages 325-371

\section{CHAPTER III}

\section{- INTELLECTUAL INFLUENCE}

Conquest of men by mind-Army of intellectual women-Isabella d'Este-Anne of France-Margaret of France : her theory-The friends and guests of Margaret-Intellectual headquarters of France-Egerias - Difficulty of this government-Vittoria Colonna and Aretino-Flatteries and compliments-Supervision of manuscripts-Affection-P_suniary aid-Necessity of feminine patronage.

Pages 372-397

\section{CHAPTER IV}

\section{INTELLECTUAL INFLUENCE (Continued)}

Results of feminine influence-Literature in praise of women-Pompeo Colonna--Two schools of taste : passion, sensiluility-CastiglioneLiterature of conversation-Fugitive poems-Temples of high poetry-Literature of poodles and birds-The ancestor of VertVert-Spanish women-France, Lyons-Accusation of frivolityGerman scepticism-The struggle in France-For or against women-Timidity of Frenchwomen-Spirit of the prelates.

Pages 398-421

\section{CHAPTER V}

\section{RELIGIOUS INFLUENCE}

Progress of religious sensibility - Women compared to the moonEntrance of the sentimental spirit-Free enquiry at Rome and in 
Italy - Philosophic religion-Entrance on the scene of wnmen as priests, as well as plysicians-Religious tradiiions of women in France-Decay of faith-Roman liberalism--Situation of the French clergy-Alliance between women and the aesthetic clergyLiberal principles of this alliance-The bibliennes-Aristocratic religion-Writings of the mystic women : Gabrielle de Bourbon, Catherine d'Amboise-The nystic writings of Margaret of France, her ideas-Her relations with the palinods-The mystics-The mysticism of divided application-Direct communion with GodSmiling character of the new mysticism-Spiritual petrarchismCorreggio-Vittoria Colonna-Vergerio.

Pages 422-453

\section{CHAPTER VI}

\section{RELIGIOUS INFLUENCE (Continued)}

Scorners of mystic liberalism-The savants-Reproaches addressed to the liberal party: paganism, materialism-Women's struggle against these tendencies-The monks: the monastic spirit-Struggle against the monks: the pros and cons-RruelaisFolengo-The German monks--Rising of the lower clergy against liberalism and aestheticism: Luther, Calvin-Struggle of the Reformers against women and liberty of thought-Vittoria Colonna and Ochins-Direction of the liberal and aesthetic party in France - Margaret of France and her active rôle-Feminist theory of Postel-Replies of Luther, the Sorbome, the theological parties.

Pages 454-474

\section{CONCJ,USION}

Total want of success of the feminist movement-Disappointments of Margaret of France-Reaction against cosmopolitanism and in-. tellectualism-The spirit of the Pleiade-Love of free airMargaret of Savoy-Fall of the Roman spirit-Montaigne-Last effects of feminism-The triumph of Death-The mistakes of the Renaissance feminisu-Disappearance of the aesthetic systemSensualism of the 18th century-The naturalism of Ruskin.

Pages 475-503 

bewitching, has cradled them on her kindly bosom, and has already accomplished for them half of the task by reflecting the sky in her feminine smile. But no; for lack of discipline, the idle tend toward sensuality. Consequently, women will address themselves more especially to the men who can work.

And their scheme will be this. They will interpose, almost like angels, between heaven and earth; they will love us and we shall love them; they will gently invert the order of things, so as to make of life a work of art. They will efface two of the three blind forces which govern usDeath, Fortune, and Love. If they do not prevent all failures and weaknesses, they will cheer and comfort them by means of a potent elixir, obtained from a God of philosophy, like physicians who cure by allopathy. So many springs are creaking and snapping for want of a drop of oil! they will pour out that drop. So many noble things lack the sap of life! they will give them that sap, that vitality, that soul. The sap of love brings grapes from thorns!

Si l'amour fault, la foy n'est plus chérie;

Si foy périt, l'amour s'en va périe.

Pour ce, les ay en devise liez:

Amour et foy. ${ }^{1}$

And thereby the transformation, or at any rate the amelioration, of the world is to be achieved. Men are not, perhaps, so intractable and brutal as they pretend; by their own account they would be quite content to accomplish the journey of life eating and sleeping behind drawn curtains. We must not believe them. They have shut themselves up in a bare workshop: throw open the windows, let the sun stream broadly in, bringing light and warmth and the balmy breath of nature. The effects of the old system of morality, with its bolts and bars, have been seen only too often; the loathing of vice, the noble pride of virtue and aesthetic intelligence are also forces; and they alone can make of our terrible abode a truly sacred dwelling, open, free, dear to our hearts, the monument of human affection and of happiness.

${ }^{1}$ Clément Marot on the motto of Madame de Lorraine:

[If love fail, faith is surely slain ;

If faith die, love flies hence amain;

So in one motto link the twainFaith and love.] 
Thus, briefly, the conclusion was reached that women can transform themselves and become the chief element in human society, that of happiness. Hitherto they had been understudies to their husbands; they had believed themselves bound to take an interest in the work, ideas, and tastes of a man, with no other recompense than the satisfaction derived from a duty done. They had to issue forth like butterflies from the chrysalis, and to become women full of charm, in order to direct the affairs which men believed they had in their own hands, and in order to fascinate, to enfold, to struggle if need be, but without violence or parade. Then they had to rise a step higher, become objects of love, propagate love, and bring all things into harmony.

Thanks to these ideas, Italy at the end of the fifteenth century had taken a marvellous bound towards the beautiful. ${ }^{1}$

Spain likewise had leapt towards chivalry; it was like the raising of a curtain, so sudden was the change: women, hitherto shut up in their boudoirs, appeared in all their radiance like goddesses.

France, on the contrary, viewed these new ideas with profound mistrust, and long rejected them because of their Italian origin. We knew Italy, but under very false colours; she gloried in rising superior to wealth and rank, in the importance of women, prelates, and artists in her life; while we only knew her through merchants and soldiers. Her bankers established in our towns- "Lombards," as they were scornfully called-passed in the eyes of the people for men without a country, for birds of prey akin to the Jews; our knights, still bewitched by the joys of their expeditions, spoke carelessly only of a people without weapons and of defenceless women. The French clergy chimed in with their note of bitter opposition to Rome. And thus Italy was readily imagined as a hot-bed of pleasure: but to go there in quest of the philosophic secret of happiness seemed absurd.

In the intellectual point of view, Italy created a wrong impression among us through the persons she sent us:

1 One of the most distinguished women of Italy to-day, the Countess Pasolini, assures us that the great influence still exercised by women in Italy springs from their approximating more closely than men to fifteenth-century ideas. 
professors more or less broken down, ${ }^{1}$ exiles more or less voluntary $;^{2}$ impecunious, ravenous, and pretentious characters, ${ }^{3}$ not very philosophic in their attitude towards their rivals: all those also who rang the changes on the honour we had had in beating them, the Stoas, Soardis, Equicolas, wonderfully assiduous in making Louis XII. out to be a second Charlemagne (in those days Charlemagne was still a Frenchman); Caesar Borgia and his brilliant retinue, at whose brief passage we looked on in contemptuous unconcern. Because Caesar Borgia did not take our fancy, or because some of us had met light women on the highway to Italy, any Italian idea appeared to us a false one; we shut ourselves up in what Pontanus, Julius II., and other Italians remaining in Italy called our "barbarism," and as we plumed ourselves on our logic, we only abandoned our antagonism to adopt all the Italian fashions completely and indiscriminately. To that end, Louis XII. had to oblige by dying, and Francis I. by reigning; so at least Castiglione, the master of the new school, formally declared after the accession of Francis. So it actually turned out.

Thus women are queens; they move like fairies. "It is a small thing to say of a woman that she does not destroy the flowers on which she sets her foot; she must refresh

1 We may say, in passing, that the Italianism of the end of the fifteenth century, usually regarded as originating with the Italian expedition of Charles VIII., really goes back to Louis XI. Louis was Italian in education and tastes. Italians flocked into France during lis reign.

${ }^{2}$ Cornelius Vitelli, styled Corythius by the public, came to France in 1482 , for the simple reason that his own country had become unsafe for him. We have not many details about him or about his colleague, Girolamo Balbi, a pompous and quarrelsome character. A third Italian, Fausto Andrelini, made his appearance in 1488, under the auspices of the. Marquis of Mantua. Andrelini, who lived very comfortably at Paris till his deatl in 1518, had no other effects than the memories of a little love-affair, which he confided to us in three books of verses, his " pages of youth," as we should say to-day. Exiled, penniless, almost naked, but a poet, he was, as soon as he arrived, petted, adopted, and idolised, the favourite of Chancellor Guillaune de Rochefort and of fortune.

${ }^{3}$ Fausto Andrelini was the object of incredible adulation; Erasmus, wise man, simply calls him "divine," but some did not hesitate to proclaim that "he alone had rendered France filled instead of famishing, cultivated iustead of waste, verdant instead of barren, Latin instead of barbarous." One of the noblest characters of the time, Guillaume Budé, actually dedicated to him this amazing epitaph: "Here lies Fausto. If the Fates had not given him to us, Gaeta herself would not have been more barbarous than France." But he was no sooner buried than everyone regarded him as a knave. 
them. The violets should not droop when she passes, but burst into flower." 1

We do not claim that this system is perfect; our aim is precisely to examine with the utmost care its strong and its weak points; but it is certain that, to begin with, by the side of almost all the illustrious men who then flourished in such numbers, we see the indispensable woman silhouetting herself, not as tyrant or even director, but as mentor and guide-as mother, rather, since she brings them forth into the higher life; or, still better, as light and sun, as reinvigorating, vivifying warmth: according to the saying of Schiller, "Love is the sun of Genius." "Without women," says Castiglione, "nothing is possible-neither military courage, nor art, nor poetry, nor music, nor philosophy, nor even religion: God is only truly seen through them." This was no new observation: Solomon had already said the same thing; but we must believe there were new conclusions to be drawn from it, since men hoped to find in it the answer to that vexed question of happiness which has been put in vain since the foundation of the world.

To realise how women transformed themselves, we must follow their example and open our minds. They had the courage so to do: they looked life fairly in the face-with their woman's eyes, it is true, fine, subtle, and complex; they looked, and often they did not really understand their own impressions, vivid, and rather strong than clearly defined. Often, also, under the impulse of these impressions, they acted in the genuine woman's way, with tricks and reservations, evading the consequences of their own theories, going round the obstacle they advanced to attack in front. Their achievements and thoughts are difficult to determine. We cannot here, as in an ordinary history, be satisfied with a mere string of facts; we must play the chemist, analyse these various and complex elements, and seek to evolve a general formula.

That formula is this: to live, that is, to love life, to attain a mastery of life without allowing it to crush or dominate us. The attainment of this result is well worth the trouble of deciphering a few women's hearts, even though the handwriting should be less clear than our ordinary manuscripts. In those days they sincerely studied to love life; they loved

${ }^{1}$ John Ruskin. 
it, rejecting all negations and obstructions, all that overwhelms and paralyses, scouting death itself! Instead of yielding to scepticism in regard to things, they wished to push love to the stage of Stoicism, to lift the heaviest burdens, to gaze upon the star of consolation which speaks to us of love eternal.

Every woman will begin with her own redemption. She is at first thrown out into the world while still a child, almost in childish innocence: very soon rigorous duties, material and oppressive in character, seize upon her: she is, so to speak, battered and rolled out by very rough forcesthe firm authority of her husband, the idea of obedience, the trials of motherhood, fruitful in joys, but also in hardships and cares. Whilst her will is annihilated and enslaved, and her heart often remains an undiscovered country, she assists with pain and disgust at the downfall of her flesh-that flesh which has become the abode of pain, a body of death, to give birth to life.

- How is the sudden thrill brought about, turning the dull, torpid larva into the bright butterfly? How do women succeed in drawing from this essentially human condition something of the divine, passing from physical production to spiritual production? These above all are the questions we must seek to determine.

It must not be expected that we shall present to our readers fair barristers, or engineers, or professional scholars, still less pedants. No; these ladies were simply modest women, who took their share in the humblest duties of everyday life, but discovered, apart from charity in the material sense, the absolute necessity of another charity, moral charity for moral and spiritual penury, for those destitute of happiness, so numerous and found everywhere, even within the walls of the Louvre.

If they accomplished a revolution, it was a peaceful and internal one. They piled up no barricades, issued no manifestos, launched no declaration of their rights as women and citizens. Though the laws were not generally favourable to them, they demanded no amendment of the laws; the same magistrates continued as in the past to deliver the same judgments from the same benches, politicians still made their fortunes, ploughmen still followed the plough, engineers continued to construct bridges and make roads, 


\section{THE WOMEN OF THE RENAISSANCE}

notaries to scan the cause-lists. Nothing was changed, in appearance, in the material course of the world, except that a moral power had come into being, and that women, like the goddesses of happiness painted by Nattier, under the cloak of indifference had taken into their keeping a mysterious urn, whence life seemed to gush in a spontaneous stream, without the help of judges, engineers, or notaries, yet continually sending out the current essential to the sweetness and fruitfulness of the world. 


\title{
BOOK I. FAMILY LIFE
}

\section{CHAPTER I}

\author{
MARRIAGE
}

There are two ways of dealing with the heart of a woman. You may have confidence in it, believe in it, regard it as a real element of strength and happiness, uplift and develop it, touching it then to fine issues in love, religion, philosophy. These are the lines on which the modern world proceeds. Or you may treat it as a frail organ of the body, unruly, incapable of good; you may bind it down, early and with due care, with all sorts of reasonable chains, the chief of which, marriage, will keep it fast prisoned, and reduce it to nothingness and oblivion. This, of course, was the system of former days.

Singularly enough, these two systems, contrary as they are, spring from precisely the same practical starting-point, which indeed remains the sole point of contact between them: the principle, namely, that marriage and love are distinct, and must neither be confused nor blended.

To Battista Spagnuoli of Mantua, ${ }^{1}$ poet and monk, in the solitude of his cloister, marriage shone with a rosy light. Cornelius Agrippa, ${ }^{2}$ with his utilitarian and paradoxical

1 [The most prolific and popular eclogue writer of the fifteenth century (1436-15l6).

"As the moste famous Baptist Mantuan,

The best of that sort since Poetes first began."

Erasmus went so far as to match him with Virgil.]

- Alexander Barclay.

${ }^{2}$ [The celebrated cabalistic philosopher (1486.1535). He stayed for a time with Dean Colet in London. He wrote a book De Nobilitate feminei sexus.] 
mind, regarded it as a compulsory conscription of the German type, with no possible exemptions, or almost none, and fancied that if men would but go in quest of a pretty woman instead of being so much absorbed with the proprieties and the main chance, the result would prove far more satisfactory. With the exception of these two, and a few more or less ingenuous or eccentric people like them, no one believed in the utility or the possibility of love in marriage. Caviceo's romance $I l$ Peregrino was considered sheer perversity, for after innumerable intrigues and adventures it ends-how? With wedding bells! So that, according to Caviceo, marriage was to turn out a romance of cloak and sword! ${ }^{1}$

It was universally agreed that no idea could be more absurd, less practical, more detestable, more immoral even. Marriage was a transaction, an 'establishment,' a business partnership, a grave material union of interests, rank, and social responsibilities, sanctified by the close personal association of the partners. To insinuate an idea of pleasure was to rob it of its noble and honourable character, and to drag it down into the mire of sensuality. To mingle with it a physical suggestion was to degrade it; to mingle with it love, the absolute, great enthusiasms of heart or intellect, was to lay

${ }^{1}$ An extract from the marriage of Peregrino will give an idea of the Romance (Book I., cap. i., p. 32):

"There standing and awaiting the wished-for end, I heard the voice of a minister of Jupiter, who, regarding both of us, thus spake: 'Peregrino, and you Geneva, are you clear and free from every manifest or secret bond?' 'We are free, nor anywhit bounden?'-Minister: 'Are you not conjoined in affinity?' Peregrino and Geneva: 'Naught in affinity, and little in amity! Minister: 'Have you promised marriage or betrothal to any other man or woman?' 'Peregrino and Geneva: 'No, never.' Minister: 'Are you by common consent disposed to celebrate this present holy sacrament of matrimony? Peregrino and Geneva: 'We wish it heartily and in faith.' Mfinister: 'Thee, woman, give I to him, and Peregrino will put on the ring.',

"Having done his bidding, as it is the wont, we sat ourselves down," and a tender conversation ensues between the two spouses.

"O matchless eloquence!" cries Peregrino, "O thrice lucky hour! o blessed day! 0 my hope in the sovran guerdon rouchsafed to me! With thee, sweet my dame, love, and gentleness, and discretion, and prudence have their habitation, in thee every good thing doth lie hid. Thou art very music, of all discords the harmony. In all parts I find thee whole and perfect. Thou art abundant in all humanity and sweetness, and in thy making the lord and maker of heaven hath created the true copy and sovran revelation of all things." The couple dream their souls away in these platonic effusions. The bride is bedded there and then, and the author omits no detail. The sun is already high when a young maid. servant ventures to come in and light a fire of twigs. 
up for oneself disasters, or at least certain disappointment. "Love-matches turn out badly quite as often as arranged marriages." A romance lasts a week, the reality for a lifetime. No passion can survive the humdrum, the monotony, the deadweight of matrimonial experience : and what marriage can hold out against passion? Heart freedom, the storms, raptures, revulsions to be anticipated on all sides-what amalgamation is possible between these and the peaceful domestic life which is looked-to to furnish forth a very solid, united, and well-ordered existence? A certain equality is the rule of passion: what it demands is a perfect union between two persons who are mutually attracted and whom there is nothing to keep apart. What would become of married life under these conditions, without some directing authority, without one to give law to the other? In regard to marriage, the time-honoured principle, rigorous though protective, was this: the husband ought always to take the helm, imbecile, madman or rake though he be: woman is born to obey, man to command.

Wedlock then is good solid household bread, not by any means cakes and ale. It is the modest squat suburban villa in which you eat and sleep: passion is a church-spire piercing the sky - the spire we see high above our smoky roofs, whence on Sundays and festivals our ears are greeted with the sound of bells.

To try to import passion into marriage is like trying to pack a cathedral into one's bedroom.

And so marriage is to retain its actual character as a simple, natural function of the physical life, like eating and drinking: the husband a domestic animal, presented to the woman by the usages of society, the accident of birth, and the terms of the bargain. There is no reason for choosing him except in so far as he fulfils these conditions. Do women choose their family affections? Do they select their father, brother, relatives? The husband also is a relative, a partner, to whom every possible duty is owing except that of love. The woman's duty to him is to keep house for him, present him with children, nurse him in sickness, and regard his liberty as sacred.

In short, at whatever point of view one placed oneself, marriage excluded, every idea of personal fancy; indeed, of all the contracts of life, marriage was the least tolerant 
of any such idea. Its traditional character as a business transaction no one would have dreamed of contesting.

So far as the woman was concerned, the practical consequences of this principle were very simple. It was not for her to seek a husband, but merely to accept the man whom fate, that is to say, Providence, had destined for her. Nothing was more ridiculous than here and there to find some portionless girl, or one who, like Mademoiselle de Clermont, was no longer in her first bloom, waxing sentimental and speaking with a sigh of the "unaccustomed pleasure" of loving the man one married. "This pleasure," she says, raising her eyes to heaven like a virgin martyr, "if it sets at nought human wisdom, is inspired by wisdom from on high; so fine, so exquisite must it be, that of a truth it is keener than sorrow at the loss of the loved onea commonplace and everyday sorrow." Whereupon, whatever sympathy may have been inspired by Mademoiselle de Clermont's misfortune, her friends cannot help smiling: "So you mean to say," they exclaim, "that a woman has more pleasure in the embraces of her husband than pain at seeing him slain before her eyes!" 1

The idea that a young girl should submit passively to be married was almost the only one on which there was complete agreement. Everyone was thoroughly convinced that in adopting any other course she would almost invariably be committing a folly sure to bring repentance. If young and unsophisticated, she would allow herself to be lured and snared by mere illusions from which there would be a speedy awakening; if she had lost something of her youth and innocence things were still worse, for then she inevitably said and thought and did ridienlous things, like poor foolish Mademoiselle de Clermont. A spinster of twenty-five or thirty, seized with a yearning for marriage, ${ }^{2}$

${ }^{1}$ [The quotation is taken from the Heptameron, Tale 40. There the lady is named Nomerfide, whom the author identifies with a certain Mlle de Clermont.]

2 " Anna: The maiden invokes with all her prayers the sweets of wedlock, and yet with the first amorous intoxication begin the woes of the conjugal bed; the woman is scarce nestled upon the heart of the man than with one consent they long for separation. Phyllis: Anna, little it recks me that thou decriest the bonds of wedlock and the crabled sour race of men; my heart is a-fire with love and I am tormented with thirst for marriage. . . I I deem it better far to marry betimes; wellock is a refuge where modesty may shelter herself."'-(J. Cats, pp. 6. 7, 16.) 
would be subject to attacks of mental vertigo springing rather from vanity than from love; one could believe her capable of the veriest follies and the most surprising judgments. ${ }^{1}$ 'That was the opinion of all serious women, from Louise of Savoy to Anne of France, ${ }^{2}$ whether they were of matter-of-fact intellect, spiritual in their affections, or somewhat wayward in their imagination. The whole mechanism of life exemplified this fundamental principle: a young girl should have "no choice, ambition, or wish" of her own; "experience, failing God and the Law, proves to girls the necessity of discretion, and of not marrying to please themselves; their marriage should be left to their relatives, or in default of relatives, to their friends." 3

Very frequently, the "best" marriages were negotiated by intermediaries more or less obliging, relatives or friends. Princes and princesses were married through the good offices of diplomatists. Indeed, ladies and gentlemen of the Court did quite a respectable trade in match-making; for a consideration.

But, after all, the task of marrying his daughter was essentially and especially one for the father.

For the most part, the father would be only too glad to wash his hands of the business. In every case he was in a hurry to bring matters to a head, and believed that in losing no time he was acting in the interests of his child. She was to belong wholly to another household, since it was a woman's lot to belong to her husband, and so it was well for her to enter upon her new life as early as possible, before she had formed ideas of her own, and at an age when

\section{Heptameron, Tale 21.}

2 [As these royal ladies are constantly cited in subsequent pages, the reader will allow us to remind him once for all of their relationships. Louise of Savoy was the wife of Charles, Count d'Angoulême, cousin. german of Louis XII., and the mother of Francis I. and of Nargaret of Valois. She was a passionate and masterful woman and completely ruled her son, and her greed and intriguing spirit brought disaster upon France. Anne of France, also known as Anne of Beaujeu, was the eldest daughter of Louis XI., and wife of Pierre II. of Bourbon. She was virtual ruler of France during the first eight years of the reign of her brother Charles VIII. : see further Book III., chapter i. She is connected with Euglish history in so far as it was largely her money that financed Henry of Richmond's successful enterprise against Richard III.]

${ }^{3}$ No law in the world had yet authorised them to marry "without the knowledge, advice, and consent of their fathers" (Rabelais). 
the paternal household would not yet have set its stamp indelibly upon her.

In this respect the betrothals, the "marriages for the future"-marriages, that is, solemnised in infancy for future consummation-were of great service, and the higher the position occupied in the social scale, the earlier such marriages were. Kings have even been known to marry their daughters two days after birth, but such a compact, it is true, was in the end aeclared by the lawyers to be immoral and hardly serious. Indeed, later on, when the time for carrying out the bargain came, some princes and princesses felt constrained to protest against this arbitrary disposal of their persons. Happily, such engagements were not of the most stable kind, and, often enough, political considerations were sufficient to upset them before any harm was done. ${ }^{1}$

${ }^{1}$ The good Anne of France, married to a husband much older than herself, had in her life a romance which has escaped notice. She was fond of her first fiancé:

"Le predit duc de Calabre, famé,

En l'espousant luy donna ung aneau,

Non de grant pris; mais si fut il amé

De par la dame et plus chier estimé

Qu'or ny argent, ne bague, ne joiau

Qu'elle garda, mieulx que plus riche et beau,

Jusque a la mort, c'est vérité patente..."

["Calabria's foresaid duke, a prince of fame,

Plighted his troth and gave his bride a ring,

Of no great price, I wot, but yet the dame

Loved him so dear, so high esteemed his name

As never gold nor any precious thing,

Silver nor gem, did her more pleasure bring,

Until her death. 'Tis very truth I tell.']

The duke died six years after the betrothal,

"Qui fust ung deul qui bien tost ne passa,

Mais grefvement poingnit et trepersa

Le noble cueur de la jeune espousée.

Par quoy, tost fust la chose disposée

Qu'aultre mari prendroit notable ct bon,

Ung sien prochain, feu Pierre de Bourbon."

[" And 'twas a sorrow that not soon did pass,

But smote fell sore and heavily, alas !

The noble heart of this young winsome bride.

Nathless, ere yet her brimming tears were dried,

Another mate was found lier, good and high,

Pierre de Bourbon, of ber own family."'] 
In distinguished families, betrothal was by no means unusual at the age of two or three. At this tender age Vittoria Colonna ${ }^{1}$ was betrothed to the Marquis of Pescara.

Consummation usually took place at the age of twelve. That was a favourite age with the husbands; though, according to the best judges, fifteen was the age when the physical charms were at their best, and the soul was most malleable - a view dating as far back as Hesiod and Aristotle. Tiraqueau, ${ }^{2}$ the friend of Rabelais, vaunts his exploit in having wedded a girl of ten. In vain did the French

But the princess clung to the ring of her former lover, symbol of

"Loyalle amour dont estoit anoblie...

... En cest aneau que luy aroit doné

Son amy mort, voullut Pierre espouser."

["Of loyal love's ennobling influence.

And with this ring, gift of her lover dead,

Would she her husband Pierre de Bourbon wed,"]

in order to preserve the memory of him whom God, in his unfathomable designs, had seen fit to take from her-

" Pour petit cueur, d'une jeune pucelle,

Bien garde est d'amour honneste

C'est quant jamais ne varie ou chancelle..."

- Poème inédit de La Vauguyon.

["To the sweet guileless heart of tender maid

'Tis surety of a chaste and noble love

That changeth never, nor will ever fade."]

The princess was as pure a woman as any of whom we have any account, but the author dwells on this innocent romance in order to keep her memory alive in the hearts of lovers.

'[Vittoria Colonna (1490-1547) was the most illustrious member of an old and illustrious Roman family said to derive its name from the column to which Christ was bound for His scourging. At the age of seventeen she married the Marquis of Pescara, and when he died of wounds received at Pavia (1525) she refused many offers of marriage, and devoted herself to literature and works of piety. She wrote poems in imitation of Petrarch.]

${ }^{2}$ [Tiraquean was the learned and genial seneschal of Fontenoy who released Rabelais from the tender mercies of the Franciscans, for which kindness he was eulogised in Pantagruel. He had a large family, wrote many books, and was a water-drinker; whence an anonymous epigram which, roughly rendered in English, reads :

Tiraqueau, fruitful as the vine,

Got thirty sons, but drank no wine;

Not less prolific with the pen,

Produced as many books as men.

And had not water sapped his strength,

So strenuous a man at length

Had filled this world of ours-who knows?-

With books and little Tiraqueaux.] 
physicians implore the men in mercy to have a little patience, beseech them to wait at least until the fourteenth year: they demurred, for it was humiliating for a father to have a fifteen-year-old daughter on his hands: at sixteen they would have called it a catastrophe. Champier, ${ }^{1}$ one of the gravest of writers, proposed that after the age of sixteen young women should be provided with husbands by the State, on the lines of Plato's system. Some parents betrayed such haste to get their girls off their hands that they anticipated the ceremony, handing them over to their husbands-elect on the strength of a mere promise of fidelity. It happened at Milan, among the Sforza family, that a mother, becoming apprehensive, refused at the last moment to part with her daughter on such terms, and the matter ended where it should properly have begun, in a mutual arrangement, the young lady being formally placed in charge of her husband to save appearances. But difficulties like these were always very dangerous. In this case a dispute arose in regard to the dowry, and blood waxed hot; the bridegroom broke off the match, and took to wife another girl of the same family, a child of ten, whom he led off like a horse-dealer returning with a filly purchased at the fair.

Sometimes, in great families, the girls were married in advance by proxy. Certain wives grew to womanhood without even making their husbands' acquaintance.

Urbino is not a great way from Mantua, but the diplomatic agent of Urbino found it necessary to urge his master, Francesco Maria della Rovere, a youth of eighteen, to come on a visit to Leonora Gonzaga, whom he described in the most alluring terms: 'If your Excellency saw Madame Leonora, and the Marquis's little mare, you would see the two loveliest things I ever set eyes on. I do not think there is in all Italy anyone more beautiful or virtuous than Madame, and I am sure no king or prince in Christendom has a mare to match his Excellency's." Ultimately La Rovere yielded like a lord, and set off incognito to see his wife, a girl of fourteen years and a half, a merry little creature, pretty, well-bred, and a pupil of the historian

${ }^{1}$ [A famous physician of Lyous (1471-1540), who founded the College of Medicine there. He was also a man of action and a writer, and his $\mathrm{Nef}$ des dames vertueuses made him so popular with the ladies that he had to choose back ways to avoid affectionate mobbing.] 
Sigismondo Golfo. She was presented to him at the palace of Mantua, in the Hall of the Sun. He stepped forward to greet her, and embraced her in the most correct style ; then, on Cardinal Gonzago remarking loudly that this was a somewhat frigid demonstration, he went forward again, eaught Leonora by the arms and head, and planted a becoming kiss upon her lips. And then they sat down and began chatting on the topics of the day, notably a portrait which had just been finished.

To find marriages of mutual affection it would have been necessary to go down among the lower ranks of the people, in country places; "good matches were made" 1 as they danced together at the fair or at the village merry-makings. But in the great world the future spouses were subjected to a system of "interviews." Louis de la Trémoille, ${ }^{2}$ who conceived the eccentric idea of escaping the infliction, found no other means than to introduce himself into the house of his prospective wife, Gabrielle de Bourbon, disguised and under a false name, as they do in the comedies. With a widlow, perhaps, a little less ceremony may have been permissible, and then-! In one of his diplomatic despatches Bibbiena ${ }^{3}$ relates with much humour an interview of this sort:

"To-day there took place an interview between the Duke of Calabria and the divine lady of Forli. ${ }^{4}$ Needless to say,

1 “ Ainsi, comme j'ayme m'amye,

Cinq, six, sept heures et demye

L'entretiendray, voyre dix ar

Sans avoir paour des médisants,

Et sans danger de ma personne."

-Clément Marot, Dialogue nouveau.

[Thus, as I love my doxy dear,

Five, six, seven hours, nay full ten year

I'll court her, free from fear of slander:

And scatheless-for I but philander.]

${ }^{2}$ [The great general (1460-1525) who served Charles VIII., Louis XII., and Francis I. He conquered Lombardy for Charles, and was killed at Pavia.]

${ }^{3}$ [See Book II., cap. v.]

4 [i.e. Catherine Sforza, the natural daughter of Galeazzo Sforza, Duke of Milan. She married the prince of Forli, and on his assassination by rebels was thrown into prison with her children. But hearing that Rimini held out for her against all assaults, she offered to carry in person an order for its capitulation. On arriving before the eity, however, she bade the rebels lay down their arms, and cowed them by sheer force of character. She married later Giovanni de' Medici, father of Cosimo. She defended Forli against Caesar Borgia, but was captured, and imprisoned in S. Angelo; thence escaping, she retired to Florence, and soon afterwards died there.] 
his excellency was admirably groomed and attired in the beight of Neapolitan fashion. His arrival at Bagnara was welcomed with a salute of musketry, and he stayed to dinner. He spent two hours here with the countess, but it is patent to everyone that $\mathrm{Feo}^{1}$ has the lady well under his thumb. His excellency took his leave very well satisfied; but he was only moderately taken with the countess : he told me that they joined hands very gingerly, that he caught some winking and shrugs. And so we are off again, like a cricket into its hole."

The final scene was enacted between the bride's father and the bridegroom or his parents. It was remarkably like any other sort of bargaining: and on this subject an old author throws a charming side-light: he urges paterfamilias to bestow as much care on the choice of a son-in-law as on the purchase of a dog!

$A h !$ if the wife is ever to become an instrument of love, there is no sign of it here! Her father occupies himself with calculations of the frankest and most practical kind; he has lived long enough to understand the importance of questions of money or worldly interests, and on this score is usually more than a match for his son-in-law. It is all very well for the preachers to extol virtue naked and unadorned! The ideal of a self-respecting father is an eligible elder son, heir to the paternal dovecot, a man of leisure, or at any rate a "gentleman," in other words, wellconnected, moving in good society, with fine friends. Trade he rather looks down on: he has seen so many failures:so many substantial traders have taken to setting up as "merchant gentlemen," like the Genoese, and have come to grief! The law, on the other hand, is extremely popular; in these days there is nothing better than an alliance with a lawyer. The young man who is waiting for the death of his father to buy an appointment in the judicature may hold up his head in any company.

Having once come to a decision, the father is at no loss for excellent reasons both for himself and others. "He plays the guitar well, is a beautiful dancer, a delightful singer, an excellent writer, a good-looking decent fellow ! He has the promise of a post as Lord High Whipper-snapper to the King: 'tis a fine thing, a place at Court! given oppor-

1 'The countess's lover. 
tunity and a friend, and your fortune is made." . . . "He is a sensible fellow, keeps a still tongue in his head, answers you only with nods or Italianate shrugs." . . . "Oh! it's all the same to me. I am a gentleman myself; here's to all gentlemen! Zounds! but 'tis expensive, worse luck! Come now, I'm as good a gentleman as the king. I don't keep up his style, to be sure, but, mark you, I hunt when I like, come and go as I please, bustle about, flog and bawl at and curse my people, let 'em know I am master; and the hundred or two serfs I have under me daren't stir, egad, without my leave." . . . "Tut tut! a little less gilt and a little more gingerbread! My girl marry a lord and then forsooth go footing it in the mud to canvass Jacks-in-office for a flower-girl's corner or some twopenny-ha'peuny matter! A fig for your gentlemen!" . . . and so on, with endless variations on the same theme of utilitarianism pure and simple. Perhaps the girl is already smitten with a handsome officer: no matter, she will have to marry some surveyor from Paris, especially if he holds a good appointment on the crown lands, because that provides opportunities of feathering one's nest. In such matters the fathers relentlessly enforce their authority, apparently with every right. The pleadings in a criminal case reveal to us the Biblical Machiavelism of a well-to-do peasant who had conceived the idea of getting gratuitous service for ten years from the candidate for his daughter's hand and fortune: the period expires, and then the father with singular bad faith proposes to exact another ten years' service; but this time the future sou-in-law rebels, and has the misfortune accidentally to kill his prospective father-in-law, and this brings him before the courts.

The father's egotism was only equalled by that of the bridegroom elect. The man wbo thought of marrying, that is to say, of taking a wife, was a man of some thirty years (Plato proposed thirty, Aristotle thirty-five); he had enjoyed his youth, and was now shutting the door upon it. Why? Often he was not very clear himself: because the time had come, he supposed, for doing what everybody did. Celibacy was not the vogue: "We are no longer in the age of the vestals," as Egnatius ${ }^{1}$ excellently said. And we discover

${ }^{1}$ [Egnazio, a fellow-pupil of Leo X., teacher of eloquence and editor of Ovid and Cicero, etc.] 
from various sources that the religious vocation was not very well understood, even among girls. Luckless preachers had to toil and sweat to prove that virginity was no crime, and that a woman might quite fittingly prefer the ideal of a mystic marriage to the prospect of bearing a man's yoke and measuring out the domestic oil. Erasmus writing to nuns is too courteous not to speak of angels or lilies of the valley, but in his heart of hearts he thinks it all terribly old-fashioned, and has not the slightest belief in the virginal theories of St. Jerome. With still greater reason, celibacy was not countenanced beyond a certain age. Luther very honestly regarded it as an intolerable burden, contrary to nature and the custom of the early church. "It is as impossible to do without women as without meat and drink." And so a man took a wife because he thus fulfilled part of his duty as a healthy animal; he married because at thirty years the time had come for making a home and begetting a family. In reality a man married, in a manner, impersonally, rather for his family than for himself; and all that he desired was to complicate his life as little as possible in marrying, to be able-to preserve his tastes, habits, hobbies, without the incubus of a partner.

The worst feature of this business of matrimony was that it was so entirely at the mercy of chance, which made almost a lottery of it, and it would have been much more ridiculous for a man than for a woman to yield to a childish infatuation. The man knew nothing of the girl he was espousing, either physically or morally. He merely assumed some likelihood of her resembling her parents, with the result that he devoted special attention to his prospective mother-in-law; she was the woman he was wedding. A young woman without relatives to serve as samples and guarantees was at a discount in the matrimonial market. At the best, it is always a leap in the dark, somet?ing like a step into death: it is the burial of the past, the first sacrifice of one's life for the preservation of the race; the Stoic, says Cardan, knows whereabouts he is at his marriage and his death. A man's best course is to take comfort beforehand, to fix his eyes on the object he aims at, to reflect that the reason, the mind has no great part in it, and that children are not the off'spring of a woman's brain.

Moralists had put themselves to much trouble to cheer 
men along this difficult road, and to provide them with a series of test questions as an aid to matrimony. They assured a man that he might be quite easy in mind if he simply verified eight particulars in regard to the girl he proposed to marry: physically, her age, health, maternal aptitudes, beauty; generally, her intelligence, education, family, and dower. Unhappily, this verification was not easy.

Physically, he could verify nothing but the young lady's age; for the rest, the physicians advised him to look to her figure and in general to choose the best-grown girl; but no one can fail to see how vague and fallacious was any presumption based on that! True, there were the attractions of her features to judge by; but those were precisely what the same moralists urged him to distrust: a serious man, they said, would never build on that sand. In married life striking beauty is apt to pall, you come to loathe it, and a pretty woman is rarely elever enough to bring grist to her husband's mill-except maybe in trade, when she serves as a signboard or a trade-mark. Sensible men preferred plainness; it was only widowers or wealthy dotards who gave themselves as a last resource the luxury of marrying a pretty woman. Poor souls! they would do better to think of their rheumatism, their indigestion, the dreadful draughts! Such a match was that of Madame Dixhomme, a very sprightly young woman well known in society, who bore the name of an old husband, a shining light of the Parisian bar, who might have been her father! There is no help for it. These good patriarchs will listen to no advice, and always count on coming off well. The world is content to smile, and to look on their attitude as courageous, not to say heroic. ${ }^{1}$

So much for the physical aspect. In regard to moral principles, there was one that was firmly established. 'The man who was bringing himself to the marrying point was haunted by the spectre of feminine independence; the terror he felt in anticipation of some enforced sacrifice of his tastes or whims took possession of him and dominated every other sentiment. So when he set out in quest of a young wife, he looked for one in his own rank of society, on his own level, so that she might have nothing to hope for from him, nothing

${ }^{1}$ Heptameron, Tale 25. 


\section{THE WOMEN OF THE RENAISSANCE}

to cast in his face, that he might owe her nothing, that she might have no pretext for riding roughshod over him, but might resign herself quite contentedly to play second fiddle, regarding this subordination as natural, just as the ivy gladly embraces the asperities of the wall it is fixed to The husbands wished their wives to take pleasure in resignation and to fancy that their woes were the source of true felicity. The first condition towards attaining this end was that the ladies should not have a higher, nor even a lower station in society to look back on.

In a fit of epicurism dashed with respectability you marry your cook, thinking you are securing careful attentions, a good table, and a warm bed! Woful mistake! You are wedding a fishwife, who will treat you after the manner of fishwives, and overwhelm you with coarse abuse: she will never tire of telling you you are not man enough for her. You would not find it much more pleasant to marry a woman a little too much above you, who, at the critical moment, would hold you with an admirable curtain lecture, and, instead of doing her wifely duty, would discourse to you for the hundredth time on the splendid matches she had declined, the rage of her family, your poverty, and so forth.

It is easy to understand with what uneasiness and fatalism all these considerations, not to mention others, fill the mind of a man who has reached the age of official paternity. $\mathrm{He}$ hesitates long, and makes up his mind at last with his eyes wide open, knowing that "in the best of marriages one must expect at least as much pain as pleasure." Not that he would maintain that marriage is a mistake for men, but he does think that "neither joy nor felicity has part or lot in such brutishness." He asks advice from one and another, and always runs counter to it. Someone tells him of a girl with money-she will want to rule the roost; of a poor girl - she will be a drag; a pretty girl_-so much the better for his neighbours; a plain girl-ugh! that offends his susceptibilities. What does he want, then? A good mauager, a strapping well-built wench: if he talks of consulting an expert, he is referred to Triboulet! ${ }^{2}$ He would much rather have to choose a cow.

${ }^{1}$ Heptameron, Tale 25.

2[The Yorick of French literature : see Victor Hugo's Le Roi s'amuse. When Panurge has vainly sought advice from everyone else on the momen- 
It is in this frame of mind that he at last makes his decision. If in later years he attains to some eminence and is tempted to write his memoirs, this business of his marriage will be one of the episodes he will be able to detail, for his own justification, with perfect composure.

A dispensation of Providence was often necessary to bring him to the point. This dispensation manifested itself under the most diverse forms. The learned Tiraqueau, of whom we have already spoken, was struck one day with the fact that the Greeks and Romans had a very poor opinion of celibacy, and he culled from Valerius Maximus especially a number of convincing proofs on this head. Whereupon he crossed the street and demanded in marriage the young girl who lived opposite; he found that her name was Marie Cailler, that she was very well-bred, and that her parents were anxious to get her off their hands. But Tiraqueau was determined not to suggest a suspicion that a man of his stamp felt a real need of marriage, and so he dedicated to his father-in-law and to posterity the unparalleled account of his actual motives.

The hand of Providence was sufficiently revealed in the will of the parents, or in the eash of an uncle from whom one had expectations, and who, not having himself taken the trouble to perpetuate his stock, was determined that the duty should be undertaken by another.

It is curious enough to see Michelangelo in this rôle of the preachifying uncle. So far as he was concerned, he had long held such peculiar ideas about marriage that he would have nothing to do with it. At a time when he had come to years of discretion he worked himself up into a fine fury of indignation against his brother, who, to put an end to an old and vexatious law-suit, thought of marrying the daughter of the opposite party. Later, however, he took it into his head that the name of Buonarotti must not be allowed to disappear: " the world would not come to an end, but every living being does his best to preserve his species." For this reason his nephew was to marry. But marry whom? Not money, said the uncle, but a girl of good stock : "to wed a good, well-bred, healthy woman, is to do a good day's work," and to assure peace and quietness at home.

tous question, ' to marry or not to marry ?' he tries Triboulet, who sends him to consult the oracle of the Divine Bottle (Rabelais, Gargantua, Book III.). Triboulet was court jester to Louis XII. and Francis I.] 
The idea of a good day's work did not much take the young man's fancy: the prospect of a dowry was more attractive. But the dowry Michelangelo made himself responsible for, provided they found for him a niece who was really adaptable and likely to prove a good wife. A match was proposed, but after dragging on for a time the negotiations fell through, to be resumed and to fall through again. The uncle was content to give the nephew a start, and kept himself in the background, though he was all the time setting the bishop of Arezzo at work in the matter. He knew that the distinguished people at Florence were at that time in sore pecuniary straits, a circumstance at which he rejoiced, for it might be expected to help forward his plans. Ere long, however, the bishop of Arezzo offered a girl who was no beggar-maid to be wed for charity.

The nephew's hesitation being at last overcome, he obtained an introduction to the Guicciardini, one of the principal families of Florence, rich in the possession of two daughters. All went so well that the good uncle was soon exchanging excellent letters with the girl's father. But on the very first occasion when serious business was discussed, the bridegroom elect discovered with dismay that the style of the house, which indicated a respectable fortune, was all a vain show. Old Guicciardini, excellent man, was very careful to avoid a scandal, and there and then offered his would-be son-in-law the daughter of one of his firiends the Ridolfi. Kept well posted in these various incidents, Michelangelo at last became rather bewildered; but to him it mattered little whether his nephew espoused the Ridolfi or the Guicciardini provided it was one of the two.

Finally, the nephew wedded the fair Ridolfi in April, 1553 , and on May 20 th he poured out all his satisfaction in a letter to his uncle. Ravished, enchanted, and overtiowing with thankfulness, Michelangelo despatched the promised Jowry with a present of jewellery. In April of the following year a son made his entrance into the world under the name of Michelangelo Buonarotti ; next year another was expected, and a third the year after. Michelangelo signified his approval by a present of 600 golden crowns (about £2000). That was something like a marriage!

But Raphael, a man of the world, wedded to his independence, took a far less simple view of the institution. His 
uncle, a worthy canon, never spoke to him of a dowry ; a stroke of Raphael's brush was worth a dowry in itself. Unhappily, the divine poet of maternal love, the exquisite interpreter of women, weighed and digested the matter like a man of sense. He does not cease to thank Providence, he says, that he has refrained from wedding any of the ladies contemplated up to the present. To-day (1514) he may marry brilliantly if he likes; the choice is open to him: a cousin of Cardinal St. Maria in Porticu, offered him by the Cardinal himself - a lovely creature, of good family, with a dower of 3000 crowns, or even more. But "he is in no hurry"; and indeed, that is the sober truth : men are not in a hurry; and Raphael never married.

So it was quite with the feeling that he was fulfilling an impersonal and family duty that a man ended by espousing a woman whose attitude was as impersonal as his own. For the same reason, to consecrate the nuptial transaction and give it due importance in the eyes of the world, the marriage was surrounded with an ever-increasing ostentation. The opening scene was as imposing and brilliant as the subsequent years of married life were to prove sombre and colourless.

At a later date we find the Calvinists up in arms against these idle gawds, which they style scandalous worldliness, a "villany." Nevertheless there was evidently no idea of glozing over the real character of the contract; but aesthetic taste, however rudimentary, insisted apparently, if not on idealising the contract, at least on beautifying it.

Up to the solemn moment everything has been transacted between men. The young woman appears on this great day for the first time in her life. If she has been brought up according to the old method, many people have scarcely suspected her existence. Unlike her husband, who is taking a step backwards, subsiding from youth into maturity, she is being born into life. There she is, at the door or under the porch of the church, standing beside her husband, involuntarily, with no desires of her own, passive-an offering, as it were, to the race. In this strong light of publicity she alone seems a little ill at ease, blushing at the exhibition, agitated at this unknown something which the rest are so joyfully celebrating. The priest comes down the nave, just as at funerals, receives the young couple's 
whispered "I will," sprinkles them lightly as they stand with a little lustral water, censes them; and then the procession is formed, to wind its way up to the altar where the nuptial benediction mass will be sung-a long, noisy procession, ponderous, gothic, all stiff with velvets, monumental stuffs and gilded draperies; thirty, forty, sometimes three hundred persons, none but members of the family; but in these circumstances of parade and pleasure the family becomes extraordinarily multiplied. At the head of the procession, buried under trappings of superb finery representing a fortune, the little bride is scarcely visible; she is for all the world like the clapper of a bell. And verily under that golden robe there is after all nothingbut a woman.

They leave the church, and there is no crush; the sight attracts only a few curious folk, a few halt and blind: in those days there was nothing to draw the overwhelming throng without which no modern marriage is complete. And the procession crawls on, displaying through the town its festal finery drawn from ancestral coffers, with a majesty which may perhaps give the impression of an official pageant, but nowhere indicates the crowning incident in a love-story. All is significant of a serious, authentic, arithmetical fact, a practical and substantial fact, a performance got up for the honour of a family.

It is precisely this which sends a thrill through all who take part in the ceremony. Under these huge plumes and massive carcanets there vibrates a delirious but very real joy-the old family joy in pomp and circumstance, this, too, drawn, as it were, out of the ancestral coffers. What man is there who, however poverty-stricken he may be, dispenses with magnificence at his marriage? Perhaps this is the only day-or rather, the only period, for one is not married in a day-when he will know what luxury is. There is a truce to care; life shows a countenance all joy and geniality.

In the rural parts of France the company only rose from table to sit down again, or to dance under the elms. Deep drinking, love, quarrels, broad jests, strange customs, such, for instance, as the jus primue noctis, or the drinking-match traditional with the country lads-all this developed a boisterous gaiety. The bridegroom alone groaned under it, 
for among the middle and lower classes it was the correct thing to invite to one's wedding as big a crowd as possible. The poor man spent his time running from fiddler to purveyor, ruining himself in presents for his friends and the bridesmaids; he was expected to show everyone a smiling face, to receive his guests, have a word for all, crack jokes, be at everybody's beck and call, think of everyone but himself, lucky if at an odd moment he could snatch a morsel to eat. When night came he had not even the right of taking his rest; ordeals of every kind lay in wait for him; and in the morning he was bound to go on laughing, to receive more visits, and profess himself the happiest fellow in the world. And then comes the turn of the upholsterers and house-furnishers.

"Happily," he says, "one doesn't get married every day." Divorce will never number him among its supporters.

Helysenne de Crenne, ${ }^{1}$ the great romance-writer, sketches a somewhat analogous picture of the doings in the great world.

On some fine sunny morning, when the birds are enlivening all things with song, the groomsmen set out in procession to fetch the bridegroom, and the bridesmaids to escort the bride. She arrives in a blue robe adorned with pearls, a diamond coronet on her head. The festivities, extraordinarily magnificent, last the whole day, concerts and dances forming part of them; the men hover solicitously about the ladies; some of them get up a tilting match, ironically inviting the bridegroom to enter the lists, and his refusal lets loose a flood of pleasantries.

At nightfall the couple are solemnly bedded. At this moment, in France, the fun is only just beginning. The house seems verily bewitched: not a bolt catches, not a window but is under a spell; at the most unexpected moment an avalanche of troublesome visitors bursts into the nuptial chamber; the couple spring out of bed; the intruders wax hilarious on the slightest pretext. In her precipitation the bride has perhaps torn a little rent in her shift; a court is at once constituted to try the case, and we may imagine the full-flavoured jests that are bandied about, becoming indeed a little wearisome.

${ }^{1}$ [Of the early part of the 17 th century. Her chief work is the Angoisses douloureuses qui procedent de l'amour.] 
In Italy the marriage was a more solemn and complicated affair. The law indeed was compelled to intervene with a view to limiting the expenditure, in spite of which certain Florentine marriages cost some $£ 20,000$, without reckoning the presents - and the presents made a heavy item. At Venice the witnesses, sometimes numbering forty, could not escape for less than two hundred ducats apiece. The marriage set the artistic world in motion. Men of letters came flocking up with inflictions in the shape of epithalaniums, more or less new, descanting in Grecian style on the theme "is marriage a necessity?" or farragoes of pedantry, crammed with allusions to the ancients, full of names like Lycurgus and Plato, lauding the families of the young couple to the skies, and comparing the bride and bridegroom to Philip of Macedon, Mithridates, Dido; eclogues were rained on them, and apologues, and declamations in Latin verse. All these were printed, and constituted an authentic memorial of the event. A painter of repute would be commissioned to decorate the trunk for the bride's trousseau; he would depict on it a story from Scripture or mythology, or a genre scene, ${ }^{1}$ and this formed another memorial, often charming and always worth keeping. ${ }^{2}$

In the pages of history we find descriptions of so many weddings that it would be no easy matter to make a selection. King Alfonso of Aragon, hardly serious as a husband but a very splendid prince, was married with a magnificence that was long remembered. On the shores of the sea, the glorious sea of Naples, tables were set up for a company of thirty thousand, amid fountains running wine and pavilions flashing with light. In the neighbouring forest a hunt was organised for the Court. The Neapolitans in their enthusiasm invoked the sun to witness that nothing more beautiful could ever be seen.

The wedding of Eleanor of Toledo to the Duke of Florence in 1539 is described with abundant details in a little book

${ }^{1}$ A large number of these cassoni exists. One of the most beautiful that can be mentioned represents the story of Esther (Chantilly gallery). The anthor possesses one that represents Filippo Maria Visconti before the Emperor.

2 Two days after his marriage, Girolamo Riario sent his bride a casket containing diamond necklaces and robes of gold brocade and of velvet, embroidered with fine pearls; one robe alone carried nearly 3000 pearls; there was also a purse of gold, silver-embroidered girdles, etc.-(Pasolini.) 
compiled for the occasion. There you may read a description of the triumphal arches, the statues, the dramatic performances, and find the complete text of the stanzas, the madrigals and the comedy. The music was printed separately.

One may read also the details given by M. Molmenti of the dazzling pageants at Venice: the official proclamation in the court of the Doge's palace, the prolonged and sumptuous preparations for the festive entertainments, the canals en fête, the façades of the palaces liung with bunting, the gondoliers in red silk hose skimming the waves, the armies of servants in gold-embroidered liveries, the bonfires, the fireworks, the fifers and trumpeters, the serenades, dramatic performances, balls, banquets with lavish displays of gold plate and decorations flashing with all the colours of the rainbow-it is all like a dream; even Veronese would have despaired of painting the thousand extravagances of this feverish life.

But nowhere do we catch sight of the woman: it is the man who predominates and plays the leading part. Suddenly the curtain falls. The girl has become a wife, and then what crudities! what realism! even in those circles where delicacy is as a rule pushed to the utmost limits of refinement.

Detaiis on so intimate a matter appear to elude the historian. But though confidences are lacking, we may surmise the real feelings, the profound degradation of certain young brides, from the very circumstantial reports of the ambassadors charged with superintending the arrangements of royal marriages. These reports, it is true, relate to a very special society, but it was the highest society, and precisely that which set the fashion. No one would imagine what singular details are to be found in these letters.

Take for instance an incident that happened at the charming Court of Urbino, perhaps the most exxquisite of all courts. On the morrow of her son's marriage, the Duchess-dowager had the door of the bridal chamber flung open at dawn, and approaching her daughter-in-law, who bashfully tried to hide under the bedclothes, said to her: "Well now, my daughter, isn't it a fine thing to sleep with the men!" What a compliment from the Queen of Platonism! No one after this wil! deny that marriage is 
everywhere stamped with the character of unredeemed prose.

That phrase "fine thing" in particular, which on the lips of the duchess so often denoted the ideal, startles us here with a singular irony.

Or again, what a curious chapter of adventures was that of Bianca Sforza, who as heiress to an immense fortune had become by proxy the wife of the Emperor Maximilian! Ambassador Brascha was deputed to the delicate mission of proceeding to Innsprück to hand the princess over to her husband, but lo! on arriving they found no one to meet them but an archduchess. How was he to extricate the lady from this embarrassing situation?

Brascha wrote to Vienna, striving in the meantime to put a good face on the matter, giving balls, and so forth.

Maximilian was iu no hurry to reply, but wrote at length, asking to see the ambassador. Brascha set out instantly, taking with him this charming but singular note:

"Most serene King,

My lord, I find myself under such obligations towards your Majesty that I am quite dazed at the love you manife-t for me. I could not if I tried express the joy which floods my soul. Being unable to testify to it sufficiently in writing, I send Me-ser Erasmus Brascha to speak on my behalf : and I beseech your Majesty to believe him, and I commend myself to you.

Innspriick, December 26, 1493.

From Your Majesty's handmaid,

Blanca Maria, with her own hand."

It was two inonths before Brascha returned: he was determined not to return alone. The Emperor was very much occupied: he entertained the ambassador handsomely, invited him to festivities, waxed eloquent in praise of the Sforza family, and even mentioned Innsprïck with much urbanity; but all this did not answer the purpose of the unlucky Brascha, whose exertions, uneasiness, and distress of mind may be imagined. At last the imperial procession began to move: for Brascha it was a moment of poignant emotion. Poor Bianca had no prudish reluctance in quitting Innsprück, where she had been so long eating her heart out, and the union took place on March 9 at Ala. And on the 10th Brascha wrote, with a sounding sigh of satisfaction: "At last, thank God, we have got to the 
consummation of the marriage, to the confusion of our enemies. I spent yesterday evening with the king and queen, and we were deep in conversation, up to the time when, the Court having broken up, their Majesties decided to go to bed." Brascha was resolved to make quite sure, continuing for several nights in succession to assure himself. At last he breathed freely! Ah! such missions as this were no sinecures!

But when the time came for reappearing in public, life glowed with a new heat and resumed all its exquisite charm. If by some chance a young bride of princely rank had to cross Italy to rejoin her husband, she saw along her whole course nothing but demonstrations of joy, smiling faces, charming freaks of fancy; to give her pleasure these affectionate people used their one resourcc-invention. At Milan the poet Bellincione and Leonardo da Vinci welcomed the young wife of Giovanni Galeazzo in a sort of firmament, in which animated planets circled round her, loading her with compliments the while. Plato in his raptest moods never imagined anything sweeter or lovelier than certain tokens of homage paid by the Italians to a new sovereign lady. On returning to their domains the Duke and Duchess of Urbino found, ranged upon a hill-slope, the ladies of the city exquisitely dressed, and the children bearing olivebranches in their hands. As soon as the bridal party came in sight a screen of mounted choristers rose up before them, accompanied by nymphs in antique garb; dogs started off in pursuit of hares let loose for them; the hills resounded with the strains of a cantata specially composed; the Goddess of Mirth in person descended the slope and offered the duchess her congratulations and good wishes.

These affectionate welcomes, this show of cordiality at least warmed the sick and sad heart of a young wife, and indicated at the outset her path of safety. Yes, it was a pious and salutary work to envelop in an ideal world this timid child of nature who was being consigned to a lord and master. It would have been barbarous to check this joy in external things ; to show the poor girl from the very first the cutting of bread-and-butter as the be-all and endall of a woman's life; to shut out from her view all that lends brightness and colour to the world. On the contrary, thanks to the smiles with which heaven and earth greeted 


\section{THE WOMEN OF THE RENAISSANCE}

her, a woman of intelligence and sensibility entered upon her mission with a stout heart, in the vague anticipation that fortune was bound to smile upon her still. Where was the harm? There was nothing in her hopes to prevent her from treading the stoical path of destiny and lending herself to the material functions that devolved upon her. But her eyes were opened, she perceived the dawn for her of a life which her husband had long known. It was now her turn to blossom out; she became conscious of her soul, and understood that she too was to be entitled to her youth. 


\section{CHAPTER II}

\section{THE MARRIED WOMAN}

"WoMAN, in my judgment, is the stumbling-block in a man's career. To love a woman and yet do anything worth doing is very difficult, and the only way to escape being reduced by love to a life of idleness is to marry." "There is nothing new in this reflection, put by Tolstoil into the mouth of one of his characters. ${ }^{1}$ Such was the theory of the Middle Ages -fatal love! The new-fledged husband was under no illusion in the matter: he had married to cure himself of love, or rather to have done with it for ever, to turn from woman and towards higher things; he would never have imagined any connection between his marital duties and his soul. First and last, wedlock had no romance for him. Marriage was the worn and dusty highway of materialities.

Nor did the expectations of the young girl soar any higher. Shown the simple truth by the solemn personages to whom she owed her upbringing, sedulously guarded against any kind of illusion, she knew all there was to know about her new duties, and in regard to these it was thought peculiarly necessary to arm her against errors and enthusiasms that might bring disappointments in their train. Marriage she had always looked upon as a natural function with excellent precedents, and she had studied its rules, in their rudiments at least, so as to be able to guide her steps intelligently in a career that had necessarily its technical side.

This was why Champier the physician compiled expressly for Suzanne de Bourbon-that peerless flower among noble maidens-a little treatise quite foreign in its nature to what is in these days called "literature for young people." Yet

\section{Anna Karenina.}


it must be confessed that this treatise, frankly physiological as it is, constituted the best imaginable safeguard against being swept away on a flood-tide of passion and folly. Champier lays down, as rigorously as though stating an astronomical law, various rules for his lady's guidance in the most intimate relations of wedded life; prudence, moderation, and regularity are his text, and he gives point to his precepts by setting against them a menacing array of human ills-gout, anaemia, dyspepsia, enfeeblement of the sight. ${ }^{1}$ Prosing preachers of this sort, let us add, addressed themselves chiefly to the women, and their exhortations were felt to be necessary and moral in the extreme.

Marriage being a partnership to perpetuate a stock and beget children, the wife was naturally expected to accept without wineing the consequences of the contract-consequences it was as unreasonable to decry as to extol. All around her she saw reminders of the high sacredness and dignity of her vocation: genealogical trees spread their vast ramifications over the walls, and, while invoking the past, gravely, almost solemnly shaped for her that gigantic note of interrogation in regard to the future which distinguishes man from the brutes: the whole taking deeper significance and impressiveness from the emblematic figures of Wisdom, Honour, Reason, with which some artist had illustrated them. "Marriage is a holy and relígious bond; and the pleasure a man hath of it should be a moderate, staid, and serious pleasure, and blent somewhat with severity." 2 To attach oneself to this pleasure, to make it the axis of one's world, would have seemed beneath contempt. By the favour of Heaven, a wife could still retain her self-respect and become a moral and religious soul.

\footnotetext{
I "Y cuidez-vous avoir repos

En mariage, mes mignons? Ouy dea!"

["And think you then to find repose In marriage bonds, my jolly joes? Heigh ho!"]
}

chuckles Roger de Collérye, addressing himself here, however, to men.

2 "It ought to be a voluptuousuess somewhat circumspect and conscientious. . . . Is not a man a miserable creature? He is scarce come to his own strength by his natural condition, to taste one only complete, entire and pure pleasure, but he laboureth by discourse to cut it off: he is not wretched enough except by art and study he augment his misery. (Montaigne, bk. i. cap. xxix. [Florio's translation]). 
On these lines the straight path was marked out: in regard to circumstances, neither revolt nor rapture; between the two partners, neither love nor hate, but an amicable understanding, a little stiff perhaps, and wholly practical. To stray from this path was only to fall into difficulties and mistakes.

To what extent this wary walking really availed is a question upon which opinions have always been pretty evenly divided. Marriage was the time-honoured target at which everyone had a prescriptive right to discharge the sliafts of his wit; for all that, marrying and giving in marriage proceeded apace, and the institution went on perpetuating itself imperturbably. It may well be believed that, at an epoch when conversation, free discussion, and a mania for philosophising were in vogue, no one lost an opportunity of airing his views on the surprises and the ailvantages of wedlock; and indeed it is at this time that we see the first indication that the shafts of irony were taking effect, and that the target, after all, was showing signs' of wear.

Here, too, there emerges more clearly into view a truth which the reader will already have seen faintly suggesting itself in the careful and impartial sketch we have endeavoured to draw of the beginning of life for women: the truth, namely, that the ascendency of man developed in him strange principles of egotism. It might be supposed that married women, handed over, as we have shown, like so many sheep, would pitifully cry out against their sacrifice, while the husbands would be abundantly satisfied with the results of a "deal" (if the word may be allowed) effected at so little cost to themselves. But such was not the case: humanity is so constituted that, sunk in abject slavery, with no glimpse of anything beyond, it will hug its chains; while the more freedom it enjoys, the keener grows its appetite for freedom. So long as we are sure of a to-morrow, and believe that somehow or other our lot may yet improve, the present does not count: but, for us to love the present, the future must stretch out before us into the gloom of the unknown, and this, no doubt, is why Providence imposes on us the great enigma of death. So it was with marriage. While the women were content, the husbands railed at it. Monogamy irritated them. Despite all possible precautions 
monogamy almost inevitably endows the wife with a certain influence. Polygamy alone, in virtue of the classic principle divide et impera, can assure to a husband an undisputed authority, and that is why, at bottom, to many men who dared not avow it, polygamy appeared the most natural of luxuries. There are savants, too, who will prove to you that in many countries it was easy to slacken the marriage bond, turn it, even, to profitable account; that it was regularly let on lease for a month or a year. The Babylonians would rather have lent a wife than an ass.

With women, on the other hand, we remark a resignation springing largely from the code of perfect realism by which their marriage was regulated.

They find themselves face to face with a fact; what is done cannot be undone, nor can it be done over again. The transaction is completed: all that remains is to pay the price. Once they can think themselves quit of that obligation, the problem of liberty will present itself to them too, though not, of course, under the forbidding aspects of those ideas of divorce, remarriage, polygamy, that are floating in the air. In the eyes of the women marriage kept its character as a sacrament: the view that it was a contract freely entered into between their husbands and themselves appeared hard to accept, for several reasons. In the first place, little faith was put in that system of social contracts of which we are so enamoured to-day. Life was incomprehensible without a large admixture of fatalism. We are not, we cannot be, parties to a contract when we come into the world; but certain laws have already had their way with us, and to them we continue subject. In marriage, one of those laws, there is nothing irrational in the accessory notion of a contract, and yet, even in marriage, with every imaginable liberty of choice, the real substance of a contract is not found. Is not this contract specially complicated with latent circumstances of time, place, motive, which act unequally upon the two parties? In its very nature it involves so much that is unknown, so much that is fortuitous, admits of so many causes of error and instability, that it barely comes into the category of reasonable presumptions, much less of contracts.

Erasmus is astonished that women are still to be found willing to submit to all the trials of maternity; and indeed 
it would perhaps have been difficult to find such women, if, before venturing out upon so perilous a sea, they had not been able to insure themselves against the selfishness of men by a high conception of duty, stronger and, above all, more durable than the idea of a contract. They needed no persuasion to beware of self-delusion, to contemplate marriage under its most leaden hues; but yet they wished to retain for it its character as a refuge, rude but trustworthy. They derided the chimerical theories of Plato on free union; in short, all things considered, not one of them regretted having been married in the time-honoured way, since no other means had yet been discovered of assuring an honourable motherhood. Unions of policy and position, they very well knew, do not bring about a fusion of hearts; too often they become "suburbs of hell." But what is to replace them? Marriages of passion and love? As a matter of fact, says a caustic critic, since as mere men we are no longer of any importance, or at any rate are all of equal value in the eyes of women, the question is becoming much simpler: a princess will be able to marry after her own heart, to wed a prince, or a peasant, as there is not a pin to choose between them. Where is the advantage? retorts a sage: love matches turn out as ill as the others. The only philosophy of marriage which women must cling to is that in this matter there is no philosophy. It is useless to attempt to sublimate it; what they have to do is to make the best they can of it, and satisfy themselves with a sort of virtuous affection, in accordance with the unfathomable designs of Providence. "Marriage," says Margaret of France, " "should not admit of any objective either of pleasure or of self-interest: all the same, it is not a perfect state; let us be satisfied with wisely accepting it for what it is, a make-shift, but reputable." 2

Thus the conclusion to which women tend to arrive in their cogitations on married life-and who have a better right to cogitate?-is that though they may submit to a husband, they no longer think themselves bound to adapt themselves to him, to identify themselves with him at

${ }^{1}$ [Elder sister (1492-1549) of Francis I., and head of the Renaissance party in France. Her character is elaborately analysed in subsequent pages of this book. The quotations under her name are from the Heptameron, and the poems of which she is the reputed author.]

${ }^{2}$ Heptameron, Tale 40. 
every moment and in every caprice, or to worship this fellow-mortal with the same superstitious veneration as of yore. They see him as he is, a man, with certain qualities, human, in the nature of things, and certain defects, naturally far from divine: a physical creditor, whose claim they do not contest, but are well able to measure.

At the risk of appearing rash in a matter wherein mathematical proofs are so difficult to produce, we think we are justified in asserting that the majority of married women (we are speaking of women of position) desired to render their physical subjection as light as possible, regarding this obligation almost as the seamy side of life, an error of Providence. And they had so much the better of the position that, as rumours of the little domestic dramas always got abroad sooner or later, the ladies were almost certain to have the laughers on their side, especially in France. The French refused all rights to the married woman, but they always took her part, even when she was in the wrong, precisely because, as they looked at marriage, the husband represented the government and the wife the opposition. Domestic squabbles fed the stage, furnishing certain types which were very popular-to wit, the man who married too young, or the man who married too old, the latter a special favourite since the time when good King Louis XII., sacrificing himself to a dynastic ambition, espoused the lady he called his "torment." The husband's part, then, is in truth difficult enough to play. If he is intellectual, platonic, there is no pity for him, people are all so busy finding excuses for his wife. In regard, also, to a husband who puffs and blows and is irritably jealous, the "new right" grants to the wife the fullest absolution. Everyone knows that a silk dress is not enough for happiness!-and because a husband is pleased to be deaf or blind, it is not to be expected that the whole world is to be blind and deaf too.

On her side, a wife had the right to stand on her dignity and play the prude. In general, the average worthy man, a little vulgar perhaps, but a good father and an excellent man of business, is not a great success in his domestic relations, and in insisting on what he regards as his wife's mission, the bearing of children, he wofully deceives himself. My lady's mission is to be the lady of the house: as for him, let him go to his office and "think himself too much honoured that God 
has blessed him with such a wife." If it is a question of receiving fine fashionable friends, people from Court, madam has incomparable graces; but any tender approaches on tho good man's part are sure to bring on a fit of the megrims.

There were a multitude of good, excellent marriages which were only half marriages. Appearances were saved in the eyes of the world, and even in the eyes of the married couple themselves; they both had the good taste to drift along without undue strain, gathering merely the natural fruits of their association. Both enjoyed their liberty: the wife was unmolested and her own mistress; the husband travelled, sailed the seas, or went on embassies, striking up flirtations in his progress from court to court, and doing his household honour by his successes. Castiglione, ${ }^{1}$ a perfect type of the man of the world, saw his wife at intervals, and was always on the best of terms with her; evidently it never occurred to him to take her about with him, but he always showed her in the most delicate manner how much he valued her. At Rome he amused himself by putting into verse a letter he was addressing to her. It was at Rome, too, in August 1520, that he learnt of her death in giving birth to a daughter; just before she died the tender-hearted woman mustered strength to smile for the last time, and to dictate one more charming little letter. ${ }^{2}$

${ }^{1}$ [Baldassare Castiglione (1478-1529), the author of the famous Book of the Courtier, Hoby's translation of which has been recently added to Mr. Henley's 'Tudor Translations.' This book is frequently quoted from and alluded to in the following pages. It purports to be a recold of conversations held at the Court of Guidobaldo, Duke of Urbino (1472-1508), upon the qualities that make up the perfect courtier, and many other subjects incidentally. The chief interlocutors who are mentioned in these pages, are the duchess, Elizabeth Gonzaga; Cardinal Pietro Bembo (1470-1547), of so fastidious a taste as to revise his works forty times, the author of Gli A solani, dialogues on platonic love; Bibbiena; and the coarse and dissolute Pietro Aretino, called Unico (1492-1557), who alternately satirised and sponged on the great; he wrote several witty and indecent comedies, and his letters throw much light on the social life of his time. The reader will find some specimens of his work La Cortigiana (the Courtesan) quoted in Burton's Anatomy of Melancholy.]

2 The abate Serassi has preserved it: "My dear husband, I have got a little daughter, for which I think you will not be sorry. I have been much worse than last time, and, as I wrote you, I have had three attacks of very high fever. To-day, however, I am feeling better, and hope to have no more trouble. I will not try to write any longer, lest I be over bold. With all my heart I commend myself to your lordship. Your wife, who a little starocca with pain. Mantua, August 20, 1520." 
Montaigne has a good deal of pity for the women who were subjected to these capricious humours: "They are verily in worse condition than maids and widows." We want them at the same time hot and cold." He does not remark that, for some reason or other-disgust of too pronounced a materialism, longing for peace and quietness, coquetry, scorn of sensuality, or what not-the majority of women only accepted wifehood for the sake of motherhood, and would be more than satisfied if they could be virginmothers; some considered themselves almost as idols sacred from human touch. Pope Alexander VI, for all his humour and his nimble wit, was very far from understanding all these refinements, and this singular loathing of the flesh. In 1502 he expressed himself pithily and forcibly, but vainly, about the amusing opposition of the Duchess of Urbino, who, when she was offered urgent and incontestable reasons for the annulment of her marriage, ${ }^{1}$ absolutely refused to exchange her husband for a French husband of unimpaired vigour, whilst the duke, the cause of this contention, accepted a cardinal's hat. Laugh as Alexander might, with all his keen sense of humour, at what he called "fraternal magnanimity," this simple incident at Urbino contained the germ of an entirely new code. Other ladies carried the sentiment of 'fraternity' to preposterous lengths. Paul Jove ${ }^{2}$ himself, who belonged body and soul to the philosophic world, gives vent to his feelings when he records the remarkable feat of Julia Gonzaga, Countess of Fondi, who was left a widow after many years of marriage without having ever yielded on the essential point. Marriage so understood becomes a mere matter of policy or business.

We have no wish to dilate on this delicate problem of bodily emancipation; but it so constantly comes before us, and it is especially of such vast importance in regard to the further development of the ideas current in society, that it is hardly possible to avoid doing so. The preachers, who at one time had ardently urged the severing of family ties as inexorably demanded by religion, are now seen proclaiming from their pulpits, with the same appeal to religion, a

1 [The duke's health was ruined by early excesses ; Castiglione says 'gout.']

${ }^{2}$ [Paolo Giovio, Italian historian (1483-1552), an interesting but untrustworthy writer. As Brantome puts it, he used two pens, one of gold, the other of iron, according as the princes he served treated him !] 
totally different doctrine, and inculcating mortification of the flesh of quite a novel kind. We know the story of an excellent pharmacist of Pau "who never had anything to do with his wife except in Holy Week, ${ }^{1}$ by way of penance." Even in remote country places it became the vogue to occupy separate rooms. There was no attempt at disguising the fact, and a good deal of joking on this casuistical refinement went on in polite circles. It was one of the points on which Henri d'Albret was not backward in rallying his wife Margaret. She flung back the half-laughing, half-angry retort: "Henri, perlaaps the lady whom you think so much to be pitied might find some solace if she pleased. But let us dismiss the pastimes in which only two can share, and speak of what should be common to all." Then Henri, taking as was proper a higher tone above these trivialities, addresses humanity at large: "Since my wife has caught so well the drift of my remark, and takes no pleasure in a pastime for the individual . . . I give in." ${ }^{2}$

We have often read the eulogies on Nargaret of France, sister of Francis I., and the compliments paid to her conjugal virtue. There is no reason to gainsay them, but it is well to note of what stuff her virtue was made. Henri II. could write: "Without me, she would never have returned to her husband." And, in truth, she made no secret of it.

One day when someone was relating a scandalous freak on the part of a faithless husband, Henri d'Albret said to her with affected tenderness: "I assure you that I shall never undertake so great or so difficult an enterprise. I shall not have spent my day badly if I succeed in making you happy." And Margaret made the somewhat dry and aesthetic reply: "If mutual love does not satisfy the heart, all else will fail to do so." Towards the end of a certain December the Princess happened to be a little out of sorts; whereupon she wrote boldly to her brother: "I got this on St. Firmin's day (September 25), as likely as not." This recalls a certain bet that M. de la Rochepot made with Queen Eleanor, wife of Francis I. La Rochepot maintained that the queen was drawing the long bow-that she was not really so free with her favours as she gave people to understand. However, he forbore like a gallant gentleman

${ }^{1}$ Heptameron, Tale 68.

${ }^{2}$ Heptameron, Prologue and Tale 45. 


\section{THE WOMEN OF THE RENAISSANCE}

to insist, and surrendered to the contrary testimony of men who had the best reasons for knowing.

But now, in the midst of this cold, nicely balanced existence, or these serious misunderstandings even, a heavy blow falls suddenly in the shape of illness: the husband is struck down. Instantly a change comes over everything. Womanly kindness gushes forth as from a natural spring. The wife's concern is still, as is always the case in matrimonial questions, only with the bodily realm, but the soul breaks through. For the first time the wife asserts herself, less perhaps out of affection for a man from whom only yesterday she held aloof, than in obedience to a natural instinct for combatting material things, pain and disease. Differences of temperament, character, position, philosophical views, all drop out of sight: sensibility alone shines forth triumphant. The house is in commotion, messengers scour the country in search of distant physicians, the chaplain sets off to arrange for masses and votive candles. See, at the bedside of Pierre de Bourbon, the great Anne of France, once the haughty regent of the kingdom, now. fixing her eyes steadfastly on the sick man, taking no rest day or night, declining aid from anyone, measuring out potions and remedies with her own hand, administering the doses herself, warming the bed, doing for the patient little offices of infinite delicacy without a touch of constraint; an eyewitness goes so far as to say that she "made it her delight." The wedded wife is not a love-sick girl, a scribbler of verses; she has no need of imagination, of airs and graces, of enthusiasm: here she is seen in all her grave nobility. She is a sister of mercy. The woman who could not pardon a cross-grained husband resigns herself without hesitation to a future of poultices, cooling draughts, and rheumatism. Some there are who endure this lot for long years without flagging, some who encounter it at the very outset of their married life. It is their natural vocation.

The attraction exercised on women by suffering is one of the most singular phenomena in the realm of psychology. It is as evident as the attraction of the magnet for iron. Women are born nurses and doctors, with a passion for tending the sick, for dedicating themselves with all their wealth of tenderness, for devoting their delicate fingers to the binding up of wounds. Between this passion and the 
passion of love there is an intimate relationship; in both is involved the bestowing of life on man; but in this case the problem is very simple, presenting none of the moral complications of love. Matter-of-fact and practical women are not the least strongly convinced of the vocation of their sex for medicine.

So general was the impression in regard to this that a certain pious anthor advised that the doors of the medical school should be thrown open freely to women, that they should be taught all that men were taught, indeed a little more (Greek and Arabic), and that they should then be sent off to the Holy Land to aid in the conversion of the infidels.

But why not keep in France women so well-instructed? The reader no doubt has an inkling of the reason: the physicians are to be reckoned with, jealous guardians of their monopoly, already exasperated against the surgeons, apothecaries, and women, "nonentities," who are meddling with the care of the children. They are masculine, these physicians, men to their finger-tips: to kill, or at any rate to physic one's fellows, one must needs wear breeches. "The woman who meddles with our trade is a silly creature."

Women did meddle with it, nevertheless, out of devotion, and above all out of self-respect. And on this matter we must take note of ideas absolutely the reverse of those which prevail to-day.

To women it would have appeared the deepest humiliation and the basest servitude to depend on men for the thousand intimate and special attentions which they so often found necessary in regard to their health. Undoubtedly they held that modesty is to some extent a relative term, and that "intentions" count for something in it. So they willingly permitted all sorts of friendly, spontaneous, personal familiarities, so long as they were in good taste; but even when sick and suffering they were determined to remain women; and the idea of surrendering their womanhood, of passing like cattle under the hands and eyes of a horse-doctor on the mere pretext that the modesty of a girl or a woman is a remnant of savagery, and that all standoffishness in this respect appears almost an insult towards a practitioner, did not strike them as a matter of course; they repudiated it absolutely; and, moreover, the Roman, Greek, 
and Arabic ideas, then so fashionable, strengthened their resistance.

So far from believing that a man had more rights bècause he was paid, or because his senses had become deadened by constant wear and tear, they regarded both these circumstances as adding to their humiliation and confusion. For their special maladies they had recourse to women only; and the very fact that in such cases physical pain is complicated with moral pain and weariness of soul, led women of the world, great ladies, to take up a work of charity of real delicacy and refinement, to devote themselves to a thorough study of this class of maladies, so that they might spare their sisters the unpleasantness of mercenary attentions.

Nothing could be more gracious or more natural.

Science at this period was science, and a man was a man. He was as much entitled to study medicine, and to practise it, even without a diploma, as to study any other branch of knowledge-history, mathematics, or chemistry. To have dragged out a few years on the benches of a school is assuredly not a bad means of learning, but it is not the only one, and it ought not to be regarded as warranting for the rest of a man's life a positive presumption of his universal knowledge and impeccability. In medicine, as in other things, so-called amateurs ${ }^{1}$ have been known occasionally to bear the palm over professionals. Now, what science can women more naturally cultivate, what answers better to their requirements in regard to refinement and equality, what more legitimately emancipates them? The practice of medicine was their first conquest, the "great charter" of their freedom. A number of women, particularly women of distinction who had charitable hearts and leisure for study, in a certain sense practised medicine. A celebrated savant, while gently expressing his regret, dedicated to Diana of Poitiers, ${ }^{2}$ as to a colleague, with a thousand professions of scientific esteem, a treatise on the diseases of women.

1 By 'amateurs' we mean men who, while not professionally qualified, have leisure to devote to extended scientific study. In our own day, as is well known, M. Pasteur and M. Claude Bernard would not be entitled to give professional advice.

${ }^{2}$ [Mistress of Henri II., an imperious and avaricious woman, but a generous patron of the arts. See Hugo's Le Roi s'amuse.] 
Except that they watched for the propitious moment for regaining the upper hand, the physicians gave in; they left the patient in the hands of a woman, contenting themselves with writing a prescription on the particulars reported to them, thus securing at least formal recognition-and their fees. Even from professorial chairs medicine was extolled as a lovely and philosophic thing; and in an ofticial ceremony at Paris a "prince of science" (to adopt a modern term) declared to a large audience that Nature has a certain feminine complexion, that she has been specially bountiful to women and endowed them more highly than men.

It should be remarked that if the physicians had the good sense not to quarrel with the formidable power of women, but to come to terms, that result was probably due to the fact that they were themselves in the throes of a crisis which could not but inspire them with great prudence. People were up in arms against them; they were no longer content with rehashing stale jokes $;^{1}$ the sick expected to be cured. Further, complete discord reigned in the scientific world; men vied with each other in flinging about opprobrious epithets like "fool," "mountebank," and "specialist." Paris remained faithful to the traditional and philosophic spirit, while Paracelsus burnt the works of Galen and Avicenna. Many men dismissed medicine as a purely empirical science with no theory behind it, and capable of being mastered in six months. The activity in scientific circles only added to the intellectual confusion. Opinion went so far as to hold doctors responsible for their actions, and to maintain that their repute should be strictly proportionate to their merits. ${ }^{2}$ There were not wanting sceptics, even among women. Margaret of France, in one of her comedies, brings on the scene a sick man who, after being tossed about like a shuttlecock between his doctor

I "I affirm not but I may one day be drawn to snch fond opinions, and yield my life and health to the mercy, discretion, and regimen of physicians," says Montaigne. "I may haply fall into this fond madness; I cannot answer for my future constancy. But even then, if any ask me how I do, I may answer him as did Pericles, "You may judge by that." (Bk. II. chap. xxxvii.)

2 "O heavenly physician!" cries St. Theresa, "thou dost resemble only in name these physicians on earth! Thou visitest the sick without summons, and more gladly the poor than the rich." 
and his wife, is ultimately cured through the prayers of the cook.

Nevertheless, a real bond of friendship and brotherhood was in most cases established between the lady and this stranger who called himself a doctor. It was a sort of domestic and personal intimacy. Women, as we all know, are greatly in need of a directing authority; they love also to be made much of, as certain doctors understood wonderfully well; like that doctor who never met a woman without attempting to worm out of her some confidences as to her health, and when someone expressed his astonishment, "Aha!" said he, waggling his head, "even well-corked bottles sometimes have cracks." In reality, he fancied that his solicitude would be highly appreciated.

The doctor who won a lady's esteem became her friend. He would write to her asking how she was, and addressing her as "my sweet princess"; if he learnt of her illness, he flew to her; if she died, he mourmed her. His sentiments sometimes outran his interests; a noble lady died, and among her effects were found formidable doctor's bills she had forgotten to settle. If in special cases there were limits to the confidence patients placed in their doctor's skill, there remained still a vast enough field for private friendship, which lent itself only too well to scandal.

Official recommendations to hold medicine in respect "on account of its necessity" came from the pulpit. Priests and doctors gave each other mutual support and divided the empire between them. ${ }^{1}$ Scholars unearthed the old story of a medical student who bore himself like an angel while attending an Aspasia. But in spite of these little testimonials, ill-natured folk like Ronsard, Brantome and others continued with more or less virtuous indignation to make doctors their butt. Dolce ${ }^{2}$ amuses himself by relating the misadventure of a young husband, who, having confided to his physician his intense longing to become a father, was ere long lodging with the courts a complaint that he had too speedily obtained his wish. The public was always ready to laugh at stories of this kind. Medical

1 Doctors, further, had to take orders and were not allowed to marry.

2 [An Italian writer (1508-1568) who "wrote in all styles but excelled in none." He wrote two dialogues on matrimony and the misadventures of husbands.] 
science was often considered as an instrument of corruption. Champier, who practised at Lyons, in good set terms accuses his fellow-physicians of becoming veritable agents of demoralisation, and of perverting their patients' moral sense.

So far as medicine was concerned, women showed a becoming modesty in their ambition. Many medical women were women of the old school, who acknowledged the superiority of men. They confined themselves to a welldefined field of study. As soon as she marries, a woman will join battle with sickness; by and by she will have children to take care of, then it will be her duty to preserve her beauty and charms. Here is a medical field well marked out for her. On other points she remains subordinate to men, leaving to them in particular all lofty speculations.

An eminent, if not the foremost place in the medicine of the schools was then held by astrology, to which the physicians, wise in their generation, owed a great part of their prestige. ${ }^{1}$ Assuredly it was not hard to believe, with

1 Savonarola, who fonght in vain against the vogue of astrology (Opus singulare contra l'astrologia: a woodcut represents him disputing with an astrologer), ridicules the Roman prelates who never moved a step without consulting their astrologer. The great soldiers and sovereign princes, such as Ludovico Sforza and Francesco di Gonzaga, were no whit different. In princely houses a physician who would not condescend to practise astrology led a sorry life. He points to his phials in vain ; "against death he has no medicine" ; while the astrologer, a man of position, handsome, fat, well-fed, rich, gazes into the boundless heavens (Dance of Death); there was no profession more lucrative than astrology, none more tempting to ambition. It lent itself to dramatic effects. First the astrologer was usually a foreigner, no man having honour in his own country-an Italian or German, or, better still, a Moor or Gipsy. He puts on airs and keeps his clients waiting. If someone sends him a birth date, to have his horoscope cast, he sends no reply; his eyes are so fatigued by constant watching! he is so tired! And the awestruck princesses in the waiting-room say to one another that patience is necessary with "such geniuses." And the stars were put to marvellous uses.

Bonaventure des Périers relates the amusing story of a physician of Paris, who, alleging high astrological reasons, never showed any amiability to his wife except on rainy days. The despairing lady at last hit upon a very simple expedient: every evening she had a tub of water emptied on the roof so as to produce the sound of a shower in the gutter-spout, and it rained every day! At this game the physician came off second-best and died; and his widow, who found herself very well off, was besieged with numerous offers. She incontinently sent all the physicians packing, then asked her other suitors if they were familiar with the moon and stars. Everyone thought it well to make solemn affirmation that he was, and 
Plato and the Christian church, that the universe does not end with man, and that above us there is a hierarchy of supernatural beings, imperceptible to our senses, on whom we depend, and whose wings sometimes seem to brush us as they pass: those beings whom Ronsard has invoked, in verses of so much beauty, as witnesses of his love :

Ailés démons, qui tenez de la terre Et du haut ciel justement le milieu, Postes divins, divins postes de Dieu. ${ }^{2}$

Many physicians held that the noblest part of their art consisted in penetrating if possible the mystery of the influence of these supernatural forces.

Further, how could they but discover, even in the natural order of material things, a universal harmony, intimate relations between the health of women and the ocean tides and the revolutions of the heavens, a thousand bonds-

D'innombrables liens, frêles et douloureux,

Qui vont dans l'univers entier de l'âme aux choses, ${ }^{2}$

as M. Sully-Prudhomme sings? People who had lost all belief in the saints had in those days the strongest faith in heaven and the stars. They believed readily enough that

received his congé. There was only one who was simple enough to confess that his science was limited to taking moon and stars to witness when he went to bed. He gained the day (Contes et Récréations, Tale 95). No glory was wanting to astrology; physicians and savants practised, defended, and tanght it; great nobles gave it their patronage. Marshal Trivulze accepted the dedication of Pirovano's Defence of Astrology. The science numbered eminent adepts. Luther made use of it in support of his doctrines. Michel Servet, after vainly trying theology and medicine, began to profess transcendental astrology; he foretold eclipses, plagues, wars, and the deaths of potentates; he achieved a very great success, pupils drank in his instruction. Unhappily the jealons Faculty directed him to return to the natural sciences and give up the "Almanac." Servet then turned geographer, and it was not long before he went back into the religious mêlée. The Atlas of Astrologers, one of the most curious monuments of moral derangement, enumerates a crowd of astrologers, among them the Sibyls of the Vatican and King Alfonso of Naples.

1 Wing'd spirits, who the middle space

'Twixt earth and highest heaven possess,

God's scouts, the outposts of his grace.

${ }^{2}$ Unnumbered cords, frail strands full fraught with pain, That join the soul to things of time and sense. 
though the spirit, coming from God, is free, the vile physical body depends wholly on the stars-

\section{Aux corps vous donnez vostre loy, \\ Comme un potier à son argile. ${ }^{1}$}

These celestial torches govern the universe. In vain man struggles, suffers, battles, strains all his powers; he is in the grip of a mysterious destiny.

Ainsi vous plaist, estoilles! . . .

Eu vain l'homme de sa prière

Vous tourmente soir et matin ;

Il est traîné par son destin,

Cumme est un flot de la rivière. ${ }^{2}$

-Ronsard.

Women, particularly sensitive to the mystery of things, could not close their ears against such lofty scientific preoccupations. Renée of France implores the aid of the stars. Margaret exclaims, "their effects are felt in human bodies." Yet the surrender was not complete, as one might be disposed to expect: it is a very remarkable fact that in spite of their natural impressibility and their genius for imaginative flights, they did not readily ascribe to medicine so supernal a glory. To them medicine was a science of the earth earthy, a practical and experimental science. The only metaphysical principle they assuciated with it came from without; and that was, charity.

On the other hand they were wonderfully credulous. ${ }^{3}$ One of their passions was to collect strange exotic recipes of any and every kind. Catherine Sforza, statesman as she was, spent hours in a private laboratory, receiving a Jewess who had brought her a universal salve, or verifying formulae for a celestial water, a cerebrine made of the marrow of an ass, a magnet intended to compose family squabbles, and a

${ }^{1}$ The body 's ruled by your command,

Like clay beneath the potter's hand.

2 And this your will and pleasure, stars!

In vain doth man at eve and morn

Torment you with his useless prayer;

Fate sweeps him on, he knows not where,

As billows on the stream are borne.

${ }^{8}$ Les Evangiles des quenouilles promise to a wife a son or a daughter according as she loves battle stories or has longings for dancing and music. 
thousand other prescriptions of like virtue. One of her ambassadors sends her a drug chiefly compounded of eggs and saffron, of which he sings the virtues with a frenzy of enthusiasm: "I wish to be present when you test it. . . . I would not change places with the King of France, so happy am I in contemplating so admirable a thing; and besides, your Excellency would not find another man like me: for courage is required, not to be afraid of spirits; faith, to believe; secrecy, to betray nothing; and, finally, you need the instruments that I have; the Universities of Bologna, Ferrara, Paris, and Rome possess nothing like them." At the very moment of going to war Catherine does not forget to write an order for the jars she needs for her experiments. Nevertheless, in all these strings of formulae, often so puerile and collected for collecting's sake, we detect more than a collector's mania: we cannot but see in them the thirst for the unknown-an attempt to pierce the impenetrable beyond. This effort, it may be admitted, was not very scientific. But was that of the most highly accredited physician any more so? Women accepted the doctrine that the sun governed the heart and nerves, Jupiter the liver, and Venus the rest of the organism; but they were superior to it in so far as they drew no conclusion from it, making hygiene their chief aim, and limiting their ambition to the preservation of health and youthfulness.

In this respect they were successful; women have rarely been known to retain their beauty in so much freshness up to an advanced age as these women of the first years of the sixteenth century. Their activity was unceasing, they drank deep of life, but never to excess: therein lay their great secret-a secret that was simplicity itself, and of inestimable value, as the next generation was to find when, by dint of defying nature, by crushing themselves under busks and baubles, exposing the bosom, turning night into day, or carrying everything to extremes, the world became peopled with pale-faced, forbidding, white-lipped women. Ere long a cruel procession of maladies appeared-nervous attacks, fits of hysteria, stabbing pains at the heart, agonising births of puny ereatures-signalising the return of neurasthenia, which had seemed buried, but which was to revive in triumph, and for which no other remedies were to be found than a return to the life of nature, fresh air, repose, 
renunciation of the habits of the fashionable world, uninterrupted vegetation.

In brief, the woman whom marriage has started upon a physiological career is bent on defending her body and remaining her own mistress, in face of her husband, her physician - the whole world.

She has her work cut out for her. Further, she is beset under various forms by an irruption of materialities, which would speedily overwhelm her if she did not know how to cope with them. She has still to govern the household, to regulate day by day its eating, drinking, sleeping-the whole domestic organisation.

Husbands are all alike; it is in great measure to secure a house which "goes like clockwork," that they marry. They consider it the most natural thing in the world for a woman to consecrate herself to rounding off their life, to yoke herself in unmurmuring submission to thankless tasks, like the domestic drudge described by Solomon, necessary to the world as food or light: "She seeketh wool and flax, and worketh willingly with her hands. ... She riseth also while it is yet night, and giveth meat to her household and a portion to her maidens. . . She girdeth her loins with strength. . . . Strength and honour are her clothing. . . . Favour is deceitful and beauty is vain, but a woman that feareth the Lord, she shall be praised."

The preachers take pains to show that she shall indeed be praised, that her ideal is glorious though her lot will be obscure, and that there is a happiness in housewifely duty-in feeling that the whole household moves by her impulse aloue. "The wise woman has exalted her house"; on her wisdom and rectitude has depended the greatness or the decay of a family. To pull down is the work of fools. The wise build up, and is not to build up a splendid mission, say the preachers with growing ardour-to build up happiness for those one loves, and one's own happiness in this world and the world to come? "Favour is deceitful and beauty is vain!" Look at this massive woman, probably happy in her own way, a marvel of plumpness, with firm-set lips and a look of energy and masterfulness, unpoetic but very wholesome - this matron of Lotto, blind to all indications that ironical moonbeams are grimacing behind her; or this superb large-limbed creature, burdened with a cluster 
of children, whom Holbein presents to us as his wife. These good ladies, we may be sure, rise at six and retire at ten, and from dawn till dark their only aim in life is to take the air, to go to church, to cook and dust and darn. No Utopia worries them, no philosophic idea ruflles the calm monotony of their lot.

The majority of French women were sprung from this type in its most pronounced form, the rural form, and it was practically impossible for them to alter. In France men of rank almost all belonged to the class of landed proprietors, and the affairs of these proprietors had been for several years passing through a crisis. Even if their income were below the moderate figure of three or four thousand livres, ${ }^{1}$ they had to submit to being eaten out of house and home by a number of traditional functionaries, while on the other hand the growing needs of luxury and the depreciation of money seriously embarrassed them. More than one noble, believing he saw a mine of gold opening in Italy, had joyously buckled on his sword again, only to return impoverished, if not in debt, worn out, and. soured in temper.

The country squire bore his straitened circumstances with rather an ill grace. Rubbing shoulders with the peasants (and the humblest peasant was a lord in his own eyes) and with the village authorities; a determined foe to Jews, financiers, and monopolists; a democrat, persuaded that all men are equal, or nearly so; resigned moreover to figure as head of his village, since a head it was bound to have, but troubling himself very little about the other social magnates; he shut himself up in his estates like his father and grandfather before him, among the sons and grandsons of the people by whom those respectable personages had been surrounded. He was an excellent man, of bluff manners and healthy appetite, determined to keep his eldest son waiting for his inheritance as long as possible, and to disperse the rest of his family, sending the boys into the Church or the army, and marrying the girls to his neighbours. He had a grudge against Louis XII. for giving the landed interest nothing but fair words: Francis I., who multiplied court appointments and paid handsome salaries, appeared to him the right sort of king for agriculturists.

${ }^{1}$ One of the greatest ladies of the time, Marie de Luxembourg, Countess of Vendôme, lived on an annual income of 16,000 livres. 
That was the kind of man with whom and for whom the majority of the women of French society lived. At bottom, this husband is an idealist; he despises money, and plumes himself on the fact with a certain smug satisfaction ; but in his home life he frequently acts as an absolute realist, a cold-blooded ealculator. He will readily and with the utmost chivalrousness admit that women in general are superior beings, worthy of much liberty; but he insists on his particular woman remaining on a lower plane and occupying herself with practical matters. He relinquishes to her the honour of keeping the accounts, he even authorises her to negotiate a bargain, or to secure payment of a due, while he himself hunts, settles disputes among his peasants, potters about, or does nothing. Montaigne is eager to avow that he has no concern with business; in his view it is ridiculous and unjust "that the idleness of our wives should be fostered with our sweat and maintained by our toil." He admits in the most liberal manner the right of women to work, and does so from pure goodness of heart, since women delight in managing, and a woman who works wants no pity! While Madame de Montaigne is keeping his accounts, planting, reaping, looking after the masons, her intellectual husband is good-naturedly gossiping about mankind at large, or tranquilly contemplating the backs of his books, or dawdling through Italy, on the principle that travel is the salt of wedlock, poking his nose into everything on the way, halting at the watering-places, visiting interesting young ladies; all the time reverencing his wife, oh, so deeply! He feels that when he returns and finds her among the haymakers, his love will take a new lease of life: "These interruptions fill me with a new kind of affection towards mine own people, and make my house so much pleasanter a place. . . I I am not ignorant that true amity hath arms long enough to embrace, to clasp and hold from one corner of the world unto another. . . . The Stoics say that there is so great an affinity and mutual relation between wise men that he who dineth in France feedeth his companion in Egypt. . . . If I be at Rome ... I hold, I survey and govern my house .. I even see my walls, my trees and my rents to grow." 1

In those days the direction of a household was an admir-

2 Book III. 
able apprenticeship to philosophy, since it was a point of honour to maintain a great number of idle people. Thus Madame de la Trémoille had to rule, feed, and place forty men, four of whom were attached to her personal service (chaplain, tailor, groom, and steward), and only three women, of whom one was a nurse.

She had to maintain this retinue and give it a stamp of high respectability and discipline, which was all the more difficult because the servants were people of some consequence, there for life, holding places that had been hereditary for several generations; in other words, the house belonged to them, in virtue of some indefinable family collectivism.

Further, people had an ingrained propensity to regard generosity as the special mark of an aristocrat; and as this virtue was expected to grow in proportion to rank, it invariably had the drawback of straitening their means. Out of an enormous total expenditure, Madame de la Trémoille had at her disposal only two hundred livies for her personal use. A prince was often worse off than those who lived on his bounty.

Further, this "generosity" did not manifest itself only in money: it declared itself in affectionate and gracious actions, which after all involved expense. Thus at Blois no domestic event took place in the household without the cognizance of the Duchess of Orleans; she interested herself in the weddings and gave each couple a present: her children acted as sponsors; she even looked after her servants' lovechildren; she watched over the aged; any of her servants or even of their friends who were in trouble were sure of her sympathy; she interceded with the king to obtain pardon for a criminal or the remission of a tax: "You will do both great charity and alms," she wrote to him, "and to me a singular pleasure." Here and there in her modest accounts there is a little space vacant, importing a surrender of feudal dues to distressed tenants, a remission of rent, a cancelling of debt.

In the account-books of the leading French families there always occurs a very suggestive chapter, under the heading of alms. In vain does the charitable spirit in its shrinking from ostentation draw a veil over the few lines in which the facts are intentionally summarised. You breathe in passing an aroma of sweetness, just as in going by a dead wall you 
divine, from whiffs of their scent, the roses and violets on the other side. It was the women's duty to dispense the alms, and in so doing they obtained, across the arid waste of material preoceupations, grand outlooks towards the ideal. A lady of that period was good from pure goodness of heart; she could let her charity shed its radiance spontaneously, without effort. She lived in the very heart of wretchedness: the tilthy hovel, instead of shrinking from her sight and entrenching itself in hateful and inaceessible suburbs, hung upon the walls of the castle, like a parasitic plant. What woman could shut her ears against the cries of wretchedness so near? And charity also was recognised by the State. Louis XII. devoted to it a total of six thousand livres, which be increased in 1509 by one thousand six hundred and forty-two livres; and to ensure a more conscientious distribution he even appointed, in addition to his confessor and almoner, a special functionary, Jacques Acarie, who received the title of "treasurer of the offerings, alms, and devotions."

This fondness for almsgiving the king inherited from his mother, Mary of Cleves, who was generosity itself. She did not confine herself to the charitable doles that were traditional, or almost obligatory, such as the offerings at Easter or All-Hallows: the present of a robe to the "King of the château " on Twelfth Night; New-Year's presents to a whole village of improvised musicians who came deafening her with drums, clarions, carols, and cries of " Au guy l'an neuf!" 1 She went farther afield, to seek out the poor, and in secret she spent her pin-money in succouring them. But these private resources were far from inexhaustible. Like many women, she had a strong predilection for one special work of charity-the care of women in childbel. She organised for them a regular supply of food, besides giving occasional assistance in money or in kind.

She took a personal interest also in the Hospital, and worked with her own hands in a Doreas society which she

"["To the Mistletoe ! the New Year!" The ery of Breton peasants, " begging small presents or New-Year's gifts, an ancient tearm of rejoycing desived from the Druides, who were wont, the first day of January, to go into the woods, where having sacrificed and banquetted together, they gathered mistletow, estceming it excellent to make beasts fruitful, and most sovereign against all poyson" (Cotgrave). From a patois corruption the Scuts Hoymanay is said to be derived.] 
founded, and which distributed every year in the little town of Blois five hundred shirts and five hundred dresses.

In addition to all this there was a long list of "good works" in a more special sense : little dowries of fifty or sixty sous bestowed on poor girls, who sometimes bore notable names, like "Jeanne the Fair," "Lawrence and Jeanne de Saint-Prest"; pensions to needy students; alms to convents; subscriptions to churches. The family of Joan of Arc had a special right to the bounty of the faithful: "Perrette de Lys" used to receive fifty sous "to bring up her own children."

Truly charity flourished in France, becoming almost a new chivalry. Certain men of the world became selfconstituted alms-collectors for a convent or nunnery, under the name of its "spiritual friends."

It cannot be said that France owed anything in this regard to the example of Italy. The Italians enjoyed large incomes, much larger than the average Frenchman of ancient and sometimes crippled fortune; but their expenses were heavier; they had to give fêtes and buy pictures and villas. Without wishing to exaggerate the significance of an anecdote, it is curious enough to compare with the excellent practices of the French Court a characteristic action on the part of Julius II. In the course of the expedition against Bologna, the Pope was told that one of the old court servants had just lost his only mule. "What did it die of ?" was the Pope's curt response. "Of the bad water of Perugia." "Send the stud-master to me." Everyone believed that he was sent for to replace the defunct mule, but Julius simply said: "Take care they drink nothing but boiled water."

Many great charitable schemes were in operation in Italy, where refinement and compassion were highly developed; but the wealthy people of Italy had no great love for anonymous almsgiving. This was due, no doubt, to the fact that poverty bears itself more light-heartedly under an azure sky. In France, where, unhappily, the stars could not fill hungry mouths, the old traditions, in spite of the seductions of luxury, were nobly preserved by the women. Anne of France and Anne of Brittany both received the nickname of "Mother of Maidens," in allusion to the dowerless girls they befiended. Anne of France, who has sometimes been 
taxed with avarice, contrived to dispense her benefactions quietly, as cleverly as others trumpeted theirs. At her expense intelligent children of the lower classes were kept at their studies until they had taken their degree; orphans learnt needlework or some trade ; widows, cripples, beggars, poor folk too proud to beg, the broken-hearted, saw unexpected manna fall from heaven; deserving people were encouraged, sustained, uplifted, "cherished and nourished" by an unseen providence. ${ }^{1}$

How beautiful, how rare is the art of giving! In our day we see organised innumerable charitable schemes, "collections" without number, harvests of good works. But how many people give for love of giving?

Margaret of France, too, like a true princess, was generous, and loved to do good by stealth. In her anxiety not to appear to curry favour with the people, she refused-in the blunt phraseology of one of her biographers-to act "like a mountebank capering on a platform." "She was wont to say that kings and princes are not masters and lords of the poor, but only their ministers."

The writer of a moral history must needs explore all these sweet recesses of a woman's soul, where so mysterious a work is accomplished. Later on we shall see the women bustling about on the public stage, giving the world what it demands of them. Here, in the silence of the heart, they act only for themselves; yet, even from the social standpoint, they will never do a loftier or more efficacious work. On the rugged path on which so many of the unhappy are apt to lose their philosophy, is it not well to spread a soft thick carpet, so that the wayfarers may step more lightly and be less roughly jolted? This of itself is surely a genuine work of love, in full accord with the words of Christ: "To her much shall be forgiven, for she loved much!" From the very outset of their life, painfully spelling out the meaning of wedlock, women are, almost unknown to themselves, winging their flight towards the ideal, towards love. Here, love calls itself charity, that is to say, love for the sick, love for the poor, love for all who are weak and all who suffer.

\footnotetext{
${ }^{1}$ She provided for so many maidens "by way of marriage, and had so great care of them, that she deserved to be named their wother." $-L a$ Vauguyon.
} 


\section{CHAPTER III}

\section{THE CHILDREN}

THeIR mission as mothers, thanks to the precautions of which we have spoken, did not weigh very heavily upon the women. The tide was set against large families; in the country, six children were thought an enormous encumbrance, and as a rule the higher the rank the smaller the family. There were not a few houses which had no children at all. Somewhere in Lombardy, indeed, there was an old law granting exemption from taxes to families of twelve children, but it did not result in an embarrassed exchequer.

The physicians questioned on this phenomenon return only evasive explanations. Placing themselves as they did at a special stand point, they held the women more especially responsible, accusing the detestable experiments some of them indulged in with a view to preserving their figure, such as drinking water or vinegar, eating sour foods, never setting foot to ground; or a life at high pressure, well calculated to develop morbid germs and increase nervous over-excitement; the sort of St. Vitus's dance which affects some people; and the thousand other causes of moral and cerebral derangement. Evidently, in their view, nothing would be so likely to facilitate motherhood as a life spent in feeding the pigs and the poultry.

Yet women resign themselves better than men to the trials that a family brings upon them.

When they first recognise their condition, even those who do not feel called upon to make too much of their duty heroically accept their lot. No one pities them; it is natural 
to them to love children, ${ }^{1}$ and if there are moments of anguish to fear, there are also blissful moments to look forward to. The husband, on the other hand, is disconsolate; he regrets everything; he sces in the cold light of reason the consequences of the event, and his friends agree that he will reap nothing but worries. A man of fashion collects pictures, antiques, not children. Some charitable souls suggest that children assure a kind of survival, are a pledge of immortality, a security for the continuance of the race; but, for that matter, a much simpler, surer and more comfortable way of achieving immortality is simply to write a sonnet. Hardly any but poor drudges, "chestnut eaters," can afford the luxury of being fruitful and multiplying, because for them, in their kind of work, with their rigorous enforcement of paternal authority, a swarm of children represents an immediate increase of earning-power and tools at very little cost. A middle-class householder, who loves his. ease or is ambitious only to swell his banking account, has nothing to gain by a large family.

Among the middle class, then, the budding father is the subject of sincere commiseration. What cares, what vexations will be his! He regards himself as bound for some time to consider the slightest whim of his wife as sacred. With a flutter at the heart he hies him to the astrologer to ascertain at least if it is a boy or a girl; and when the unfeeling stars announce a girl, he still manages to smile.

One fine day (or fine night, for Nature is whimsical in her choice), see him, lantern in hand, chilled to the marrow, shivering, running off to find the nurse; and then what terrible, what wearing hours follow! In very truth it is he who demands pity, for Providence, having failed to foresee these moments for the man, has forgotten to give him strength equal to them. How ardently he wishes it were all over! "There is no saint in the calendar," he

\footnotetext{
1 Quattuor sunt que mulieres summe cupiunt :

A formosis amari juvenibus,

Pollere filiis pluribus,

Ornari preciosis vestibus,

Et dominari pre ceteris in domibus.
}

- Tractaculi sive opusculi.

[" Four things there are that women eagerly covet: to be loved by handsome youths; to be good for many sons; to be decked out in costly array; and to rule the roost."] 
cries, "but shall have his candle!" The first wail of the newcomer pours balm on the mother's heart; but what of the husband? Can he spare time to admire this shapeless, unsightly little creature? He seeks nurses for mother and child, he has the room hung with red, covers the floor with velvet rugs; if by good luck he falls asleep in a corner, it is only in his dreams to see a spectral balance-sheet dancing a frantic saraband. No, he has not his wife's strength.

The red room becomes for the young mother a palace of delight. It was a charity to visit a relative, friend, or neighbour when recovery was assured, and very few women would risk losing paradise for such a trifle. And so the room is never empty. There the lady holds a "regal court," or what we, with less enthusiasm, should call a woman's club. We may fancy how they chatter, how often the husband is hauled over the coals, how they cry shame on him. "What! this shabby dress! He wouldn't give you this or that? Ah, the old skinflint!"

There prevailed in Italy the very amiable practice of sending all sorts of little presents-flowers, fruit, trinkets, nicknacks. The young mother was. entitled also to a little tray, painted or chased, of which charming specimens exist, real works of art. All these presents came in a heap. With his grave and masculine brush, Domenico Ghirlandajo has depicted for us a scene at Santa-Maria-Novella: a maidservant is presenting a cordial on the tray, a friend is amusing herself with the baby, a high-born dame is making her entry in great dignity, a message-girl is bringing in a superb basket of fruit. It is a constant stream of visitors, wonderfully picturesque.

As to the husband, he has disappeared among his occupations and his worries; he reappears a fortnight later, to return these civilities with a grand dinner.

The child is to belong to the mother until the eighth year; an exquisite period in which the heart will expand. It is as she clasps in her arms this feeble little creature, this messenger from a new world, that a woman comprehends love; life appears to her all bathed in a mysterious light, golden, and warm, and glad. All women, whether cultivated or illiterate, have this sensation.

For some time, perhaps for several years, a mother can thus find the restfulness that springs from happiness, and, in 
making all things minister to her inward joy, she steeps her soul in a felicity to which she foresees no end.

No woman, then, ought to deprive herself of the first smiles of her child, his first prattlings, his divine fondlings, which Raphael has depicted and which Erasmus considered so beautiful a thing that he made them a theme for rhetorical exercises.

But from the very first the world interposed with tyrannous hand. In old times a woman had been permitted to nurse her child; suckling constituted a part of the maternal functions, approved by moralists and physicians. But now the fashion had changed; the cry of milk-sellers offering milk for the nursely was added to the morning din in the streets of Paris. The smaller gentry and even a certain number of country magnates ${ }^{1}$ sent their children out to nurse; and to meet this need, human cattle-rearing became a recognised agricultural industry, which flourished exceedingly, though it was rather speculative for those engaged in it, for the children were sometimes left in settlement of the bill.

In the great houses, or those of middle station, a nurse was employed, after satisfying moral and medical tests-a stout respectable person from twenty to thirty years of age. She entered the family, and there represented the life of nature, occupying, to the end of her days if she pleased, a privileged situation about her foster-child.

Not infrequently, we must admit, the husband was heartily at one with the ancient principles, and would very readily have authorised his wife to dispense with a nurse. But then some fair friend would take him aside and put him to shame: "What, he actually means to impose that bondige upon his wife! Does he not see already how worn out she is! Ah, he means to compel her to it, and we very well know why, the miser! Really, who would have thought a husband had a soul black enough to inflict such thraldom on a woman, who, thank God, still possesses some attractions!" And in that last word there is a world of meaning. A wife of fifteen or sixteen years, after a year or two of marriage, had every reason to think that life was not over for her, and that she still had need of her beauty.

\footnotetext{
1 Montaigne relates that he was put out to nurse with peasants, "and brought up in the humblest and most ordinary way of life."
} 


\section{THE WOMEN OF THE RENAISSANCE}

Further, etiquette, and in princely houses even polities, intervened: the convenances were opposed to a mother taking too personal a part in her children's upbringing, for in that case it would not have been worth while to own a whole regiment of servants. There they were, however, and their allotted functions must be respected; and so the mother had to limit her solicitude to a careful superintendence.

Nevertheless, many women ventured to set etiquette at defiance. The Princess of Orange appears just like any other woman when she writes so joyfully to her sisterin-law, Anne of France, that she has just seen her "fair niece," who called her "mummy and daddy," and "gave her as sweet a welcome in her little baby-talk as such a baby could." So, too, Louise of Savoy, when, in 1520, in the midst of preoccupations of every kind, she recalls that, thirty-five years before, Francis I. had cut his first teeth quite unnoticed, "and was not the least little bit ill."

Up to the age of seven, the children remained under their mother's fostering wing, in a pure state of regetation. Moralists and physicians taught that they must be allowed to develop freely, without having to learn anything, and without bothering about anything but good air and a regular life.

The grand principle of education is to let children grow up of themselves, alone, unaided, without grand theories, without dogmatism; and to habituate them to rely on nothing-neither fear nor love; to be themselves; and this from the very earliest infancy. Every being entering life brings to it his own individuality for development; he has the free use of his faculties; he observes much, instinctively using eyes and ears, and his soul reflects his environment like a celestial mirror. So the mother has only to help him, direct him, set him good examples.

This careful attention in early days appears of capital importance, because then or never is the time to root up any little weeds one by one as they appear. No strenuous effort is needed; it is work to be done by a woman's hand, gently.

Hitherto it had been imagined that the first thing needful was to secure a maximum of physical strength, and consequently to harden a child by means almost cruel, such as an exemplary self-repression, a life in the open air, freely exposed to all inclemencies of the weather. If a child wept he was allowed to weep. He was taken sometimes to 
church, or to see very near relatives, but never to places of amusement, to the theatre, or to the houses of the wealthy. To become ever so little accustomed to comfort, idleness, or an artificial life was considered fatal. People feared to make a mollycoddle of him, and said to themselves that the army and the gymnasium in later years would never eradicate ill habits formed in childhood. They thought only of the children; the mothers were left out of account.

The women regarded this system as much too severe, and one of the first results of their influence was its modification. Why martyr the children under pretext of hardening them? What was the good of exposing them half naked to the cold, or of making little monks of them, and assuming towards them the airs of a policeman? Was it so great a crime to show these poor little creatures some affection, to admit them to some share with their elders in the life they were bound to know, to form their minds and their manners by allowing them a place at the card table, or to give them companions-even at the cost of a black eye?

The old moralists regarded such proceedings as premature and far too unsystematic, and refused to hear of anything but muscle, maintaining that entrance into the world always came soon enough. Women were to divert education into another channel. When they come to gain greater power in the home, we shall find them demanding the right to love their children, enter into their concerns, live with them, take pleasure in them, at least until they attain the classic age of seven.

\section{THE BOYS.}

When the seven years were past, a boy became for his mother only an object of anxiety or tribulation. He came under the direct and exclusive authority of his father, who aimed at moulding him on large lines and turning him at fourteen, not into a bookish don, nor perhaps a mere 'passman' even, but into a man of backbone and individuality, armed at all points for the battle of life. Our ancestors had a particular horror of everything resembling enlistment into brigades, reduction to a uniform pattern. The collegiate system seemed to them detestable, a make-shift in the worst sense; Louis XI., though he took eare to send the princes of 
the younger branch to college, just as carefully avoided sending his son there. College, as Montaigne said, was a "factory of Latinizers," a "house of preventive correction," where men worked like day-labourers (of that period) fourteen or fifteen hours a day, until their brains were completely addled and they hated the sight of books; and what, if you please, was the magnificent result? A smattering of Greek and Latin, a certain facility in prating about Jupiter, Venus, Pyramus-without too minute an enquiry, happily, into what those august names stood for. As to ideas, they did no more than stuff the boys with a few stock notions to serve for intelligence, ${ }^{1}$ instead of vigorously developing the creative and original faculties.

Thus there was general agreement that college was to be avoided as much as possible, and that a boy should remain at home. But then came the tug-of-war. If he remained at home, the mother, who had in all probability centred precisely on this son all her affection, would claim him as her care, which is just what the father did not wish; he mistrusted her, her kindness, her "shows of love." It was an axiom that boys must be subjected to thoroughly masculine management, a life of birching, under the firm hand of the father; the father had a perfect right to forbid them to see their mother. How could he succeed in "hardening the soul and the muscles" of a boy, in giving him a physical and moral robustness depending largely on the "thickness of the skin," if the mother was always at hand, interfering, discovering that her son had been too hot or too cold, petting him, commiserating his slightest hardships? That was not the way to make a man!

Nowhere was the battle against feminism fought more resolutely than on this ground. The adversaries of women may be almost infallibly recognised by this mark, that they insist above all things on keeping in their hands the education of men, because they regard this as the direction in which the influence of women is most manifestly fatal.

They fear family life because of the freedom which reigns there, and because they know nothing worse for a man than a precocious impulse towards sensibility. "When I was twenty," growls an old man, "I knew nothing about women ; in these days, infants in arms are further advanced." That

${ }^{1}$ Montaigne, Bk. II., cap. iii. 
is a proof, someone will say, of superior intelligence, a guarantee of their virtue. Not at all. Any system, even college, was preferred to the education of men by women. From the moment when tenderness and sympathy become paramount in a house, there is no course open but to get rid of the boys at any cost.

But is not this to push rigour a little too far, and uselessly to lacerate the mother's heart, this aching heart which thought it had at last found something to fill its void? The mothers are not lacking in arguments to support their claims. They refuse absolutely to acknowledge that kindness necessarily spells weakness. Has it not been understood from time immemorial, by people who could least be suspected of sentimentalism, how important it is to preserve for a man his refuge in the affection of his mother? Have not the names of Saint Monica and so many other devoted mothers always been cited with delight? A rational education ought not to rely solely on the principle oi fear : it should be the express image of life; and if brutality and coarseness are to be banished from the world, it will not do to begin by sowing them broadcast. How many men, nobly fashioned by the hands of 'women, have been brought, by means of love's training alone, to a perfect perception of authority, reverence, discipline! Affection has a wisdom of its own, secret agencies of its own; a mother's heart can see as clearly, and obtain as many practical results, as the reason and the despotism of the father. In this, as in other things, force is not everything, and another regimen is possible than that of the "birch," or indeed of the "filliping," dear to Montaigne.

Margaret of France offers us on this subject a pertinent object-lesson; she cites herself. Her mother, Louise of Savoy, left a widow, indulged to the utmost the luxury of freely loving her children. When someone spoke to her of handing her son over to men, she made answer by installing the bed of the young Francis in her own room. And the result?

Fille et filz eut, à elle obéyssans,

Rempliz d'esprit, de vertuz et bon sens. 1

We can understand what deep chords were struck by this dispute between the fathers and the mothers, and what

1[Daughter and son gave her obedience,

Stored full of wit and virtue and good sense. 7 
echoes it set sounding in the whole life of the women. Separated as they were from their sons by force of custom, it was natural indeed that, eager to imbue the stern. spirit of men with love and tenderness, they should turn passionately to the love of their children.

In the first engagement they were often worsted. The son went off to college. Montaigne deplores it. It is within the four walls of a class-room, he says, and by doses of Greek syntax, that a young fellow is to be taught the science of life and given that clear philosophic outlook which comes through history and experience! What professor will teach him the wisdom of holding aloof from the world's Vanity Fair, swarming with upstart mountebanks and overweening buffoons? His mother would have liked to extract for him the essence of life, the secret of happiness, to impart to him the sacred spark of love. But Montaigne is one of those who regard this as very dangerous; he believes, in short, that "seeing the world" would be still more fatal than "preventive imprisonment."

In other cases, the father would select a tutor to train his. son, and then the crisis lay below the surface.

The father always has some hesitation in determining his course. To begin with, he thinks of the expense, and though enthusiasts represent that there is no better investment, he knits his brows. Then he would like to find a perfect man: a difficult matter. As a rule, he decides on the recommendation of friends, who have seen their nominee at work, and are loud in praise of his tact, his manner, his method, his knowledge; they do not explain that their man finds it necessary to expatriate himself, but he is still young (thirty or thirty-five), and is anxious to make a position.

The candidate himself takes up his pen to speak with becoming modesty of his humble accomplishments. $\mathrm{He}$ promises to ride out with his pupil, and "engage in any other exercise that may be desired"; all that he asks is that he may sleep outside the château and not have to dine in the kitchen, like some of his colleagues. This is not enough for the anxious mother; she would like to know if he is a man of honour and a gentleman. Her mind is set at rest.

For a long time these tutors inaintained a certain attitude of reserve. 
In his Calandra, Bibbiena gives an example of one who is completely uninteresting, speaking, acting, and dressing like the rest of men. But these young fellows were men, and what is more, men of education, not so foolish as, after tasting of a life of refinement, to fail long to recognise its advantages. Sometimes, under a guileless demeanour, they suffered temptations the reverse of philosophic: Vegio ${ }^{1}$ calls them, without mincing matters, "abominable bucks." They learnt by experience how hard it is to get on by zeal and earnestness, and how easy by other means. They cultivated literature to some purpose. No one thought any the worse of Antony de la Salle, the austere tutor of the house of Anjou in the 15th century, for writing The Fifteen Joys of Marriage or The Hundred Novels, or of Lemaire's ${ }^{2}$ notion of elevating the ideas of the young Charles V. by offering him delicate nourishment in the shape of a Judyment of Paris of photographic realism-a picture of the future reserved by heaven for princes and the great ones of the earth. Such things were read: dissertations on Aristutle were not.

In proportion as the women posed as patrons of literature, the tutor type appears in higher relief. The torrent of invective let loose against them leaves no room for doubt that the tutors had red-letter days. The dramatists and the writers of novels do not condone the airs of proprietorship they assumed in regard to mothers or cousins. They show you a poor devil of a pedagogue, a dried-up anatomy, void of personal merit, ill-featured, grotesque, hoorish, dying for love of some fair, rich and distinguished girl, whom he pesters with glowing love-letters, or with sonnets spiced with epicureanism. What peals of laughter there are when he, like many others, comes in due course to taste the rod in pickle!

Froin the moment when Aretino, in his Maręscalco, which

1 Maffeo Vegio, a disciple and the biographer of St. Bernardin of Sienna, secretary of Pope Martin V., was a very eminent humanist at the begimning of the loth century. He adiled a supplementary book to the Aenerd. He was ranked mueh higher than l'etral'ch. The book cited, De elncatione liberorum et eorum claris moribus, of ten republisherl since 1491 and issued in a French translation in 1508 , is a very renlarkable work, and exercised a great influence. It seems, however, to have escaped the researches of the historians of edueation.

${ }^{2}$ [Jean Lemaire de Belges (1475-1548), historian and poet. His ehief works quoted from in these pages are: Illustrations et singularilés des Guales and Le Temple d'honneur et cle vertus.] 
appeared in 1533, revealed the dramatic possibilities of such a part, the type was fixed.

Before the tutor appears on the scene you know what you are going to see: a spectacled pedant, ungainly, loutish, pretentious, a twaddling bore, full of philology and quotations. His very features have acquired a mechanical cast betraying his habit of holding forth on the obvious, as Montaigne say's, or of extinguishing youth by his stupidity, his " hoggish wisdom," to adopt the words of Rabelais.

Then, in virtue of a law of fate, the glory of the tutor waned and fell. The impulse that went forth towards liberal scudies brought so many rivals into the field that, unless he opened a private seminary or obtained a professorial chair, the tutor was ruined. His salary became diminutive, and, as we know, the man who is poorly paid is thought little of. He may take all the pains imaginable, set impositions, rap knuckles, pull ears, but no one is satisfied.

"I know no worse blockhead in the world than the scholar, except it be the pedant."

And then the poor "pedant," full of gall and bitterness, withdraws into his shell. After a long day of toil and drudgery, his only pleasure in life is to get back to his solitary room, and there spend the night in collating notes, collecting rare phrases, happy turns of expression, or hammering out verses, love poems addressed to a beauty whom luckily he does not know, or lyrical verses at a white heat of passion. And these productions of his heart (such of them, at least, as Fortune has deigned to preserve) lie to this day, bundles of them, in the dust of archives.

Needless to add that the tutor considers himself martyred by the father. The father, who does not profess to love him, treats him indeed, more or less openly, as a tradesman and a nuisance, and interferes when the whim takes him, finding fault with this and that-the boy's talkativeness, his pranks, his bad companions. He would like on the one hand less severity, on the other more progress. And then this youngster, who calls him "Sir," and whom he always regards as a child, assumes mannish ways and threatens to follow at his heels: another serious drain upon his purse ! Besides, what is the good of so many courses of study, of this "bookish swagger"? Can't he learn everything with- 
out such a fuss? What, here is a child we are going to launch into actual life, and you stuff him with syllogisms, dates, a world of merc lumber! Did Alcxander the Great learn all these things? He had, grant you, a tutor named Aristotle; ay, and with a few good moral principles for his whole kit he conquered the world! True, he respected the arts and sciences, he praised their " excellence and elegance," but was he ever seen to grow pale and bite his nails over a problem in dialectics? No, indeed $!^{1}$

The tutors were never safe from these annoyances, except perhaps in the houses of princes or kings, because then they were important personages, high functionaries, and a numerous body.

The mother, on the contrary, made herself the friend of the tutor, and by this means exercised a perceptible influence upon him. She surrounded him with affectionate attentions. They were two natural allies, two feeble and down-trodden creatures who sought support in high communings which the husband did not understand. As a man of culture the tutor leant towards feminism, and he tasted doubly, for himself and for his pupil, the attentions, the solicitous benevolence, which a mother throws about the work of education. The palace of Louise of Savoy at Amboise thus saw a succession of special tutors who came to imbue Francis I. with aesthetic principles, and they retained the pleasantest recollections of their stay. The young princess indeed spoilt them, pampered them, almost; she had them at her own table, instead of leaving them to the society of chamberlains and playactors: she made them talk, and talked with them.

In spite of all opposition, the education of men thus underwent a gradual transformation in cultivated countries. Instead of maintaining their former attitude of grave reserve, hardly distinguishable from bashfulness, and of regarding everybody, especially persons well on in years, with a distant respect ; instead, notably, of showing in their intercourse with women all the shades of respect from profound reverence to profound courtesy, the majority of these young men made their entrance into life without embarrassment and with the most charming manners. They put off the armour of social etiquette, they were docile, pleasant, 
graceful in bearing, proficient in the art of pleasing. A multitude of books on "civility," an excellent specimen of which came from the pen of Erasmus, instructed them in the science of good-breeding, formerly somewhat neglected. Moreover, as education is always the great objective of men who desire to exercise a serious influence on thought, they vied with one another in propounding theories and advocating each his own system in regard to the direction of youth, a task which engrossed such men as Cordier, ${ }^{1}$ Sadoleto, ${ }^{2}$ Vivès, ${ }^{3}$ Luther, Calvin, Erasmus, to mention only the chief. We need not follow here their far-reaching discussions, which are but the development of the struggle entered upon between the idealistic and the matter-of-fact spirits. On the extreme frontier of the two realms Zwingle, established so to speak as a mainguard, defends the German tactics. Without denying the amenities of aestheticism, be declares for an education of cloistral severity, for curricula of the exact sciences and logic, and prefers Hebraists or erudite Hellenists to elegant Latinists.

Erasmus, on the contrary, marks out the Roman frontier. $\mathrm{He}$ considers that any effort to direct the intelligence of children into one rigid channel only has the effect of drying it up. He appreciates neither the exhibition of truth in its skeleton state, the system which flourished in the schools of the Middle Ages, nor the pure apprenticeship to utilitarianism to which Zwingle inclines. The sentiment of the beautiful, in his view, offers an immense advantage in lifethat of sustaining and consoling the spirit; in education there is no other process for widening, refining, elevating the faculties. ${ }^{4}$ The new movement has his entire approval.

Indeed, he is ready to go very far. Instead of banishing all thoughts of women from their minds, he is surprisingly ready to explain to young men that there are two loves, a

${ }^{1}$ [A friend of Calvin, and a professor, who reduced himself to beggary by his unselfish efforts to improve the edncational methods of his day (1479-1559).]

2 [A cardinal, and an ardent humanist (1477-1547). He took Cicero for his model, and wrote moral philosophy and poetry. The work here alluded to is his Paedotropia.]

${ }^{3}$ [Yivès accompanied Catherine of Aragon to Fngland as her tutor and chaplain. Siding with her on the divorce question, he had to leave the country. His works were published at Basle in 1555.]

${ }^{4} \mathrm{He}$ admits astrology among the exact sciences. 
good and a bad, and to set them such subjects for composition as the question "ought a man to marry or not?" Hütten ${ }^{1}$ pokes great fun at the coy professors who so carefully expurgate the mythology, who would fain drape the Muses and turn them into angels, or who compare Diana to the Virgin Mother.

In reality, as everybody had his own programme of education, dependent on no one's theories or whims, all this fine ardour produced little but modifications of detail. So men remained faithful to gymnastics and all the sportsriding, hunting, fishing, tennis, perhaps even to sober philosophic deambulations in the style of St. Gregory of Nazianzen. But they held dancing in less abhorrence, and the love of gaming worked havoc.

Music triumphed over its detractors, who had been wont to represent it as directly tending towards effeminacy and voluptuous impressibility. Now, on the contrary, it was regarded as a child's most ennobling avocation and a precious resource for forming his mind. Instruction in the principles of design seemed a necessity for men who were called to live among objects of art, and who, without some practical experience, would infallibly fall a prey to pinchbeck.

However, it is impossible to deny that a too exclusive development of the emotional side of their nature did produce, among certain young men, untoward and even disastrous results. Education had become very widespread; everybody sought after it, rather out of amourpropre than to supply needs they really felt; and the result was that there was less anxiety to equip solidly a few choice minds than to give the mass a superficial polish. The world was overrun with amiable young men, patterns of social accomplishment, knowing how to bow, dancing well, of excellent table manners, primed moreover with a few tags of Latin or Greek, living in elegant idleness, and thus the pride of the good merchant who had the honour of begetting them and keeping the pot boiling. Their weak point was that they knew too much of life in their beardless youth: aestheticism had brought them

1 [Ulrich von Hiitten (1488-1523), friend of Luther and one of the most energetic of the Reformers, by turns soldier, poet, theologian, and politician. He is alluded to passim.] 


\section{THE WOMEN OF THE RENAISSANCE}

neither illusions nor enthusiasm; but they were pastmasters in the commercial valuation of some fashionable young lady and her belongings.

At the age of fifteen or sixteen, all these young fellows, good or bad, took flight in the most diverse directions, and escaped from their mother for good and all.

She sees them go! Some, the smartest of them, go to Court as brilliant pages, all ablaze with gold and velvet: the others into some château, where they combine the duties of head-huntsman and stud-groom, and dine in the kitchen, hoping to be mentioned in their master's will.

Others, maintained by a more subtle father, are commissioned "to attain unto the virtue and honour that knowledge gains for gentlemen." 1 Ah! the gay young sparks! They proceed, at great expense, to establish themselves at Padua, Bologna, or elsewhere, and there the lore they gather comes from profound study of Signorina Angela's ankles or Signorina Camilla's bright eyes. One of these pious youths, the son of a councillor of Paris, dismissed post-haste the private tutor accompanying him. So long as the lad's purse holds out, the father proves indulgent, and indeed is secretly not a little proud of his heir's escapades. Boys will be boys. One facetious father addresses a letter to his son "studying at Padua-or sent to study."

Many people attributed the wildness of young men to the fact that their education was not directed by women.

Calvin considers that the young men were thrown too much into women's society; Henri Estienne ${ }^{2}$ charges upon aesthetic education all the vices of the age. This is going a little too far: it would be just as reasonable to make the vices of the age responsible for the bad results of education. As a matter of fact, notwithstanding a certain measure of progress, the education of the sixteenth century did commit errors for which it had to pay. Discipline was relaxed. ${ }^{3}$ It was a common complaint that studies lost tone as they

1 Heptameron, Tale 18.

${ }^{2}$ [A 16th century scholar who in an amusing book called Apologie pour Hérodote made an elaborate attack on the clergy of his day.]

3 " My pupils do just as they please; most of the time they are digging the soil," writes an unlucky tutor, referring to the dauphin of France; "I have grave doubts whether they'll be fit for anything better," 
became more general ${ }^{1}$ the new education took its pupils too young, forced them remorselessly through too extensive curricula, encouraged them to be content with a smattering, gave them the habit of not going deep into anything, and made shallow and paradoxical men.

Two women who were the products of the most opposite principles, Louise of Savoy and Anne of France, were on their guard against this error. The one determined to have her son educated under her own eyes, the other undertook the education of her future son-in-law-a clear proof that all women cannot be charged with particular faults.

However paradoxical the idea may appear, it seems that the system of education ought to have been more completely revolutionised. Either the old principle of bringing boys up so as to make men of them should have been maintained, or a new one should have been boldly and frankly enunciated, namely, that it would be well for a boy to be brought up by his mother, since he is to live with a woman, and a girl by her father, since she is to live with a man. Of this principle, however, we nowhere find the slightest hint.

In this education there would have been something more intimate, more just, more natural, and perhaps more profitable. You can tell among a thousand the men who have been brought up by a serious mother, and the women brought up by a careful father.

Unhappily, the social customs of the time raised an insurmountable obstacle. In addition to the fears of excessive sensibility of which we have spoken, the rigid family principle ordained that the son should belong to the family and not to his mother. He was a man: therefore let him ride and hunt and be a soldier! It was better to err through brutality than through tenderness.

In reality, many mothers exercised but an indirect and ineffective influence on their sons. The sons were too much separated from them and left them too soon. Were the mothers made for the children or the children for the mothers? Judging from the number of households which were only held together by the children, one might think they were made for the mothers; and yet a woman who relied too much on this support was sure to remain in cruel loneliness.

\footnotetext{
${ }^{1}$ Numerous Latin dialogues were written for children in France and Germany.
} 


\section{CHAPTER IV}

\section{THE EDUCATION OF GIRLS}

IF the sons were destined almost inevitably to disappoint their mothers' hopes, the daughters were to compensate for that disappointment. We must crave pardon for entering into all these details. It is impossible to set forth the story of a woman's heart without first of all plumbing as deeply as possible the secret of those holy passions which move women as mothers and as daughters. We started from the solid ground of marriage after the old style, a mere physical and rational fact. The sensibility of women begius to blossom out on coming into contact with physical wretchedness; it creates the sick-nurse and the alms-distributor; it is then that the mother is born. Her love for her sons has nothing but separation to look forward to; but in the love of mother for daughter a woman's heart finds another stay. Here there is no interference to be feared from a third party. The daughter belongs to the mother, and the father does not even seek any share in their intimacy: "Women's policy hath a mystical proceeding; we must be content to leave it to them." I Let the father provide the girl's dowry, that is all that is required of him. In the formal and somewhat Philistine society which was the outcome of the Middle Ages, the several shares of the parents were very clearly defined.

But these things which the father knew nothing about are of the greatest interest for us. We want to know what went on between mother and daughter, and how the women of the future were being formed, for then we shall know also whether the mother was able to fashion for herself a lasting

1 Montaigne. 
joy in her home, and whether she was so well satisfied with the principles on which she herself had been brought up as to apply then to her daughter. Later on we shall have to treat of more momentous questions, of ideas much more highly artistic and philosophic, but we shall meet with none from which a more thorough knowledge of the inner workings of feminine souls is to be gained. In the slightest question of education all the social questions have their echoes, as we hear the roar of the ocean in a shell.

Historians are very far from agreement in the information they give us as to the manner in which young girls were educated in those days. An old, but false, proverb runs: "The mother feeds, the father instructs"; which signifies in plain language that the mother never instructed, suckling being the top of her capacity. On the other hand, as the treatises on education speak only of the boys, or at most of "children," and practically never use the word "daughters," some historians have concluded that the girls were left to vegetate and that their education was never considered, while others, on the contrary, and these not the least important-such as Burckhardt and Minghetti-have believed that the girls merely followed the same course as the boys.

We shall not traverse these two opinions, contradictory as they are, because they both appear true to a certain extent.

The question of education really depends on another question, of much greater moment, which we have set ourselves to answer in this book: What ought women's life to be? Where ought they to seek their liappiness? And at the outset we are brought face to face with a very troublesome problem. Is a woman to continue to be married passively, as we have seen her married-to be left almost a slave? or is she to be put into a condition of self-defence? Is she to be made an obedient tool, a mirror of the ideas of others, destitute of all mind of her own, and all the happier in knowing nothing beyond the narrow bounds of her bedroom? or does it seem better to render her an active, educated creature, with an individuality of her own, capable of reasoning and acting? Is the mother to remain merely a temporary guardian, charged with watching over a little girl for a master of undisputed title, who will form her and train her after his own fancy, and to whom she will belong at the 
earliest moment, even in her first flower? or is the mother to be at perfect liberty to link herself closely with her daughter, and, precisely because the girl is one day to be given to another, to arm her with independence and intelligence, even although she knows that sooner or later some portion of this armour must be dropped on the way? There is the whole question. And on that question depends the education of girls.

In the first case (that is if we adopt the time-honoured theory) the mother was preparing a blank page. She had little to do except to promote as hardy a vegetation as possible, a blossoming out into strength and beauty, to maintain absolutely unbroken quietude, to respect and even prolong the days of childhood. 1 There is no need here for lengthy dissertations: the system consisted in proscribing everything that involved the slightest mental exertion, even in the form of little pastimes; in preserving an absolute simplicity, a cloistral existence; ${ }^{2}$ in shunning even physical exercises if they were at all energetic. From the intellectual standpoint it allowed, on the artistic side, some trifling pieces of needlework (tapestry, netting, or the like); music, not suggestive or light, but classical music; as recreative reading, some elementary books of religion or morality; in science, some notions of physics, agriculture, medicine, some philosophical expositions of great moral questions, such as original sin, the Redemption, the immortality of the soul, and the Creed in general. That was what had gone to form the little bride, the robust, sedate, matter-of-fact, shy little

I " $\mathrm{My}$ daughter is of the age wherein the laws excuse the forwardest to marry. She is of a slow, nice, and nild complexion, and hath accordingly been brought up by her mother in a retired and particular manner, so that she beginneth but now to put off childish simplicity." (Montaigne.)

2 Quid tibi praecipiam molles vitare fenestras? Ad culpas aditum laxa fenestra facit.

Libera mens, captiva tamen sint lumina, quando Hanc animo invenit saeva libido viam.

Cogite fallaceis, animus ne peccet, ocellos, Cogite, libertas ne peritura cadat.

Pellite materiam, primasque extinguite flammas.

(Pontanus, De Liberis.)

["Why should I admonish thee to shun the seduction of windows? An unbolted cascment is the door to vice. Keep the mind free, but the eyes in durance, since concupiscence discovers this way to the soul. Restrain thy eyes from tricks lest thy soul sin; yea, lest thy liberty fall and perish. Thrust away the fucl, and extinguish the beginnings of flame." 
creature whom at the beginning of this book we saw led to the altar. She was ignorant, but so much the better: she was only being born into life, but she brought as her stake a solid health and a well-balanced character generally; and at thirteen years, that was a good deal. The husbaud would do the rest.

And it must not be imagined that this system, barbarous as it may seem to some, was regarded as at all ill-conceived. It had numerous friends. The learned of the Middle Ages, from the venerable Egidio Colonna ${ }^{2}$ to the illustrious Gerson, ${ }^{2}$ had formed no other idea of women's needs. Gerson even enunciated the aphorism (which, however, must not be pressed): "All instruction for women should be looked at askance." In this the philosophers were at one with the physicians, whose advice was to err on the side of caution. In support of their position, they invoked the great name of St. Chrysostom, ${ }^{3}$ and that of Lycurgus also, who wished to prolong the childhood of young girls to the eighteenth year (and this in Greece), and to devote the whole period to the care of the body.

On this system, the mothers could not form close ties with their daughters, still less enter into their life. One mother, however, inspired by her ardent devotion to an only daughter, and at the same time thoroughly conversant with the actual necessities of life-Anne of France-has shown to what good account these apparently rudimentary opportunities might be turned, while paying due respect to the advice of Gerson and the physicians. She set down her views in a little work, of a purely practical and intimate character, designed for her daughter's use, and written day by day with a certain desultoriness, according to the line her reflections or her reading happened to take, and without the slightest intention of supporting a thesis. This book imparts to us ex abrupto the secret of her thoughts.

She piuned her faith to education, not to instruction; she

1 [A disciple of Thomas Aquinas: he died in 1316.]

${ }^{2}$ [The famous mystic and theologian (1363-1429), who so stoutly opposed scholasticism, astrology and magic. The Imitation of Christ has been ascribed to him.]

3 "Take care of your daughters; let them be always at home, gentle, pious, scorning money and outward adornments. And thus you will preserve not only these young girls, but the men who will one day wed them, and you will assure a good posterity from a healthy stock." 
desired an education that was spontaneous and in some sort automatic, which would result, not from a perfect intimacy between mother and daughter, still less from a sentiment of equality, but solely from a kindly, frank, and affectionate association, of such a nature that the mother would colour her child's character "as good wine colours its cask."

This gentle prescription assumes a wide mental culture to begin with, and a certain robustness of intelligence. Anne of France intended the moral and philosophic education of the girl to be carried out with the aid of Boethius, Plato, the fathers of the church, the ancient philosophers, and, it need hardly be said, in conformity with the "Instructions of St. Louis."

On the other hand she did not trouble to develop the imagination or the emotions: she had a horror of affectation, of all that appeared to her to smack of the studied, the conventional, the theatrical: she would not permit it anywhere, either in dress, in which she rejected false simplicity and false elegance alike, or in conversation, studies, or conduct. She loved only the splendour of truth, the glorification of the real in its noble aspects. It was her aim to temper the young girl's soul by instilling into her the habit of searching enquiry and deep thought, and of building her reasoning al ways on clear premises like the certainty of death or the existence of God.

From these principles there resulted, not a critical scepticism like that of Montaigne, Pascal, or Descartes, but, if one may say so, a vigorous and affirmative scepticism, that is to say, the absolute, perhaps even harsh determination to look the facts of life fairly in the face, as serious but ephemeral matters; and to abstain from giving them colours, shapes, an import which do not belong to them, from throwing a false halo about them. As a drowning man clings to a rope, so Anne of France clung to a precise and objective morality, which, firmly anchored on religious faith, defied discouragements and fatigues as well as illusions. Beyond the restless sea of mundane realities in all their nakedness, it pointed to other realities, which appeared to her just as clear, just as positive, and in which she found a steadfast beacon light.

In thus basing feminine education on individualism and a severe conception of the True, Anne feared rather than 
desired the intrusion of aestheticism. What was required, in her opinion, was to form strong women, vigorous in body and mind: she wished to develop strength of will and stability of character, which are practical virtues. Assuredly she had no personal scorn for the beautiful: she gave proof enough to the contrary. She loved an art full of sap and zest; she was a subtle connoisseur, a royal patron! Delight in beautiful things was so natural to her that she counted on transmitting the taste to her daughter. And she was accomplished in philosophy; she read Plato, a first step which some of the most confirmed lady platonists neglected. But she was persuaded that the period of struggle was only opening for women, and that they must arm themselves to maintain the fight. She had no bent towards German utilitarianism-she could not have contented herself with the studies Luther sanctioned, nor with the elementary programme of virtue which Calvin found all-sufficient: at the same time, she had no greater confidence in the idealism of Rome. The world was not yet perfect enough! She joyfully bailed the dawn, but did not believe that the day was yet fully come. Women must not be content with a dilettante reliance on impressions; they must make what they love an object of thought, and having formed their reasoned conception, must seek to realise it. For them to be queens would be admirable indeed; but for the present it is enough for them to escape crushing. What they need is will, and, as a consequence, intellect and individuality.

This was a clear enough scheme of life. In Spain the same ideas obtained so striking a success that people were not satisfied with the compromise devised by Anne of France, and with this wholly moral education which would leave the daughter for a few short years to her mother. Circumstances were urgent; there was no time to waste; ideas were at boiling-point: a part of the ancient principles, the physical and moral repose recommended by the physicians, was sacrificed, and the children were flung headlong into the whirlpool. Little girls sucked in Latin with their mother's milk; then, the soul being expropriated, so to speak, for the public good, they were given a tutor at an age when they ought to have been learning nothing but how to walk; at seven they were expected to be able to 
maintain a conversation, and at thirteen to have finished their studies and be ripe for matrimony.

This programme, so vigorous that at first blush one would be tempted to think it a mere figment of the imagination, was not only propounded but largely practised by one of the most conspicuous men of the time-Vivès, the tutor of Isabella the Catholic's daughters. Vivès went to England in the train of Catherine of Aragon, and in that country of matter-of-fact aspirations he could still have believed himself in Spain, so successful was he in rousing the same fire and enthusiasm for his ideas. His fervour led to a revolution, or rather, as Erasmus said with a smile, to a "topsyturvydom" in high society; the men, who continued to scour the seas and do business in great waters, fell quite to the rear, while the young ladies, stepping to the front, engaged with a brisk rivalry in marvellous exhibitions of precocity. At thirteen, Lady Jane Grey read Plato in the original, and Mary Stuart delivered in public her first Latin speech; at fourteen, Queen Elizabeth translated a work by Margaret of France, The Mirror of the Sinful Soul. These wonderfully clever children were not confined to any particular country, and the same breeze fanned the same flame from John o' Groats to Gibraltar. Saint Theresa, who was born in 1515, is an excellent type of her contemporaries. Bereft of her mother, and one of a family of twelve, she was certainly not the object of any special training, but kept pace with girls of her age; yet at six years she was already, to use her own expression, "swept away by a violent movement of love," and had to be prevented from hurrying to Africa in the hope of being massacred and winning heaven cheaply. What singular girls!

The thing that urged them on was the general fear in which the husband was held, the pressing need of attaining, ere it was too late, a good condition of defence and even of superiority. The rising spectre of marriage fascinated teacher and taught alike. At ten years of age, to tell the truth, such personages as Anne of France and Margaret of France had already disposed of their heart! so that to overwhelm them with work was believed the best way to protect them against themselves. "The craters of Etna, the forge of Vulcan, Vesuvius, Olympus cannot compare their fires to those of the temperament of a young girl 
inflamed by high feeding," cries Vivès. The more effectually to extinguish these flames Vivès reinforces the regimen of work with a course of cold water and a vegetable diet, and this he austerely names "the perpetual fast" of the Christian life; he proscribes dancing, and counts on serious studies to preserve them from vanity and to widen the scope of their intellectual activities. In short, while more sharply accentuating the scientific note than Anne of France, he has the same end in view. Like her, he is convineed, passionately convineed indeed, that it is right to set a straight course for marriage, having now only a halfhearted belief in the old ideal of virginity : he has, further, so rooted a horror of vain sentimentalities, affectations, romances, poetry, all sensibility real or affected, that he throws overboard Italian and French for his pupils: he wishes them to have wills and energies of their own. But like a true Spaniard, an enthusiast and yet a Stoic, he loves these warm, ardent natures. $\mathrm{He}$ is a little like that lordjustice who in his official tone interrupted a too pertinacious advocate, but under his breath bade him continue. $\mathrm{He}$ shrinks from the flames, but sees in them the instrument of regeneration. These little girls of thirteen, inured to the reading of Scripture, tricked out with history and ethics, with Xenophon and Seneca, he sends forth to the conquest of the world, to fulfil their vocation as women. He hopes that their initiation into Biblical exegesis will lead them to construct a philosophical religion for themselves, and that they will attain a rational appreciation of Catholicism as the source of justice and knowledge, and the sole panacea for society. That is the gist of his preaching to the daughters of Isabella the Catholic. Did Luther himself probe nearer the heart of the matter, or outline a scheme more novel and more magnificent?

Let us complete our portrait of Vivès, and at the same time that of many a young woman of the new generation, by adding that he by no means looked down on the practical knowledge of plain cooking, of domestic economy or the common medicines. It might be thought that he had no ardour but for the Bible, and there is no lack of ill-natured jesters who cast a stone at his Latinist ladies; ${ }^{1}$ whereas, on

1 " From a braying mule and a girl who speaks Latin, good Lord, deliver us." (Bouchot.) 
the contrary, he spoke up for the kitchen, though to the detriment of dress and dolls. "What," he cries, "is not a hand smutted with coal as good as a snow-white hand that is open to everyone?" It only needs a father or mother to fall ill, and he is perfectly happy, for then you will see his fair Latinist in neat white apron, bringing a cooling draught she herself has mixed, and bestowing one of those smiles for which one would gratefully gulp down a whole druggist's shop. Here, according to him, is the distinguishing mark of his system: a practically useful intelligence, and a physical as well as moral devotion.

The Italian school drew its inspiration much more directly from the need of the ideal; it rejected passion as full of peril and made mere sensibility its goal. But it too pretended to take its stand on conceptions of absolute truth, though more elementary ones; and these it did not represent as intellectual acquirements, because it regarded, not knowledge, but feeling and judgment, as the end a woman ought to set before her. The education dear to this school was above all an education of impressions and enthusiasm, in which scientific truth only came in to supply ballast and to prevent an exaggerated serenity, or an over-confidence in life. In its refinement and elegance this school preserved as it were an after perfume from the noble city of Rome, where fastidious and ceremonious prelates, gourmets but not cooks, let money flow into their pockets through immense spiritual aqueducts, and set about pouring it away again in perfect cascades of ostentation. Hands smutty with coal indeed! A lazzarone would blush at the thought! There are none but princesses in Italy.

Dolce, a supreme example of the Italian, took, for the formation of an Italian woman, the recognised elements : chastity, modesty, reserve, composure, and a regular study (this was to be particularly free, with no expurgation) of the classics and the church fathers $;^{1}$ and from all this he would fashion for you the sweetest creature imaginable.

${ }^{1}$ It was to an expert in high culture that Renée of France entrusted her daughters, in the persou of Olympia Morata, who was noted for the eloquent Latin and Greek discourses she delivered as a precocious child of thirteen. While still under fifteen, Olympia's pupils were sufficiently advanced to act a comedy of Terence before the pope. This education by means of the theatre was completed with serious readings in Ovid and Cicero, and the final polish was given by a Greek monk of known liberal views, Francesco Porto. There was no idleness or melancholy here. 
Idleness and melancholy were his two great foes: he had no hostility to love. What reason was there to abstain from carefully cultivating a young girl's capacity for loving, seeing that as a woman she would find in it her chief resource? To reject the thought of love, to avoid the very utterance of the word, and then, like Vivès, to rack your brains to create infinite derivatives, was, according to Dolce, a childish and an untrustworthy proceeding; it would be much better to face the ordeal frankly, and deaden its shocks beforehand by anointing oneself with the healing balm of platonic doctrine, by exhibiting, on the one hand, the body in its wretchedness, the vileness of earthly love, and on the other the beauty of love divine and pure. Women may fall through passion, but they can win salvation through sensibility, and therefore Dolce nourished them on the appropriate classics: Virgil, parts of Horace, Dante, Petrarch, Bembo, Sannazaro, ${ }^{1}$ and, more especially, Castiglione. To his opponents, however, this system seemed overventuresome; they reproached him with going half-way to meet danger, with putting into hands still weak the twoedged sword which so often wounds lustier hands. To this objection Dolce returned on behalf of the beautiful the same answer that Vivès made on behalf of the true. He was convinced that a liberal education was most surely calculated to form strong souls, citing in support of his contention Corinna and a thousand other old-world heroines rendered impeccable by culture, and, of his own time, the four daughters of queen Isabel, pupils of Vivès; all four, indeed, equally accomplished and yet equally unfortunate-but could anyone begrudge them their misfortunes?

Thus, according to Dolce, abstract or severe studies were not for girls: "vain and futile quackeries" he called them, which could only bring them in subjection to men. "All that is needed is to awaken and foster the faculties which are in women." To rule as with a rod of iron, women need only remain as they are, with the talents given them by nature. ${ }^{2}$ What is the good of teaching them, for example, the dates and the nice problems of history? They should be taught

${ }^{1}$ [An Italian poet, pupil of Pontanus (1488-1530). The Arcadia, his chief poem, ran into sixty editions.]

2 Montaigne (who, however, deduces from these premises altogether different conclusions). 
to read history, to derive from the accurate narrative of facts an impression of the poignant emotions and moral struggles which the historian necessarily indicates with a more or less light touch, and then, linking these events together in their minds, to get at the heart of them, deduce the lofty moral principles controlling them. In philosophy they have no need of great metaphysical principles; but what is important for them is to understand that misery exists, that there is suffering everywhere, often hidden away and yet only too real. Woman is a fellow-worker with God! It suffices to lop off the thorns which cumber her; she will shoot up naturally towards the light, sucking, like a flower, the earth's sap, which is love. The corn which is to go to the mill and make bread needs the plough's rude toil, a lovely delicate flower often asks no more than a handful of earth and a bountiful sky.

And it was in this way that so many sweet Italian women blossomed out, almost spontaneously, delighting in life, themselves the joy and felicity of the world, all compact of poetry, archaeology, rhetoric, and philosophy-Attic through and through at thirteen years. The efflorescence was universal save at Venice, a country half-Germanic, halfOriental, where they insisted on keeping the girls immured until their wedding-day, showing nothing of them but bundles of millinery on Sundays. And yet there do not appear to have been more angels at Venice than elsewhere, and no one succeeded there in resuscitating the type (henceforth unknown) of matrons hypnotised, as it were, by their husbands' frown or the idea of death. Italy was peopled with fairy-like creatures, who thought nobly of all men and wore to admiration the double ornament of fine jewels and a fine intellect. "A little girl," said Bembo, "ought to learn Latin: it puts the finishing touch to her charms."

Louise of Savoy brought up her daughter Margaret according to these Italian principles at a period when France as yet did not uuderstand them. Margaret blossomed like a flower: she knew something of everything (too much indeed), notably of philosophy and theology: she learnt Latin, Hebrew, Italian, and Spanish; but she could speak nothing but French.

At nine years of age, she was wonderfully clever and 
accomplished; at thirteen, she inspired so much admiration as to be considered "rather Persian than French."

The defects of the system were not at once perceived, though these were developing in women a thirst like that of Tantalus, exciting a state of restless agitation and nervousness, which the old doctors of Gerson's school professed to guard against and which Vivès fancied he had avoided by directing their activity towards a definite end. People were struck only with the immediate advantages. Erasmus uttered heart-rending plaints about the little girls he was ever meeting in the Low Countries, poor ignorant little creatures, thick-lipped, podgy, stuck on high heels so as to appear grown-up, over-dressed, rigged out with a load of ribbons and feathers, with all the airs of innocent little baggages: "I ask myself," he cries, "if these are dolls, or monkeys, or girls." How he would have liked to tear off all that flummery, and fill their beaks with a little Greek or French, or even a little Latin!

A simple fellow said to Margaret: "Men and women have different functions, but their virtues ought to be equal." He was making a mistake; the virtues of women ought to be superior.

But if women believe that it is their mission to rule instead of to obey, or, at any rate, that the obedience they owe has well-defined limits; if they are no longer the burden which a father used to get rid of as soon as possible, and which a husband received as his absolute property, body and soul; if they desire to count for something ; if marriage is regarded as the union of two persons equally free, as the close and not the commencement of education; if the wife is no longer the pupil of her husband, and it is considered better for her to come to him fully instructed : then a very natural consequence wil $l$ inevitably ensue, whatever may be thought or said : women will marry later, will insist on exercising a choice as men do, and on laying down their own conditions: they will in this way imagine that they have greater freedom and are probably making a better bargain, for they have become women of sense.

The fortunate discovery was made that Lycurgus, in the main, considered twenty years the best age for marriage: with the result that in the most aristocratic families, and 
those most swayed by tradition, they waited with the most perfect resignation until the seventeenth year, ${ }^{1}$ while ladies of exceptional courage held that it was "modern style" to marry much later. Margaret of France was not married till she was thirty-seven.

This reform, important as it was, did not end in making what we should regard as a happy girlhood possible.

However the Italian theory might wreathe life with roses and preserve a happy ignorance of physiological problems, it was not easy for a French girl to reach that point and retain this beautiful innocence, surrounded as she was by people who called a spade a spade, idealising things no more than in the days when she was married as soon as born.

Girlhood was not a delightful fiction which permits infinite hopes to be cherished, and keeps realities hidden; it was rather an apprenticeship; and after all, since the wife has a personal mission to accomplish in the world, which will consist, so to speak, in patching and renovating hearts that are rent, this apprenticeship seems as necessary to her as to a laundress or a dressmaker.

The art cannot be learnt more successfully than in maidenhood.

From the moment this was admitted, it is correct to say, girls received the same education as men: with this qualification, that their education was more thorough, because they made a later beginning in life.

In the first place, they had male teachers, or even a tutor. Margaret of France, like her brother, was taught only by tutors-a singular anomaly at a time when women plumed themselves on their superiority, and one which we shall not seek to explain. Humanists with the highest admiration for woman's intellect held governesses in horror, ${ }^{2}$ and allowed no discussion about the monopoly of instruction; even in Spain, the country of learned women, Vivès insisted on instruction by men.

And yet the market was not overstocked with women's tutors; the part usually fell to more or less second-rate

1 "Let us retard the age of marriage," cries M. Legouvé, "if we wish girls to exercise free choice and live free lives."

2 [Praeter naturam est, feminam in masculos habere imperium. (Erasmus.) "Tis against nature for a woman to have rule over males."] "I allow woman to learn ; to teach, never." (Bruno.) 
persons, who accepted it light-heartedly enough; even in princely houses there was considerable difficulty in keeping a man of real earnestness.

These young fellows readily transformed themselves into friends and comrades: Brantôme accuses them of a thousand irregularities, and goes so far as to match them with the physicians and apothecaries. Some of them were known, it appears, to elope with their pupils, but that we must believe to have been purely casual, and their gaiety to have taken, as a rule, a more delicate form. Eustorg de Beaulieu ${ }^{1}$ smilingly reminds one of his pupils, now a staid wife and mother at Tulle, of the time when she raved about her lessons, and said she would rather go to the clavecin than to confession. Another pupil of his, the young Helen Gondy of Lyons, called him in fun "her Hector," a title which he accepted on the distinct understanding that he was not stupidly to die for her, "like the other Hector." A third, Mademoiselle de Tournon, conceived the idea of making a bishop of this excellent, jovial, amiable professor; but this time Eustorg raised objections, and declared flatly that he was sure his skull was too thick.

And so Dolce's advice was followed; melancholy was banished. But I am not sure that very fine distinctions were drawn between the two kinds of love, or that the young masters possessed the delightful art of developing only the fancy and the softer qualities. In France and elsewhere, to all appearance, they rather treated their fair pupils in masculine fashion, with a fearless handling of ideas; that at least is the impression we get from Erasmus' dialogues, The Girl and the Lover, The Youth and the Courtesan. Brantôme taunts them with a certain tendency to make special use of the risky passages in the Bible and their authors for teaching theology and an elegant style.

In this way the young girls attained a perfect independence of mind. They cannot even be compared with the American girl of to-day, for the old hardy, somewhat wild French stock had undergone a wonderful grafting with Italian refinement. Many of them, having reached a certain age, pursued their studies with marvellous gusto; Petrarch and Erasmus they thought rather poor stuff, pre-

${ }^{1}$ [A poet of Lyons, who lived about the middle of the sixteenth century.] 
ferring to work at Poggio ${ }^{1}$ and Boccaccio. Their style of talk was intrepid! Ah! there was no standing on ceremony with them! Fun was fast and furious.

They devoured romances, novels and plays: these fine intrigues, these riotous passions seemed to them to constitute the ideal life. They were demi-vierges. "With all these lascivious romances, spotless virginity will be unknown."

To describe the indignation and grief of old-fashioned people at this sight is impossible. "I would rather see a girl deaf or blind," cries Vivès, "than thus overstimulated to pleasure." Of course it was pleaded that the artistic instincts were being satisfied! But all these romances bore but little likeness to the subtle analyses of our days, which are sometimes masterpieces of philosophy: they were a tissue of adventures all equally untrue to life. Vivès did not understand how, if only from the point of view of taste, girls of any intelligence could go into raptures over such extravagances: a knight who is left for dead, but comes to life on the next page; a hero who massacres a hundred foes single-handed; nor how they couId worship as a demi-god the author of such trash. He begs the mothers for pity's sake to interfere, to take the trouble to glance through a book before leaving it to their girls; but the mothers are accustomed to live their own life, and besides, a lady of fashion has so many occupations! He beseeches the preachers for help, waxing almost indignant when he hears them pompously stringing together their platitudes on dogma instead of boldly attacking questions of living interest and condemning books that are absurd or of evil tendency. But the preachers go on preaching.

Anne of France took a more dispassionate view : she saw clearly enough that girls ought sometimes to put aside the church fathers, if only for the pleasure of going back to them, and she did not despair of finding a practical solution of the difficulty. Her dream was a very simple one-the dream that recurs again and again and yet remains but a dream: namely, to have good romances for young girls, pure, high-toned stories, replete with the practical philosophy

1 [One of the most active of the Italian humanists (1380-1459). He brought many ancient Mss. to Rome, and translated Xenophon and other Greek writers. His conti are as obscene as some of Boccaccio's.] 
of life, and at the same time interesting, dramatic, thrilling. She has left us a specimen, somewhat archaic indeed, of what she desired : a historical romance founded on a passage in Froissart about an unfortunate captain of Brest, one M. du Chatel, whose son is, with flagrant bad faith, threatened with death by the English if he does not betray the town into their hands. This eminently patriotic subject is the groundwork of a little story, short, simple, illustrated with a tair number of pictures, and in every way innocuous. In the opening scene, Nadame du Chatel swoons; further on, however, it is she who, like a true woman, has all the strength of character, and cheers her trembling husband with words worthy of a Roman matron, or with magnificent appeals to the divine mercy, "although," as she says, "children are in a special sense the sons and daughters of their mothers." (How touching is this claim, interpolated quite incidentally!) So the story proceeds with alternations of strength and weakness. On coming to after a long swoon, the poor mother learns that her son is dead. "God's will be done!" she says, without a tear; "may our Lord receive his soul!" And then she goes and dons her mourning, and, as soon as she is alone, weeps!

And here, so please you, you have a story for young girls!

Unluckily, for a girl of eighteen or twenty life is no longer "such stuff as dreams are made on," and as a rule the romances, good or bad, are at last thrown into the shade by a certain practical romance in which she must needs play her part, and which demands her whole attention.

Not, assuredly, that all this led the young ladies to gild the pill or modify their first conception of marriage ; on the contrary, the more they considered the matter, the more they weighed, in as just a balance as men, the advantages against the disadvantages. Very often, princesses of the blood royal loved simple noblemen, or even men of lower rank: they never married them. It was too well known that love and marriage were two different terms, and that certain old books, preserved in the libraries, maintained the theory that married women, "possessing what maids seem o seek," should remain at home and never again exhikit themselves for the pleasure of others, or even for their own. Formerly a girl of ten years, repressed and secluded, could pieture marriage as a source of "liberty and pleasure"; and 


\section{THE WOMEN OF THE RENAISSANCE}

these blessings once secured are sedulously guarded. You must be grateful to men for giving you their name and fortune, of course ; but some men are so odd! It is impossible to take too many precautions. Many an excellent young man, pleasant enough to all appearance, may turn out an insufferable husband.

And so it was with mingled prudence and dilettantism that these fair sixteenth-century Americans set out in quest of the Golden Fleece. Little hampered by parents who thought their whole duty was done when they paid over the dowry, they learnt how pleasant it was to take life into their own hands, to show themselves in society, to talk, laugh, dance, frolic-live, in a word, without a by-yourleave to anyone. And yet the Latin delicacy and grace betray themselves in various prejudices: to practise archery, to pad themselves for a pass with the foils, or merely to have their photographs taken as naiads-these resources were not yet open to them! The poor things could only triumph by their charm and enthusiasm, quite in the Latin way, at the risk of rubbing off a little of their bloom here and there.

Outcries came from the dowagers: What! throw themselves at men's heads in that way! how scandalous! and how silly! Do they think then that men are so stupid as not to consider serious qualities? For their amusement indeed they like the coming-on disposition, but not for marriage : it is Cinderella that attracts Prince Charming. Anne of France cites an illustration in point: three young Germans of the highest distinction arrived one day from the heart of their distant wilds with the sole object of wedding the three maids of Poitiers, of whom marvellous tales were told. It was a terrible shock when they found themselves each face to face with his own fair damsel. The first had so squeezed her waist that she well-nigh fell inanimate into the arms of her wooer, who was thoroughly put out; the second chattered like a very magpie; the third rather naively displayed a sentimentality in the latest mode; and the upshot was that, with never a word to one another, the three Germans were soon stride for stride footing it back to Germany. And Anne's conclusion is very reasonable: "Would it not have been better to cultivate a staider manner?" 
But it remained to be proved whether a staider manner would be right after all, and whether a princess, of however high descent, could indulge in the luxury of waiting at the chimney-corner until the man of her dreams was pleased to appear. Unhappily the contrary was the general belief. Someone has remarked that if men do not often marry the girl who pleases them, they do not always marry the girl who displeases them. And that is just the reason flirtation held its own.

The art of flirting is a very subtle one, and yet it is incredible how little time was required to bring it to perfection. Everybody had to do with it: even princesses wanted to fancy that they chose their husbands.

The young girl "came out" into the world in two ways. If she had no mother, or her parents found it convenient to separate themselves from her, there was in France a patriarchal custom, peculiar to that country, which consisted in the girl's entering the service of a "dame" or "demoiselle" of good repute. So highly was this custom esteemed, that Anne of France recommended her daughter to conform to it should occasion arise, although the heiress of the duchy of Bourbon had certainly no need of entering anyone's service to push her way in the world.

Anne herself, and Anne of Britanny, thus kept "schools of manners"- a sort of fashionable boarding-school, where the young men never addressed the girls but on bended knee in the ancient style, and where the somewhat cloistral austerity seemed mitigated by the belief that so excellent a place and so well guaranteed a virtue could not fail to tempt the most fastidious husbands. But this institution, intended to serve as a bulwark against the new manners, floated along, on the contrary, in their current: Catherine de' Medici's "flying squadron," as it was called, completely lost the character of a boarding-school, and discharged its functions with freelance recklessness.

For the most part, it was at her mother's side that a girl set off in quest of a husband. The plan of operations varied so greatly that no one will expect us to unravel its principles. All these young girls matched one another in chic. They never spoke to their mothers without bleating "Madame ma mère," or lisping "By your favour, madam," like so many well-behaved silly sheep. Many of them were for 


\section{THE WOMEN OF THE RENAISSANCE}

ever showing their teeth: they had a laugh for anythinga phrase, a fly, a gentleman with a bald head. One laughing sent the others into fits too, and that was thought remarkably witty. They were experts in the "sedate management of their green-blue eyes, full of softness and opened neither too little nor too much." They wore lovely dresses-monumental robes which yet seemed rather an accompaniment than a vesture for their limbs. Some old folk (Vivès, for example) professed horror at their ring-loaded fingers, their pierced ears (a barbarous custom, to be sure!), those light, delicate touches of the brush with which they did up the face, and those subtle perfumes wafted from no one knows where: in all this they saw woful error, and even worse, rank folly. They sharply reprimanded the mothers, reproaching them for a multitude of things: for withering the natural goodness and charitableness of their daughter's by fostering expensive habits; for inciting them to a false luxury, all vulgarity and tinsel, which is neither comely nor virtuous, and helps not a whit towards matrimonyat least it is to be hoped so, for it would be a great imprudence to depart so far from reality, and to entice a man into marriage by means of the rouge-pot and sham charms. $^{1}$

But materfamilias is a lady of fashion, accustomed to shine in society, and seeing no harm in it; further, she is too good a mother not to desire success for her offspring, not to applaud a venturesome flight. She, too, has dreams of a Prince Charming; she has her enthusiasms, which take clear and definite shape in her mind as positive hopes. As for the father, he becomes cantankerous, and considers only, the expense of the game; he is quite of the dowagers' opinion, and thinks well enough of men to believe that they

${ }^{1} \mathrm{Nil}$ est simplicitate prius.

Haec placet; hand ulla est quiesitae gratia formae, Quae studio pecas, simplicitate places,

Nulla est ornandi, nulla est, mili i crede, parandi Gloria, naturae est forma, nec artis opus ;

Ars odio digna est, ubi nullo fine tenetur.

(Pontanus, De amore conjugali.)

[" Nothing comes before simplicity. That is pleasing; there is no grace in artificial beauty. By artifice thou wilt err, by simplicity thou wilt please. There is no glory in adornment, none, believe me, in farding oneself ; beauty is the work of nature, not of art. Art is hateful when not kept within bounds."] 
pay most attention to serious qualities. And so, in order to compose once for all this perpetual domestic wrangle, a great wag, Coquillart, ${ }^{1}$ proposes to clothe the girls in parti-coloured dresses, one colour for the father, another for the mother.

When a girl makes a successful start, certain mothers are seized with a sort of fanaticism; we are wrong in calling it fanaticism : it is really a new outburst of good-heartedness and the passion for self-sacrifice of which women are possessed, for, if they reflected, they would clearly realise that personally they have nothing to gain by a brilliant match for their daughters.

Some of them push self-sacrifice to the point of servility; they efface themselves, walk in the rear, with the meek and deprecating bearing of a waiting-maid. That is a form of goodness which the women of former days would not have understood-Anne of France choked at the mere mention of it. She had commanded armies, bearded diplomatists, made men her puppets, checkmated her judges, manipulated her States-general, set her whole country in a ferment without a sign of feeling: but here she lost command of herself: "It is tomfoolery . . . it is overweening presumption in the daughter, and in the mother sheer madness."

Kisses, caresses, secret trysts, presents, love-letters, showers of rondeaus and ballads, stolen glances, songs more than gay-all this made French flirtation an exquisite pastime, essentially intoxicating in its charm. The good, modest young damsel, who would cast down her eyes in the street, was not a whit shocked at a pretty broad jest in the company of men:

Aucunes sont, qui, en humbles manieres,

Avec les folz jouent leurs jarretières. ${ }^{2}$

- Bouchet.

In the evening by candle-light, ensconced in some nook of the spacious fire-place, young men and girls would sit unceremoniously on one another's knees, laughing and talking nonsense. People who have got past these maidenly frolics themselves find it more and more difficult to become recon-

${ }^{1}$ [A vigorous and witty social satirist (1421-1510).]

${ }^{2}$ [Some maidens, in their modest way,

With fools their garters stake at play.] 
ciled to them. Jean Bouchet feelingly describes them in his book, Les Regnars traversant les voies périlleuses, at a period when the art was still in its infancy. Young men easily get absolution: they naturally profit by opportunities of amusing themselves; and, besides, theirs is the passive part. But the girls! how venturesome they are, how light-heartedly they chip, at least in spirit, the poor remnant of their semivirginity!

It would be a mistake to suppose that flirtation will in time lead to the introduction of the love element into marriage. These damsels are by no means anxious to allow the principle of earthly love-that is to say, a germ of divorce - to steal into their married life. Their ideal consists in falling in love with a man of wealth and established position, and so far it has a reassuring character, worthy of respect. At this stage of their life they are working for themselves, as later they will have to work for humanity. M. Bourget has discovered in America the different varieties of the sixteenth-century flirt: the professional beauty; the girl of ideas, who stumps a platform and stands for the parish council; the "jolly good fellow"; the girl of well-balanced philosophical mind; the coquette; the girl of ambitions ; all are ambitious and to some extent coquettish, and even the philosophical girl gives the ideal only a secondary place.

But amid this charming round of coquetting and artless sensibility, passion sometimes flashes out-passion, at once the great peril of the Latin races and their eternal charm. One may be convinced that the heart has been subdued by cold calculation, and that love is laid under a spell by means of philosophy; but they burst their bonds! And here the parts are not distributed as one would wish: this generation is about to inflict a wound on platonism! Often it is the wife who, instead of serving as an idol, gives herself to love. In the terrible veins of French and Spanish women there flows a blood which they do not always succeed in mastering, the old blood of knights or peasants; they bruise themselves against the invisible mail-armour of modern life.

In the second act you would almost invariably see the serving-maid appear on the scene-the "confidante" of the plays, a good soul, as indulgent to everyone as she is to herself, devoted, and not more thick-headed than becomes 
her, thoroughly convinced that she has something to gain from every intrigue. The mother has her own affairs and her dignity to attend to, which keeps her in ignorance of what is going on; whilst with the maid there are private conversations, mutual unbosomings, a companionship in study of the facts of life. Lucky, indeed, if some smart lackey, let in on the strength of his ingenuous manner, does not put in his word!

Saint Theresa thus plunged with masterful strokes into the swirling tide of existence, with the aid of a servingmaid, at the age of fifteen. Her father placed her in a convent, but the walls were no barrier to her: she performed unheard-of feats, broke through the roof, wrenched away the gratings. She had to be despatched to a more reposeful situation-to an uncle stuffed with the fathers of the church, a man after Vivès' own heart; from his care she returned with a passion for religion, and escaped once more, this time to enter a Carmelite convent in the teeth of opposition. She was now in her nineteenth year, and her trials, repentances, revolts were only just beginning; eighteen more years of struggle were required ere this tempestuous character was at last soothed definitively into mildness.

Unhappily, the girls' little love affairs sometimes had graver consequences. Plays and novels show us situations awkward enough: in one of Parabosco's comedies, the mother arrives a little behind the fair.

Laughing, boisterous, pitch-forked into life, the poor children do not pretend to have the ferocious virtues that men have not.1 Is that their fault, since they have been brought up like men? If they go wrong, it is not from a bent towards wrong; it is as the birdling errs, buffeted by the storm on its first escape from the nest. To avoid risk altogether, they would have to remain for ever under the mother's wing, as the early educators wished.

In the sixteenth century, there were still good people who wished girls to become deaf-mutes again, and constitute Our Lady "the guardian and warder of their hearts." But such talk was not very effective.

Wise counsellors and practical preachers who advocated "retreats," and knew the world, addressed themselves

${ }^{1}$ Nifo sincerely admires princesses who go to their husbands virgines intactae. 


\section{THE WOMEN OF THE RENAISSANCE}

directly to the girls and sought to touch the chord of selfinterest. The grave Jean Raulin, ${ }^{1}$ from the eminence of one of the most fashionable pulpits in Paris, reasoned with them somewhat as follows: "To wed a widow, well and good! There is no fuss, no golden ring, no benediction, but withal it is a marriage: whilst with a counterfeit young maid presenting herself at the altar-! Ah! fair ladies, guard your purity to the very hour of your espousals, whether you be earthly or spiritual brides! That is the precious treasure you must at all costs save, and for many reasons : because of human frailty, according to the words of the 2nd Epistle to the Corinthians, "We have our treasure in earthen vessels'; because of its inestimable value, according to the words of Ecclesiasticus, chapter xxvi., 'There is no price worthy of a continent soul'; because of the irreparability of the mischief, according to the words of St. Jerome, 'God can do all things save restore a lost virginity.'

Many could not help regretting the free country life, and fancied that fidelity to a more rigorous system of education would have yielded better results. Of a truth it would have been better to make women frank creatures of passion than coquettes or mere worldlings. But an honest glance at the life of rural folk was enough to assure the observer that utilitarianism does not elevate the manners. Yes, seen from a distance, the ways of country folk seem compact of smiles and caresses, love and candour: pigs and cows meet in the meadow or at the fair; lovers too meet, at church, at a dance, after those winter parties so hotly denounced by the preachers, nay, every morning and evening if their hearts bid them; and they can exchange little presents, meet to scrape the fiddle or twang the guitar, without anyone finding fault, save perhaps a rival with whom they are quits for a few rounds at fisticuffs, or at most a thrust with a knife. A fashionable young girl, you may be sure, would not be horrified at the exchange of a few good swashing blows for her; she is apt to regard life as too tame. It remains to discover whether to reduce life to its primitive simplicity is really to elevate it. The idealists thought not.

${ }^{1}$ [A doctor of the Sorbonne and a Dominican (1443-1514). In one of his sermons occurs the story of the church bells, repeated by Rabelais à propos of the marriage of Panurge.] 


\section{CHAPTER V}

\section{THE HUSBAND AND THE VARIOUS WAYS OF SLIPPING HIS YOKE}

THE most troublesome question to be settled in regard to feminism is that of the authority of the husband. Legally, the husband was head of the household, an idea which found ready acceptance among the lower ranks of society, and which the people applied with its habitual logic. It won warm approval from Rabelais. Nothing struck men as more grotesque than a husband suspected of having allowed his wife to get the upper hand. An artisan of Bourges, at whom some unpleasant neighbours hummed a refrain about a woman who thrashed her husband, on that ground alone brought against them an action for slander.

In all sincerity, the husband considered himself an absolute owner, the lord and master, the head and soul of his wife, that "feminine and feeble creature" whom he condescended to take to his hearth, and who owed him, in the name of God and the law, "perfect love and obedience." As to the wife, she was, so to speak, stepping into a railway train driven without her assistance. She had paid her fare, and wedlock stretched itself rigidly in front of her like the driver's footboard, a place for manliness and nerve, but unromantic in the extreme. What matters to her the scenery along the line? The rippling sea may chant its amorous strains, the spring sun may dot the wilds with flowers, the tempest may sweep through the gorges, but the track stretches on and on in its direct unswerving course, with never a thrill, never a smile, unfaltering, unreflecting, mathematically.

What was the wife but the principal servant, or the eldest 
of the children? She only addressed her master with the most profound respect. "Sir," she would say to him, or "My good frieud." She was his "wife and subject"; if she wrote to him she signed, "your humble obedient handmaid and friend." But her husband spoke to her stick in hand.

The stick! that was the only argument the women understood.

Bon cheval, mauvais cheval, veut l'esperon, Bonne femme, mauvaise femme, veut le baston. ${ }^{1}$

Preachers spoke of the thrashings with a smile. Needless to say, the police did not interfere. Margaret of France did indeed think it a little vexatious that a lady honoured with the king's attentions like the beautiful Madame de Chateaubriand should still receive correction of this sort under her husband's roof-tree.

But this was not all: the authority of the husband was often coupled with the tyranny of the mother-in-law. The husband's mother, especially if she was a widow, rendered life horribly galling and difficult.

On the other hand, the married woman, no matter to what lengths her husband might carry his ill-usage, knew well that there was no redress for her anywhere. Unhappy wives sometimes in the madness of despair fled from their homes in the most shocking plight, only to be remorselessly dragged back by their father, brother, or cousins, as a result of the appalling freemasonry between men. To rely on her own nother was out of the question for a wife; the two women belonged to two distinct houses, with a barrier, a great gulf fixed between them. In the early days of wedlock a husband, not to appear a tyrant, and because he was in no way inconvenienced, would allow his wife now and then to visit her mother; but he contrived that these visits became gradually rarer, and when he was not at home, a wife careful of her repose and dignity would never cross her mother's threshold without first writing to him: "If it be your good pleasure, I would fain go."

That was a woman's life. As it was not all smiles and rosewater, there was good reason for marrying the girls off early, before they had learned to care one way or another, 
their equipment being a few simple maxims inculcating obedience, and some odds and ends of medical knowledge. Wives who owed their training to Vives could not but be very unhappy, according to the principles of marriage held by Vivès himself. For Vivès not merely approved of early marriages, he was also one of those who believed that the wife was created for the husband, and an irresponsible and inferior being; he looked at the husband as someone to bring her out. Erasmus, Bouchet, Dolce himself, nay, everybody had much the same impression.

The supremacy of the husband was the sacred ark; bold indeed would be the person who dared lift a hand to it! So in modern times we have seen aesthetes, like Ruskin, capable of every possible audacity but that. Ruskin does not understand women, and yet he has gone out of his way to exalt their rôle in the world; but, as soon as he comes face to face with the husband, he loses countenance, his candour vanishes, his words become cold and colourless.

How is one to explain this singular phenomenon, that so many good and even generous-minded men, after expressing a heart-felt sympathy with the sufferings of women, after proclaiming their intelligence and their right to live, falter and hide their heads when the question of liberty at home is raised? It is not because they believe there is no more to be said. La Rochefoucauld declares that "there are few "good wives but are tired of their calling," to which it would be easy to reply, "There are few good wives whose calling is not tiring." But what is to be done? No one is inclined to go like Plato to the root of the matter and suppress marriage altogether. Marriage obviously necessitates a husband; it is a vexatious, clogging, disagreeable necessity, maybe, but there are no visible means of escaping it. A wife too is necessary; well, once a man and woman are united in wedlock, one of the two must needs hold the reins. There are many reasons, even physical ones, why a woman should not undertake to earn bread for the family and to flog the husband. And so the husband retains that right.

But if we go a little deeper into the psychology of domestic life in the sixteenth century, we shall note other important phenomena, pointing to a different conclusion.

To begin with, investigating facts from the outside, who was it that complained of marriage? The man; always the 
man. In actual working the woman found compensations, or at least advantages in it. For her it was a state leading to boundless possibilities if only she cared to open the door. The more ardent paladins of feminism, indeed, were often disconcerted by her outwardly conciliatory attitude towards it. But the husband, married though he was, could not forget that setting up an establishment had involved the turning his back upon life. His chains appeared to him, if not heavy (to him they were not heavy), at any rate the sign of a monotonous, unvarying servitude. In the words of an old ballad, the monk may change his order, the canon his stall, the official his functions,

But we that be poor married men Can neither go up nor down.

If we enquire of the spouses themselves, we find that the disagreements and difficulties rarely sprang from the larger facts-those that were regarded as irreparable.

Heaven seems to have taken care to arm us, in regard to important questions, with a veritable long-suffering. There are fools, it is true, who seriously think of keeping their wives under lock and key, not reflecting that no better means could be devised for making them desperate and leaving them at the mercy of Tom, Dick or Harry-the first passing officer. Such men only get their deserts. But there are also shrewd men who keep their eyes shut to what it is best not to see: everybody advises them to do so, or, what is better, gives them every assistance. There must be a special providence, even, watching over the wives. ${ }^{1}$ A wite, on the contrary, can hardly remain in ignorance of her husband's laxities, for these most often manifest themselves in the broad daylight, and sometimes under his own roof. Many stories might be told about chambermaids such as we read of in Scripture, but a little too mercenary, to be sure: for the courts showed so much generosity in assessing the damages due in such circumstances that artless

${ }^{1}$ In the long run the best things become wearisome: men at last believe they are sacriticing themselves. "Christ died only once for His church ; we die every day for our wives," is the heartfelt cry of a husband; to which a lady retorts: "Go to the wars, then, and lie for a month on the bare ground; and you won't be sorry to get back to your good bed! Men only appreciate their comforts when they've lost them." (Heptameron, Tale 54.) 
little Chloes have been known to bamboozle the judges and profit handsomely by a mishap that was wholly imaginary.

In Italy, men of the world had a sure and simple custom, which consisted merely in buying a young slave-girl. In the market of Venice, a pretty Russian, a fair Circassian, a well-built Tartar girl between twenty-five and thirty years of age would fetch from six to eighty-seven ducats. It needs no showing how well this institution was suited to platonism; the most eminent platonists did not disdain it. The mother of Carlo de' Medici was a lovely Circassian girl, purchased in this way by the grave and aesthetic Cosimo. It would never have occurred to a wife to desert her home for such a grievance as this; to do so would have made her a general laughing-stock. She might feel keen inward suffering; perhaps her heart would close a little more towards the earth and open out towards heaven; but this experience would be of use to her, and a woman who was genuinely an idealist would almost rejoice at it. It would teach her to show a firm and lofty front to the world, to live among her ideals, to form a low estimate of men.

Domestic quarrels really spring from the crabbed sour virtues, the insufferable respectabilities. Men are hard to please. One moment they find a wife in the way; the next they expect her to be perfect. She ought every morning, as an old author explains, to put on the slippers of humility, the shift of decorum, the corset of chastity, the garters of steadfastness, the pins of patience, and so on; but it is by no means proved that in such a case a husband would not think his wife a little over-dressed.

The wife, too, is up in arms about mere trifles-her husband's commonplace soul, his narrowness, his materialism, his egotism, his gross old-bachelor ways. Her real grievances, to say nothing of her fancied ones, are innumerable. One woman finds, instead of the "morning dew" of her dreams, that she has espoused a lumpish lout.. ${ }^{1}$ Another,

1 Femme bonne qui a mauvais mari

A souvent le cœur marry.

Femme aime tant comme elle peut,

Et homme comme il veut.

-L. de Lincy.

[A good woman with a bad husband has often a sore heart. . . . Woman loves as much as she can; man as much as he will.] 


\section{THE WOMEN OF THE RENAISSANCE.}

brought up in a part of the country where hunting was the stock topic of conversation, feels aggrieved if her husband tries to engage her practical interest in literature or music, the result of which is so complete a discord that the husband at last packs her off to her father, who promptly sends her back again. Another lady is wretched because her good man loses his appetite, and in bed does nothing but sigh; on this foundation she builds a whole world of suppositions, and finishes by making life impossible to the poor man, who is all the time at a loss to know why : as a matter of fact, he has been worried about an investment. There are some women odious because of their incessant chattering, their tempers, their vanity. Many women are desperately fond of contradicting their husbands, tormenting them with pin-pricks. At table a husband inadvertently poured water into his wife's glass. The lady handed the glass to a footman, saying hotly: "When it is dry, I will ask for it back." 1 These are the things which destroy domestic happiness, which poison a man's life ("wine and women have their poison," says an old proverb), which disgust and shrivel the heart of a woman and drive her to a life away from her home, in pilgrimages or what not. A man does not need to be a saint to bear with a woman of easy virtue, but only a saint can endure a wearing woman.

And so what is wanted in domestic life is a great deal of prudence and wisdom, and as little as possible of illusions and passion. Marriage is the most sacred bond in the world, but only so long as it is not strained. To yield to the temptation of loving would be fraught with great peril ; that is the forbidden fruit. Champier, a philosophical physician of the time, calls it fatal : it kills. Leaving out of account the physical vicissitudes of life, the spirit of man is too fickle to permit him safely to stake his life on one head. $^{2}$ Of this, Europe had a terrifying proof.

Philip the Fair was a notorious lady-killer; and his wife Joanna, like a genuine Spaniard, loved him to distraction. On one occasion when he was travelling in the Netherlands,

1 A woman, irritated at her husband reading in bed, calls out to the servant: "Ah well! Bring me my distaff!" (Billon, Le Fort inexpugnable de l'honneur du sexe féminin).

2 " He who loves not him by whom he is loved is regarded as a homicide, and not merely a homicide, but a committer of sacrilege and a thief." (Champier, De vraye imour). 
she worried herself into a sort of prostration. One wild, bitter night, as November nights are in Navarre, this poor Joanna, seized with a sudden hallucination, rushed out halfclad into the courtyard of the castle of Medina del Campo. People hurried up to her, and the governor stopped her and ordered the gate to be shut; but the unhappy woman, her eyes starting from her head, clung to the gate, and no human strength could tear her away. When morning came she was still there, panting and shivering, with wild, sunken eyes. Her mother, Queen Isabella, who was lying ill at Segovia, despatched an admiral and an archbishop in hot haste to the castle, but neither the archbishop nor the admiral succeeded in getting the poor mad thing away from her gate. They only managed, with great difficulty, to induce her to enter an adjacent shelter for the following night. Only the Queen was able to put an end to this distressing scene, the memory of which thrills Spain to this day. Yes, La Bruyère has well said: "Women go to extremes! They are better or worse than we." There lies their danger. They would assuredly do well to beware of their ecstasies, and to keep above or below the husband with whom it is their lot to live.

If they are reasonable and resigned, like those of whom we have to speak, not believing in the necessity of a matrimonial passion, then the humanists resume their dulcet strains. They have no intention of bringing about a violent rupture, but make their appeal to finesse.

The old type of the hectoring husband, even with his bludgeon, is no longer a terror. No one is so likely to play a puppet's part as the man who fancies he is monarch of all he surveys. The foolish fellow is so convinced of his superiority that he never perceives the slender cords by which he is led. He works like an ox, ${ }^{1}$ and his wife calls him a selfish beast and curmudgeon. She croaks of the

\footnotetext{
${ }^{1}$ Il se commence à soucyer

Et à chagrin s'associer.

Il plaint la teste, puis les dents,

Et a les oreilles pendans

Ne plus ne moins comme un lymier.

[Hc begins to fume and fret, $-R$. de Collerye.

Becomes sworn brother to regret;

Headache, toothache he bemoans,

Chapfallen he sighs and groans.]
} 
workhouse if things are not going well with him, while if everything is going smoothly she "cockers and cossets him," and then gets, not a beating, but a dress or a blouse. She has tears or smiles as occasion serves, and, if need be, practises her blaudishments on the friends of the dear man. She wheedles even Heaven itself, for all that is required to ensure peace is to bring the shirt that her lord and master is to wear on Sunday into contact with the altar during Friday's mass, and there is no difficulty in that. It is commonly said that "a woman is easy to manage provided 'tis a man that takes the trouble"; a man is still easier to manage provided a woman is good enough to take him in hand. In short, the women had long before this quietly juggled away this harassing domestic problem. That is why, despite the bogey of principles, the women thought highly of marriage. They reconciled themselves to obedience, so long as they did not obey. For the same reason the warmest friends of women found no better means of combating marriage than to defend it. The men alone girded at it, because, accustomed in their bachelor days to eat their own cake, they did not easily get into the habit of working for a little community.

Erasmus has very cleverly summed up the situation in the form of a dialogue between a young bride and a matron of sense and sobriety. ${ }^{1}$

The former makes loud outcry. "What a hell is marriage!" she exclaims, "what a slave's business! And for whom, ye gods! For a gambler, a brute, a rake! 'Twould be better far to sleep with a pig!"

The other soothes her. She must take her husband as she finds him, that is to say, a coarse animal, a sort of elephant, to be tamed with a lump of sugar. ${ }^{2}$ She must appear to give in to him about trifles, to put up with some of his whims and eccentricities, and above all to lay in a large stock of good temper and never be idle or dull, for the husband has a perfect horror of being bored, perhaps because he is such a

\section{${ }^{1}$ Dialogus de matrimonia.}

2 " You have been to seek a little school-miss, an angel who dared not lift her eyes, and who to all appearance was candour to the finger-tips. . . . She was thinking things over : she was enticing you into her trap, because your rank and fortune suited her, but determined at the bottom of her soul to give you a 'combing 'later: she says in confidence to her friends, ' randy steeds need breaking in '." (Jean d'Ivry: Les Secretz et Loix de mariage). 
bore himself, and sulkiness upsets him, especially if he is sulky. What she must do is to leave him what he has, and give him what he lacks, those charming possessions with which the new system of civilisation has endowed women. She may even add a little affection, and then, one fine day, she will be struck with astonishment (for men do not shine at finesse) to see this rough husband of hers at her feet, and, instead of considering her a nonentity, taking her for the image of God. From that moment she possesses the affection she has sought; and the task is not very difficult.

Truth compels us to add, however, that, apart from this moral recipe, another circumstance contributed to give the women greater importance in conjugal life. In France, as in every country where men are the ruling spirits, they were not fond of giving the girls a dowry, or at all events they gave them the smallest possible allowance. When the girls married, they received a sum representing in a way what would some years before have been called their "night-cap," but what was then styled a "chaplet of roses," and they renounced all claim on the inheritance. Accordingly a rich man did not think it at all extraordinary to wed a girl without a fortune, since that was the usual thing. Louis de la Trémoille married Gabrielle de Bourbon on those terms. Further, there was not the same difference between large, middling and small fortunes as there is to-day. With an income of three or four thousand livres, equal to $£ 3000$ or $£ 4000$ to-day, a man was thought a nabob. The husband, then, brought the money, and in addition he guaranteed a contingent jointure on his own property, so that it was really a home of his providing that the woman entered. A man in those days knew nothing of that pride now universally felt in wedding a millionaire's daughter from Cincinnati, or even from Paris.

To marry money struck people as shameful, alınost infamous. A husband supported on his wife's income was the object of heartfelt commiseration, and an establishment so organised seemed unworthy of the name. No sarcasm was keenenough for the classical "son-in-law of Monsieur Poirier,"1

${ }^{1}$ [Title of a brilliant comedy by Emile Augier and Jules Sandeau, produced in 1854. M. Poirier is a wealthy retired cloth merchant who has married his daughter to a spendthrift marquis in the hope of getting a peerage through his influence.] 


\section{THE WOMEN OF THE RENAISSANCE}

the dapper lordling, all genealogy and sport, whose sole accomplishment is a knack of plunging deep into debt, from which his worthy father-in-law (who made his money in treacle) toils behind the scenes to extricate him.

On the contrary, Monsieur Poirier was highly esteemed in industrial countries-the Low Countries, for example, while as to the Italians, they, openly and unashamed, regarded big dowries as at once legitimate and desirable. They had the courage of their opinion-for instance, that physician of Pistoja who had to choose between two girls, one of whom was warranted a sensible creature, while the other was less sensible, but richer by three hundred crowns. The doctor did not hesitate an instant in choosing the richer, for in his opinion the risks were equal, and the difference pointed out between them was not worth a few crowns. No Italian was at all loth to marry a woman who brought him a dowry large enough to live on. At Florence fifty crowns a year would almost keep a household of moderate tastes, and a woman of the lower middle-class as a rule received a dowry of two or three thousand florins, which yielded an income of at least a hundred and fifty florins. The Visconti and the Sforza, by means of dowries which were by all accounts colossal, got their daughters into the principal royal houses of Europe. In short, the Italian system continued to exercise a wonderful fascination even over outsiders, and in starting on the expeditions to Italy more than one French noble fancied that a rich wife would be the reward of his prowess.

It is not very surprising that these ideas at length overcame all resistance in France. Louis XI., who was a pupil of the Sforza, did much in this as in other things to snap the chains of the old traditions. We have elsewhere related how lightheartedly he made and unmade marriages, with the sole object of rewarding various adventurers at the expense of the most honourable families.

Louis XII., on the contrary, set himself passionately to oppose these new manners. Although he plumed himself on his chivalry as much as anyone, he did not admit that the heat of passion could excuse the abduction of a young girl, even if she were rich-and in such cases she was almost always rich. His firmness did not prevent some picturesque exploits; but the authority of the church, with its strong weapon the canon laws, lent him aid. 
We have moreover had occasion to show elsewhere how much difficulty Charles VIII. had, after the event, in getting the legitimacy of his marriage with the heiress of Brittany acknowledged. ${ }^{1}$

And so it is that, at the epoch of women's triumph, we find in France two distinct species of husbands. The first, without shutting their eyes to the importance of money, refused to make it the principal question in marriage. Undoubtedly it was unfortunate if the wife came quite empty-landed, and in such a case a girl ran some risk of the "pain " of remaining an old maid or falling into an unhappy plight. The most insignificant workgirl set her heart on getting a little dower together, even by methods not altogether innocent, ${ }^{2}$ and

${ }^{1}$ [Charles had been solemnly betrothed to the daughter of Maximilian of Austria, and Anne of Brittany hac been wedded by proxy to Maximilian himself. Both repudiated their contracts, and their alliance united Brittany to the crown of France.]

${ }^{2}$ Cf. the following ballad by Alione :

Qui veut ouir belle chanson

D'une fillette de Lyon

Qui d'amour fut requise, Ale houe!

En venant de l'église.

Mais elle en fut reprise ! Ale houe !

Un bon copain lui voulut donner

Cent florins pour la marier,

Mais (Pourvu) qu'elle fât s'amie.

Ale houe!

Prencz-les, je vous prie;

De cœur les vous octroie.

Ale houe !

A sa mère s'en conseilla,

Qui lui dit que bien la gardera

De cette maladie.

Ale houe!

Il peut bien dire pie,

Car il ne l'aura mie.

Ale houe !

" Les amoureux du temps présent

Font des promesses largement,

Et montrent main garnie.

Ale houe!

Mais folle est qui s'y fie :

Trop conte la folie !

Ale houe!" 
we know that the purses of princesses dribbled out a beneficent response to this desire. But many marrying men were quite content to be fobbed off with some sort of equivalent. Thus Louis XII. created François de Melun Count of Epinay to induce him to marry Louise de Foix; and Louis de la Trémoille gave twelve hundred livres to his

La fillette ne voulut pas

Son conseil croire, en celui cas ;

Car elle eut plus grant joie,

Ale houe!

De gagner sa monnaie,

Cent florins de Savoie.

Ale houe !

Cent florins sont beaux et luisants;

S'elle eust fillé vint et cincq ans,

Voire toute sa vie,

Ale houe !

Toute sa fillerie

N'en vaudrait la moitié.

Ale houte!

[Who lists to hear a famous ditty

All on a maid of Lyons city,

Who as she came from church one day

(Hey nonny!)

Was sought in love the usual way-

And sore she smarted, gossips say-

(Hey nonny !)

The jolly youth would give, he said, A hundred florins her to wed

If she would first his leman be.

(Hey nonny !)

"Prithee, take them, dear," says he,

"With all my heart I give them thee."

(Hey nonny !)

The hussy home did straight repair :

Her mother counselled her: "Beware!

Lest it repent thee by and by ;

(Hey nonny !)

For though he speak thee fair and sigh,

His precious gold is all my eye !

(Hey nonny !)

"The young men of the present day,

Promise more largely than they pay,

And though their purse well filled appear,

(Hey nonny!)

The girl who trusts to it, I fear,

Will find her folly cost her dear."

(Hey nonuy!) 
servant, Robert Suriete, to compensate him for the portionless condition of a pretty girl, Marie de Briethe.

The other kind of husband, which was destined more and more to outnumber the first, saw in money, on the contrary, the real, substantial element of wedlock. Anyone who thought that a woman would appreciate a sacrifice made to marry her struck them as egregiously simple. The richer women are, the better they are, as Montaigne says: there is no reason why a man should sacrifice positive "commodities" to uncertain (and not particularly useful) quantities such as birth, beauty, virtue, wit.

The ball once set rolling spun along merrily. Especially in Italy, the exploitation of marriage attained imposing proportions. Indignant fathers of families protested; the Venetian senate, composed mainly of fathers, passed various decrees more and more restrictive, contemptuous and scathing, but all in vain. The whole class of idle young men of fashion, and it was a numerous one, avowedly regarded marriage as a unique means of enriching thenselves and assuring an idle life, a charmingly easy means, too, not above the level of the meanest intelligence. Guez de Balsac likened it to a fat prebend which does not require the holder to become actually a canon, but which does unhappily necessitate occasional residence.

This custom does not perhaps indicate very warm feelings on the part of the young men, but it cannot be denied that it satisfied the secret wishes of the women and gave a sanction to the evolution of their ideas.

From the day when they pay the household expenses, women consider the parts reversed, and begin by assuming

Alack ! the hussy tossed her head,

Heedless of what her mother said,

For' 'twas to her a greater joy

(Hey nonny !)

To get the money from her boy-

Those hundred florins of Savoy.

(Hey nonny !)

A hundred! how they gleamed and shone !

Had she sat spinning on and on

Full twenty year, till worn and old, (Hey nonny !)

Not all the thread she'd spun and sold

Had brought her half that shining gold.

(Hey nonny !)] 
the most perfect liberty. Henceforth no more constraint, no more subterfuges, no more Judas kisses. They are now, mark you, equal ${ }^{1}$ or superior to their husband in those material concerns which are the essence of domesticity; and as moreover they fancy that morally they excel the men, that they are at once more affectionate, more chaste and more steadfast; as they are reminded on all sides of the example of paragons like Cleopatra, they make up their minds to be Cleopatras too. They consent, out of goodness of soul, to try their prentice hand on their husbands. They make him happy, sometimes even in his own despite; they are going to transform him "from a battered ingot or a base coin into a new crown piece." In his heart of hearts the husband may fret and fume, call to mind the old-time ways, wonder at his wife's continual absences from home and her choice of friends, and at times even try to interfere; but he is quickly given to understand that my lady is not going to be held in a leash or shut up in a band-box, that seraglios exist no longer. She will devote herself to his happiness, provided he shows himself docile and recognises his incapacity and belplessness. Ay, and let him reflect: how could he get on without so virtuous a wife? He would go into a consumption. She is there, regulating his expenses, his pleasures, the frets and sallies of his temperament; she watches like a sister of mercy over his physical and moral well-being, and it is by this means that the household represents henceforth a unity, sound, robust, with two bodies, four arms, and two souls.

Obviously (to repeat it once more), we have no intention of enunciating an absolute rule. In speaking of households, we do not mean that all the households in France were cast in the same mould, and that everywhere at the same moment they were all acting precisely in the same way. No two were alike.

The truth is that, one way or another, a very large number of women no longer suffered themselves to be snuffed out, "trodden under foot," to use the current phrase. As to the manner in which their controlling influence showed itself, that depended on events, tastes, how the wind

${ }^{1}$ One of the friends of Margaret of France, the worthy La Perrière, thunders against marriages for money or beauty, which only end in putting "a fox into a hermitage." 
blew, circumstances. A favourite idea of Margaret of France, and one which it would have been difficult to get out of her head, was that women always err by their meek and quiet spirit, their excess of long-suffering. In vain is the reply made that more than one woman makes a virtue of necessity, and that, face to face with a violent creature threatening to break every bone in her body, a woman needs all her patience; Margaret protests that she would rather be flogged than despised. This magnificent declaration sets some of the company smiling, and enraptures the women. One pert widow alleges that she loved her busband so much that if he had beaten her she would have killed him. "In other words," retorts Henri d'Albret, "you mean to rule the roost. Well, I am agreeable, but you would have to get all the husbands to agree." Margaret winces under this intellectual cut; she is put out, for natural as she would regard it for her husband to take her orders, she dares not say so. Even she falters, and admits that the man is the natural head, but not that he has a right to desert or maltreat his wife. ${ }^{2}$ Can this be Margaret? Yes, the words are her own, and are exactly to the point. Women do lack decision-and she was the very first to show it!

Some young ladies, to elude this difficulty, thought it well to marry a ninny-if not an absolute fool. Worthy folk were amazed and sang the praises of mind and its attractions, "the treasures of knowledge," and asked them what pleasure they promised themselves. What a question to ask! Why, since a husband was in question, they promised themselves precisely no pleasure; nothing but money, or a name! That was how the Duchess of Medina-Sidonia married; she espoused an income of sixty-thousand ducats, with a grandee of Spain. True, this grandee, when paying a visit to the archbishop, asked very politely to see the children! There was nothing here to hinder the duchess from having as much mind as she wanted. But it must be confessed that this was an extreme remedy, and it would be preferable for a woman to feel and believe herself able to mate with a man of intelligence.

Domestic manners thus underwent a profound transformation. In humble homes the wife continued perforce to cook, to make the beds, to wash her husband's head and

\section{${ }^{2}$ Heplameron, Tale 37.}




\section{THE WOMEN OF THE RENAISSANCE}

feet, with no loss of dignity. But in the great houses, it was no longer common to find hard inelegant matrons who rose with the sun, were continually chevying the children and servants, and knew no pleasure but the joy of piling up well-bleached and well-darned linen on Saturday, the housewife's field-day. As Fourier has pointedly observed, disdain of such mole-eyed habits is the test of a people's progress in civilisation.

It is much more delightful to float through life with a smile on the lips, and to govern imperceptibly, by means of a languorous Creole grace.

Such grace abounded, and many instances of it might be given. Here is a specimen which seems to us characteristic; it is a simple little note from Isabella d'Este ${ }^{1}$ to her husband, dictated to a secretary:

"My Lord,

Prithee mock not at my letter, nor say that all women are poor things and ever smitten with fear, for the malignity of others far exceedeth my fear and your lordship's mettle. I should have written this letter with my own hand, but 'tis so hot that, if it last, we are like to die. The little knave is very well and sendeth a kiss to your lordship, and as for me, I do ever commend myself to you.

Longing to see your lordship,

Mantua, July 23rd.

IsABELLA, with my own hand."

"With my own hand," the signature and no more. It is so hot! But does not this very air of fragility convey a charm exactly of the kind to subjugate even a husband?

This charm does enfold him-and it keeps husband and wife apart! Seen at a distance these distinguished women, genuinely Stoic at heart under a mask of abandon, in reality overawed their lords and masters, and, even in their private intercourse with them, kept themselves shrouded in mystery and the unknown. Vittoria Colonna's husband, who took little pains to be agreeable at home, ${ }^{2}$ became so devoted a lover of his lawful spouse when far away as to compose in her honour a whole volume of charming verses entitled A Book of Loves. This book was never published, and has disappeared. Brantôme keenly regrets its disappearance,

${ }^{1}$ [See Book III. chapter iii.]

2 Vittoria Colonna's bed, preserved in the Pescara palace at Naples, is extraordinarily wide. 
because, he says, it would have given us an opportunity to see the poetry of conjugal love, and to know it that ought to draw its inspiration from platonic sentiments or notfrom celestial love or from love legitimately terrestrial.

Poor Brantôme! We think we can solve the question which troubles him. The women of that time were waxing philosophic, they had set their minds towards acquiring a good deal of knowledge and yet remaining alive, instead of minimising themselves, humbling themselves, following behind like a boat in tow. They had become vestals (if we may put it thus) in regard to marriage, and considered that their true mission was to shed abroad the love which welled over from their quivering hearts; for it is always the lack of men that turns women into feminists. In the world they were going to become "goddesses," and it would be impossible any longer to live without them.

Francis I., in a court without women, found himself getting too proud and despotic; his gardens appeared to him "flowerless," so he summoned and cnticed young women to him, and treated them "like goddesses in heaven." $\mathrm{He}$ shewed them their new mission.

And yet, what unsuspected depths of loathing rose to the lips of those divine women! I do not know whether the number of women sick of their husbands was larger than at present, but it was large enough. Pride and a high sentiment of duty in the gaze of the world long watched over them, like those grand statues of splendid, almost menacing virtues which the sculptors of former days were fond of setting before a tomb, at either end of the grave. But after they had accomplished, unostentatiously, devotedly, the mission for which men married them, namely, kept the house in order, loyally studied the master's comfort, poulticed and physieked him, borne him children, replenished the stock (pardon the expression) like good brood-mares, and humbly occupied the foot of the table, there came a time when this primary duty was done, and then they sprang up as though from a sleep, and looking at the sun, enquired of him whither they must fly to find life. They were born to sow flowers behind them. Their children were these flowers, painfully plucked out of their very vitals and flung into the future. It remained yet to pluck from their hearts, with a more vivifying joy, immaterial flowers, flowers of love, 
flowers of happiness, children of the soul, their real children, for if the woman is a passive being in physical conception, in spiritual conception she plays another part, she becomes the active being. The seed is hers to sow.

By this time they were no longer at the "angelic age," as Alfred de Vigny called it, namely, fifteen years. As a rule, they might confess to thirty, the age when women have "a spice of the devil," the age at which one ought to know how to deal with soul and heart.

The sort of revolution they brought about was no new thing. There always had been and always will be women of thirty years, quite aware of their age; but these were in addition keen-sighted, psychological women, who meant to get to the bottom of the phenomenon and measure its intensity with the eye of a connoisseur, for it seemed to thern that they were entering into life.

The children, who had been the raison d'etre of the home, were about to go out into the world, or had already gone. As soon as he could, the first-born son, that dear little boy whom the mother loved, asked and obtained a little money and disappeared. Henceforth he was hardly mentioned; he now had his own affairs, his own pleasures, and when he wrote it would be a postscript, affectionate but rather concise : "Madam, I had forgotten to write and say I have learnt that you have given me a little brother named Guy. I beseech you, Madam, see him well nourished, for I love him well." Sometimes news came that, far away, Death had rudely snapped the last remaining tie, and from the truly heroic words which then burst from certain courageous mother's' hearts, we see how hardened their souls had become, and how the noblest and most dearly loved of them had been compelled, in their thorny life, to form the painful but admirable habit of sacrificing their affections to the very uttermost. Gabrielle de Bourbon was announcing to her officers the death of her only son, killed at Marignan. Aloud she said: "in this battle that the King has won"; but in a whisper she added: "which has brought such" heavy woe upon us."

That sweet women whose very nature is to love should go out, when all fails them thus, into the world, like the bees of God, to gather a little honey and labour for the common hive, is not very surprising. They prefer " a little 
love from many to a great deal from one," 1 -especially when that one does not love them!

And so marriage comes to serve them as a refuge when on their honey-quest. It is like the lodge in which hunters take up their quarters, to be nearer their game and to shelter themselves from the weather. The women rejoice at having it. Nevertheless, before studying these emancipated women as they play their part manlike away from home, we have still to examine a final objection of principle, which was strong enough to hold some of them back.

Many moralists, even without bias against feminism, reproach the women with owing their philanthropy to a horror of marriage; according to them, the mission to the world upon which the women wished to enter was for them a means of evading their domestic duties.

That is not the fact. Without appealing to the obvious arguments, we wish for no other proof of the women's good intentions than their very manifest desire not to carry their separation from their hnsbands beyond a certain point. They did mean to render their bonds lighiter, and even elastic. But, as we have already seen, they defended the institution of marriage and affectionately tended their husbands in sickness; and it is certain that they had no wish to lose them.

Divorce originated in the masculine countries. It appeared a step in advance, because hitherto public opinion had shown itself singularly cruel in regard to separated wives. There was neither pity nor justice for them. The - husband had no shame iu deserting his wife, and it was always she who was blamed.

To put a stop to separations, the Senate of Venice, evidently convinced that as men they were not there for nothing, preseribed in 1543 a system which was simplicity itself. All separated women were metaphorically to be buried in a

1 A lady of Florence, Alessandra Bardi, on learning of the sulden death of one of her sons, wrote to another the following beautiful letter, so touching in its resignation: "My sweet son, I have learnt how, on the 23ril of last month, it pleased Him who gave me Matteo to recall him to Himself, in complete consciousness, in full possession of grace, with all the sacraments necessary to a good and faithful Christian. I have felt the bitterest grief at being deprived oi such a son, and methinks his death has done me great affliction apart from filial love, and likewise to you two, my sons, now reduced to so small a band. I praise and blcss the Lord for all that is His will" (Mïntz, History of the Renaissance, i. 18). 


\section{THE WOMEN OF THE RENAISSANCE}

heap; they were forced to wear a special costume like lepers, and were forbidden access to any public place. The clergy revolted. In the end, the august Senate contented itself with a milder punishment; it placed the unfortunate women under the surveillance, not of the state police, but of their ex-husbands.

But a time came when the Venetian measures no longer appeared feasible, and then in the countries where men ruled opinion it was generally admitted that woman, being a secondary creature, needed an owner and employer. Instead of trampling upon her when she found herself without a master, they deigned to do her so much justice as to provide her with a new lord. Calvin, generous soul, permitted her, in case of proved desertion, to take another mate.

In the Roman countries, deserted wives were objects of eompassion. But marriage remained indissoluble; there was no remarriage; and a woman in a country where women were a force had nothing to gain by placing herself in a false position. All that Roman charity could do was to throw open houses of refuge where she might find a retreat in honour and solitude. The true way of getting rid of a husband was to keep him.

Nor did the women, even the more philosophic of them, find any substantial advantage in being widows.

Certainly we must make some deductions from the rather theatrical demonstrations customary at death-beds. The custom was an old one, dating from the time when it was agreed that in losing her master a woman lost her all; these poor women were stricken to the heart-core, and thrilled with an emotion half comic, half touching. That was their manner of receiving their liberty; it seemed as though they had nothing left them but to die themselves, especially if they were young, and for some time everyone seemed of that opinion. In lugubrious and lachrymose tones their friends would remind them of overpoweringly wonderful examples: Artemisia, who drank her husband's ashes in a cup of water ; Portia, Cato's daughter and wife of Brutus, who, on learning of her husband's death, finding no knife at hand, did not seek one but swallowed live coals. Those who had simply opened a vein or cut their throat, or who had without ado plunged a dagger in their heart, were past 
numbering. We can realise what delicacy, what aristocratic charm there was in the Indian widow's suttee.

But for her children, who after reconciling her to marriage reconciled her to life, Louise of Savoy would have died on the corpse of her husband; so, at least, Jean de SaintGelais, her chamberlain, assures us, and he was suspected, only too reasonably, of over-familiarity with the secret tastes of his mistress. But for her religious scruples the beautiful Isabella Richisentia had killed herself on the body of Raymond de Cardoña. ${ }^{1}$ Bouchet and Moncetto, nicknamed Lycurgus, deliberated in great distress of mind whether they should persuade Mary of England ${ }^{2}$ to live, after the death of Louis XII.; they reminded her of Lucrece, Penelope and others, and Moncetto wore himself out in speaking of them to her in every known language and in verse. But for the young Englishman she espoused only a fortnight later, Mary, perhaps, would have died.

As a rule these widows, like reasonable creatures, at last made up their minds to live, under pressure from those about them; but it was also customary for them to display at least gorgeous mourning finery. ${ }^{3}$

Let us first see how they buried their husbands.

There were quiet women like Anne of France who contented themselves with the celebration of a very impressive service, and to all appearance shed no tears, for they spoke neither of drinking the powdered bones of the dead man cor

1 The story is given in Nifo's De Amore, cap. cii.

2 [Sister of Henry VIII. She was Louis' third wife: he was in his decrepitude, and died three months after the marriage. She at once married the handsome Charles Brandon, Duke of Suffolk, who had escorted her to France.]

${ }^{3}$ The diplomatic agent of Mantua thus reports his visit of condolence to the Duchess of Urbino: "I found her in her room among her ladies, all in black, the shutters closed, the apartment lighted by a single torch placed on the floor. She was seated on a cushion, a black veil on her head, and wore a high-necked dress, or at any rate her bosom was covered with a veil as high as her chin. .. . She held out her hand and burst into tears; a moment passed before her sobs and mine permitted us to speak. I handed her your lordship's letter, and dispatched my visit, my condolences, and my attempts at solace in a few words, so as not to prolong her grief. I imparted to her also the recommendations and offers with which I was charged by my most illustrious lord. Both were well received." Then they talked of Mantua and the Gonzaga family: the Duchess kept the ambassador for more than two hours. Next day, there was another visit of three hours; this time, her spirit got the upper hand, an interesting discussion ensued, and the ambassador succeeded in making her laugh. 
of spending the rest of their life in the bed of the dear departed. Anne of France indeed considered these proceedings as "useless, unworthy and detestable follies"; the only mourning that appealed to her was simple, silent and lasting. But more than once people were staggered at the quantity of tears women's eyes could contain. "Vainly do they tear their cheeks and dishevel their hair; I go off and enquire of a chambermaid or of a secretary how they were, how they lived together. We would much rather they laughed at our death, if they would but smile on us while we live."1

A Spanish lady, the Countess of Consentana, in officially notifying her vassals of the death of her husband, signed herself, "The sad and unfortunate countess," and, the better to indicate her distress, she dropped two ink-blots where her name should have come. The facetious vassals replied to their "sad and more than very unfortunate countess" in an address which, in their agitation, they all signed with enormous daubs and flourishes. Spain smiled, from Bilbao to Gibraltar.

So a widow left nothing undone to show how inuch she deplored her solitary condition. To this first conclusion we must add a second not less manifest: almost every widow strove earnestly to regard her husband as alive, so true is it that her aim was to act under the shadow of a husband as little in her way as she in his.

Of all the species of husbands, the dead husband is the one who would require the most special monograph. However little heroic his life may have been, his widow made it her business to sing his praises in public. A woman whose married life had notoriously been one of discreet indifference, if not of discord, would spend her nights and days in celebrating the glory and the memory of the dead man. So profoundly would she identify herself with him in heart that ere long she would develop into the widow of a great man and rise into a superior atmosphere. The greatnesses which the deceased perhaps never possessed she first gave him and then appropriated herself, and in the fire of this love she was gradually consumed. Besides, some-

\footnotetext{
${ }^{1}$ Montaigue, bk. ii. cap. xxxv. He himself desires no tears, no funeral oration: "I renonnce henceforth the favourable testimonies men may will to give me, not because I am worthy of them, but because I am dead."
} 
times she happened actually to have got past the age for love.

Margaret of France consoled herself frankly enough for the loss of the Duke of Alençon; but Vittoria Colomna never ceased to address sonnets to her captain, and when she was urged to marry again, her reply was simple: "My husband Ferdinand, who to you seems dead, is not dead to me." Diana of Poitiers manipulated this principle of "beyond the grave" with wonderful dexterity: she never was a widow. Her husband was dead, to be sure, but she displayed as her device an evergreen tree-stem springing from a tomb, with the words: "Left alone, she lives in him." As late as 1558, at the moment of her greatest worldly triumphs, she remained faithful to him.

Here, then, we have reached a second and a very important point: a woman of the world, so to speak, had her husband's soul packed in straw (like her china), and in principle she always considered herself as a wife.

In regard to the employment of their widowhood the widows fall into two classes. First there was the widow of the classical traditional school, who no longer belonged to the world, but buried herself in her maternal duties or in charitable work. She was only a survival of the old-style housewife, of whom a good many were produced even in the sixieenth century. For example there was Anne of Polignac, who, in her retreat at Verteuil, where she divided her time between her children and a splendid library, amazed the Emperor Charles V. with her well-regulated and dignified life. Again, there was Charlotte d'Albret, the widow of Caesar Borgia; she was a little more worldly, and by nature fond of show, splendid plate, magnificent jewels, and a large retinue.

These widows were administrators of the first order; so far as the interests of the family were concerned, it was an advantage, as a proverb ran, "for the husband to go first to earth." They excelled in getting full value for their money; sometimes even they were not averse to dabbling in usury: Charlotte d'Albret rather liked it. It would certainly not have been safe to reckon on their alleged feebleness; some of them were of mettle enough to mount the ramparts like Catherine Sforza. After the death of Grisegonelle Frottier, various relatives of his conspired to capture by force of arms 
the manor of Blanc which belonged to him. His widow, Françoise d'Amboise, learning of their plot, immediately appealed to the "picaulx," a brotherhood of Poitevin knights who were vowed to protect widows and orphans; and instead of leaving her cause to the halting march of justice, she organised an expedition and overthrew her adversaries. In spite of the rather energetic character of the proceeding, Louis XI. was touched, and willingly gave his pardon.

The most of these good widows spent a part of their life in convent chapels, and it was in this direction that a breach was made in their spirit of economy, for, according to pious author's, the devil worms his way through the vestry door. They would meet there a lay brother, charged with the duty of nurturing simple souls into fruitfulness. Beginning by sending some delicious tarts in exchange for a De Profundis, the ladies would by degrees make up their minds to found a chapel, then to have it decorated, then to endow it.

Or they received charming letters from the good nuns: "We are poor women whom your departure has left in distress, and we may say that we have lost all the good of life.... We are still wearing the cloaks you made for us, and we are going without pelisses, as our custom is. The convent has not changed since you left us . . . except it be that we suffer cruelly from cold during the winter."1

Many grave and strong-minded widows, after having mingled in affairs, took advantage of their widowhood only to forget a world in which their heart had not found sustenance. So soon as they had fulfilled unavoidable duties, it was a pleasure to them to distribute their property and retire from the world. We can hardly realise how the vision of a few sweet, peaceful years consecrated to the soul haunted the hearts of women whom the evil star of too high birth had flung into political affairs.

Such was the end Margaret of Austria ${ }^{2}$ would have desired.

${ }^{1}$ June 8, 1508. Sisters Domicella and Elena, from Forli, to Catherine Sforza.

${ }^{2}$ [Daughter of Maximilian of Austria, and regent of the Netherlands. She was affianced as a child to the Dauphin of France (Charles VIII.), then married to the Infant of Spain, who died in a few months : finally at the age of twenty-one married Philibert of Savoy, who died after four happy years of wedlock. She was a great patroness of agriculture and the arts, and a poetess.] 
Such was actually the end of two exquisite princesses of the house of Lorraine: Margaret of Lorraine, duchess of Alençon, who first connected herself with a hospital, then with the strict order of the Poor Clares; and Philippa of Gueldres, who entered the same sisterhood when her son ascended the throne. She lived with them for twentyseven years in the deepest humility, styling herself "a worm of the soil," though her companions might continue to call her " our reverend Mother the Queen."

The new generation was to see little of these sublime modesties. The majority of widows lived in the world; but what liberty they enjoyed they bought very dear, and on the whole they had less liberty than wives. They were gay and did not darken too often the vestry-door; they did not flaunt the time-honoured widow's cap, still dear to Englishwomen-headgear that would disgust anybody with widowhood. Was that a crime? By no means; and yet - the slightest slip or suspicion of a slip was in them unpardonable. Men saw in every widow either a naughty woman or a hypocrite, and they did not shrink from saying so. A physician was once bargaining for a mule in the presence of a fair widow, and said he: "I want one that's a widow": and as the dealer did not understand him, he added: "Yes, a widow, that is, plump, and light on her heels, and a good feeder." The saying ran: "If a man thinks his wife a little too thin, he had better make her a widow." A widow was regarded only as so much raw material ; and from the moment when "Goodman Danger" was no longer at hand, sin itself seemed to lose its sweetness. Widows were recommended to frequent none but deserted chapels, to contemplate the crucifix during the night. This condescending pity sprang sometimes from good-heartedness; but it was often odious to them, and all the more so because everyone, even the most confidential servants, fancied they had a right to throw in their sympathetic suggestions. Anne of France was indignant at this universal treason, which shocked her sense of right.1

And yet society added one more tyranny. For a widow

${ }^{1}$ She herself, however, employed on occasion the most convincing arguments. She had confiscated the jewels of her cousin, the Countess of Montpensier, who was regarded as rather too hot-headed for a widow, and she refused to restore them to her. 


\section{THE WOMEN OF THE RENAISSANCE}

to marry again was scarcely tolerated.' She would have been just as severely chided for finding a second husband as she would have been for not finding a first. ${ }^{2}$ She would be sooner forgiven for a frailty, a yielding to temptation, than for contracting a new tie. What woman was this who had not had too much of one husband, and was not amply satisfied? Among the people she was favoured with a sort of skimmington ride. Margaret of France defied the prejudice and married again: it was in sooth the deed of a philosophic woman. But in general, widows were still chained to their widowhood by various considerations; in the first place, the practical difficulty of finding another husband. Men were quite ready to court a widow, but very few would make the sacrifice involved in marrying her. A woman no longer young, a "shelled peascod," who no longer had anything to give and had settled habits of her own, was the antipodes of the little maiden of twelve so much in request. Besides, the widow herself was enjoying a large and tranquil life, thanks to the jointure of which a second marriage would deprive her; sometimes the whole of her husband's fortune had come to her on condition that she devoted herself to the children. She held in all matters the authority which had belonged to the dead man, and indeed it was not uncommon for the husband expressly to bequeath her this authority in his will. ${ }^{3}$ The drawback to this life of business management is precisely that a woman loses in it something of the bloom of her grace and sweetness, she no longer needs to employ persuasiveness and love since she has force at her disposal, and the result is that she becomes a sort of man, and acquires some of the defects by which she has suffered at the hands of her husband. We can thus understand quite well that a woman who wishes to remain a woman will do her best, for her own security and

${ }^{1}$ The Fifteen Joys of Marriage include among domestic calamities to return from war after a long captivity and to find one's wife wearing the finery of a new lord and master.

2 "There's no man will have you !" is an insult flung by a peasant at a woman during a squabble.

3 " Be obedient to your mother, show her honour and reverence, and take care to please her in everything you can, as is her due, as much because it is God's commandment as that I know she merits it, and that you ought so to do if jou wish to succeed, for having known her, I know that she will advise you so well that you will be therewith content" (Instructions of a Duke of Nemours to his sons). 
charm's sake, to live under the fostering wing of a precious memory, and will cherish with the utmost devotion her (so to speak) posthumous husband. There lies her real strength.

The Renaissance woman, then, a woman of essentially tine grain, and well versed in everything it was her business to know, was a woman of absolute sincerity, and we must believe her when she speaks well of marriage. She considered that institution as perfectly reconcilable with the fulfilment of a mission in the world, indeed as favourable, almost indispensable, to it. She had no more reason to give up marriage than to give up eating and drinking: it is not this that enchains the soul. The idealists differed from the utilitarians solely in the belief that one marriage is enough: the former covered their faces if a widow, not ethereal enough to satisfy them, went by on the arm of a new husband; the latter applauded, and fancied that by this transaction the animal nature was held in check. But this is of little interest to us. The only result important to note is that a woman, without ceasing to be a woman, could win freedom for her affections and her activities as well as a man. When she had attained that condition of liberty, she ascribed all the honour to marriage, and blessed it instead of thinking that she owed everything to herself. Marriage, like many human inventions, is a contrivance capable of producing either liberty or tyranny, and women had simply altered its direction.

They wielded intimate and domestic powers. Their rival was not the husband, they came to terms with him; it was the man who looked after their body or their soul, and to whom, out of weakness or indolence, they were led to attach themselves like an anaemic ivy-plant. To mark their place in this world they had themselves to learn how to obtain what brings happiness: health of body and of soul. Respected in regard to the body, it remained for them to gain self-respect in regard to the soul, and to show that true Christianity consists in bestowing power and liberty, not in withdrawing them. 



\section{BOOK II. LIFE IN THE WORLD}

\section{CHAPTER I}

\section{THE PHILOSOPHY OF LIFE}

Margaret of France said, very incisively: "The defect of women is timidity." They are born to fear.

Women had become habituated to a passive and secondary part. They desired to escape from it, they felt the need of activity and a freer air, their wings were growing and they adored intellectual liberty, at any rate they said so-and they had in fact already snapped many of their chains; but when you come to close quarters and exchange confidences with them, you perceive that they are still held fast by a multitude of secondary diffidences, by tenuous invisible threads starting often enough from social conventions of little or no importance. They are unable to wing their flight, or they require a man to go first and shew them the way; or an absolute necessity, an enthusiasm, an impulse of devotion is necessary to start them off.

They move at last, not through reasoning, but as the result of the more or less vague sentiment that while their homelife has brought them no love, yet they are made for love and have a love mission to fulfil. A modern aesthetic writer-but a man after all and only moderately sensiblehas thus explained the appeal of grace as it affected himself: "I had nothing to love. For me my parents were in some sort only the visible powers of Nature." How much more does this apply to women! They want something to love! Separated from her family the wife finds in her husband the 


\section{THE WOMEN OF THE RENAISSANCE}

incarnation, in the fullest sense of the word, of the visible power of Nature, and so it is that the ardent instinct drawing her towards the light is very complex, much interwoven with pain and passion; it is a thirst for love almost cruel in its intensity. Just as the husband wins honour for himself by means of external activity and public service, so the wife hears destiny making a similar appeal to her. Around her there is a life to diffuse, a sweetness to sow, hungry folk to feed, wounds to dress, a great cry of distress and hardship to soothe; and act she must. A tradesman's wife may shut herself up in the narrow egotism of her back shop. Could a woman of heart shut her eyes to the profound unrest of society? Ought she to remain a helpless pawn on the board, a mere victim? Was she not called to take her share, as an intelligent and free creature? Willy nilly, she must step forth from her house-burst her shell and wing away! At twenty it is excusable to confuse one's ideals with life; ten or fifteen years later this illusion has dissolved. One feels then the need of setting one's heart upon some firm, sure, noble spot out of reach of the swirling tide of existence; and a day thus arrives when every woman capable of reflecting and of loving throws a questioning look on what is around her.

And then, what answer does she get from the great mystery of life? She sees a gigantic system of force and matter in interaction, set in motion, working, displaying itself under the silent impulse of an invisible power, and having neither existence nor beauty apart from an end external to itself. The governor of this world is man; endowed with an intelligence more potent than matter, so that he finds himself placed here below as the ambassador of life and the type of beauty. He himself obeys practically one only motive power, love ; he cannot be strongly stirred save by passion. Thus the whole world obeys the law of beauty and of love. Truth and goodness form, so to speak, its skeleton; beauty is its life ; love, the instrument of its life. Certain modern aesthetes, seeking to establish an antinomy between man and Nature, represent man as a foe who in employing Nature necessarily violates and deforms her, whereas left to herself she would be always lovely. ${ }^{1}$ To subordinate man to Nature in this way seems to us untrue

${ }^{2}$ Ruskin's favourite theory. 
and disastrous. Surely the contrary is the case: we may put anything to wrong uses, but material forces cannot but gain if we direct them aright. Our part is to live in harmony with Nature, conformably to the magnificent and universal law that love grows by spending itself. "Go and give all your goods to feed the poor," says the Gospel : that is nobility! Sow, give: give always! Give the labour of the arm to the fields as yet sterile; give your heart to hearts that are dull and dead! Beauty and niggardliness cannot live together. At one end of the scale there are those who are incapable of giving, frozen hard, as it were, against love: at the other are those who in a splendid profusion of generosity pour out their gifts without taking count of them: and the whole world lies between. From the pebble sensible only to mechanical attraction, to the flower that scents the air, one profound idea holds good, one great song rises, all mortal things cry in unison, and the burden of their united voices is, love. Every moving thing tends to entwine itself about something else, to unite inextricably with it; all life tends to pour itself into another, to surrender itself, and thereby it has a second birth, and all individual vibrations coalesce into one grand note. And, above this symphony of material things, the heart of man outpours itself in similar strains in the spiritual spheres of true life which stretch up to God. The love of man, to adopt the phrase in the Imitation, is a cry flung out towards God.

Love, then, is the ruling principle of the world, a noble, superb, necessary thing; extending its broad wings it easily dominates the littlenesses and conventions of life, responds io all needs, whether of the individual soul or of society, sets frail hearts athrob with life. But it is obvious, too, what a strife it is sure to excite, by its double nature, between spirit and matter-a strife wonderful and delightful and fierce.

Women are so constituted as to understand this sharp antagonism between material love and spiritual lovewomen, who, at a certain crisis of life, feel so strongly the contrast between the cruelties and ironies of material things and the refinements of the heart. They drag about a body often feeble, suffering, wretched, a misshapen, bleeding, shamefast body, a pain-stricken body, born for love and worship, but subdued to the surgenn. 


\section{THE WOMEN OF THE RENAISSANCE}

There comes a time when they would fain forget the animal and wash it of its impurities if possible; their soul has become more intensely spiritual. If they shudder at the recollection of certain physical necessities, through that very fact the secret of happiness appears to them simpler, more luminous, less clogged with matter; branded by life, as certain mystics bore the brands of divine love, with sides pierced and limbs explored and broken by the hands of men, they are athirst for love, enthusiasm and worship, they understand that no intellectual hair-splitting, no doctrinal analysis, is worth a snatch of love. They know the sweetness of things. I will go farther: they know the extraordinary influence of moral forces on physical health; the body, like society at large, needs to be reinvigorated by soul and heart.

The truth strikes upon them vividly by a sort of intuition. But it is far from being the case that, all women are able to profit by it, because they have to reckon with a thousand practical obstacles: they require great liberty of mind and a large share of energy if they are to avoid being restrained by a host of more or less respectable prejudices, conventions, and usages. After all, timidity, indifference and frivolity are very natural things.

Particularly in France, women needed genuine courage to assert their resolution to act and take part in social work, in the midst of a society essentially constituted to prevent them from giving effective expression to their ideas-a society that was strenuous, Philistine, utterly strange to philosophy and imaginative thinking, hidebound to traditions of very rudimentary common-sense and a proud simplicity, composed of families desirous of living in their own fashion under the direction of their head, with no grand notion of forming parts of one stupendous whole. The king was the head of the principal family; on this account, men showed the most artless veneration for his person, but so long as the army was duly organised and the frontiers properly defended at the least possible expense, they troubled themselves very little about their sovereign's existence. So the despotic power of the husband was not merely domestic, but political : the man was lord of the lands and the village as he was of his wife, and he administered the whole without stirring up many ideas, in intimate communion with his 
oxen and his oaks. Again and again we find in portraits the rubicund faces of these honest-eyed country squires. There was nothing extraordinary or gigantic about such a man; he was a man of iron, that was all; and beside this substantial creature vegetated, half-stifled, that fine and precious flower his wife, sometimes a frail delicate thing with liquid eyes charmingly veiled, all compact of concentrated passion, placid tenderness, and impressionability.

On the other hand, in strange contrast with this individualistic society which lived in isolation as a matter of priuciple, there then flourished at court, in the cities, and in certain great châteaux an extremely active society, that of the salons. Effervescent, noisy like fresh arrivals, ceremonious, gilded, of a refined and factitious elegance, it represented what many writers called the "theatre of the world": marvellous stage scenery, which underwent remarkable transformations under the shifting play of the side-lights, forming a background against which the players strutted through their parts. Who were these actors? Whence came they, whither were they going? These were questions about which often enough there was little information and less concern; sometimes it was thought best to ignore them altogether, for, thank heaven! it was not to grow mouldy in the depths of the country that a man intrigued, nor was assassination a means towards opening a grocer's shop. Occasionally, and usually when the curtain fell on a financial act, someone disappeared, but without tragic accompaniments, and then (except Semblançay, ${ }^{1}$ who was hanged) he reappeared and went on with the pantomime. There was nothing but praise for the noble use Admiral de Graville made of his princely fortune, which was the object of some discussion. $\mathrm{Du}$ Plessis so cleverly extricated himself from the toils of justice that he could bequeath to us the admirable Cardinal Richelieu. The Bohiers, Briçonnets, Robertets,

${ }^{1}$ [Minister of finance to Francis I., a faithful and honourable servant of the crown. Lautrec, governor of Milan, having asked for 400,000 crowns as arrears of pay for his troops, the queen-mother, Louise of Savoy, who had a grudge against him, seized all the money in the treasury on the pretext that it was owing to her, and even intercepted what little coin Semblançay was able to get together. The result was that Lautrec's army melted away and Milan was lost. Louise made Semblançay the scapegoat, and when Francis, after his defeat at Pavia, was carried a prisoner to Spain, she threw Semblançay (he was 72 years old) into the Bastille, had him tried on trumped-up charges, and brought about his execution.] 
Duprats, ${ }^{1}$ and many another, small or great, erected in all security their splendid châteaux, triumphs of art, but a sort of affront to the old machicolations crumbling in cold neglect under the moss. In those days Gold was king.

All this splendour and grace, this brilliant life, which seemed bound to make everything around din by comparison, nevertheless by no means dazzled the common herd, but at first aroused a feeling of repulsion, if not of jealousy. Outcries arose. Wealth was apparently losing its character of a kindly and patriarchal simplicity, to bring in to greater prominence the figures of proud and self-important men who believed their wealth would purchase everything-virtue, wit, honour, as easily as a rare picture. A poor man accordingly was set down as a "soulless body"; the virtuous man was one who lived in a palace, while the man who gave a diuner-party was a master-mind.

To tyranny of this sort there was added the individual or social misfortunes of a society naturally unstable and continually recruiting itself by means of speculation. Thence arose outcries: "You make so many poor folk cry alack! alack! that we long to see you fall headlong in the dust!" 2

Gold and pleasure were the deities to whom we owe the charming eighteenth century. But they lead to revolutions. This fact came out clearly, indeed too clearly, in Italy, and compelled men to endeavour to restrain these two great world forces within wholesome limits. In the fifteenth century Christian socialism reared its head high at Florence and Rome, and under stress of its menaces a science of philosophy came to birth.

In presence of this social peril, certain men, compelled to issue from their egotism, pointed out the road for timid women to follow to avoid vengeful reprisals. Men of affairs, bankers, notaries and others banded themselves together with the firm resolution of forgoing business, interests, ambitions, even their for the most part despotic hopes in state intervention, of seeking to practise self-devotion, and of borrowing, if necessary, something of the idealism of

${ }^{1}$ [Bohier was a jurisconsult, Briçonnet, bishop of Lodève and Meaux, and an insincere persecutor of the Reformers; Robertet was treasurer of France under Louis XII. and Francis I. ; and Duprat a venal minister of Francis I. and a partisan of Louise of Savoy.]

${ }^{2}$ Coquillart. 
philosophers and artists, so that they might give a practical sanction to their high station by working to raise others. The Florentine people swallowed the bait; at once ardent and refined, they admirably blended practical reasoning with ideal aspirations. And so the first step was taken.

However, it was more particularly at Rome that this idea, still rudimentary and ill-defined, of purifying life and pursuing social happiness by means of the tender charm of the Beautiful made progress. It found there a well-prepared soil. Intellectual culture and elegance of speech did not represent at Rome, as they did elsewhere, a mere ornamentation, they were the very substance of the state. Money was intellectualised as regards its origin and its end, and nowhere had men a better conception of an oligarchical society, a republic regulated by absolute power. The heads of the church formed a unique world of their own, as little tainted by the military or frivolous character with which certain aristocracies were reproached as by the taste for coarse pleasures natural to some self-made men. They showed indeed a living example of a true aristocracy, in the exact signitication of the word, that is to say, a body of men of varied degrees of rank, raised high above the common run of men by some eminent gift-some by high political position or distinguished birth, others by a large fortune, others by great accomplishments, renowned virtue, profound learning, striking talents. They abhorred cliques and their pettinesses; to greatness of position should correspond greatness of ideas. And this splendid aristocracy, thus composed of the choice flower of society, delighted in tracing its descent from remote ancestors. It set no store either on high ancestry (though some were of brilliant descent), or on a display of wealth (though some had enormous fortunes); it ventured to connect itself with all the most illustrious and conspicuous names in the past history of the human race from the time of the Greeks and Romans: Plato, Socrates, Archimedes, and Cicero were its ancestors. And thus, with a strange persistence, it constantly tended to lift into its own ranks by its example, its doctrines and its easy accessibility all men who felt within themselves a spark of genius or talent, or even ambition merely.

This atmosphere was very favourable to the development of the theory of social aesthetics of which Castiglione 


\section{THE WOMEN OF THE RENAISSANCE}

has etched the principal features. "Luxury must be opposed, even if we have recourse to law; social life must be given a moral and governmental goal; to keep the appetites under, the laws must find effectual support in custom. The power of a single ruler fosters corruption; but it has this advantage-that wisdom, goodness and justice are more easily found in a single individual supported by strong traditions than in a fortuitous assemblage of obscure citizens." What is wanted is to institute a kingship in the world for which justice and beauty are the qualifications, and which is thus more real and of a diviner right than any other. Mammon, that is, the love of gold, the love of power and pleasure, can only reign in a world of night, when we have eyes but cannot see, when we have lips from which no human cry issues, when we are dead to enthusiasm, and when our whole life consists in eating and drinking.

In France the socialist danger, presenting itself in a much less acute form, could not produce the same effects. The people who were to show their teeth fifty years later were as yet silent, and there was no anxiety about the future except among the cultivated classes. Moneyed people bore themselves with becoming modesty, and remained on the best of terms with the most notable representatives of the old nobility. But the nobility, being no longer feudal, was no longer of much account, and a moral crisis of exceeding gravity took place in the ranks of this aristocracy based wholly on birth and fortune. Sheer vanity took the place of pride; the "smoke" 1 of titles became a more powerful motive than the love of glory.

The great financier's almost all became barons, in order to get above finance; the holders of fiefs became barons, counts and marquises. Ordinary mortals came to hold fiefs; the most insignificant dovecot was transformed into a château. Society moved on a step, and everybody was satisfied. It was quite a steeplechase in the Italian style. Pontanus, ${ }^{2}$ for all his malicious ridicule of it, had himsalf vainly solicited the title of baron. The good duke of Urbino, a great philosopher whose elevation was of very

1 "Have you never reflected, then," says an old author, "what this smoke is worth?" (Baltazar Gracian).

'[Italian poet and historian (1426-1503), the most 'elegant' writer of the sixteenth century. He wrote Amorum libri $i i$., on conjugal love.] 
recent date, employed the assassin's knife to put out of the way a girl of the lesser nobility whom his eldest son loved and wished to marry, and Louise of Savoy warmly approved of this magnificent implacability. ${ }^{1}$

Pedigrees assumed wonderful proportions. Only those who had the moral simplicity of Margaret of Austria were content with the ancient kings of Germany for ancestors; every Scottish archer, no matter how insignificant, claimed descent from the ancient kings of Scotland. Louise of Savoy made a beginning by modestly connecting the French house with the most ancient of royal dynasties, that of Babylon.

Some went even farther. They dived into the remote and shadowy depths of history, the ages of stone and iron, when some wild girl became their ancestress through a chance meeting with a savage in a wood, and when five minutes' rain instead of sunlight would have been enough to wash a whole race of men from the page of immortality. Anne of Brittany was descended from one of the giants sprung direct from mother Earth. Rabelais with great gravity presents his hero to us in his exact style as son of one of the original sons of Earth: "Would to God," he adds, "that everyone was as well acquainted with his pedigree from the time of the Flood!"

But in reality, under cover of these novel and pedantic vanities, money, with its brutality and vulgarity and appeal to vulgar minds, led the dance and dragged the pick of the nation pellmell after it. The Balsac of the time, Robert de Balsac, fills a good many pages with examples of the crowd of worldlings who, as he expresses it, hurried in unbridled, almost frantic haste on the road to beggary. ${ }^{2}$ There are

\section{${ }^{1}$ Heptameron, Tale 51.}

${ }^{2}$ Gallants, ambitious men, fashionable men late abed and late up, those who live on credit, litigious fellows, spendthrifts, poor devils who marry for love without a penny, loafers, philosophers who live from hand to mouth, soldiers who run through a quarter's pay in a month, husbands ruined by their wives' dressmakers' bills or their servants' guzzling, men who keep no accounts, who, without being princes or lords, put eighteen yards of velvet into one costume, who spend much and get little, who let their horses starve, their tapestries and furniture moulder, who leave their orchards to be robbed, who would not spend a penny but fling away a shilling, who endow their daughters too largely, who toil without rhyme or reason, who accept financial responsibilities. . . . weak-kneed men who back out of their lawsuits, who are led by the nose by those about them, who are always singing a gaudeamus and never a requiem, braggarts, giddypates, boasters, "Roger Goodfellows," gormandisers, debauchees. 
voluptuaries, debauchees, spendthrifts, men gorged with gold, yet athirst for more, tumultuously dashing on and upwards in frightful torment and agitation towards a will o' the wisp; one after another they fall headlong into the gulf, while the foreground is filled with the eternal procession moving on with slow pace and clockwork regularity. Alongside of this mad insolent triumph of gold fierce hatreds develop, and men begin to speak under their breath of the horrible triumph of wretchedness approaching, and can foretell the hour when materialism from below will make its awful response to materialism from above.

Women ought to have remedied this state of things. They ought to have prevented men from becoming besotted and ruining themselves. Anne of France dared not suggest to all these idle nobles that they might occupy themselves with intellectual things, but she was anxious at least to brace them up by a life of physical endurance. Without military courage, she declires, the nobility resembles "a withered tree," without valour "it is nothing worth."

What she was losing hope of, a fraction of the clergy set themselves to win. There was, among the mass of cassocked peasants and rochetted aristocrats, a small group of cultivated men drawing its inspiration from the Cardinal of Amboise, ${ }^{1}$ less audacious than Rome, less retrograde than Germany. These recognised the traditional merits of military glory, birth, and money, but would have liked to reconcile them with the newer virtues, blend them together into one radiance, homogeneous like the sunbeam, which is composed of colours so various; they would have liked to see all these glories combining, as at Rome, into one rainbowlike effulgence. A monk of Cluny, Clichtoue, begs, beseeches well-born young men to shun the enervating paths of infatuation, idleness and vice. $\mathrm{He}$ has endless examples showing the possibility of alliance between literary tastes ${ }^{2}$ and the military life; he reveres the principles of rank so highly as to discern them in application everywhere, even among the metals; but he longs ardently to bind into one

[ ${ }^{1}$ George of Amboise, the wealthy Archbishop of Rouen: a great builder and art-patron, who brought many painters and sculptors and architects into France from Italy. When he died Pope Julius II. "thanked God he was now Pope alone"! The cardinal's tomb in Ronen Cathedral is one of the finest pieces of Renaissance work in France.]

2 Which included, we may say in passing, music and gymnastics. 
sheaf all the vital forces of society; he is a philosopher, one may even say a sort of John the Baptist. He proclaims Plato; he is more scriptural than Luther, and has as much antique culture as any Roman prelate $;^{1}$ to him the future seems to outline itself clearly. "After virtue," he says, "a noble can have no comelier ornament than letters. Philosophy is not the recipient, but the source of nobility." $\mathrm{He}$ adjures distinguished men to pay real attention to the social obligations incumbent on them, under penalty of losing their rank. He does not disavow the natural plcasure a man takes in the thought that he has had ancestors and will have descendants, but to him this does not seem a sufficient though an honourable aim in life. If no means are found of uniting the two nobilities, that of the body and that of the mind, no doubt (in his opinion) the nobility of the mind will get the upper hand; Solomon, who is not generally considered a modern or even a socialist, had already said so long ago: "I myself also am mortal, like to other men, and am sprung from the terrestrial lineage of the first man. And in the womb of a mother was I moulded into flesh. And I also, when I was born, drew in the common air and fell upon the kindred earth, uttering, like all men, for my first voice the self-same wail : in swaddling clothes was I nursed, and with watchful cares. Who among the kings had any other beginning? All men have one entrance into life, and a like departure."

Clichtoue, however, as well as his friends the Lamennais and Montalemberts of the period, confined himself to counsels and prognostics, which indeed the future was in great part to justify; he had not yet discovered the exact formula. He had it at the tip of his tongue, but could not give it utterance; it seemed as though in France the words 'beauty' and 'love' were no words for a man or a churchman. These noble and lofty words were to come from a higher sphere, and from women's lips.

It was Margaret of France who at last uttered them, and they were echoed around her.

Here we find the remedy so ardently sought for against materialism, as Jean Bouchet explains it on Margaret's behalf: "To purify the world, to eliminate its coarser elements; to give wealth only the lowest place as a source

${ }^{1}$ But he did not mean to be absorbed by either the one or the other. 


\section{THE WOMEN OF THE RENAISSANCE}

of social distinction, and even then only on condition that the plutocrat lives nobly, that is to say, unselfishly, and makes noble deeds his constant study." True nobility is not a cockade, a label, a name, but a moral reality; "it springs from the soul, and not from wealth." Noble and lofty spirits are recognised precisely by their innate simplicity; they leave the gildings, the pompous blazonments, to "the sons of swineherds, sempsters, stockingers, and other mechanical folk. But those who are illustrious by long descent reveal their nobility beyond possibility of mistake, for they have in them something, I know not what, of naïve goodwill that manifestly separates them from the arrogant assumptions of false nobles." Spirited, showy, a genuine blue-blood, restive under marital authority, but quivering to her inmost fibres at the slightest appeal of a refined sentiment, Margaret of France remained obstinately faithful to these principles, finding in them the pole-star that guided her steps throughout life. The words we last quoted were uttered in circumstances which give them a special force, namely, in the funeral oration of Scaevola de Sainte-Marthe, who thought he could cast upon the princess's tomb no sweeter flowers, none more likely to blossom eternally. Margaret herself never lost an opportunity of emphasising with all her force the terrible fear she had of the power of money.

Aimer l'argent,

Sinon pour s'en aider, c'est servir les idoles ! ${ }^{1}$

In regard to those who deal with humanity like brokers, and believe that happiness is purchasable, she gives vent to passionate apostrophes worthy of the most ardent Christian socialists :

Ilz ont plaisirs tant qu'ils en veulent prendre,

Ilz ont homneurs silz y veulent prétendre,

Ilz ont des biens plus qu'il ne leur en fault. ${ }^{2}$

And this was precisely what men were aimingat. The military framework of society was broken; to replace it by a finan-

1 To love moncy

Save for its use, is rank idolatry.

2 They have what pleasures they desire,

Honours whereto they dare aspire,

And wealth much more than they require. 
cial framework would have been considered almost criminal; and that was where the great danger lay. To employ a comparison approved by Francis I., two cars are running the world's course side by side; a choice must be made between them. One is the car of Plutus, filled with gold, lechery, vice; the other is the car of Honour and Love, thronged about by all the virtues. ${ }^{1}$ The choice is clear : for its own happiness, for its own glory, the world must reject the worship of money, trample on the power of money, and proclaim the power of virtuous love.

Thus, little by little, the formula sought for emerges into view. A wonderful light is thrown on the problem when it is admitted that to be happy it is necessary to rise above material things, and establish society upon a philosophy of love. Life and beauty, they are the true riches! The feeblest of men, the most hopeless invalids, the vilest outcasts, woman with her feeble body and ardent soul, are richer than a nugget of gold, more eternal than the Alps, greater than the sea and the vast realm of nature, for this very reason that they have in them life, the true life, that is, consciousness of life, confidence in life, and love of life.

And the same idea that happiness must be sought through true life, led men to recognise the necessity of considering the 'hygiene' of this life. Medicine, care and pity had been up to that time only for the ills of the body, for the gaping, gory wounds that came under the eye; the wounds of heart and spirit had been forgotten. To render life sumptuous and brilliant, to fritter it away in a sort of giddy excitement or intoxication, was the utmost of men's achievement. The heart cannot be bought; there is no specific for healing its wounds; they must heal themselves.

The art will consist then, in realising as far as may be the plenitude of life; in other words, in extracting from Christianity, which is Hope and Charity, an aesthetic philosophy. "I am the God of the living," said the Master. If we combine the sayings on life scattered through the gospels we obtain a true code of aestheticism, while the sayings on

${ }^{1}$ Almanque Papillon's La Victoire et Triomphe d'argent (Lyons, 1537). A copy belonging to Baron Pichon includes two miniatures: (1) the Triumph of Money, (2) the Triumph of Honour and Love, represented by Francis I. in a car drawn by two unicorns, and led by Diligence, Sapience, Sobriety and Virtue. 
love form the warp and woof of the doctrine. On the morrow of the Resurrection, when the rude fishers chosen to disseminate the sacred tidings are in utter ignorance of the event, the Master shows Himself first of all to Love; $\mathrm{He}$ appears at the gates of a mysterious garden by which Mary Magdalene is about to pass-Mary, a woman pardoned, glorified, because she loved much, because she sinned through superabundant kindliness.

This doctrine of love had not prospered in the world, where it found briers too deeply rooted, thorns too cruel; it had become a supernatural and sacred thing, so sublime that it fled the world and took refuge in the cloister, like a sickly plant in a hothouse, leaving a free field for vice. Tenderness seemed to come only from feebleness; every form of art seemed immoral, all love a degenerate and ill-balaneed thing, and no one realised the need goodness has of intelligence. The pettinesses of feminine religiosity, encouraged, unhappily, by a section of the clergy, tended to make divine love itself ineffectual and almost ridiculous. Yet the author of the Imitation has defined love as the true source of activity:

"Nothing is there in Heaven or earth sweeter than love, nothing stronger, broader, higher, fuller, better, or more winsome, for love is of God, nor can it rest but in Him, above the world ereated. The lover rumeth and flieth, and is alive with joy; he is free, and nothing restraineth him; he giveth all for all, hath all in all, because he resteth above all things in the one sovereign good whenee all other goodnesses proceed and flow. He looketh not to gifts, but raiseth himself above all to look only to the giver. Love often knoweth no limit, but its fervour carrieth it far above measure. Love feeleth no weight, making light of toil, would do more than it is able, pleadeth no impossibility, because it thinketh it may and can do all. Wherefore it is strong for anything, and where he that loveth not doth faint and fail, love doeth and achieveth many things." I

Why then had not this beautiful religion, this beautiful philosophy become the religion and philosophy of the world? Why harl they not sent their streams of activity flowing in ever-wideuing channels? Men wished to solve this problem, and restore to the world the philosophy it had

\footnotetext{
1 Imitation of Christ, book iii., chap. v.
} 
so misunderstood-to interpret love as it should be interpreted, through impressions and sensibility, and not through the intellect. Hence Castiglione's saying, "God is only seen through women."

This saying, it is elear, does not apply to all women; it has reference to those who are worthy to exercise an active influence.

Natural obstacles oppose themselves to this mission of philosophically raising the world to nobler ideas by the social religion of beauty. The French are a matter-of-fact, practical, sceptical people; between the peasant and his cattle, the lord and the peasant, there exists a solid and after all a pleasant relationship. Further, the French are specially hostile to ideas of an intellectual hierarchy, they lack sensibility, the beautiful displeases and shocks them, and when a revolution gives them what they call a moment's freedom, they amuse themselves by defacing as many statues as possible, destroying their cathedrals, burning their historical monuments with all the enthusiasm of hate a personal grievance can inspire. Likewise, in regard to love, modesty, the ideal, and all refined and aesthetic sentiments, we experience a certain pleasure in scouting them; when we have won any sort of diploma, that is the use we make of it.

And yet, do what we may, lofty things alone can elevate us: on the mountain-top we breathe a different air from that in the valley.

We must raise on heights above us eminent women who will crucify themselves, if need be, to draw soil-stained men to them, aceording to Christ's words, "I will draw all things unto me"-women endowed with all that glorifies-money (to scorn money is the luxury of the rich); a noble blood clarified on stricken fields, or through intellectual wrestlings, a spirit original and pure. Christ was at once the son of kings and the Son of God! This is the consecration of happiness through a philosophy of emotion and sentiment. Plato said that what was needed for the happiness of humanity, was "philosophers who rule, or kings who philosophise." Do not believe it! What is wanted is kings who govern, and women who philosophise. Men will always imagine that liberty and equality are established by act of Parliament; philosophy is to them only 
a means of livelihood. Cremonini, a famous professor, but a wit, said when he took leave at the close of his lectures: "All that I have taught you is true according to Aristotle, but not in an absolute sense: you might as well believe St. Roch or St. Anthony." Nifor contradicted himself with charming serenity, though he allowed no one else to contradict him. In truth, how were these excellent professors of philosophy to know that, three and a half centuries later, a Mabilleau, a Fiorentino, or a Ferri would doggedly set themselves to unearth their unpublished lucubrations from the dust of libraries, and throw on them the searchlight of criticism?

Men had reached that stage of lassitude and of wisdom when one understands perfectly how vain, how unworthy of occupying a thoughtful man, are the vagaries of logicchopping. There are only two vital forces: ambition and love. Anve of France reckons four: beauty, youth, wealth, and ambition; but these four terms are reducible to the former two. A doctrine of love, therefore, was necessary, and it was discovered in Plato.

Thus there were two masters in opposition, Plato and Machiavelli.

Plato is as much a poet as a philosopher, as worthy of admiration for his impressions and intuitions as for his ideas. He believes in beauty. It had been said that beanty was of no account, that it had no place in the gospels, that form signitied nothing except perhaps by way of symbol, that truth was metaphysical. That error had to be dismissed. Beauty has a real existence, and plays a supreme part in this world. God has not disowned it, Scripture reveals Him as bestowing life bountifully, and as taking pleasure in man as $\mathrm{His}$ own image. Plato in effect develops this same theory; what is more, he sings the praises of aestheticism in one of the finest languages ever lisped by human tongue. It was he then who furnished the desired formula. With him, men thought only of loving their fellows, of expelling evil passions by means of pure love. A sweet breath of spring fanned men's hearts; it was

${ }^{1}$ [Italian scholastic philosopher (i453-1539). His lectures attracted lorils and ladies who came to laugh at his ugly grimaces and ungainly antics, and at his amusing ancedotes and witticisms. His works include treatises on Beauty, ou Love, De Principe, etc.] 
philosophical and Christian. Did Luther conceive a reform as trenchant, as vital as that? Men went back to that blessed time when, without employing the quiddities of the Sorbonne and of German science, Heaven spoke the simple words to us: "Love one another." They believed they had found the secret of rejurenescence, of re-birth, and there were men so intoxicated that they went so far as to ask themselves whether Charity countenanced trade or taxes. The whole idea is summed up in a single line: power results in barbarism, civilisation is the product of bcauty.

This formula suits both strong and weak, everyone, indeed; it belougs neither to men nor to women, hails neither from north nor from south. The northern peoples, however, looking at Plato with a purely philosophical and technical eye, failed to discover it; at Venice, the headquarters of perfect editions of Plato, and at Paris, where he was acclaimed as a prophet, an ancestor of Christianity, where Florentine commentaries on him poured fast from the press, and where even a neglected commentary of Ficino ${ }^{1}$ was published, no one dreamed of seeking the recipe for happiness in Plato's philosophy. So greatly was he distrusted that the Italian Vicomercati, appointed in 1542 to the professorship of philosophy at the College of France, thought it his duty by way of returning thanks to immolate Socrates in his inaugural lecture.

It was the Florentines, with their keen appreciation of the good things of life, who discovered the artistic side of the platonic life. Women did not count for nothing in their first deduction, which consisted in so linking the objects of nature to the human personality that they should form thenceforth nothing but one long procession of the affections. At Florence this new religion was observed with tender and pleasing rites.

On the anniversary of Plato's death, the master's bust was crowned with laurel by invited guests, and then at a magnificent banquet spread under the pleasant shade, laudes and canzoni were sung in honour of the new spirit. Almost all were poets, and Lorenzo de' Medici chiefest among them. They maintained a strict conformity with Christian ideas.

1 [The leading Italian humanist (1433-1499); the first professor in Cosimo de' Medici's Flor'entiue Academy. Ile translated Plato under Cosimo's auspices]. 
The young Giovanni de' Medici, the future Leo X., who was bronght up among them, received at the age of seven valuable benefices with the ecclesiastical tonsure, and at thirteen was given the cardinal's hat. All the leaders of the movement, Ficino, Pico della Mirandola, ${ }^{1}$ Politian, were honoured with pontifical patronage. Rome also was the centre of a similar movement; there the academy of Pomponius Laetus ${ }^{2}$ resuscitated the grand days of the republic ; there men breathed as at Florence an intellectual air, light, keen and eminently free. To the Facetiae of Poggio, babbled out in a room at the Vatican before a select circle of jovial monsignors, corresponded the joyous atrocities of Panormita, the boon companion of Lorenzo the Magnificent. Everyone smiled, everyone was happy: the very bezants or golden pieces, the glory of the Medici escutcheon, sparkled in the sun like flashes of their wit.

The luscious warmth of the air, shady groves, birds, gardens, statues, antique marbles, thus played an indispensable part in the platonic philosophy. A banquet in honour of the nine Muses serves us as a map of this new world; Marzilio Ficino, chosen by lot, chanted to the glory of the divine character of love a superb song whose echoes were long to resound.

Learned critics have sometimes reproached Ficino with not sticking close enough to the text of the master, and with permitting himself ontbursts of virtuosity tinctured (so they say) with Alexandrinism. Likely enough; Ficino was Ficino, a man, independent, enthusiastic. no fanatic; he steered for happiness, and whatever his admiration for Socrates, he did not imagine that that great man had necessarily said the last word about everything, any more than he believed men eternally committed to Corinthian capitals. His dream was of a human dwelling-house, noble, coinfortable, habitable for us all, a living shelter for life! While pushing out glorious reconnaissances along the roads to heaven, Plato had clearly left men's minds undecided on

${ }^{1}$ [A prodigy of learning who wasted his energies in attempting to reconcile theology and philosophy, and died young. He knew twenty-two languages].

2 [An illegitimate seion of the house of the Sanseverini (1425-1477). He foumded an aeademy for the study of antiguity, and pushed his enthusiasm so far as to worship at an altar erected to Romulus, and to roam the streets garbed as Diogenes]. 
some points of great importance to their happiress, and it seemed wise to supply his deficiency by aceepting with closed eyes the explanations furnished by Christianity.

A thousand voices exclaim, like Montaigne and Charron, that the immortality of the soul cannot be proved by sheer force of reasoning. In any case, how long we have to wait! cries Margaret of France. For how many centuries have some who have fallen asleep looked for their awakening!

The Middle Ages replied to this question with their own terrible logie. They set us on the edge of the abyss, and there told us that in this world there is no happiness, but merely consolations; they linked us with a supreme life lying beyond us, like those hard, emaciated, immovable statues incorporate with the stone of eathedrals and themselves of the same stone. We live, they told us, with another life than our own, and love with another love; if we lose one dear to us we may cast flowers on the vacant chair or the needless cradle, altars of true life! Platonism prefers to take us for what we are. Not supposing that Providence sets man upon the earth to struggle against its own blessings, the platonists believed that in making religion more lovable they would make the world less pagan, and that in giving it a philosophical cast they would make it acceptable to unbelievers. Love seemed to them to be a reservoir of life, like those noble springs which leap down in some shady nook of a park, and flow on through a network of arteries more or less conspicuous, to give life even to the desert. Soon we shall no longer be; the hours of our life are sacred: what is the good of rufling them with so many disquietudes? It is a law of our life to yearn for Paradise, and there is nothing to hinder us desiring it in this present world.

The study of Plato, then, was entered upon freely, with the addition of anything that could throw light upon the doctrines which that great man hat founded-the Bible, for instance, which in the Roman world men prided themselves on consulting directly; then Arabic and even Mussulman philosophy, with which it was fashionable to claim acquairance. And it was well understood that a quest pursued with so subtle a magnificence, in seorn of realities and brutal sensualism, demanded a keen and eminently free intelligence, a soul at leisure, and a great loathing of the 
flesh; otherwise all hope of falling under the exquisite fascinations of love at once terrestrial and quasi-divine must be abandoned. That explains why from the outset this philosophy addressed itself to women and to the salons. Plato began to be talked about as we in our day have heard Schopenhauer and other eminent thinkers talked about by persons who have been at little pains to read them. It was known that Plato harped on the necessity of love, that his smile was less forbidding than that of S. Francis of Assisi, and that his method was dialogue, so naturally dialogues and conversations became the methods of the new platonists. From these tender colloquies the vulgar were excluded; they could make nothing of them; one could not expect common folk to apprehend the delicate devices by which love is etherealised and rendered impalpable; from these they would only have got a theme for gross perversions. Those who had the gift of knowledge and understanding ascended the Acropolis like M. Renan, to chant their canticles in a little temple of their own, whose dimensions seemed to them sufficient; the aristocratic mystery replaced the old priestly mystery; so Cataneo whispered, as it were under his breath, his book on love addressed only to the priests and temple choristers. Bembo took great care not to name the interlocutors male and female of the Asolani, "so as not to scandalise the populace"; all were agreed in religiously respecting the ignorance of the people, as to-day we respect the ignorance of young girls. And for the same reason, again, they made too prodigal a use of that strange mythological jargon which appears to us in these days so entirely pathetic. Mythology has its aesthetic advantages; it is an incarnation of the passions; but that would not suftice to explain its sickening vogue in a society full of taste, scepticism and levity, if it had not presented the one special advantage of furnishing a sort of technical slang by which the initiated recognised one another, and which sifted out the vulgar. The princes of wit felt so strongly the need of such distinctions that before adopting this garb for their works they began by muffling their own identity in an antique livery ' a Greek or Latin name served them as a uniform, ${ }^{1}$ as when San Severino called himself Pomponius

${ }^{2}$ So that nothing should be wanting, a Diogenes started running about the streets with his lantern and his tattered cloak (Paul Jove). 
Laetus, the old aristocratic pride yielding before this newfangled vanity. Artistic glory donned the conventional garb; no one had the preposterous notion of lamenting in Raphael the exquisite interpreter of Madonnas; what was deplored was the rival of Nature, the painter after the antique. "Raphael has resuscitated ancient Rome," exclaims Castiglione, "he has recalled to life and glory that Rome of old, that corpse devoured by sword and fire and time." That was the language of the courts, the ladies and the princes of the church ; they had said all when they compared Raphael to the painters of the Augustan age (with whose works we are notvery well acquainted), and when they remembered that the new Rome was only a degenerate if not a moribund Rome.

We dwell at some length on a state of mind of such peculiarity and complexity as this, and from which contradictory deductions were sometimes drawn, because we find in it the only possible explanation of the movement about to arise in France. Platonism was an impression, an essence of free-thought, purely aesthetic, Christian in principle though sometimes pagan in its results, warranted platonic in label and origin though somewhat eclectic in composition; a mystic incense in the worship of Venus, a subtle aroma floating in the air both of churches and of theatres; breathed in assemblies in the city; dominating the effluences of Nature under the shadow of country villas; open a book, and one caught a breath of it; even painting and music strove to interpret it fittingly; at the dinners and dances and in the thousand avocations of fashionable life it filled the air ; it exhaled as it were an immortal savour of orange blossoms; this was what they called a philosophy.

The platonist spirit, as Plato understood it, was often exactly the opposite. The women and the poets whom Plato condemned, ${ }^{1}$ the prelates who were the heads of Christendom, were its propagators. They were not greatly enamoured of Plato's somewhat socialistic theories. They went to Plato as we go to Nice, to obtain a little sunshine and escape the incessant din of controversy. It is a profound saying of Plato that "those who see the absolute and eternal and

${ }^{1}$ Erasmus archly observes: "When Plato appeared uncertain whether to set woman among rational animals or among the brutes, he did not mean that woman is merely an animal; he merely intended to point out the stupidity of this charming animal." 
immutable may be said to know, and not to have opinion only." That is what men desired: they would have run after illusions and even errors if only they made for happiness. What is the good of pursuing mutabilities? The wise man clings to that which tranquillises. Others may wear themselves out with anxiety and restlessness, but he enjoys his life of placid ease; in the end they die and he dies, and there is nothing to choose between them.

Before it could be turned to profitable account, platonism thus underwent a long and difficult preparation to bring it into line with the tastes of the day. The work was accomplished in Italy, whence the product was sent to us in a finished state. Good Plato, with his rather old-fashioned eyes, had seen beauty only in man; from one man he passed to the species, then from the species to the soul, that is, to intellectual beauty, which to him appeared the only true beauty. It was necessary to bring this doctrine into line with the practical doctrine of the special attraction exercised on man by the beauty of woman. Now Plato, besides giving man the beauty and woman the lave, attributed to love the secondary character of a sensual and egoistic phenomenon in which no spiritual element was discoverable save perhaps the instinct of immortality. Of this very instinct, however, Plato had an imperfect appreciation, for the immortality we might hope to gain by replacing our decayed bodies with the fresh young lives of our offspring, if it serves the interests of the human race, does not much serve those of the individual; at any rate, Plato considered it at once vulgar-everyone or nearly everyone being able to aspire to it-and incomplete, for transmission and conservation of life are not the same thing, and only a person very barren of intellectual resources could content himself with so modest a glimmer of immortality. A man only survives through his thoughts. The last shreds of the thoughts of Homer or Hesiod will live long, and will long cause temples to spring from the earth; what child of flesh and blood is likely to bear his father's glory thus on through the ages?

The earliest interpreters of Plato, Ficino and Politian, had departed with no little timidity from his teaching; the one eclectic and cantious, the other adventurous, they went nevertheless not much beyond formulating a general doctrine of love. Ficino exalted love as the supreme wis- 
dom, the creator and preserver par excellence; the link binding earthly things together, and the earth itself with heaven; the inspirer of great deeds and noble thoughts, a necessary element of life. He preached the love of love itself: "The man who loves, loves love above all; love is sufficient unto itself and finds its goal within itself; it is true and good and pure." But in order to bring himself into conformity with the new spirit, Ficino admitted as derived from Plato (though as a matter of fact it is not to be found in his works) ${ }^{1}$ a capital distinction upon which the platonism of the Renaissance was entirely to rest: there are two loves, different in degree, the one heaven-born and fixing its gaze upon heaven, the other born of Jupiter and seeking only to produce a form like him.

Francesco Cataneo insisted strongly on this invaluable distinction. Analysing man, he found in him a mind, the source of true spiritual love, and a sort of intermediate force hard to define, a "soul or life" whence sensual or, if the term be preferred, profane love has its' being. Cataneo moreover dealt hardly with profane love, representing it as bare-footed to indicate its foolishness, lean for lack of nourishment, and winged, for it is evanescent, dependent on physical beauty, on "worthless dross"; and it was because the world knew no other love that the preaching of a Reformation became necessary. As to women, Cataneo never ceased to consider them as stones of stumbling; inheriting all the old prejudices of the sehoolmen, he saw in women nothing but imperfect men created for the sole end of perpetuating the race, and man ever seemed to him the perfect type.

But with what warmth, with what passion Bembo, the Roman prelate and future eardinal, expounds the modern principles before the charming coterie of Urbino, and, flinging away the swaddling bands of early days, confesses himself frankly a feminist !

1 To this day this theory of two loves is commonly attributed to Plato, even in philosophical treatises.

${ }^{2} \mathrm{His}$ ardent oration has been reported in the Courtier of Castiglione, which became the breviary of the new society; we know that Castiglione faithfully reproduced his words, and, for greater accuracy, first submitted the manuscript to Bembo. [It may be as well to state that the passage quoted here is not a continuous quotation, bnt an admirable condensation of several pages of Castiglione. See pp. 343-363 of Hoby's translation in Mr. Henley's "Tudor 'Translations."] 
"The terrestrial beauty that excites love," he says, "is an inflowing (influsso) of divine beauty irradiating all creation. It rests like a beam of light on regular, graceful and harmonious features; it beautifies this countenance, shining in it, attracting all eyes to it, and through them penetrating, stirring, delighting the soul and bringing desire to birth therein. Love is thus really born of a ray of divine beauty. caught through the medium of a woman's face. Unhappily the senses interpose: a man sees in the body itself the source of beauty and longs to enjoy it. How deceived he is! It is not beauty that is thus enjoyed; an appetite is appeased, and soon comes satiety, weariness and often aversion. These deceptions and regrets abundantly prove what an error has been made, for a man must needs have found joy and restfulness if he had sought the true end, whereas on the contrary love gives rise to a thousand illsgriefs and torments, vexation and sullen fits, despondency, catastrophes even; the heart never attains the limit of its desires, or perhaps the man is so sunk in sensual love, declines so far towards the level of the beasts, as to become incapable of comprehending the supreme radiance. All these experiences are dearly purchased. Knowledge how to love comes only in ripe manhood: only the old indeed really have it, and their skill lies in eluding the impulse of the senses, in fleeing from all that is vulgar. If he can do no otherwise, a man must set his face steadfastly towards love divine, taking reason for his guide."

True love, then, is a disinterested love inspired in man by woman. And therefore Bembo, who was the more knowing in these things because he had loved deeply, was still young, and had not yet heard his own clear call towards love divine, lifts up his voice in a passionate prayer: " $O$ love, most good, most beautiful, most wise, thou that comest from divine goodness and wisdom, and returnest thither again, $\mathrm{O}$ thou cord binding us poor terrestrial and mortal folk one to another, thou bendest the higher virtues to dominate the lower! Thou dost unite the elements, thou dost perpetuate the life that perisheth, thou makest imperfection perfect, thou bringest discords into harmony, thou turnest foes into friends, thou givest fruit to the earth, peace to the waves, and to heaven its light of life! O father of true pleasures, of grace and peace, of lowliness and goodwill, 
O enemy of wildness and pride and slothfulness, thou art the alpha and omega of all good!

"Thou dost reveal thyself in terrestrial beauty! Hear our prayers, lighteu our darkness, guide us through the mazes of this world, rectify the falseness of our senses. Humbly we beg of thee balmy breath from the spiritual world, a touch of celestial harmony, an inexhaustible fount of true contentment! Purge our eyes of ignorance, and make us to see in its perfection the beauty of on high! Love is communion with the divine beauty, the banquet of the angels, immortal ambrosia!"

It is now time to answer an objection which the reader has no doubt formulated long ago, and which Bembo very clearly perceived.

Assuredly it is woman's mission among us to represent beauty, and consequently love, and love is the inspiration of noble thoughts and great actions. But these are such old truths that to find them hardly needed so much intellectual and poetic effort, or the harking back to Plato.

The learned book On the Nature of Love, in which Equicola essays simply an enumeration of the different species of love known since the thirteenth century, resembles a collection of butterflies. Every colour is there, brilliant or dull; the sentimental view is there represented in almost infinite shades, from the magnificent love of Boucicaut, who served all women for the love of one, the Holy Virgin, to the art of loving for love's sake, always fashionable in the salons, and sedulously cultivated as an excellent prescription for innocuous emotions and a cheap renown. Men well knew how to love, to be sure!

But love is rarely reciprocal; as someone has said, one loves and the other takes the kisses. So far, it was the woman who was recognised as the beauty, and consequently as the loved one, and who took the kisses.

The novelty of Plato's system was to transfer the beauty to men, which ran counter to a!l accepted notions. To Bembo this theory seemed intolerable. That women are capable of loving he firmly believed and rejoiced to believe. But to give up loving women appeared to him too cruel. He would much rather give platonism the go-by and acknowledge the reciprocity of beauty and love. In short, he fell back on Petıarchism. 
Michelangelo proclaimed the true modern platonism with extraordinary ardour in professing a love at once virile and pure. "I have often heard him reason and discourse on love," writes Condivi, "and I learnt from persons present that he spoke of it no otherwise than may be read in Plato. I do not know what Plato says, but I know well, having long had intimate intercourse with Michelangelo, that I never heard issue from his mouth aught but the most becoming words, apt to repress the lawless and unbridled desires that might spring up in the hearts of young men."

Michelangelo said more than once that God is seen in terrestrial beauty; love is only a hymn to the Creator; "for if every one of our affections is displeasing to heaven, to what end would God have created the world?" A great love makes only for the highest morality, it provides man with wings for a sublime flight: ${ }^{1}$

\footnotetext{
Thy wondrous beauty, image of the grace

That fills all heaven with glory, to us shown

By the Eternal Artist's hand alone,

When time and age have worn it from thy face,

Nor age nor time can from my heart displace,

But ever deeplier graven shall it be ;

For in my thought that beauty I shall see

Which Time's cold finger never can exase.
}

If the soul were not created in the image of God it would seek after nothing but external beauty; but it does in truth penetrate beyond this deceptive outer form, to tix itself on the essential, to rise until it attains the ideal or universal form: Transcencle nella forma universale. ${ }^{2}$ Thus beauty elevates and quickens us into the world of spirits and the elect. Many of Michelangelo's verses convey the same idea under different forms :

The fount that feeds my love is not my heart, For though I love thee, yet my love withal Is not to heart of flesh and blood in thrall,

But ever yearneth toward a goal apart,

Where no base mortal passion dare intrude, Nor any guilty thought nor impulse rude.

${ }^{1}$ Sonnet viii. $\quad 2$ Sonnet lii. 
A love without heart! Here indeed is the formula of the new platonism ! 1

Unfortunately, Michelangelo is a striking and titanic exception. He can scarcely be considered the head of a school: and platonism became for the most part nothing more than a fashionable science, the antidote to marriage; an intellectual union between a hard-headed, lusty-armed man and a woman all tenderness and wisdom; the formula of the government of man by woman. Its origin and its end remained equally philosophic ; in short, it was a sentimental sociology. If it had been a question of philosophy, no one could better have represented Plato than Savonarola. ${ }^{2}$

${ }^{1}$ Distinguished as she necessarily was, the lady who inspired such accents had herself nothing so tragic or so sublimc. She wrote :

Amor, tu sai, che mai non torsi il piede

Dal carcer tuo soave, nè disciolsi

Dal dolce giogo il collo, nè ti tolsi

Quanto dal primo di l'alma ti diede.

Tempo non cangiò mai l'antica fede;

Il nodo è stretto anchor, com'io l'avvolsi ;

Nè per il frutto amar, ch'ognihor ne colsi,

L'alta cagion men cara al cor mi riede.

$\nabla$ isto hai quanto in un petto fido, ardente

Puó oprar quel caro tuo più acuto dardo,

Contro del cui poter Morte non valse,

Fa homai da te, che'l nodo si rallente, Che a me di libertà già mai nol calse,

Anzi di ricovrarla hor mi par tardo.

[Thou knowest, Love, I never sought to flee

From thy sweet prison, nor impatient threw

Thy dear yoke from my neck; never withdrew

What, that first day, my soul bestowed on thee.

Time hath not changed love's ancient surety ;

The knot is still as firm; and though there grew

Moment by moment fruit bitter as rue,

Yet the fair tiee remains as dear to me.

And thou hast seen how that keen shaft of thine,

'Gainst which the might of Death himself is vain,

Smote on one ardent, faithful breast full sore.

Now loose the cords that fast my soul entwine,

For thcugh of freedom ne'er I reck'd before,

Yet now I yearn my freedom to regain.]

2 "Ye women who glory in your ornaments, your hair, your hands, I tell you you are all ugly. Would you see the true beauty? Look at the pious man or woman in whom spirit dominates matter : watch him, say, 


\section{THE WOMEN OF THE RENAISSANCE}

But Savonarola did not represent the inteliect of society; behind him men thought they caught a whiff of all the wretched tatterdemalions in revolt at Rome against the Academy of Laetus, at Florence against the Medici. On the other hand, Tullia d'Aragona, a courtesan, exercised a platonic influence through her excellent book On the Infinity of Perfect Love. Others unceremoniously dismissed Socrates and Plato as liars and knaves, and yet passed for good platonists since they extolled the religion of beauty, and woman as essentially its priestess; and since they saw in love the chain binding earth to heaven, and the bulwark against socialism. In short, platonism and feminism are one and the same. It is quite possible to believe implicitly in the dogma of love without splitting love in two and pinning ourselves on an impossible dilemma-matter without spirit or spirit without matter. This latitude of appreciation is not to be called materialism, but merely the need of a material perception in order to arrive at the idea of beanty.

This explains why the platonist spirit was so coldly received in France. Platonism was the art of rendering virtue pleasant and contagious; but in France it was the conviction that virtue needed to defend itself like the fretful porpentine. ${ }^{1}$

when he prays, when a ray of the divine beauty glows upon him, when his prayer is ended; you will see the beauty of God shining in his face, you will behold it as it were the face of an angel." (2Stin Sermon on Ezehiel).

1 “Monsieur, si vous estiez aseuré de la prudence et discrétion que vous dictes estre en moy, rous ne prendriez peine de m'escripre courte ne longue lettre, car ou deux telles vertuz consistent, une n'a lieu: qui servira de briefve response à tout ce que m'escripvez. De mon vouloir, il est tel, sans jamais changer propos, que je seray telle que je doibz estre, et que ne m'estimez estre si bonne par vostre lettre; ouy bien autant qu'il me sera possible, et quelque jeune d'aage que je soye, si cognois je bien que en suyvant ces deux devant dictes vertuz, l'on ne se peult desvoyer. Quant à l'audience que me demandez, je ne puis, et ne veulx; et, sans plus m'escripre, à Dieu prenez en gré et ne vous desplaise." (La Fleur de toutes joyerisetez).

[Here is the letter of a woman of the old style: "Sir, if you were assured of the prudence and discretion you say are in me, you would not waste your time writing letters, whether long or short, for where two such virtues are conjoined, a letter is but vain: which will serve as a brief response to all you write to me. My will is such that I am firmly resolved to be good, as I ought to be, though from your letter you do not think I am; ay, so far as lies in my power: and though I may be young in years, yet know I well that in seeking after the two aforesaid virtues one cannot go astray. As to the interview you ask of me, I cannot and I will not; and, without writing further, I pray God you may take it in good part and not be huffed."'] 
No one troubled about spiritualising love; the inferior clergy, parish parsons, applying in every matter a roughand-ready system of ethics, drew no distinction between sentiment and sensation, but proscribed everything. They summed up the religious life in a multitude of observances all having for result the subjection of women-a contracted morality which gave rise to startling inconsequences. It was pretended that the mere sight of a lady fidgeting about on her balcony was enough to tell you she was a Frenchwoman. ${ }^{1}$

Anne of France forbade lovemaking between fiancés, the best, most innocent, most legitimate in the world, just as strictly as the grossest intrigue; but Louise of Savoy was as little shocked at the one as the other.

There was bitter hostility between the two camps.

Madame de Taillebourg remorselessly turned her back on her nieces, Louise of Savoy and Margaret of France, as being tainted with the new spirit. Queen Anne personally led the crusade in favour of the old ideas; Antony du Four, her almoner, published semi-officially a collection of the lives of ninety-one pious women, as a counterblast to the Italian collections; and he implored ladies not to succumb to the new contagion, not to run out of their salutary groove, for, he said, Frince had never produced "more wise and good women than at present," beginning with Queen Anne, "a bottomless well of virtue." "Under the mask of science and philosophy" all these "prating and scribbling fellows" who wished to give women a great part to play were only seeking, declared Du Four, to sap their modesty and wreck their good name.

In these criticisms there was certainly a modicum of truth. But they went too far in anathemising the good and the evil without distinction.

${ }^{1}$ La Françoise est entière et sans rompeure :

Plaisir la meine : au proffit ne regarde.

Conclusion : qui en parle ou brocarde,

Françoises sont chef-d'œurre de nature...

Pour le desduict (le plaisir).

-Marot, Rondeau 13.

[Our ladies flawless are and all complete :

'Tis pleasure leads them; they look not for gain :

Conclusion : men will talk and scoff in vain,

For pleasure they are Nature's master-feat.] 
France, like Italy, had its "primitive" women-philosophers, apostles of the philosophy of love; but their numbers and above all their influence, owing to the opposition we have just indicated, were very small. They were women of admirable endowments and sterling qualities, highly educated, afire with energy of that somewhat melancholy cast necessarily developed by contact with a stern world. It is natural to cite, by way of example, that sometime lady of Beaujeu, Anne of France, a figure after Michelangelo's own heart, grand and severe as a cathedral.

We picture her always in her capacity as regent-the politician, soldier, and diplomate upholding the fortunes of France, and displaying in the greatest difficulties her incomparable genius. And yet her heart was not in this work; she filled her part as a family duty, she devoted herself to it entirely, but it was the cross of her life. As soon as she could she forsook her toilsome life of affairs, for no other reason than to return to the life of the affections. She shirked neither toil nor responsibilities, and understood perhaps more fully than anyone else the profound and mysterious joy experienced by lofty souls in impressing their own individuality widely upon others. But she was only too conscious that in plying a rnan's trade she was acting like a widow or an elder sister, not like a free woman or a princess, and that neither politics nor military service was directly conducive to happiness. She knew that in crushing rebels she would not make them happy, and that she herself would be the first victim of her devotion.

She was right. We know how, in the swing of the political pendulum, she fell beneath the strokes of Louise of Savoy, ${ }^{1}$ who owed everything to her. Wounded in her

${ }^{1}$ Cornelins Agrippa furnishes a curions piece of evidence on this point. Disuraced by Louise of Savoy, he asked himself what had caused the princess's hatred. While pondering the matter he mechanically opened his Bible and lit upon the passage where Ahab says in regard to the prophet Micaiah, "I hate him, because he doth not prophesy good concerning me." "That's my very own case," cries Agrippa, and remembers that one day he had foretold a victory for M. de Bourbon. What victory?-he did not say, and for good reasons: but that was enough. So he takes his pen, and writes a long address to prove that he is not, has not been, and will not be of the Bourbon party, in spite of the overtures made to him. He got nothing by his prose; some time afterwards Bourbon was killed at Rome, and, adds Agrippa, "Jezebel possesses his vineyard. The angel of the Lord has warned me and saved me from the evil woman. Nothing remains but to fling Jezebel headlong and give her carcase to the dogs." 
liveliest interests, in her dearest affections, in the sentiment of dignity she held so high, she died proudly, as Caesar died, with her mantle wrapped about her:

Elle attendoit venir l'heure opportune

Que la justice on Dieu y mist la main, ${ }^{1}$

as a servant of Francis I. wrote.

Her coldness then was assumed, but she kept up the appearance of Stoicism so well that many a man, even among her friends and admirers, really believed in this lamentable insensibility. Again, Anne of France had no love for the vanities, the whole trivial round of court life; "she dismissed Cypris to Paphos," for which some persons found it difficult to forgive her, particularly Octovien de Saint-Gelais, who nevertheless has extolled her sweetness, calling her "a second Semiramis, a new Queen of the Amazons, come to life again to establish peace." Her vigorous intellect, her frank and remorselessly sincere disposition, her way of treating everything on broad and general lines, puzzled the rude yet feeble folk around her. The only thing she lacked, as one of her friends said, was love:

S'elle avoit un peu de cella,

Ce seroit la plus accomplye

A qui Dieu donna oncques vie. ${ }^{2}$

She had a large, indeed an immeasurable quantity of "that," but she took it seriously; it might well be said that she did not set "her whole imagination spinning round problems of sentiment." She had no idea of bringing imagination into her affections, but distrusted it; it was through the soul and the rea? needs of the soul that she caught glimpses of the ideal life of which we have just spoken. But having faith in, rather than enthusiasm for, these ideas, and considering as she did that the heart's activities were perfectly reasonable, beneficent and necessary, she saw no reason for ruffling, gilding or engarlanding them. She was somewhat lacking in suppleness, self-sacrificing, of un-

I Awaiting thus the seasonable hour

For justice or for God to interpose with power.

${ }^{2} L$ 'aisnée Fille de fortune. ["If she had a little of that, she would be the most accomplished lady God ever gave life to."'] 


\section{THE WOMEN OF THE RENAISSANCE}

bounded good-heartedness, staid in demeanour, firm in resolution, but also warm, passionate, loving to devote herself to others and not doing so by halves. In her heart of hearts she adored all that a good woman adores-her son, a poor child whose death almost killed her, her daughter, her son-in-law, whom she loved as a son; she took an ardent delight in friendship, and above all in that special, delicate, tender, profound affection which is only establisived between a man and a woman; to win love was her sole ambition. ${ }^{1}$ She buried deep down in her heart an innocent romance which no historian has related and which even her intimates appear never to have suspected-a reserve which paints her to the life! Till the day of her death she wore a ring on her finger. We have discovered her secret: the ring was the pledge of her betrothal to a young duke of Calabria from whom her father had separated her, who had soon afterwards died, but whom she was never able to forget.

This certainly was one of the women most likely to understand and to promulgate throughout France the programme of the quest for happiness. She did not believe with $\mathrm{Du}$ Four that a sort of passive naïveté was the ultimate expression of virtue; she sought another goal, anxious, doubtless, that love should give a powerful stimulus to woman's activities, as it had done for the women of Spain, whose imagination was filled with Zenobia, Queen of Palmyra. Her friend Champier has rounded off her thought by recalling Plato's saying that "the lover is dead to himself and lives in another." Deeply read in the church fathers and the philosophers, she hailed with joy the principle of platonic love, "the love of which the philosopher speaks, that is, a love founded on purity."

For all her lofty station, however, Anne of France never found herself able to popularise her ideas in a country where an idea only succeeds when it becomes a fashion; the new philosophy had perforce to come like a flood, sweeping good and evil along with it, and imposing itself by the authority of the court. That is what happened around Francis I.; as soon as it became a mark of good taste to

${ }^{1} \mathrm{La}$ Vauguyon describes with emotion the sorrow of her servants and vassals: "What will become of us now?.. Death has seized our mother." 
talk philosophy and occult sciences, ${ }^{1}$ Hellenism, ${ }^{2}$ and above all Italianism, and to adopt ultramontane fashions wholesale, people chattered about Plato. The king dearly loved the ladies, and could not despise anything that glorified the sex. He set some store by "Noble-Heart," "Feminine Noblesse," 3 and other subtle evocations of the old chivalry; he hoped that platonism might succeed in renewing them, and requested Castiglione, the oracle of the new school,

\author{
1 Bonnet entendoit la magie \\ Aussi bien que l'astrologie: \\ Bonnet le futur prédisoit, \\ Et de tout présinges faisoit... \\ Bounet sçeut la langue hébraiqque \\ Aussi bien que la calclaïque; \\ Mais en latin le bon abbé \\ N'y entendoit ny A ny B. \\ Bonnet avoit mis en usage \\ Un barragouin de langage \\ Entremeslé d'italien, \\ De françois et... saroysien. \\ Bonnet fut de l'Académie, \\ De ceux qui souflent l'alchnmie.
}

-Du Bellay, Epitaphe de l'abbé Bonnet.
[Bonnet knew astrology
As well as demonology.
Bonnet the future could foretell
And cast your horoscope as well.
Bonnet knew the Hebrew tongue,
And in Chaldee spake and sung,
But, good soul, in Latin he
Could not say his A B C.
Bonnet used with good intention
A jargon of his own invention-
Words from France he would employ,
From Italy and from-Saroy.
And in academic state
Of alchemy Bonnet would prate.]

2 Montaigne, bk, iii. cap. $x$.

${ }^{8}$ A naïve French poet, with the words 'grace' and 'hope' ever on his lips, somewhat scornfully depicts the French court guarded military fashion by two Italians, Pasquil and Aretino, whom he styles Bohemians of sinister aspect. 'Diligence' and 'Bon Vouloir,' old deities of the past, had much difficulty in approaching. "Noble Cœur," says a poet, "found his 'temporal joy' in chatting witl and serving ladies ; Nature encourages Noblesse-Féminine to rule men, who include good and bad. In a delightful garden the tree of Humanity flourishes; this splits into two equal branches, that is, between the two sexes 'one in being, one in substance, one in dignity,' and differentiated only by accident. Vilain-Cœur and Malebouche have long been devising mischief against Noblesse-Féminine; at the instigation of Nature, Noble-Cœur at length arms himself in her defence." 
to furnish a pendant to his Courtier, to be called "The Courtesan." Castiglione declined this flattering invitation.

When Francis I. ascended the throne it was as a member of a sort of triumvirate, the other two being ladies-" a single heart in three bodies."

Louise of Saroy, aged and old-fashioned, reserved politics as her sphere, as far as possible; Francis retained the pageantry, the money, the passages at arms, the material satisfactions of power; Margaret of France, in the Italian style, assumed the direction of men's minds and souls; she was far more queen of intellectual France than Duchess of Alençon or Queen of Navarre.

She so completely identified herself with her brother as avowedly to borrow from him her whole status, and particularly her name. People have called her by the most various names without really understanding why, owing to the fact that she usually adopted her brother's name, which frequently changed. As sister of the Count of Angoulême she called herself Margaret of Angoulême; under Louis XII., as sister of the Duke of Valois and the heir to the throne, she called herself Margaret of Valois or of Orleans; as sister of the king she became Margaret of France, her definitive name, under which she accomplished her mission.

For thirty years she presided thus over an amazing intellectual movement; the whole thinking soul of France hung upon her smile. She was the incarnation of platonism.

In one of the galleries of Chantilly, that sanctuary of the Renaissance, her grand face, with its long, severe, clean-cut, distinguished features, somewhat hard as though chiselled out of alabaster, continually smiles upon us and encourages us. Her eyes are clear and full of fire; her mouth is fine, intellectual, with something of irony, of benevolence and of reserve; something at once yielding and defensive, acerbated and enthusiastic, a singular sibylline countenance, the enigma of a spiritual governance-the rule of mind and heart; a woman to the core, attractive and wishing to attract, but two personalities in one, each interpenetrating the other, concealing her real self within two or three inner entrenchments after the old feudal tactics, like St. Theresa in her "fortresses of the soul."

She reigned with undivided sway, with all the powers of 
her affection, with her infinite womanly delicacy, with triumphant skill.

She was in very truth a woman of fire, this woman who wrote to her brother while a prisoner in Spain: "Whatever may be required of me, though it be to fling to the winds the ashes of my bones to do you service, nought will be strange, or difficult, or painful to me, but solace, ease of mind, honour."

And she was loved; men never tired of praising her. Her name became a household word, and lives on even in our own day in charming books, like that devoted to her by a lady of rare genius, chosen by Nature to revive the traditions of woman's influerce-the Countess d'Haussonville. And yet we are always wondering what is behind that smiling countenance at Chantilly.

Margaret is doubly complex, first as a woman, and then as a typical woman of the sixteenth century. She is essentially a woman of her period, and that is why she cannot but interest us. Her thoughts, somewhat hazy, and sometimes wrapped in rather odd garbs, are difficult to coordinate because, unlike those of Anne of France, they have no spontaneity or originality. Almost all of them are derived from without. Her lovable mind is like a mountain peak of fair height, with nothing rugged or bleak about it: it promises no sublime effects, no Pisgah sights; it pleases and interests us precisely because we can reach its summit by an easy road, for which many of us are grateful. Is not that better for poor tired folk than lofty masculine heights profitless and perilous to scale? It springs gently from the landscape, like the pleasant mountains in the heart of France, and while enabling us to take observation of the sky, keeps in touch with the earth, and from this standpoint we can contemplate, spread out like a map, a smiling country and highly decorative craters. It is the "Belvedere" par excellence. Nowhere could we judge her period better than from the vantage ground of her mind.

But it is very clear that it would be a mistake persistently to look for in her the peaks and abysses she does not possess. It has been proved to demonstration that, given certain circumstances-if, for example, he had only been killed at the siege of Toulon-Napoleon would have died a 
captain of artillery; and doubtless Margaret of France, but for the accession of her brother, the wave of feminine Italianism, and possibly many other circumstances, would have died wife of the Duke of Alençon or the King of Navarre, or even less. Yet we can realise better than ever to-day how vastly important her leadership was. Her generation was that from which we are sprung, to which we owe our blood and sinews. Our society is experiencing almost the same uncertainties and the same attacks; it needs intelligent and active women as much as ever. Margaret was less bent on being an exceptional woman than on fulfilling her part as first lady of France. She played her part very well; she had her Pléiade. ${ }^{I}$ And at her side she brought up as her successor another Margaret, her niece, the future Duchess of Berry and of Savoy, who did in fact continue the tradition-not less amiable, not less distinguished, but coming later and consequently more charming still, and above all, more calm and self-contained.

Margaret of France had never read Plato until towards the end of her life, and then, when she discovered him, she believed she had found her guiding star. On the other hand, she did not permit Boccaccio to be forgotten. Her philosophy, then, was not very psychological, but it was eminently social. The theories of Bembo seemed to her to endow women with a large and beneficent measure of power; and that was enough. It must be confessed, however, that she looked at social questions themselves from a somewhat superior standpoint, and with a necessarily discriminating favour. She knew but one person, her brother, who even in the most manifest errors appeared to her the ideal of perfection, "the true Christ." Apart from him she loved none but God, and she adopted as her emblem a marigold turned towards the sun, indicating her purpose to live and breathe only "for high, celestial and spiritual things"; other things, husbands included, seemed to her paltry and mean. And thus, as a woman of intelligence, she hoped to

${ }^{1}$ [In reference to the group of seven literary men who banded themselves together to reform and classicise the French language and literature. Ronsard, Du Bellay, and Baif were three members of the Pléiade who reappear in the following pages. But as the manifesto of this coterie was issued in 1549, the year of Margaret's death, the name Pléiade is anticipated for the literary court she maintained, the most notable members of which were Marot and Bonaventure des Périers.] 
reign through the affections; her most assiduous flatterers only extolled her heart; even after her death a pious respect continued to watch over her works, of which a selection was published. And yet she gave only her intelligence to the world.

Her theory of love is peculiar enough. Love of course appears to her the corner-stone of the social edifice: in itself it is always good, only becoming bad by the use made of it. Margaret is eminently platonist in the sense that she proclaims the existence of two loves, a good and a bad; but to her the distinction between them is simplicity itself: the one is man's love, the other, woman's; men love with an evil, earthly love, women alone can love celestially. Sometimes they chance to allow themselves to be caught in the snares of men; let them flee then, for "briefest follies are always the best." Thus loving is for women. The love of a woman, established firmly in God and on honour, the same love that Henri d'Albret styles "hypocrisy or covert malice," forges a divine and holy chain. Margaret never tires of expatiating on the virtues of women's love, a pure and ardent love, the instrument and the end of civilisation, the highest form of human activity, the prayer admirable beyond all other prayers that a living creature can address to the Creator. In the vineteenth tale of the Heptameron she gives this love a very eatholic definition, borrowed almost word for word from Castiglione:

"I call perfect lovers those who seek some perfection, either goodness, beauty or grace, in the object of their love, those who incline always to virtue and have so lofty and refined a heart that, even at the price of death, they would not aim at base things that honour and conscience condemn. The soul was created but to return to the supreme good, and so long as it is encased in the body, it can only long and strive for holiness. But the sin of our first parent has rendered dark and sensual the senses, the soul's inevitable intermediary; seeing only through them the visible objects which approach perfection, the soul hastens to find in outward beauty, in visible grace and the moral virtues, the sovereign beauty, grace, and virtue. It seeks them, and finds them not, and passes by ; it essays to mount higher, like children who, as they grow bigger, must needs change their dolls. And when at length mature experience shows 


\section{THE WOMEN OF THE RENAISSANCE}

that neither perfection nor felicity is to be met with in this world, the soul pants after the great Author and the very source of the beautiful. But then may God open its eyes! otherwise it must speedily stray into the paths of false philosophy. For faith alone can reveal and bestow what is good, which carnal, natural man by himself never could attain."

Thus the worship of beauty is not necessarily mystical, but it is a true religion. We come from God, and we return to God through hope and love much more surely than through any sort of reasoning. The holy love of the beautiful, of perfection, purifies the soul better than any practical efforts, and little by little raises it to the ideal perception of perfect beauty. The soul then wings its flight towards God, sustained by faith above unfathomable abysses.

And so it is necessary to proclaim happiness, peace, gentleness, joy to men of good will, and even to others, if they are to be lifted above themselves, their ambitions, their hatreds, their coarsenesses. What a mistake it is to preach a religion of terror to poor creatures too wretched as it is !

Oh, que je voy d'erreur la teste ceindre

A ce Dante, qui nous vient icy peindre

Son triste Enfer et vieille Passion. ${ }^{1}$

Let women learn their duty!

They are priestesses in the religion of Beauty.

They must win love, they must themselves love! They must be balm poured upon aching wounds, the beauty that soothes, the love that accomplishes a new Passion, taking upon itself all the sorrows of others. Of old, a great noble had been recognised by his knowing how to give, and by his giving, not of his superfluity, but a portion of himself -his blood to his country, his strong arm or his affection to his brethren. It only remained to feminise and spiritualise this superb tradition. Women will give their hearts, in other words, they will diffuse happiness, fellowship in the supreme life, life itself! "Love is that which really makes a man, and without which he is nought."

\section{Margaret to the King, 1534.}

[Al, with what error Dante's head is crowned, Who comes to paint his Passion, antique tale, And with his gloomy Hell our souls astound.] 
Life! Alas! at this word Margaret shudders. She longs to penetrate the great secret of our destiny. She stoops over one of her gentlewomen lying at the point of death, to see if she can catch the passing of her soul! She receives a lover at the tomb of the lady he came to meet, and with a tragic gesture cries "She is there!" She loves and preaches nothing but life. She knows that death is inevitable, but hopes that this accident may come to her without lingering in long "suburbs," and she casts herself with confidence upon the God of platonism whom she believes in, whom she feels to be all love. From terrestrial love she expects to escape at one bound into the arms of the other, the Great Love; "from the felicity which alone in this world can be called felicity, to fly suddenly to that which is eternal."' And thus in her eyes man's natural end is enfolded in love and hope resting on faith. There, in the heart of the villages, covered with moss and honeysuckle, are the humble tombs, the sacred shelter of those we have loved, clothed all about with life hard by the radiant crucifix! A sunbeam floods them in light, like a stream of love from on high. The same ray penetrates our hearts, telling us that all is not ended, and that a little joy is still blossoming upon this spot of earth. Let us leave God to count the flying moments-leave it to Him in full confidence and peace!

Like all human things, platonism cannot attain perfection; it necessarily has little to say in regard to man's birth and death. To complete the reformation it would perhaps be necessary, as Goethe suggests in the second part of Faust, to discover a means of manufacturing homunculus, in other words, of effecting human reproduction in some other way than the old; moreover, instead of being allowed to die, men might comfortably be translated to other worlds. But, meanwhile, platonism is the philosophy of the living, and in truth it is remarkable to see a secular movement basing itself on such lofty systems, and turning to such noble account, intellectually, morally and religiously, the natural desire which the world always has of amusing itself.

A strange generation was arising. Between 1483 and 1515 Luther, Calvin and St. Ignatius, Rabelais and St. Theresa, were born pell-mell. And yct, thanks to this philosophy, everyone wore the livery of happiness. Dagger

${ }^{1}$ Heptameron, Tale 40. 
and poison hid themselves in the shade. Never were the most agitating problems more cheerfully discussed. Yes; women know the real value of the visionary and the immaterial, of something higher than hoards of mere gold and silver-the value of the riches of the soul. The Latin world was at this moment becoming a vast workshop of beauty, the real worker being no longer the digger or the merchant, the mason or the hodman, but whatever man lived a life of thought and love. There was extension and broadening out in all directions; material barriers were being overthrown; the religion of Beauty was bringing nations as well as individuals together. And the women, the ministers of the affections, had for their mission to watch, to judge, to temper, to develop the faculties of men. They thought it a beautiful mission. Can we wonder at it? They burned with the ardour of paladins; they fancied themselves knights-errant, and displayed devices-Non inferiora secutus, a masculine hemistich which men had relinquished, but which Nargaret of France resumed, to show that she bore high her white petals and her heart of gold: "Love and Faith", in other words, "Women and God," the motto of Madame de Lorraine-a motto full of joy and charm, for if men love because they believe, and believe because they love, life becomes an unalloyed delight.

Between mysticism and debauchery a middle term had been found, namely, love.

When women know how to attach men to them by means of pure-love, all individual forces gain vigour, a nation flourishes, and the people are at peace.

That, at any rate, was the new conviction. 


\section{CHAPTER II}

\section{THE SCIENCE OF PLATONISM}

THE doctrine we have just indicated never excited any very determined opposition as a theory; its adversaries re. served their objections for its practical working. The New Law, it is true, had redeemed us in love; but the politicians held the same opinions as the moralists of Du Four's school. From Machiavelli to.Calvin, many men thought the bludgeon a simpler and more effectual gaide for humanity than sentiment. At best they would have favoured a sort of sentimental sociology. They regarded everything else as a mere philosophic dream-Eden, of which barely a glimpse had been caught before it was guarded by the angel with the terrible sword; the burning bush from which issued the voice of God, but near which Moses dared not kneel for fear his garments should take fire and the flame scorch his flesh.

Assuredly, the practical science of platonism is more difficult than its metaphysic; it assumes that women have the knack of cleverly taming men by means of love's blandishments, without getting scratched themselves. The cleverest lion-tamers are sometimes clawed, but they have been known to die in their beds. Here is the question in a nutshell: Are women capable of following this tamer's vocation and making themselves sufficiently invulnerable? and secondly: Are men tamable?

On the first point the friends of the beautiful displayed the utmost confidence. They made their appeal to women, sensitive-more than sensitive, refined-fortified by marriage against materialities, and inspired only with disgust by the vulgar vice that came under their eyes and even in their 
own circle. As Du Bellay says, Cato's manners harmonised perfectly with Plato's discourses. Margaret of France unhesitatingly descended into the den and grappled with her friend Bonnivet. ${ }^{1}$ She believed in the invulnerability of women, as also did Castiglione and many others. The platonists found no difficulty in justifying their position; they cited heroic examples of feminine virtue even in the remotest antiquity, and they met other admirable examples in the ordinary intercourse of life. Castiglione and Dolce show us women who in the vilest environments were angels of chastity. In most cases they were young girls, for instance a poor girl of Capua (very often cited) who flung herself into a river to escape a troop of Gascons; a poor peasant girl of Mantua, who, betrayed by a scoundrel, drowned herself with a sort of frenzy, flinging away all the ropes held out to her-a tragic suicide, anti-Christian as such, yet so Christian in its grandeur of despair that the Bishop of Mantua proposed to erect a statue to this noble woman of the people. Unhappily he died before he could carry out his idea; in those days people fought shy of inartistic statues.

Such examples of virtue were not met with only among the lower classes, which are naturally the most exposed to danger. All Rome was stirred to its depths by the dreadful fate of a young gentlewoman who, having been decoyed into the catacombs of St. Sebastian with the connivance of a maidservant, strangled herself rather than yield to the violence of the miscreant who devised the snare. She might well have been left to rest in the dim twilight of those silent vaults, where so many pure victims sleep under the seal of a cross and a dove; but Rome could not leave this flower of virtue to be forgotten, even in so sacred a spot: the poor body was crowned with laurel and borne in triumph like a trophy through the thronged streets of the city, the same fever of euthusiasm infecting both hovel and palace.

No, women are not naturally sensual; animalism is utterly abhorrent to them, and however much their education may have been neglected, their deepest feelings are

${ }^{1}$ [French admiral (14SS-1525), who after the defeat at Pavia deliberately threw his life away. He rivalled Francis I. in gallantry, paid sedulous court to Margaret, and is said to have been the luckless (and wellscratched) hero of the nocturnal escapade described in the 4th Tale of the Heptameron.] 
won by a man's intellectual qualities, his moral authority, much more than by his physical beauty, a beauty often hard to trace. When they love deeply, even when they yield themselves, it is still with a sentiment of reserve and modesty; it would also seem as if they cannot dispense with the additional refinement of respect. Man, on the contrary, as all the world knows, has no sense of shame, and to get every possible enjoyment, love or no love, is his only aim. It is to singularly terrestrial Venuses that peoples and kings, judges and culprits, flock pell-mell. Is this a reason for despair? Cannot the obvious feebleness of women, their delicacy, the almost religious character of their love, become an element of attraction and power? Women, we are told, deliberately expose themselves to sharp tussles. That is true. But if men were platonic, what merit would women have in being platonic too? And surely no one would impose on men, as the first rule of intercourse, the obligation of remaining in marble coldness beside beautiful creatures of passion, whose very nature is to set their pulses throbbing! "Ah! impossible!" cries Margaret of France, to whom the mere idea seems almost an insult. It is wise to recognise danger, but it would be disgraceful to flee from it! In France, a country hostile to the beautiful and to sentiment, the women who preached the gospel of love were, as we have said, high-born dames, whose very position made them wardens of men's souls, and whose nobleness constituted part of the public patrimony. Maybe they did not believe themselves predestined to impeccability; but while enjoying a wonderful store of goodness and benevolence, they were at the same time proud, high-strung, courageous. Far from terrifying, peril inspirited them; to shrink from it would have appeared disgraceful to Anne of France, who represents prudence incarnate. Women are not so frail as people are pleased to say. They are only frail when they wish to be ; and then it is duty that guides their steps.

The real difficulty, then, does not lie in this direction. The difficulty is to discover a sure method of capturing men. We have already outlined the two theories; there are likewise two practical systems.

The first consists in really devoting heart and soul to the matter, the second in the mere playing of a part. The first 
is concrete, actual, full of zest and energy; the second is nothing but abstractions, coquetry, poses, and never extends beyond mere sentimentality. Anne of France, manifestly wedded to the first system, speaks of it with a warmth and yet with a wealth of circumlocution that show, not only how much the' question interested her, but how troublesome she found it.

A woman, she thinks, should not push enthusiasm so far as to run to meet love; she may wait for it, it comes soon enough unsought. In spite of her very real simplicity, she always impresses us as having a touch of pride; and besides, she was writing for her daughter. But what a noble heart is hers, how ardent and how generous! She distrusts the love excited merely by physical beauty, because she regards it as imperfect, undistinguished, commonplace, of little stability, subject to all sorts of disappointments and regrets; but no less-accustomed as she is to deal with things broadly and grandly-does true love, that which wells up from the heart and mind, and is only strengthened and sanctified with increasing years, seem to her precious and firm. When a man can analyse his love and tell himselt that it depends on some definable beauty, however exquisite-that of the eyes, perhaps, or that of a charming. manner or an uncommon mind-in this case the love is slight. But when it takes entire possession of him, when he knows not how to describe it nor to what to attribute it, when it surprises him in the plenitude of his vigour, and keeps him in subjection to another person of whose will he becomes the mere echo; above all, when it inspires him with the overpowering consciousness that henceforth his life may be bounded by no other horizon: then it has a superb. range; it possesses soul and heart; the rest is merely supplementary - a more complete intimacy, a pledge of affection. The woman a man most loves is not the one he covets most. At twenty it is easy to confuse sensations with sentiments; and that is why true love is not known till later. It is a gradual unfolding; and then it becomes so ardent as to bring into play all the impulsive forces of the mind. It is by this new emotional fruitfulness, by this responsiveness, so to speak, to the spur, that a man's worth is measured. Externally, on their commonplace side, all men are alike; their souls alone have different physiognomies: a time comes. 
when they are stirred to the depths, shaken out of themselves, and then it is seen that there are great souls and small. Not too great, however, nor too small; but quite human! We cannot expect miracles, or look for the perfection God has reserved for Himself. But sometimes the reality is better than appearances promise: "'Tis not the cowl that makes the monk." We should not be too ready to take fright at an inconsistency, or to despair of men who err by excess of genuine sensibility. These are the easiest to convert.

Anue of France believes in a method of princely candour. She objects to any woman, with the best intentions in the world, appearing to promise what she is firmly resolved never to grant; in this regard it would be better to retreat at once, with no false shame, and quietly await another occasion for giving battle.

If, on the other hand, love presents itself under reassuring aspects, it may be accepted. Honourable love is so beautiful, so full of "benefits and honours"! But precisely because it is so delightful a condition it is rare, and the devil leaves nothing undone to poison it,and therefore it is well to advance with much practical prudence,even with distrust! The world is so vile! Sweet love has often come to a bad end! In discussing this tender and mournful psychology, the great princess would seem, under her mask of impassibility as a philosophical woman, to utter a cry of pain as though bleeding from an internal wound: "I have known a knight," she says, "who heaped oath on oath of the most sacred character, even on the holy altars, on the gospel, and who did not keep them even till the evening." She is one of those who, giving the heart, give it wholly, and how perilous that is is manifest. A genuine platonist, however, she acknowledges no degrees in honour; there is no splitting it up ; it must be preserved in its entirety: and the primitive, strenuous, almost naïve lady concludes that chastity does not consist solely in "saving oneself from the overt act." Among the women who skate more venturously near the danger point there is not one in a thousand, she thinks, but has lost something of her honour or of her illusions.

Of this sculptural view of love-majestic, holy, like certain of Wagner's harmonies, but necessarily very rare-Michelangelo is a practical exemplification. 
Madly smitten, at the age of fifty-one, with a lady of thirty-six, whom, however, he did not see till twelve years later; so mastered by his agitation as to pen two extraordinary letters-which, incomprehensible as they appear, Messieurs Milanesi, Gotti and Mézières have succeeded in interpreting-writing one letter three times over without making up his mind to send it (it never was sent) - that was the man known as Michelangelo.

Why did he love the Marchioness of Pescara! For her beauty? No. For her wit? No. He loved her because he loved her: there is no more to be said. He asked nothing of her. She was the woman of his heart; to her he dedicated all the fibres of his being. He saw with her eyes, acted by her inspiration, " no longer conscious of aught but the memory of her." And he was happy, and unhappy. What energy of expression there is in his sonnets when his vigour bursts out in passionate laments! But for the most part this vigour seems itself to yield to respect and enthusiasm.

A genuine patrician, sweet and unaffected, the marchioness understood with wonderful intuition the man who was addressing her, and proved what in such a case a woman may do with a man. Condivi, who had seen her correspondence, described it as full of a grave and profoundly moving love; the fragments which have come down to us indicate a thousand little tendernesses: "Our friendship is stable, and our affection very sure; it is tied with a Christian knot." And here is the address outside a letter: "To my more than magnificent and more than very dear Messer Michelangelo Buonarotti."

It was the same with their talks together; love only served to give their conversation an elevated tone. A certain François de Hollande, who happened one day to be in their company, has preserved some characteristic fragments of their conversation. The marchioness was formulating quite a scherne of splendid idealism: "Painting," she said, "better than any other means, enables us to see the humility of the saints, the constancy of the martyrs, the purity of the virgins, the beauty of the angels, the love and charity with which the seraphim burn; it raises and transports mind and soul beyond the stars, and leads us to. contemplate the eternal sovereignty of God. . . . If we 
desire to see for ourselves a man renowned for his deeds, painting shows us him to the life. It brings before our eyes the image of a beauty far removed from our experience, and Pliny held this to be a service of priceless value. The widow in her affliction finds solace in gazing every day upon her husband's picture; young orphans owe to painting the happiness of recognising, when they have come to man's estate, the features of a beloved father."

Is not this true love, to love the beautiful, the object of love to so many besides ourselves? Is not this the enchanting joy dreamed of by Anne of France, so sweet for a woman, and lifting a man "beyond the stars"? But this love is terribly individual and exclusive!

Twenty years Jater Michelangelo lost the lady of his soul. He stood by her death-bed. With reverence and pity he pressed a long kiss upon her hand, not daring, even at that tragic moment when Death purifies all things, to touch ever so lightly that pale cold brow; though many a time, in truth, he regretted the timidity of his farewell. Condivi tells us that he was frantic with grief. Night had closed her wings upon his life; he could never hear the marchioness mentioned without tears starting in his eyes: "We had a great mutual regard," he said; "Death has snatched from me a great friend." A great friend! He became religious; in his robust old age his soul maintained its fire, like some deep pool which, in the blackness of night, still reflects the sunset glow. He died at the age of ninety, and among his papers were found the letters of the marchioness, and the sonnets he wrote for her-though cunning pilferers had carried off a portion of these, which, unhappily, they kept for themselves.

The other, and more numerous, school of platonists started from an absolutely different principle. It was much less individual, and much more sociological. It was cultured, to all appearance without enthusiasm, keenly sensitive, wholly of this world, or if it moved at all toward the ideal it was by many tortuous, obscure and labyrinthine paths of which it would sometimes be difficult to draw an accurate map. It was philosophical; its method was to coax the human animal, to converse with him, to lure him with smiles and soft words, and to wind about him a multitude of slender cords till he was reduced to helplessness. 
The method was considered eminently laudable, and indeed it demanded infinite tact, time and patience; for what was involved was nothing less than the training of "the other partner" in habits of refinement and discretion-to content himself with a few tit-bits of love or kindliness, to refrain from constantly showing teeth and claws with a cry for his "reward"- - the wolfish cry, the roar of the beast of prey! A light hand was needed. Men, snared in cold blood, appeared so commonplace, so much alike!

The little favours by which men were held captive were in no way open to censure; they were virtue itself, for the end justified the means. The art which regulated the dispensation of these favours may justly be regarded as a complicated one. It grew out of long habit, and was not learnt from books; it was the Machiavelism of a special charity, a supreme devotion, very often the immolation of self; and it was precisely this admirable feature which distinguished platonism from coquetry: "O Love!" cried Bembo, "it is by thee that the higher virtues rule the lower." How many of these strange, admirable women might be mentioned, who devoured men like veritable Minotaurs, and who, after devouring them, would have liked to resurrect them for another meal!

The Marchesa Scaldasole, of Pavia, was one of these terrible harpies; yet she acted with absolute frankness. One day, at a ball, she said to a young protonotary named De Lescun, who was losing his head a little: "You see, I do as your guards do, who fix a tassel to their horses" cruppers, to warn people not to go too near," and she pointed to her sky-blue dress: in Italy, blue denoted heavenward aspirations. Lescun was devoured like the rest. By a strange freak of fate, he happened to be severely wounded beneath the walls of Pavia in the famous battle of Francis I. When he was picked up, covered with blood, he asked to be carried to the house of his "dear lady and patroness." The marchesa received these quivering shreds of humanity with transports of tenderness, and it was in her arms, sustained by her loving look and consoled by her pious words, that Lescun breathed his last.

I know not how La Rochefoucauld could say: "The first lover is kept long when no second is taken." It is the vice of men not to know when to stop Nothing grieved 
Margaret of France like the thought that a man, to qualify as a "man of honour" and a "pleasant companion," was expected to kill someone for giving him the lie, and to love a dozen women. She objected strongly to a happily settled man, as she says, going prowling over the world, were it ever so platonically: "it is wisest to remain satisfied where love has once attached us."

The women, on the contrary, anxious to fulfil their social duty, thought themselves bound to sow love broadcast, to distribute their favours widely; by that means they protected themselves against the tongue of malice, though at the cost of desperately hard work and many embarrassments. For every man of intelligence and breeding who knows better than to display too much whimsicality, how many jealous, touchy, tiresome men there are! A princess could do no less than be kind to a number of favourites; Margaret of France loved not far short of a dozen, and the number was only so small because of the difficulty of finding recruits for platonism.

We must remember the idea from which these women started, which was absolutely the reverse of that which now prevails. In these days women are careful not to generalise; they prefer to personalise everything-medicine in the doctor, religion in the priest, the family in the husband, love in the lover. The women of the sixteenth century, we cannot repeat too often, had an ardent faith in things, but none at all in men; they had no intention whatever of being in bondage to a man, whoever he was, but preferred to go straight to the idea, and then to make its interpreter their apostle, or what they pleased. They were in love with love, but were unquestionably prone to regard the lover as of secondary importance, or at the most as the minister of their cult, not their master. Trustfulness and self-surrender struck them as delightful, desirable, religious, almost necessary, when based on a broad principle of liberty, and when they furnished a goal at which the affections might aim.

We must insist also on another most important consideration, which the reader will already have suspected. These ladies did not labour for their personal happiness; in most cases they had no hope of ever attaining it. They discovered a means of giving life to others, but larked it for 
themselves; they had known either too much or too little of existence. They were dissatisfied-out of conceit-with everything, perhaps with themselves; they had been mothers, and were yet maids. For the soul, like the body, needs to give itself, and on this condition depends its life and fruitfulness. Now many of these women had shadowy and inscrutable souls - souls whose pages no one had troubled to turn; they smothered their feelings, but they had suffered much, and still suffered. Hitherto they had given only their body, the poorest part of them, the contaminated part, the part that is lost in the giving; while the soul is ennobled and purified by self-surrender. They had perforce to cut themselves in two, and as maidens to look on at the ruin of one part of themselves, and nothing was more painful than this cleavage; philosophers even maintained that it was an impossible one, and that, when a woman yielded her body, under obligation or necessity, sometimes with disgust, she gave nothing, but remained immaculately a virgin, because the true virginity is that of the heart. Indeed, a favourite idea of that time was that whatever vicissitudes the bodily mechanism might undergo, only the soul could endorse them.

Here, then, were unhappy dilettanti of love, who, regarding animal passion as the antipodes, almost the negation, of true passion, rigorously safeguarded their purity, and adopted platonism as the channel through which to bestow their souls on mankind, with a smiling disenchantment, almost happy in possessing at least the assurance that in this harmless game there would be only occasional outbursts of the violence of love. They chose the good part, sowing broadcast, in a soil often ungrateful, the seeds of a love of which they had been harshly deprived, and the fruits of which they hoped probably that others would gather. Many of them had lovers, but true love comes only once, and among these charming women, all fire in appearance, there were some who bore, deep down in their hearts, an unsuspected burden of sorrow which oppressed and overwhelmed them. With some of them passion had never ceased to rumble; some had been seen to become desperately attached to a man (maybe their own husband), or even to fling themselves into a nunnery. The most of them, more sick than those they wished to cure, and faltering 
inwardly under the outward charms of their devotion, went their way, vainly seeking in life's desert the heart, the one only heart, sensitive enough to comprehend them. They steered their way composedly among the billows, in complete security, alas! and without adventuring anything but their good sense, at most their good nature, which Anne of France severely calls their hypocrisy. Ah! how they smart for this hypocrisy! How much of their life-blood it costs them! We yearn to strip off their veils, to beseech them to take thought for themselves and put some faith in passion! But no, they lead our woful procession like singing children, and, forcing back their tears like Margaret of France, they strew a few rose-leaves in our doleful path:

De petits amours à fleurettes,

D'autres petites amourettes,

Mesmement de vieilles amours, ${ }^{1}$

- Voiture.

and the sole benefit is reaped by us, or at least by men capable of enjoying an illusion. Sometimes, in their infinite goodness, they may give us divine moments that compensate for the painfulness of life; they succeed in thrilling us with that magnetic influence which quickens our faculties, sends our life into a wider channel, makes commonplace actions seem interesting to us, gives higher relief and brighter colour to all our surroundings. They do a good work, a pious work, a social work. And that is why this loveless love fell especially to the lot of princesses. At first sight the idea of making love so excessively aristocratic appears somewhat singular, if not repugnant. What is the value of distinctions of birth in such a matter? 'To sincere hearts they can only raise obstacles to genuine happiness. This was especially the opinion of Anne of France. Could it be right to dignify with the name of love or platonism a wretched coquetry which consisted in attaching oneself to the most conspicuous women, whoever they were?-for some were plain, and, what was worse, influential !-so that this so-called love would oscillate between snobbishness and solicitation of the kind nowadays practised upon a minister of state-whose ugliness does not matter. Assuredly it is

1 [Loves like little budding flowers,

Loves to sweeten idle hours,

Likewise old amours.] 
possible to love a plain woman with all one's heart; such love, indeed, is said to be the strongest. But how difficult it must have been in those days for a princess to believe in a disinterested love! And even supposing such happiness were hers, could she ever have relied upon it?

So the love of princesses, which was an essential characteristic of platonism, sprang in reality from a very special principle. The princesses (and other great ladies) had no experience whatever of the sentiment (very masculine and somewhat modern) that everything was theirs by right, and that a certain lofty egotism was the natural complement of a lofty station. On the contrary, they imagined themselves to be the property of society, so to speak, and not their own -and further, as they realised that a great name is just as isolating and paralysing as a large fortune, if not more so, they considered themselves specially bound to keep their activities in full play. Their efforts were sweetened by their pride. That the woman should have the castle and the man the cottage, that she should be rich and he poor, seemed to them a good thing: it was the subversion of old ideas, but the consecration of the idea that was to be. They found a special charm in material inequalities of position; it was often distressing to have to raise a man morally, but it was delightful to raise him in a material sense; as Balzac has said, "No man has ever been able to raise his mistress to his own level, but a woman always places her lover as high as herself."

This explains why, in the eyes of all the friends of the Beautiful at that epoch, every princess was beautiful, in other words, she piloted the world towards the idea of the Beautiful. Failing a princess, or a lady of title, or an eminent woman, a man might content himself with a simple maid-of-honour; but it would be almost to fail in respect towards princesses of the blood-royal not to fall in love with

1 Amoureux suis d'une paintresse,

Qui est belle en perfection.

Son geste plein d'affection

La fait juger demie princesse.

_Gilles d'Aurigny.

[I adore a painter dear,

Perfect grace and beauty she,

And her loving ways to me

Make her half princess appear.] 
them, since they were born for that end; and indeed a certain accent of ardour did not displease them, for, as they told themselves, "everybody knows that a fortress is only stormed when it seems hopeless to expect weakness or treachery." 1 Nothing flattered them more ; in the admirable words of Alfred de Vigny: "In the purest relationships of life there are nevertheless things which are only poured into one single heart, as into a chosen vessel." This chosen vessel must be rare and delicately fashioned, all compact of idealism, intellectuality and tenderness.

The love of princesses, therefore, however sincere and intoxicating, manifested itself with crystal purity. When a poet makes extravagant boast of the beauty of his mistress, who is sometimes of mature years, we may be quite sure he means beauty of soul, "which is all-suficient," as Margaret ingenuously says. The only misfortune of the princesses was often their scant knowledge of the human heart; they saw too much of the worldly, showy, conventional exterior, and it was that usually which made them pessimists. But they exerted a powerful sway. And as their favours, coming whence they did, had no important sequels, they were not niggardly in bestowing them. Of what is not a woman capable who has nothing to fear, either from herself or from others? In such a case there is danger only for the man. Certain ladies took men and stirred them up, shook them as you shake a tree whose fruit you desire to bring down. And, to tell the truth, they were even taunted with carrying this science of theirs too far. Margaret of France in particular has been generally regarded as a consummate virtuoso ; unquestionably she often puzzles us, and gives us the uneasy feeling that she is making fools of us. She herself boasted of juggling with the hearts of men, of "winning her devoted servants," and of managing them so well that literally they no longer knew what to make of her. "The most daring," she says, "were reduced to despair, and the most down-hearted saw a ray of hope." while those who know her story most intimately-Madame d'Haussonville, M. Anatole France, Madame de Genliscome forward as guarantees of her absolute virtue, those who, like Brantôme, peep at her through the window regard her as a coquette, which indeed was her mother's ${ }^{1}$ Heptameron, Tale 18. ${ }^{2}$ Ibid., Tale 58. 
opinion. Shall I confess it? I myself, during the years, now no small portion of my life, which I have devoted to the service of these adorable women, during the many long hours spent in delightful intimacy with them, wholly absorbed in deciphering the enigma of their hearts, have known and felt these singular perplexities. One day the ladies have enchanted me, almost given me wings; another, they have crushed me into the dust: one day I would fain kiss their hands with all the ardour of a loyal worshipper; another, long to obliterate their very footprints. Sometimes I have glowed with pride, fancying myself master of this fervent love of which they used to speak so well; and thrilled through and through with their overflowing enthusiasm I have seen the world become transfigured behind them, our pale northern mists dissolve in radiant colour, our sky become translucent-and next day I would trudge mechanically behind them in utter mystification. Passion and irony have in turn moved my pen, and having mutually slain each other, I know not whether anything is left. And to-day even, when I aim seeking earuestly to lisp the praises of these ladies, when as the prize of serious and constant effort I beseech of them some positive pledge of their thought, they flit like butterflies before me!

Yet they had hearts, large hearts, it is impossible to doubt, -hearts staunch and ardent; but they shrank from employing them. They dallied in a dim twilight sensibility, like that noble lady of Genoa, Thomasina Spinola, who had broken all material ties with her husband in order to devote her thoughts to King Louis XII. One day the rumour spread, falsely, that Louis was dead, and soon it was reported at Blois that Thomasina was dead also. Thereupon the official poet recited an interminable elegy. Happily, both Louis XII. and Thomasina had many years to live. No one durst smile at matters so eminently respectable, though Anne of France was indignant; in her opinion love was dishonoured by such proceedings, and she would readily have forgiven men for not taking these pleasant comedies too seriously.

Strange women! Perhaps they themselves dared not probe their souls! The artists who painted them must have dropped their brush and peered into the heart of their idol, and asked themselves whether it was a Beatrice or a 
Venus they were painting. A strange veil covers their features; as a skilful artist contents himself with vague suggestions where a perfect rendering is impossible, so their souls have deliberately blotted themselves in mist, blurring their outlines, and throwing us into uncertainty. These women are frank, and reserved; they attract, and repel; emtrace us, and hold us at arm's length; allure us, and alienate us. Now they are like virgin soil, now like paths too many feet have trod. Their contemporaries were baffled by them; we too may well fail to comprehend this platonism-we who see it from afar-

Such is the magic haze in which Leonardo has en wrapped his Gioconda. Everything is there, but he tells us nothing save that this is she. He barely hints at her subtle mind, her soft, pure flesh; you seem to catch a delicate perfume floating in the air. The world around her seems sunk in torpor; the landscape fades away in indefinite and fantastic suggestions. And the woman dominating it all pursues us with her complex look-the look that all these women have; she seems to be several women superimposed-a succession of appetites, a mingling of languors, thoughts crowded on thoughts, an encumbrance of flesh. Voluptuousness and intelligence are there too, held in reserve. She terrifies us, for she is too richly endowed; she will give nothing: she is a woman of brains.

And yet we err in not trying to understand these women! We do not understand them because we set them apart, picture them as solitary in their defensive attitude, shutting our eyes to what engrosses their mistrustful looks - the cruel welter of humanity around them.

With Anne of France and Vittoria Colonna we met Michelangelo. But whom shall we find flocking about these gracious priestesses of love? Contemptible drones, ambitious men, empty-headed fools, young fops, youths anxious to push their way in the world, society clowns, scholars in the sere and yellow leaf, a whole herd of men who have their reasons for liking the tame cat's rôle, and certainly would never think of love unless someone mentioned it. Is it in any real sense cheating to cheat such men? There are sceptics like the excellent Montaigne, who love in order to find relief from their worries; others who love for a wager, like Nifo, who went sweethearting 
because it amused Cardinal Pompeo Colonna. There are pedants and hair-splitters; men who analyse and refine and talk of social duty-speak too of their love for humanity at large, for irrational things, for the All-in-all, for supernatural beings, for the angels. They make love an amusement like dicing and racing. They tell off on their fingers. the various species of love.

Nifo amused himself by cataloguing the motives leading to love or "re-love." He found tifteen chief motives: (1) Youth. (2) Nobility (since aristocracy springs from love, and love from aristocracy). (3) Wealth; a tainted source, but abundant. (4) Power. It is to this last that he maliciously ascribes the love of princesses, the best and most practical of all. Ambitious by destiny, he says, princesses necessarily yearn for glory; wherefore they are more accessible than others, and no one renders love graver, loftier, more substantial. (5) Beauty', a very stimulating factor, but secondary. (6) The mere rapture of the senses. Alas! many women, even in the highest stations, must have owed shameful connections to this cause! (7) Fame. The thought of hearing themselves sung about, of seeing themselves in pictures and statues, of being analysed and made the subject of dissertations, is a strong incentive to love: women love posterity in this guise. (8) The love of love, the artistic pleasure in knowing themselves loved, adored. (9) Elegant love, a matter of gay doublets and a good stable. (10) Obsequious love, not very amusing, but practical and very common; a love made up of little attentions, little symbolic presents, balls and banquets; Nifo had seen Prince Ferdinand of Salerno win his lady by means of a ball. And after these principal categories, there come secondary inducements to love, which, in spite of their commonness, are constantly successful ; fine melodramatic rages, comprising disdain, jealousy, frenzy-all excellent. investments; or the more peaceable and rudimentary means, such as entertainments (provided they are intellectual), flattery (highly recommended), prayer, this too, excellent, according to the maxim of Martial-

Nor prayer nor incense e'er did Jove despite.

Lovers have only too many methods to choose from, and the advantage of these sentiments (generally feigned), is. 
that thanks to them anybody, however modest his resources, can find something to suit him; it is the bazaar of love.

And thus raw individualism, the mainspring of human energy, was to become transformed and to tend towards a collective end.

Poor women! they were under no illusion about the superficial effect they for the most part produced; they knew that perhaps it would all amount to no more than an outward show of improvement, and that at bottom man would remain the vulgar and self-seeking creature he was. ${ }^{1}$ This thought confirmed them in their platonism and their virtue; if there was no better result, they told themselves that, after all, to awaken mere sensibility was not an absolute waste of time; that it was a merit to refine vice, to "polish it up," to drape it with hypocrisy, to rule men and impress their intelligence even by indirect means: they found the occupation every whit as interesting as piling up household linen or polishing the furniture. They hoped that the future would justify their devotion. After all their love was only i means; the end was to pour upon life a little joy, a little balm, light, power, happiness-to shower happiness everywhere.

1 Heptameron, Tale 14. 


\section{CHAPTER III}

\section{THE MISSION OF BEAUTY}

BeFore we can make others happy we must draw upon the sources of happiness in our own nature and in the world around. It is reason's ungracious way to show us the realities of life in the mass, and even in their darker aspects; it is aestheticism that turns their bright side to us. Absolute ugliness does not exist, any more than absolute beanty, and a careful analysis -detects an element of beauty and love in everything. The quest for this element is women's work. In moulding us into beings sensitive to the least manifestation of happiness, they restore us to health.

Their first duty is to exhibit in themselves every loveable quality, physical and moral; for platonism is not the art of loving, but the art of guiding men towards happiness through love. Their second duty is to make good use of the elements at their disposal, and force life to yield the very pith and essence of the Beautiful. Or we may liken them to conductors of orchestras, who draw unexpected tones out of space. How noble, how difficult is the task! Surely there is enough in it to fill a lifetime! What intelligence, what knowledge, what skill, even to charming sympathetic accents from a stone, are needed! Platonism would be narrow and inadequate indeed-would be indistinguishable from the most hackneyed sentiments-if it were satisfied with the triumph of feminine coquetry, and did not extend its mission to the whole of nature.

To render themselves beautiful and admirable, therefore, women will have to make the most of their resources. Whatever their occupation, they can always mingle with it something of the ideal, or turn it to the glory of their sex, 
even if it is a mere matter of dining or of walking in a meadow; how much more so if it is a question of the manifold usages of social life, and more especially of its intellectual occupations! Through their fostering care all things should become imbued with a sentiment of peace and love, and tend in common towards happiness. That is where their talent lies.

Clearly the method employed will vary according to circumstances, situation, possibilities, temperaments. Different women will pursue different aims, and avail themselves of different weapons; but, in the long run, none is neglected. While therefore we cannot hope to produce a thoroughly accurate picture, we shall pass in review the principal circumstances which provide a lady with her means of action, starting in logical order with the material and proceeding to the intellectual facts.

In the material universe, it is woman's capital duty to possess what pleases men; for here we are entering a purely practical field, and the quest of the ideal is of much less moment than the skilful dressing of the hook !

Physical beauty is not an indispensable condition of pleasing; on the contrary indeed, a certain homely plainness does not come amiss, platonically speaking. If many of the celebrated women whom we know only in their portraits were to come to life again, perhaps we could not resist their fascinations; but they are dead, and to us they are plain; their plainness served them as a sort of lightningconductor. We may go even farther; true beauty was held suspect. As Anne of France severely says, it is the most. prejudicial and least valuable grace tnat Grod can bestow on a woman, especially a princess. It is made too much of ; it inevitably jumbles the sentiments, mixing with the purest an alloy of instability; there is always a risk of its upsetting the best-laid schemes. A princess acknowledged as a beauty cannot choose her servitors; she knows neither how far they will go nor perhaps how far she will go herself. She seats her empire on very precarious foundations, since the less sensual love is, the longer it endures. In fine, women are what they are, and it is impossible to ask them to change. But any woman who knows her duty may be asked to practise the feminine art, and this art is called charm.

Many men do not know the meaning of the word "charm"; they speak of beauty as savants or as grocers 
might, not as faithful worshippers. If you pull women to pieces, if you judge them as you would a yard of calico, a donkey or a slave, you will see naturally but a form of flesh; you may estimate its geometrical dimensions, count on your fingers thirty or thirty-six special beauties; if you profess an intellectual standpoint, you will perhaps go so far as to measure the cranium, and that will be all. You will be content as an artist to produce a "semblance of life," by dint of scrupulous attention to detail ; you will not perceive what it is that speaks to us, fascinates us. Charm is not expressed in terms of arithmetic or algebra: it is an art, perhaps the highest of all arts, because more than any other, more even than poetry or music, it speaks from soul to soul; it is a sort of witchery, a woman's knack, as it were, " $\sigma f$ enveloping all around her in an invisible net. It is not purely intellectual, but avails itself of physical means and disdains everything in the way of formulae. The Italians, adoring this delightful art, have vainly devoted innumerable and often very prolix writings to the attempt to fathom it. All their reasonings are condensed in this vague sentence of Firenzuola:" "A beautiful woman is one who is universally pleasing"; and Firenzuola is no better able than the rest to say why she is pleasing. If we were speaking of a good housewife, it would be easy to catalogue her virtues: the talents of a managing woman, a woman who can look after one's health, keep the books and train the children, have often been computed. Of a charming woman, never! Each one has her own secret. And yet the art of charming is very widespread. To that art the Italian women owed their positions as queens of the world (or, to satisfy Montaigne, let us say the "regents"); they were not superior to Frenchwomen in beauty of form or in originality of soul, but among them there were more "beautiful women," that is to say, captivating women, than elsewhere. They were imbued with platonic sweetness, had acquired an indescribable magnetism, a perfume of human graciousness, so holy, so all-pervading that it seemed to purity the air and make the world a temple instead of a hospital : like the precious

${ }^{\text {I }}$ [Poet and translator (1493-1545), friend of Aretino. He wrote 'amorous discourses' in imitation of Buccaccio; comedies in imitation of Plautus; a translation of the Golden Ass of Apuleius; and a prose work on the beauty of wcmen.] 
spikenard poured long ago upon the feet of the Saviour, all soiled with the dust of the world.

Like all other arts, charm is a gift of nature. The first rule for a woman is to know herself thoroughly, so that she may bring her individual gifts discreetly into play, especially those which affect the man she has in view. It will not do to let her art appear. A woman's charm depends upon her acting spontaneously, even though imperfectly; it is impossible to insist too strongly on this principle, which of itself explains the evolution of women's power in the sixteenth century. So long as women frankly assert their personality in their actions, taking counsel only of themselves, their power never ceases to grow, and produces excellent results; but when, whether from indifference, timidity, the instinct of submission, or a mistaken education, they no longer see in platonism anything but an art to learn, a lesson to rattle off, a conventional pose, all is over; men of real virility escape their influence, and deride their charm as a puerile thing, and the women find no men to govern but the insignificant herd whom they do not care a straw for, and who are distinguished one from another only by the colour of their pantaloons. This is the practical result of the parallel instituted between true platonism and the platonism of convention, between Michelangelo and Bembo, between the vigorous Anne of France, who was willing to assimilate certain delightful principles of the new spirit so long as no sacrifice of character or caste was involved, and the amiable Margaret of France, who was much more inclined to go over bag and baggage to the Italian methods, in order to obtain in France the same results as in Italy.

Nevertheless, apart from originality, which is indispensable, and diversity, which is essential, it is possible to mention some elements that go to the making of charm, consecrated, apparently, by experience or tradition. Of these, some are physical, some intellectual; for the present we shall speak only of the former.

It is ageneral rule (if we may speak of rules) that the physical charm of a woman springs entirely from whatever accentuates her feminine, arch-feminine character. Thus it must above all express the completest, most absolute sweetncss.

For a long time this characteristic sweetness appeared to 
spring from gracefulness of form and feature: a face of aristocratic oval; a swan neck, a wasp waist; in short a general effect of reed-like slightness and fragility, a veritable mantel ornament, so delicately balanced that to touch it was more than one dared, and that one was puzzled how so frail a thing had ever managed to stand on such tiny feet, to hold out such a poor little hand-a virginal figure of fifteen years. $^{1}$ This wonderfully pure ideal persisted in Spain; but in Italy one of the first signs of decadence was the preference for more sensual forms. The Florentines, with their fastidious ideal of elegance, were almost alone in resisting the current; good Firenzuola did not yield to it to any extent, and at most there was at Florence a small section in favour of muscle and robustness, of whom Michelangelo is the representative. But at Venice, a fine opulence of flesh, luminous and warm, wonderfully substantial and soft, "full of a delicious comfortableness," carried all before it-a beauty such as the pagans have celebrated in their lyries and such as the East adores: nothing seemed more charming.

In France, the national spirit, always eclectic and vacillating, was neither idealistic nor materialistic enough to take any side in this dispute.

Autant me plaist la grassette,

Comme me plaist la maigrette. ${ }^{2}$

- Ronsard.

The great goddesses who ruled and dominated the classical epoch, Madame de Chateaubriand, Madame de Canaples, ${ }^{3}$

${ }^{1}$ Son âge estoit d'envyron les quinze ans, Qui est le temps que desirent amans.

La taille en fut longue, menue et droicte,

Espaulle platte, et par les flancs estroicte.

(Anne de Graville.)

Toutes les nuyctz, je ne pense qu'en celle

Qui a le corps plus gent qu'une pucelle.

[Her age was fifteen, as I guessed, (Marot.)

The age that pleases lovers best;

Her figure long, slim, straight as arrow,

Her shoulders broad, her haunches narrow.

I lie awake o' nights, and my thoughts are sure to go

To the maid whose body's comelier than any maid's I know.]

${ }^{2}$ Is she plump, or is she lean?

My pleasure is the same, I ween.

${ }^{3}$ [Both these ladies were mistresses of Francis I.] 
Diana of Poitiers, were representatives of vigorous stocks; an old lusty blood coursed visibly enough through their veins; but they mastered it as they mastered everything, diluting it with an effeminacy which had, however, a charm of its own.

The colour of the hair and eyebrows always appeared a characteristic factor in a woman's expression; without fair hair there was no charm. According to a twelfth-century chronicler, the sweet Saint Godeliva of Bruges vas called a "horrid crow" by her hag of a stepmother on account of her dusky hair; it was to her hair indeed that she owed the tribulations that won for her the aureole of sainthood. In all probability the dukes of Burgundy, when they created the order of the Golden Fleece, were thinking rather of the charming women with heads like a golden harvest-field than of the exploits of Jason. It is impossible to imagine Botticelli crowning Spring with black, or Raphael representing his Virgins as goddesses of night. The blonde had it all her own way. And yet even in this matter the fastidious Florentines did not commit themselves, and had something to say for the pretty dainty little dark heads that were to be met in the fields of Umbria. In France the chestnut locks which set off so many charming faces were greatly admired.

But there was absolute unanimity in favour of a soft complexion of creamy white. All men, whatever their nationality, whether idealists or not-poets and aesthetes, dandies, elegant or melancholy men, as Firenzuola and Tibaldeo ${ }^{1}$ called themselves-united in praise of the charm and sweetness of the lily and the rose.

As for the eyes, they are the very fount of charm; by their aid heart is linked with heart in exquisite communings, in them the soul ranges the whole compass of its utterance. The Italians were particularly fond of speaking eyes, black, velvety, dreamy or deep; the French, while by no means insensible to the charm of languorous Creole eyes, much preferred eyes full of animation and intelligence, and these were usually of a light grey or brownish colour. On one point they were almost nnanimous : a French girl of piquant expression and mobile features, all sparkle from eyes to lips, was the top of admiration.

${ }^{1}$ [A poet (1463-1537) who having lost his all in the sack of Rome was succoured by Bembo. He wrote sonnets and pastorals.] 
Such are the few summary and exceedingly vague notions of charm, from the physical point of view, to which women could look for inspiration.

They could choose among these various characteristics, or they could at least go some way towards them. There is no mystic virtue in the advice; the important thing is to succeed; but if a woman lacks any one of the recognised instruments of charm, it is better to look for another than to attempt the impossible. Women have been known to delight men merely by the beauty of a wide intellectual brow: Mademoiselle de Vieilleville's charm lay in a sweet little lisp, and the fair Chanteloup's in her delicious little mouth. A pretty pout, a little wanton laugh, lips fine and so red that a man asks himself "which is the cherry and which is the mouth?" the carriage of the body, the play of the features-all these and many other things may become the "fount of amorous sweets." All that is necessary is that in one way or another a woman should enwrap herself with her sweetness, as with a goddess's veil.

Leonardo da Vinei sometimes painted good housewives, frank and precise in countenance, but he took no pleasure in them; he hardly regarded them as women: a bold look, he said, only suits women who are no longer women. Whenever he was in love with his model he has given her a modest port, one arm shielding her breast, and he has half submerged her in a kind of penumbra. In France a trim, sprightly, noticeably handsome woman was obliged to disguise lerself in an air of languorous affability. The most stony-hearted of Frenchmen surrendererl to "a sweet and gentle face," "a sweet look, a sweet bearing, a sweet countenance."

Another quality which idealists regarded as conducive to charm was a certain stifliness and reserve of manner. Woman, like the ark of the covenant, was to be worthy of all respect. She was not thought the worse of if, like a mimosa, she shrank within herself when the sun's rays were no longer there to warm her, and if she was afraid of the dark. The woman chary of her smile was considered a delightful creature. In platonist circles they would searcely even admire the beauty of the shoulders, and indeed there were no longer seen flaunted in the streets or churches, under the eyes of the common herd, certain liberties in 
costume, from time immemorial the despair of preacherslow-cut dresses, like that of good Isabel of Bavaria, whom the monk Jacques Legrant admonished from the pulpit for showing everything "down to her navel": robes scalloped at the sides; long-pointed shoes so much in the way that a woman had to lift her petticoats very high to be able to walk. Castiglione goes into raptures about the simple little velvet boot of a lady who, on going to mass one morning, fancied she had to spring lightly across a brook. Aretino, naturally an expert in such a matter, declares that no one has a greater horror of a gratuitous display of her charms than a courtesan! Refinement and delicacy seemed to make women more fastidious and more shy, because they realised their value, and because they wished to be loved, prineipally at least, for their soul. And then great ladies, like everyone else, come in time to the verge of forty, and their taste and diseretion are remarkable. Persuaded that perfection is always rare in this poor world, they appreciate the importance of a good appearance, especially in a blasé society, and they are not unaware how much they owe to the skill of the dressmaker.

Here, however, there arises a question on which a few words nust be said, for it not only occupies a certain place in the history of art, but it commonly leads to what appears to us a not very correct estimate of the aesthetic rôle of the women of the Renaissance: the mistake has perhaps been made of not treating it as seriously as it deserves.

It is well known that the sixteenth century displayed an immoderate fancy for Venuses, delighting in them, going into ecstasies over them, setting them here, there and everywhere with a sort of intoxication,-like a man issuing from a too long seclusion into fresh air.

It must indeed be confessed that the grave, austere art of the Middle Ages had erred a little in the opposite direction. The influence of asceticism had generated the alsurdly exaggerated desire to put out of sight the existence of matter; artists attenuated corporeal forms until on their canvases the body represented merely a thought; and the raiment, consequently, in which the body was delicately and gracefully draped, served as resture to this thought, and contributed, so to speak, to immaterialise it. The influence of Greek art was needed to effect a reversion and 
to set upon physical beauty the stamp of a living art. The platonist aesthetics contributed in large measure to strengthen this movement, since it brought into favour the theory that the human body is the perfect type of terrestrial beauty, just as the human soul is the queen of the universe. Thanks to Plato, man, full of wit and love and liberty, appeared in his single self more intelligent, more free, more worthy of worship than all the rest of nature; and as the Bible reveals him also as the image of God, it seemed right to pay him honour. It cannot then be said, even on this matter, that to break with the aesthetic traditions of the Middle Ages necessarily involved breaking with their traditions in psychology and morals; platonism believed it was merely developing and amplifying Christian art, gaining for it all the superb expansion of which it was capable; and consequently, in the early days, it was often with perfect good faith and highly spiritual intentions that artists deified the vital forces of the world in the nude. Michelangelo is there to prove to us that it was possible to glorify the human figure fearlessly and unblushingly without weakening in any way the general conception of vigour and chastity. Whether he paints men or women, the result is the same : in bringing his wrestlers upon the scene he seems to fling at them this old apostrophe of a mystic: "I love you, not because of your tine garments, but because you have suffered much." "Who would ever say that his Eve in the Sistine chapel is yielding, through any languor whatever, to the suggestions of the serpent! This woman of his has assuredly strength enough to withstand a serpent unaided! She goes resolutely to meet the knowledge of good and evil, with the perfect freedom of an accomplished athlete, with more determination than curiosity, because she feels that her body is capable of every endurance; and besides, no one has yet told her that children are brought forth in anguish. Michelangelo has clothed with purity even the lamentable mother of mankind!

And assuredly when an artist of the same school pushes the audacity of realism so far as to stretch openly on the royal tomb in the cathedral of St. Denis nude effigies of Louis XII. and Anne of Brittany, of Henri II. and Catherine de' Medici, he is giving a lesson in morality, lofty, stern, admirable, and of splendid eloquence. 
From this standpoint, the sight of the human form appeared absolutely conformable to aesthetics and philosophy, so much so that a whole generation of wellintentioned tutors, at whom Ulrich von Hütten pokes a little fun, set themselves ingeniously to explain to young people the religious significance of nudities. It was on the same principle that François de Moulins, the excellent cleric specially entrusted with the moral instruction of young Francis I., inserted in his manuscripts a picture of the Graces, and taught his young pupil that Charity is rightly represented as a nude figure, in order to symbolise her gencrosity, or rather to bring it more vividly home to one.

It is hardly necessary to add that if the spiritualistic and platonist school derived these noble effects from the new aesthetic idea, there was another school of artists and anateurs, much more numerous, which saw in the exhibitions of the academies only an entertainment of a wholly different order. We eannot know (and we do not ask) what was Dürer's secret feeling when he thought, as even he did, to imitate Niclielangelo; but what can be affirmer is that he is not altogether successful; he cannot get away from domesticity; the good ladies he presents to us have nothing superhuman about them; far from it, they are women just escaped from their shop-counters (and their corsets!), or very matter-of-fact bathers, or a statuesque "Fortune," who, despite her broad wings, yet appears ill at ease in what Montaigne calls her "animal's costume." The Italian artists, except for a few of the early ones, have not in similar cases allowed a like embarrassment to appear. By their own account, they moved with the greatest ease among these physical beauties, like perfect aesthetes. Undoubtedly many of them believed men, and more especially women, to be the loveliest of created things, and in fact they display them to us everywhere, with striking ability. Salons, public resorts, promenades, even the walls of churches and cathedrals in those days looked more or less like a psendoparadise. The triumph of the flesh was pealed forth with a brave clarion eall. And we must not forget that this sort of painting formed a capital trade, which brought in both money and honour.

By degrees, however, this licence evoked murmurings, which grew stronger day by day, and as Michelangelo more 
than anyone else had ennobled the practice, by inscribing above the private altar of the popes the sublimest and most terrible page of philosophy ever written by painter's brush, he was specially marked out for attack. Undoubtedly he was generally recognised as the responsible enunciator of this new principle of art, and it is a clear proof of the general and almost unopposed onslaught on him that the man most keenly alive to the drift of fashion, Aretino, ventured to indulge in virulent invective against him upon this subject. After the Council of Trent, a veritable crusade was organised with the noble end of purging the churches of too lifelike anatomies. It is the correct thing, in the Joanne, ${ }^{1}$ to make merry at the expense of Pope Paul IV., dubbed by facetious and satirical people with the humiliating sobriquet of the "breeches maker," because he caused some veracious but really unessential details in the work of Michelangelo to be timidly covered with gauze, and because he generously presented the Holy Virgin with the dress she badly wanted. At the risk of incurring the same reproaches and of becoming a by-ivord to guide-books past, present, and future, we shall here confess that it seems difficult to blame him. The Last Judgment, though absolutely pure in intention, became for the popes quite a stumbling-block from the moment they entered upon the highly legitimate crusade of artistic purification; when in 1573 Veronese was reproached for introducing into Last Suppers details little tending to edification, he did not fail to plead the example of the Sistine chapel. There is not a doubt but that Calvin would have shown himself much more rigorous than Paul IV.

This fascination for the symphonic harmonies of the body was not only an anxiety to the popes; it distressed also the noble women who wished to constitute themselves directors of the aesthetic movement, or rather to become the very incarnation of beauty and love. How far these women, possessed by the desire of securing the triumph of intellectual beauty, found themselves compelled to make certain concessions, is a knotty question to which, as it seems to us, people have as a rule furnished somewhat too liberal answers. So far as the men were concerned, there is no possible doubt about their materialistic tastes; we have, in ${ }^{1}$ [The French Baedeker.] 
a by no means small number of records and anecdotes, not to speak of legends, excellent evidence of their partiality for lifelike representations; they demanded them, insisted on having them. To satisfy them, art set itself to picture the unclothed; it is plain that the platonist women had no option but to rise in revolt. But there exist some Venuses, sculptured or painted, to which the artist undoubtedly intended to give the spicy attractiveness of portraits. The figures show realistic touches, sometimes positive deformities; there are hump-backed Venuses, emaciated Venuses, Venuses of mountainous bulk. They invariably wear beautiful jewellery, a necklace, for example, and have their little dog beside them. A characteristic detail is that their hair has been the object of the most sedulous painstaking; it is a masterly scaffolding of crimped and waved and curled locks, interspersed with jewels in such a way as to make quite clear that this is no shy woodland nymph, but a woman of fashion, a woman of wealth, and even, as far as that can be shown, of birth and breeding. This class of figure is admirably represented on certain of Titian's canvases, and it is an almost immemorial tradition to take them as the painter seems to intend, namely, as portraits of distinguished women.

Are we to believe that the religion of beauty, in purifying all things, led women to adopt so extreme a custom? We do not believe it.

That would have been the total failure of all their tactics, and on this point Plato was beaten out and out. Even in that coterie at Urbino where to cultivate the purest platonism was the delightful occupation of life, there was a general smile when one of the company, smiling discreetly himself, reminded them of the Master's recommendation that young girls should practise gymnastics in a costume of primitive simplicity. Ladies were not at all enamoured of a troglodytic beauty, and anyone who fancied that the contemplation of Michelangelo's or Signorelli's works would turn their heads would have been greatly mistaken. Julian de' Medici, on being bantered by his friends about the way he kept his fair lady out of sight, humorously replies: "Madam, if I thought her beautiful I would show her without her finery, as Paris insisted on seeing the Three Goddesses; but in that case she would 
need to be attired by those divinities themselves; and since 'tis thought she is pretty, I prefer to take care of her." 1

Platonist women felt extreme repugnance for anything resembling publicity or vulgarisation-anything likely to come under the common gaze. One day, at a ball, a young girl seemed a prey to a gloomy pre-occupation from which nothing could rouse her, and her friends wore themselves out in vainly conjecturing the reason. At last they got the key to the mystery: "I was pondering," she said, "a notion which haunts and worries me, and I cannot rid my heart of it. All our bodies have to rise at Judgment Day, and stand naked before the judgment seat of God, and I cannot bear the distress I feel at the thought that I too must appear stark naked." 2

It cannot be denied, of course, that there exists a certain number of Olympian portraits. But these have nothing to do with platonism, and further, many of them were executed without assistance from the model.

When a fashionable woman was having her portrait painted, she did not pretend to patience, and would not sit. Proof enough, surely! The artist had to dash off a hurried sketch with the speed of a present-day photographer; the portrait was afterwards worked up from this sketch in the studio, and a succession of replicas was made from it. It is obvious that, getting possession of fashionable ladies' heads in this way, the artists had every opportunity of making an ill use of them, and supplying them with a costume not bargained for.

Nowadays the fun would strike us as in rather doubtful taste; but women were in those days so good-natured and quick-witted that they were the very first to laugh at a sorry jest of this kind, especially if their personal rank placed them above suspicion, and still more if the portrait was pretty and flattering.

The poet Michel d'Amboise relates how he gallantly offered the lady he idolised a portrait of herself as Venus. The fair damsel looked at the object with not a little pleasure; but as it was necessary for the sake of principle to reprimand the painter, she asked him where he had

${ }^{1}$ Castiglione, Courtier [(Tudor Translations, pp. 212, 213.)]

${ }^{2}$ Castiglione, ibid. p. 166. 
managed to see her in this unusual guise. He replied, like a genuine courtier :

J'ay ta façon sceue par celuy

Qui est à toy trop plus qu'il n'est à luy.'

"Indeed!" she cried. "But he has never seen me either."

We owe to Ronsard, to whom it was an every-day affair to be in love, a description of the lover's method. He goes to Janet Clouet, ${ }^{2}$ and requests a portrait of his lady-love with every possible charm. Actually he has seen no more of her than the graceful oval of her face and her lithe swanneck, but that does not prevent his describing the rest of her, and bespeaking for the portrait, with the fullest confidence, the most ravishing details. Clonet sets to work there and then on a very charming portrait, which will perhaps not be a very striking likeness after all.

In such a case (from a sentiment that sufficiently explains itself), when the desire was to do homage in some way to the presumptive beauty of some particular lady, the most elementary idea of discretion prompted the artist to idealise her features a little, with the result that, the features being all there is to guide us, we may say that pictures of this kind are not, strictly speaking, portraits ; they are ideas, arrièrepensées, illusions more or less transparent. If tradition could be trusted, how many portraits should we have, for instance, of Diana of Poitiers? That noble lady herself commissioned a fair number of Dianas, which may pass for symbols, for the glorification of her name and work. But, without speaking of likenesses that are more than doubtful, among all those which M. Guiffrey has so ably catalogued, even those signed by the most illustrious names, we do not find one that is really a likeness. This defect might be pardoned in the enamels, even those signed by Leonard Limosin, ${ }^{3}$

1 "'Thy shape! Ah, lady!'tis to me well known

Through him whose soul is thine, no more his own."

${ }^{2}$ [Jean Clouet (1485-1545), painter to Francis I. : Janet was his pet name at court. The reference is to Ronsard's lines-

Peins-moy, Janet, peins-moy, je t'en supplie,

Sur ce tableau les beautés de ma mie.]

${ }^{3}$ [A master in portraiture in enamel (1505-1575.) As many as 1840 of his works are known, all signed. Specimens may be seen in the Louvre]. 
but what excuse can be made for Jean Goujon? 1 Look for instance at the superb Diana in the Louvre: done for Anet, it triumphantly challenged all heaven to surpass this human beauty, synthetised in one vigorous woman, one true divinity, monumental, imposing, of commanding port between her deer and her hounds, in no wise voluptuous -a remote cousin of Michelangelo's Eve, though degraded to rule over forests and dogs and men. Clearly it was the châtelaine's own wish to glorify her creed, her ideal, her patroness; Jean Goujon has deified her, sung her praises, interpreted her; and yet we have no difficulty in recognising, from certain realistic touches, how careful he is to remind us that he was celebrating a terrestrial divinity. Is this a portrait? No. It is enough to compare this statue with the authentic likeness of Diana of Poitiers on medallions. If Jean Goujon has suggested anything of the duchess's beauty in the head, it is with a restraint well calculated to baffle us.

Besides the portraits on canvas or in marble there were also others, pen portraits, which. were all the rage; and indeed in after years we find painters complaining of the competition thus set up against them by writers. Though portraits of this kind were necessarily less agitating, people amused themselves by seeking physical details in them; it was a feast for fine wits to "blazon," as they said, this or that part of the body, and it may be that certain blasons ${ }^{2}$ were less anonymous than they seem. This special art has given us one celebrated portrait which has not ceased to pique the curiosity and stimulate the sagacity of critics. The philosopher Nifo, a welcome guest in the house of the young Joan of Aragon, where he justified his presence by platonically courting one of the ladies-in-waiting, wished to offer the princess, with the orthodox dedication, a concise treatise on the Beautiful, and, to give his folio a certain piquancy, he inserted in it a portrait, complete, circumstantial, ruthless, a study in pathology and anatomy, of all the endowments visible and invisible of the young lady to whom the

\footnotetext{
${ }^{3}$ [Sculptor to Francis I., born 1515, killed in the St. Bartholomew massacrc, Aug. 24, 1572. His statue of Diana adorned the front of Diana of Poitiers' palatial ehîteau of Anet. Diana is represented nude, reclining upon a stag, with a bow in her hand, and surrounded by dogs.]

2 [The blason was a short poem celebrating a single feature, or some small possession of a lady-an eyebrow, a rose, or a jewel, for instance.]
} 
book was dedicated. In accepting the dedication, the princess took upon her shoulders the responsibility for the work. How could she approve of this dedication?-a remarkable problem which commentators have endeavoured to solve in every way but the right one. To us, at any rate, the explanation is very simple.

All the critics have set out with the idea that Nifo was rashly indiscreet-a position difficult enough to defend, since a liberty officially sanctioned is one no longer, and, if fault it was, there is no trace of absolution. Now what was this alleged impudent fellow? A fortunate and braggart lover, say some. Can we conceive this old simpleton, forsooth, hideous, gouty, a mountain of flesh, a trifle ridiculous-who was overjoyed at courting a waiting-maid (who laughed in her sleeve at him)-boasting thus publicly of a conquest over the impeccable virtue of a young girl of eighteen, the pearl of Italy! That would have been no occasion for self-glorification: if the conquest had been really his, the book would have appeared without dedication.

Bayle has offered another explanation, still more amusing : he has simply translated by "médecin" Nifo's honorary appellation of "Medici," and founding on this little slip of his, he takes occasion to thunder against physicians who abuse the confidence of their fair clients. Even so, there would still have been no liberty! Besides, Nifo was not a physician, and even if he had been, he would not have found himself much further on; for ladies, as we have shown, had no belief in the neuter sex of the experts who tended them, and were wonderfully ready to regard them as veterinary surgeons rather than philosophers. They al ways drew a distinction between the nude and the unclothed! Nifo simply ventured on the same pleasantry as Michel d'Amboise and Ronsard and all the second-rate idealists, ready to pay intellectual adoration to a woman, and yet susceptible to her physical charms-if only like a fish on a baited hook. He ascribes to his platonic princess, but in an aesthetic and abstract sense, a beauty well calculated to increase the number of her courtiers and shed lustre upon her philosophical activity; he acts like a good lieutenant and henchman, rendering her a philosophical service of which she cannot but show herself sensible. Those who 
have the patience to read Nifo will find later in his book an explicit corrective, the strict necessity of which, however, is by no means obvious. In another chapter, to remove all misapprehension, he enlarges with fervour on the moral virtues of Joan of Aragon, putting in the forefront the two which seem to him the most salient-the beauty which attracts, enflames, enraptures, elevates men; the modesty which serves her as breastplate and armour : "In these two points," he cries, "you eclipse all other women!" Poor Nifo! Even of Phausina Rhea, the waiting-maid to whom he declared his love without any beating about the bush, he knew nothing but her chignon! And it was just this perfect, if a little vexatious, security that gave such a zest to his pleasantry about the princess.

In the seventeenth century also, a century of masculine predominance, people fancied they were deifying men, and especially princes, by representing them nude. La Bruyère was compelled to laugh when at a street corner he contemplated the head of the state, the grave Louis XIV., posed as a stone Apollo. The idea may be as ridiculous as you please, but who would ever dream of being disturbed at the sight? Did La Bruyère himself imagine for a single moment that Louis XIV. had taken the trouble to leave an authentic torso to posterity?

Margaret of France, however, who was all soul, had a singular idea in regard to this subject. She was patently shocked at the mere thought that anyone could say he had admired some Italian princess or duchess lying in the most voluptuous simplicity in the midst of a beautiful landscape, set off by drapery that only half covers her. To this fascinating, but as she thought degrading, spectacle she resolved to oppose another-the spectacle of the soul. The project occurred to her, it is true, at an age when all her charms but those of the soul were dead; she had herself painted, therefore, like the others, before a landscape on which the sun is rising (or setting), and in front of a curtain; but instead of lying at length, she stands erect. She is clothed in her shift, transparent enough indeed, but carefully fastened about the neck, and, to give greater point to the interpretation, she is admiring herself in a little hand-glass, in allusion no doubt to her book The Mirror of the Soul. She wears neither necklace nor jewels; a few ordinary trinkets negli- 
gently placed on her toilet-table alone indicate her quality. Her whole body in its tender austerity is a revelation of her soul. And the moral effect of this representation appeared so lofty that this little portrait was treasured in the princess's family as her true likeness, the portrait at once authentic and piously esoteric. ${ }^{1}$ Margaret thus drew from art its ethical teaching, and gave a lesson to ladies who rely too much on mere beauty of form.

Such is, we believe, the key to the enigma. To win their triumph platonist women do not fling away their weapons, as someone has wittily said; they lay them by.

On the other hand, in the second half of the century, when platonism had disappeared along with feminism, the scruples of the women underwent considerable modification. A compromise was effected; the body was, so to speak, cut in two. The lower part remained inferior, but the upper, the bust namely, was regarded as superior and of a beauty that might fitly be exhibited. At the end of the century we have portraits of great ladies conforming to this new fashion. Perhaps also, out of a spirit of mischief, people amused themselves by distributing under this form portraits of ladies who enjoyed almost a public reputation for beauty, such as Gabrielle d'Estrées and her sister. The more masculine society becomes, the more do women become fleshly. And we should only have to point out another instance of this phenomenon if we were not convinced that the fashion of which we speak sprang up in an atmosphere of semi-platonism. Diana of Poitiers, apparently, was delighted to exhibit her bust, and indeed it is this peculiarity which led M. Vitet to believe that he recognised her in a family portrait of Henri II., at present in England, which includes all the royal family, namely, Henri II., Catherine, his official wife, Diana, spouse of his heart, and his children. We have not had the opportunity of seeing this portrait, and consequently cannot verify M. Vitet's conjecture. But we think we have sufficiently proved that, even from the purely aesthetic standpoint, the platonist ladies did not

${ }^{1}$ This portrait, painted by an Italian, no longer exists, but an excellent miniature copy, executed in Henri IV.'s time, is to be found in the rare manuscript known as the Book of Hours of Catherine de' Medici. The other miniatures in this manuscript are made after French portraits, and do not admit of so extravagant an interpretation. Louise of Savoy is represented as a widow, in the classical severe and ungainly costume. 
depart from the practical principles of conduct they deemed the best and most profitable; the solitary example of Diana of Poitiers, who cannot be cited as a thorough platonist, does not strike us as sufficient to prove the contrary.

It is true that sometimes the ladies had to yield to the exigencies of their time, and tolerate, on the part of the men about them, customs and a style of talk in which they could take no pleasure. They had to do so or risk being neglected and causing often worse evils.

The intimacies of family life sanctioned in those days truly astonishing liberties. Thus, on the morning of Innocents' Day in December, a man would consider himself entitled to surprise in her bed a lady of the family, or a woman of the household (generally a young woman), and to administer a slap with the open hand, which was called "giving the innocents." 1

In one of the stories of the Heptameron, ${ }^{2}$ a husband gravely announces to his wife "that he means to go at daybreak and give the innocents to her waiting-maid, to teach her not to be so lazy," and the good lady is blissfully unsuspicious.

In vain did the women most liable to such treatment have recourse to all sorts of subterfuges-sleeping elsewhere that night, or rising at dawn; escape was almost impossible. Margaret of France knew all about it ; for all her demureness, Clément Marot wrote a scrap of verse expressly to threaten "to give her the innocents" and "see that comely body." Her nephew Charles of Orleans made merry at her expense because, "having risen too late" on Innocents' Day, he impudently made up for it next day with his poor aunt and another lady: "I won't tell you just now," he wrote, "all that I saw." His letter tells a good deal as it is. It is not surprising that a princess habituated to such buffooneries strove at least to raise their level a little.

As there was no help for it but to exercise their charm on man the brute by such proceedings, the women displayed neither pedantry nor affectation. Besides, if the sensualists thought only of the body, women thought only of the soul; and here, under a new form, we again trace the idea that in giving heart and mind and soul to the man of her choice a woman had really given him all that was

${ }^{1}$ Night-dresses, by the way, were not yet in use.

${ }^{2}$ Tale 45. 
dearest, most prccious to her, all that constituted her personality, and that the rest had only a secondary importance. She had lent her material person to a husband who had not troubled himself about fathoming her soul: why then should she think of refusing favours of no consequence to the man who had really gathered the early blossom of that soul? Just as the most trifling familiarity disgusted her when it sprang from a vulgar material motive or was forced, so the greatest seemed to her legitimate and even pleasant if it was spontaneous, if it consecrated a genuine affection. The lady who, while taking her bath, would have thought it more seemly to dismiss her maid, did not fear to receive there in all honour a visit from a gentleman.

Why should distinguished ladies have deprived themselves, at the levee they held on rising and retiring, of the pleasure of an intimate bedside conversation with their lover? In their eyes it had exquisite advantages: first, the very intimacy of the conversation; then the intellectual and emotional relish it imparted to the purely physical operations of the toilet; finally, for the favoured visitor, there was the tiny reward of platonic love, the little personal token, the special boud which no one else had. Mlargaret of France tells us explicitly that she could not have insulted a man of position and a friend of the ling, like Bonnivet, by excluding him from her "dressing and undressing"; that, further, there was no harm in Bonnivet's "taking this opportunity to increase his affection," seeing that platonic love consists precisely in loving up to the very verge of the forbidden.

In short, women genuinely platonic used their physical beauty as a first means of developing their charm. In this respect they were at odds with the mystics, who regarded the body as a negligible quantity and an encumbrance; but they were still more sharply divided from the sensualists. Their idea was to deify the body, enslurine it, so to speak, and glorify it as the vesture of the soul, the servant of the heart. Platonists of a lofty flight pushed this idea as far as possible: Michelangelo so closely identified soul and body as not even to admit that the face could have wrinkles when the soul had none; so great was his enthusiasm for the beauty and youthfulness of Vittoria Colonna's soul, that

\section{${ }^{1}$ Heptameron, Tale 4.}




\section{THE WOMEN OF THE RENAISSANCE}

he had that strange artist fancy never to perceive a line on her face. He himself, when a scarred and battered octogenarian, never felt withered; to his last day he never ceased to ascend with shining countenance the altar of the Beautiful, like those priests who bow hoary heads before the altar of the Eternal Beauty, the Eternal Sacrifice, as they invoke "the God who rejoiced their youth." He has sometimes been twitted with having represented the Virgin as a woman of thirty, even after the death of Christ; he did so, it is true, and to him nothing appeared more natural. To him such a woman was always thirty. On this point Anne of France did not quite agree with him; it was one of her favourite maxims that a woman had much better accept the inevitable with a stout heart; conceal nothing, dress to suit her age, and persuade herself that wisdom is worth as much as beauty. But Margaret of France could not bring herself to believe that a few marks of physical deterioration dim the radiance of a woman's moral beauty or impair her charm. That such is not the case was the assured conviction of these noble princesses. Unhappily it was not easy to persuade men so. La Rochefoucauld retorts: "There are few women whose worth survives their beauty." To men a woman no longer exists if she can say: "When I was younger"; every possible defect is then laid to her charge; she is found to be ugly, jealous, washed out, viperous. Wisdom may be worth as much as beauty, but what can she do with her wisdom? In Italy a woman was reckoned to have reached the wisdom stage at thirty, and Anne of France only consented as a great favour to allow her another ten years.

A part from any sort of notion of coquetry, it was therefore of the greatest importance to a woman, from a mere sentiment of her duty and her mission, never to be forty; the theory of charm would not have been complete without the addition of the science of never growing old.

This accessory science was, so to speak, a traced copy of that of love; it also had its two schools: the school of truth and candour, the " honest skill" which consists in keeping old age at bay; and the school of cleverness and subtlety, which seeks to recover the lost youth, to employ a little trickery, to repair time's ravages-"a perpetual optical illusion," as Erasmus calls it. 
The first demanded much forethought and prudence. From the earliest ycars of wedlock, with no immediate cause for alarm, it was an unremitting mortal struggle against a foe as yet imaginary. The wife found her weapons in solemn tomes and in the prescriptions she herself had collected. A firm opposition to her husband formed part of her scheme. As to special modes of treatment, they comprised aromatic baths, massage, and so forth, means which were very restrietive and mundane and tiresome, but wonderfully effective.

A lady of that period could write in all pride and truthfulness, "Women remain almost always young." There were some who, when close upon seventy, still merited the good opinion of connoisseurs.

Others allowed themselves to be lulled asleep in the joy of youth, and only awoke under the stroke of some sharp warning; but then they sprang erect to their full height like a wounded tiger, and there was no act of unquenchable courage they did not accomplish. They had their teeth drawn, their skin scraped till it bled, they reduced their colour by dint of galping down sand or cinders. They were heroines of unselfishness!

But if, alas! decay proved in the end irresistible, and they had to resort to sham, how disastrous was the result! Around a made-up face ill-natured folk saw nothing but shams-sham tapestry, sham bronzes, sham conversation; art and platonism alike were banished:

Ostez luy le fard et le vice,

Vous luy ostez l'âme et le corps. ${ }^{1}$

-Ronsard.

The dressing-room became like a universal factory of pinchbeck. On the door might have been written the dictum, in general so utterly false, of Cennino Cennini : ${ }^{2}$ "Art consists in creating, or at least in persuading men that that which is not, is." Let us drop the subject.

It is evident, on the contrary, that the honest art of

1 Washed of her paint, of her vices bereft,

Body and soul there is nought of her left.

${ }^{2}$ [A painter of the Florentine school (died 1440) about whom nothing is known but a treatise on painting discovered in 1820, and some frescoes at Volaterra.] 
dressing played an important part in practical platonism, so long as it was not carried too far.

Since women were messengers of joy to the world, it followed that this mission must be declared by outward signs. What more natural than to give a princess a magnificent trousseau! It was not a luxury, it was the implement of her profession. Anne of France was sure that simplicity had been formerly pushed too far : everyone, she said, ought to maintain his rank and perform his duty in it; the world has a right to what belongs to it, that is, to everything save a woman's heart: to neglect to study appearances, to cultivate false simplicity, is to commit an "unseemly and most dishonest" act. To dress must be considered a duty.

A simple little " mirror of the soul," like that of Margaret of France, was not sufficient for an apostle of beauty. Mirrors of every kind and style, hollow or pyramidal like factory chimneys, circular, angular, in columns or spirals, rightly absorbed her attention every morning and gave her a philosophical and serious conception of her person. It is not at all to be wondered at that the lady whose appearance was to thrill the world should begin by setting all this machinery in motion.

The care of the complexion, and especially of the hands, naturally took some time to begin with, not to speak of hygienic attentions. A delicate little touch with the brush on the face is quickly given, but it demands wonderful skill: it is nothing, and it is all.

But the hair required an exemplary patience. Remember what we have said about the infallible charm of light hair. At Venice Veronese never met a brunette! When a brunette was mentioned everybody understood that she was a woman who had given up dyeing and all pretensions to beauty! That is why the Roman ladies, whom Tertullian reproached with flaunting "barbarous colours," and why our modern artists in hair-dressing, have never discovered any more beautifully effective recipes for golden tresses than those furnished by Marinello ${ }^{1}$ or Cennini to many a convinced devotee of platonism. The Venetian blonde, with her beautiful, glossy, golden-brown locks, enjoys even to-day a renown so much the more legitimate in that Nature has

\footnotetext{
${ }^{1}$ [Author of Gli ornamenti delle donne (the ornaments of ladies), published at Venice in 1574.]
} 
never succeeded in imitating her.-When the hair had received its golden hue, it was spread at length in the sunlight to dry, and then began the real operation of the day - the grand masterly operation of hair-dressing.

In France, singular customs in regard to this matter had long prevailed. A lady would run a comb through her hair, probably quite perfunctorily, slip on a hood, which she would keep on the whole day, and trip off to Mass. This was still common as late as Anne of Brittany's time: that good queen herself was faithful to the hood to her dying day.

By Heaven's favour, Mary of England brought Louis XII. beautiful fair locks, quite genuine too, and the fashion of wearing hats. Then, despite the invectives of a few insignificant people like the poet Coquillart, the feminine head-dress attained altitudes more and more complicated: crimpings came in, and curling irons, paddings of false hair, huge coils stuck with jewels in the Italian fashion. The quest of intellectual charm displayed itself in some ladies by an artificial broadening of the brow; to become philosophic, it sufficed slightly to shave off the hair in front and pile it up high behind. The hair-dressers, who had now become men of substance and repute, lengthened their showcases, and invented those charming wooden heads which we have not ceased to admire.

That the hair-dressing operation lasted three hours need not surprise us; but how mortally tedious these hours would have appeared without the help of conversation! The fair patient settled herself accordingly, garbed in a chemisette of tine linen, cut pretty low at the neck and in no way impeding her movements; and that was the hour when she showed her heart to her friends.

She had then only to dress herself, that is, to put on a wide-sleeved cloak of damask, with a very low, squareshaped opening in which the waiting-women slipped a plastron, usually red; this they laced with care so as to fit the figure exactly; if necessary they inserted an artificial bust, and remorselessly tightened the waist.

In the great old-world houses, the last of these evolutions was superintended by the master of the robes in person. Saluting with a low bow, he announced the costume for the day. The serving maids, aided by the squires, busied 
themselves about the lady, and packed her into a doughty accoutrement of crimson and cloth of gold, a sort of clumsy casing, a veritable strait-jacket, treacherously supported since the close of the fifteenth century by busks or whalebones, the furtive origin of the corset. Around her neck was thrown a necklace of gold, rubies, emeralds or diamonds, and on her head was set a sort of tiara.

Not one of these details is unimportant, since the whole performance had a lofty aim. And this is just the opportunity we have been waiting for to judge the women; or rather, their dress passes judgment upon them. Will they, we ask, have the courage to make their clothing expressive of their own individuality, to render their garments in some sort living and personal, or will they, with mere vulgar coquetry, copy and wear the costume that may be seen trailing in any street? The courage to indulge an individual taste in dress seems a thing of no consequence ; it is, really, a great and a rare virtue; it stamps a woman at once, shows if she has a soul above her tailor, if she has self-knowledge, if she reflects, if she has a feeling for art, if she is determined to show the world her own intelligence, her own beauty. Hands all round for liberty and truth! Anne of France and many others rebelled against the craze for a slim figure, stifling in summer, freezing in winter, regardless of the claims of physical health, and even seeking to conceal the signs of motherhood. How they wished that aestheticism would lead them back to the Greek art, that is to say, to wide flowing garments, dignified, comfortable, healthy, elegant! Or, as Lonise Labé ${ }^{1}$ poetically besought, that women, instead of fastening themselves in a straitjacket, would condescend to resemble a leaf-cone, which opens spontaneously to bear its fruit! But no; the only approach they made to Greek art was that they sought to indicate the lines of the figure through close-fitting casings, but the casings were whalebone and artiticial. Health, even life itself, was of no account; to graces which, however imperfect, had all the attractions of naturalness they preferred a stuffed and padded ideal. For alas! with the majority of women, a dialogue of Plato could not hold a candle to a conversation with a dressmaker. Fashion was omnipotent; under Louis XII. there was nothing but high-starched neck-

1 [A poetess of Lyons, author of some remarkable sonnets.] 
ruffs; under Francis I. nothing but low-necked dresses cut square in front, and boldly gored to a point behind.

The philosophic spirit, untrammelled by physical barriers, manifested itself in the internationalisation of fashions.

It was known throughout western Europe that a fashion adopted by Isabella of Mantua was one to be followed, and that the ladies of Paris were adepts in matching bright colours, and ridiculonsly concealed their faces under thick veils. It was the acme of good style to dress one day like a Frenchwoman, the next like a German, Italian or Greek.

The platonists somewhat resented this vulgar application of their ideas; that was not their conception of cosmopolitanism. To weld the minds of men, to introduce into men's hearts far and wide the truly refining leaven of affection, fraternal concord and tenderness, by means of the common love of the beautiful-that they could applaud. But masquerades like these-what a mockery! In this matter, however, their authority was ineffectual; a stronger was required. Francis I. knit his brows when Spanish mantillas made their appearance at his court; he had his own reasons for not being fond of them. He said that he believed himself among a rout of devils. This one saying accomplished what no arguments would ever have succeeded in doing: the Spanish frippery was packed away in the wardrobes until the political sky changed.

Nevertheless, the intellectual preoccupation made its way, and people were willing to pay regard, up to a certain point, to Plato's principle that the soul rather than the body is to be clothed: in other words they proclaimed a correlation between the colour of the petticoats and the state of the soul. Everybody knew that there are physical harmonies which hold absolutely; that sober tints suit the pale, dull colours people of bilious complexion, and bright tones faces inclined to ruddiness. But people rarely thought - they did not trouble to think-that there might be for souls a similar harmony, much loftier, of much greater importance, and much more necessary to observe; for the complexion may be improved by a touch of the paint-brush, while the soul must be kept as it is. M. Jules Lemaitre, whose genius is thoroughly French and whose opinion it is always a pleasure to quote in matters of good sense, has in our own time this quaint idea: "Our fathers, who wore 
lace and feathers, coats red, blue, dove-coloured, apple-green, and soft-hued lilac, could not but feel more disposed to joy, seeing each other blooming like flower-beds. If fashion should some day make us walk the streets in purple silks, we should forthwith be rescued from doubt and despair."

That is philosophically true. It must be remembered that we cannot isolate ourselves; we are dependent in a high degree on the world around us. The inward joy we seek to create needs an external joy for its support; the sun, the blue sky, the luxuriance of flowers, the clearness of the air, the boundless gaiety and infinite cordiality of Nature quicken and penetrate us; a grey sky and a dull horizon will never kindle glowing reflections in our soul.

It is needful and right that men, and above all women, should display an infectious joy and vitality also, that we should not have to puzzle out the real person under the tasteless guise of a vulgar fashion-plate, cut from a price list and flung over the shoulders. Everyone should make his dress a palpable expression of his life and joy, like the flowers and birds and fruits. The Catholic religion intuitively seized on this profound truth; it retained and developed, with the pageantry of its ceremonies, the goldembroidered copes flashing with sombre brilliance, and all this red and white and blue the purpose of which is to make us forget that these celebrants singing as they move are men, and to represent them to us as the very flower of our ideas, as the essence of our tenderest prayers and affections. Of this admirable demand for the embellishment of life we have preserved only one melancholy symbol, mourning. Men, with their customary suits of solemn black, may be said to carry every where with them the idea of disenchantment, of the awful paltriness and the perpetual mournfulness of the soul: there is nothing of a man about them; they go about the streets like the scattered parts of one huge machine.

And this self-abnegation has nothing to do with material questions of comfort or economy; there is no woman so poor that she cannot, if she wishes, rise above her wretchedness by means of these external symbols. Such at least was the opinion of the sixteenth-century women. To them every colour spoke of the soul and to the soul; it was the ensign of one's spiritual fatherland, or, to use a modern metaphor, a railway signal-light; white, the line is clear! it signifies 
a heart free as air, a soul unappropriated or at any rate overflowing with youthfulness; green, it is springtime with the soul, in the full vigour of sweet acknowledged hopes; red, an utter despair! The cloth of gold, the golden jewcls then so much in vogue, represented the rich glow of sunlight, the spacious joy of life! Whoever wished might approach and find warmth and gladness. Celestial blue meant to the Italians soft ethereal happiness; to the French, a tender and fortunate love. Black was regarded as melancholy: yet this colour, incapable of fading, symbolised constancy, firmness, and had its fiends in consequence. Why restrict it to mourning, as though our feelings for our dead are alone eternal? Margaret, who loved and encouraged the use of black, protests :

Le noir, souvent, se porte pour plaisir,

Et plus souvent que pour peine et tourment. ${ }^{1}$

However, people generally preferred not to take their pleasure in black. Rabelais allowed in the Abbey of Thelema none but brilliant costumes: he wished to have one colour a day, and that the days should be told off as white, pink, yeliow, red, green-never black.

Thus the sartorial art, in spite of little encouragement, itself canse at last to exhale a perfume of life and the ideal. Unhappily it had a cruel, powerful foe, which was incessantly to check its aspirations and keep it in perpetual bondage to materialism. 'This foe was the vulgar passion for sumptuous display, the terrible taste that substituted a mere ostentation of wealth for a garb expressive of art and sentiment.

The French never recovered from that fever.

When Charles VIII. found himself face to face with the court of Ludovico Il Moro, ${ }^{2}$ sinking under the weight of golden shoulder-knots and jewellery, a thrill shot through the French army.

From that time it was vain for the preachers to join hands with the philosophers and demonstrate the infinite vulgarity of luxuriousness and its deplorable moral effects; it was vain for the legislators to enact laws; the die was cast.

${ }^{1}$ For pleasure oft my black I wear,

More often than for woe or care.

${ }^{2}$ [Ludovico Sforza, Duke of Milan, one of the most vigorous opponents of the French king's Italian expeditions. The surname "ll Moro" came from his cognisance, a mulberry-tree.] 
People were dazzled, fascinated by wealth: they knew not nor wished to know what wretchedness it cloaked, how many women, and some of the noblest of them, ruined themselves in their vanity, how many others lived by expedients that would not bear the light. ${ }^{1}$

Assuredly, magnificence had a glory of its own: there was no lack of gazetteers to applaud to the echo the marvels seen on great occasions: "Signorina Bulcano, in white cloth with gold trimmings and a golden girdle; her Excellency the Countess Maddaloni in red velvet; her Excellency the Countess du Rugo, in red cloth with large gold necklace." There is this to be said, indeed, that these chroniclers, superior in this respect to some of ours, were destined to come down to posterity.

Nevertheless, this was inevitably the death of platonism, the ruin of all it loved and all it desired. A fine thing to characterise a lady by the cloth or velvet with which she garbed her bust or limbs! In this profound decadence of taste people came to see some good in the general worship of close-fitting garments, for, now that women were nothing but dolls, it was certainly better that they should appear jointed. And what seriousness could be expected of, what noble idea or worthy aim could be suggested to, a woman who was a slave to her gloves, her hats, her jewels, who spent part of her day in close confabulation with her dressmaker or jeweller?

Cest anneau est du temps passé,

Ce ruby est mal enchassé,

Ce saintureau n'est pas fort gent.

Ma troussoire n'est que d'argent,

J'en veuil une batue en or ...2

and so on indefinitely: that was how she talked; she was no longer her own, she was a slave. Satan in the pit of

1 Alione, in one of his farces, has related the amusing story of a Lombard lady (and she was not the only one) who gave herself to a French soldier passing through, on the mere promise of a dress of Venetian velvet, and to whom the rogue afterwards sent six crowus, with the excuse that an everyday dress was good enough for a casual lady.

${ }^{2}$ This ring is old and out of date,

This ruby's badly cut:

This girdle's precious ugly-wait,

This casket's silver, but

I wish for one of beaten gold- 
hell was bewailing, it seems, the fact that he no longer saw rustling about, as formerly, dresses "open down to the waist"; and he cursed platonism! $\mathrm{He}$ might make himself easy, there were still most melting sights for him! And his colleagne Lucifer sets himself to cheer him, showing him the league of vanity mounting to the assault of the Beautiful, the almost invincible might of money, combated and proscribed above, triumphing and swarming on all sides under the most pitiful forms of jealousy and coquetry : among good housewives, who have neither grasped nor retained anything of the new ideas but an instinct for rigging themselves out to play the countess or the duchess-among kitchen wenches who deck themselves in fallals and furbelows in apish imitation of their mistresses.

Unhappily, the king went over to the side of vanity; official France allied itself with the most dangerous adversaries of Roman philosophism and intellectual splendour: with the Milanese, whose tinsel and fripperies amused all Italy; and the Venetians, a people of large expense. The struggle was thus fought out between sensuous gratification and aestheticism. It did not alarm the platonists: they were prepared for it ; as Castiglione says: "There are fools everywhere."

But this was of all battles the most arduous, because the dividing line between coquetry and a woman's duty to be pleasant was not always very clearly marked. A few exceptional persons had the gift of admirably combining the two tendencies; these as a rule were Italian women. At a celebrated ball given by the court of France in 1518, two ladies, Italian both, were queens-queens of beauty and of charm; the one, Clara Visconti Pusterla, devoted to white, made a brilliant figure with her silver embroideries and ropes of pearls ; the other, a sister of Count Borromeo of Milan, was a dazzling apparition in cloth of gold and diamonds. Yet it was felt how secondary and precarious were successes of this external kind, and how wrong it would be for women to regard them as the real basis of their influence. They were only one means.

The fashion in regard to dwelling-house and furniture followed almost the same rules as that of costume; for in a well-ordered house everything harmonised with the people inhabiting it. The house is, so to speak, a magnificent 


\section{THE WOMEN OF THE RENAISSANCE}

garment, the garment defending our existence against the weather, the night, the intrusions of external life. Here, too, symmetry of arrangement and studied designs are of little moment : the house should exercise a charm, and there are ugly houses which are infinitely pleasing.

A house is pleasing when its appearance is original and homogeneous; when its inhabitant has lovingly put into it something of his own individuality, when it is not merely a classical and regular arrangement of stones erected on some vacant spot, or a gimcrack toy with pretentious and purposeless decorations; it pleases if serious thought has gone to the arrangement of its parts, if it has projections, angles, recesses judiciously contrived, and making it, so to speak, a living, breathing thing. This is the first rule: a masculine purposefulness.

The second and the feminine rule is that the house should present a great aspect of pleasantness, an appearance of amiability. It is of vast importance that it should not clash with the landscape; it should fuse with it, espouse in some sort circumambient nature, so as to radiate an influence far beyond its actual site. This harmony results as a rule from mutual accommodations; a gloomy house, for instance, will not be planted in a smiling landscape; in a wooded or rugged but spacious locality a man will set an extensive abode, without fantastic decorations, a house which dominates outbuildings and approaches; no gildings, no polychrome effects will be thrown up against a leaden sky: a church will not be constructed in the style of a hammam, nor a stock-exchange in the form of a Greek temple. The house, whatever it be, must smile, with a frank and loyal smile, speaking through its façade and its approaches to the good folk who pass, and beaming on them a look of friendliness.

In the interior, to furnish it, that is to say, to render it habitable, all smiles and happy memories, - this again is to enlarge oneself, to complete oneself: and it is here that woman's art is absolutely indispensable. A human dwelling in the nature of the case can make no claim to a proud immortality. Every passing season attacks and tends to destroy it; whilst the objects of nature renew themselves unceasingly by the automatic movement of their latent vitality, it is needful for us at every moment more or less 
to reconstruct our shelter, under pain of seeing it crumble and fall before our eyes. It is like one of the fruits of our life. Thus, while it should be as solid as possible, while reminding us of the persons with whom it has successively lived, it must show itself supple and give expression to our present life, if only by fleeting suggestions, corresponding to the various impressions of our existence, and dying when we die.

It was in this direction that the fine taste of prelates and ladies gave itself free and glorious scope. A lover of the beautiful is so keenly conscious that everything about him ought to be the manifestation of some flash of thought! A chair, a couch, a piece of tapestry, all must speak to us and exhort us to live the life of the heart, without allowing ourselves to be crushed or numbed. At Rome, the home of this dominant spirit, and even at Naples, the rays of its influence extended almost illimitably; and it so well attained its object that a people wonderfully sensitive, amiable, enthusiastic, ignorant of physical wants, became enamoured of these glories of high culture of which, however, it barely caught the reflection, and attuned itself to them. Men hoped the time was at hand when all mankind would delight in beauty, they fancied that they were born to live under glorious ceilings, among palm-trees, gushing fountains and marvels of art. To this day the humblest of flymen dilates with pride in the artistic treasures of his city. And how diplomatically Isabella of Mantua went to work to surround herself with splendid objects! What care Vittoria Colonna took in the mere ordering of a casket! They appreciated equally the charm of collecting antiques, diamonds, pictures, pottery, plate; the sole desideratum was that the object of their quest should be beautiful or rare, the expression of an artistic idea or an evocation of the past, that it should add to the Attic charm of life, play its part in the cultivation of taste; in a word, that it should be loved. Life thus, in its superb radiance, assumed a grandeur and delightfulness of which we too caught the secret, in those days when the palaces at Rome still had their galleries, the villas their delightful rows of oleanders, the ruins their majesty. It was a genuine and glorious sumptuousness, well calculated to elevate men's minds! No wonder that the desire of sharing in it spread through the world, 
and that, unchecked by natural divisions, men's hearts were simultaneously possessed by one grand impulse towards beauty. This embroidery of life contributed in large measure to the sentiment of the brotherhood of man which then declared itself, and which appeared so singular; to-day we do not truly realise its importance, because, thanks to the mechanical lessening of distances, all men have become neighbours (and unpleasant neighbours at that): a varnish of uniformity has spread itself over everything; milkmaids and princesses often read the same books, wear almost the same hats, marry at the same age and with the same ideas. But in those days it was an absolutely new thing, when national diversities and individual liberties were so strongly accentuated, to create a harmony of ideas and a fellowship in love, of which the women were the natural harbingers.

Enter the palace of Margaret of Austria at Brussels, and, if you do not find yourself back in Rome or Florence, yet you will at once perceive that the remarkable mind of a princess has there gathered together all that gives charm to life: a vast library, well supplied with romances, history and poetry; furniture of priceless value, stately busts, brilliant mirrors, portraits of all the princes and princesses of the time, and by their side the portraits of notorious fools: a medley of life and ideas; various pedigrees of the house of Austria, a trophy of Indian feathers of brilliant colours, fierce shaggy heads of wolves, broad fans, glistening armour, crystals, priceless caskets, medallions, majestic chandeliers, articles in jasper and adamant; on the walls, admirable Flemish tapestries spangled with gold or silver; on the floor, warm, thick-piled carpets; here and there valuable pictures in profusion. The visitor's curiosity, solicited on all sides, knows not at first where to stop to admire. And these various objects, individual as they are, become animate and dwell together in a sort of high, grand, collective existence : the one mind which discovered their affinities seems to permeate them, sets them vibrating in unison, and thus penetrates the soul of the visitor.

Through this great science of intellectually adorning the material conditions of life a first result was obtained: men loved life. Sadness concealed itself, joy kept the whole world dancing to its melry pipe. It was impossible to be anything but gay and amiable. If it chanced that someone 
was to be buried, it was with full orchestral accompaniment, amid the twinklings of a thousand tapers, and with a ceremony quite lyrical. If perchance a man desired a melancholy funeral, he would do well to say so in his will and prescribe the number of candles; but most often men set their hearts on dying gallantly, and did not dream of depriving their friends of an honourable entertainment or of economising on behalf of their heirs. 


\section{CHAPTER IV}

\section{THE EMBROIDERY OF LIFE}

Meanwhile, there is a life to live, there are things to do! A woman must get happiness from the exercise of all her activities, both spontaneous and enforced-even more than from her drawing-room or her jewels. We propose to pass in review as large a number of these occupations as possible, to show that, small or great, there is not one but appears to a wornan a source of joy and glory if she mingles love with it. Everything she does, however infinitely humble, be it kneading bread for her husband or washing his feet, is vivified with a transfiguring radiance whenever the spirit of abnegation animates her toil, whenever she reflects that this husband is not the sole man existing in the world, nor a sort of domestic drill-sergeant, but represents the eternal idea sounding in every heart. We have already seen these noble women in days of trouble quivering with devotion at the bedside of their sick husbands; it is the same in days of happiness. They find strength in abstraction; the things that surround us so marvellously change their aspect, contract, expand, according as we take them for what they are or glorify them with thoughts of higher things-thoughts, not idle fancies, wheiher roseate or gloomy, whether too brilliant in prospect or too distressing in reality. It is chiefly in domestic life that abstraction is useful. The woman must steep her hands in beauty, fill her eyes with love, and then look at things courageously and truthfully. Everything, even vice itself, appears frigid, vulgar, and commonplace to materialists; women ought (yes, ought, not merely can) to render everything warm and gay-even virtue.

Let us take haphazard some of the doings which most strikingly exhibit them-their eating, walking, country 
habits, Sunday occupations. From each of these they are able to strike the sacred spark. We shall see how everything is transfigured in their hands.

First then, their eating. Nothing is more material in itself, and nothing better lends itself to spiritualisation.

A house was characterised by the way in which a formal dinner was managed; this was the touchstone of true style. On the table was placed the massive and weighty silver plate, the family treasure which the mistress of the house kept under lock and key, and which was worth a fortune. The plate of some families was valued at a million francs. On days of high festivity the table blazed with ponderous gold, but they were content with silver for private dinners.

The regulation of the menu was rightly regarded as a matter of such difficulty and importance that men of the highest merit made it their study to lay down fixed principles on the subject. Fulvio Orsini ${ }^{1}$ has acquainted us with all the best traditions of ancient Rome. Platina, ${ }^{2}$ the Raphael of the tribe, published under the auspices of Cardinal Roverella a treatise which may be cited as a perfect model.

In countries strange to the new ideas, men thought only of their palates, os sublime, in the ironical phrase of Brandt. ${ }^{3}$ In Germany guzzling, at rare intervals but in enormous quantities, was the only joy. So late as the end of the century Montaigne asked a former ambassador in Germany how often he had been obliged to get drunk in the service of his sovereign, and the ambassador reckoned up with all gravity, and declared that he had got off with three occasions, all told.

The French traditional practice was the same. Fairs, markets, pilgrimages, weddings, baptisms, funerals, anniversaries, meetings of gilds or corporations all served as pretexts for village gourmandisings characterised by enthusiastic drunkenness, and often enlivened with brawls in

${ }^{1}$ [Librarian to Cardinal Farnese (1529-1600), a great authority on antiquities, especially coins; he spent the greater part of his modest income on pictures and bronzes.]

${ }^{2}$ [Historian and member of the academy of Pomponius Laetus (1421. 1481). He was Vatican librarian under Sixtus IV., wrote a history of the popes, and a curious work on hygiene entitled Opusculum de obsoniis ac honesta voluptate - the work here referred to. 1

${ }^{8}$ [Sebastian Brandt (1438-1521), jurisconsult and poet of Strasburg, author of the famous Ship of Fools, referred to in subsequent pages.] 
which both sexes took part. At the end of one of these feasts we find the wife of the gild president dealing most energetically with a toper who had called her an "old witch." The châteaux were no less fond of high feeding. ${ }^{1}$ Historians ought to consult the kitchen account-books! Without them they will never succeed in arriving at wellfounded judgments; we know no human document more convincing, none which enables us with more certainty to reconstruct a bygone mode of life. Unhappily the old kitchen books of France reveal a deplorable spectacle; it is one long procession of herds of oxen and flocks of sheep, innumerable poultry, rabbits and partridges by the dozen, small game in hundreds, and pigs in disgusting profusion. The whole of the delicacies consists, even in the most distinguished houses, of a few cloves or sticks of cinnamon to make hippocras of. As to the wine, it is wine of the current vintage drawn from the cask! Caesar Borgia must have been greatly surprised one Friday, in the winter of 1498, while staying with Madame de la Trémoille, to see filing in a course of two hundred and fifty fish. The next day, again a fast day, the avenues leading to the château were thronged with carts loaded with fish, in honour of the visit of King Louis XII. ; in particular there arrived seven hundred and fifty eels. This was in Rabelais' country. Further, in regard to tutelary geniuses of the table, they were acquainted with none but appalling spectres-Dame Gout, ${ }^{2}$ Madam Gravel, or my

${ }^{1}$ On ordinary days, the household of Marie of Cleves easily disposed of half a calf, a quarter of an ox, five or six sheep, and dozens of fowls.

2 "Gout," cries Cardan, "is queen, gout is noble! She is a synthesis of ills! She is discreet and courteous; she attacks only the showable parts of the body. There is nothing hideous about her as about leprosy. She purifies man and raises his moral worth, as all pain does, but more than any other pain. Why is she the enemy of grand dinners, and of midnight toil, and of all the charming occupations of mind and body?" (De malo medendi usu.) A Cerman song was dedicated to her:

O Gout my goddess, Gout my queen, What mortal wight but fears thee?

Earth, sea and sky have ever been Thy subjects : Jove reveres thee.

0 mighty goddess, hear the prayer Of those that now implore thee:

Give peace to every gouty toe,

And grant to all who limping go

Freedom from pain, release from care, And perfect health before thee.-(Podagrae Laus.) 
Lady Apoplexy, to whom they gaily made their salutations.1

Then comes philosophy to preside at their feasts with salutary effect. It teaches men that dining is a spiritual function. The table becomes idealised. Much thought is devoted to its decorations, to regaling the eyes with the sight of beautiful birds in their charming many-hued plumage-peacocks, storks, or small and pretty birds strung on skewers. The mistress of the house shows her art in having the daintiest courses served on gold and crystalthings which while tickling the palate content the mind; first dessert, composed of fruits and sweetmeats, then compounds of eggs or fish, light dishes, in which pistachios, pepper, ginger, rosemary, thyme, peppermint-everything that has sweetness or aroma insinuates itself and figures in manifold combinations. Just as in Plato's Symposium, people take their places at table not to eat but to talk, because conversation can have no warmer, more cheerful, more restful setting. Often in the platonist system some incomparable lady presided, and everything centred in her; from her eyes "rained love," that is, in the words of the guests, "meat and drink, ambrosia and nectar." She set the pitch; there was a cross-fire of witticisms flashing over the table like fireworks, or else wit fluttered lightly about amid a subdued hum of laughter. With one consent these were voted delightful hours. Men fuddled themselves with talk: "'Tis my greatest vice," confesses Erasmus.

This art became so well acclimatised at the court of Francis I. that it soon became the joy of France. Margaret of France writes enthusiastically about those dinners at which they used to "fill themselves with words more than with meat." French wit, which always owes a little to good cheer, sparkled quite naturally.

In Italy they were at fault in using aesthetic means too freely to support the dinner. They durst not trust simply to conversation, but employed music, a proceeding which appeared rank heresy in France. King Alfonso of Naples, indeed, long regarded as the pastmaster of good living, complicated his dinners with all sorts of refinements; after the first courses, the ears were enchanted with harmonies soft as the breeze of Capri blowing over the sparkling,

${ }^{1}$ Gout was very common. Louise of Savoy suffered from it. 
rippling sea; or else there were mimes, the pulcinella, ${ }^{1}$ and roars of laughter. Then his guests returned to the table and remained till the moment when, their heads swimming with the strong and generous fumes of Falernian, they removed the plate and withdrew.

In Germany the whole day was spent at the table, with a licence that was often gross, and with all that old mediaeval gaiety of which the Table-talk of Luther has preserved an excellent specimen. Yet the Rhine is not so broad nor the Alps so high but that such customs soon appeared disgusting and lamentable when compared with the politer modes which were spreading through the world. Many writers endeavoured to polish these table manners by publishing manuals of etiquette and collections of bons mots. If they did not establish the complete art of conversation they indicated its rudiments, and indeed their success was sufficient to necessitate in 1549 a recasting of the fourth edition of the classical collection of Gastius, ${ }^{2}$ and the suppression of a certain number of pleasantries which seemed out of place "in view of the distresses of the time." Thus the art of table-talk became so popular that even in Germany people endeavoured to cultivate it; but sprightliness, which is its very salt, remained till further orders a distinctively French quality.

The ball and the dance, though much more aesthetic in themselves, were a great deal more difficult to idealise, because in them the sensuous element bulks more largely. Hele, however, there was no need to exagrerate, and to proscribe dancing would have been absurd. What conld be more ridiculous than the jealousy of certain husbands (husbands do not stand sufificiently in awe of ridicule!). And it was so useless, too. A woman who has her wits about her is never at a loss for a pretext for going to a rout; there is always a young girl at hand who needs chaperoning. Someone, indeed, mentions a young matron of Louise of Savoy's own court, who, to save an old husband an apoplectic fit, had the heroism to immure herself at home; but this is dead against the spirit of sociability. Why forge useless chains? Vivès himself, who is not open to suspicion, agrees

[ [A sort of farcical comedy.]

${ }^{2}$ [Jean Gast, Swiss Protestant theologian (died 1553): author of Convicalium sermonum liber, meris jocis ac salibus refertus. 
that "dancing is a very natural accompaniment to the pleasures of society and the table." But there is dancing and dancing. The ideal of platonist joy and happiness would be a free and thoroughly intellectual dance with a calm and delicious rhy thm, a dance that would add a pleasure to life, the dancer in light floating drapery, bare-footed, bareheaded, ungirt, in the sweet air of springtime, on a smooth, soft lawn among jasper and coral, under the long-leaved palms, amidst the scent of roses and pine-trces-an intoxicating dance the pure motion of which harmonises with the vast music of Nature, the cooing of doves, the mighty arpeggios of the sea. The woman who, alone or hand in hand with her companions, abandons herself to this exquisite charm, this magical sweetness, who associates herself with all things in this imponderable rhythm-does she not represent a goddess of happiness, and does she not come to incarnate for us the divine charm of Nature?

In practice the dance hardly attains this ideal; yet, even confined within the walls of a room and reduced to a social art, it can still meet the high demands of moral fellowship and become for women an instrument of the most legitimate charm. The Italians especially excelled in giving it a solemn air of sentimental gravity; some of their fêtes are remarkable in history-for example, the ball given at Milan by Francesco Bernardino Visconti on October 15, 1499, in honour of the conqueror, Louis XII., or, in point of magnificence, the subseription ball got up by the household servants of Venice in February, 1524. These were memorable triumphs of art. But this high significance of the ball was never understood in France. When people gave a ball they troubled themselves very little about posterity, but a great deal about a certain number of trifling present joys; and these made women descend a little from their pedestal.

c There was in particular one peculiar custom, eminently pleasant in itself, but not very celestial, and lending itself to abuses. This was the custom of kissing.

Well-bred men in every country used respectfully to kiss a lady's hand. ${ }^{1}$ The Italians did so with fervour; if required they would have kissed the feet; and a man had to

1 Entering a lady's house, a man would kiss her hands; and to recall to mind a first presentation the graceful formula frequently employed was: "The first time I kissed her hands." 


\section{THE WOMEN OF THE RENAISSANCE}

be a German to stigmatise as idolatry the kiss applied to the toes of the Pope! Italian women disported with this kissing with perfect grace and all sorts of little refinements. At a casual meeting they confined themselves to a pleasant handshake; but tête-à-tête with a man they wished to honour, they would be the first to kiss his hand, fondly, and without any of those affectations of bashfulness which sometimes inspire such bitter afterthoughts. It was a charming and very natural custom; but in France it took quite another complexion. Men, bcing the masters, knew nothing of fine shades and nice distinctions; the having to greet or take leave of an agreeable woman was sufficient pretext for kissing her lips, and the motive they alleged for this proceeding was that it struck them as being "amiable and sweet." In the ballroom it was another story; every dance-figure ended in a kiss, and if we must add that it was complicated with wild and giddy horse-play, it must be remembered that a French ball was racy of the soil. Like a genuine Frenchman, Louis XII. felt it his duty at Bernardino Visconti's ball to kiss one after another all the ladies presented to him, in other words, every woman in Lombardy.

Ah! if the platonists and the true friends of women had been heeded, things would have been different! They were scandalised at such spectacles, which poisoned their intellectual joys. Years before, Petrarch had risen against customs that much less affected their position: what would he have said if he had come to life again! The worst of it was that these French manners were like the little leaven, and Castiglione notes that the leaven was creeping into Italy-Castiglione, who had seen the time when a man durst not even take the hand of his partner! As to Vivès, he dashes off a picture of dances and kisses with his Spanish impetuosity: "What is the meaning of so many kisses? Of old time it was lawful to give a kiss only to one's relatives; now 'tis a general custom, in Burgundy and in England, to kiss whomsoever a man pleases ... As for me, I would fain know what means so much osculation . . . What is the use of these many leaps that girls make, held by their companions under the arms so that they may kick the higher? What pleasure do these grasshoppers take in torturing themselves thus and remaining the greater part 
of the night without wearying of the dance body and soul?"

The question was more than once raised as to what extent good manners authorised, or rather obliged, well-born women to offer their lips to all and sundry, and to lend themselves to promiscuous capering. ${ }^{1}$ This question was much debated: in general the most sensible folk considered that they could not absolutely avoid the custom, accepted as it was in good society, but that it was possible to practise some reserve; for example, to present the cheek instead of the mouth. Montaigne pities with all his heart the women "who have to lend their lips to any Jack with three lackeys in his suite"; but so trivial a subjection seemed to him, by its very triviality, to be of no consequence: "A high price adds a flavour to meat!" He holds rather with those who saw in it a simple act of courtesy, to which an honest woman could have no possible objection, or at most so insignificant a favour that there was nothing to make a fuss about. We are bound to add, however, that this was not everyone's opinion; and there were not wanting dilettantes who by no means regarded this farour as so unimportant; Ronsard in all frankness considered it delightful and took infinite pleasure in it. ${ }^{2}$ As to Melin de Saint-Gelais, on one occasion when he had won a dozen kisses at forfeits, he swore that it was not half enough: "Twelve is too few, compared with the infinite."

Here again fashion was more than a match for philosophy; and, barring a few isolated exceptions, kissing and dancing carried all before them. Examples come from all sides:

1 To civilise his dominions, Peter the Great required his subjects of both sexes to learn dancing, and he directed the performance, like a general directing mancurres. He insisted on the gentlemen kissing the ladies on the lips.

2 "Ou soit d'un baiser sec, ou d'un baiser humide,

D'un baiser court ou long, ou d'un baiser qui guide

L'âme dessuz la bonche et laisse trespasser

Le baiseur...

Ou d'un baiser donné comme les colombelles."

[Dry kiss or wet kiss,

Long kiss or short kiss-

Kiss that lures the kisser's soul,

Leading him to sin and dole-

Kiss that scals the purest loves,

Inwocent as kiss of doves.] 
from the court with its licentious masked balls, and from the heart of the provinces; witness that singular strike of the ladies of Aix in Provence. The courts having interdicted, on the score of modesty, the dance known as the volta (a sort of cancan), these ladies at once threatened to betake themselves en masse to the pope at Avignon, and their affrighted husbands had to obtain the annulment of the decree.

The platonists and their friends knew the world too well deliberately to open a campaign against abuses they could not destroy. They confined themselves to bewailing them. It struck them as deplorable to see men amusing themselves hour after hour in cutting their clownish capers at the expense of honest women. They considered it absolutely ridiculous to pretend to forbid men in the ordinary intercourse of life to smirch by word, look or gesture a lady who pleased them, while at a ball everything was permissible.

The remedy, they thought, would be found in giving women more serious and more elevated tastes; they believed that a woman habituated to really noble ideas would know how to set herself high enough to win love without yielding to the caprice of the first comer.

The Huguenots pursued a different policy, and did not shrink from attacking with all their force every kind of dancing: it would seem that they did not dance at all. They spoke of animals coupling, of disastrous confidences: "Look," cries the good Daneau ${ }^{1}$ with horror, "look at this lady with her head high, vaulting, whirling, swinging herself about, making a clatter with her feet." That was what you saw at the ball: could anything be more ridiculous? But what most strikes him is that she leaves her modesty and her mantle together in the hands of the lackeys in the cloak-room. "There any man may run his eye over the ladies as they stand, even with their husbands or mothers, and may choose any woman he pleases, in other words, the woman who excites his lust: those whom the eyes have chosen the hands clasp, and the men, as though already in the thrill and enjoyment of their desires, kiss them, hug them, lead them through the room; the young fellows exert

${ }^{1}$ [One of the earliest of French theologians who accepted the Reformed faith, born in 1530. He wrote a tractate on dancing.] 
themselves to appear lively and gay, so as to entertain and caress with a thousand tricks and approaches the girls they hold, and the girls show no reluctance to respond in kind. In the voltc there are regular tricks for making one's partner bound and rise so high that the calves, even the thighs are shamelessly exposed and prostituted to the eyes of the throng. The dancers go up and down, lose sight of each other, then find themselves close together again; and when they meet there are oglings and caperings, redoubled gaieties, all showing how their hearts are bounding with joy at seeing themselves once more so near the accomplishment of their desires. Every kind of dance gives opportunity for discovering ways of pleasing, seeing, touching one another more familiarly; and all this goes on to the strains of all sorts of instruments."

The Huguenots, it will be seen, did not mince their words. But dancing was never a whit the worse. According to the feminists it was in itself neither evil nor ridiculous; the art consisted in idealising the play of the limbs, as the work of the digestion had been idealised; and they were agreed that, the brain being in this case farther away, the task was obviously more difficult.

On the other hand, women readily gave up anything that was not congenial to sensibility : gaming, for instance. With their husbands gaming was a frenzy; mature men, boys, busy men, idle men, everybody gambled. At the gaming table all distinctions of rank disappeared; a great lord would borrow a hundred crowns from his barber. What was a gaming-hall? A place where not a word was uttered save as an exclamation or an oath. The ladies pernitted a game of draughts, chess or trictrac, but would hear of nothing else. They preferred the embraces of which Daneau, Vivès and the husbands complained.

For ladies of middle station a usual means of exercising their charm to the best advantage was to go to mass, especially on a Sunday, to the "church parade"; that served them instead of a drawing-room.

We have nothing to do here, of course, with their religious sentiments, but only with their visible devices for captivating men. They went to church as to a common haunt or a family reunion. God is the good Father who collects His children about Him once a week. Sunday is the day 
consecrated to lofty impressions, to the enjoyment in common of the things that constitute life-the day of beauty, the day of music, lovely frescoes, and displays of the latest fashion. The sanctuary was treated with an affectionate familiarity, against which the preachers had long been protesting in vain.

In the northern parts indeed this familiarity was accompanied with very objectionable scenes, and the clergy were at great pains to restrain its abuses. At Tournay, for example, it appeared very disagreeable to the cathedral clergy to serve every year as lay figures in the grotesque procession of the Holy Innocents, and afterward to be abbots of misrule in taverns; they obtained the suppression of the festival in 1489. But the coarse merriment was not scotched; everybody, the principal personages of the town included, made common cause with the children dispossessed of so venerable a privilege; and in 1498 the agitation took the shape of a nocturnal kettle-drumming which gave great concern to the Parliament of Paris.

In the south there was no need to fear such eccentricities; the church was the temple of the Beautiful because it belonged to the women. The congregation gathers in a motley, swaying, chattering crowd; it takes some time for every lady to succeed in settling her finery on her cushion, in a convenient place for seeing and hearing well. Then there arises a confused hum of gossip more or less discreet, a sound of stifled laughter, a rustling of cushions: "There is no better place for a chat than church"; it is for all the world like a concert of "magpies caught in a snare." Ladies call each other by name, "Jeanne, Catherine, Françoise." A lady who comes late tries to skip in before another who arrived early. The orchestra can barely drown all these noises; the opening prayer is delayed. Many men standing in the aisles fancy they are on 'change, and talk over their affairs; at one time dandies used to come hawk on fist or dog at heel : others, motiouless like machines, are meditating -who knows what? Nothing at all, probably. Some are watching the many-coloured undulations in the nave-the crimped hair, the dainty hats. They quiz a handsome blue bodice with yellow strings and green sleeves, cut very low. The ladies have a wonderful talent for sitting stiffly erect, posing in such a way that they show their profile or half- 
profile to the best advantage, their eyes sparkling, and sometimes stealing a wicked little side-glance. That is what they call high mass; those are the accessories of a fashionable confessional.

In this way a fine philosophic equality establishes itself with the utmost perfection at the steps of the altar, far more successfully than in any palace; all cliquishness even disappears; a woman who has toiled all the week at her spinning-wheel displays her charms by the side of the lady of rank, moved by the same sentiment of elegance, idleness, and art. For anyone with the least spark of sensibility or love of the beautiful, church becomes the land of dreams, the starting-point for every elevating influence. The Gothic church, with its lofty, light, graceful columns, lifts the soul into a sort of mystic accord; there is something warmer, more human, more genuinely intimate about the Italian church; women high or humble experience there a sensation of unmixed delight. They contemplate with tender trustfulness the imperturbable Madonna who has already seen the passage of many generations, and who continues to regard them from her nook in the wall with her woman's smile-that smile of infinite sweetness, of lingering and universal pity, directed towards the children and the dead, towards all who suffer and love, weep and laugh, a smile like a sweet-savoured incense of purification and grace. The Italians loved the magnificence of their temples-the marbles bathed in sunlight, the shadowy arches where the soul could unbosom itself without blasphemy, and all those little secluded chapels in which every man found his own saint, and came to offer up his poor, trembling, fainting heart as the whole ex-voto of life. In these hidden splendours, in the charm of mystic music soaring amidst paintings and sculptures, gilded ornaments and exquisite perfumes, midway between the past and the future, there is a wonderfully soft and voluptuous pleasure. It is with profound philosophy that Caviceo lays the scene of the first interview between his hero and heroine in the shade of an altar; assuredly, in wrapping itself with this veil of refinement and modesty, love puts on a sacred character. So the church becomes, in its wealth of compassion, the haven of refuge for pure and sensitive souls, and even for some others. Anne of Rohan gave tryst to her 
lover in the chapel of Amboise $;^{1}$ a young girl of Orleans with Machiavelian cunning made a Franciscan friar her catspaw to attract the student she loved. ${ }^{2}$ Pontanus depicts the prolonged meditations of the Neapolitan ladies, long after the last of the candles had been extinguished in the dusky nave. ${ }^{3} \quad$ A thousand incidents of this sort might be cited: Francis I. in the church of Amboise pursuing a charming girl with his devotion ${ }^{4}$ Panurge, whom Rabelais sets to dog the footsteps of a noble lady, piously offering her holy water, slipping inflammatory love-letters into her hand during mass, and playing the most impudent tricks to attract her attention; the poet Crétin, furious because at Lyons the church services are turned to account almost exclusively by young fops and paunchy bankers.

Pilgrimages also were capable of becoming a source of exquisite emotions for artists in happiness. The author of the Imitation has said that to be often on pilgrimage is seldom to be a saint. Indeed, at the moment when the indulgences were pronounced, the church porches were quite invisible behind the smoke from the cookshops or the booths in the fair, and an old author complains that you could not even catch sight of your friends. But how these gross indulgences were transfigured by the aesthetic spirit? What ravishing effects it derived from them!

It was no longer paintings or sculptures that troubled hearts and pure hearts gazed upon: they penetrated the clear heavens above. Blessed are the pure!

The sweet, tender Isabella d'Este set out thus to transport her soul across the plains of Umbria, towards the calm and glorious homes of peace and art, Loretto and Assisi. It was early spring, when the days were clear and sunny; every morning after mass the little caravan resumed its march with its picturesque escort, piously, tranquilly, ideally. During the Easter festival it made a halt with the Duke and

1 Heptameron, Tale 21.

2 Bonaventure des Périers, Tale 114.

3 Templa pudicitia.ı muculant, ni rite peractis

Rebus abis : templi noxia saepe mora est. (De Liberis.)

[The temples stain thy morlesty unless when service is over thou departest: to delay in the temple is often hurtful.]

- Heptameron, Tale 4. 
Duchess of Urbino in the delightful palace of Gubbio, smiling down from amongst its gardens and fountains.

The woman who has been able to live these hours of pure enthusiasm is conscious of accomplishing a large part of her dream. She is within sight of reconciling two opposing forces, the forces of Nature and the forces of the human heart, and forming out of them a love in harmony with Plato's thought and Raphael's brush.

In their dealings with Nature, the platonists sought above all to elevate and sentimentalise it; they did not care for it masculine and stern, but wished it feminine.

They did not ask it to express itself in vast horizons, in a display of wild vigour. Untamed Nature displeased them; it struck them as a tyrannical mechanism which would keep moving and straining itself without definite purpose, whilst it should be influenced and controlled by human thought. On the contrary, the more supple Nature became,--the more docile, urbane, almost affectionate-the better she answered their expectations. They did not appreciate the objects of Nature; but they valued a beautiful sunny day, a beautiful horizon, the flowers which scent the air, the glistening, rippling, soothing sea, the buds bursting with sap and life, because this life is one with man's. Plato has indicated the need he felt of such a setting in the celebrated prologue of the Phaedrus, where Socrates and his friend, strolling along the bank of the Ilissus, seat themselves near a temple of the Muses, in the shade of a lofty plane-tree, on one of those velvet swards in which every footstep leaves its trace. Stirred by the fierce heat of the glowing sun, life buzzes and sings on all sides; the murmur of water mingles with the chirp of grasshoppers and innumerable confused dronings; odours of all kinds fill the air, and life is quaffed in deep draughts; but amid all these myriad voices blending into one grand symphony the mind of the philosopher reigns supreme.

Man, then, must in no way be considered the enemy of Nature; he is her friend and master. Nature speaks to us, and we speak to her, and are subject to her influence in the highest degree. Not merely do climate, temperature, the beauties of the scenery exercise a paramount influence upon us, as the monks so well understood who loved 
extensive horizons and noble summits, but it may be said that there is not a tree or a plant but influences us by its vicinage. The love of Nature emits a radiance like the love of a woman, like all love, though in a less degree. It is good then and right not to neglect so important a source of emotion. Nature herself delights us because she smiles on us and we feel she loves us,-because a higher power settles her proud rocks and governs her volcanic fires. How pleasant it is (especially in warm countries) to shape for ourselves in the broad world, too vast for us, a private and particular nook : to send our very selves, as it were, out through the woods by straight paths which make our will felt far away; to give the flowers what forms and tints we please; to impress our character upon everything; thus we banish all savour of imperfection and ugliness and allow nothing to be seen but uniformity and affection; for, in the words of a man of that time, if you go into the country, it is not to "descend from light into the gloom."

Salut! palais, jardins, parãdis de délices,

Dont les beaultez font ignorer les vices. ${ }^{1}$

Under these circumstances, ladies, philosophers, and prelates considered the country a perfect setting for the intellectual life. They there got deeper, intenser spiritual enjoyment than in the city (though city life in those days was not such a rush and bustle as it is to-day). The dread hours of solitude will themselves contribute to this pleasure if you know how to bring a delightful egotism unobtrusively into play; they will enable you to recall many fleeting thoughts, to ruminate on them, feast on them for your sole pleasure, in the spirit of the sublime preoccupation of Lucullus when he chanced one day to be dining alone: "Is not Lucullus entertaining Lucullus to-day?" We find, then, in the country the same mise-en-scène as in the town - the same furniture, the same plate, but ranged under the luminous ceiling of a surnmer sky; the same dances, but by the light of torches and the stars. ${ }^{2}$ All Nature breathes and

1 Margaret of France.

All hail! ye gardens, mansions, Edens of delight,

Whose comeliness and beauty put your vices out of sight!

2 See the frescoes in the Borromeo palace at Milan. 
thinks: the trees, artistically shaped, hang their sombre drapery behind statues; charming walks wind or disappear among labyrinths of laurel, thyme, and rosemary; a cascade leaps lightly and with musical bickering from a tiny artificial rock, and speeds away swiftly but noiselessly into the miniature presentment of a well-mown meadow. Or if the owner's wealth is equal to measuring itself royally against Nature, he adorns the landscape with splendid villas, the glory of Rome, like the Este villa at Tivoli, a sort of proof before letters of Versailles, so moving still in the spectral life of its deserted groves, its silent fountains, its shattered marbles.

We must note, too, the singular phenomenon that the urbanity and bountifulness of Nature appeared to these lovers of beauty a thing of course. Nature is loved for herself only in countries where she plays the step-dame. Lombards, Frenchmen, Englishmen, on leaving the smoky scenes of their daily toil, did not shrink from a life in the depths of a dull place in the country, or from intercourse with the rustics; they might be seen any day chatting and whiling a way an idle hour with the farmers on the village green. At Paris people were passionately fond of natural flowers, the annual consumption of which was valued by statisticians at fifteen thousand golden crowns; even the University preferred them to paper garlands. ${ }^{1}$ The people of the south, on the contrary, spoilt children of a soil which yields fruit of itself, trampled roses and violets beneath their feet with never a thought of gathering them. The Italian painters used to adorn manuscripts with elaborate golden scrolls; the ladies framed their faces in gold and pearls, and valued flowers only for the delicate soltness of their perfume; many of them strewed lilies and roses and violets about their bowers, as the quintessence of sweetness. But everyone abhorred a country life. Castiglione has only one word for the existence of gentlemen-farmers: "It is indecent." As for Margaret of France, she could find no stronger abuse, no more expressive appellation for a froward heart than: "O rough heart, rural and bucolic."

Nor would one expect to find a liking for animals among the platonists. Ladies valued only the boudoir pet, the little affectionate, obedient animal, their very own, which

${ }^{1}$ [In allusion to the wreaths used at the ceremony of laureation.] 


\section{THE WOMEN OF THE RENAISSANCE}

meekly took their kisses and upon which they lavished without misgiving a portion of their tenderness : a bird for instance, or a pug. I say a pug, for there was seldom more than one. What was the good of a troop of shaggy animals however graceful, like those which fill the canvases of Veronese? A lady much preferred her one little lapdog, which she carried on her arm against her heart, took to bed with her, and had painted in her own portrait. "Love me, love my dog." Titian's Venus of the Prado is nude, but she keeps the indispensable ornaments-a pearl necklace, a musical instrument, and a little dog. Margaret in witing to M. de Montmorency ${ }^{1}$ tells him gaily that she is looking after her niece's "belongings," that is, "her parrot and her daughters." The death of the darling bird or the little pug was a cruel event. What tears were shed! So faithful a little dog! How many men might have learned a lesson from him! Friends could hardly venture to speak of the fleas of the demised, or the hair that he dropped all around, or the other objects which his mistress might perhaps find for her affection.

People did not care for flocks and herds, except perhaps as a distant ornament of the landscape. The King of Naples and the Cardinal of Amboise kept peacocks and stags. Anne of France founded a sort of Zoological Garden in which she acclimatised turkeys and bred parrots. But that had nothing to do with aesthetics.

From country life we naturally proceed to the grave question of the utility of physical exercises for women-a question much more difficult to decide than appears at first sight. Suppose a number of old-style French châtelaines, sun-baked, inured to the inclemencies of the weather, dashing huntswomen, had been asked to relinquish violent exercises like hunting, fencing, boxing, tennis, on the ground that to indulge in them was to waste their charm? They would have ridiculed the idea. And yet, after mature deliberation, the Urbino coterie decided that these exercises were altogether incompatible with the feminine temperament.

${ }^{1}$ [Anne de Montmorency, the coarse, violent Constable of France, who mumbled his prayers and his orders to his men together, because, as Brantôme says, "he was so conscientious that he always tried to combine the two duties."] 
One had to come to Lyons to find a pretty and clever woman like Louise Labé posing as Bradamante or Marphise, and boasting of her riding and her skill with the lance. Every well-born Italian woman detested such mannish ways. When Charles VIII. arrived at Naples, the princess of Melphi, to humour the barbarian's tastes, presented to him her daughter on horseback, but mounted in such a manner "as not to do wrong to her sex." Here there is a problem in pure aesthetics. Not that women like Isabella d'Este and others are deficient in energy; when need arises they will give proof of an extraordinary vigour; Margaret of France, in her passion for serving her brother, bestrode a horse and galloped to the Spanish frontier with a speed and endurance that the postal service has rarely attained. But if, impelled by strong feeling, they accomplished feats like this, they did not boast of them. What charm would Margaret with all her heroism have for us if we had to see her flying with loose rein astraddle on her nag? It is impossible to cite a military woman of a more energetic tenuperament than Catherine Sforza: when did she shrink from sleeping on the bare ground and passing her nights in the open air? Yet this was the lady who, when she had a minute's peace, solemnly dispatched a Jewish old-clo' man to her neighbours, to discover for her a certain down for bed-ticks which was repüted exceptionally soft.

The very decided disfavour in which physical exercises were held by women had its counterpart among the men, and very largely diminished their ardour for anything in the way of sport or athletics. Even at the court of Julius II. a young cardinal was mercilessly chaffed because, instead of showing his visitors his books, coins, or pictures, he hurried them off to a jumping-match in his garden! In France the taste for violent exploits utterly died out, at least in court circles. When ladies were by, there was much talk, in language borrowed from the romances, about the virtue of arms and the nobility of valour, and as they spoke the striplings brandished inoffensive swords. Tournaments were in favour as a show adapted to captivate ladies' eyes, and purely decorative-barring accidents! Some in silver habits, others in red, green, and blue, the combatants would make a few passes, and when they had done, the victor, followed by his pages, galloped all round the fine- 
sanded lists, to receive his meed of applause. After all, the ladies had little appreciation for this relic of barbarism; they did not see the philosophic necessity of equipping oneself with lance and steed to run the grand prix of life; in their view that prize was called "repose and sovereign joy"; and that is not won at a gallop.

The question of the chase gave rise to somewhat various opinions. Hunting, like war, gave man pleasure; to him it was a noble and sacred occupation, since its end was the shedding of blood, - a point in which it displeased the platonists. But, on the other hand, man is a born fighter, and he should only be encouraged to work off his combativeness against animals created precisely to be slaughtered by him. There is nothing criminal in the trade of butcher, and it is far better to kill an ox than a man, a boar than an ox. The chase was thus a valuable expedient.

But in an age of such exquisite refinement, when the infinite sweetness of the Beautiful came at length to penetrate men to the very marrow, people became niore fastidious, and asked themselves if any brilliant idea could be derived from the chase, or if it was not a sufficient concession to the animal spirits to ramble about casually, to take the air without excuses, and to go out riding under the eyes of the ladies, even though too manifestly like a groom exercising his cob. Perhaps that would have been better.

But the chase was popular at Rome.

The hunts in the Roman Campagna were of old renown. The deer there was reputed very fleet, and the boar a particularly tough customer; the hounds belonged to those idolised and sagacious breeds which could not be bought at any price, and whose whelps were begged for by princesses and potentates with absolute servility. ${ }^{1}$ Further, in default

1 "Most illustrious and excellent lady, most respected madam," wrote the countess of Forli to the duchess of Ferrara: "the credible accounts and perfect information brought in by innumerable persons about the extreme kindliness and rare munificence of your excellency, inspire me with the boldness to address you in confidence. I know that the most illustrious lord your spouse and your most illustrious ladyship adore bunting and birds, and that you always have in abundance dogs of all kinds, excellent, perfect. I beseech your excellency very earnestly that you would deign to make me a very beautiful and very precious present, namely, a pair of greyhounds, well trained and fleet-footed, for the deer of the Campagna, 
of military pomp, the glory of the chase, material as it was, seemed essential to the political interests of the papacy,--and consequently to the interests of religion,-with respect to certain eminent personages more accessible to such arguments than to those of theology; and it must not be forgotten that the Roman prelates, unfortunately for themselves, were politicians as well as devotees of art. While closely allying themselves with women, they had to reckon with men. The hunt organised by Paul II. for Borso d'Este in 1471 has remained justly celebrated in the annals of the church. It was therefore less a question of slaying animals than of saving souls, and it may be said that in this respect the chase conduced towards a spiritual end.

The great Popes of the Renaissance, however, were somewhat lukewarm in cultivating it. Alexander VI., though an excellent horseman, was but an infrequent and inexpert huntsman. Julius II, went out into the rich vinelands rarely, if at all; for, born of a sea-faring stock, he preferred to cast his nets into the deep like St. Peter. Leo X. rode more, owing to threatenings of obesity; he hunted with application and brilliance, and with his habitual love of perfection, but without that quality which makes hunting an art, that indetinable something which hunters call the "sacred fire" or the "devil may care" spirit, and the friends of the Beautiful call love. He was a Florentine, and manifestly did not regard the hunter's rôle as a fine one; he could not imagine that to spur a horse was to stimulate one's ideas. To men of his stamp Nature was, so to speak, truly feminine; they would have liked to put her under glass. On the other hand, a number of prelates revived the chase with their enthusiasm; they portrayed it in their poetry; they brought to it all their gravity, urbanity, and decorum. When the ancient walls of pagan Rome or the limestone benches of the Coliseum were blushing under the first rays of dawn, or when the old triumphal arches were looking

which are very swift : a couple of good deer-hounds and a couple of handsome pointers, so good that I may hope to say regarding their exploits when they catch their quarry, 'these are the dogs the most illustrious duchess of Ferrara gave me.' I know that your excellency will not send me anything but what is really good." She cordially recoumends to the duchess the falconer she is sending, to fetch the hounds, and probably to choose them. (Letter of Catherine Sforza to the duchess of Ferrara, 1481). 
young again under the smile of the Sabine mountains, a brilliant procession set the pontifical flagstones ringing under their horses' hoofs. Look at these great figures who are passing. Here is the proud Catherine Sforza; Tebaldeo, the poet skilful in following the forest tracks; Pontanus, the methodical huntsman, the taciturn philosopher; the pride of Venice, the sprightly Bembo, somewhat excited, for he wishes to "stick" the boar and cut off its head, and therewith to do honour to the Virgin of the woods, "in verses which will go down to posterity." Here is the fair Lucretia Borgia, "the glory of her race," and, in close attendance, Ercole Strozzi, just writing for her his great poem called The Chase, a medley of venery and politics. Who next? Here is the omnipotent Ascallio Sforza, vice-chancellor of the Roman church, all impetuosity, full of the boyish animation which he will retain through the most cruel trials till that day when he goes to his long rest in the church of Santa Maria del Popolo. Behind him comes cardinal Adriano Castelli, the witty diplomatist who wins all hearts, the admirable humanist who is going to celebrate this chase. These ladies and prelates sing the praises of Diana; it seems to them that the noble goddess in person is guiding their long cavalcade among the tombs, in the impressive silence of this great Roman desert where long aqueducts (odd vegetation!) lend sombre decoration to the landscape.

\footnotetext{
Her broidered chlamys she has raised;

Her golden locks float in the breeze,

The purple buskins reach her knees;

Her gilded quiver's ringing sound

Wakes echoes in the woods around.

Ascanio, courteous, debonair,

Rides close to show her every care;

Collects the troop, on Lybian steeds,

And harks them forth to doughty deeds.
}

View halloo! The boar is started at the foot of the hills, the hounds are off, the hunters scatter and gallop up hill and down dale, dogged and indefatigable. Presently, shouts, bayings, howls of wounded dogs! All is over. Cardinal Ascanio appears, with flaming eye and flaming cheeks, his coat red, his knife redder still, near the boar dripping red. This is the epical, the intoxicating moment. The hounds tumble over each other, the whippers-in bestir themselves, 
the hunters come panting up from all directions. Suddenly all is hushed; as if by magic an exquisite repast is served; the sweet measured tones of guitars, the voices of singers, the plaudits of the banqueters alone wake the languid echoes, while huge flagons of a generous wine go round. Then Cardinal Castelli rises, and in his elegant Latin recites a Pindaric ode in honour of the victorious huntsman, "the empurpled senate's glory and grace." Nothing could be more piously orthodox or more delightful than this hunting ode. The Cardinal recalls how the Redeemer, "true religion's lord and emperor," has put vain deities to flight and given solace to perishing humanity, bringing life and strength and joy. Ascanio responds with this invocation :

O Dian, virgin goddess of the woods and groves,

Or whether it behoves

To hail Proserpina, light of the glooming sky,

Iuncina, Hecate, or e'en

Of the dim nether world the woful queen,

Dictynna else, or Trivia-whosoe'er

Dost to my swinking hours apply

Thy constant care,

Thee in my heart I hold eternally !

Evening creeps on, and the shadows extend. Soon the joyous clatter of hoofs is re-echoing along the Sacred Way; these are the masters of Rome, whom the shades of Tiberius and Constantine salute in the darkness.

While at Rome the chase was thus allying itself with poetry, in France, as may be surmised, it followed no such bent. The good Louis XII., ruling with circumspection, would not have been hard put to it to give his exploits a character of seriousness and tranquillity, for his health obliged him to hunt in a litter, and more often with hawks than with hounds; indeed, even at the kennels of Blois the spirit of poetry modestly crept in; the court poets, not having at their disposal the Roman mythology, or the shades of Tiberius and Constantine, extolled the royal hawks and hounds. They honoured with a charming epitaph the venerable Chailly, doyen of the pack, and a model of probity and honour, who, after having followed the king even to war, had peacefully finished his course at the feet of Queen Anne. They sang also of the famous 
falcon Muguet, the terror of herons, "little of body but wondrous full of courage":

Trois passetemps parfaits a eu Louis douzième:

Triboulet et Chailly, et je fus le troisième. ${ }^{1}$

But all this fine poetry only celebrated the mettlesomeness of the animals; it did not protect the game from slaughter; it left hunting with its primitive characteristics, which continued to wound the finer feelings, and snuffed out the faintest glimmer of the spiritual life.

One man was found, with the heroic determination to reform the French style of hunting in the Roman direction. This man was Guillaume Budé, generally known as the founder of the College of France, but as good a hunter as a Hellenist, and in this regard as worthy of renown.

Budé is a brilliant example of the intellectual development of many men of his generation. Come of a line of high officials, he went through the usual experiences: a tutor, fashionable masters, a special Greek tutor, one George Hermonymos, brought direct from Lacedaemonia to teach him to lisp the Greek alphabet at the remuneration of five hundred crowns monthly; but Lefèvre d'Etaples ${ }^{2}$ did not succeed in making a philosopher of him, nor Fra Giocondo ${ }^{3}$ a mathematician. Then, after lolling for a while on the long-suffering benches of the Orleans University of Law, Budé resigned himself to run in the paternal grooves; apart from hunting, he was not known to have any accomplishment or passion except fishing. So he went to Rome as secretary to an embassy at the time of the election of Julius II. This proved the turning-point of his life. The aesthetic splendour of Rome struck him and held him spellbound; he experienced the electric shock, the complete change of view which the sudden revelation of the

1 King Louis Twelfth had perfect pastimes three :

Triboulet first, then Chailly, lastly me.

The anthor has collected the varions pieces, still unpublished, in which these hounds and hawks of Louis are celebrated.

${ }^{2}$ [Professor of mathematics and philosophy at the Cardinal Lemoine college at Paris (1455-1537): a broad-minded man, the quarry of a heresy hunt: chosen by Francis I. as tutor to his son Charles.]

${ }^{3}$ [Architect and antiquary of Verona (1445-1525). He spent eight years in France at the invitation of Louis XII, designing bridges and buildings: he was afterwards one of the architects of St. Peter's at Rome.] 
spirit of beauty has from all time occasioned in choice minds. He came back a changed man. He became an apostle of beauty; he resigned his diplomatic appointments, and his office as secretary to the king; he even refused a coinfortable retreat on the bench, in order to devote himself to that noble intellectual life, the radiance of which had filled his soul.

He gave up everything except hunting. And it was then that he had to face the trying problem that rose in his mind with peculiar intensity - how to spiritualise the chase.

The solution he arrived at was of the most original kind. He has communicated it to us in the form of a conversation, real or imaginary, between himself and King Francis I. This dialogue attained a measure of popularity; written in Latin (following the Roman fashion), it had the honour of being translated by the great court translator, Louis Le Roy, and in our time has been re-published by M. Chevreul.

Budé's idea was wonderfully simple, and nicely calculated, he thought, to make an impression on Francis I. The king was not very clever, but he was very willing to learn, and had great confidence in the new ideas, particularly those of his friend.

Buảe merely suggested the adoption of Latin as the language of venery. At first sight, Francis did not quite catch the piquancy of this proposal; however, he made no opposition; and discovered on reflection, indeed, that it hit the mark admirably. Certain persons were agitating for the suppression of Latin in law proceedings, with the professed object of rendering them more comprehensible: here was an excellent means of silencing the agitators, by showing them that Latin, if it can serve for the slang of the turf, can serve for anything.

History does not relate whether Francis halloed his hounds in Latin verse; but the seed dropped by Budé was not lost, and another scholar, Michelangelo Blando, the commentator on Aristotle and Hippocrates, took up the same subject as a second study. In a learned Latin treatise on hunting, Blando shows how important it is for the huntsmen to be men of literary culture; for their benefit he investigates every branch of canine lore from the earliest times: breeds, regimen, maladies, training-on all these points he admirably collects the various threads of tradition. 
Nor does he forget the lives of the most illustrious of hunters down to and including Francis I. Among these, naturally, he makes honourable mention of a number of noble ladies who were ardent devotees of the chase, and with whom the sport almost always meant a dedication of their virginity; for example, the fair Atalanta, who disdained marriage; Calixto, daughter of a king of Arcadia; Arethusa, daughter of the Centaur Hippochrome; Amimone, a Breton nymph, daughter of Danaus; and a thousand other vestals whom it is unnecessary to recall, says he, "being bousehold words with all hunters worthy of the name." After such an enumeration, one might indeed be tempted to believe that, for women at any rate, the chase elevates the soul and has platonic virtues.

But, all this notwithstanding, the lady artists in charm did not think it deserved either encouragement or sympathy on their part. In what respect had this sport any moral efficacy? It had, on the contrary, the disadvantage of giving a woman a somewhat masculine appearance, of diluting in her all that constitutes the essence of platonic sweetness. ${ }^{1}$

Riding to hounds was no longer indulged in, except by some few over-energetic and rather old-fashioned ladies like Margaret of Austria, who was so proud of her stuffed wolves' heads; or Anne of France, a passionate and classical huntress, whom one of her faithful henchmen, the seneschal of Normandy, enthusiastically styleś the "grand mistress"

1 Kathin alloit bien montée a la chasse,

Portant espieu. Cupido la pourchasse

Avecques son arc, et luy dit: "Combatons,

Puisqu'ainsi est que nous avons bastons."

Elle respond : "Amour, que penses tu?

Longtemps y a que je t'ay combatu

Sans estre armée : a présent, je le suis ;

Retourne-t-en, et plus ne me poursuis,

Car seure je suis que tu seroys batu."

(Michel d'Amboise.)

[Kitty well mounted to the hunt was hying,

Holding a spear; Dan Cupid her espying,

Loosing his bow, gave chase and caught her. Said he :

"Come let us fight, since both are armed and ready."

Then answered she: "Love, art thou then so daring?

Long have I fought thee, weapon never bearing ;

Now am I armed, turn, never more pursue me,

For I would beat thee, ere thou couldst undo me.'] 
of this "glorious trade"; but whom he calls also its last representative. Anne hunted in the same way that she did everything; coldly and methodically she with her own eyes examined the trail, and gave the word to hark forward; then she set off with her dogs, and suddenly warming to the work, grew animated and vociferous, and smartly handled her hunting-spear. Such ways as these have caused her to be always wrongly judged, even by her closest friends, and lave given her a reputation for mannishness, whereas in her heart of hearts she was infinitely feminine, and femininely philosophic.

The large majority of her contemporaries would have been careful not to imitate her, and if they resigned themselves to the chase, it was for some good reason. Personally they went in for little else than hawking. It was indifferent to them whether men rode out and effected more or less slaughter; but they loved the associations of the hunt-the delightful evenings, favourable to flirtation (when the hunters were not too hungry or sleepy); the succeeding days of tranquillity, when the unconstraint of country life allowed them to rise early and come down into the fresh air without stopping to do up their hair or their complexions, but with clear, rosy cheeks; to hurry through a hunter's mass, and then start gossiping in the shade on the respective merits of dogs and birds until it was time for breakfast. In short, to platonist ladies, the less hunting there was, the more genuine and admirable the chase appeared. If men absolutely insisted on spilling blood, why not get it over quickly? Why not fill their parks with tame stags and one fine morning go out and massacre a few? But for pity's sake let there be no more talk of their Red Indian stratagems, or of competing in instinct with the animals! "Tell me," cries Margaret of France, "is the capture of a stag fit work for a prince?"- -he might as well turn mason or hind!

They came to the conclusion that, if they did not wish to live in the kennel, there was nothing for it but to give up hunting: and this was more logical than Bude's or Blando's attempt to imbue huntsmen with lofty and fantastic ideas which would never make a good sportsman.

Like all human things, the charming theories we have just indicated had their dark side. The habit of suppressing 
nature, of making her all grace and attractiveness, of embellishing and transfiguring her, is pretty sure to lead to the loss of any real knowledge of nature. A landscape is transformed into a drawing-room. Lemaire de Belges and others discourse to us of nothing but branches gently swaying, rustling leaflets, the waning autumn, huts in which mock shepherds in sham goat-skins listen to the moaning of the winter wind with a ravishment which it is difficult not to fancy humbug too. If only this mawkish sentimentality always led to the ideal! But no; the coy Phillises sport their demure little tricks at all hours but the lover's hour, when perhaps they would not be out of place.

The fleshly Venetian school, with its feeling for colour and its somewhat pagan naturalism, much more successfully expressed man's relations with Nature. It opens for us not a mere garden bower, but a huge factory of sensuous pleasure, whence ascend a thousand high-soaring aspirations and a penetrating effluence. Giorgione and Titian have wondertully rendered the poetry of these love-filled horizons. From the smooth sea, or the foaming billows, or the flowery meadows depicted by their pencils, loud voices speak to us; and nothing but the old, imaginative mythology is wanted to personify all the unknowable and unknown unions whence we feel that the physical world is every day drawing its life and its overmastering thirst for renewal. The epicureans let themselves drift along aimlessly, resting on their oars, ${ }^{1}$ and do no more than sing their little part, hardly audible in this colossal orchestration. The platonists, on the other hand, will not allow themselves to be seduced, and combat nature even while caressing her, preferring to keep her too much in subjection rather than to yield her too much obedience. Nature untamed or sensual would slay man, they think. She is a slave, meant to be subject to us, meditating revenge, and eager to suck or shed our blood; and she is set among the slaves.

Finally, a word must be said about a life which held a place midway between country life and city life, namely, the life of the watering-places, both inland and by the sea. In France the fashion was difficult to introduce, good

I Ship of Fools, sixth engraving. Critics almost always represent epicurism in a boat. 
society preferring the large and comfortable existence of the country house; but to take the waters was all the rage in Italy.

Except at church, there was no scene where people could better meet together, or take one another more seriously without hypocrisy. A public bath represented the ideal of equality. You go in, cut a figure, and come out again, and Jack is as good as his master. It is an open drawingroom, in which people who elsewhere are strangers to one another, acquaintances, and bosom friends all have one idea-to distil their soul drop by drop into the ears of kindred spirits, like the neighbouring spring.

The difficulty with which the custom became acclimatised in France has been attributed to very various causes. Following an old tradition, many preachers so late as the 16 th century inveighed against the habit of bathing. Out of thirty women who go bathing, says one, not one can call herself pure. "O fatal laving, prolific in elements of death!" exclaims another. "Ye women who stew yourselves," says Oliver Maillard," "I summon you all to the stewpots of Hell!" The Calvinists went to still greater lengths of indignation, and more than one physician, even, thought well to adopt a cautious attitude. At the end of a long treatise on hygiene, Gazius says: "I have still to speak about the baths, and I shall do so briefly, for the custom of batling does not exist among us, and further, it is a pleasure which is not devoid of danger; perhaps it would be better not to speak of it, lest I should appear to recommend it. For myself, I have never taken a bath, and I am none the worse for it, thank God!" However, Gazius, not to come to loggerheads with the ancients, or the Arabs, or his colleagues, goes so far as to acknowledge that cold water is in use "in very distinguished countries"; for his part, he sees nothing objectionable in a douche followed by brisk friction or massage.

But we must get to the bottom of this matter, a question of morals rather than hygiene.

We have unexpectedly come upon principles which we recognise as old acquaintances. Neither preachers nor Calvinists were willing to admit that any consideration of

${ }^{1}$ [A Franciscan friar (1440-1508) and a vigorous and racy preacher. His sermons were larded with buffooneries.] 
utility could induce a self-respecting woman to strip herself of all, or nearly all, her clothes, either in the open air as in ancient times, or in one of those public bathing establishments which were cried every day in the market-places between the artichokes and the cheese, ${ }^{1}$ and where the authorities winked at certain familiarities. Many historians have concluded outright that Calvinists and preachers had a horror of water; but this is not strictly accurate; they recommended baths at home. Thus the council of Basle passed a canon inviting persons to set bathrooms in their houses. The platonists fell in the more heartily with the council's recommendation in that they treated their bodies with sacerdotal attentions, so to speak, and that no refinement appeared to them unreasonable in forging the weapon of delightful love. Some discriminating women preferred dry methods to water-powders, pastes, scraping of the skin, which enabled them to say "that they did not wash their hands"; but the majority owed a great deal to water, and the room.devoted to this work of regeneration was a sanctuary. The little bath-rooms of the 18th or the beginning of the 19th century, hung all round with mirrors, are familiar to us. The idolatry of the 16th century was less blatant but not less ardent; Raphael himself decorated Bibbiena's bath-room, and, as we know, the subject chosen by the charming prelate for his frescoes was the story of Venus and Cupid.

In one of her most amusing letters Madame de Sévigné bewails the necessity of taking shower-baths at Vichy, which she regarded as a "humiliating" situation to be in. To give herself courage, she conceived the singular idea of

${ }^{1}$ C'est a l'image saincte Jame

Ou se vont baigner ces femmes;

Et baignez, et estuvez, allez.

Bien servies vous y serez

De varlet $z$, de chambrière,

De la dame bonne chère.

Allez tost, les baings sont prestz.

(Les Cris de Paris.)

[To the image of St. James

Go for bathing these fair dames.

Haste ye, ladies, bathe and stew,

Maids and varlets wait for you,

Service good, delightful fare ;

The baths are ready: speed ye there.] 
keeping her two maids with her, so that she might "see familiar faces." At the same time, she got her physician, a man of parts, to conceal himself behind a curtain, so that she might chat with him during the operation.

We do not know what the impressions of Madame de Sévignés descendants are, but we know that her ancestresses were on this point extremely fastidious. Margaret of France, not to lose sight of the story of the chaste Susanna, had it embroidered on a table-cover.

We get an idea, then, of the cantious attitude adopted in regard to hydrotherapeutics. But on the other hand the friends of antiquity restored water to a place of honour; scholars proved that the Romans had been devoted to it; the higher clergy became its apostles. George of Amboise and his brothers multiplied the spas at Rouen, Blois, Gaillon, Clermont, as the pope did at Rome.

In regard to mineral springs, there appeared, under the auspices of the pope and the Venetian senate, a large folio official guide, ${ }^{1}$ which explained that there were waters for all sick bodies as there were saints for all sick souls, ${ }^{2}$ but that no one should venture to them without seeking advice in the proper quarter.

A person wishing to go to the waters would consult a physician. If he was a specialist like Savonarola, he would look at every thing with aquatic prepossessions, and commence his patient's initiation at home with baths of various kinds -baths of oil, of wine, of milk, of fire, of compressed air. One fine morning he would announce that mineral waters were spoilt in transit, that he was tired of making the patient drink stale water, and he would then dispatch him to some natural spring.

Most of the Italian springs, at any rate such as were much frequented, had the good taste to flow in or near a city, and

1 "A work, for our epoch, in which the use of mineral waters is so common, very useful to physicians, but still more to all other persons, and very entertaining."

${ }^{2}$ For example, Le Bain de St Barthelemy: "A man of Feltre named Petrarch, after an accident to his knee, having been attended by a series of, I will not say bone-setters but, bone-breakers, experienced the keenest anguish; a flux resulted: astringents and cold remedies were applied; and an induration ensued, which compelled him always to walk with a stick or a crutch. At the end of two years, he came to see me; I prescribed the baths. They did him so much good that after a fortnight he left for home without his crutch." (De Balneis, 1563). 
thus people were likely to meet familiar faces, if only among the regular visitors. Under Louis XII., the city of Genoa revolted because its French captain, the Sire de Roquebertin, instead of attending to business, tiresome certainly, passed his life at the waters of Acqui.

A lady of distinction, however, first of all secured a good escort to keep her company; Margaret of France, for instance, carried her whole party off to Cauterets. Then she had to listen to the parting exhortation of her doctor, a punctilious and intelligent man, who apparently had no excessive confidence in his colleagues or his fair client, and who catechised her and made her read the folio. $\mathrm{He}$ mentioned eight enemies lying in wait for her-headache, insomnia, and the rest; - he instructed her how, by watchfully studying her little secret vices and never for a moment forgetting her digestion, and so on, she would put them to rout. Then he carefully consulted the horoscope, the direction of the wind, the temperature, his chart of epidemics; he assured himself as to the character of the year (for there were some years in which the waters killed off the invalids or made them worse), and finally he pronounced the exeat.

Flinging off this wet blanket with his terrestrial visions, the patient sped away. Pity if it was towards Porretta, near Bologna, a very popular haunt but dreadfully purgative. However, the spirit of Beauty can idealise everything, and an agreeable poet, Battista of Mantua, undertook to show all the moral and aesthetic satisfaction to be got in drinking three glasses of a laxative water, and then leaving Nature to herself.

$\mathrm{He}$ describes this regimen in admirable verses:

"Far from the bed and all its joys, You go and come and eke advance In the slow measure of a stately dance,"

and so on.

In fact, the idea of becoming young again, the thought of gaining new freedom of mind, new warmth of heart, new suppleness of the bodily frame by sacrifices so slight, of seeing the wrinkles vanish of themselves, in short the pursuit of beauty as a bounden duty, threw the glamour of poetry over many things, and was well worth the self- 
imposition of twenty-one days of hardship. For all that, fashionable people preferred the bathing-places to the spas.

Life at such places presented the admirable advantage that people could there enjoy the most perfect liberty. Nowhere were there better opportunities for seeing one's friends, for intimate conversation, for deriving real profit, from companionship. It was that which made this life so precious. A man who had followed in the train of the princess he loved had absolutely nothing to do but to devote himself to her, for he put up with the rubbings and purgings only as a sop to his conscience. What delightful opportunities between two glasses of water to improve the mind or tell stories! Many collections of Novelli originated near a spring. It was during a season at Lucca, in April 1538, that Vittoria Colonna made the acquaintance of Carnesecchi, the adventurous theologian, and launched out with him into the abstrusest religious speculations. Everyone followed his own bent, and the gentlemen who did not love husbands were less irked there than elsewhere.

We shall not go so far as to say that platonism exercised undivided sway over the bathers $;^{1}$ but to have a place at all was something gained. There is no indication that a much parer virtue reigned north of the Alps among the virtuous races. The goings-on at Baden in Aargau scandalised even Brantôme. A Florentine, ${ }^{2}$ who thought life at Florence pleasant enough, has related his impressions at Baden with a naïve stupefaction; he was dumbfounded the very moment he arrived. The beautiful platonism of his own province, flanked always by jealous husbands and impedimenta of all sorts, appeared to him mere food for babes, a phantom, a faded flower, an unsubstantial pageant, beside those Piccadilly manners. But they did not offend him: "Bravo!" he cries, "who wouldn't be platonic, since Plato preaches the community of women? Here the husbands take everything, absolutely everything, in good part! How wonderfully sensible of them! These Germans don't rack themselves for suspicions, they enjoy the present." And then, Florentine as he is, he goes on to describe the

${ }^{1}$ Gregorovius gives in his Lucretia Borgia an account of an extremely free fête got up at Sienna for fair bathers, from which husbands and brothers were excluded.

2 Poggio. 
charms of Baden with genuine enthusiasm: the handsome streets in which never a sign of intirmity is to be seen (Baden was recommended to childless women); exquisite fine ladies; men in cloth of gold and silver; somewhat. exotic beauties sprung from God knows where, attended by a lackey and one or two waiting-maids; here and there a. few noble abbesses of reasonable piety. . . What a whirl! It is one mad race for pleasure!

Serious people who take care of themselves and desire a cure, have two or three baths a day, living like so many ducks. For ordinary folk there are common swimmingbaths of wonderful picturesqueness, but every respectable hostel possesses one bath for men, and another for women, with a gallery to which men are admitted in their dressinggowns. To describe the gaiety that reigns there is impossible. There is chatting and laughter, eating and drinking, dancing in a ring; the gentlemen fling down coins which the fair bathers catch with the tips of their fingers or in their linen chemisettes, with much contortioning and struggling. Sometimes, when the company are on intimate terms, they end by fraternising in a single tank, which is much more arnusing, and pleases the physicians, because nothing ensures more conscientious bathing. Honi soit qui mal y pense!

In the erening a broad meadow serves as a casino; there is more dancing and singing: and these amusements are mingled with various pastimes such as the game of balle à grelots, ${ }^{1}$ which leads to all sorts of horse-play.

That is Baden.

One singular fact is brought out. Platonism was regarded as nothing if not complex and elaborate, and indeed it believed itself to be such; antiplatonism, on the contrary, affected airs of the most complete simplicity: yet whenever the two are confronted, it is platonism that proves the more ingenuous.

${ }^{1}$ [The balle à grelot was a hollow ball of metal containing something that caused a jingle when the ball was moved or thrown-like our horse-bells.] 


\section{CHAPTER V}

\section{INTELLECTUAL RESOURCES}

IT is all very well for a woman to be beautiful, to lend grace to the world, to diffuse sweetness and light; but this would be but a vain show if she did not with jealous care nourish in herself the flame of love of the Beautiful. Castiglione, who liked to give a mathematical precision to his definitions, tells us: "Woman must nourish herself on the life of the world and the life of the arts"-thus in appearance relegating the aesthetic life to a second place; but he is very careful to add: "She must occupy herself with literature, music, painting, dancing, and entertaining"; in other words, the heart must reverse the parts, and in the conscience secret preoccupations must come before visible occupations. His view is logical. How could women govern the world if they were in reality its slaves? The first necessity for a lighthouse is a light.

Further, we ourselves have a right to ask where these ladies think of leading us. Their art consists in pleasing us and in indoctrinating us with their principles. To please is their secret, with which we do not meddle; it is of little consequence to know if Lucretia Borgia cut out her own dresses, where and by whom Mary Stuart had her hats made, or if women always please by what pleases their husbands. But when they speak of ruling our intelligence, it becomes of very great importance to know how they will deal with us.

The intellectual provision of the Renaissance women consisted chiefly of impressions of art, in accordance with Castiglione's prescription. In this, painting (still more the inferior manual arts-lace-making, embroidery, tapestry) 
held the lowest rank, on the principle universally accepted in the platonic world that the less an art needs the co-operation of the senses to touch the soul, the greater is its excellence. Music stood higher than painting, because it directly transmits an impression; vocal music in particular represents almost the speech of soul to soul, with but an insignificant admixture of materiality. Poetry was the supreme art, the truly aristocratic thing; no one would have dreamt of comparing it to painting or any manual art. The poet with one stroke paints soul and body; in Ronsard's words, "he paints in the heavens."

To lay in her stock of happiness, a woman will begin by living in close communion with the Beautiful. Sciences are useless to her; she has little taste, and still less time, for their cultivation. But just as she finds breakfast a necessity, so she ought every morning to give her soul nourishment, if it be only one sip of the beautiful. Louise of Savoy on rising used to read a psalm, "to perfume her day," as she put it. These few moments' reading. were sufficient to flood her soul with a radiance to light her through the day.

Further, reading is a duty having special claims on women. Not only is there always some new thing to learn, some new chord to touch, but the intellectual life demands a constant outgoing of energy,-I will venture to say, a continual "education." Could a tree flourish and bear fruit if it refused to suck up its sap? How long would it be before it stood a bare skeleton against the sky?

Thus, with complete independence of mind, as great as her material liberty but much more difficult to acquire, a woman will supply herself with spiritual food; she will seek Beauty in truth stripped of all conventions. The real foe to women's freedom is not this or that man, but themselves, because of their frivolity, their inconsequence, and their innate passion for the superficial; in other words, for the conventional or fashionable. They need a real force of soul to go deeply into anything; they are perfectly happy in yielding to the glitter of a thought which, though obscure at bottom, is dazzling on the surface. When the taste for precision has not been carefully instilled into them in childhood, they run a great risk of wasting their minds in habits of cursory curiosity, like many men of the world.

Books played a prominent part in the psychology of the 
Renaissance. They were regarded as the highest type of luxury; a house was characterised as much by its library as by its plate. Among the ladies, Anne of Brittany, Louise of Savoy, and many others are essentially deserving of the name of bibliophiles, nobly loving the beautiful books with beautiful miniatures produced for them. They were even accused of reading them. In that epoch, the artistic aroma exhaled from a fine edition seemed necessarily to accentuate the written thought, just as music accentuated the uttered thought. We have become wiser; we have discovered that beautiful books are herbariums in which ideas must be left to dry, for their better preservation.

There was no lack of scoffers to make mock of this "bookish sufficiency." "What a heap of books! . . . These folk must surely mean to carry the world on their backs! What a frittering away of intellectuality!" And, indeed, Margaret of France not only believed in books, but doted on them; to her a library seemed a sanctuary.

\footnotetext{
"Tant y en a que le seul remembrer

Et les nommer n'est pas en ma puissance, Mais il faisoit beau voir leur ordonnance . . . Et du scavoir qui est dedans J'en laisse aux folz craindre les accidens . . . Des livres fiz ung pillier, et sembloit Que sa grandeur terre et ciel assembloit."1
}

We writers think it natural enough that people should buy our books, keep them, and even eut a few pages; if it is women who show us this attention, we do not complain. We dig away in darkness under the soil, labouring like a miner with his pick; why should we complain that above us, in the bright sunshine, someone sifts and mints our metal, and circulates part of it through the world?

It is even a not wholly disagreeable surprise to meet in an odd place here and there one's own ideas, which have

1 So many books there are, my memory fails

To number or to name them; but to see

Their fair array's a pleasant sight to me.

And as for fearing what they have inside, 'Tis a mere folly I may not abide.

I piled a pillar of them, and methought

It heaven and earth together brought. 
flitted away and found warm foster-parents in people who have so far adopted them as to believe them their own. Sometimes it is another writer who is good enough to saddle himself with them thus, and in that case our feeling is not perhaps unalloyed pleasure; but if it is a reader, man or woman, we are well rewarded. Often, too, our idea as it goes round has altered in feature, and if it now and then appears to us enfeebled, it also happens sometimes to have gained strength.

Everyone cannot be a writer! 'Amateurs' have a rôle of their own, which is not that of 'stickit' authors-a rôle of synthesis, generalisation, criticism, support, sanction!

The end we pursue-thought, namely, and truth-can only be attained by the aid of conversation,- - only if distinguished and enthusiastic women set themselves to distil from our books any good they may contain, and to diffuse its essence around them.

From this almost indispensable collaboration between pure learning and its popular interpretation results a vigorous life. As Madame d'Haussonville has so well said: "An eager desire for knowledge possessed the entire sixteenth century. The quick and supple intellect of the women was carried away in the general current. Erudition was the passion of the age, not that cold and microscopic erudition which arises in ages of decadence, and which is often only the useless lumber of scholastic pedantry, but an erudition living, intelligent, and animated"-animated, that is by aestheticism.

By the side of exquisites like Bembo, laborious students like Lefèvre d'Etaples, Hebraists, and exegetists cultivating their little patch with dogged tenacity, there were brilliant minds, perhaps more brilliant than profound, but unprejudiced, who synthetised particular studies and started them on an unlooked-for career. For the Hebraists, exegetists, philosophers, and historians of every description, the spread of intelligence would of course have been fatal; but it was the raison d'être of a lady whose mission was to put in circulation the results of her individual study.

Thus the aim which women had to set before themselves in their reading was twofold: first, a personal, aesthetic aim, the reinvigoration and refreshment of their own souls ; secondly, an aim relating to their apostolic mission, the art 
of understanding men's souls, then of charming and leading them by means of conversation.

But it is impossible, by merely scanning a man's bookshelves, to form an idea of the man. In great houses, the king's, for example, some of the books were inherited, others were presents, others were books that no gentleman's library could have been without. Francis I. bought the Italian novelties, Bembo, Pontanus, and Politian. In reality his chief reading was the Arthurian romances.

The princesses had also, besides the books of the hour, books that they had been obliged to buy or accept, books left to them-those which were kept "for their backs," as Montaigne said. The bookshelves made a brilliant display in a spacious gallery adorned with the choicest objects of art. The bulk of the library usually consisted of books on the elements of religion, history, and morals; it also contained romances, poetry, Petrarch, Boccaccio, and books with engravings, which too often replaced those charming manuscripts of which Louise of Savoy was one of the last protectors.

The books that were read were treatises on history, especially Roman history, and on practical medicine. ${ }^{1}$ But custom varied.

Ccrtain ladies, like Anne of France, browsed on the early fathers, the philosophers, and the moralists. Many, while loving studies of this kind and calling themselves highly philosophic, preferred to have their food peptonised, and to be furnished with ready-made convictions which only required ventilating and disseminating in conversation. A number of Italian treatises proffered themselves for this little service, the best of which was Castiglione's book, The Courtier. To name Castiglione is to name the Bible of platonism, the code of aestheticism, the Machiavelli of antimachiavelism; Castiglione was in the hands of every woman who meditated on the ideal.

From a purely aesthetic standpoint the classics were in favour, except Virgil, to whom only the Mantuans remained faithful, probably from local feeling. Ovid, who speaks so well and so much about women, ranked very high.

${ }^{1}$ Lucretia Borgia took to Ferrara for her personal use only beautifully decorated Books of Hours, a few devotional books, a manual of history, a collection of songs, a Dante, and a small Petrarch. 
He had been popularised in France by the translations of Octovien de Saint-Gelais and André de la Vigne; illustrated editions went off rapidly, even though the engravings were old. In the very highest artistic spheres, people swore by Cicero. ${ }^{1}$ In Margaret of France's circle the favourite names were Terence and Cicero, Castiglione and Boccaccio.

On the reading days, which were principally (we are bound to say) the grey days of existence, when one feels abandoned by God and men, when one is left to "one's own devices," people rather sought for light entertainment, if possible gently emotional, or at any rate lively, cheering, affecting. The Bible was very useful for getting glimpses of Heaven without having to run to a monk or a parson, for an intelligent woman cared for nothing lower than a bishop. If they wanted psychology, they went to poetry, novels, romances. A mere sonnet, a little story, very short but with movement and savour, would suffice to cure a casual fit of dumps; in more complicated cases they took up some voluminous romance, which engrossed the attention for long hours and reflected life for the nonce in warm and sunny hues.

The literature of the Renaissance was well provided with Nouvelles and Facéties, answering all the demands for spiced and piquant reading made even by the platonist ladies.

They revelled in such works with no touch of coyness; it was a mark of breeding to discuss them, laugh at them, and quote from them. Often some courtly abbe, the spiritual director of these ladies, and soon to be a full-blown bishop, undertook explanation or translation.

Some persons have questioned whether the custom of reading narratives so strongly spiced did not in the long run obliterate the moral sense, especially among women. Brantôme maintains that this was the cause of all moral obliquities. Margaret of France did not believe it; her faith in art was so ardent that she regarded it as a proof of mental vigour to face all sorts of literature without blenching. Her friend Marot told her so with a smile, for in the contest

${ }^{1}$ Especially Castiglione, who borrowed entire passages from Cicero. A translation of the De Officiis was published at Lyons on Feb. 11, 1493-94. 
between flesh and spirit he held with the flesh; he mentions a select list of the works reputed the most naughty, and adds :

Tout cela est bonne doctrine,

Et n'y a rien de deffendu ! ${ }^{3}$

Margaret, brought up on Saint-Gelais and Boccaccio, was in truth inoculated. Further, like some other women of narrow mysticism, she was not afraid of contrasts; - soul and body in opposite pans of the scale, Petrarch as a corrective to Boccaccio, and vice versa. Good humour and gaiety were part of the platonist hygiene, and ladies took them where they found them. Coarse pleasantries did not amuse, as a German ${ }^{2}$ who had spent great pains in writing a Eulogy of Baldness frankly confessed. "We are ridiculous even when we write of serious things, but we are never gay. When we try to be jocular it is, in the words of the proverb, like setting an elephant to dance." Professed humorous writers are such bores :-a crusty old philosopher like Nifo, to wit, or that excellent La Perrière, a friend of Margaret, who dedicated his lascivious verses, his Hundred Considerations of Love, to a clerk in the Woods and Forests!

There was no help for it, ladies had to return to Boccaccio, since amusement was his monopoly! The chance discovery of a by no means remarkable unpublished fragment of Boccaccio covered Claricio of Imola with glory, and was published at the expense of a Milanese Maecenas, Andrea Calvi, under the auspices of Leo X. and Francis I. Castiglione and Margaret were not disposed to attack such a renown: their ambition was to eclipse it. Margaret had a fresh translation of Boccaccio made. She herself, as we know, was ambitious to imitate the master; and to do so was really a profitable business: by donning Boccaccio's mantle Firenzuola became a dignitary of the church, and Bandello became bishop of Nérac; while a common saddler, Nicolas, gained the favour of the king. The test of skill was to tell true stories under transparent pseudonyms. Yet Louise of Savoy was almost as fond of the Acts of the Apostles.

\section{${ }^{1}$ All this is excellent good lore, And none of it locked in the cupboard.}

$2^{2}$ [Rheinauer (Latinised as Rhenanus), a famous German philologist, a friend and correspondent of Erasmus.] 
The Facétie had a less brilliant fate. Poggio and Cornazano, always dear to the ladies, handed down many of their stories to imitators like Domenichi, Delicado, Boistuau, who in their turn passed them on to Shakespeare, La Fontaine, and others.

The old romance continued in high favour-a favour that was so far merited in that the romance combined with the sentimentalism of chivalry sufficient spiciness to induce a good lady to leave it lying on her table. Women doted on the venerable romance of cloak and sword, ${ }^{1}$ long, diffuse, and heroic; it had long ago captured Italy. It delighted princesses by its idealism, and peasant girls by its flavour of mystery and marvel. When the efflorescence of humanism, aestheticism and the new ideas was at its height, the Romaunt of the Rose made its reappearance, and year in, year out men saw defiling past, as though resuscitated by some terrible incantation, all the old knights of ecstatic or sorrowful countenance, the champions of the Holy Grail and of Melusina-Lancelot of the Lake-and Perceforest, Fier-àbras and Percival, Ponthus, Meliadus, Pierre de Provence, all that Gothic world which was believed to be dead and buried. With them they brought their friends and relatives -The Fair Elaine, Theseus, The Destruction of Troy, The Doughty Hector, Oedipus, Alexander the Great, these worthy, up to a certain point, of rubbing shoulders with Plato; but also Baudouin, Le Grant Voyage de Jherusalem, La Conqueste de Trébisonde, in an age when people troubled themselves very little about Crusades! Even the Italians went mad over Charlemagne. It was like an electric spark -a reciprocal attraction. France lost her heart to Italy, and Italy opened wide her arms to France; the women of the south, the men of the north. In vain did the platonist men ridicule the event; in vain did their spokesman, Pulci, at the court of Lorenzo de' Medici, the sanctuary of platonism, empty the vials of their wrath and give the paladins a terribly hot time of it; nothing could stem the tide, and a romance-a shockingly bad one-entitled I reali di Francia, became the germ of a whole new literature.

1 The duchess of Orleans was so fond of them that her husband could find no finer present to give her than the romance of Troilus and Cressida, and one day she sent a messenger in hot haste after a lady of the court who had borrowed a Cleriadus and forgotten to return it-as of ten happens. 
Men succumbed to this craze because the women drove them to it. Besides, nations, like widows, love the dear departed. Since chivalry had ceased to exist, people naturally swore by nothing else. The more our activities decline, the more we gloat over the memory of past excesses. Charlemagne, then, filled the horizon; doting looks were cast at rusty old sword-blades, and while works of quite charming beauty left women almost unrnoved, spectres had only to appear, to vanquish them. Sometimes these showed themselves naked and unadorned, in all the strange dignity of their powerful frames; at other times an intelligent editor paid some attention to their toilet, smartened them up, decked them with little rosettes of pink or blue. How many times was Amadis, perhaps the most famous of these romances, thus tittivated! No one remembered that France had given it birth ; it was re-imported into France by way of Spain and Italy throngh a translation of Herberay des Essarts, with fabulous success: "Any one who spoke ill of the Amadis romances would have been a hissing and a byword." Out of four books it grew into a dozen; it might well have lengthened itself indefinitely, like some law-suits in our own time.

These old romances are to-day scarcely known except by scholars. If we open any one of them at hazard-Lancelot of the Lake for instance, one of the most classic ${ }^{1}$-we find that the colouring is crude. Side by side with mystic virginities we see the reek of coarse appetites. Wives and maidens have blood in their veins, and, like all persons of rather primitive education, do nothing by halves; her husband has only to turn his back for a moment and queen Guinevere is feeling her way towards a reconciliation with Lancelot (bearded like the pard), and the gallant knight has no need to supplicate to get the window opened. Sir Gawain holds very brief parley with the daughter of the king of North Wales, when he surprises her extended on her ermine couch in a virginal but ravishing deshabille! Arthur very quickly forgets Queen Guinevere amid the solace brought him in his cell by a damsel "courteous and fair of speech."

As it mixed in the best platonist society, the old romance

1 The reading of Lancelot of the Lake inspired Dante, as is well known, with the exquisite passage on Francesca da Rimini. 
of chivalry picked up more refined manners. King Arthur ends by gathering about him a noble enough company; Roland leaves Charlemagne in the lurch, to hasten after his well-beloved; and (horror of horrors!) Angelica philanders prettily with a Saracen page! The old torrential romance euded like the Rhone-fell into a tranquil lake.

And yet the dignitaries of the church invariably denounced it, and had the courage to break with the women on this point. They countenanced neither the old masters nor the new-the eloquent Cataneo, the gay Boiardo. Nothing disarmed their opposition-neither the success of romances like La Célestine, ${ }^{1}$ nor blandishments. When Ariosto offered to Cardinal d'Este his masterpiece packed with dithyrambs in honour of all the Estes past,. present, and to be, the amiable prelate said to him: "Where on earth did you get all this nonsense?" 2

In short, women who read, read what spoke of love: that was what they set store by. Philosophy spoke of lovethey were philosophers; romances, facéties, novels, poetry spoke of love-they sipped also of that philosophy. But in some cases it was philosophy that bred the spirit of love, in other cases it was the spirit of love that led them to philosophy; and from this wide differences resulted.

The first class were coldly sentimental,-but no real sway is exerted through coldness; they lived in the absolute,--but the absolute lends no governing force. They lost touch with things, they had nothing of the communicable warmth which makes apostles. They were princesses, sacred beings, to be admired but not touched.

Plato had not evolved a practical rule for happiness, and his best friends agreed that his social ideas presented many chimerical sides.

But the ladies who learnt their philosophy from love were the ardent, active women who knew that the world is swayed by passions, good or bad, and that the secret of feminine power lies far more in that than in any amount of reasoning. Reason may produce an artless blissfulness, but passion has lynx eyes. Love is not reasoned out or manu-

1 ["In which there are divers relations of the deceptions of servants towards their masters, and of pimps towards lovers, translated from Italian into French." Paris: 1527.]

${ }^{2} \mathrm{He}$ had got it in the library of the Palace. 
factured, it is a give and take; life also is only a perpetual exchange, and happiness comes from life, while Plato seeks it in self-contemplation and egoism. To act on another, one must be acted on; to make others happy we must gain happiness through others. An illogical process? What if it is? Nothing is more illogical and more relative than happiness, since it has to do with us. That is for many women the science of life, and they love romances as a pictorial philosophy - not cold precept, but a living forcea philosophy in which the heart cries out instead of patiently suffering dissection.

Books appealed to the feelings. Poggio tells the story of a worthy man, a merchant and a Milanese, and therefore doubly unemotional, who almost died of grief after reading about the death of Roland: yet Roland had been dead seven hundred years! Much more were women justified in showing their sensibility!

So, when they read, they attached the highest value to the external forms which produce impressions: they were affected more by these than by ideas. The wife of Guillaume Budé declared that she loved her husband's books, not for their contents, but because she regarded them as his offspring. Women adored magnificence of expression -the rhetoric, the rhythm, the "gay trimmings" of style; poetry seemed to them the supreme enchantment, because it answered at once to their personal craving for "sensibility" and to their mission, which consisted precisely in sowing a little charm in life, that is, in garnishing life externally with a little poetry.

However, what they called poetry we should rather call music. Poetry in those days was only a perpetual libretto; there was rhythm and cadence in the arrangement of the words, and the impression they gave was a musical one. Perfect clearness was not insisted on; the thought was allowed to remain in semi-obscurity, like a melody flowing uncertainly through a strain of music, rather betrayed than revealed by the harmony. Our great Lamartine, with his lofty but indefinite thought, has been regarded even by us as the first of poets. On the other hand, the aim of musical melody was boldly to seize all these words, to give them a precise value, intensity, brilliance, and force. The employment chiefly, or indeed exclusively, of human voices brought 
this quality still further into prominence; the delicate modulations of the voice, thrown out with matchless skill, seemed to outline the very soul of the singer, like traceries against the sky.

The admirable inspirations of Vittoria and her predecessors will never cease to touch us. In that old idealistic music there lies a whole intangible world; our vows, our love, our poignant sorrows, our prayers gush forth in it like a fountain, flash like a bursting rocket in the sky: "God has given us nothing more pleasant, nothing more sweet," exclaimed a poet: "music is a messenger from heaven, the solace of all our woes." 1

The sonnets of Petrarch were set to music and sung; they had indeed been composed for that purpose. Teodoro Riccio furnished an accompaniment to the famous romance, Italia mia, and Ciprian van Rore one to the sonnet, Fontana di dolore, Albergo d'ira. Ronsard, too, wrote his sonorous rhymes for music; Baï, as is well known, went so far as to propose to turn writing into a sort of notation, and when his academy was instituted, composers of music and even mere singers were admitted on equal footing with poets. The art of music consisted in giving to thought all the external beanty of which it was capable. Philosophers counted metrical music (in other words, poetry) or vocal music as a part of philosophy. The art thus intellectualised became quite a religion. In his painting of Parnassus at the Vatican, Raphael shows us Apollo singing like an ancient bard. In all the pictures of Paradise that we have seen we have never found a palette, or a sculptor's point, or even a rostrum or an inkstand; nothing but direct and pure communion with God through contemplation and music. And what could be more delicious than the little choirs of angels which Giovanni Bellini's imagination placed at the feet of his Madonnas, like an incense of homage from the world! Melozzo gives a queen an organ as her emblem, ${ }^{2}$ and Titian one to his Venuses. Music would seem to have been the very breath of happiness.

A woodcut, thrice repeated in the Illustrations des Gaules (1528) represents France on a throne, with Ill-hap at her feet; on her right is Noblesse, represented as a maiden playing a violin; on her left, the People, depicted as a young man playing a guitar.

${ }^{2}$ National Gallery. 
The common people themselves were strangely enamoured of intellectual harmonies. In Italy a number of poets spent their life in the market-places, like Homer. Aurelio Brandiolini, for example, who sang in the squares of Verona the praises of antique heroes, went on, stimulated by popular applause, to execute veritable tours de force, such as singing in verse the thirty-seven books of Pliny's Natural History. 'The celebrated Bernardo Accolti wandered from town to town giving recitals in the principal squares. The moment he arrived, people flocked about him, business was suspended, far-distant shops were shut, lights began to appear on the balconies, and the police hastened up to keep order. Making way through the crowd by favour, the notables formed up round the poet as a guard of honour; and then, under the lamp of some sleeping Madonna, amid breathless silence, the poet's voice arose towards the starry sky, singing love to the accompaniment of a guitar.

Nothing more truly characterises the period than this popular passion for musicians, poets, and buffoons. Far from becoming degraded by contact with the mob, poetry seemed thereby to gain in breadth. A pure Virgilian named Andrea Marone (Virgil's surname) never felt at ease unless sitting on a stone post; in that position inspiration seized him like an ancient sibyl or a fakir; his veins dilated, drops of sweat stood on his brow, his whole being expressed itself in gestures which gave emphasis to his song, lightning flashed from his eyes; it seemed as though a part of his individuality left him and shed itself upon his audience like a rain of fire.

Almost all women were fond of music, for men were very accessible to ear-charming sound. Even in Frauce, in spite of the poverty of aesthetic education, the villages harboured a surprising number of harpists and taborers. The duchess of Orleans patronised at Blois a crowd of more or less official "gitternists," fiddlers, and trumpeters, without reckoning strolling guitarists, always sure of a warm welcome. Like all the princesses she had her private band, and also two taborers, magnificent in their crimson badge, -so magnificent that during her lyings-in she had them to play at the foot of her bed. It was a great sorrow to her to have to clismiss, from a prudent motive of cconomy, the ducal choir and even one of the taborers; Pierre de 
Vervel, once her master of music, always remained her friend.

We have in a former volume shown Louise of Savoy, a cithara in her hand, surrounded by a harp, an organ, and a complete orchestra. Louise Labé approved of young girls devoting to music the best part of their time. It was incomprehensible how any lady who possessed this divine means of fascination ${ }^{1}$ could neglect it; when a Mademoiselle de Hauteville had to be pressed to display her magnificent voice, her false modesty was censured as a sort of professional error. Mary of England, accompanying herself on a guitar, used to sing of a morning to Louis XII., her doddering old husband, and the poor prince felt himself revived, such "wondrous pleasure did he take therein." Margaret of France, who has left us thousands of verses, evidently betook herself to poetry as nowadays we go to the piano, to let her thoughts wander at large; instead of singing with her lips, she sang with her pen. It is highly probable that many ladies abandoned themselves thus to their inspirations, half music, half poetry.

Sometimes people had too much of it. It was irritating to meet certain people perpetually humming a refrain. As soon as you entered a drawing-room, you saw an instrument looming menacingly before you, and you had to perform. And then, how many amateurs would do better to muzzle themselves than to go quavering out their little songs!

Music also was charged with enervating effects; some went so far as to call it an art of decadence, and maintained that the ancient Medes had perished through love of music. Castiglione almost gets into a passion on this subject. "What! Music effeminating! But, I ask you, were not Alexander, Socrates, Epaminondas, Themistocles musicians? Lycurgus was almost one! Did the harp prevent Achilles from shedding blood-if that is what you are driving at? Effeminating! Why, without music how can you praise God? What would comfort the sunburnt labourer at his plough, the peasant woman at her wheel, the sailor in the storm, the traveller on his weary way, the nurse in her tiring night-watches by a cradle? Music, on the contrary, is the charm of life-its light, its sunny grace! No art

${ }^{1}$ So well interpreted by Giovanni Bellini in his Girl Singing in Hampton Court Palace. 
responds better to the demands of our emotional nature, none more liberally brings us vivid and various impressions. It softens, calms, penetrates us, it moves, indeed enraptures us; it raises us to heaven with the rapid, vehement, urgent beating of its wings!"

Castiglione almost regards music as love itself: they were to him such nearly related terms that we cannot be sure but that in his opinion song was more excellent than love.

In regard to what was expected of it, namely, a little happiness, music was a performance of feeling rather than of skill. Notes a little venturesome or even imperfect were pardoned if they blended, and had resonance and passion. People would boldly attack and smoothly carry to its conclusion a two-part fugue. The ideal was to hear in a drawing-room a pure and mellow voice, supported by a single lute; or rather to see the voice, for the lute, not an ungraceful instrument like the piano, seemed a living thing, and became one body with the fair singer; it was one personality thrilling with song.

To idealists of the very highest order, Flemish, French, and German music was far superior to Italian music, because it expressed ideas, whilst Italian music barely went beyond sentiment or even sensation. Rome herself fell a willing victim to the northern races. ${ }^{1}$ Among many distinguished and often admirable artists, the great figure of John of Ockeghem, ${ }^{2}$ who died at Tours in 1495, stands out as that of the old master who more than anyone else ennobled his art.

His successor, Josquin Desprez, a Fleming trained in the same school (the very name of which has been lost in the loss of its tradition), and a member of the choir of Sixtus IV., became a Roman by adoption, and only left Rome in 1508 to proceed to Ferrara. Josquin was a stickler for correctness and perfection, skilful in linking

${ }^{1}$ Charles VIII. was even obliged to threaten serious consequences in order to secure the restitution of a singer and a lute-player who had been enticed away when he passed through Florence.

${ }^{2}$ Ockeghem, it has been said, "breathes into his music the soul of song, envelops it in a vigorous harmonic body, and clothes it with a fine tissue of ingenious thematic developments, imitations more or less close and more or less extended. One finds in his pieces, often in their inner parts, phrases of great melodic beauty, and full of an extraordinary sweetness and depth of expression. His harmonies are of ten enough peculiar and archaic, but they are striking and rich. He also brings his pieces to a close in a manner sometimes surprising and odd, but certainly very interesting." (R. Eitner.) 
discords and in combining independent parts. From the dim arcana of a sanctuary his profound inspiration rose into the clear light of day, blossoming out in soft and brilliant colours. His phrases are like many-coloured curves of light shot into space, describing their several parabolas without confusion and without clashing; there is white and green and red, but they all spring from the same flame.

Many Italians censured, as fit for dreamers and doctrinaires, the exclusive employment of the human voice. They wished to have at least one instrument: the bass viol (developed into our violoncello), or the viol, from which the famous Amati, about 1540, derived the violin. It is a viol that Raphael places in the hands of his singers, who seem to identify themselves with the instrument with a passionate ardour:.

In the smaller courts chamber-music was cultivated. Happy states! Nothing took precedence of the quest for a good musician; dilettantism reigned supreme. The court of Ferrara was practically a conservatoire; it had a celebrated orchestra, from which Caesar Borgia borrowed violinists when starting for France. Care was taken that the performance of music should take place in the most favourable circumstances and amid the profoundest respect; there was no question of being stacked in a hall, too hot or too cold, of being tight wedged and sitting askew to hear music by the hour. Lorenzo Costa depicts a very differènt concerthall. Peacefully reclining on a grassy lawn, beneath the shade of light-foliaged trees, sheltered from sun and breeze, the ladies form the centre; they are discoursing of pure love. Their own sweetness seems to envelop everything. They are crowning a lamb or an ox with flowers; the landscape seems to spread life out into almost boundless space, intersected by a sheet of limpid water as blue as the sky. In the middle some persons are unobtrusively performing music or writing verses. No one pays any attention (so profound is the spell !) to a troop of soldiers in the distance repelling an incursion, nor to a handsome chevalier, a solitary and elegant figure, occupied in daintily killing a reptile, nor to certain groups which have wandered away beneath the leafy shade, towards the extreme verge of platonism.

${ }^{1}$ Harmony, by Paul Feronese (fresco at Masera): Parnassus, the Crowoning of the Virgin, by Raphael (Vatican). 
Purely instrumental music, the music of a full orchestra, appealed to the commoner feelings; it served for dinners and dances, as in the banquets depicted by Veronese. It represented the voices of nature. It was best understood on the water, and then the most staid and stolid of people found it one of the joys of life. It was the delight of pleasureloving nations: "Abolish music, and we must e'en fall to prayers." 1 At Venice, as soon as the old cupolas, the tall statues and the long façades-decorations for a dance in motley-became blurred in the evening haze, the city seemed to swim in music: a thousand bells chimed out the Ave Maria; jangled sounds of serenades and concerts rose from the palaces, the alleys, every nook and cranny; the sea sent back its response; noisy parties lightly skimmed the glistening surface of the Grand Canal; illuminated barges splashed their oars under a window, with an orchestra or band of singers. Strange intoxication! Many pious Italians, like Alberto Pio, thought it so delightful that they loved to transfer it into the churches. Why not? These thrilling symphonies did not follow the sacred texts very closely, it was said; they were not always of the highest class. "You hear the boys whinnying, the tenors bellowing, the counters braying, the altos bawling, the basses scraping the bottom of a well," and in all this the Puritans could see no trace of deep religious feeling, "no well-modulated pronunciation, the perfect enunciation which brings the words home to the soul." 2 It was a deafening, stupefying music. But if it is necessary for our happiness that senses and enotions should be appealed to simultaneously, why say no?

Even dance music may ennoble the dance and become an element of enthusiasm, peace, and joy. This was admirably expressed by one Madame de Sillé. A canon sitting beside her was laughing at the sight of men leaping about, while another was bursting his lungs blowing into a hollow stick. "What!" she said, "aren't you aware then of the power of music? The sound from this stick penetrates the mind, the mind directs the body, and these buffooneries are the expression of the soul! Would you prefer to play at tennis?" The canon held his tongue, more especially as he caught oblique glances in his direction, and had premonitions of being dragged into the dance by way of reprisal. Even from

$$
{ }^{1} \text { Neapolitan proverb. } \quad{ }^{2} \text { Erasmus. }
$$




\section{THE WOMEN OF THE RENAISSANCE}

all this racket of the dance-from the harps, lutes, organs, manichords, checkers, psalteries, rebecks, guitars, tabors, bass viols, flageolets-a measure of expression was demanded. The harpist whom Mantegna shows us setting the Muses to dance is throwing his whole soul into his work; he is leading the dance. ${ }^{\circ}$

Here we should properly say something about the drama, but we shall treat it briefly, seeing that in those days it was very far from displaying the same activity as at present. In particular, the women's share in the drama was only that of a section of the public. It was above all the art of the prelates, who devoted as much care to altering its character as the women did to preserving the old romances. Thus the two great forces of platonism were pitted against each other - the prelates eager to advance, the women anxious to hang back.

The drama with its modern tendencies took possession of Italy in the 15th century, and Rome was almost its birthplace. Pomponius Laetus, officially licensed to produce the plays of Plautus and Terence, died a few days after Savonarola. The ashes of the monk had been scattered to the winds; but all Rome was eager to accompany the remains of Laetus to Ara-Coeli, since it was a work of true piety to increase the joy of life.

The palm for dramatic art was, with one consent, awarded to Bernardo Dovizio da Bibbiena, who had the happy notion to shake off the yoke of translation and to write a new piece in imitation of Plautus-the Calandra.

Bibbiena ${ }^{2}$ is one of the best types of this prelatic world, which after all cannot be dissociated from the world of women. He belonged to the inner circle of Leo X.'s friends, having been brought up with him, though the son of a peasant. He had a spirit and verve which, according to Paul Jove, "carried the gravest of people off their feet." He was supremely in his element at the table. Moreover, he was one of those astonishing men who live at the same time a life of toil and of pleasure. On becoming a cardinal he displayed vast activity-acted as legate, preached a crusade, and died at fifty. He has left a

1 In the Louvre.

${ }^{2}$ The Madrid museum possesses a magnificent portrait of him by Raphael. 
goodly number of treatises, poems, and letters; but it was the drama that made him famous.

It is impossible to describe the stir the first representation of his Calandra made at Urbino, the home of platonism. Everything was planned with the care and skill of perfect "amateurs."

The stage represented stucco monuments and other scenic illusions executed by such artists as that age afforded. The auditorium, which was not marked off from the scenery, represented fortifications, and the spectators lolled there at their ease on excellent carpets, amid lustres and garlands of flowers. The orchestra, placed out of sight, was heard now on one side, now on the other.

Nor had the organisers neglected any means of strengthening the play itself by a great variety of spectacles-a prelude played by children; a prologue; four pantomimes between the acts, representing the story of Jason, with bulls made of stuffed hides, their nostrils flaming, Venus surrounded by Cupids, Neptune drawn through the flames by fantastic monsters, Juno encircled by a flight of birds so natural that even Castiglione, who had had them made, for a moment believed them to be real. These pantomimes were danced through in the cleverest fashion, with wonderful mechanical effects. At the close a Cupid recited some verses, concealed viols gave forth a 'song without words,' and a quartette of voices concluded with a hymn to Cupid.

And after all, if the ladies had not actually the direction of this platonic entertainment, they lost nothing thereby; it was dedicated to them, and the whole performance had for its aim the glorification of ideal love. Such a representation assumed an elevated and almost solemn character, similar in kind to the performances at Bayreuth in these days.

Was the Calandra a masterpiece? No. The plot turned upon the difficulty of distinguishing between two twins, brother and sister, who changed clothes as circumstances demanded; from this Bibbiena derived risky situations, broad jokes, and a complicated dénoûment. But it achieved an immense success. It was represented again at Urbino in 1513, and afterwards at the Vatican on the occasion of a visit from Isabella d'Este. On that supreme stage its licenses came under the fierce light of criticism, and scandalised some of the cardinals; but on the other hand it 
was so magnificently interpreted, it was so excellent "in dramatic elegance, in wit, well-knit construction, and gaiety," that the enthusiasm was unbounded. The marchioness Isabella did not rest till she had organised a similar performance, an event which took place in 1520. From that time innumerable editions popularised the Calandra, which was chosen many years afterwards by the town of Lyons for its festivities in honour of Catherine de' Medici.

The drama of the time attained its highest perfection at the Vatican under Leo X. The skill of the actors, all men of fashion, their sober Attic style, without a trace of the mere craftsman, made the drama an artistic delight. As yet no women appeared on the stage. Their parts were sustained by men, and in this connection we must present to our fair readers a young prelate named Tommaso Inghirami, who was the coryphaeus of female parts at the court of Leo X. A Florentine and an intimate friend ${ }^{1}$ of the pope, who, as everyone knows, had his own portrait painted along with Inghirami by Raphael,-so perfect a writer that Erasmus calls him "the Cicero of the age,"-Inghirami could have taken one of the most notable positions in this illustrious generation if his amiable and indolent dilettantism had not led him to believe that writing books was carried to excess. He was satisfied with shining in conversation, and in that he was inimitable: Bembo and Sadoleto constantly speak of him with enthusiasm, and, moreover, in one of the most appreciative but critical societies that ever existed, he won for himself as a conversationalist a European renown. If he had not the extraordinary gaiety of Bibbiena, he spoke with dazzling passion, wit, and fire; his larere coal-black eyes have an astonishing power: looking at them, one feels light flashing from his soul.

He had an ardent love for the theatre. One day, when playing the part of Phaedra in the Hippolytus of Seneca before Cardinal St. George, he so captivated the spectators by his distinction, and especially by his passion, that the name of "Phaedra" becamc inseparably fastened to him. He was a preacher, the learned librarian of the Vatican, the dignified Bishop of Ragusa; but, for all that, from one end of Europe to the other he was no longer known except

${ }^{1}$ He vas born, like Leo, in 1470 . 
as "Phaedra," or at most "Thomas Phaedra." Only, the name was masculinised: thus Erasmus wrote: "I knew and loved Phaedrum."

Unhappily, about 1505, letters from Rome spread a deplorable piece of news: Phaedra is putting on flesh, Phaedra is big. "So much the better," retorts Bembo in Greek, "we wish she may have twins!" The portrait in the Pitti Palace shows him to us, indeed-this superb platonist type of the pseudo-woman-as by no means a slender man. There is no doubt he had been handsome! His eyes continue to flash and throw their unabated fire towards the ceiling; he still has his fair, plump hand, his fine mouth; and yet, seated at his table, he no longer looks anything but a handsome prelate.

Radiating from Rome under the auspices of ladies like Isabella d'Este or connoisseurs like Ludovico Gonzaga, bishop of Mantua, the dramatic art reigned nobly in the courts and castles of Italy, without losing anything of its elegant and artistic cachet. It adapted itself to all circumstances with marvellous flexibility, ranging from the opera-ballet played in the open air $^{1}$ to genuine comedy and tragedy. But, like the Novels and Romances, it assumed a licentious and even cynical character, which everybody regarded as natural. Thus at Turin, in the early days of Lent in the year 1537, a comedy of the most daring kind was performed: "How warmly the ladies here received it!" exclaims an eye-witness. At Foligno, the pontifical prefect, a certain Orfino, superintended in person the staging of MIarescalco, an extremely light production of Aretino; and soon after the performance this worthy pillar of pontifical "tyranny" wrote to the author, begging another piece of the same stamp. The Ruffiana of Salviano and many other pieces of a salacious turn won tempestuous applause. Some people took alarm and declared the theatre to be a hotbed of immorality. The Senate of Venice, by decree of December 29, 1509, forbade any performance, even the recitation of an eclogue in a private drawing-room, under penalty of a year's imprisonment and exile, "irremissible," in the wording of the decree. (However, in a secret addendum, the Senate reserved the right of pro-

${ }^{1}$ An opera-ballet was got up in the open-air by Bergonza di Botta, in his park at 'Tortona, on the occasion of the marriage of Isabella of Aragon. 
nouncing the penalty, and by a large majority.) In spite of this, the Calandra was performed at Venice in 1524. without any difficulty arising.

The Italian drama, lacking the support of the ladies, had little success in France. ${ }^{1}$

They lived there on the old Mysteries. The performance of these was usually got up in a convent, or by a city; and, unlike the Italian drama, it retained a character of patriotic and moral instruction rather than of a work of art. ${ }^{2}$ Thus we find Louis XII. bestowing a pardon on an impresario guilty of some criminal peccadillo, on account of his excellence in his profession.

Italianists and French platonists respected this tradition. In 1506 the town of Amboise got up a performance before Louise of Savoy of the Mystery of the Passion, "the most beautiful that could be discovered." A priest played the part of Christ; the performance lasted a week, and was so successful that two years afterwards M. de Longueville wished to repeat it at Chateaudun, and engaged in a somewhat acrimonious correspondence on the subject with the functionaries of Amboise, whom he accused of purloining the copy. This performance was very costly; the town took five years (which seemed an enormous period in those days) to liquidate a debt of four thousand livres contracted on the occasion. It does not appear that Louise of Savoy, who was then residing at the chatteau, contributed in any way towards the expenses, as M. de Longueville did at Châteaudun; but she certainly did not disapprove of it; and towards the middle of the century it was again in the presence of a thoroughly platonist woman, the second Margaret of France, that the last known representations of the art of the Mysteries are said to have taken place.

With all her daring on other points, the first Margaret maintained a remarkable attitude of reserve in regard to the theatre. She contented herself with experiments in an

${ }^{1}$ At Metz, in 1502, the public violently interrupted and rendered impossible the representation of one of the comedies of Terence which were constantly played at Rome; the performance liad to be postponed till next day, when it was continued before a select audience, composed in great part of clergy.

${ }^{2}$ E.g. The Mystery of the Passion ; of the Three Gifts, played in 1509; of St. Andrew, played in 1512; of St. Barbara, and St. Eustache, played in 1504 . 
intermediate style of drama,-religious comedies, a sort of Italianised 'morality,' easier to produce and not so longdrawn-out as the ancient Mysteries, yet neither very pious, nor very amusing, nor much calculated to take the public by storm. The result was that the drama long retained traces of its original character. So late as the 18th century Voltaire dedicated a tragedy to the pope, and fumed at not being able to get it performed at Geneva. The only cosmopolitan kind of piece was that of the farces, knockabouts, ${ }^{1}$ harlequinades, carnival drolleries, to which the most illustrious platonists of Florence attached their names. ${ }^{2}$ Harlequin and Punch were always a success in France: "They have something that sets you laughing without being amused"; but they introduced nothing new. The French farce lad long been flourishing on the boards; the Italian was only a competitor.

To sum up, the women of the Renaissance, as we see, did not try to be savants or blue-stockings. They skimmed the cream c,if books and works of art so as to get what suited their rnission, that is, something to talk about and to go into raptures over. They did not rise to what was called "humanism," like the prelates; they stopped short at loving intellectual beauty more than plastic beauty; they cultivated a literature of sentiment and passion, and took a keen delight in beauty of form. They behaved as instructed women, and above all as women of feeling, as women who wished to please, nobly faithful to their singleryed pursuit of elevated love.

\section{${ }^{1}$ [Pochades]}

2 Lorenzo de' Medici, Pico della Mirandola, Agnolo Dovizio da Bibbiena, Bernardo Ruccellai [see George Eliot's Romola], Machiavelli, and others: it was a singular, incoherent, burlesque procession of characters of all sorts and sizes-devils, deaths, nymphs, courtiers, old husbands, young wives, merry nuns, hunters and huntresses, pages, winds, furies. 


\section{CHAPTER VI}

\section{CONVERSATION}

WE come at last to conversation.

This was the goal, the sanctuary of happiness, nay, bliss itself. All that we have hitherto spoken of led up to this all-engrossing object, for love was the supreme end, and speech is the vehicle of love. A circle of men about a lady, and she talking or making them talk,- this was the supreme and final formula of life.

Conversation, then, was the great art of the platonists, infinitely greater than painting or sculpture, greater than music, poetry or oratory, because it alone established real communication between soul and soul, it alone was privileged to body forth a whole realm of unexpressed emotions which would freeze at the end of a pen or pencil, and which music itself would render but ill. Words that well up with the eloquence of spontaneity possess an indescribable vital forces. impossible to analyse; innumerable details contribute to it - the inflection of the voice, the gesture, the expression of the eyes, the movement of the lips, the play of all the features. A mineral water taken at its source has, as every one knows, singular virtues which are impoverished if it is carried to a distance, and which the most skilful chemist cannot restore. So also the fount of human intelligence must be drunk at its source. If need be, it is well worth a journey.

Without women there would be no conversation. For a man who thinks he can converse without wearing the feminine yoke there is nothing but to go off by himself like Cardan, that intolerable chatterbox, who, though the author of two hundred and fifty-five volumes, had the audacity to publish 
a book In Praise of Silence. "Never," he exclaims, "am I more truly with those I love than when I am alone." Our opinion would rather coincide with that of the amiable emigré whom his friends urged to marry the object of his passion, and who answered, "But then, where should I spend my evenings?" To draw a man out and show him what he is capable of, it is necessary for a woman to throw out the bait; an ambition to please, an instinct of sympathy, a thousand fleeting intangible nothings, veritable microbes of sentiment, will do the rest. But we do not hesitate to add that, without men, women would hardly know how to talk. Men have often inveighed ägainst the loquacity, ${ }^{1}$ the backbiting, ${ }^{2}$ the imprudence, the frivolity, the paltry and scandalmongering spirit of the rudimentary and inartistic conversations that women engage in when left to themselves; this kind of conversation can no more be called conversation than certain intrigues can be called love, or than daubing a house front can be called painting a picture.

Certain of women's little defects remain defects or become virtues according as the women know or do not know how to make use of them. Gossips, the women who can think and talk certainly are, and they plume themselves on the fact. That can only be called a defect in those who have nothing to say. Margaret of France confesses that when she opened her mouth, it was long before she shut it again. ${ }^{3}$ Sometimes, however, women are troubled with a certain intellectual timidity arising either from their education, as their friends say, or from their temperament, as their enemies maintain. They easily make up their minds, but can seldom give you their reasons; their intellect clings like ivy to some principle reputed substantial, in other words, one that is affirmed by their neighbours, or is traditional, or is ingrained from childhood; and the slightest breath of raillery only attaches them to it the more closely.

This disposition would be fatal to a writer. To write one needs the power to think for oneself and to give virile expression to one's thoughts, at the risk of getting a name

1"With the tongue seren men are not a match for one woman" (Eras. mus, Colloquies).

2 "He who keeps his mouth shut knows no care" (P. Meyer).

${ }^{3}$ Heptameron, Tale 10. 


\section{THE WOMEN OF THE RENAISSANCE}

for paradox or eccentricity; but for conversation nothing is less necessary; on the contrary, the trite is eminently serviceable. Conversation serves to test current ideas; it gives them so to speak a stamp, a hall-mark, a label, and women understand its utility all the better because they largely avail themselves of it and acquire their convictions through it. On the other hand they possess as the gift of Nature that which is the very life of conversation,- facility of assimilation without the necessity of going to the root of the matter; the ability to express quickly, clearly and copiously the impression of the moment; a feeling for fine shades; skill in fitly garbing their thoughts, and in maintaining them with the necessary unction, grace, and warmth. No more is needed.

The age in which we live, priding itself on its practical spirit, has neglected this art of conversation. We have almost entirely lost the feeling for it because of its unpretentiousness, and we declare it unimportant on the ground that we are no longer platonists and can no longer find in mere phrases the supreme felicity of life. Yet it is an art of eminent vtility in regard to the charm of existence,--a genuine and highly intellectual art, an art that in the 18th century was one of our national glories. By their witty conversation the ladies of the house of Mortemart did more to make their race illustrious than all the artists and all the soldiers. Saint-Simon has given us an excellent description of the talent of three of them, who boasted neither of mysticism nor perhaps of philosophy-Mesdames de Montespan, de Fontevrault, and de Thianges: "Their court was the centre of wit, and wit of so special and fine a savour, yet withal so natural and pleasant, that it came to be noted for its unique character. . . . All three possessed it in abundance, and appeared to impart it to others. This charming sympathy of theirs still delights us in the survivors of those whom they bred up and attached to themselves; you could tell them among a thousand in the most miscellaneous company." That was the goal aimed at by the 16th-century women, since it made men immortal, and gave them a full life on earth meanwhile-since, in a word, it was happiness.

We could scarcely realise the empire certain women exercised if we neglected to take into account thr: $\mathrm{r}$ 
wonderful conversational powers, and judged them merely by their writings, or by their letters even. Justly or unjustly, the writings of Margaret of France met with no success. Marot, in complimenting his dear princess on them, had recourse to an evasion of no little ingenuity: "When I see your poems only, I marvel that people do not admire them more; but when I hear you speak, I veer completely round, amazed that anyone is so foolish as to marvel thereat." Like many others, Margaret held sway through conversation.

Some cross-grained people imagine that to women talking is the easiest thing in the world, that friends spring up around them spontaneously, that the art reduces itself to finishing their toilette by lunch time and then letting their tongues wag till evening. It is extremely simple, they say. Simple! They think it sufficient then to fling their doors open on certain days, and to deal out here and there among their guests a few formal and chilling inanities! "Men are so scarce that when you have them you should rate them very high," said Anne of France, very justly. Simple, not to rest satisfied with the mere glitter of small talk, but to take full possession of one's visitors, to form a warm nest of friends! It is a heavy task. If in these days women no longer exercise any serious influence, is it not to some extent their own fault? A superficial and cramped education has often rendered them incapable of effort. They are afraid of a conversation on broad, serious lines; they will not be bothered with it. But to form a set, a woman must belong to herself no longer, she must belong to her friends ; conversation is her bread of life, to adopt an expressive phrase, and she does in fact become so habituated to her part that she cannot do without it; she must talk, if only with her husband. Mary of England used to talk to Louis XII.-

Soubz le drap couvert d'orfebvrerie,

Qui reluisoit en fine pierrerie,

Passions temps en dictz solatieux

Et en propos plaisans et gratieux. ${ }^{1}$

1 Beneath the broidered sheets we lay-

Sheets flashing with gems and gold-

And whiled the dreary hours away

With comfortable tales of old,

And converse debonair and gay. 


\section{THE WOMEN OF THE RENAISSANCE}

Bereavements and misfortunes only render conversation more necessary. Emilia Pia, ${ }^{1}$ proscribed, stripped of her all, and persecuted, could not appear in the streets of Rome without an adoring throng of prelates and admirers, just as there was never more laughter and gossip than in the crowded cells of the Reign of Terror.

A well-bred man considered himself literally entitled to command the conversational abilities of women. In this connection a very curious misadventure befell some judges of the Parliament of Paris who in the course of their duty went to hold assize at Poitiers. In the heart of the 16th century, when everybody went the pace, and the air was charged with moral electricity, there was still found one town where the women would have believed, as they did three hundred years earlier, that they were lost if they opened their doors. Jean Bouchet, ${ }^{2}$ loyal Poitevin as he was, has described the boisterous amusement with which France heard that some bashful ladies answered these poor judges through a peep-hole with a Non passumus. The ladies of Paris themselves sent a petition to their "colleagues" at Poitiers, beg ging them not to let their husbands die of dulness. The ladies of Poitiers replied with blushing cheeks: "Tis not our way at Poitiers." They hugged the tradition of dulness.

At Lyons, which on the contrary was a modern town, squire Sala, chancing to be at his window one fine spring morning, perceived in the street three ladies to whom he was related, going on pilgrimage to St. Irenaeus. To dash after them and make them promise to call in on their way back was the affair of a moment; and then he was a happy man, sure of a pleasant day. We are no longer, you perceive, at Poitiers. The ladies return; they dine gaily with their cousin, and pass into the library; and then, during a desultory conversation, one of the fair guests mechanically opens a Bible at the book of Kings. Nothing more is needed. What a charming subject! The lady avows that she loves to lie back in a cosy chair

\section{i [One of the Urbino ccterie.]}

${ }^{2}$ [A lawyer of Poitiers who is said to have composed a hundred thousand verses, mostly dull. He called himself Le Traverseur des voies périlleuses (the traverser of perilous ways), and wrote moral and familiar letters and Les Regnars (foxes) traversant les voies périlleuses.] 
and read the history of the kings of France; everyone joins in the conversation and cites some notable fact about royalty; and thus the procession defiles past-Alexander, Agis, Brennus, Caesar, the Merovingians, the classic heroes (Charlemagne, (Godfrey of Bouillon), divers kings of France, Louis surnamed the Fat, Philip the August, the noble St. Louis, all the princes of the 15 th century; finally Sala promises to relate a story of Francis I. Unhappily it is long past the hour for separating, for tearing themselves from this intoxicating pastime; and, to tell the truth, when they got home these ladies found that their liusbands had put the lights out.

If this was bondage the ladies took it in very good part, and the men left nothing undone to soften it for them. We have all known men expert in the manipulation of feminine conversations, and deriving from them a large measure of influence; for instance (to speak only of the dead), Monsignor Dupanloup, ${ }^{1}$ or in a different kind M. Mérimée, that waif from the 16th century, who combined with extraordinary scepticism an incurable impressibility, and, while free in mind and heart, was always leaning on a woman! The men of the 16th century became charmers. A political exile from Milan, fresh from a milieu of women-the physician Marliano-acquired an unprecedented influence in the Low Countries by the mere attractiveness of his conversation; people vied with each other in praising its suavity, its "heavenly ambrosia," its "honey," its "sweetness."

Men moulded by the hands of Italian ladies could be distinguished among a thousand; they could talk about anything and everything. Many writers of eminent ability would have gained much by being less serious.

No one could help succumbing to this charm; and in truth it is easy to believe that the platonists sought happiness from conversation, futile as it was reputed to be, since they were constantly saying: "I was happy, we are all happy." Cardan himself recalls with enthusiasm the time when he was supposed to be studying medicine at

${ }^{1}$ [The brilliant Bishop of Orleans (1502-1878), noted equally for his eloquence, his pugnacity, and the huge blue umbrella he carried on sunny days. It was said of him that he was " a journalist who had strayed into a bishopric." He wrote Letters on the Education of Girls, and especially opposed the opening of university courses to girls: he did not wish them to go "from the bosom of the Church to the arms of the University."] 
Venice: "I was happy."1 Ever the same word! People cultivated their happiness.

"Ferrara," says Lamartine, "resembled a colony from the court of Augustus, Leo X., or the Medici; cultured princes-princesses who were heroines of love, poetry, or romance,-cardinals aspiring to the papacy-scholarsartists-poets half knights, half bards-met there every evening, in the splendid halls of Ercole d'Este, in town or country."

At Urbino, the conversations were broken by ridingparties, hawking expeditions, balls, sports, music; life resembled a kaleidoscope, but wit slipped into every pattern as the necessary element of beauty. The duke was in bad health and used to retire early. After his departure the evening flew by delightfully: the young duchess "seems a chain holding us all pleasantly together," said Castiglione. There was no standing on ceremony; she was always the centre of a circle composed of men or women alternately as chance directed. In addition to the regular group, the company pretty often included some accomplished stranger, some scholar or 8 rtist who happened to be passing through. They spoke freely to the ladies on a footing of friendliness. As the evening drew on, some went off for dancing or music, the others continued to start discussions or tell stories enlivened with transparent allegories. In summer this brilliant reunion was held in the garden.

Our pictures of society in olden times may often give the impression that only wolves, lions, wild beasts, or else strutting cocks and clucking hens served as models. But to paint this polished society of Urbino, so enthusiastically bent on happiness, we should need colours no palette contains,--transparencies of the Grecian sky, the indigo of certain seas, the liquid azure of certain eyes. For more than a century the court of Urbino was regarded as the supreme exemplar; in the 17th century the Hôtel de Rambouillet was still striving to make itself a copy of it; unluckily such things as these are not easily copied.

\footnotetext{
${ }^{1} \mathrm{He}$ adds: "We gambled, played music, took walks, supped, and worked (not often that): no cares, no anxieties! We were often with the Venetian nobles : my life flourished like a growing plant. Nothing could be more pleasant than that life, which lasted five years and a half (September, 15:6-February, 1532): we used to chat with the prefect, whose palace was our kingdom and rostrum."
} 
It would be difficult enough to deduce from the conversations at Urbino a series of rules for the art. No programme was pasted on the walls. But still we may note certain principles: a remarkable good-fellowship, ranging from perfect courtesy to affectionate familiarity; a real sentiment of equality, genuine equality, springing from an exact appreciation of the various degrees of worth, and consequently in that sense aristocratic; finally and especially, freedom, the most absolute openness of mind, the absence of ambitions and pretensions, at any rate so far as appeared; a joyous skilfulness in playing on the surface of things, or in striking out into the vastest regions of thought without effort or constraint.

Throughout Italy a somewhat Ciceronian and Attic beauty of form played a highly important part in conversation. Men were distinguished by their dignity of style and by a high-bred refinement free from the slightest taint of the stable. We can only judge of their manner of talk indirectly, through their letters; but an idea of it may be gained from the letters of Bembo, Castiglione, and others, in which a lady could see how to win men's hearts while retaining all womanliness of style, and how much affection-whether it be called love, friendship, or simply a good understanding-gains by displaying itself delicately. Women played the part of judges: they were permitted, if need were, to stand on their dignity, to be silent or to speak freely at pleasure; but no man could succeed without a highly suave manner; merit had to be shown by some external mark: "Merit is not enough unless prolific in the outward graces on which the praiseworthiness of actions depends." But appearances were sometimes sufficient. Even in their portraits, men like Castiglione retain a something infinitely engaging and attractive-a bloom on the lips, a softness in the eyes. ${ }^{1}$ When at Venice we come upon portraits of men all energy and self-assertion, the inference is that the women must have lost their empire; and we do in fact see opposite them portraits of passive women, all softness and sensuousness.

And these tender lips that opened only to speak to women, these caressing eyes, do not deceive us. The prattle of these men was impregnated with a dove-like gentleness, ${ }^{1}$ Raphael's portrait of Castiglione in the Lourre. 


\section{THE WOMEN OF THE RENAISSANCE}

an adoration, in appearance wholly spiritual, for the beautiful. Castiglione, an eminently graceful, caressing, and persuasive talker, spoke with fluency, with something of flabbiness and redundance, perhaps-a sort of perfumed talk, with nothing of "French filthiness," as he said. Vittoria Colonna wrote a charming letter to Paul Jove, in which she spoke with great enthusiasm of "her" divine Bembo. Paul Jove lost no time in passing this letter on to Bembo. "I send you," he writes, " a letter from your ladylove, the most illustrious marchioness. It is very pretty, and speaks of you, and I send it you at once without any of that resentment which rivals are so apt to feel, for I am fully assured that Her Excellency's love for your lordship is in all points like to my own love for her, that is, celestial, holy, altogether platonic. Her Excellency is come from Ischia to Naples with the other noble dames; I mean the serene Amalfia and the superb Vasta, with the Francavila, a mirror of virtue and verily a matchless beauty."

Apart from the graces of manner, the charm of these relations between the ladies and the prelates sprang from their perfect skill in effacing their own personality, in suggesting that what they were giving was pure soul-for suggestion was enough. A boor will strut about, listen to his own voice, arrange his smile, select his words with a view to effect-little absurdities, much less easy to endure than a really serious fault. It was by their overweening though unconscious self-conceit that the inferior clergy made themselves so odious in Renaissance society; the monk would talk of nothing but his order, the parish parson fancied that no service was so attractive as his, and that good music was not to be heard except in his church. ${ }^{1}$ They had better have been less virtuous-and less fatiguing.

Conversation can glide along like a shallow stream. A pleasant talker is not always capable of writing or painting profundities; there is something more beautiful than a picture, and that is the face of the woman watching him and enjoying his talk. In those days they ridiculed-and

\footnotetext{
${ }^{1}$ Like the good curé who, seeing a lady shedding hot tears at the conclusion of a superb exaltet, charitably approached her to console her for what he believed to be the effect of the music, and stopped aghast when the good dame replied, "Ah ! I fancied I heard my poor dead donkey!"
} 
not without cause-certain brilliant talkers clever enough to win a wide-spread renown (without ruining their health by profound study of Horace or Virgil) by nothing in the world but talking on every subject in the same airy wayappearing to have forgotten half they knew and to know half they had forgotten-able to bring in without false modesty a stanza pat to the oceasion. Such talkers are in reality very seennd-rate, and it is not long before they get into difficulties. Sometimes abstruse subjects crop up without warning in a drawing-room, and then the conversation takes a course which gives opportunity for judging men. At the instant when it appears to be merely disporting itself on the surface, shining in full view, it takes a sudden plunge, rises again, starts on another flight and again plunges; to follow it demands an intellectual force and suppleness that eannot be improvised. We can see this from the portrait Castiglione draws of the duke of Urbino. The duke, notwithstanding his habit of keeping early hours, was a good taiker, like his guests; his speech was bland, polished, fluent, and picturesque; he brought down his bird with one shot. But under this appearance of ease and readiness he possessed an unequalled fund of information. He could reel off long passages from all the classical writers, partieularly from Cicero. He spoke ancient Greek perfectly, and lived by choice in intimate fellowship with the Greeks -with Lueian, and more especially with Xenophon, whom he called "the Siren of antiquity." "We used to eall the duke," adds Castiglione, "a seeond Siren."

Ancient and modern history, geography, the learning of the East, were familiar to him. He died at thirty-six, after a long and very painful illness; he had studied his complaint, and watched the slow-paced approach of death, knowing perfeetly that neither the pleasant elimate of Urbino nor the most assiduous attentions would retard it by an hour. And yet, even under the burden of his last anguish, he retained full possession of his intellect, with its charm and flame and serenity. His friends pretended not to have given up hope: "Why envy me so desirable a blessing?" he said to them gently. "To be freed from this load of terrible suffering-tell me, is not that a blessing?" At the very last he turned to Castiglione and recited to him one of the finest passages in Virgil. $\mathrm{He}$ died talking 


\section{THE WOMEN OF THE RENAISSANCE}

Thus, with noble colloquies like these, radiant with natural kindliness, men lulled even pain asleep.

Philosophy and love were naturally frequent subjects of conversation. People sought by their means to refine their sentiments, to analyse themselves, to set themselves ingenious problems to be investigated at leisure, to spiritualise love. For example:

"Is it easier to feign love than to dissemble it?-Answer: Yes, because a voluntary act is always easier than an involuntary one."

"Is it more meritorious for love to lead the wise to folly than fools to wisdom?-No ; it is better to build up than to destroy, and you can build nothing on folly."

"Is excess of love fatal?-Galen says yes; indirectly, through disease."

"Who loves the more easily? - Woman, because of her fickle nature?"

"Who can best dispense with love ?-Woman."

"Which is easier, to win love or to keep it?-To keep it."

"After perseverance, what is the best proof of love?The sharing of joys and sorrows."

"Which is the stronger, hate or love?-Love."

"Can a miser love?-Yes, love can destroy avarice."

And so on.

Bembo, in a little book dedicated to Lucretia Borgia (for three years the object of his passionate admiration), has left us an account of three days of conversation which followed a wedding. After a charming fête, in which young maidens furnished with tuneful viols had chanted hymns for and against love in turn, three noble damsels remained in discourse with three gentlemen on a flowery lawn, amid marble fountains and well-trimmed groves.

One of their number, selected as the detractor of love, conscientiously makes the most of its bitternesses, despairs, tears, revolts, catastrophes. A discussion ensues, so searching, so touching, that at times real tears are shed. The people who are perpetually at a white heat and flaunt a salamander as their emblem come in for some ridicule. But with what warmth the friends of love take up the defence of this divinity, who is represented as nude because he is devoid of reason; as a child, because like Medea he inspires eternal youthfulness; and torch in hand, because 
in his school there is much burning of fingers! It is towards this little torch that the whole world flits and gravitates like a swarm of moths, while the divine archer speeds his shaft at the heart of his victim.

Love, they add, is strength and life. When a man loves, he has no fear of death. One of the company even declares in his excitement that he invites death, and when the rest twit him with being beside himself, he persists, and explains his subtle languor; he invites death, but does not desire that most miserable condition! In spite of the extreme gravity and conviction with which these questions of the heart were always handled in Italy, the company cannot here repress a smile. But the speaker sees nothing and waxes warm; his martyrdom is only too serious; the flame of love can only be extinguished in a "lake of tears." And another makes answer: "When you see in famous sanctuaries a heap of votive offerings bearing witness to the innumerable perils of the sea, do you go and deny that these perils exist, or resign yourself never to set foot on a boat? You do not, I trow. Well, we must likewise accept love's crosses with resignation." And thereupon he glowingly describes its advantages.

At the end of three days, a hermit closes the discussion with a short and sedative discourse on the vanity of the world!

Naturally conversation, even in Italy, did not always soar to such altitudes. It passed easily from a vast subject to a pin's point; to make bricks without straw was a mark of talent! It was not everyone who had the wit to frame an original remark about the weather, and follow it up with a brilliant firework display of paradox! What did the idea matter, so long as the shaft flew home? They would just as soon concern themselves about the canvas a picture was painted on! They expatiated at leisure on a large subject; but no one dwelt on trifles; they laughed, wept, sparkled, they were pleasant and gay, elegant, coquettish, artistic $;^{1}$ and all

10 liberté aujourd'hui clairsemée

Et cher vendue, on te doit bien servir,

Car en tous lieux souvent est réclamée.

[O liberty, to-day so rare

(Alione.)

And dear sold, we must serve thee well, For thou art asked for everywhere.] 
that they said was excellently expressed, with a sure, keen, delicate touch. Conversation took a feminine stamp which it had never had in olden times; it was the art of paying honourable court to a lady.

The French did not approve of conversation taking this sentimental and emotional turn. They talked to amuse themselves, for laughter's sake. To laugh was their chief concern; it was a mark of taste to take everything with a laugh, even affairs of the heart; and any genuineness of sentiment was sure to appear ridiculous, whereas in Italy a false sentiment strove to appear genuine. Moreover, to speak of serious things, to appear in any other character than that of an absolutely useless and incapable man, far above (or below) everything literary, was unfashionable. On the other hand the French appreciated the unexpected, a crispness of phrase, the sword-play of wit, smart retorts. ${ }^{1}$ Conversation was a duel. The Frenchmen of that time were inimitable in verve and wit; they had a really unrivalled ease and sprightliness of manner. When the Italians tried to imitate them, they only succeeded in losing their suavity and making the mselves look foolish.

At the court of Francis I. talking and flirting were subdued to no platonic considerations. If a man was inspired with a good thing, he said it frankly and bluntly and with much gesturing. As La Bruyère observes: "It costs women little to tell what they do not feel; it costs men still less to tell what they do feel " ${ }^{2}$ and the more crudely the latter expressed themselves, the more they were looked upon as right good fellows. A woman of the world would listen to anything, and reply with her "yes" or "no," without ever taking offence.

'The more the domination of man asserted itself, the more pronounced this liberty in word and action became, and women came to think that they could employ no better means of getting even with men than to adopt the language

${ }^{1}$ Here is an example: "Why, Dagoucin," says Simontaut, "don't you yet know that women have neither love nor regret?"-_."I don't yet know it," he replies, "for I have never dared try for their love, for fear of finding less than I hope for."- "You live on faith and hope, then," says Nomerfide, "as the plover lives on wind? You are very easy to feed." (Heptameron, Tale 32.)

"2 When women confess, they always tell what they have not done." (Old Italian proverb.) 
of the barrack-room, and make frequent quotations from the grossest books. They made men a present of their garters. Naturally the men were very well pleased, by no means detesting women of so facile a disposition. A German would entertain the young lady next him at table with tomfoolery of the coarsest description, prating, for instance, about heavy drinking, or low-necked dresses, or a woman showing her leg or hunting for fleas: or perhaps, to appear intellectual, he would maintain that evil has no real existence, but is only a human invention. Another would allow fun to be poked at his wife or fiancée. Rabelais and Hütten were the shining lights of this class of talkers. Even Savonarola, in his character of a monk of the people, sometimes went very near the border line; here and there in his sermons there are phrases at which a salted skipper would blush.

Italian platonism was no enemy to laughter; it was quite the other way. In the evening after dinner (the time when in these days men are lighting their cigars), men who had wit and gaiety and no cares (three conditions for which the cigar alone would hardly be a sufficient substitute), langhed without stint and told pretty warm stories as a relaxation from the ideal; but as the ladies were present and no one would have dreamt of doing without them, form was always more carefully studied. Platonism was nothing if not fastidious, correct, and ceremonious; and a platonist, even when retailing a broad joke or when there was no occasion to put himself about, did not cease to employ exquisite phraseology.

The French, on the contrary, laughed somewhat boisterously after dinner, or on one of those oppressive afternoons when the dull sky seems to seize us like mice in a trap. Our passion for broad wit has never allowed itself to be cooled by the exhortations of moralists ${ }^{1}$ or preachers. Nor were ladies more successful in selecting subjects for conversation; they had either to leave us to our own devices and be regarded as nuisances, or to pitch their tune to the same

${ }^{1}$ Rusticus est vere, qui turpia de muliere
Dicit, nam vere sumus omnes de muliere.

(Facetus.)

[He is truly a boor who speaks ill of women, for verily we are all of woman born.] 
key. An awkward dilemma for them! They faced the music, and contented themselves with declining to laugh when the jest displeased them; but in their hearts they preferred a lady's man who knew how to show them tenderness and respect.

Conversation is naturally composed of dialogues. Whenever it attains a certain height, contradiction is necessary to keep the ball rolling. Some one has said that contradiction is woman's forte, and in this connection La Fontaine retold the old fable about the drowned woman whose corpse, from sheer perversity, insisted on floating up stream.

That may be true of worn, untutored women, good housewives to whom the artifices of taste are a sealed book. The woman of fashion, preferring to profit by all her privileges, hovers over a conversation, mingling with it only to throw out a suggestion, a criticism, a reflection, an argument, or to give a finishing touch. Margaret, for instance, launched this aphorism in the midst of a discussion on love: "Women of large heart yield rather to the spirit of vengeance than to the tenderness of love." 1

It was often a man who had to devote himself to this duty of contradiction; intellectual epicures took rather kindly to the little amusement, and acquitted themselves with at least every appearance of conviction. It was even a mark of genuine dilettantism to maintain now one idea, now the contrary, like Filippo Beroaldo, ${ }^{2}$ who has recorded two of his declarations, one in favour of drunkenness, the other against it. The question of the merits and defects of women furnished in France an inexhaustible theme for social debate, and there was no lack of disputants on either side. In Italy this subject was less popular, because the ranks of the anti-feminists were thinner. At Urbino, however, Fregoso ${ }^{3}$ threw himself into the ungrateful task of attacking women, and valiantly depicted them as imperfect animals

\section{${ }^{1}$ Heptameron, Tale 62.}

2 [Filippo Beroaldo (1453-1505), professor of ancient literature at Bologna, so learned that Pico della Mirandola called him the 'Living Library.' His most curious work is Declamatio ebriosi, scortatoris et aleatoris, in which three brothers, a drunkard, a lecher, and a dicer, dispute among themselves which of them, being the most vicious, their father will disinherit.]

${ }^{3}$ [Italian poet (1445-1515) attached to the court of Ludovico il Moro at Milan. When Ludovico was captured by the French, Fregoso went into seclusion and became known as the Friend of Solitude.] 
of no intrinsic value, whom it was impossible to compare with men, upon whom only modesty and self-respect had any restraining power, and whose few merits were a purely artiticial endowment.

Yet, as it was impossible to be always engaged in dialogues or debates, there was a large field for clever retailers of anecdotes and stories grave and gay, and the talent was cultivated to perfection by certain men of the world. Among these witty story-tellers we find another member of the Mortemart family, Aimery de Mortemart, and the name of Germain de Bonneval used also to be cited.

Story-telling in Italy was conducted with the same gravity and method that were carried into everything. A "queen" was first elected, ${ }^{1}$ and she called upon each member of the company in turn. The stories very easily verged towards salaciousness, but art ennobles everything! Firenzuola dedicated a collection of such stories to the memory of an idolised lady whom he calls his Diotima, his Monica, his Vittoria Colonna:

In France, story-telling ranked high among social amusements, filling up the interval between mass and vespers. Everyone had fair notice of his turn to speak, and made provision accordingly, whetting his own invention on what fell from the lips of others. The Heptameron is, so to speak, nothing but a succession of conferences (without the platform and the glass of water), at which each person present contributes his mite to the discussion. Sometimes the remarks are rather free; when the anecdote is likely to overstep the recognised limits, the speaker saves himself by a gentle preliminary precaution:

Si ce n'estoit que j'ay peur d'offenser

La netteté de vos chastes oreilles.-Des Périers. ${ }^{2}$

Margaret of France, who was not specially bashful, "could tell a capital story, and could laugh, too, when she heard one."

1 An attempt was made to revice this system in certain notable salons of the 18th century. The rules for the Lanturelus drawn up in Madame Geoffrin's salon included the obligation of being just, loyal, cheerful and kindly; they forbade one to grow old, that is, to become peevish and mis. anthropical. The sittings held under the direction of a "queen" were divided into two parts, one devoted to song, poetry and facéties, the other to philosophy.

${ }^{2}$ But that I fear to shock beyond forgiveness

The soilless purity of your chaste ears. 
Another art which was still highly appreciated-a very elegant, charming, and widely cultivated art-was that of impromptu verse-making - a pastime for prelates and men of keen literary tastes. Leo X.1 and Octovien de SaintGelais ${ }^{2}$ practised it with eminent success.

Boutrimés, or "ventes d'amour," though somewhat antiquated, contributed a share to the entertainment. A man gave a lady, or vice versa, the name of some flower, and a response had to be made in verse of as epigrammatic or complimentary a turn as possible. As aids to improvisation, manuals of polite rhymes were published.

Such was happiness! Conversation in its various forms was the port to which the barque of life made under full sail, trimmed with all the safeguards, manœu vred with all the dexterities which we have described! And the difficulties were compensated by the satisfaction derived from bringing souls into communion one with another, from closely uniting them, welding them in one enthusiasm of affection. Such a result is beyond the attainment of writing. Genuine exquisites like Inghirami thought writing was overdon', and if they employed the pen it was from necessity, or at most to preserve for posterity the conversations, the tales, the sonnets that pleased them; when a work involving time and labour was asked of them, they wrapped themselves in an air of austere solemnity, like people going to a funeral. All these brilliant talkers lived quiet lives out of the public eye, seldom shifting their quarters, with none of that moral trepidation in which the railway and the telegraph keep us: they were light-hearted but not shallow, with something of oriental insouciance,

${ }^{1}$ He used to amuse himself with a drunken impromptu-monger, a Roman named Querno, whom he jestingly called Archipoeta. Querno says to him: Archipoeta facit versus pro mille poetis.

[Arch-poet makes enough verses for a thousand poets]

Leo replies :

Et pro mille aliis Archipoeta bibit.

[And driuks enough for another thousand]

Archipoeta responds :

Porrige quod faciat mihi carmina docta, Falernum,

and Leo :

[Give me some Falernian, to inspire my song]

Hoc etiam enervat debilitatque pedes.

[That also renders your feet weak and shaky]

2 [A clerical poet (1466-1502) who translated Ovid's Epistles into French. 
never forgetting that man has but one life on this nether world, squandering their wealth of wit in lavish profusion, with no attempt to economise it in order to sell specimens to an innominate mob. They enjoyed to the full the exquisite pleasure of letting their ideas float off at the mercy of chance; their thoughts took flight and were seen no more, it is true; they burst like bubbles in the air; but there remained the wherewithal to shape others like them.

And here was the great sphere of women. Their mission was to cause this happiness to blossom, to tend it, nurture it, turn it to fitting use-to make these bubbles a source of good.

This duty like every other had stern laws. It was not enough to be a "queen" by election, or even by birthright, to fancy that the goal was attained.

Women's sway only imposed itself by dint of patience, tact, and a nice regard for detail, and above all at the cost of genuine self-denial. How many little trials and crosses had to be endured! To make herself agreeable to the starched Spaniard and-the boastful Neapolitan; to lis'en resiguedly while a Frenchman discoursed about his hunting and his limited income, or while a Milanese or Genoese prated about his business; and then with all gentleness, with a woman's instinctive subtlety, almost by stealth, to select among these men-to hold by an unconstrained and loyal welcome those in whom she perceived some merit, and to bind them to her by speaking their own tongue-wisdom to the wise, piety to the pious, practical interests to the practical, gaiety to the young - and thus to set them all on the path towards the desired perfection-what a task for a woman! However, all that she needed in the rudimentary stages of this education was to plant herself securely on her own rudimentary gifts-in other words, to avoid scandal and tittle-tattle. But how difficult her task became when she had to deal with men of parts, of warm affections, of ardent temperament! Then, no doubt, it became interesting, and the woman herself was reaping a profit which amply repaid her trouble. "Ladies," cries Champier, "if you must take pleasure in hob-nobbing with men, choose at least those who can improve you and guide you." There was no question now of retiring to the Aventine, and fancying 


\section{THE WOMEN OF THE RENAISSANCE}

themselves constantly in mortal peril ${ }^{1}$; a lady had to hold herself erect and tighten the rein on these unruly men-to know the power of a word, a gesture, a flash of silence. ${ }^{2}$

To retire to the Aventine! That would be criminal! Speech is necessary to one who would minister to a mind diseased.

Conversation was not merely a pleasure. If they strove earnestly after the Beautiful, it was because the reign of beauty is the most effectual assurance of the reign of truth and goodness. Does anyone imagine that a woman can shut herself in her drawing-room, and that all she need do is to show herself beautiful, amiable, sweet, intelligent, tender to the men worthy of forming her circle? No one thinks so. Woman rules because she redeems. To direct or actively to engage in works of charity, to send money to the wretched, without looking out of doors to see what men are actually suffering or dying - this would be the absolute negation of the social aim of conversation. Through conversation a woman comes into living touch with realities. She must show herself as real flesh and blood to the wretched; she owes them her smile, her beauty and her grace; aye, it is her bounden duty to be beautiful, amiable, gentle, intelligent, tender for the sake of those whose lot is solaced by no ray from heaven. She must welcome the poor and lowly, and though she may not be able to speak to them in Plato's language, she must none the less tend them with the supreme medicine of the Beautiful, enter into their interests and their troubles, talk with them, shower on them her manna of hope and patience, and-if she have it-light.

Perhaps we shall now be asked how many women attained to these altitudes in the apostleship of beauty, and if we can cite many who attempted to put their ideas into practice. Assuredly, we can. In spite of the somewhat too artistic cast into which social intercourse was thrown by platonism, more than one woman found in her own heart a commentary which neither Ficino nor Bermbo

1 " De son cheval on fait une rosse,

Et de sa femme une catin."

[Of one's horse one makes a jade,

And of one's wife a harlot.]

${ }^{2}$ Heptameron, Tale 52. 
ever knew. In France we may mention Anne of France as one who was thoroughly convinced that conversation was a duty to society at large. In Italy, ladies of the highest rank, like Isabella d'Este and Vittoria Colonna, slightly intoxicated with Beauty, consorted almost exclusively with princes and prelates and men of culture, and in this regard the Renaissance is perhaps rightly accused of over-refinement; yet they possessed in a rare degree the talent of diffusing around them an atmosphere of sweetness. At Urbino, a provincial court of no little exclusiveness, even the stalls of the handicraftsmen were lapped in a delicious air; Raphael grew up like a natural plant; a thousand trivial incidents in the life of the place give us glimpses of grace and amiability. The influence was indirect, but very powerful.

\section{CORRESPONDENCE.}

It would seem logical to consider correspondence as the complement of conversation-as talk between persons at a distance. But it was not so; talk it might be, but in writing, and consequently no one was very fond of it ; people distrusted it because of the risks involved. Yet certain intellectual women of the 16th century displayed amazing activity as letter-writers. While one might have supposed them to be wholly engrossed with their rouge-pots or their friends, their intelligence and vivacity actually carried them away; the pen appeared too lumbering a vehicle for their impatient thought. In the letters of Julia Gonzaga, for instance, it is often evident that the lady took the pen from her secretary at the third or fourth line and finished the letter herself, rapidly, and without troubling her head about grammar, handwriting, or decorum. ${ }^{1}$

To the student of handwriting, letters betray many little philosophic secrets which are well worth attention. The handwritings of the 16th century (for the most part illegible, particularly in France) are large and free, highly nervous and characteristic of the writers, released from the methodical and commonplace style of former days. The strokes are fine and distinguished, sometimes a little angular, displaying all sorts of vagaries, abbreviations and

${ }^{3}$ Seventy-five letters of this princess have been collected by M. Amante. 
flourishes. What a "mirror of the soul" is the close and tangled handwriting of Margaret of France, or the gaunt, nervous, firm, aristocratic, jerky, disorderly style of the duchess of Etampes! 1

The style of Vittoria Colonna is clear and plain, somewhat masculine in character, but equally nervous and irregular, with a multitude of abbreviations and splotches. A mere glance at the letters of these influential women fills one with pity. Poor souls! At what a cost of secret torment, distress, and agitation did they mould happiness and peace for men! Looking at these human documents, these nervous handwritings, one asks oneself if those sages are right who assure us that to bestow happiness on others one must needs possess it oneself. Was it at the cost of His happiness, or at the cost of His blood, that Christ redeemed us? I may be deceived, but I sometimes fancy that I see in these handwritings as it were a drop of blood. It was otherwise with the men: they were happy. Castiglione's writing has a graceful, tranquil movement; his pen ran lightly and cursively; and if sometimes the strokes seem laboured, it is due to an affectation in his manner of joining the letters. Bembo placidly retains the old style, stunted, heavy, and sprawling.

The tone of the letters confirms the casual glimpses we have already obtained into the social relations of the time. People troubled little about family letters; these were simple and short, of the "dutifully affectionate" order, and composed of almost stereotyped commonplaces. Hardly anything is referred to in them except the material affairs of life-business, medicine, health, domestic events $;^{2}$ the sentimental part is dismissed very briefly-probably because family sentiments are necessarily sincere.

On the other hand, letters written to friends, which were very numerous in Italy, were charming, tender, and graceful,

${ }^{1}$ [Mistress of Fraucis I.]

2 Anne of Laval, for example, writes to her sister: "J'ay entendu que Monsieur mon frére ce vante que à son retour j'auré ung petit neveu. I'lust a Dicu qui fust ainsi, d'aussi bon cueur que je le desire. L'espérance que j'en ay me faict vous envoyer des poix en gousse, qui est viande de femme grosse."

[I have heard that my brother is boasting that on his return I shall have a little nephew. God grant it may be so, of as good heart as I desire it. The hope I have induces me to send you some peas in the pod, which is a food for pregnant women.] 
ending often most prettily: "Your little sister .... who loves your lordship as her own soul-Isabella, with her own hand."

These last words, "with her own hand," were not unnecessary, for a fashionable lady, not pluming herself on a telegraphic style, was obliged on principle and out of regard for her dignity to leave as much as possible to the pen of her secretary. Unhappily the secretary, not caring to serve as a mere scribe, pay's attention to style, and touches up his periods, so that, failing an actual autograph, it is impossible to be sure what in a lady's letter was really her own. Moreover, a liddy of any position knew that her letter would be shown about, perhaps even transcribed or published. Bernardo Tasso, Aretino and many another were not startled when they saw books made out of their letters or of letters written to them; and the most interesting letters of Vittoria Colonna appeared early in the 16 th century. It may be said then that letters came midway between conversation and books. In a lady's letter there was nothing directly from the writer but the signature and the one or two autograph words preceding; in spite of which, the letters of the marchioness of Pescara and of Isabella d'Este form very pleasing and characteristic collections.

After a visit from Isabella, the duchess Elizabeth of Urbino addressed this note to her: "I know not how to cure myself of the regret your ladyship's departure has left me in. Methinks I have not only seen a dearly loved sister leave me, but that my very soul is gone. I must needs write you ever and anon, and make shift to say on this paper what I would fain say with my lips; if therein I could clearly express my sorrow, I am very sure 'twould be so potent as to cause your highness out of compassion to turn back. If I feared not to be a burden to you, methinks I should not hesitate myself to follow you. Neither thing is possible; my sole resource is to beg your highness to think of me as often as I bear you in my heart."

Many examples of this delicate and sweet-almost too sweet-graciousness might be cited. Emilia Pia, for instance, one of the Urbino set, writes almost as she speaks, with great liveliness and humour, and always with equal vivacity whether the subject be toilet specifics or philosophy. The men have the same charm, and sometimes 


\section{THE WOMEN OF THE RENAISSANCE}

think themselves entitled to employ the same exquisitely tender formulas. Brocardo ealls Marietta Myrtilla "my very sweet and dear little sister . . . my sweet and matchless little sister, lover as my own soul," and signs himself: "Thy sweetest, sweetest Brocardo."

The terms in which a well-bred man could, indeed was expected to, address a fashionable lady, may be seen from a letter from Castiglione, then ambassador in Spain, to Vittoria Colonna.

"I have felt," he says, "so much joy in the victories of the marquis that at first I would not write a letter-a letter is so vulgar a thing! One writes letters about events of no importance. I had thought of fireworks, fêtes, concerts, songs, and other vigorous demonstrations, but reflection has shown me that these are inferior to the concert of my own affections; and so I am come back to the idea of a letter, convinced that my marchioness will be able to see what I have in my soul, even though my words fail to express it." And he dilates on this talent of the divine marchioness for penetrating hearts, and for reading there what the lips fail to utter, and then congratulates her on the delight which she cannot but feel. "And as to my duty towards your highness, seek, I beseech you, the testimony of your own heart, and give it credence, for I an sure your heart will not lie to you on what not only yourself, but the whole world, sees shining through my soul, as through the purest crystal. And thus I remain, kissing your hands and humbly commending myself to your good favour. Madrid, March 21."

Two years afterward he wrote in regard to the death of her husband: "Calamity has fallen upon you like a deluge. I durst not write to your highness at first, for I deemed you had died with the marquis; to-day in all verity and admiration I hold that the marquis still liveth in you."

Do we need other specimens of these gracious and somewhat ultra-refined letters? Here is a letter from Castiglione to the famous Marchesa Hippolyta Florimonda Scaldasole: "Most excellent lady, if your ladyship were as pleased to know you dwell eternally in my memory, as 'twould be infinitely delightful for me to dwell in yours, I should be keenly desirous of giving you proof of it in this letter, since for the moment I can do it in no other way. But as your 
ladyship has shown the world, along with your many other wondrous gifts, that you are a woman valiant in fight, and not only beautiful, but warlike also like Hippolyta of old, I fear me lest you be somewhat puffed up with pride, and somewhat forgetful of your servitors-and I would not have it so. Therefore have I made bold to write to you, and to pray Hesser Camillo Ghilino, my very dear friend, to speak on my behoof, and to tell you that in Spain, as at Milan and at Pavia, I am your man; and that, when I had come to Pavia, whither the army led me, those walls, those ramparts, those towers, that artillery, all those things spoke to me of your highness, knowing that behind them you were all aglow with the thought of combatting so great a prince as the King of France. You have gotten the victory, and now and henceforth no one will be so daringhardy, I trow, as to fight with you. Deign to believe him, lady, as myself; and I beseech you, if you be not of all ladies the least loving, bid me to be at Milan and where you are. Messer Camillo will be able to tell how different it is to be in such sweet company as your ladyship's and to be in Spain. I kiss your hands, and ever commend myself to you, deeply desiring to know that this benedictus fructus be reaped by a husbandman worthy of it. Toledo, June 21, 1525."

After all, there was a necessary resemblance between a letter and a conversation. In Italy, the note of tenderness is always dominant, flattering and caressing even when gay. Some of Bibbiena's letters are full of deep feeling, and yet it is impossible to mention a more jovial man : his fun bubbled over at the slightest provocation. Isabella d'Este once scolded him for no longer visiting Mantua. "How," retorts he with affected indignation - "how have they managed to drop into those dainty little ears so many gross accusations against me? . . . Here I see your danghter, who appears to me the very image of that serene highness her mother. Tell me again I am a lecher, and by God it shall be true as Gospel! Would you have me swear otherwise? ... Most devoutly do I kiss your hands, and to my dear lady Alda I commend myself a thousand times." The amiable prelate was at that time assiduously courting Signorina Alda Boiarda, maid of honour to the marchioness; and, as usual, the mistress was not altogether pleased. 
Another charming custom in Italy was for a lady to recall herself to the recollection of her friends by means of a little present. Vittoria Colonna sent her portrait to Bembo, accompanied by a few verses from her own hand: "Verses pure and dainty!" cries Bembo, "that touch the heart far more than a mere letter." On another occasion she charged one of her friends, who was going to Mantua, to convey to the marquis "a friendly and sympathetic" greeting, with some small token of her regard. The friend thought he was doing right in offering a basket of roses, and the marquis lost no time in sending his respectful thanks direct to the fair donor. And then Vittoria formally apologiserl in very affectionate terms that her messenger had "honoured him so little" as to offer so modest a souvenir.

Truth to tell, Frenchwomen showed much less feminine grace in this matter, which explains our dwelling on the charm of their Italian neighbours. The most Italianised of them could not attain this seductive charm. In all the correspondence of Margaret of France you will not find one letter recalling those we have just quoted almost haphazard. Margaret did indeed sedulously strive to attain that charm, as we cannot but perceive, but her languishings resulted in little else than prolixity. It will not do to strain one's talent.

Renée of France, though she became duchess of Ferrara, never acquired the Italian trick; she continued to write with French brevity. Diana of Poitiers and the duchess of Etampes amaze us by the almost arid precision of their style; they might have given points to the most dry-as-dust of attorneys ; there is never a sign of a gust of passion or of love's finesse. The rising generation of Henri II.'s time came nearer the attainment of a pleasant style. The king's two daughters, Madeline and Margaret, wrote excellent hands-easy, graceful, even, with a uniform slope, the letters broad and clear, the whole style very distinguished; and they employed pleasant and engaging forms, phrases of genuine affection, especially in their family correspondence. ${ }^{1}$

${ }^{1}$ Here are some samples of these private letters :

"Monsigneur, tant et si tres humblement que je puis a vostre bonne grace me recommende.

Monsigneur, je vous suplie tres humblement croire que la créance que remais a ce porteur n'est que la plus grande obaissence que james tres 
But they too were at their best in short notes, and their most pleasing letters are always very brief. The higher charm remained the secret of Italy.

humble fille ne servente vous saroit porter et coume la plus obligée de ce monde.

Monsigneur, prie Dieu qui vous dont tres bomme et tres longue vie.

Voutre tres humble et tres obaissente fille,

Address: Au Roy mon souverain seigneur." Magdalene.

[My lord, as truly and as humbly as I can I commend myself to your good favour.

My lord, I beg you very humbly to belicve that the letter of credit I confide to this carrier is only the greatest obedience that ever humblest maid and servant could bear to you, and like the most dutiful in the world.

My lord, I pray God to give you a very good and very long life.

Your very humble and very obedient daughter, Magdalene.]

" Ma cousine, je n'ay point voullu que ce porteur soit passé par Chantilli sans vous porter de mes laitres; je vous en usses plutost envoié, mes les piteulses nouvelles qu'avons repsues de Hedin m'an onst engardé, car je n'aime poinct a mander de mauvesses nouvelles, et en cete perte j'ay esté tres esse d'entendre que Monsieur le coute de Villars vostre frere est seulement prisonnir (sic) avecq tant d'onneur que je suis sure que vos prieres luy onst beaucoup servi. Vous feres tant pour moy, ma cousine, de croire que tout ce qui vous touchera que je ceray mervelleucement esse qu'il soint anci hureulx comine vous le desires et moy anci ce que je suplie de bien bon cueur Dieu et de vous donner bonne vie et longue et a moy l'eur de vostre bonne grasse a laquelle de bien bon cueur me recommande.

Vostre melieure cousine et amie, Marguerite de France.

A ma cousine Madame la connestable [duc]esse de Montmorency."

[My cousin, I would not let this carrier pass through Chantilly without taking soine letters from me for you. I should have written sooner, but the dreadful news we have received from Hedin has prevented me, for I do not care to send bad news, and in this loss I was very glad to hear that the count of Villars your brother is only a prisoner, with so much honour that I am sure your prayers have much profited him. You will do so much for me, my cousin, as to believe that, in all that touches you, I shall be wonderfully glad if all falls out as lucky as you desire, and myself too, and I pray God so with all my heart, both to give you a good and long life, and me the bliss of your good favour, to which with all my heart I commend myself.

Your best cousin and fricnd, Margaret of France.]

"Mon pere, je ne voulu leser aler se pourteur sans vous faire savoir de mes nouvelles, lequeles sont bonnes, pour se que je aeudire souvan des vostres qai me pabise (?) bien, car s'et au proufit du roy et a vostre ouneur. Je prie Dieu vous i vonloyr tenir; je ne veus oblier, a vous faire mes reconmandasions bien fort voustre bonne grase.

A Monsieur le grant maistre."

Vostre bonne fille, Marguerite. 
[My father, I would not allow this carrier to go without letting you have news of me, which are good, because I have often had news of you which please me, for 'tis to the profit of the king and your honour. I pray that God will keep you in the same; I do not forget to commend myself very earnestly to your good favour.

\section{Your good daughter, Margaret.]}

“Mon pere, j'ay esté tres esse d'entendre par vostre cegretere presant porteur du bon partement du Roy et du vostre et aucy que toutes les afaires continuent de mieulx en mieulx; cant a cele compagnie, la Royne et monsieur ce portent tres bien, aucy faict tout le reste. Nous ne fesons faute de prier bien Dieu tout les jours pour le Roy; après luy, mon pere, je vous puis assurer que vous estes le prumier (sic) en mes auraisons. Je vous prire (sic), mon pere, presanter mes tres humbles recommandasions au Roy et me tenir en sa bonne grasse et an la vostre. A laquelle de bien bon ceur me recommande, et prie Dieu vous donner bonne vie et longue.

Vostre milieure figle et cousine,

Marguerite de France.-A mon pere, Monsicur le connestable."

[My father, I was very glad to hear by your secretary the present bearer of the good departure of the king and yourself, and also that affairs are going better and better: as to this company, the queen and monsieur (the king's brother) are very well, as are all the rest. We do not neglect to pray God every day for the king: after him, my father, I can assure you that you are the first in my prayers. I beg you, my father, to present my very humble greetings to the king and to keep me in his good favour and in yours. To which with much love I commend myself, praying God to give you good and long life.

Your best daughter and cousin, Margaret of France.] 


\section{BOOK III. THE INFLUENCE OF WOMEN}

\section{CHAPTER I}

\section{POLITICAL INFLUENCE}

THE foregoing pages will have enabled the reader to see how little the platonist women sought to exert a direct influence in affairs. They aimed rather at moral and social influence. In no sense were they women of action, believing likely enough that the course of events would become modified naturally when men had changed. Conforming to the aphorism, "Woman is supreme only as woman," they devoted themselves to the skilful development of the sources of their superiority, leaving their inferiorities carefully in the shade. They avoided all masculine modesthe rustic sort of sexless unattractive women, most at home in the stables, strong-minded creatures who looked for a love they never inspired; they studiously left to men the keen-edged activities of life-law, politics, military service, all the needful barriers against social inundation. Louise of Savoy was almost the only woman who so far cherished the old ideas as to regret that she was a woman; who loved to play a part in politics, and whose intelligence and energy won praise in terms that recalled the great women of the past, notably Blanche of Castile. She was a realist of the old type, who had lovers as a matter of course, but gave scant thought to winning hearts: thus wholly differing from the new order of women. And yet, by a singular chance in the working of the old laws of monarchical succession, the world has perhaps never seen more women 
called to fill the places of men in the sphere of statecraft. After all, monarchy is not a principle of pure reason: it is incapable of mathematical demonstration : it is a prineiple springing wholly from sentiment. Its advantage lies in this - that in a world of tragic pettiness it gives a nation something to love.

Many women played important parts in these masculine struggles, among which they were thrown in their own despite. The period was one of constant turmoil, and they had no opportunity of enjoying a life of quiet secluded happiness.

Among them was that unhappy mother, Isabella of Aragon, who was persecuted by Ludovico il Moro, the uncle, and, as some said, the assassin of her husband, and held captive in France by Louis XII.-a luckless, warmhearted, valiant figure who, in the effort to win Milan back for her son, maintained a desperate struggle with the whole of Europe.

Then too there was Joan of Aragon, that beautiful sunny-haired woman, with features of rare distinction and sweetness, in her day the idol of Nifo and the prototype of beauty. She had married Ascanio Colonna, a soldier of fortune who had brought his affairs to a desperate pass. Poor woman! On every side she saw blank desolation. She had just lost her eldest son by a sudden death when creditors hegan to harass her and drive her second son to ruin; and from the magnificent windows of the Colonna palace, where she was imprisoned by order of Pope Paul IV., she saw the pontifical troops marching by on the way to seize her castles. She could endure it no longer. One morning she disappeared, no one knows how, but probably in disguise: at one of the gates of Rome she found a horse ready saddled, and she performed the astonishing feat of riding to Naples without drawing rein. At Naples she became the centre of a cruel strife: her husband had her son arrested, and the son denounced the father. Ascanio fell, struck by an unknown dagger. And when his charming wife, whose golden hair had never a fleck of grey, came in her turn to die, they must bury her with her husband, and could find for the shuddering tomb no inscription but the touching words: "A great-hearted woman, a very loving wife." 
In a higher sphere even Margaret of Austria was but a genuine woman, an admirable mother who never had any children. Compelled by family duty to rule the Netherlands during the long minority of her nephew Charles the Fifth, through all those years of toil and difficulty she set but one aim before her, the preservation of peace. She was good, benevolent, intelligent, but not happy: "Twice married and yet a maid,"' as she said, then the widow of the handsome Philibert of Savoy, she would have preferred the 'tiniest grain' that satisfied her heart's craving to the dignities that were poisoning her life; and she made no secret of it. On her tomb she ordered to be set this striking emblem of disillusionment: 'Fortune, Infortune!'

And the great Anne of France, 'the lady of Beaujeu,' condemned to an attitude of 'knitted brows' and drawn sword as a means of reassuring her good subjects and keeping the bad in awe, that haughty, ambitious, closefisted, masculine woman, as she was called by those whom she had reduced to a proper sense of the duty of prompt obedience-no one was in reality less like the cold statue she appeared in official life. It was enough to watch her features in the hour of strife, and of triumph even; they twitched and quivered, and were only controlled by a visible effort. ${ }^{3}$ A modest, it might almost be said a humble woman, she was constantly a prey to self-distrust, never acting without advice, almost heart-broken at her victories, for her one dream was of quenching animosities; caring for nothing but peace, justice, and a well-ordered State, and carrying her loathing of extreme ideas to the point of appearing obtuse.

When her brother was able to assume the government she disappeared from the scene, quietly, with the least possible display, happy to seek retirement at her splendid place at Moulins, amid all she held dear. She had conceived so little taste for political life that she gave her daughter a forcible recommendation to avoid its mazes: "Mind your own busi-

${ }^{1}$ [She came near perishing by shipwreck on her way to join her young husband, the Infant of Spain, and composed her epitaph :

Ci-git Margot, la gente demoiselle,

Qu'eut deux maris, et si mourut pucelle.]

2 She died in 1530 , barely fifty years old.

${ }^{3} \mathrm{Her}$ portrait is in the Louvre. 


\section{THE WOMEN OF THE RENAISSANCE}

ness," she said; in other words, keep strictly to your own part, and if duty demands a temporary withdrawal, resume it as quickly as possible, and be egoistic enough to make the winning of love your sole quest.

Such was the attitude towards civil emancipation and the careers proper to men that was taken up by women of the highest distinction, whom glory might well have led off in the wrong direction. La Rochefoucauld could hardly have had them in mind when he enunciated the unsound maxim: "There is no renouncing ambition for love." To renounce ambition was all that these women desired, or rather their ambition was love itself; when the chances of life forced them upon the stage, their one desire was for a man to lean upon. Diplomatists, of necessity psychological folk, were under no delusion in the matter; when they had dealings with a princess, forth with we see them on the lookout for the man or men behind. "Giacomo Feo appears to me the pivot of the State," wrote Prudhomme, ambassador at the court of Catherine Sforza; the poor man had just made the discovery that Feo's will was law. The great trouble of Anne of France was that she could find no support in her husband, a man of complete integrity and excellent disposition, but unstable as water.

On the other hand, among women of but average intelligence, there were busybodies with a lust for notoriety, parade, admiration, always ready to interfere in anything and everything, to the utter despair of serious workers. Of these Renée of France, duchess of Ferrara, may serve as an example. Born a daughter of France, she considered that her insignificant husband had been too highly honoured in wedding her, denied him ler bed, lived in her own circle, and entered into diplomatic relations on her own account. Not that she had any definite political aims: her method was the simple one of pulling in opposite directions to her husband, which at a distance gives her conduct a look of inconsistency. Did she hold with Rome, or Geneva? She would receive Ignatius Loyola in the morning, Calvin in the afternoon, and anyone else when the fancy took her. To her France was all in all; but the French government had only to request someone to cross the frontier for her to receive the exile with open arms. In somewhat limping verse Marot acknowledged her grant of a pension (diminu- 
tive, it is true) which entailed upon him no duties but those of a lover:

Mes amis, j’ai changé ma dame;

Une autre a dessus moi puissance,

Née deux fois, de nom et d'âme. ${ }^{1}$

Re-born indeed both were, and it may even be said that their life was a constant succession of re-incarnations, in creeds and amours of hues as shifting as the chameleon's; for Marot notoriously proved faithful to nothing but his pensions. Neither of them had any part or lot in platonism. Marot chose to become its recognised flouter; Renée was merely a woman of a restless spirit, without any solid abilities. In public ceremonies she appeared at her husband's side; within their own doors she was perpetually at odds with him: an exasperating woman indeed, dead to the finer feelings. The duke of Ferrara was not master in his own duchy. One day he banished one of the most obnoxious of his wife's ladies, a Madame de Soubise: the lady instantly proceeded to arrange an interview between the duchess and the King of France, and it was with the utmost difficulty that this menacing combination was prevented from becoming an accomplished fact.

The duchess had a lover, by no means of the platonic order, in the son-in-law of this Madame de Soubise. He was a M. de Pons, a scion of a family which enjoyed the singular privilege of rendering services of this nature to royal ladies. Again the duke of Ferrara had much ado to stifle scandal in this direction. Having recourse to the time-honoured method, he sent M. de Pons on a mission to France, with sufficiently general instructions, which found a natural reffection in the vagueness of the official despatches. But the private letters of the duchess to the ambassador were explicit enough in all conscience. She tells him, for instance, that she is giving the hospitality of her bed to the little poodle he had left behind at Ferrara, fondling it and kissing it, "since," she adds, "I have no one else here now." Now, mark the complexity of this feminine diplomacy! Attached to the service of our gay ambassador

${ }^{1}$ Friends, know that I have changed my dame;

Another holds me at her will,

In soul Renée, Renée her name.

(Renée $=$ re-born : the pun cannot be translated.) 


\section{THE WOMEN OF THE RENAISSANCE}

was a spy in the duchess's pay. But this was matched by the fact that her own letters were intercepted and read in the "dark closet" of Ferrara, with the result that the duke lost whatever remmant of doubt he may perchance have nourished, but had the charming consolation of locking up in his archives the journal in which she set down her doings and secret thoughts for the sole benefit, as she imagined, of her absent lover. The inevitable outcome of this game of cross purposes was the impossibility of foreseeing when the mission of $M$. de Pons would be concluded. But it would argue great simplicity not to imagine that the duchess also had her "dark closet"; and in fact, she had arranged for the interception and perusal of letters addressed to the lucky Pons by one of her own ladies of honour, letters which, like hers, embodied a private diary, and were as ardent as her own. It remains only to add that Pons had left at Ferrara a lawful wife (the inspiration of Giraldi's muse) who loved him with equal warmth and devction, and bore him beautiful children. But all things come to an end, even diplomacy when there are more reasous for concluding negotiations than for commencing them. So it came about that M. de Pons returned, and the duke philosophically shut his eyes and stopped his ears until the day when he took the liberty of turning the key on the daughter of France whom he had been so much honoured in espousing.

The duchess of Ferrara belonged to a school which was unhappily of large extent, and was in great measure the cause of the ruin of feminism: the school namely of women who were somewhat intoxicated with their power, and who forced their way by look or crook into politics and life. In France more than one woman of this sort might be cited from the reign of Heni iII.

Serious women, however, very clearly saw that if they were to avoid a fall they must take only an indirect part in affairs. When the great sculptor Sansovino appeared on the point of sinking under a moral crisis, it seemed quite natural that Aretino should appeal to his young wife to come to his aid! There you have the woman's rôle! Vittoria Colonna, likewise, restrained her husband in the flush of an intoxicating and perhaps perilous triumph, by a letter which has justly remained celebrated: "Not by the great- 
ness of your domains or titles, but by your virtue, will you win the honour which your descendants may make their boast. For my part I hare no desire to be the wife of a king; I am the wife of the great captain who has vanquished all kings, not by his valour merely, but by his magnanimity."

Such was the language of a philosophical woman, accustomed to take lofty views of things, and to live in the atmosphere of the Beautiful, that is to say, a life of mingled serenity and strength. Her reserve of energy, lying hid under a wealth of kindliness, could only show itself in times of difticulty: "The tongue is feminine, the arm is masculine," said an old Italian proverb. ${ }^{1}$ The tongue directs the arm; there are circumstances in which the tongue may sustain the arm, but that is not its chief duty.

Woman's part, it is admitted, is to act as a moderating influence in joy or grief. We shall therefore not dwell upon that point, but confine ourselves to answering a question of some delicacy. Women have been reproached with misusing their powers, and with holding men too much under their thumb.

To loathe war, to advocate perpetual peace, conciliation, hatred of everything resembling an appeal to force, is admirable enough; but this advocacy itself has its limits. Is not war also a salutary thing? Does it not brace up nations sunk in the torpor of bourgeois materialism? War has a nobleness and beauty of its own. And indeed, are we to degrade men into carpet knights, jousting in cap and feather before a court deliciously feminine? Horses, standards, heraldic devices, the sheen of armour, the clash of weapons, the din of clarions and trumpets, of flutes and hunting-horns and all the instruments that stir the blood,inspiriting as all these are supposed to be, and well as they may symbolise courage, are they sufficient to preserve the masculine virtues? Love is often enervating. Where will the army be, ${ }^{2}$ what will become of the country, if women

1 "I fatti sono maschi, le parole femine."

2 Clément Marot writes :

Adieu le bal, adieu la dance !;

Adieu mesure, adieu carlence,

Tanbourins, aulboys, violons,

Puisqu'à la guerre nous allons ... 


\section{THE WOMEN OF THE RENAISSANCE}

carry us up with them into the clouds? Mantegna replies by showing us Samson and Delilah, Botticelli with his picture of the cupids stripping Mars of his armour as he lies sleeping by Venus' side. ${ }^{2}$

But we have already given the true answer.

Certainly woman's place is not in the camp. The virago has no vogue: men do not fight women nor take them prisoners. Women do in truth loathe war. But when the war is noble they become its advocates. War is a noble thing when it is waged in self-defence, when honour and life and liberty are at stake. Then, be sure, women are not lagging in the rear. Beatrice d'Este with a stout heart dragged Ludovico il Noro to the camp facing the French; and there, showing him an army quaking for all its cheers at that solemn hour the eve of battle, she set the feeble heart of her husband beating in time with her own. In November 1502 the ladies of Urbino besieged the ducal palace with offers of their jewels for the purpose of repelling Caesar Borgia. At Sienna, the women, led by ladies of the highest rank, set to work to carry baskets of earth upon their heads, and, what is still more extraordinary, they agreed to perform this service systematically under the orders of three lady captains recognisable by their satin petticoats. One young girl pushed her enthusiasm to such a length as to disguise herself in a soldier's uniform in order

Adieu les regards gracieux,

Messagers des cours soucieux;

Adieu les profondes pensées,

Satisfaictes ou offensées ;

Ariien les armonienx sons

De rondeaulx, dixains et chansons ...

Adieu la lettre, adieu le page!

(To the court ladies.)

[Farewell to dance, farewell to ball,

And cadenced measures, farewell all!

Fiddles, hautboys, tambourines,

For we go to warlike scenes.

Sweet looks from ladies' eyes, that tell

How much they love us, fare ye well!

Farewell to meditation deep,

That gives us joy or mars our sleep ;

Farewell to all harmonious strains

Of ballads, rondeaux, and dizains;

Letters and pages, all farewell !]

1 National Gallery.

${ }^{2}$ Ibid. 
to pass the night on the ramparts. Monluc ${ }^{1}$ himself, that hardened old warrior, waxed enthusiastic in praise of such notable courage, and promised eternal glory to these fair ladies. And was not Anne of France familiar with the camp? Have we not told the story of that Françoise d'Amboise who raised a troop to repel a band of brigands !

But to fire a woman's heart a just cause is needed, otherwise she execrates war. Clever people may talk as they please,-praise the Amazons of Georgia, the ancient Ligurian women who tilled their fields, or recall the visions of Plato in the fifth book of the Repreblic or the seventh of the Laws on the military and political aptitudes of women: these are paradoxes which influence no one. Maria Puteolana, who attained the rank of captain in the Italian army, was laughed at; and, to tell the truth, the military inspiration of certain heroines at critical moments was regarded as purely adventitious. It came to St. Catherine of Sienna "by the riches of grace"; to Joan of Arc "by divine grace, by mystery divine." So strong was the belief in Joan's saintship that it brought her to the stake. She resembled Deboral and Judith; her story was repeated in the most insignificant hamlets, and all France gave ceaseless thanks to God for so clearly manifesting Himself through the feeble arm of a woman, a shepherd-lass: "sicut populum tuum per manum feminae liberasti." But this was only an additional stanza in the love litany (long enough already) lisped by poets and the faithful to the Virgin of Virgins: a love-poem, but at the same time a malediction on war and the spirit of conquest.

When men spoke, even in favourable terms, of the women who had been thrown by the force of circumstances among tragic incidents like these, it was as though they were celebrating a sort of suicide. Castiglione has devoted verses charged with real emotion to the memory of a young girl who was mortally wounded at the storming of Pisa in 1499, at the moment when she was leading on the defenders. She was carried away dying, he says, and as she lay upon her mother's bosom, she exclaimed that her country owed her no other bridal! "Virago," he adds, wiping his eyes. The last word on these military women was said by a

${ }^{1}$ [The brilliant captain whose Memoirs or Commentaries, it is said, were afterwards called the Soldier's Bible by Henri IV.] 
woman, the charming Isabella Villamarina, who was resolved to don man's clothes and start for the army like the wife of Mithridates, with no thought of fighting, but to be with her husband, the prince of Salerno, whom she madly loved. But the prince insisting on her staying at home, it occurred to her to pass the whole of the day in bed, hoping to see her husband in her dreams!

It was not simply by dint of philosophical reasoning that women avoided active and masculine occupations. They were well aware that they had everything to lose if they lived the life of men. IIen rode rough-shod over them. Such women as an evil star did actually fling into the vortex-and these were rare-were invariably women of a robust and sensuous type.

Could a more striking example be cited than Catherine Sforza, a luckless princess perpetually condemned to stand on the defensive, and on this account fated to remain on the outskirts of the world in which she might have played so lofty a part? A notable woman, endowed with nature's most prodigal and magnificent gifts; tall, strong, goodlooking enough, with a clear, superb complexion; in speech warm, forceful, impulsive, her voice ringing out for the most part like a trumpet call, but capable also of enchanting caresses. There was nothing theatrical in her wonderful force of mind, which asserted itself in grand outbursts on all occasions, as when, for instance, she wrote to her sons from the depth of her dungeon in the castle of Sant' Angelo, bidding them not to be concerned for her. "I am habituated to grief," she said ; "I have no fear of it." Or on that other occasion, the day of the storming of her capital, when the boldest of the French, forcing their way into the innermost entrenchments, succeeded finally, after unheard-of exertions, in capturing her, like a lioness caught in a snare. Here we have the reverse of the medal: strip her of her armour and she is a woman, one of the feeblest of her sex. Catherine exhausted all her vigour in politics: she was swayed by her senses; almost unknown to herself she imparted to all about her the unquenchable thirst for sensual pleasure by which she was herself devoured. Her first three husbands died by the assassin's knife. The magnificent Ordelaffi, one of her foes, would never have wrested the county of Imola from her by mere force of arms; but to vanquish the woman 
herself by the magnetism of the senses was but the sport of an afternoon. And when Catherine, hopelessly entangled in these toils, heard the people discussing her, the lioness roared: sentences of imprisonment and the strappado were the outward and visible signs of her love. The scene changes; the amiable Ordelaffi gives place to a lover more worthy of her. Before the virile force of this man, threatening constantly to sell his soul to the devil, and (a more serious matter) the state to the Turks, Catherine is subjugated: she marries him. Feo becomes an odious tyrant: denunciations, persecutions, tortures are his wedding gifts. As was to be expected, Feo fell stabled to the heart under the very eyes of his sovereign, and then Terror spread her vampire wings, and the silent prisons swam with holocausts of blood.

Were we wrong in saying, at the outset, that under the exquisite charm of life's manifestations, the brute in man was struggling all the time! Possibly it was imagined that in muzzling the brute, women were obeying a natural instinct, and that there were certain sensualities and bestial horrors little to be feared in regard to women brought up in an atmosphere refined almost to rarefaction. According to Nifo and others, all that was wanted was to encourage recourse to the platonist theorics. And yet here we see, in appalling contradiction, this great figure of Catherine Sforza dominating her epoch, as though to show to what a pitch the intoxication of masculine women could rise. For at bottom she was a woman of an excellent heart-this Catherine who died under the name of Medici; a genuine sister of mercy, thoughtful, generous, diligent in feeding the poor in time of famine, and, when an epidemic was raging, marvellous as a sovereign and a sick-nurse! And how lovely she was 1 How well she knew, in the intervals of her frenzied existence, how to enjoy life, when she gave herself up to the beauty of her flowers, the charm of her garciens, the delight of seeing her splendid drove of cattle peacefully grazing in her parks! Dogs never had a more tender protectress. She evoked her people's enthusiasm and applause when, riding in a red skirt at the head of her huntsmen, like a legendary fairy, and reining up her horse with her delicate scented hand, she smiled upon them all, her beautiful white teeth flashing between her full ruby lips. 


\section{THE WOMEN OF THE RENAISSANCE}

What did she lack, then, to make her in very truth a woman? Only womanliness, and the exquisite power of using love as a quickening instead of a destroying spirit. With her, it was quite useless to assume airs of ethereality. The style she needed is that which we find in the letters of one of the men she loved, Gabriele Piccoli. This Piccoli served her as ambassador, and one day Catherine scolded him for making too free a use of poetry in his despatches. Upon that, he lost his head; he felt that his heart was all aflame, "boiling over" he says; he was beside himself with exultation, speaking of his Divinity, his Hope, anxious to take flight and abandon everything in order to live "under the shadow and in the confidence of his princess"; then, with a sudden transition, he reports in the most precise terms various diplomatic schemes, not a little complicated. In reality, the letter is that of a man speaking to a woman of forty, and seeing her as she was, good-hearted and tender, yet vigorous and virile. Why did he love her? Because, all said and done, she intoxicated men. In the evening she would dance like a mad thing,, and next morning go on a pilgrimage: a strange wild creature. She ended by marrying a Medici, a man of delicate, idealistic, almost effeminate temperament. There is nothing so strange as the colloquy which took place between her and Savonarola. She had written to the monk to request his prayers, and he replied in a charming letter, of mingled serenity and strength, in which he takes high ground in rebuking her life. This letter is dated June 18, 1497, the very day on which all the churches in Florence were thundering with the papal proscription launched against him. Ah! how tragic, how impressive an encounter was this, between two souls equally belated, though in a different sense : the pure monk face to face with death: the woman, born too soon or too Iate, the prey of destiny! The French formed an excellent judgment of this woman of bronze and thunder, who had ceased to be a woman: they called one of their most formidable pieces of artillery "Madame de Forli."

There was one woman, perhaps, who diffused through the camps a real chivalrous enthusiasm: but this was in Spain, and faith and fatherland were concerned. Isabella the

1 "Catherine, if you make the dance go thus, Atlas will find the world a lighter burden," exclaims a yoet. 
Catholic ordered that she should be buried on the battlefield of Grenada, wrapped in the broad folds of her royal mantle, as though to preach lessons of valour even after her death. To this day her great soul appears to hold sway in Spain.

She was a wonderful mixture of different kinds of heroism. She was brave and resolute without a touch of the virago. After a night spent in dictating orders, she would tranquilly resume a piece of church embroidery, or, like Anne of France, the practical education of her daughters. In her own private affairs she was plain and simple, in public she was all ostentation. She was a conversationalist of the first order, and loved to attack high philosophical questions, here and there dropping into a discussion some original phrase, some bold and clear-cut thought, while her deep blue eyes lit up and darted upon her company a certain glance of warmth and loyalty the renown of which still clings to her name. A strange woman! ardent like Anne of France, guileless, straightforward, somewhat starched perhaps, but all heart for her friends, so fond a mother that she died of the loss of her children, so thorough a woman that she declared she knew only four fine sights in the world: "a soldier in the field, a priest at the altar, a beautiful woman in bed, a thief on the gibbet."

No king could ever have exercised the same ascendancy. Spain is too proud a country! A Spaniard to whom you speak of an army will tell you with perfect coolness that it consisted of 3000 Italians, 3000 Germans, and 6000 soldiers, that is to say, 6000 Spaniards. Isabella and Anne of France were of a style which could only succeed in Spain or France. Castiglione himself shrinks in awe before such figures, declaring that he knows nothing like them in Italy.

Michelangelo showed himself to be less pessimistic, and has constantly endowed his women with ideal traits of greatness of soul. His Virgin of the Casa Buonarotti, with the profile of a Roman matron, holds herself erect and looks straight before her with the forceful eye of a woman who would dare anything in defence of her treasure, this feeble little man to be, gathered so cluse to her breast that but little of his back is visible: in very truth, fructus ventris tui.

Every lady must have seen the exquisite Pietà in St. Peter's at Rome. ${ }^{1}$ It is the finest inonument ever erected

${ }^{1}$ Francis I. regarded this as Michelangelo's masterpiece. 


\section{THE WOMEN OF THE RENAISSANCE}

to the honour of the sex. Overwhelmed by the tragedy of Savonarola, Michelangelo has given utterance in that picture to the ery of his soul: he makes his appeal to women in the name of Christ.

On her knees, with simplicity, without sensible effort, the Mother bears her dead Son-a cruel burden! Her wideflowing drapery, her beautiful form, the purity of the lines of her face, all reveal so great a force of soul that the fact of her appearing as youthful as her son causes no surprise. But the Christ is not, for His part, pressing heavily upon her. Though $\mathrm{He}$ is dead, one feels that $\mathrm{He}$ still lives, from the love which speaks forth from His wan, worn features: by the power of love He has vanquished divine Death, a death He sought, and almost loved. And the pure, grave mother, filled with a profound compassion, seems yearning to bring Him forth a second time, into a complete imperishable life: hers is an impersonal type, not representing this or that woman, this or that mother:

Le corps, enfin vaincu, recule devant l'âme,

Et la terre, ayant vu cette Vierge et ce Dieu,

Va comprendre l'Amour et respecter la Femme. ${ }^{1}$

Michelangelo exalts the eternal woman, sustaining the Man of Sorrows by the strength of love. He has left us as his final bequest, as it were, the symbol of all the strenuous women of the fifteenth century, who had just run so glorious a race in Italy, and who saw from serene heights the suffering they themselves never felt-the ancestors of Vittoria Colonna and Margaret of France, And yet he had no wish to exaggerate. When he came to paint the Last Judgment, he no longer set woman in the foreground, like the naïve old masters; he placed her respectfully in the rear, giving her an attitude of humility, suppliance, and compassion, because, even for him, woman was before all things the incarnation of sweetness and kindliness, and because, in those dread hours when it is for power and justice to pronounce the final doom, every woman must needs stand in the shade.

1 Emile Trolliet, La Vie silencieuse.

The veil of flesh is rent; the spirit's light

Pierces and routs the clinging mist of sense ;

And Earth, this Virgin and this God beholding,

Learns what Love is, and worships Womankind. 


\section{CHAPTER II}

\section{MORAL INFLUENCE}

THE moral purification of society is assuredly one of the conditions of happiness; hence it was one of the chief ends of platonism. The 16th century, unfortunately, was one of the most corrupt periods known to our history, an undisputed fact from which some people have concluded that art was the cause of moral decadence, because art in itself is unmoral, and never acts otherwise than as "a stimulus to debauchery." These good paradoxical souls had ancestors as long ago as the 15th and 16th centuriesancestors who held the same theory and saw in aestheticism a fatal blight to humanity. They refused to acknowledge the idea of the beautiful: and the belief that a careful observation discovers some trace of beauty everywherethat even in the mind of a criminal there are sometimes uncommon, indeed splendid faculties, unhappily turned to evil-seemed to them, as it seems to their successors to-day, a miserable error calculated to lead mankind to perditiou. Platonist women and the Roman world saw in it, on the contrary, a pledge of regeneration and civilisation.

We have already said that the world needed no further urging on the downward path; love was only understood apart from marriage, and all that remained to settle was whether this love should remain material or might possibly become spiritual.

All the contemporaries of platonism who regretted the "good old times" (and in France they were many)-Narot, Rabelais, Collerye nicknamed Roger Bontemps, Coquillart the sworn foe of the fashionable world, "bucks" as he called them-all these clearly explain their position; they 
lamented the disappearance of love " $a$ la française," a whole-hearted love without qualifications and periphrases; a love that was very pleasant if not very moral. And as to the folk who believed that virtue was corrupted by the salons, they had only to stroll through the fairs, look in at the rustic festivities and balls, and chat with one or two tavern wenches or a village "old wife," or even to penetrate into some of the country houses. In Germany, where morals retained their antique savour, it cannot be pleaded that Dr. Faustus, with the little crippled love who waits on him, or the coarse bourgeois Venuses of Wohlgemuith or Albert Dürer, existed only in imagination!

The first contact with Italy, so far from purifying these manners, only brought about the exaltation of sensualism; one of the most popular of French writers, Octovien de Saint-Gelais, had no scruple in raising a statue to "Sensuality." 'The French saw in Italy only the pagan side of the Renaissance, that of the Malatestas ${ }^{1}$ and others, and, as often enough happens when - the field of contemplation is so narrow, they perceived nothing but the more striking and startling phenomena-the flash of daggers, the poison bowl; so much that an excellent young man, Louis de Beauvau, who had wedded a young person of humble rank against the wishes of his family, and repented of it, profited by the expedition of Charles VIII. to get together a fine collection of poisons as he went from town to town. Certain Italians who had come to France were regarded as so many jinnish heralds of moral anarchy. "The only way to escape women is not to see them at all," exclaims one of them, Andrelini. In truth, it was not long before Italian society presented a lamentable spectacle of decomposition; observers felt painful heart-burnings and overwhelming disgust. "This is too much," cries Palingenius, dubbed the Star of the Renaissance: "let me flee away to some peaceful, solitary shore."

From the year 1515 onwards the court of France advanced boldly along the same path, dragging the country, with it. "Paris is a fair city to live in, but not to die in." What a pass things had come to! When five years had

1 [The sovereign family of Rimini and Romagna, a race of warriors and cut-throats. Robert, commandant of the troops of Sixtus IV., was poisoned by Riario in 1483.] 
elapsed, Lemaire, who had been one of the prophets of the new order, paints the situation in terrible colours, demanding as remedy a convocation of the Courts of Love. Charming tribunals, indeed: but what good would they serve? In the forefront of this corrupt and putrid society the official poet shows us his young king, with his coarse sensual lips wrinkled in a hideous smile, "consumed by women" body and soul.

Free love flourished. The saying, "In case of love, one dame doth not suffice," 1 answered to the accepted axiom on the fickleness of women. The noblest of ladies declared themselves "lieutenants of Venus." It was love in its basest form, a matter of trade and barter, cold as ice; nothing was wanting to its degradation-diplomatic husbands, women who were "merchandise for kings," but a merchandise which proffered itself! It is alleged that Louis XII. in his decrepitude knew not in Italy how to defend the virtue of which he was so tenacious. The excellent Margaret of France was amazed when a young girl of good family did not rush to sacrifice herself to a caprice of her brother. ${ }^{2}$ Young or old, it made no difference. Women were known to get up bogus law-suits for the pleasure of corrupting the judges. Others, with greater attractions, flocked to the favourite or the minister of the day; others, more numerous, threw themselves at the moneyed men, as rivers rush to the sea. No one would guess what shameful shifts masked some lives that seemed a brilliant round of music and receptions and play; or what a singular population of waiting-maids, pimps, and procuresses of all ranks, forced their unwelcome services upon a respectable man-

Piteulx comme ung beau crucifix $!^{3}$

Vice was everywhere the same, except for some trifling shades. If an Italian and a Frenchman told the same story

${ }^{1}$ En cas d'amour, c'est trop peu d'une dame,

Car si un homme aime une honneste femme,

Et s'il ne peut à son aise l'avoir,

Il fait très bien d'autre accointance avoir.

(Melin de Saint-Gelais).

[In case of love, one dame doth not suffice,

For if a man loveth one fair of fame,

And cannot have her at an easy price,

'Tis well for him to have another flame.]

${ }^{2}$ Heptameron, Tale 42.

${ }^{3}$ Coquillart. 


\section{THE WOMEN OF THE RENAISSANCE}

of an honest woman seduced by means of gold, they practically differed in nothing but the tariff; the Italian lady exacts a thousand crowns and disappoints the purchaser, the Frenchwoman asks only a hundred and faithfully keeps her word. When the matter comes to light, the Italian husband is very deferential to the seducer, but poisons the lady; the French husband contents himself with sending her home to her parents for a time.

We must not be understood to believe that honest women no longer existed: on the contrary, there were still many. The only difficulty was to find them, because they kept out of sight, or, at any rate, were too apt to regard the exercising of an influence as beneath them.

Good women are often passive, incredulous, or at least resigned in regard to evil. Many of them, brought up on the ancient principle of subjection and abnegation, would ask nothing better than to shut eyes and ears with the quasi-felicity of mummies petrified in an eternal sleep, and to decline to believe in evil. There. the evil is, under their own roof, touching them closely, wounding them: yet still they smile and smile, wishing to appear crowned with roses, and doing their best to fancy they are happy. ${ }^{1}$ What delightful reasoning, and how precious to feeble and timid women who would fain eschew strife, and love always!

Vittoria Colonna, for instance, feigned sleep one night while her husband, by her side, indulged in wild anties that pained her deeply. Nifo relates, with the perfect serenity of an egoist, an incident that happened to himself. He had shut himself up in his study to write a Thesserologia astronomica. After some days his wife grew anxious, and employed all kinds of stratagems to induce him to relax the rigour of his seclusion. Not succeeding, poor woman! she went in search of a young lady in the neighbourhood, of whom she knew her husband was enamoured, and whom, after she had given her a piece of her mind, she brought back with her. She shut the two up together, with the simple happiness of a faithful dog, flattering herself on having discovered the solution of the puzzle. But no, Nifo remained glued to his Thesserologia. Then the good woman lost her head, vowed herself to saints innumerable, made pilgrimage after pilgrimage, and gave many a votive offering.

${ }^{1}$ Heptameron, Tale 8. 
Three months afterward, Nifo, when he had written his last line, issued tranquilly from his tomb, and condescended (so he assures us) to raise his wife from her depression.

Devotion of this kind was apparently not rare among the women of old. There was indeed a classical little story which passed from hand to hand about a lladame de Varambon. Monsieur de Varambon (so the story ran: we must do him at least this justice) was a thrifty fellow, and his wife was grieved to know that his mistress's apartments were rather poorly furnished. She ended by going herself to look after the furnishing, in profound secrecy. This story excited the hilarity of men every time it was told; some of them regarded Madame de Varambon as an old humbug; others, as a poor godly old soul $;^{1}$ and that was the sole leward of her virtue!

A part from this bent of women themselves for submission and seclusion, we must note also that Frenchmen formed thernselves into a sort of leagne, by no means chivalrous, against women who got "talked about." If a woman was talked about, it seemed a necessary deduction that there was something bad to say about her, and the mere fact of a lady acquiring any sort of public reputation, though entirely to her honcur, apparently gave everyone the right to fling mud at her. This was one of the most formidable obstacles to the moral influence of women. It seemed to many people, in short, that there was no choice between virtue starched, prosaic and wearisome, or no virtue at all: that it consisted for women in the simple devotion to an ideal of family duty -in which, however, they did not always find happiness, and which religion did not always suceeed in beautifying, for the family affections are terrestrial, and doubtless will not survive the earth. Husbands maintained this position, finding it convenient. Vice and virtue in all their coarseness (there is a coarseness of virtue) were each shut up, so to speak, in a water-tight compartment: "to each his calling"; no compromise, no nuance, no degree was acknowledged; virtue is always represented by Titian and others with harsh malevolence as uncouth and ill to look upon, while opposite her they represent the true woman as an embodied caress.

Untrue and untenable as this distinction was, no one ${ }^{1}$ Heptameron, Tale 38. 
cared to seek a way out of the dilemma, not even the moralists. Lotto as well as Titian represents the virtuous woman as a goose-girl, in conflict with Venus! And indeed the singular comparison in course of time penetrated to the core of platonist society, though it was softened down like a much attenuated echo. Raphael, then a charming boy of twenty, fresh moulded by the tender hands of two princesses, was conscious of the same thing in his Vision of a Knight in the National Gallery.

To him also the grave woman holding a sword and a book seems a timid creature; he leaves her in the background as though unwilling to show herself, and limns behind her only a rocky steep and a church spire soaring into the sky. The other lady, on the contrary, graceful in form and feature, stands out distinctly before lovely meadows sloping down to a swift-flowing stream. What does she hold? A flower, no more. This is love indeed, but eminently tender, eminently reasonable, almost ineffectual. Raphael was so young!

Why then, even in the eyes of this delicate-minded stripling, does virtue keep this character of ungainliness and frigidity? Were there in his day none of those women of sound mind and steadfast soul who, while knowing how to leave men undisturbed in their pride, how (so to speak) to respect them, knew also how to stimulate them to set happiness above the woes of life? It is not even the lash of passion we are speaking about; great love has some trenchant quality that cleaves a way through materialities; it is purification par excellence; it would remove mountains and still the waves. Happy the woman who has once encountered it, thrice happy she who has been able to recognise it and seize it ere it passed! For it has but one defect, its exceeding rarity; and if the moral regeneration of society were absolutely dependent on it, a woman would do better to fling up the struggle, encase herself in triple brass, mystically shut her eyes to evil, await a miracle, and hope for nothing on this earth but the repentant tears of her husband!

We are speaking merely of women of vigour, made to support and guide men-the women whom men style "dragons." They are a species which achieves little success in the world; men regard them as somewhat too 
masculine, and are constantly making fun of them, especially when there are good reasons for so doing. At Naples, for instance, one of these dragons-Doña Maria d'Aragona, a respectable mother of seven-created no little amusement because (so the story ran), in her desire for a large experience, she had wished to live with her husband three years as a wife, three as a sweetheart, and three as an enemy. Men do not understand such women; it is a sense they are deticient in. These women were out of date,-women of the 15th century, of the time before Savonarola. They remind one of those old, high, rugged ramparts which perforce srumble away, and to which we prefer a spickand-span, vulgar boulevard, blocked up with gingerbread stalls.

And yet the moral influence of women, from a social and general standpoint, did make itself felt, especially in Italy. "You must not judge men from the crust," as Anne of France very well said. The opposing parties were so little divided from each other that it is not easy to distinguish them; there were materialists who did not scorn the ideal, and idealists by no means unsympathetic to the material, and it was that which gave an opening to the moral preacher.

For instance, Nifo, whom we have mentioned as a personal foe to Plato, had kegun by fighting against Thomas of Aquinas in the materialist camp; but on being shown his folly by the Bishop of Padua, a prelate of parts, he changed sides with a great flourish of trumpets, fell lustily upon his master Pomponazzi, and became a Roman count with the name and the arms of the Medici: to his own satisfaction and delight, for logical minds love success. And by and by we discover him, folios in hand, falling at the feet of female beauty with surprising agility,--quite eclipsing Victor Cousin, whose passions were of the mere milk-and-water order and very much behind the times. Renan, who has left us an excellent appreciation of Nifo, reproaches him with the somewhat wobbly character of his doctrine; but this is the very thing that interests us. If men were not inconstant, platonism would have no further utility. Nifo, in short, was a converted character. If men are bent on fighting, we must not complain that a woman's hand can sometimes draw them into the crack regiments. 


\section{THE WOMEN OF THE RENAISSANCE}

This means, someone will say, that the conscience and the lofty deductions of a serious or even a distinguished man depend on the rustle of a petticoat or the colour of certain eyes? Even so; if the woman stands for more than a petticoat and two bright eyes, if she really has a heart, ardeut and vigorous affectious in which the man's spirit finds refreshment, what could be more natural or moral?

Look at Nifo again. Ugly, hideous, untractable as he was, he completely changed his tune under the influence of a few artificial (perhaps too artificial, indeed!) courtesies; if he retained some of the claws of the primitive man, some thorns of the wild stock which it was so difficult to graft, what does that prove but that under a woman's fingers the roughest bushes burst into brilliant flower? Nifo even came to wear almost the same moral livery as Bembo. $\mathrm{He}$ speaks of Plato only with respect, and of materialism only with disdain as a not very formidable doctrine from which good taste and spiritual refinement cannot but preserve women; he pretends to go as far as the "imaginatives" in the direction of sociological love; he adopts in principle Plato's theory of love as an intermediary between the Creator and the creature; "beauty-aye, I gladly confess it-is that which produces love." His only weakness (a very natural one) is that he cannot arrive at the Absolute, as Socrates understood it, without traversing this earth; that he prefers to vague, immaterial, supersensual dallying with love the personal encounter of two living beings. On this head the meanest logicians do not allow themselves to be silenced. They unreservedly, enthusiastically recognise the religion of beauty and love, and its admirable effects on society and the world; but at the same time they are not quite at one about definitions. They pause in a sort of numb fascination before a pretty little piece of piety who suddenly pretends she forgets her body and is only a soul; they are like Dante in Purgatory, when he opened his arms and clasped nothing but air 'They do not prostrate soul and body in adoration before a shadow, a reflection, a transient gleain of beauty; it seems good to them to love a particular woman in virtue of a special affinity, or a need of settling down; and in these circumstances they would in good sooth think it great folly to torture themselves under the fallacious 
plea that sweet love if gratified is slain. Love, they say, is one and indivisible, not too base nor too divine "You may cite me your heroes, your saints, your angels: you inay explore the whole realm of antiquity to unearth types like Socrates and Anaxarchos (or, if you please, Xenocrates, who spent a whole night in tranquil admiration of Pbryne): everything is possible. I myself furnish a magniticent example in loving Fulvia without any base desire. But these are masterly achievements of saints or philosophers, and St. Jerome shows a keen insight into humanity when he ordains that men shall either regard all the Lord's virgins with a generic affection, or shall not love any of them. Horace maintained that with greybeards the flesh is dead; St. Jerome replies: "You say that the flesh is dead, and I tell you that the devil is eternal.' Love must be distinguished from friendship."1

In France it was another story. Men were much more self-assertive. We do not find them appealing to these circumlocutions or these tender ironies. The annihilation of matter would have struck them as almost an outrage. Among them things took an entirely different complexion from that which we have indicated in the feminist society of Italy. Being the masters, they regarded love as indispensable, and beauty as always good: "If we thought ladies were without love, we should long for death"; only, adds Erasmus, "they grant women nothing but from love of sensual pleasure"; and the more highly placed they happened to be, the more natural it seemed to them to degrade love. "To gratify a prince"--we know what that means; there is no question here of an elevated love like the love which fills princesses' dreams.

The moral conflict on this point was in France acute. When Margaret essayed to purify the society of her court by a leaven of beauty, her entourage checked her, refusing to allow any effort towards embellishing human life with the ideal. These men held too closely to the old logical and realist spirit. They loved Plato, but truth still more. They did not realise that their brutal realism had the effect of throwing women off at a tangent, for a religion of some sort is always nccessary; to save themselves from men, women of high birth and noble bearing, carried away by

${ }^{1}$ Nifo, De Amore, cap. xvi. : De viro aulico, Bk. I., caps. xxx.-xxxiv. 


\section{THE WOMEN OF THE RENAISSANCE}

an enthusiasm in some sort heroic, attained to a mystic conception of a life of pure sensibility.

But then what is the beginning and what the end of the dream? Without touching on the cruel questionings of philosophy about the reality of our physical perceptions, or on many of the ambiguous phenomena, where does the vision begin in the moral life, if life involves so many fancies, illusions, loves, gleams, which act upon us but have no real existence?-so many vague aspirations, admirable but unsubstantial? To fall headlong from a height into an abyss is a violent experience which kills too quickly; the mystic vision is only possible on condition of coddling the soul within the four walls of a convent; out in the world it falls and is lost: that was the opinion of the logicians. When Margaret relates with what energy of virtue she escaped the realistic assaults of Bonnivet, and how, at the cost of a few scratches, she has reduced him to the cold comfort of the Ideal, her husband is the first to laugh, saying: "If I had got so far, I should think myself disgraced to fail of attaining my goal." 1

It is a cynical saying, and raises a general protest; but Henri d'Albret explains it very placidly, and we cannot give the gist of his retort better than in the following sentence of M. Bourget: "You have the morality of life, without having the morality of the heart." Henri rejoices to see his wife keep up appearances, but, from the moral standpoint, he finds no great difference between her and himself, except in practical conduct: "She and I are both children of Adam and Eve." $\mathrm{He}$ laughs and sneers at the nebulous philosophical aspirations of the princess, and is not the only man who has got this strange impression that the sins of the spirit and the sins of the flesh are equipollent. "A fortress which parleys is half won," says with feigned good-humour one of the speakers in the Heptameron, appearing to forget that Margaret as an inveterate gossip had readily accepted the sobriquet of Parlamente. ${ }^{2}$

Not merely did the adversaries of platonism accuse it of being only moral in appearance, but this very semblance of morality, resting on a misapprehension, seemed to them an hypocrisy that aggravated the fault. They regarded platonism as evil and wanting in seriousness; Louise of Savoy,

${ }^{1}$ Heptameron, Tale 4.

${ }^{2}$ Heptameron, Tales 18 and 25. 
an inveterate kill-joy, at once sour and sympathetic in regard to pleasures she is past enjoying, inveighs bitterly against love that is only skin-deep-the vanities and tricks, the husk and chaff of love that is simply a comedy in which two actors show their skill; she prefers a fault without scandal to a scandal without fault. However, the issue seems to her perfectly clear: "Either you love, or you do not. If you love, why impose on yourself the torment of Tantalus? If you do not, why impose it on others?" She would rather succeed in a piece of folly than fail in a virtuous action, however logical and practical.

She has a way all her own of squelching the fanc:es of her daughter; she allows them to swell and swell, and then gives the merest little pin-prick. Someone speaks, for instance, of a queen clever enough to impose seven years' preliminary probation on her lover: "Then she didn't wish to love or be loved!" 1 If someone feelingly exclaims: "When love is strong, the lover knows no meat and drink but the look and voice of the loved one," she retorts that she would much like to see how he looked on such fare $!^{2}$ At the conclusion of a droll story, a maid of honour who is a little over-excited declares that she would rather be flung into the river than live in intimacy with a Franciscan; and Louise replies with her placid smile: "Then you can swim well?" The other retorts in great irritation: "I know some who have resisted more prepossessing men than a Franciscan, without blowing their own trumpets about it." Louise, laughing more than ever, replies, "Still less do they beat the drums about what they have done and granted." 3 She is a sceptic and a logician; with all her boldness of speech, she is never over-paradoxical. Moreover, she applied her principles to herself, and had such a way of encouraging her daughter's lovers that they quite naturally paid their addresses to her. At the opening of the Heptameron, for instance, one of Margaret's numerous admirers, furious to see his princess receive a passionate declaration with laughter, hies him to the mother.

Almost everybody in Frauce shared the views of Henri d'Albret and Louise of Savoy. Platonism sprang up among thorns. And so far from there being any bias in its favour, there awoke a reaction against the finuikin
${ }^{1}$ Heptameron, Tale 24.
${ }^{2}$ Ilid., Tale 50.
${ }^{3}$ Ibid., Tale 5. 
absurdities of bygone days,-for instance, against the "bashful knights" who sported furs in summer, and summer cloaks in winter, in order to give ocular demonstration that "love was all-sufficient." That sort of mysticism struck men as sickly. They preferred frankness and vivacity, - the frothy sparkle of champagne to the sugared liqueur, golden, soft, limpid, heavy, old in bottle, which bore the Italian label. Rabelais, who is our Michelangelo, takes great care not to dive into the mysteries in Ficino's way, or to pile up a heap of folios after the example of Nifo. Look at him, with his learning and his consummate intellect, sitting before a dish of peas fried in fat, seized with inextinguishable laughter as he thinks of the "celestial and priceless drug" of Plato's Symposium, and deriding all the Picos della Mirandola past and future in the person of Messire Pantagruel, who maintains against all opponents 9764 conclusions, some of them highly platonic, on "the philosophical cream of encyclopaedic questions," on "the platonic idea, hovering dexterously under the orifice of cha03." Rabelais dedicates his Life of Gargantua to topers and the gouty.

And then you hear the loud chant, the babel noise, of gold, of Plutus, rising above and drowning all other sounds. Artists no longer cling to the old shabby studio in which they strove after the ideal: they have now come to dwell in palaces, and some there are whose art consists in coining false money or running after the philosopher's stone-if not iu worse occupations. Even where men are wistful and dream, in the heart of melancholy Brittany, the poor human soul, compared by a preacher to a runner started upon the long race for eternal life, halts and stoops at every moment like Atalanta, to pick up apples of gold. ${ }^{1}$

Thus the battle was joined on all sides at once, and the struggle was fierce. Among so many ingratitudes, so many keen-pointed shafts, women needed a proud courage to continue imperturbably spreading through the world the spirit of love, the religion of beauty.

They did not succeed in subduing mankind at large, nor in directing their moral energies. That dream had to be

${ }^{1}$ Calvin regards his co-workers as " playactors," worthy of bespattering with mud. "The future appals me," he cries: "I dare not think of it: unless the Lord descends fror. heaven, barbarism will engulf us." (Preface to the Geneva Catechism.) 
relinquished. They rosigned themselves to the thankless task of individually doing what little they could do through their sympathy and tenderness. This was all they could give, and it cost them dèar, for it too often involved concessions, many bitter and secret tears, a love mingled with disgnst, an unavoidable duplicity!

They had perforce to content themselves, then, with this measure of suceess. To show clearly in what this success consisted, we shall divide our brief account into two parts; for their sensibility was exerted in two directions. Under their influence virtue and vice became each an art: their defects and excesses were moderated. On the one hand the orer harsh virtues were softened, or, if we may coin a word, de-austerified, and endowed with a cheerfulness of aspect they had formerly lacked; on the other, vice was ennobled, and the gap between vice and virtue thereby diminished. In brief, women tried to make life beautiful rather than good, and piously to rehabilitate everything which had possibilities of beauty, in virtue of the principle that the Beautiful is good and purifies all things.

\section{THE SOFTENING OF VIRTUE.}

The principles already established are, briefly, as follows: happiness resides in love, love consists in self-surrender. Of this there are several modes : one may surrender body and soul, or soul alone-or nothing at all! To give the soul is the true platonism; to give nothing is the false. The surrender of the body is the time-honoured sacrament of marriage.

How did they set about reconciling these various elements? In a manner that was simplicity itself.

We have said that marriage had become a human and reciprocal contract, coneluded with a definite object between two fellow-creatures; and logically there was no reason why it should not have ended as it began, by mutual consent, that is, in the community of women ${ }^{1}$ according to Plato's idea.

But on the contrary the platonists, who looked for no poetry in the prose of wedlock, regarded one marriage as

1Aretino wrote placidly: "I have legitimated my dear girls in my heart; no other ceremony is needed." 


\section{$33 S$ THE WOMEN OF THE RENAISSANCE}

quite sufficient, if not excessive. Further, the institution was an ancient one; it was a matter of use and wont. To maintain the organisation of society and the foundations of aristocracy, it was necessary to retain the formula and merely to draw from it the moral consequences implied in the principle of equality of rights.

Up to that time the morality of marriage had been regulated by the authority or even the caprice of the husband. A bastard (provided he was begotten by the husband) had almost the status of a legitimate child; in many cases he was bred at the paternal hearth, away from his mother, under the charge of his father's wife; and in Italy he very easily secured legitimation, ${ }^{1}$ and, if other heirs failed, carried on the family. What was much worse than deceiving his wife, the husband believed he had the right to neglect her. From that time forward retaliation appeared to be the guiding principle; instead of remaining headnurses, of adopting children from heaven knows where, of toiling to efface all signs of the caprices of their lords and masters, women "unhappily married" no longer saw the necessity of fettering themselves, of refusing their share of happiness, of carefully guarding what was despised.

Luther gave material fixity to this principle by permitting divorce; he maintained marriage, but at the same time allowed re-marriage; in other words, he retrograded as far as possible towards the manners of the past. In case of default, even involuntary, on the part of one of the contracting parties, he thought it quite right to replace "Vashti by Esther." We know what fortune attended these ideas. Melander, 2 when blessing a "duplicate" marriage of the Landgrave of Hesse, proceeded to say that everything in this world wears ont, and that monogamy had had its day. A book of extremely liberal views attributed to Bugenhagen ${ }^{3}$ adduced examples of bigamy

${ }^{1}$ Natural children easily obtained recognition by the concession of the right to bear arms, or their legitimation. In Italy, legitimation was only a fiscal formality; Innocent VIII. gave his nephew the right of granting it.

2 [The Grecised name of Otto Schwartzmann, German jurisconsult (1571$1070)$.

[3'The "Pomeranian doctor" (1485-1558). He married Luther, and buried him, and was one of his coadjutors in the translation of the Bible.] 
among the early Christians. Polygamy met with some support; near the end of his life, Ochinol became its advocate.

The platonists, however, allowed no retouching. The ancient doctrine that the body, with all its weaknesses and infirmities, received with marriage an indelible brand, as in former days convicts were marked, after all seemed to them to be salutary, since the end of marriage was obedience to the physical law "increase and multiply." But, the law once fulfilled, by what strange aberration did they wish to bind souls to this abandoned body, truly a derelict of life? iso far as heart and soul were concerned, the community of women (or rather, the community of men) seemed a moral reality, constituting indeed the clearest distinction that could be drawn between mankind and the animals. This "spiritual libertinage" was condemned. Calvin flouted it and preferred divorce-a singular taste, not very refined, eminentiy worthy of countries where fleshly love was cultivated, with rope-ladders and without platonism. ${ }^{2}$ Wedlock has its good points, but, as everyone knows, it is never supremely delightful; love ought to be a delight and a religion. The wife, stepping forth in her turn into life, has a right to think a little about herself and her highest needs, to cuitivate her heurt and soul, to blossom out and comp'ete herself. "Complete herself!" some one will say: "then 'tis a question of a subsidiary marriage?" Yes, but of a marriage wholly moral, in which the carnal concessions are pureiy aesthetic and ostensible, - in which she boasts (so far as essential points are concerned) of a platonism as perfect in regaid to her lover as in regard to her husband.

In the year of grace 1523, a young lady of the Roman aristocracy, whom history names Costanza Amaretta, pretty, retined, and pious, made a journey of devotion to Florence for the Easter festivals, and there met her ideal in the shape

'[Bernardino Ochino of Sienna (1457-1565). He was a monk, and for three years general of the Capuchins, but turned Protestant and got into hot water with the Charch. He spent a few years in England at the invitation of Cranmer A man of rare independence of mind, his opinions soon velged towards heresy, and his Dialogi, in which he opposed the doctrines of sle Iucarnation, the divinity of Christ, and others, and spoke in farou: of polygamy, brought on him the displcasure and even persecution of his co-religionists.]

2 "Difficiles aditu fugias in amore puellas." (Celtis, Quattuor libri.) 
of a cultivated and distinguished man named Celso. They lived together under the same roof in perfect chastity. When Easter was past, they set out with four kindred spirits for a couritry house of Celso's, and there, in the joyous spring weather, among the cypresses and tufted pines and early flowers, this idyllic society of platonists gave themselves up to the delights of poetising and philosophising at large. Costanza, elected queen of the coterie, unbosomed herself to them. She had been married when very young, as the custom was, to a man of business with little of the ethereal in his composition-a man of eminently practical mind, and manners almost intolerable. With him she had contracted no real moral ties. "But for this man's desire of having children by me-for he thought me beautiful-we should have felt nothing but hatred for each other." In Celso's company, however, the path of virtue seems to Costanza covered with roses instead of thorns, and hence today her eyes are opened to the truth, she perceives with perfect clearness the moral utility of the platonist distinction between the two kinds of love, the one bestial, matrimonial, fraught with peril, a thing of this world, perishable, - the other celestial, life-giving, a foretaste of Paradise, a love that enraptures the soul and fills it in truth with a radiance divine.

Perfect lovers thus found perfect pleasure in making an offering, but not a sacrifice, of their flesh-in deliberately lifting themselves above gross physical rules and living delicately as angels incarnate. Castiglione with extravagant eulogy reminds us of the wonderful feat accomplished by two of these dilettanti of love, who spent six months in conjugal intimacy and perfect continence; that was what he calls love, the ideal existence, pure beauty! There was even, at Milan, a religious order devoted to the mutual edification of the sexes on these lines, but after a time the archbishop decreed its dissolution. ${ }^{1}$

Truth to tell, we do not know exactly how far this species of platonism extended; it is a land dificult to map out; in such matters no statistics are available, and even in these days when we can reel off the number of bushels of wheat or dozens of eggrs France can produce in any month, there is no official return on the virtue of women. 
But we are not indisposed to believe that the platonic life à deux numbered more adepts than might be imagined. So many women of loveless heart aspired to the happincss of finding for it some safe repository, and regarded the body as so much dross, intinitely inferior. The example of Judith struck them as not only above criticism, but sublime. If one had groaned under the burden of the first marriage, surely it was all the more needful to set the second upon a pedestal, and so to preserve above everything the illusions, the dreams, the anticipations, however vague, which bring us out of moral and physical distress into light and life! The young platonist lady, all soul, who lived in the arms of her lover and relinguished nothing but her soul, fancied that she was realising a holy and religious dream; love, which purifies all things, wafted her in peace and confidence towards the celestial spheres; for faith, hope, love-what are they but the sheet anchors of the soul? That was her whole position. If by this means she conld enter into fulness of life, was she so very foolish in availing herself of it?

Unhappily, love sought as a rule only its own abasement, and the mission of these fair apostles declared itself rather in aggressive sallies than in spiritual edification. Platonism had to come down a peg, and to meet the demands of men it had to turn distrustful, descend to trivialities and deceit,-to place reliance on artifice. Thus was born a new species of platonism - more popular, and more open to critieism in point of morality.

This secondary art of platonism was hardly known beyond the borders of Italy; it demanced a patience and a consummate suppleness which we do not possess The impatience of Frenchmen in matters of love was proverbial; they would rather seize than woo; they would boil and chafe, utteriy unable to appreciate the wily tactics of Ovid or Martial, very oftei expecting to begin at the end without any preliminary finessing, and making flirtation altogether impossibie. And Frenchwomen, too,-must we confess it? -were but poor hands at the game. Some of them caught fire instead of winning love without loving, and there were young girls like Mademoiselle de Piennes who wrung their hands before the whole Court in despair at a lover's desertion. The French were so constituted; they anplied principles they did not possess, while the Iialians 
excelled in holding principles without applying them. And thus, whatever else they did, the former were not very successful in finding salvation through chimerical ideals, and virtue had infinite trouble to convince them of her intoxicating charm: they could not manage to persuade themseives that stones and arabesques are man's proper sustenance, but remained faithful to the realities they knew through the senses. Everything else was only ridiculed, and, as few women are insensible to mockery and a cutting phrase, the ladies were sometimes led where their own hearts would not have taken them.

Platonic love, then, was regarded in France as a complicated business. The women had to confess that no means had yet been discovered of crystallising the things of life apart from the dispensation of Providence which has given us bodies, nor of curbing men by the mere vision of the ideal.

So, as we have seen, Margaret of France strove to make her body the transparent vesture. of her soul. We have seen, too, what tender familiarities the ladies authorised at their morning toilet, and at other times.

Modesty to them consisted not in the more or less brutal systems of the "all in all or not at all," but simply in remaining women.

Chary of making a confidant of doctor or chaplain, because unwilling to subject themselves to either, they valued the man who regarded them as women and had eyes only for them; as a reward for his exclusive attentions they certainly thought they owed him some little privilege beyond what they allowed to others. It was they who were the doctors, the confessors, or rather the rescuers; they sprang into the water to save the drowning man. To save him by bestowing on him the true gift, a little of themselves, appeared to them a good, a moral, a meritorious work! risis was far, you perceive, from the commonplace, masculine handshake which women nowadays grant to all and sundry! Seriously, they fancied they were thus winning heaven; their own hearts constantly heard echoes of the sweet strains of Plato's Phaedo or Crito; his exquisite distinction between soul and body made music in their ears, and the familiar spirit of Socrates bound them to an immaterial world, whispering his 
counsels and intuitions. ${ }^{1}$ They saw no harm in bestowing their indulgent favour, their smile, and a little more. It was enough for them "to hold fast unto the end," and to remain firm as rock on the essential ; they were innocent of "false scruples," and would have thought it cruel and ridiculous to torture a man by refusing him "familiarities that Nature has permitted to beauties," now that this small change cost them so little, and above all touched them so little. Ah! that was not where the temptation lay! At the bottom of their hearts, how they despised the shallow, insignificant men who, with their large and canting talk of love and sentiment, could be caught like gudgeon with this paltry pliysical lure!

The critics of a certain lady went so far as to accuse her of "losing all shame," because when receiving one of her friends, as she lay in bed in the morning, she tolerated not a few familiarities, "without any offence to my honour," as shè observed. She replied with heat that she saw in her conduct nothing but what was excellent; her friend would estcem her doubly for having seen body and soul united in her "in one strain of cliaste beauty." As to the danger of this familiarity, listen to her subtle and delicious reply: "The man I love, the man I dread is not he; it is another who has laid siege, not to my body, but to my soul. Ah! if I did not keep a rein on my heart, it would long ago

\footnotetext{
1 Sonvienne-toy, regaignant ta raison, Que ta maitresse est cle grande maison, De noble sang, et non pas amusée A dévider ou tourner lia fusée;

Et que son cil, mais plutôt un soleil doré,

Et son esprit, des antres adoré,

Et ses cheveux, les liens de ta prise,

Sa belle main, à la victoire apprise,

Son ris, son ehant, son parler et sa roix, Méritent bien !e mal que tu reçois.
}

(Ronsard.)

[Remember, when thon eanst regain thy nous, Thy mistress is of high and famous house, of noble blood, nor is she wont to play At wheel and distaff all the livelong day. Remember that her eye, a sun of gold, Her mind, by otlier worshippers extolled, Her hair, the bonds of thy captivity, Her lovely hand, well trained to victory, Her smile, her song, her speeeh, her gentle voiee Deserve that for thy sumart thou shouldst rejoice.] 


\section{THE WOMEN OF THE RENAISSANCE}

have spoken to me in favour of the other man!" 1 This is the cry of the fastidious woman who dreads only the rape of the mind! We do not discuss her moral scheme, we pass no judgment, we confine ourselves to relating. ${ }^{2}$ Her end was to make herself loved, and in a manner which would be worth the trouble.

It is not hard to believe that the bounds were sometimes overstepped: some men abused their privileges, especially with regard to princesses of literature like Louise Labé ${ }^{3}$ and sometimes it happened, indeed, that cries a little too genuine broke from the lips of women, and were heard above this tender, philosophic poetry, and this scorn of earth. Yet many women, in their devotion for spreading

I Et, si l'on dit que le privé toneher

Faiet prés du feu le tison approeher, Je respondray: Il y ha ja longtemps Que, si l'honneur, oi tousjours je prétens, N'eust en moy deu faire plas de dememre, Un, que nommer je ne veux pour ceste heure, Par les cfiors de sa langue cliserte Auroit plus tost tiré caing cle ma perte, Que par baisers, ne par approchements Qui de la chair ne sont qu attonchemens.

Héroèt (one of Margaret's friends)

[And if one says the intimate caress Is fire to tinder, then will I confess That if the honour hitherto my pride Within my soul no longer would abicle, Long, long ere now a man I will not name (Lest at this hour it bring us both to shame), Would by his tongue's delicions eloquence Have won his profit at my dear expense Far speedier than by kiss or dalliance hot, That titillates the flesh, and is forgot.]

2 The aneient Valentinians went mueh farther, and maintained that it is impossible to the witty to become cormust, whatever their actions.

\footnotetext{
${ }^{3}$ Qu'eust fait ce gree, si ceste image nue Entre ses bras fust V'enus devenue?

Que suis-je lors, quand Louize me touche Et, l'accollant, d'un long baiser me baise? L'âme me part, et, mourant en cet aise, Je la reprens ja fuiant en sa bouche
}

[What would that Greek of old have done if in his elinging arms His naked statue had beeome Venus with all her eharms? And when Louisa touches me, ah! what is then my bliss, When all my body tingles with the thrill of her long kiss? In that sweet agony I die, my soul then from me slips;

But I catch it as it passes 'twixt my lady's burning lips.] 
pure happiness, for holding men captive lest they sold themselves, would often have preferred that conversation should be the sum total of their intercourse, and that their friends should be coutent to dip in their eyes and their soul.

Their aim was to reduce everything to conversation; they had little love for a contemplative silence, for songs without words: conversation allowed opportunities of probing, caressing, penetrating the soul, turning it inside out without the least inconvenience and with many benefits. Among close friends they showed their art by getting someone to sing to them the old cantilena, "I die of thirst bevide the fountain's edge"; sometimes they held under their eyclicls a large unsuspected tear. They made a hungry man forget his food; "they contented their lovers with words, promised a reward, and deferred it till to-morrow."

The Italians, as we have said, delighted in tasting love thus at leisure in little sugared sips; they were not gluttons like the French : they appeared horn, not to construct railways or to inflate ballocus, but simply to love, to lore loving, to nourish themselves on futilities and surprises, to sing always the same meaningless song. They cut marvellous fignres at the feet of those women "before whom desire burnt away like candles at a shrine"; they glossed over realities, as if they really believed more in happiness that came from the unknown than from the known, as the great scomer of women, La Rochefoucauld, has well said; to such an extent that the inexhaustible springs of the heart were sufficiently dopleted, so far as they were concerned, to spare them the risk of embarrassment from love, and to enable them safely to find the recreation necessary to the overtaxed human mind. Happy creatures, these men without a care! The narrow world in which they fluttered seemed too big for them, and their long wings touched the ground; they were young, yet old; they were gay with brilliant, yet facled colours; a woman could take their arm in complete confidence that a!l would end where it began. Iife was for them one aimless flirtation, a mere battle of flowers.

Love, as thus carried to extreme perfection in society, came in for no little mockery. No one was under any 
iilusion as to the impossibility of finding in it a secret source of strength and life; it was a mere avocation, a little intellectual pastime-with no overpowering demand on the intellect.

The Italian "cicisbeo" or "death of love" became a sort of amiable spectre, a harmless necessary cat; he was practically non-existent to his friends, and had the right of not answering his letters. Sweetly scented, with a well-hosed les, a rose in his hand and a flower at his ear, his lips pursed up, his bearing graceful and gallant, at his heels a lackey whose duty was to flick off the least speck of dust-there you have him, always the same, whoever the object of his passion. All he troubled about was rightly to place his glances and sighs, his nods and salutations, and when he had been rewarded with a gracious smile or an arch look, he would go off humming to indite a sextain or a madrigal.

The mawkish execrable creature! more womanish than women, a woman spoilt in the making, a half-woman! Sticking like a shadow to the lady of his thoughts, his function was to carly her lapdog, her prayer-book, or what else she pleased. At her house he installed himself as the centrepiece of her receptions, kept the conversation alive, and overwhelmed the husband with affectionate attentions.

He was a hypocrite, a rakish fop! In the Roman aristocracy he usually took the shape of a sanctimonious recluse; at Naples he was a man of energy and go ; at Venice a man of mystery; in Lomburdy he had the joyous self-assurance of the North; ${ }^{1}$ at Florence he was a vivacious talker, responding to the challenges of silvery voices with audacious quips. He took everything as it came; he had not an ounce of sincerity : his cleverness consisted first in adapting himself entirely to the beloved object, in abdicating all individuality, in being hers and hers alone; secondly, in proceeding platonically and without passion, with

1 There are some rather lively and amusing letters of Bibbiena. On February 7, 15l6, he wrote to the Marchioness of Mantua. "The compliments your Excellency has been good enough to pay me on behalf of Isabella have given me supreme pleasure, for $I$ have always loved and still love lsabella more than myself. I am wholly Isabella's, body and soul; so that, whether loving or not loving Isabella Mario, I am wholly hers, and desire above all things in the world to be loved by her." 
extreme prudence, trusting to suavity and tenderness, always securing a line of retreat, and striving above all to melt the obdurate heart. In all this part of the programme the eyes often were better servants than the tongue.

'This point rounded, every man for himself! An eclectic, a hot lover, an abstract philosopher, a symbolist, an idealistlet him be any of these if his heart bids him. He is a tine talker; well, 'tis a great talent, which will permit him to turn to account a thousand lititle incidents, but will often (let him not deccive himself) lead to only superficial successes. A wary woman holds fine talkers in awe; with them, she thinks, there is all the making of domestic broils; she knows how indiscreet they are, and she smiles on them and keeps them at a distanee, knowing that this is the way to set them proclaiming her virtue abroad. Gften she prefers a taciturn, above all a bashful man, "a lenten lover," as someone said, easy. to feed. ${ }^{1}$

But it is impossible to enumerate all the eccentricities that were part and pareel of this flirtation. The ridiculous became the rule: it was an afllicting spectacle for human dignity. Old men cut capers, young men lost their heads, the witty turned imbecile, the imbecile set up for wits. What a masquerade! The lugubrious blubbered about their love, siglied in prose and verse; the sincere embraced a whimsey-adopted a colour, for instance. One of these, having vowed himself to green, so strictly embargoed the rest of the spectrum that not only was everything on him green, even to his shirt-buttons, but he ate out of none but green plates, drank out of none but greenish glasses, never rested till he had discovered green bread, and made green meadows and groves the exclusive burden of his song.

Happily, conversation somewhat raised the level of this extravagant and lamentable affectation. Surrounded by a circle of friends, a man would amuse himself by launching a graceful declaration concealed in an aphorism or a double entendre; it sometimes happened that a lady who had never entered the speaker's head fancied that hers was the heart aimed at, and that was provocative of fun. Or perhaps they would linger out the pieasure of a tête-à-tête,

${ }^{1}$ Heptameron, Tales 20, 25, 14. 


\section{THE WOMEN OF THE RENAISSANCE}

reel off ther witticisms ${ }^{1}$ and amiable compiiments, and unravel little puzzles in sentimental casuistry. Sometimes they reached the stage where the tête-à-tête that was really delightful was one in which neither said a word.

Here some one will stop us and ask whether all this did not have an end. Bless you, no! An end was in no wise necessary; genuine platouic romances never end. ${ }^{2}$ And what years and year's they may last! A clever woman excels precisely in spinuing them out; if she feels that the fire is burning low, she has a thousand means of fanning it into flame-a word, a tender gesture, ${ }^{3}$ a little present, a

'Here are specimens of Phansina's talk, that Nifo found so delightful. "Phausina," said he, "since it befell me to love you, you have become an Aurora, superb, resplendent! How happy it makes me!"-"Near such a sun as you," she replies, "ought I not to become the finest dawn ever seen?"

"One day I asked her how it was that with her sixteen years and her charm she could love an old fellow like me, reciprocity of love resulting philosophically from a eertain similarity."- "True, we are different," she replied prettily, "yetwe are wholly at one in the basis of our mutual love" (she meant beauty of soul).

"Who is the true lover?" he said. "The idolater," she replied, "is he who adores the imare and not the divinity; the false lover, he who loves the face of a girl, but docs not respect her modesty."

"Phansina, how ean you love a man with me foot in the grave?" "Tis not the dotard I love so warmly, but he whom neither age nor anything can affect; he who, after his death, will come to life again."

"One day I was teasing Phausina: to provoke her 1 said, 'Come now, Pliansina, when you are quite oll, do you think I shall still love you?' 'Why, of comrse,' she sild: 'what you lore in me will not grow old. Petrarch lored Lanra arlently, young, mature, living, dead: he saw no mark of age, which nevertheless he might have earnestly desired, so that he might enjoy her beauty withont any suspicion: And I then asked Phansina what would be the reward for such a love. "That you will not be a liar when you shower your praises on me."

2 "One day, anong the gronp of girls, someone set the little problem of guessing what gave me the greatest pleasure in my relations with Phausina. One of them said it was to gaze at so pretty a woman, another that her conversation was vely sweet, another swore that in reality it was because we wrandel so pleasintly, and that she linew it. Phausina smiled and said : "We all know, my ciear Nifo, that all those things go to produce my pleasure : but my deepest satisfaction is to be able to enjoy everything, frequently, freely, without fear of material seductions, leeause of your age." "

3 Ma dame, un jour, daigna tant s'abaisser,

Parlant à moy, de doncement me dire :

'Je ne te veux, amy, rien escond[u]ire

Qui soit en moy, je te pry le penser.'

Et pour encor du tout récompenser

Mon triste cueur de l'euduré martire, 
gracious act here, a secret gentleness there, a touch of jealousy; and then she suggests that you should recommence the little game-church, the park, sighs, tears, oaths. And thus you may go on for ever.

There are, however, some romances which do end, well or ill. As a rule the event is announced by rolling clouds and a lightning-flash. The majority of men only enter the platonic life with the idea of an early departure, and implicitly believe that in the life of every woman-even though she be a "dragon"-there is one inevitable, irrefragable hour. Psychologists, philosophers, poets, preachers ${ }^{1}$ all have repeated ad nauseam the saying of Ovid: "A chaste woman is she whom none has tempted," 2 or, as La Rochefoucauld and La Bruyère will phrase it later: "An insensible woman is she who has not yet found the man she must love."

The lady affects not to see the storm brewing; she bears up against it gallantly; gentle banter is her cue; she declares that talk of love is very pleasant to her, but 'tis well known among decent people what that word signifies; there is no question of a coarse, sensual love, but only of amorous discourses. The man gives himself up to demonstrating his love anew; his plaints become louder, his tears more copious; his lady-love never gets to sleep o' nights without hearing serenades or "Spanish lamentations" beneath her window, or sighs that would seem belled out by some

Sa blanche main hors du gand elle tire

Et me la tend pour la mener danser.

(Magny, p. 7.)

[My fair did condescend one day

Sweetly to speak to me, and say :

"My friend, notbing will I deny thee

Of all I have, come prithee, try me."

And for to recompense my heart

For all its grievous dole and smart,

From ont her glove she drew her lily hand,

To lead her forth to dance did then command.]

1 " And you, Madam, if you succumb to the flesh, beat your breast, for you do not shum temptation. Why do you stand at your window? why chat with young men?. . Why go to the ball and give yourself to so many idle conversations? Shun temptation, and the devil will leave you in peace. Resist him and he will flee from you!" Woman's tongue is one of the greatest of the devil's instruments : "I did that because the devil seduced me:" it is Eve over again: "The serpent beguiled me." (Baraleta.)

2 "Casta est quam nemo rogavit." 
familiar spirit, but which are really a performance got up by obliging neighbours, for a consideration. All day, at church, in the ballroom, in the street, under the thin disguise of masks, he is here, there and everywhere, never out of her sight.

One morning the maid announces to her mistress that the gentleman is at the door with something most urgent to say -here he is, indeed, pushing past the girl; and he will be eloquent, you may be sure. Or he resorts to the grand means of melodrama-false keys, rope-ladders, narcotics, sorcery, lying confessions of apostate monks; or to the stale and hackneyed devices of comedy, he enlarges eloquently on his high qualities, proffers a thousand services, and even opens his purse; full of promises the while erecting beautiful castles in the air. One will employ menace, another will boldly haggle and argue with father or husband. What a warmth of language, what sighing and sobling, what fretting and fuming! "Fulvia being come on horseback to see me, I straightway feigned a superb wrath, as though her action seemed to me that of too forward a minx. And this fine choler of mine was of great avail in my courting." There are some who carry the fortress by dint of lavish praises, superlative verses, outbursts of jealousy. Others by continual dropping wear away the stone.

If a princess had the idea that her rank would prove a sufficient rampart against this final assault, she had to find out her mistake, especially in France. Why should not the man she loved-the dear good fellow:-after so many labours, and discreet frenzies, and stratagems, and covert approaches, expect an advancement he so well deserved?

A bien servir et loyal estre,

De serviteur on devient maistre ! ${ }^{1}$

"Madam," proudly says one of the young nobles of Margaret of France, "when our mistresses stand on their dignity in halls and assemblies, seated at their ease as our judges, we are on our knees before them; we lead them out to dance with fear and trembling; we serve them so sedulously as to anticipate their requests; we seem to be so fearful of offending them and so desirous of doing them

1 The servant that is brisk and trusty

Becometh master ere he be rusty. 
service that those who see us have pity on us, and very often esteem us more simple than foolish," and sing the praises of ladies able thus to win service. "But when we are by ourselves, and love alone doth mark our looks, we know right well that they are women and we are men, and then the name of liege lady is converted into sweetheart, and the name of servitor into lover." 1

And it need not be supposed that in such circumstances they remained satisfied with words or menaces, even in dealing with ladies of the most exalted station. There were violent characters who stuck at nothing, like Bonnivet! It also happened at critical moments, even in the most platonic of circles, that love turned into rage. "Unico Aretino," one of the Urbino talkers, upset by what he thought a piece of base ingratitude on the part of the charming duchess Elizabeth, got so beside himself with anger as to call his sovereign lady "Urbino's traitress, witch, trickster." (Aretino was an exceedingly clever man, but after all he was only the fourth part of a prelate; he filled at Rome the fourth-rate office of "apostolic abbreviator," and pretty badly at that; but as he afforded the Sacred College a deal of amusement he was licensed to indulge in all sorts of jocularities.) $\mathrm{He}$ never forgave the duchess, and even after her death pursued both her and her daughter with persistent rancour. ${ }^{2}$

The ideas of men in these matters simply beggar imagination. They fancied that they erred on the side of bashfulness, that they suffered wrong when ladies suggested "reckonings," to use their term. They thought it would be ridiculous to die of despair like the heroes of romance, and that it was "folly and cruelty" to praise the beauty of a

\section{Heptameron, Tale 40, and prologue of first day.}

2 "Most illustrious and wicked girl. When the terrible duchess Elizabeth was alive, she made me her martyr and protomartyr; and you perhaps, nay certainly, with your angel's face and your serpent's heart, were her perfidious counsel to my detriment ; and now look at me, compelled by aid of medicine to support as best I can the miserable remnant of a life thus exhausted. 'Through that pity which you know not, either in life or in fiction, you will condescend to do me the favour to send me a baratollo or rather a little tree of barbe di calcatrepuli, a specialty of Urbino, so that I may boast of once having had a prayer granted by the flinty ladies of the house of Gonzaga. I do not commend myself to your highness, not wish. ing to waste my words on the air. I only pray Heaven to keep you long in health and happiness, so that you may long make mincemeat (macello) of your servitors.-Your servant for life, Unicus." 


\section{THE WOMEN OF THE RENAISSANCE}

fountain to a poor, thirsty fellow and then kill him because he wished to drink.1 "Whom will you get to believe," cries Henri d'Albret, " that we ought to die for women, who were made for us, and that we should hesitate to require of them what God bids them give us?"2 That was the conclusion that must be expected : everyone knows, in Calvin's words, whither "all roads" lead. So a woman was neither surprised nor panic-stricken in the hour of battle. She had taken or onght to have taken her precautions; her first care, as we have said, was to distribute her favours. She went forth to the fight with a gallantry which some old fogies called impudence; her sins were no longer sins of omission, like those of her grandmothers. And that she often triumphed there is no manner of doubt. Margaret of France, at the turning-point of the battle, is found as firmly fixed on principles as Anne of France. Billon assures us that in Normandy, a land of pretty women, where he would not care to go bail for a single man, he would not hesitate to name a very large number of women whose virtue he could guarantee with every confidence. Assuredly there existed stainless women,-just the women to play with fire!

But did they always come off scatheless? No one will believe it.

Further, it must be remarked that the point of view of casuistry had changed. The body was, so to speak, the sign-manual of the soul; just as the base, passionless, sensual vice prevalent in the world seemed ignoble and disgusting, so it was remembered that love had a purifying power. The merciful words of the Gospel were recalled, and, remarkably enough, it was those who were most rigorous in regard to themselves who showed the most indulgence towards an eiror springing from sincere affection.

Margaret of France spreads her nets, like the Gioconda, but for the good of others, for she knows whither the mistenveloped paths lead; she cannot tear her eyes from the vast and gloomy background of life, and all that passes in front of it inspires her at times with cruel loathing. She loves mankind, but without the least touch of fetishism, to look aloft and not believe in any individual man is the condition of her love; her sole consolation is the thought that Italian morals are worse than French. Her approval

${ }^{1}$ Heptameron, Tala 8.

${ }^{2}$ Tales $9,10$. 
of a German husband, who had the fantastic notion of locking his wife up along with the skeleton of her lover, ${ }^{1}$ was so exaggerated that all her friends were compelled to laugh. And yet, when pulled up short about the ethics of love, and asked if the sin is venial or worse, she gets a little muddled. Assuredly, nothing is more "untuneable and harsh" among the joyous strains of the divine concert than the frailty of the flesh: "truth compels us to condemn it"; but is there any need to get huffy, to decline to see any extenuating circumstances, because the spider's web that has been centuries aweaving is rent by one dab of the paw-because, in spite of all the cooings and flutings, no one has succeeded in turning men into big babies instead of villains, or even ( $I$ go this length) because in the heat of the battle some women may have lost their heads and gone over to the enemy? Is the conclusion inevitable that the outcome of platonism is necessarily evil-more evil than anything else?

How stood the fashionable ladies who rebelled against platonism? . . . On the principle that "the honour of a man and that of a woman are the same," and that a wife, whether from love or vengeance, has a right to the same independence as her husband, it was the husbands' game to wink at things. Far from making an outcry and playing the Othello, they meditated philosophically on their own position ${ }^{2}$ and the virtue of silence, and, drawing in their horns with something of fatalism, could not find fault with their wives for "using their power" as they themselves did. It was rare for a husband to kill his wife; wedlock had become a stagnant pool of mutual indulgence, in which unlawful love was but an incident so long as it left no more trace than a pebble cast into the surface slime, or a bird flitting through the air. As to believing that Lauras or Beatrices could still exist, not only did the sceptics deny it

"One of the ladies replies tranquilly: "I should prefer all my life long to see the bones of all my servitors in my room than to die for them: for everything can be amended but death." (Heptameron, Tale 32.)

2 "Je le sçay bien, mais point ne le veux croire, Car je perdrois l'aise que j'ai reçeu."

(Clément Marot.)

[I know it well, but will not it believe, For I should lose the comfort I receive.] 


\section{THE WOMEN OF THE RENAISSANCE}

outright, but they even declared that if Laura or Beatrice were to revisit the glimpses of the moon, great would be her disillusionment. ${ }^{1}$

The only matter that Louise of Savoy troubled about was to keep things dark. ${ }^{2}$

Can we wonder that, in an atmosphere so saturated with immorality, many even of the best-intentioned women allowed themselves to drift with the tide, or that Salel, the Attic friend of Margaret, represents them even on the shore of Acheron as still enchained to ungovernable love, and imploring pardon for their tyrant?

When they succumbed, it was with a sublimity of passion which the world almost always misconstrued. "The fortress of the heart, where honour dwells, was so battered that the poor lady granted what she was never a whit inclined to refuse." 3 "You mean to say, then," says a lady, "that all is lawful to those that love, provided no one knows?" "In good sooth," replies the other, "'tis only fools who are found unt." 4 Their love, fashioned out of dreams, thus dissolves into reality. Pure women, platonists armed at all points, let themselves go from a spirit of gentleness ("for pity in their spirits rules"), from a tenderness of compassion, out of charity toward others, if not for themselves. They are almost martyrs of love or kindliness, since their kindliness goes such lengths as to be taken for love, just as their love, reserved as it is, may be taken for kindliness. Unlike the anti-platonists, though they may perchance be surprised into a fault, they surprise no one, they commit no follies. It is the fault of poor human nature that platonic love does

\footnotetext{
${ }^{1}$ Hütten writes: "What shall I say of Samson, who while all but in the arms of a woman received the inspiration of the Holy Ghost? . . . And of Solomon, who had 300 queens and an infinite number of concubines, till his death, and who nevertheless in the eyes of the divines passes for saved? What is the inference? I am not stronger than Solomon, nor wiser, and one must sometimes have a little joy. The doctors say 'tis necessary to cure melancholy. Well, what do you say of these grave authors? Ecclesiastes says: "There is nothing better than that a man should rejoice in his own works.' So I say to my love, with Solomon : 'Thou hast wounded my heart, my sister, my sponse, thou hast wounded my heart with one of thy hairs. How fair is thy breast, my sister, my spouse! How much better is thy breast than wine!' and so on."
}

${ }^{2}$ Heptameron, Tale 15.

${ }^{3}$ Ibid., Tale 18.

${ }^{4}$ Ibid., Tale 13 and end of First Day. 
not remain always a "stork love," as Montaigne calls it. There is never a battle but some dead and wounded are left on the field. Pity the dead by all means, but the survivors are already inviting those who have never sinned to cast the first stone!

A woman "so cozened," concludes Castiglione philosophically, unquestionably merits such indulgence as is accorded to messieurs les assassins. She was toiling, as Michelangelo said, "to lift souls to perfection. Sensuality slays the soul."

And hence Margaret of France, in her profound yearning to blot out and pardon the sins of the world, is herself inspired with a tender, helpful tolerance. Assuredly the wounds she observes are deplorable, but they do not necessarily point to absolute frowardness of heart; they may result from a "naïve folly," from "the misfortume of loving not wisely but too well"; in other words, from an over-abundance of natural goodness, the very consequence of our organisation. The perfect being would clearly be an androgyne; but we are imperfect beings, an odd mixture, godlike, and yet profoundly, lamentably human. The power of love

vient de la divinité,

Et son tourment de nostre humanité. ${ }^{2}$

We seem to hear this spotless woman crying to God: "O Christ, Christ of the Magdalene, gasping and crucified, how Thou didst suffer, how Thou didst love! This streaming blood, these wounds gaping eternally,- - these are the handiwork of the hate of men, whom Thou didst bid to love one another with a pure heart. Thou wilt not pardon their hate! Thou wilt not pardon their fierce lust of wealth, nor their pride and naughtiness of heart, nor their wild anger, nor their shameful sloth of soul. Thou wilt pardon nothing but the error of love, the error of a moment, since this is but the overflow of the goodness Thyself hast given, the wofulness of too great love!"

${ }^{1}$ [Referring to the fable of the Stork and the Fox, versified later by La Fontaine. "The stork with his long neck could not pick up a bit."]

${ }^{2}$ Comes from divinity, And its torment from our humanity. 


\section{THE ENNOBLEMENT OF VICE.}

The second moral effect of the theory of beauty and love was still more pertinent than the first. It consisted in an extraordinary levelling up of purely terrestrial and unlawful loves. From the principle, with which we are already acquainted, that the virginity of the heart survives the professional ordeals in which the heart has no concern, we shall find that moral deductions were drawn, in Italy and even in France, so important that we cannot pass them by in silence.

In Italy, among the women whose trade was pleasure, there was formed an aristocracy so real that some of them presided over salons, were part and parcel of the court world, and truly merited the name of "courtesans." Their bearing was irreproachable, their distinction extreme; we are bound to say, indeed, that, apart from their origin, they were absolutely indistinguishable from virtuous womenexcept that perhaps their manners were a trifle more correct.

Their high influence is explained by the fact that in the official world of Rome there was a plentiful lack of women. Etiquette required that none but birds of passage should be seen at court, a restriction which gave cruel but entirely honourable pain to the heart of more than one platonic prelate. It was believed for a moment that the half-sister of Leo X., Philiberta of Savoy, was about to take up her abode at the Vatican: "God be praised!" cried Bibbiena exultantly, "all we lack is a court with women!" This happiness was not realised; women continued to be conspicuous by their absence. We see how it was that, in the supreme sanctuary of human glory, in the Eternal City that served as beacon to the world, the Ninons de l'Enclos, ${ }^{1}$ for want of better women, fulfilled in their own way a singular apostolic mission by playing the part of court ladies, and by magnificently entertaining the pick of poets, savants, artists, prelates and diplomatists, at a period

${ }^{1}$ [Ninon was the celebrated courtesan who, withont any great beanty, retained her ascendancy over men through a long life (1616-1706). She was well-born, wealthy and witty, and capricions in the bestowal of her favours. She is the original of Clarisse in Mlle de Scudéry's interminable romance Clélie. Herself a writer and a lover of literature, she left Voltaire 2000 francs to buy books.] 
when every man plumed himself on bearing one of those labels and on sporting it about some petticoat.

Bewitching pictures of the receptions of these ladies have been bequeathed to us; many a poet who knew the world chiefly in this quarter has vaunted with enthusiasm the aroma of grace pervading their noble salons, the honour of admission to them, the relations established there, the superb fêtes which consecrated their charm and set a seal upon the connection. This was no new thing; Socrates and Pliny testify how keenly the society of ancient Greece and Rome had felt the need of guidance by women more deeply experienced in life and more naturally active than high-born ladies are likely to be. To name these ladies Ninons de l'Enclos, however, would be to give a very imperfect and mean idea of them, for their influence was at once moral and intellectual. Doubtless they could pretend to no virginity but that of the heart, but since that was the better part, they honoured pure love quite as conscientiously, if not more than other's did. Energy of a very special and sincere kind impelled them to react strongly against the scorn of a world they had an equal right to scorn; and further, they felt the necessity of stopping their ears if they were to save themselves from blank hopelessness, and of setting up noble illusions about themselves.

Several of them were genuine patricians, whose only possible reproach was a tincture of pride. One would flaunt her descent, which she possibly traced back to the Colonna or even the Massimo ${ }^{1}$; another would modestly sign herself "Roman patrician." The entrée to their salons was particularly difficult; some of them imposed somewhat rigorous conditions, insisting for instance that a man should mount guard for two months with the Swiss at the palace gate, or should pay his devoir on his knees. The style of their houses and appointments left nothing to be desired; they maintained an extreme decorum. It is not for us to boast of their virtue: their talent consisted in being as virtuous as possible and getting rich more particularly by way of legacies; it would have been a great mistake to deal with them cavalierly. 'Tullia d'Aragona, who thoughtlessly allowed some rather broad pasquinades to be addressed to her, '[An ancient princely family of Rome which claimed descent from
Fabius Maximus the Dictator.] 


\section{THE WOMEN OF THE RENAISSANCE}

was unfortunate enough, on a visit with which she honoured the court of Ferrara, to turn all the gentlemen's heads. But the most diverse ordeals found her inflexible; she rejected with indignation the miserable offer of a golden necklace worth three hundred crowns. The daughter of another of these ladies had been so excellently brought up that she has a place among the martyrs of virtue and patriotism; she slew herself to escape the importunities of the governor of Sienna.

They were queens of elegance, and never a brunette among them. At their houses people discoursed most excellent music. They were great dancers. They were the happy owner's of fine jewels, fine pictures, fine statuary ; on their tables might be seen the newest books, choice editions, sometimes adorned with a manuscript dedication in verse. They knew Greek and Latin; they corresponded with their absent friends in gracious and affectionate letters, Ciceronian in style, and with no lack of wit. In conversation it required very little pressure to tap a bountiful spring of elegant extracts from the classics-most often got secondhand from Petrarch or Boccaccio-or even, on occasion, a learned disquisition on Roman archaeology. Sometimes they shot out a phrase in the high pietistic fashion of the day. What lady of recognised position could have written more charming sonnets than Imperia or Veronica Franco?

They excelled in keeping wit in play : Aretino confesses that, without an incentive of this sort, he would have been good for nothing. Occasionally some poor devil was graciously permitted to give a taste of his quality, but, as a rule, the mistress of the house preferred to inspire men who had well-lined purses. Yes, it was a grave and distinguished society, and if sometimes the conversation touched on subjects but indifferently mystical, what immaculate drawing-room but was open to the same reproach?

On saints' days these ladies went to pay their devotions at the neighbouring basilica, and if they were not very devout they were at any rate beautifully dressed. Their accustomed air of good breeding and conscious dignity, which drove many ladies to despair, gave them genuine rank, and made them the indispensable ornaments of important festivities. Thus several of them lent lustre to the magnificent reception given in 1513 by the Cardinal of Mantua to young Federico Gonzaga, then in his fourteenth 
year, as he passed through on the way to Rome. In truth, there were some who behaved exactly like highborn dames, and were pre-eminent in all deeds of devotion, whole-hearted love, and even disinterestedness. Poets innumerable have vouched for their virtue. Vittoria Colonna and Michelangelo dedicated sonnets to them.

Not infrequently they ended their days in the odour of piety, and were buried in the churches ${ }^{1}$; to this day prayers are offered in the shadow of their tombs. Michelangelo wrote an epitaph for one of them. Other's prosaically married men of the world, and these ladies, as a rule, took rather a superior pride in their virtue and their coat-of-arms. A clever woman of the time philosophically hit off the subject: "Life is a comedy: so long as the last act is successful, the whole piece is fine."

Nevertheless these interesting creatures necessarily had their detractors. They have been accused of trickery and deception. With all allowance for the prejudice of their enemies, it cannot be denied that eccentricities here and there gave a handle to the slanderers. The lady, for instance, who wore slippers covered with diamonds, and made men kiss her feet (like the pope), alleging that her foot too was beautiful enough to merit adoration, was considered to have overstepped the bounds. But with the general public, and even with connoisseurs, such dainty exactions did not produce the same astonishment that they would produce to-day. The religion of beauty touched such deep chords that the beautiful appeared always beautiful under all forms, so much so that in certain Italian collections of "Lives of illustrious women," saints and courtesans stand cheek by jowl.

Men professed for these ladies the same veneration and idolatrous respect as for a princess; they plied them with the same sighs, the same verses, the same little tendernesses. The game cost a little dearer, but in reality they were not unwilling to regard a courtesan's drawing-room as more

1 Panormita, who died in 1471, had already employed his muse in lamenting departed courtcsans; for example :

Hoc jacet ingenuae formae Catharina sepulcro ;

Grata fuit multis scita puella procis, etc.

[In this tomb lies Catharine of uoble beauty: pleasing was the fair gir] to many a wooer]. 
moral than certain reputable drawing-rooms, since a man was not likely to meet a ridiculous husband there, or embarrassing young cousins of both sexes, or certain fashionable girls whose tongues had a tang. And it was much less compromising.

Was there a moral advantage in elevating what had till then been so degraded? For a long time it was sincerely believed there was, and this belief was held almost throughout Italy. On this point it is sufficient to read a very curious letter addressed by some unknown person, concealing himself under the pseudonym "Apollo," to the witty and eminently virtuous Isabella d'Este. It is dated Ferrara, June 13, 1537, and refers to a visit then being paid to the city by Tullia d'Aragona. It runs: "'There has just arrived here a very pretty lady, so staid in deportment, so fascinating in manner, that we cannot help finding in her something truly divine. She sings all sorts of airs and motets at sight; her conversation has matchless charm; she knows everything, and there is nothing you cannot talk to her about. There is no one here to hold a candle to her, not even the Marchioness of Pescara." An ambassador exceeded even these rhapsodies, and wrote gravely to his government that he was composing his despatches under the eye of this pretty woman, who assisted him with her advice.

'Tullia d'Aragona, who was, we may remark, very proud of the noble blood in her veins, thus played Egeria to the most exalted personages, and they had no hesitation in comparing her to a mother of the church like Vittoria Colonna, or in placing her even higher. She justified this enthusiasm, not only by her physical beauty and her wit, but by real moral qualities. She proved that the spirit of the beautiful elevates the basest things, and if she did not turn Trappist, if she continued to live the life she was born to, she brought to it a contempt of money which was itself a purifying virtue. This admirable creature, after holding all Italy spellbound by the charm of her velvety eyes, died in destitution; she gave instructions that she should be buried in the quietest way beside her poor mother in the church of Sant Agostino, where she had endowed masses; her belongings had to be sold by auction, and they realised twelve crowns and a half. 
Imperia attained even a higher place than Tullia, and we are compelled to believe that the aegis of virtue, like charity, ean cover a multitude of sins, since we find Sadoleto, the type of sincere piety, singing the praises of this amiable woman, and Raphael setting her, so it is said, at the foot of his Parnassus in the apartments of Julius II.

We do not know (and it is almost better so) what Imperia had done to excite so general an enthusiasm: she died at twenty-six! All that we know is that August 15, 1511, the day of her death, was observed at Rome as a day of public mourning. On her tomb was engraved an epitaph in the purest lapidary style. The poets, maybe with a very subtle irony, lauded her to the skies as a new goddess of Latium: we hardly need to repeat these fine phrases. "Our fathers mourned the Empire (Imperium); we mourn Imperia. They had lost the world: we have lost our hearts, our very selves." "The whole city was moved when this young deity was snatched away on Tiber banks," exclaims Vitalis - " the whole city, even the old pagan walls, even the fasti of the consuls!" "No longer is she beneath this marble," cries Silvanus; "heneeforth she holds her place among the constellations, she will guide our fleets." But Silvanus becomes a little mixed in his mythology, and in connection with the new star unaccountably couples the names of Julius II. and Jupiter.

For all this glory and honour, Imperia and her kind inevitably became rather burdensome, and the most aesthetic of the popes, Leo X., struck them a fatal blow when he expelled them from Rome in 1520. They took refuge at Venice, despite the heroic opposition of the senate.

But at Venice they lost all their peculiar charm: Venice, the metropolis of pleasure, "the foam of the sea," set its stamp upon them. Venice was the earthly paradise of matter-of-fact folk like Brantôme and Aretino. The latter wrote to an amiable lady: "You cannot picture these water-parties in the open air, these coaching expeditions on terra firma, these secluded groves, these banquets, these unaccustomed consolations. . . From your windows you will have a panorama of musicians, singers and buffoons," a tempest of pleasure. "You would fancy yourself a queen." But at Venice such queens did not govern, as at Rome; men added them to their collection, that was all. 


\section{THE WOMEN OF THE RENAISSANCE}

Thus disappeared one of the most striking curiosities of the platonist society,- the one which has left the most vivid memories. It was only possible under the caressing warmth of the Roman sky.

Leo's decree evoked loud cries of distress, and the loudest of all came from the French, who, though they had never understood this art of harlotry and had made great fun of it, thought it a capital thing all the same. Rome, they as good as said, was no longer Rome: "How doleful the Jubilee will be!" cries a pilgrim: "what shall I do in Rome now ?" Du Bellay, while a melancholy guest of the gloom-beclouded eity, apostrophised this new ruin in wellknown verses. (O Rome, sad, tender Rome, to whom every passing generation must needs bequeath a new triumphal arch, new catacombs!) Many years later, distinguished travellers like Henri III. and Montaigne did their best to hunt up the last of the courtesans.

We cannot but confess that the attempt to rehabilitate the demi-monde and to employ it in the heavenward voyage strikes us as extremely ven iuresome; the younger Dumas, like a true Frenchman, was not bold enough to persevere. Our ancestors felt the same qualms: unhappily, it was not from virtuous scruples. They recognised the work accomplished by platonism, so bent were they on transfiguring love through coquetry, ${ }^{1}$ and so hopeful, in the interests of humanity, of rendering virtuous women more come-at-able. But when it was suggested to them, as necessary to complete their work, that they should render come-at-able women more virtuous, they were steadfast as rock.

I Women " may accept of our service unto a certain measure, and make us honestly perceive how they aisdain us not; for the law which enjoineth them to abhor us, because we adore them, and to hate us forasmuch as we love them, is doubtless very cruel. . . . A queen of our time said wittily that to refuse men's kind smmmons is a testimony of much weakness, and an accusing of one's own facility, and that an unattempted lady could not vaunt of her chastity. . . . If rareness be in any thing worthy estimation, it ought to be in this." And again: "In ny time, the pleasure of reporting and blabbing what one hath done (a pleasure not much short of the act itself in sweetness) was only allowed to such as had some assured, trusty and singular friend; whereas nowadays the ordinary entertainments and familiar discourses of meetings and at tables are the boastings of favours received, graces obtained, and secret liberalities of ladies. Verily it is too great an abjection and argueth a baseness of heart, so fiercely to suffer those tender, dainty, delicious joys to be persecuted, pelted and foraged by persons so ungrateful, so indiscreet, and so giddy-headed." (Montaigne, Bk. III , cap. v.) 
They discovered another way of giving an aristocratic stamp to things that could not be spiritualised. We are bound to touch upon it, because this also throws back a vague reflexion of platonism; besides, in approaching these delicate problems in morality, which it is so expedient to look at dispassionately, we have no intention of dedicating our work to girls.

It was sought to blend the idea of an immaterial union of hearts-an idea borrowed from platonism, and one whose beauty and importance were not disputed-with the other idea that such a compact must necessarily be sealed by an absolute and unreserved intimacy, or it would remain chimerical and oppressive. This idea the French could not part with; and consequently there arose the notion of what may be called a second marriage, supplementary to the authorised marriage-a union de facto, recognised, acknowledged, declared, and so highly honoured that one would be tempted to call it an eighth sacrament. Similar unions, recognised by the world, were still known at the end of the 18th century, and even under the Restoration during the early years of the 19th, having survived the worst trials of the Revolution, the Emigration, penury, and exile, to say nothing of the still more ruthless test of time.

This custom of giving publicity to secret unions was not a direct outgrow th of platonism; yet platonist women looked on it by no means unfavourably. In the first place, they thought it rather lucky that their husbands, enjoying an irregularity in some sort regularised, more highly respected their wives' dignity, quiet and health.1 Secondly, we have already shown how little platonism there was in morals under Francis I., and what unbridled licenee reigned at, court. Melin de Saint-Gelais portrays the king as a cock in a hen-run-or as a sun in a firmament of stars, amid Canaples, star of the morning; the lovely Saint-Paul, star of evening; Diana, the crescent-moon ; and many other stellar beauties eager to shine-Helly, Rieux, Tallard, Lestrange-who, if their names were not mentioned, "would have thought it strange."

1 Vice was incredibly base and ignoble at the courts of Charles VIII. and Louis XII. Ragged and loathsome wretches went everywhere in the train of the court, to whom the princes gave alms on fête days. 


\section{THE WOMEN OF THE RENAISSANCE}

Francis I. said plainly that a man without a mistress was only a nincompoop. In that case was it not a mark of progress to arrive at the institution of a regular mistress, recognised and with no rivals? Margaret of France would have been only too glad to see her brother fix his affections prudently on some eminent lady, who would rank next the queen and might be called the queen and "mirror of all propriety." That explains, no doubt, the affectionate, obsequious, humble welcome she gave to the duchess d'Etampes, whose reign seemed for a moment likely to be lasting. She wrote for this noble lady the Coche or Débat d'A mour, a little treatise intended to prove that, apart from pure platonism, there can still exist a laudable love; and in the presentation copy Margaret, the king's sister, had herself represented, in complete black, before the queen of the day in all the brilliance of her beauty and her jewels, and saying to her: "Plus vous que moy"; in other words, "You are more than I."

With a like feeling of feminine delicacy, perhaps somewhat exaggerated, Veronica Gambara, who was probably virtuous and quite certainly platonic, went into raptures over the good fortune of the "siren" who succeeded in holding for some time the volatile heart of Aretino; the words of Laura and Beatrice rose instantly to her lips, as if the ideal were on the point of attainment.

Henri II. showed himself a platonist in this sense; his double establishment did not constitute an infidelity. He was faithful to two wives, one official, responsible for perpetuating his dynasty and acting for him in affairs, after the old tradition; the other personal, to satisfy his heart as a man.

Diana of Poitiers, it must be admitted, besides her beauty which long retained its ripeness, had all the qualities for beguiling and captivating a lofty heart-birth almost as good as the queen's (who was only a Medici), wit, warmheartedness, self-devotion. She has herself explained, in excellent verse, how her position, false as it seems to us, was born of a genuine passion. One fine morning, she tells us, a young Cupid in all his fresh, light-footed, bashful youth came roaming in her neighbourhood, filling her mantle with marjoram and jonquilles, casting a spell upon her. She resisted, shutting eyes and ears against him, though she felt her heart melting; she would listen to no promises, 
no oaths. He held out to her a wonderful laurel wreath, a queen's crown. "No," she replied, "better far be good than a queen," and yet she felt herself "thrilling and trembling."

Et comprendrez sans peine

Duquel matin je prétends reparler. ${ }^{1}$

Love did not speak her false : he offered her a kingdom, a great part to play,and kept his word, as the walls of the Louvre testify. To all her contemporaries the position of Diana appeared magnificent, divine. Du Bellay has sung of it as the most beautiful of marriages, the marriage of true minds :

Dieu vous a fait entre nous

Comme un miracle apparoistre,

Afin que de ce grand Roy,

D'une inviolable foy,

Vous peussiez posséder l'âme,

Et que son affection,

Par vostre perfection,

Brulast d'une sainte flamme.

Les Roys monstrent aux humains

De Dieu l'exemple et l'image. ${ }^{2}$

To the French, this was the perfect type of platonism, at once practical and sacred.

Vous avez acquis le cœur de tonte la France. ${ }^{3}$

And Ronsard is not less explicit:

Seray-je seul, vivant en France de vostre âge,

Sans clianter vostre nom, si craint et si puissant?

Diray-je point l'honneur de vostre beau croissant?

Feray-je point pour vous quelque immortel ouvrage? 4

${ }^{2}$ [Nor will you find it hard to tell

On what fair morning this befell.]

${ }^{2}$ [God hath sent you to this place

Like some miracle of grace,

That you may both have and hold

Our great sovreign's heart of gold,

And that like a holy fire,

Purified in all desire

His affection light may shed,

By your true perfections fed.

Kings to mortal men below

God's own form and image show.]

${ }^{8}$ [And you have won the whole great heart of France.]

4 [Shall I alone of all this age in France

Forbear to sing thy dread and puissant name,

Nor tell the glory of thy crescent flame,

Nor by some deathless rime thy praise enhance?] 


\section{THE WOMEN OF THE RENAISSANCE}

In spite of all these dithyrambs, it is very clear that the platonism of Diana of Poitiers is a sign of decadence. It was the ideal of platonist women to be loved for their soul; men's ideal being the opposite, there had been a compromise. $^{1}$

The compromise, indeed, was greater than they were willing to admit, even in Italy, and in the purest centres of platonism. Our readers are already acquainted with the charming Bembo, the quintessence of platonism, the admirable chiseller of phrases, the secretary of Leo X., the friend of everything beautiful, noble and aesthetic, the magnificent collector, the apostle of Plato and Petrarch, of Boccaccio and Dante, the idol of the ladies, in short, one of the men who clung to the skirts of princesses, parading their everlasting sentimentalities under the most perfect, exquisite, elevated form. We have a moring letter of his. Among that numerous bevy of princesses who nourished him on ethereal glances from their bright eyes, there was one he loved, the Morosina, a pure and charming woman, to whom, as Honsignor Beccadelli has said, "he had the good sense to devote himself," 2 and who had given him, in the most common, everrday fashion, a goodly number of children. He lost her. The unhappy man was stricken to the core; his whole being bled. What a state in which to find the divine Bembo, the prophet of the celestial felicities! Death has plunged a knife into his heart. Love-yes, he too had lored. He unbosoms himself to one of his friends, Gabriele Trifon. We were struck with surprise when we first came upon the letter; it was the intimate revelation of a soul; a Bembo of real flesh and blood, grief-stricken, palpitating. "You," he writes, "have soltened the anguish which overwhelms me, in speaking to me as a man, not as a philosopher platonic and divine."

He adds that he has sought to reason with himself, to preach himself lessons of wisdom, to find relief in his passion for work; but the most delightful book slips from his hand. Between the book and his eyes the sweet image re-appears

${ }^{1}$ Some historians have maintained that the love of Henri II. for Diana was purely platonic.

${ }^{2}$ As a prelate and an aspirant to the purple Bembo was tied to celibacy; but he was only in the lower ranks of the clergy so far as actual orders were concerued. 
to him in a mist of tears; and as he makes this confession, tears gush out afresh and soil the paper, his heart is stripped bare; the whole man is before ns. "I have lost the dearest heart in the world, a heart which tenderly watched over my life, which loved it and sustained it neglectful of its own ; a heart so much the master of itself, so disclainful of vain embellishments and adormments, of silk and gold, of jewels and treasures of price, that it was eontent with the single and (so she assured me) supreme joy of the love I bore it. This heart, moreover, had for vesture the softest, gracefulest, daintiest of limbs; it had at its service pleasant features, and the sweetest, most graciously endowed form that I have ever met in this country. I cannot forbear lamenting, I cannot but curse the star's that have deprived us of enjoying each other in so innocent a life."

What a singular underside of platonism! What a warmth of grief! Where are all the platonic paraphernalia-the beautiful ladies all smiles and ice, the careless disdain of physical beauty, the adoration of social life, the horror of solitude? Where are the many-faceted phrases, the philosophic dissertations? Bembo has turned pious like all the unhappy; he will not aceuse Providence mujustly ; though it has snatched happiness from him, he gives thanks for the happiness enjoyed. But sentiments are not snapped in a moment-sentiments "which with time have rooted themselves so deeply in our humanity that 'twould seem impossible to cradicate them." He writes, effusively, thanking the friend whom he knew to have been bound by genuine friendship "to this beantiful and precious lady." He speaks of the children; he will care for them, since he is their father, and becanse ere she died the Morosina, having fulfilled her rehigious duties, had faintly whispered these words, which piereed his soul like a hot iron: "I commend our sons to you, and beseech you to have care of them, both for my sake and for yours. Be sure they are your own, for I have never done you wrong; that is why I eould take our Lord's body just now with soul at peace.' Then after a long pause she added: 'Rest with God,' and a few minutes afterwards closed her eyes for ever, those eyes which had been the clearshining faithful stars of my weary pilgrimage through life."

Ah, these tears! They had hearts, then, these fashionable platonists. Never in any of his fine discourses has Bembo 
touched us, nor even (if we may say so) rejoiced us as by this simple stifled cry, these tears of solitude. He is prone upon the earth, having lost the wings that bore him on from flower to flower.... Four years after the death of the Morosina, we find that, despite his good resolutions and the counsels of his friends, he is as profoundly crushed as on the first day. He seeks consolation from poetry; he has begun a canzone on the death of his "fair and good Morosina"; he has finished the first strophe and sketched out the second, and he sends these still formless attempts to his intimates, to show them all that his feeble faltering hand can accomplish.

To sum up, the great moral movement of platonism resulted in a wide dissemination of sensibility, and a general softening-a softening of virtue and vice, of women and men. This was no small thing; there is certainly an advantage in cutting the claws of men but scantly idyllic, and in doing nothing rather than in doing ill.

This softening was often only external, and not without an admixture of hypocrisy. But why deplore it? For men to appear worse than they are is no proof that they are better. Men showed signs of sensibility, even though they knew little of love. Under a mask of amiability and tenderness their egotism remained intact; they talked of contemplation, of devotion, of the worship beauty required,-without conviction, it may be; but then they might have employed their time worse, and they unconsciously contributed to spread salutary ideas. One of those ridiculous creatures who spent their lives in haunting their idols like a shadow, perceived with horror that on entering a church his lady refused alms to a beggar. He was so deeply shocked that one of his friends had much ado to prove to him, while chating him back to life, that the beggar was ill-bred, importunate, impudent, and unworthy of assistance. Here at any rate was a man of sensibility.

But an untoward thing happened. In cultivating sensibility to the utmost, women enfeebled men instead of forming them. Anne of France undoubtedly foresaw this danger when she so ardently commended vigorous and matter-offact occupations, and uttered a warning against the abuses of the religion of beauty. Many other ladies, unhappily, 
genuine artists in refinement, took a complacent pleasure in the very perfection of their conduct, with the result that always ensues in such cases: their art became degraded, and in sinking into a matter of routine, came to ruin. In true love there is, as it were, an outpouring of one's nature, a vivifying joy, a sort of intense feeling which strengthens; but in love in the more vulgar sense there is a spurious and meretricious poetry which enervates. An old French proverb ran: "When the woman rules the man, he hasn't much will of his own." This the anti-feminists repeated, with too much reason. "Ah yes!" cries Nifo, "tis in good sooth a fine dream of yours. What a magnificent moral state if all men loved one another! No more war, no more crime! . . But is that the result you have obtained? You have distilled I know not what mawkishness. Where are the energetic, young-witted, happy, high-minded men born of your affections?" And what was the age of love which was to spring from this generation?

We cannot impute to platonism the creatures of watery blood and hang-dog look who were to form the nucleus of the court of the Valois-these Panurges, false from top to toe, who had early wasted their substance physical and moral-these young tired-eyed voluptuaries whom Lotto paints so well, too weak to pluck the petals of a rose, their hand on their heart as though to point out the source of the mischief. But alas! we cannot but ascribe to sheer gallantry the mob of carpet knights, pale-faced, gilded cap-a-pie, gay ornaments of tourneys, sleek and fawning, ready like Ariosto to sing imaginary exploits, "provided that beauty, which every hour robs them of some fresh portion of intelligence, leaves them enough for the fulfilment of their promise." They are rigged out as elaborately as the ladies, if not more elaborately (save that instead of displaying the bosom they display the leg), with flying plumes; in winter, smothered under furs; in summer all unbraced, not being able to endure even a loose garment; loaded with diamonds, so that you would take them for walking showcases of the king of Naples or the duke of Berry. They are philosophical, in the sense that they soar high above ideas of patriotism, and prove it by disguising themselves in costumes of all nations, the Turks included. They are learned, that is to say, they think it smart to stuff the French language 


\section{THE WOMEN OF THE RENAISSANCE}

with heteroclite words, as though eager to tear from it its pith and heart, and make this also a delusion and a snare, as universally acceptable as blonde wigs and padded busts.

The great, wonderful reform effected by platonism in the higher ranks of society was-that the men, copying the ancient sages and the orientals, let their beards grow! Up till then, no man could pretend to strle unless he shared, or even, for the sake of greater perfection, depilated his chin; there had been one cry of horror when Cardinal Bessarion appeared with his beard at the court of Louis XI. But now that Castiglione, the Roman prelates, and the high platonist society sported the philosophic beard, there wis a sudden craze for going unshorn among the young suobs of Louis XII.'s court, - the Bonnivets and others.

This reform, strange to say, excited between the higher and lower clergy one of the most acrimonious disputes with which we are acquainted. Vicars and curates belaboured the bishops with texts against the beard. The prelates parried with abstruse disquisitions; they claimed that a good beard did no offence to honour and probity; they sifted the sentiments of the ancient Romans in regard to the beard and found them in sympathy with their own; they made out that the apostles had never dreamt of shaving, and proved to demonstration that a decree of a comeil of Carthage, appealed to by the lower clergy, was an interpolation, and in any case was of no authority, the infallibility of the Church not dating back so far; and a decree of Alexander III., which they were also clamorous about, applied only to the hair of the head.

For the other part, to say nothing of the beard of Julius II., one only had to turn over the leaves of church history to find on every page bearded saints, sometimes of high eminence; bearded hermits, strangers alike to the care of the body, to Plato, and to women. The dispute occasioned a terrible waste of eloquence, erudition, vivacity, irony and earnestness. It was of the highest importance, and bore on the mont sacred interests of what some eminent personages called plittonism.

I Before hecoming pope Julius had shaved. It was during his pontificate that the discussion waxed hitter. Clement VII. lent his name to the tratate l'ro acerdotum barbis of Piero. 
And now it cannot fail to be asked by what strange and cruel logic a century, cradled at its birth in the idea of the beautiful, of love and happiness, was to become a hotbed of hatred, the arena in which the most savage animosities were implacably to contend. Must we believe that in throwing down the barriers of a rigorous code and invoking liberty we must inevitably bruise ourselves against force, rendered thereby freer and more ferocious? That would be a sad and disheartening conclusion, for then we should have to consider human progress as a perpetual recommencement, seeing that, though the lawless rise insurgent against tender hearts, though gospel wisdom warns us of the eternal despotism of the violent, there are still found and will ever be found among us incorrigible wretches, hungering for sympathy, and unable to live without a ray of love. 


\section{CHAPTER III}

\section{INTELLECTUAL INFLUENCE}

Wones approached intellectual questions in the same dilettante spirit as questions of affairs; and this dilettantism was their chosen method. It was waste of time to speak to them of discoveries, creations, speculations, ventures, struggles-of the scientific furniture of life, of all the irksome material tasks on which the intellectual existence itself is based. They sought only to crown the edifice with happiness, which does not concern those who clear the ground. ${ }^{1}$ La Bruyère fancied he was saying a very cutting thing when he declared that "women are cured of idleness by means of vanity and love"; it is really very amiable ; would to heaven the same might be said of certain men! Women are cured of idleness by sentiment; they reason with their feelings. You must not ask them to pry and delve into the stubborn heart of things; they look at the bright surface, and penetrate what yields to the touch. And by this simple method they perceive things that escape the microscope, things that defy analysis, thanks to an intuitive impressionability which enables them to see rather than to know, and which would be wholly admirable if it were never misused. Further, they have a marvellous and mysterious talent for expressing their enthusiasm; a phrase feelingly quoted by a lady strikes our mind with a quite peculiar force when we afterwards come upon it in the pages of a book. Again, they love the men

1 "Well may a piece of marble raise your titles as high as you list, because you have repaired a piece of an old wall, or cleansed a common ditch, but men of judgment will never do it." (Montaigne, III. x.) 
who love what they love. How strong and firm a bond is a common love! And how delightful to make mind the handmaid of love, and perhaps even to make love the handmaid of mind! To live happy, what does it matter whether you have an exact knowledge of a peacock's or a nightingale's anatomy? Similarly women do not want you to pull words to pieces and set them in accurate alphabetical order, but to place them in a living order, so as to draw from them their vital force. As they ascribe everything to love, and believe the establishment of a balance in human affairs absolutely necessary, so they think also that their duty in intellectual matters is to foster men's productivity, their beautiful art is concerned with men. Hence they do not trouble to investigate very profoundly the secret significance of surrounding nature; it is of little moment to them whether an artist seeks to reproduce natural forms with photographic fidelity-which is in any case impossible-but they insist on a general resemblance, they require the artist to indicate how a tree or a landscape reflects itself in man, and what impression it produces. In a word, they charge themselves with the mission of elevating our views, whether by developing by means of artistic sensibility the ideas that lie in germ in material nature, or by constantly renewing our thonghts by means of a liberal philosophy.

The Italian women who at the end of the 15th century devoted themselves to this intellectual programme were legion; or rather, they all did so. There was no maiden, however modest her station, who did not consider herself in a measure responsible for the future, and who did not make real preparation for becoming the intellectual queen of a salon, or of some sort of home of her own, while her husband attended to his external occupations. And when her parents were happy enough to detect in their little daughter the mysterious spark of the beautiful, far from mistrusting it, they welcomed it with rapture as a sacred gift of Providence and left nothing undone to develop it. Signorina Trivulzi, a spoilt child of fortune, was in all seriousness thus "consecrated" to the Muses at the age of fourteen.

Impressionability is a gift of nature; but that does not imply that there is no need to strengthen it by means of 


\section{THE WOMEN OF THE RENAISSANCE}

an earnest intellectual culture. People were only too well convinced of the necessity of this precaution when they saw women who were impressionable and nothing else spinning round like weathercocks. The Italian ladies of the classic generation had known how to take a firm stand and a steady hold on life, so that they united to perfection the eminently becoming qualities of solid intelligence and modesty with an ardent impulse towards beauty in its philosophic, religious, or artistic form.

If examples were necessary, our only difficulty would be to choose among women like Cassandra Fideli, Costanza Varano, Isotta Nugarola, and many another worthy of honour. There is little risk in our indicating among the queens of the period Isabella d'Este, marchioness of Mantua.

Isabella, who was born in 1474, and died in 1525 , belongs in time to the earlier generation, of whose characteristics she was thoroughly represenvative; that is to say, along with a transparent soul, a heart full of passion, and a quick intelligence, she retained virtues which were to become rare -individuality of mind and sureness of taste. She was not one of those impressionable women who are inevitably caugight by the glamour of established reputations, and who urge men on to achieve a noisy notoriety; she could form her own estimate of things, and become the originator rather than the follower of a movement. She travelled frequently and to good purpose; her friends and agents, scattered as far as the East, kept her informed of every event which might have any bearing on the cult of beauty, such as the bringing-out of notable books or fine editions, the works issued from great studios, excavations, sales of collections. At the sale of the celebrated Vianelo collection at Venice in 1505, she followed with the liveliest emotion the bidding for a certain Passage of the Red Sea by Jean de Bruges, which she passionately coveted, and which Andrea Loredano remorselessly ran up to a hundred and fifteen ducats. An antique Venus which much occupied her thoughts happened unluckily to be in too good handsthose of Caesar Borgia; but Caesar was not immortal, and one day the Venus rejoiced the heart of a new owner, the duke of Urbino. Before long Cardinal d'Este had willy- 
nilly to gird up his loins in pursuit of it. (What a lucky windfall the sack of Rome in 1527 was to collectors!) The marchioness, at the moment, emptied her purse, indeed, rather more than emptied it,-always pretty easy to her; she had to charter a boat to carry off all her treasures, but alas! the boat was seized by some rascally pirates, and was never heard of again! For all these little vexations, those were glorious days! One person's calamity was another's opportunity, and as the result of the growth of culture, a stone newly unearthed, a well-turned verse seemed diamonds of happiness.

Isabella was a royal, frank, delicate patroness of the human intellect. She cherished in undisturbed harmony around her the Sleeping Cupid of Michelangelo and a choice collection of antique statues; she covered her walls with the works of Mantegna, Costa, and Correggio; Leonardo da Vinci and Titian were her portrait painters; she herself painted her soul in two words: "Neither by hope nor by fear." As an ideal for life and an emblem for her house, she commissioned of the great idealist master Perugino a Combat between Love and Chastity, ${ }^{1}$ and wished to arrange its composition to the minutest details; but poor Perugino, whose soul was as simple and unspoiled as his head was thick, got a little befogged in so intricate a scheme, so utterly unlike his usual Madonnas; and for all his good will, perhaps he did not on that occasion produce his masterpiece.

In France, the notable women of the generation of Isabella d'Este did not plume themselves on playing a similar part; they rather avoided it, whether because as partisans of physical activity they feared to carry too much dilettantism into life, or because circumstances did not strike them as favourable. Queen Anne of Brittany, in spite of her surname of "refuge of learned men," never regarded art as anything but a royal and magnificent supertluity. Anne of France made her court a veritable nursery-garden of literary men and artists; many works of real magnificence were added to the library at Moulins; but Moulins did not radiate an influence like Mantua. It was only the next generation that saw the appearance of women of the Italian type, those queens of the intellect of whom

In the Louvre. 


\section{THE WOMEN OF THE RENAISSANCE}

\section{Miary Stuart was to leave us the enchanting memory -Mary, to whom Ronsard could say without undue exaggeration-}

Le jour que vostre voile aux vagues se courba,

Et de nos yeux pleurans les vostres deroba,

Ce jour, la mesme voile emporta loin de France

Les Muses qui souloient y faire demourance.

Depuis, nostre Parnasse est devenu stérile ;

Sa source maintenant d'une bourbe distile ...

Son laurier est séché, son lierre est destruit !1

Then the taste for pure art and the influence of the South towards preciosity came in with a flourish of trumpets. The first French Renaissance, in close contact with rural traditions, had devoted itself mainly to the development of force of intellect. It had attached only a secondary value to the worship of form and to external beauty; persons who composed verses, like Charles of Orleans, did not proclaim the fact. Classical relations were established with ancient Rome, the city which drove its iron into the soul and le th indestructible landmarks on the soil of France. A ready assent would have been given to the saying of Seneca: "There is only one art that is truly liberal and makes a man free, and that is the study of wisdom; all other arts are base and puerile. ... I cannot give the name of liberal arts to painting, statuary, and the decorative arts."

This prejudice was persistent, with the result that, even while yielding unreservedly to the religion of beauty, people could not bring themselves to grant the plastic arts the same pre-eminence as in Italy. Moreover, even in Italy, painting had had much difficulty in securing a footing: many people at any rate gave sculpture the preference, that being plastic indeed, but less decorative, more scientific, durable, and complete. The comparison served as a theme for jeux d'esprit. Some people amused themselves with

1 The day thy sail dipped to the dancing brine,

And from our streaming eyes robbed sight of thine,

That fatal bark bore far from weeping France

The Muses erst who dwelt there-sad mischance!

And now Parnassus thrums a tuneless lyre,

And Helicon distils an ooze of mire;

Our laurel is all parched, our ivy sere,

Our song-birds stint their singing-thou not here! 
defending the superiority of painting, by calling God the first of painters, the sublime decorator; others carried the paradox to the point of demonstrating that painting is necessary to war, if only for drawing up plans or making sketches; that it evoked the enthusiasm of the greatest conquerors, like Alexander the Great, and Demetrius, who relinquished the siege of Rhodes rather than risk setting fire to a district of the city where a picture by Protogenes might have perished in the flames. In reality the Italians were fond of painting because they found in it one of the most tender and delightful forms of poetry. Castiglione well expressed this feeling to the sculptor Cristoforo Romano: "It is not my friendship for Raphael that leads me to prefer painting: I know Michelangelo, I know you, I know all these masters! But I find in painting a marvellous charm; it has its plays of light, its chiaroscuro ; it demands as much skill in design as sculpture, and offers special difficulties in regard to foreshortenings and perspective. It gives us the colours of reality; it renders more satisfactorily the flesh, the eyes, the sheen of armour, the delicious golden hues of hair, the radiance of love. It alone can speak to us of Nature, reproduce for us the starry skies, the burricanes and tempests, the rosy dawn, the earth and sea, hills and woods, meadows and gardens, rivers, cities and houses."

Among the French, on the contrary, the triumph of aestheticism led to the lowering of the plastic arts in general esteem; painters, sculptors and architects no longer received the same personal and affectionate support from high-born ladies as formerly from Anne of France or Anne of Brittany; they lost caste at the court of Francis I., and gained nothing but higher wages; they were treated rather like house-decorators or upholsterers. People applied to art the general principle: Seek ye first intellectual beauty. All were agreed that thought must be worshipped in its highest possible purity; and as thought nevertheless needs a material vesture, poetry was its fitting garb, as "daughter of the skies"; and consequently the movement followed a bent almost exclusively literary and philosophico-poetical. It is hardly necessary for us to say that we are here confining ourselves to the sphere of feminine illusions. No one disputes the beneficial effect of mountain air on certain 


\section{THE WOMEN OF THE RENAISSANCE}

complaints; but it would be exceedingly tiresome if all mankind were condemned to live on the summit of the Righi.

Margaret of France set herself in opposition to these Alpine ladies, who took such delight in the ever-receding altitudes of the intellect. She was driven to adopt this attitude of temerity partly by her position. As sister of the king, she had to fill the part of "queen of the sex," and so far as higher matters were concerned, it appeared natural and right that her brother should follow her advice. ${ }^{1}$ This explains why the poets so decorously did homage to her : "heroine of the age," they called her, "mind and knowledge in person ... fllower of flowers, the choicest of the choice . . less human than divine."

Apart from the inconveniences of too lofty a station, Margaret suffered from those arising from her training, having like many women the misfortune of being particularly sensible to influences; her flights are often those of someone else. She remained unswervingly faithful to the habits of her childhood, in other words, to a brilliant and sceptical environment, in which ready wit was regarded as the supreme gift, and liberty consisted in seeing everything, reading everything, hearing everything from a detached eminence, superficially, and without caring for anything in particular except the satisfaction of a sense of form. The only dogma tenaciously held was the pre-eminence of women, and it was an accepted maxim in that society that one woman of real accomplishment conduces more effectually to human happiness than all the lumber of sciences and all the litter of books.

Margaret was thus a. philosopher, generous and variable, sceptical and enthusiastic, somewhat visionary, because the speculative spirit spells freedom and distinction. But she

${ }^{1}$ Prince Françoys, veulx tu, comme seigneur

Supérieur, estre dominateur,

Prans pour faveur, par amour et mérite,

Celle qui est en florée verdeur,

Digne d'honneur, nommée Margarite.

[Prince Francis, if thou dost desire

To rule indeed as lord and sire,

For love and worth in favour set

Her who is filled with youthful fire,

Deserving honour, Maroaret.] 
was lacking in that ballast of serious studies ${ }^{1}$ which, after all, alone permits the development of one's personality.

Thus lost in the clouds, unstable and vacillating, in reality she took no one intellectual party under her wing; she smiled on everything that was beautiful or pleasant, in other words, on every means of acting on men. She was fond of the music of that period, a wholly psychological art with very little to tickle the ears of the groundlings, but speaking to the soul; she loved any product of the intellect provided the setting was worthy of the gem-ribald stories if they were witty, the drama, lofty speculations on the emotional life, thoughts of divine love, the religious contemplation of God. All these manifestations of the soul, so little alike, she regarded as forming a single philosophic chain, a chain of beauty leading up to God. This idea enabled her to link together conceptions which appear to us disconcerting in juxtaposition, and which her contemporaries themselves were at a loss to reconcile.

Her patronage was above all an art, the art of playing upon the human intelligence as on the finest of keyboards, as on a magnificent and genuinely divine instrument, and of drawing from it the grand harmonies of which it is capable, the tones with which the Supreme Artist has endowed it. Here she strikes a grave and profound note, there a note shrill or thin; she sets men vibrating. "What!" she seems to say, "they say that love deadens! No, no! People of feeling may find their joy in their own natures, but that does not hinder them from finding it outside themselves." Bouchet and Rabelais, two men of the traditional school, were dependents of Margaret, as well as Charbonnier and Marot, the poets of the day, or Du Bellay and Ronsard, the poets of the morrow. Surrounded by Catholic prelates, herself the intellectual lieutenant of a king hostile to the Reformers, the princess interested herself in everything: Lefèvre d'Etaples and Vatable discussed the Bible with her, Nicolas Mauroy translated the Psalms for her; Jean Brèche translated Plutarch, and Le Masson, Boccaccio. Her own intellect volatilised itself, and was content to perfume the atmosphere.

1 This is especially noticeable in her first work, The Mirror of the Soul, which she modestly called the work of a woman "who had in herself neither science nor knowledge." Besides, she employed a good secretary. 
It was the same in regard to persons; she admitted to intimate fellowship with her the most diverse personages provided they were able to love; and freedom of sentiment was apparently the essential condition of life. Moreover, the intellectual life had not yet assumed the rectangular and rigid forms under which we know it; and as people were particularly eager for impressions, they were on their guard against all the checks by which we so cleverly destroy them. A ruined wall was a ruin, moss and neglect were part of its being; no one dreamt of scraping it, ticketing it, surrounding it with an iron fence and a ring of pebbles. An ancient monument showed itself as it was, covered with all the vegetation which gave, so to say, artistic expression to the life of succeeding generations; no one dreamt of rebuilding it as it originally stood; objects of art were objects of art, which people left in the places they were made for, well in view and fittingly displayed, instead of carting them away and piling them up in gold frames and lifeless desolation on the walls of a museum.

To understand the intel ectual dilettantism of Margaret we must steep ourselves in these ideas of liberty and life, which are so alien to our modes of thought, and which even then were on the point of disappearing. Margaret loved to make an emotional impression on others, but she was not at all anxious to guide their reason, any more than she was anxious to be guided herself. Her zest for liberty, pushed to its extreme limit, went almost as far as anarchy. What a singular intellectual harem was hers! Here was a gay dog whose humour had a touch of obscenity; there was a dear friend, the protonotury D'Anthe, author of witty trifles particularly wanton, for insuance the Blason d'une jeune fille, which we could hardly venture to reproduce; or again, in an entirely different direction, the oppressively virtuous Lavardin, a mighty fang-extractor, whose special duty was to expurgate improper books; or the squeamish La Perrière, who was a century behind the times, apologised for employing the names of mythology, and had the worst of all defects, that of being a bore. These various minds, working symmetrically, produce somewhat the same effect as those many-paned mirrors set revolving by an invisible hand, which might flash for ever without luring an eagle, but are very serviceable for catching larks. The defect of 
this society was that it attracted second-rate personages, pushing men, notoriety hunters. Moreover, platonist society had always a strong tendency to degenerate into snobbery; it had too much worldliness of character not to suit drawingroom intriguers and men who knew how to get on in the world. Platonism knew nothing of the modest and intelligent men who kept in the background to enjoy the human comedy. This defect amused Castiglione: "To be learned," he said, "you must belong to the learned set." The result was sometimes amusing blunders; through being attributed to the wrong author a poem or a piece of music would be received with hearty applause, but afterwards, when better informed, the applauders would hiss, or vice versa. It is the same with everything: wine is good or bad according to the label; Castiglione guarantees he will present you any fool and get you to believe him a genius. ${ }^{1}$

Margaret of France had a taste for notoriety, and sought to bring together all the men who could voice the various opinions of France. She showed them so much affectionate attention that each believed himself to be the favourite, and every cause looked on her as an adherent; to this day, after three centuries and a half, the witchery of the princess remains so potent that everyone loves her and lays claim to her; the platonic think she was a platonist, Rabelaisians rank her as one of themselves, Protestants call her a Protestant. She contented herself with disseminating love, with reconciling and discreetly moderating bitter differences without ever bemoaning those which had brought suffering to herself. It is a singular thing that at a distance she is sometimes taken for a domineering, masculine bluestocking, one of those women who shake men as the wind shakes the trees, stripping them of leaf and blossom; whereas near at hand she was all softness and loving-heartedness. The most ardent declarations brought no frown to her brow (and left her heart untouched); she pardoned them, laughed

${ }^{1}$ Another anecdote of the court of Urbino. A Bergamese peasant had just entered the service of a noblemian. The princesses were told that there had arrived a retainer of Cardinal Borgia, who was a fine musician, a dancer, and a great oddity. They fetched him in, welcomed him, sat him down among them, and lionised him with great respect. Unhappily the good man spoke an indescribable jargon. The author of the trick made the princesses believe that he was shamming the Lombard peasant for fun. The scene lasted a rather long time, while tlose in the secret were splitting their sides. 
at them, sometimes received them with a smile of pleasure. Thus a nobody named Jacques Pelletier permits himself to call her "the half of my soul," and boasts of her "bittersweet favours," by which he means tender and coy. But Margaret for all her bashfulness does not care for bashful men; she prefers energetic and robustious men who set the pulses beating, who even make themselves tiresome and are not incapable of follies. A certain M. de Lavaux swears he will die if she does not take pity on his martyrdom; she promises him an admirable De Profundis. The amiable Hugues Salel praised her pretty hand in extremely graceful little verses ; $^{1}$ she sends him a pair of scented gloves and a bracelet. But she never forgets Marot; beyond thetomb, when all follies are over, she still proves her sympathy for him.

Apart from this spirit of love you will probe the depths of her soul in vain; there is nothing else to be found.

Margaret has photographed herself in her dressing-gown, surrounded by her intimate friends, in the Heptameron ;

${ }^{1} \mathrm{O}$ main polye, unain divine, Main qui n'as ta pareille en terre, Main qui tient la paix et la guerre...

Main portant la clef pour fermer

Et ouvrir l'huys de bien aymer,

Main plaisante, main délicate,

Je n'oserois te dire ingrate.

Tu peulx blesser, tu peulx guérir,

Tu peulx faire vivre et mourir.

[O fair smooth hand, $O$ hand divine,

Hand never match'd on earth before,

The arbiter of peace and war,

That bears the key to lock or loose

The door for happy lover's use,

$O$ pleasant hand and dainty, ne'er

To call thee thankless conld I dare.

"Tis thine to wound and thine to heal,

And thine both life and death to deal.]

2 The question has often been asked whether the Heptameron is a work of imagination, or whether it should be taken seriously. After the labours of MM. de Montaiglon, Franck, and Gaston Paris, to speak only of the principal authorities, there can be no longer any doubt. Margaret, like Castiglione, certifies in a general way the veracity of her stories. She worked at this collection for several years, beginning probably in $\mathbf{1 5 4 5}$, and with so much eare that in 1549 , when she died, she left it incomplete. The Heptameron then is not a juvenile work, but the testament of her court life and her philosophic career, and an autobiography, since several anecdotes relate to her, her brother, and her intimate friends. Moreover, among the large number of manuscripts she left in her portfolios, Boistuau (another strange character, to judge by his works!) chose this one to 
the authenticity of the portrait is guaranteed by herself and her danghter. And what strikes one most forcibly in her doctrine is a pretty style and an excellent solicitude to avoid dulness.

Her gospel was, in heaven God, on earth Francis I.; after them the Beautiful, in which she believed with all her heart as the source of all goodness and all truth. So far as happiness was concerned, she boldly steered for love, which she regarded as the port for the Good and the True. But she had little faith in passion, and confined herself to drawing a most careful distinction between sentiment, which she praised, and sensation, which she condemned; her system was built up on casuistry. She thought that a woman might frankly accept the offer of a virtuous and perfect love; if the man secretly harboured any carnal design, so much the worse for him! Having never loved deeply herself, while on the other hand she had heard so much talk of love, she believed that love was not fatal and that a woman was by no means bound to push charity to the point of absolute self-sacrifice. But remember, she did not commingle the ideas of love and marriage, which were absolutely distinct. As no one can love God without first loving one of His creatures, her design was to lure men thus towards the perfect love of God, and then towards a mystic and philosophical contemplation of the Godhead.

Unluckily, she did not reach her goal, or even get within sight of it. Not for want of ardour: it may well be said of her: "Woman is a flame flaming for ever." For Bonnivet, "even in their ashes" lived her "wonted fires," lighting up in him the happy memories of youth. She spoke with fervour, overwhelmed the sceptics with biting taunts or lofty deductions, stimulated the timid by a cheering word, a flight of sentiment. But she wore herself out in this perpetual skirmishing; what she lacked was the will and the intellectual power to effect a sharp, decisive stroke.

As for those on whose conversion to the system of beauty and love she uselessly spent her strength, she got little satisfaction from them.

publish under the title of History of Fortunate Lovers, with some touching up, and a few excisions he thought it well to make in certain risky passages. This precaution gave offence, and Margaret's own daughter took care to get a new and authentic edition published, two years later. 


\section{THE WOMEN OF THE RENAISSANCE}

Attached to her car she dragged along two lovers, who ought to have been the apostles of her philosophy. In reality these very men resisted her.

One of them, the steward Jean de Montausé, an excellent type of official, gallant, frank of speech, amiable in manner, and infinitely courteous, never succeeded in realising the transcendent and virtuous object she had in view. Learning, he finds, is turned to bad uses: religion he respects on principle, without studying it deeply, and laughing in his sleeve at certain mysteries; but virtue he recognises in Madame de Montausé (he is married), not elsewhere. How Margaret exclaims at him may be imagined! Louise of Savoy takes Montausé under her wing.

The other lover, Nicolas Dangu, bishop of Seez, possesses all the princess's affection. He follows her to wateringplaces, sentiment oozing at every pore. $\mathrm{He}$ has good sense, modesty, and so eminently conciliatory a spirit that he does not deny intelligence to monks and the common people; he even has a profound admiration for the genius of certain malefactors. What a delightful creature is the genuine platonic prelate, so polished, so amenable! How tender, how honeyed, how bland! But he too opposes an almost insurmountable obstacle to her philosophy in practice; he dares not love her love, think her thoughts; he does think, but it is of dying of love, and he has a thousand ways of doing that. He is always dying; he would die rather than say a foolish thing or betray a secret; he dares not put woman's love to the test, for fear of finding it wanting; if it proved real, he would die of joy. He gets angry with Henri d'Albret, but personally seems quite content with what he has not got; he is the perfection of wisdom and prudence! Yet he gently insinuates that too coy a virtue may become cruel. Margaret is a little troubled; she replies that before she can trust men she requires good sureties, and meanwhile she forgives Dangu's rash speech because he speaks well of women. That is all she has been able to get out of him, the perfect platonist! But that also is all she gives him.

This social governance, then, does not go to the heart of the question at issue, and does not even convert those who from the first were apostles of the dawn, still less the ${ }^{2}$ So we identify "Simontault," [one of the raconteurs of the Heptameron]. 
indifferent, the soi-disant serious men of the world who are met with almost everywhere. The Heptameron presents us with several types, eminently true to life, who clearly show that conversation is not to be relied on to propagate the philosophy: a trim little widow, Madame de Longray, infatuated about her dead husband and very bewitching to other women's husbands, a veritable scatter-brain in all purity and honour; Mademoiselle Françoise de Clermont, ${ }^{1}$ a plump little soul, a bit of a goose, who loves naughty anecdotes, but is extremely shocked at the naturalistic theories of Henri d'Albret and Louise of Savoy; the hoary Burye, who has lost all his illusions with his teeth, convinced by experience of the necessity of platonism, without feeling the want of a brand-new deity expressly manufactured for him; Mademoiselle de Clermont calls him "Old Father Virtue." Then there is the mother of the famous Brantôme, Anne of Vivonne, ${ }^{2}$ the fin de siècle woman, a friend of canons, but a foe to monks; virtuous in principle, but so kind, so very kind! She cannot understand how a woman can live without being loved; she can refuse nothing to anybody; she has a warm affection for St. Magdalene.

"Saffredent," a well-preserved white-headed beau, cannot make head or tail of all the new theories, and does not mean to. They humiliate him. Do people take him for a mummy, a valetudinarian, a blown-out salamander-for one of those golden-tongued Italians who are all tongue and nothing else? For a dull student with no wants beyond his waterbottle and his cook? He is a knight, esteems only valour and daring and integrity. His speech is like a clarion-call; true virtue, he maintains, consists in loving according to the law of nature,--in loving one woman with all one's heart rather than in idolising thirty-six on paper. Use is better than abuse. At this unkind and clinching phrase there is a general outcry, and Madame de Longray sighs.

Philosophy limits itself to these extremely superficial passages at arms. Margaret takes pleasure in them; she resembles a blue, transparent sea, chafed and rippled by the sportive breezes, every moment glistening and changing form; but the wind is not set nor the sunlight steady.

1 Thus we identify "Nomerfide."

2 "Ennasuite." 
She has left us a large number of writings, in which we might at least hope to find or to seek for a more definite groundwork of ideas.

M. Le Franc has devoted himself to the difficult task of examining them all, and in these, again, he has found something of everything-philosophical mysticism, solemn farces, pious impieties, moralities half moral, aristocratico-democratic diversions. The only note common to all is a profound sense of the emptiness of things-which has nothing in common with happiness! Sometimes through the most magnificent fantasies one catches sight of a big rolling tear. Margaret tells us that she knew three lives: a life of love, an intellectual life, and a life of contemplation. But she is lost, as it were, in the desert of her thought, and when her god on earth, the big, jovial, sensual Francis I., dies, she breaks down altogether, and falls back almost desperately upon religion with its terrors.

Life is an instrument of vulgar joy, which exalts only those who humble themselves; Margaret's mistake was in wishing to remain always on the heights.

Her maxim was to distinguish flesh from spirit, "darkness from light," and to love love for love's sake: "Thy love loves thee." But, apart from the fact that these ideas were not absolutely her own, and that the second already denotes a declension from platonism, we are disturbed on perceiving here and there a strange finger-mark. Margaret had for her private secretary and collaborator a sort of scoundrel, a demon of wit, but one who believed in nothing, not even in his "Minerva." On reading the Mirror of the Soul, her first work, and one which betrays the prentice hand, Bonaventure des Périers at once perceived that there was a place to be filled about the author; he plied her with entreaties, and with puns, and thus became a lieutenant of platonism. The princess showed him infinite kinduesses; in his Cymbalum, in which he flouted the only principles on which men were still at one-the existence of God and a few truths of elementary morality-Des Périers was mean enough to hold her up to ridicule; he represented her as seeking to imbue poets with a "chaste and divine" spirit, aud sending to Pluto (with a $u$ ) to ask at once for news of the painter Zeuxis and for patterns of tapestry. ${ }^{1}$ Margaret

'Margaret excelled in artistic needlework. She made a piece of tapestry, 
forgave everything; she granted the villain a "prison" in her house, and tried again to improve him by setting him to translate the Dialogues of Plato. But Des Périers, not finding in them the secret of happiness, escaped for good and all by suicide in 1544, and Margaret once more showed her pity by patronising a posthumous edition of his works. That was the man who had doubtless a most intimate part in the composition of writings which he heartily despised, and which he called a "Pactolus of verse and prayer." $\mathrm{He}$ boasted of being their "miscreator," and in offering one of them to the author he said, with matchless impudence, "Here is your immortal book, and you will find my faults there."

Thus, if you come near Margaret of France, who appears to govern everything, you find nothing but a mere dilettantism, a manifestation of intellectual epicurism, which influences either ideas or the expression of them. She fixed her eyes not on truth, but on happiness.

As a guiding force Diana of Poitiers showed more precision and vigour.

Having innumerable reasons for leaning less towards the Medici, with more physical beauty than Margaret, more highly endowed in respect of will, she did not devote berself exclusively to the cultivation of the intellect; she loved all the arts, the plastic included, in the good old way. She had a pretty skill in poetry, and appreciated books, especially beautiful manuscripts and tine bindings. She had in her library the Bible, the church Fathers, and books on mystic theology, alongside of her favourite romances, particularly the Amadis, which she recommended to the King; to these, as an eminently practical woman, she added books on medicine and natural history; no philosophy to speak of; a copy of Politian, a few treatises on history and geography, a Plutarch, a fair amount of poetry. For her, Philibert Delorme built Anet, Jean Goujon wrought sculptures for it, Jean Cousin, Leonard Limosin, and Bernard Palissy decorated it. She was in fact a French counterpart of Isabella d'Este, a marvellous type of the "lady art patron." Without aiming at the quintessences of pure love, she really and practically laboured to elevate the cult of beauty.

representing a high mass as perfectly as a picture could have done. While she plied her needle, she liad near her someone to read to her, or a historian, poet, or writer of some kind to talk to her. 
Women who feel within themselves the power to bear on the sacred torch and to draw minds directly towards the idea of the beautiful certainly ought not to hesitate. But after all, to appreciate art in its practical results, to criticise it, to support it by one's approbation, is a very noble end, and one suited to any woman, however retiring. History and experience show that these practical influences are often the most effective. This secret society, that religious association accomplish more by simply living their creed day by day than by all your dogmatic teaching. What extraordinary power might not women wield if they were all animated by one spirit urging them towards a common end! And what a noble end-to sustain in the world the healthful principles of beauty, to fill the life of men really and truly with things they can love! To assign to art this social mission, to carry out in regard to it this magnificent part of " patron," would be to vivify it! Vivify! Let us say rather save it from itself and its abuses! Art would speedily come to ruin if the whims, fads, and prejudices which creep into the studios were not held in check by the necessity of reckoning with the individual and original ju jgment of experts.

Alas! this is an evil of our present-day society,-this awful slough of commonplace in which we are flounderinga cause or an effect of our moral degeneration and our utter depravity of taste. Big houses built to a specification, decorated at so much a yard, invisibly heated on some patent system you never heard the name of, peopled by lackeys whom you don't know and only see when they open the doors! Dolly women, clothed by their tailors, a pattern or a copy of their neighbours, with the habits of their callers, the ideas of the men they know, and the conversation of their grooms, - with nothing of their very own; not women at all! "People in olden days were so thoroughly, persuaded of the real social necessity of forming "amateurs" that the old Italian educators of the fifteenth century wished men to be brought up with that end. How much more women, who have leisure and an inborn refinement! It is very easy to demand that an object, however simple and unpretentious one may suppose it, should bear a stamp of originality and good taste. Is it not at least possible to insist on simplicity in all things, to banish tinsel and brummagem and all our horrible pretentious magnificence?-to 
seek breadth instead of narrowness? - to give ourselves the pure free air of the Beautiful ?-and further, to put writers and artists in a position to express wholesome things with sincerity, in other words, to see things healthily? It would be foolish, deplorable, fatal to ask them to express what they do not feel; but they must be made to feel what they are to paint. There is here an important task to accomplish, and, to a certain extent, an easy one. Everyone knows how sensitive mental toil, particularly if excessive, makes tho man who devotes himself to it. Taine goes so far as to consider us the direct products of the influences that encompass us! It is certain that we bolrow much from our environment, that the dulness or cheerfulness of the sky, for instance, tinges our thoughts with very different colours; how much more does the sadness or joy of those whom we love! - We must create then for art a good moral atmosphere. And when Castiglione writes: "God is only seen through women," he is not wrong in crying up this spy-glass of his, he understands the need of which we have just spoken; it is as if, on entering a cathedral, he were inviting us to look into the benitier, as if he were showing us a picture in a mirror. There are women's souls, clear, thrilling, passionate, which reflect things with a distinctness and a vividness of colour that would otherwise be unsuspected. And without launching out into speculations as lofty as those of Margaret of France, mere "women amateurs" can play an artistic part of the first order.

As a rule, Fgerias have less need of a transcendent intellect than of an ample provision of good sense, tact, and above all patience, for they may look forward to struggling against terrible temptations.

The intellectual and artistic tribe of the Renaissance was no better than any other. It teemed with crotchety species; it included the usual specimens-the pedant, the man with a grievance, the ingenuous prig, the strutting peacock, the matter-of-fact aesthete always on the look-out for a place or a pension. The proud were always the best, and the least troublesome. Play their cards never so carefully, women found this society difficult to rule; in general, to govern well you have only to make your subordinates discontented, but here you can only reign on condition of satisfying them. 


\section{THE WOMEN OF THE RENAISSANCE}

The first step in the intellectual tutelage consisted sometimes in doing little material services, in a quite friendly and natural way (for you can't live on love). To give "a few crumbs from her table," to aid the friends of her friends, to look after orphans,- -nothing was simpler or less remarkable in a lady: many men would have done as much. Bembo, badly treated by a farmer who owed him two hundred and thirty ducats in "broad gold," did not hesitate a moment to tear Vittoria Colonna from her celestial preoccupations, to beg her to deal with this little matter. To venture on this ground, however, demanded no little caution. Aretino has shown how easy it was to make a simple expression of friendliness an opportunity for self-advertisement and extortion. What a perfect master he was! Titian applied to him for assistance in disposing of a certain Annunciation which was hanging fire. This was how Aretino proceeded. He issued a flaming advertisement, which fairly hooked the Empress Isabella of Portugal, who raked up from her husband's cash-box the sum demanded, two thousand crowns. Aretino instantly unmasked and offered to her "sacred and renowned Majesty his inkpot and pens"; in plain English, asked for a pension. What a fine tooth-puller he would have made!

This Aretino fluttered about Vittoria Colonna, whom he sought to capture through her vanity. "Read my books," he writes to her; "read the Courtesan; you will see if your praises were not always at the point of my pen."

Everybody knows how deeply impressed Aretino always was by the honours of the marchioness, and when his style is defective, there is abundance of will to make up for it. "I have always known you to be of a generous spirit, a magnanimous nature, an active mind, an absolute virtue, a noble faith, a good life. If it were not so, I would have told you."

That was the beginning of the oddest of correspondences. The lady naïvely thought that she could content the monster with fair words; but he undeceived her by the present of a highly seasoned book, with an explicit request for commendation and money. So far as commendation was concerned, Vittoria thought the request very natural ; but the excuse for asking money she thought rather thin. However, she promised sixty crowns, and even fancied she was only acting 
the great lady in at once sending him thirty, accompanied by some gentle advice. Aretino, in his turn deeply wounded, did not quarrel with "the most excellent lady"; he confined himself to dotting the i's. "I have to consider the tastes of our contemporaries," he said ; "amusement and scandal are the only things that pay; people burn with concupiscence, as you burn with an inextinguishable angelic flame; for you sermons and evensong, for them music and the play!" Why write serious books? He had sent one to Francis I. five years before, and was still awaiting acknowledgment; he had just addressed his Courtesan to the king, and by return of post received a gold chain: "after all, I write for my bread."

Vittoria's purse remained shut. Our fine gentleman would have liked to return the thirty crowns; unluckily he had spent some of them, and he sent back only some epigrams. The marchioness suggested that he should give the balance to the poor, hinting that no worldly pelf was worth as much as the love of God. In consideration of a recommendation to the duchess of Urbino, Aretino condescended to keep what was not already spent. "I too," he writes with his habitual impertinence,- "I too am a virtuous and Christian beggar, and deserving of your alms; I do not think the poor of Ferrara, of whom you speak, so poor that you cannot assist one of the poor here, since for you it suffices to be rich in spirit through the grace of Christ."

This little dialogue will show whether women needed an angelic soul to influence for good rarely-gifted men on whom pure love had no hold. But lofty motives must have sustained them; there was really some truth in Aretino's plea; yes, fortune and glory are only reached by devious paths. Little sketches and dialogues in the taste of the day paid Aretino very well, without great labour on his part; a bookseller in the Rue St. Jacques at Paris made his fortune merely by retailing them, and in the simplest way. $\mathrm{He}$ would sell to a lady a book more or less licentious, and as such books are never lent, by and by another lady was sure to pay him a visit. "Madam, here's one that's much worse," whispers the good man in his half Italian jargon, slipping into her hand another very expensive book. It was just the same in the artists' studios; Ledas and 


\section{THE WOMEN OF THE RENAISSANCE}

Venuses went off like hot cakes, but Titian's Annunciation gathered dust on the easel, and Carpaccio had infinite difficulty in selling at so much a foot a religious picture which he considered one of his best.

In France, the position was for a long time not quite so bad, in the sense that the men of letters, excellent fellows who mixed little with the world, esteemed themselves infinitely lucky to receive after solicitation an ecclesiastical benefice which made them independent. One historian becomes incoherent in pouring out his gratitude because a good book, the fruit of many years' toil and travel, has secured him a life-annuity. But this patriarchal simplicity also disappeared in the end. Publishers had to cater for the public, and one curious affair shows us how they tanght authors their trade.

Vérard, the famous publisher whose magnificent productions are still a joy to connoisseurs, had agreed to publish in 1500 a book by Jean Bouchet, entitled The Foxes traversing the Perilous Ways. The author was already received at court, the book had an excellent title, piquant and suggestive. Nevertheless, Vérard began by erasing the name of Bouchet, and substituting that of Brandt, a German as well known to the French as the Scandinavians are to-day, and whom, moreover, Bouchet had sought to imitate.

The young poet durst not complain; however, when he read the volume in print, he noticed that Vérard had unceremoniously cut out entire passages, replacing them with passages pillaged from right and left. Bouchet seized the occasion and commenced an action; whereupon Vérard, utterly surprised at so much virtuous indignation, came to terms like a lord; he paid over a good round sum, and asked for no receipt.

Still, this sort of thing was rudimentary, and, apart from the question of private morals, harmless. What was much less inoffensive was the passion of the authors themselves, once they had learnt their cue, for the novel, obscene, or sensational effects which alone secured the attention of the public. They speedily got level with the Italians. Ulrich von Hütten gave an admirable send-off to his Epistles of Obscure Men by surreptitiously putting manuscript copies in circulation. Bonaventure des Périers almost attained to 
Aretino's skill. The alleged official destruction of his Cymbalum justified a clandestine second edition, which of course was priceless. "Let us write some vile thing," he says in one of his dialogues, "and we shall find a bookseller who'll give us ten thousand crowns for the eopy." That is true; the public only buys and circulates and really eries up the books it contemns. Many notorious books of that time, which we take seriously to-day, probably had no other origin.

An author, indeed, has a perfect right to desire to live at the expense of his readers. But, after all, he must beware, in matters of art, of eommereial inducements, and the more indifference, weakness, and unconcern the good public displays, the more one ought to thank the distinguished women who undertake to oppose the high bids of naturalism or extravagance. They do not always succeed; they are sometimes the dupes of noise and faslion; let us forgive them for what they have given us, for the sake of what they have spared us. In these days, people are ready enough to abuse the old system of patronage, which they charge with subverting the dignity of man; to seek something from the State, from a member of the Government, seems natural enough, but many writers would think themselves humiliated by submission to any social patronage-which, however, society is not eager to offer. In the 16th century, among intellectual cireles, men were republicans even in a monarchy: they were not enamoured of the idea of the State. And private patronage, in spite of its imperfections, often served as a home for meditation, a shelter for independent men who preferred high thinking to popular applause; if it proved deadening, it was only on mediocre minds. When we see what eireumlocution, and what subtle diplomacy the most influential princesses had to employ to gain admission to Raphael's or Giovanni Bellini's studio, we have no further misgiving as to the disadvantages of patronage. For a lady to send a poet in distress "a little sugared solace" as Des Périers said, and with so much diseretion that the source of the gift remains unknown, or to express her sympathy in the form of a costly present-in this we see nothing to impair the dignity of man; indeed, to be frank, it appears to us delightful. 


\section{THE WOMEN OF THE RENAISSANCE}

Moreover, patronage did not confine itself to a purely material and administrative support, as the State necessarily does. Besides sending a present in season, the ladies were still more ready to distribute the small but not less precious coin of tendernesses and compliments. We are here returning into their proper domain, and an intellectual man capable of withstanding this influence would be a rarity. The lady author who praises a writer smacks a little of her trade; Veronica Gambara, after overwhelming Aretino with rhapsodies, cries naïvely, "Praised by you, I shall live a thousand years!" It was "Kae me, I'll kae thee." But from a genuine lady of rank, eminent and bountiful, who asks for nothing, one charming phrase, even though it be qualified and far from flattering, is glory, and a glory that can be solicited without humiliation. "They say I am an aristocrat," wrote Taine, and he was, as we all are who pretend to lead men's minds. That is why we need this sybaritism,-need to be sustained and perchance guided by a smile. There is hardly a philosopher or poet of the 16 th century whose page: are not illuminated and gladdened by the smile of some higa-born lady.

How can we analyse this smile? We could not without seeing it, and we only know it very indirectly. We divine it under an infinitely caressing word; in a pretty diminutive, "my little sister," "wifie"; in an affectionate superlative; Vittoria Colonna calls her friend Dolce "Dolcissimo," and speaks to him, with a quite natural grace and without apparent exaggeration, of his "divine sonnets," for which she has not words enough to thank him; with her friend Bembo she permits herself to gush forth familiarly in artless enthusiasm. What a curious litany is the correspondence addressed to that "very magnificent" rogue Aretino, who highly valued the honour done him, and took all possible advantage of it! 'The writers are the marchioness of Mantua, with her grace and reserve; Mary of Aragon, "the sovereign marchioness of Avalos," on particularly good terms with him because she has not altogether given up hope of turning him into a monk; the duchess of Urbino, warm, gushing, who calls him " my magnificent most loving lover"; then the good ladies who have lost their hearts to the man of the hour, who take him as he is, a scoundrel but famous, and who write to him as the "fount of 
eloquence, astonishing, admirable, miracle of nature, most virtuous, (yes, you are!) most wise, my father, my brother." 1

The relations of a lady with her protégés were established by slow degrees, or simply through her chancing to hear of a work that bespoke her practical interest. The lady learns through her secret agents that a book is about to appear, in prose perhaps, perhaps a history; she wishes to have the first peep at it; the author, taken by surprise, makes excuses with profound modesty, but sends his manuscript all the same; and the ice is broken, the circuit is complete. The connection will continue under various forms; the writer tells her in confidence of his various works, then in his turn begins to beat the coverts for talents of hers that are lying concealed. In return the lady announces his work urbi et orbi, and takes his friends to her heart. A real intimacy is set up between them, sometimes so entirely spiritual that they never even see each other. Thus, before publishing his Courtier, Castiglione submitted the manuscript to Vittoria Colonna under the seal of the profoundest secrecy. Vittoria kept it rather a long time, and when at last she had to return it, she excused herself very prettily, being still, as she says, only half-way through the second part: she omits to add that she had lent it rather indiscreetly. She has no suggestion to make, except perhaps that he should not give the names of the ladies whose beauty he is praising in a book intended for the public. Otherwise she applauds everything with all her soul : the freshness of the subject, the refinement, elegance and animation of the style. She is horribly jealous of the persons whose words are quoted in such a book, even if they are dead. As to the passages on the virtue and impeccable chastity of women, she adores them and considers herself, as a woman, honoured by them; but on this point she prefers not to say all that is in her mind.

With Michelangelo she exercises the same supervision; she begs him, in a charming note, to send her a

1 Very few poets had the audacity of Clément Marot, who, harassed by his creditors, went a-begging to the Queen of Navarre, beslavering her with love the while: she replied with a dixain. He acknowledged receipt of it ironically, saying that on the strength of her verses his creditors have called him "Monsieur," and have permitted him to borrow again, which he proceeded to do. 


\section{crucifix he is working at, and to come and have a chat. $^{1}$}

Far from dissembling the patronage of which they were the objects, the writers and artists boasted of it. In all sincerity they believed women to have been created and sent into the world to inspire them with intelligence. If they had their portraits painted seated in their studies, it was not in the midst of a litter of books, weapons, or carpets, nor even with an air of deep thought or abstraction; it was simply as natural men, writing beside a little Cupid who serves them as tutelary deity. It was accepted without question that a woman's hand must shake the bough to set the mind winging its flight. "My mind, my strength, my Pallas, is Lydia," exclaims Catti. ${ }^{2}$ Antonio de Gouvea ${ }^{3}$ declares that he had no suspicion of what was in him till the fair-haired Catherine of Bauffiemont discovered him as one discovers a treasure under the snow: "I should have thought the snow cold, but lo! it was fire." Michelangelo sings the same song in every key: "Through your fair eyes I see a tender light which my blinded eyes could not have seen. ... Wingless, I fly with your wings; through your quick spirit I am unceasingly uplifted towards heaven. . . . I have no other will than yours; in your soul my thought has birth; my words are moulded in your mind. I'am like the moon, who never shines in the sky but as reflecting the brilliance of the sun;" and he adds this profound saying: "O Lady, who by fire and water refinest and purgest the soul for happy days, ah! grant me to return never more to myself!" That was the simple method by which many women in those days directed the minds of men.

We must not exaggerate: we do not pretend that you must everywhere chercher la femme, that without her nothing is possible, that she has confiscated the key to all

I "My heart's friend, I beg you to send me the crucifix for a short time, even if it is not far advanced, so that I may show it to the gentlemen of the Most Reverend Cardinal of Mantua. And if you are not very busy to-day, come and talk to me at any hour that suits yoll.-Yours to command, the Marchioness of Pescara."

${ }^{2}$ [Usually known as Lydius Cattus. His Latin poems in praise of Lydia appeared at Venice in 1502.]

${ }^{3}$ [A Portugnese writer (1505.1566) who spent the most of his life in France and tanght philosophy at Paris. He is chiefly notable for his crushing reply to Ramus's attacks on Aristotle.] 
human learning. On the contrary, she has done little for the exact sciences; she has contented herself with piercing the heavens or clambering in somehow or other. But the great kindred of impressionable beings, every man who has lived by beauty and sought after happiness, from philosopher to artist, from talker to poet, every man capable of feeling an emotion, has owed much to women. "Emotion, which is only an accident in the life of man, is it not woman's whole existence?" And in such a matter, can a better judge be found? Woman is freer from prejudice than man: "she does not need to give abstract reasons for her enthusiasms: her passion, her pity well up spontaneously while man is still discussing and deliberating. And in so doing, she almost always sees more truly." 1

Women are the eternal guardians of the Beautiful, and it cannot be said that in this respect the Renaissince introduced any absolutely new idea. Long before, noble châtelaines used frequently to shelter under their roofs the churchman employed to illuminate their Books of Hours, and princesses encouraged the ballad-monger and the image-vendor. Women have always cultivated their souls! But it was a new thing to devote this fervour and enthusiasm to a religion of beauty. In other directions, the women have been condemned; but their aesthetic influence has seemed legitimate; and, in a word, "the works they patronised, the châteaux built for them, have endured, when the doughty deeds of knights on the battlefield have hardly left a trace."

1 Paul Bourget, address in the French Academy, Dec. 9, 1897. 


\section{CHAPTER IV}

\section{INTELLECTUAL INFLUENCE}

(Continued)

THE influence of women declared itself in certain wellmarked results. In the first place, it led to the germination of what may be called a technical literature: that is, of works intended to prove the legitimacy and necessity of feminine sway.

The classical type of this literature is Boccaccio's book, of Illustrious Women. Boccaccio lived in a backward age, which is the excuse for certain epigrams of his; but he remained none the less the women's favourite writer, because he had had the courage to ransack antiquity, to quarrel with Virgil, to extol Dido, and to collect for the first time a multitude of immortal examples-Cleopatra, Lucrece, Semiramis, Sappho, Athaliah. Nothing, therefore, was safer than to republish, amplify, and imitate his work in every shape and form, and the opportunity was not lost, God knows!

In addition to this Boccaccian literature, which was already extensive, we must note the appearance of a numerous family of semi-philosophical, semi-historical writings, devoted to the glorification of the reigning sex; winning causes never lack defenders. The names of Bruni, Portio, Lando, Domenichi, and many others would certainly merit a page in the annals of feminism; Benedetto da Cesena specially demonstrates the honour and virtue of women, Capella their excellence, Luigini their beauty. The feature common to the most of these works is that while claiming to be very lofty, abstract and impersonal speculations, they are all the time aimed more or less covertly at the 
heart of one woman in particular. If Firenzuola discourses like Plato himself, it is because he has the countess of Vernio as his ideal. Nifo compiled his treatise On the Court under the auspices of the prince and princess of Salerno, but his ardour was more especially inspired by the charms of Phausina Rhea. Ravisius Textor wrote his Memorable and Illustrious Women because there happened to be one Jeanne de Vignacourt, wife of President Gaillard. We ourselves ought to have conformed to this fascinating custom and to have inseribed a lady's name on the titlepage of this book; but we are writing for fair readers of the 20)th century.

Except in size, the books we allude to were as like as two peas. Chénier might well have called them "old thoughts new versified." To see one is to see a thousand. The upshot of them all is the equality, if not the superiority, of woman in regard to man. To give an idea of them it will be enough to mention one, of no great renown (it has never been printed, and no complete manuscript exists, to our knowledge), but linking the names of two personages of the first rank. It was written for Vittoria Colonva by her cousin the famous Cardinal Pompeo Colonna, vicechancellor of the Church of Rome.

The Cardinal begins by very gravely preparing to crush under a weight of learning various anti-feminist propositions, almost all drawn from the antiquated repertoire of the Middle Ages; for instance, is woman an imperfect animal, an inferior being, unfit for public duties, good for nothing but to gad about and commit indiscretions? Is it not the custom, even in everyday talk, to say "men" when meaning the human species? Are not the Bible and Plato agreed in teaching that man is the prototype of creation, the receiver and the transmitter of life? Having settled these and a few other questions, the cardinal proceeds to his demonstration of the merits of womankind.

He finds it much to the point to invoke evidence from the pagan world. He sets defiling before us the Sauromathian women, the warrior Amazons, the women of the Balearic isles, every one of them esteemed equal to three or four men in the exchanges of war; the Lycian clames, through whom nobility was transmitted, and the Celtic ladies, who exercised the functions of diplomatists and 
arbitrators. On this evidence he declares himself an outand-out feminist; an advocate for the admission of women to all occupations; gymnastics and military service, commended by Plato, have no terrors for him; he would have been an enthusiastic apostle of cycling for both sexes. If some timorous objector hints at the moral perils of launching women into public life, he almost angrily laughs the objection to scorn, zestfully seizing the occasion to show what men are good for when left entirely to themselves. His type is the strong woman, sure of herself and cased in the armour of her modesty, the energetic woman who fends off the light strokes of stratagem as well as the heavy strokes of violence, the woman who is generous and just, with something of that young Spartan captive who had the force of soul to feign love for her vanquisher and to persuade him with her caresses that she was endowed with a marvellous secret of invulnerability, and who thus got her head cut off. "Heaven above!" ends the cardinal suddenly, "where could one find a more accomplished type of strength and maguanimity than yourself, O Vittoria! It is you, you, $\mathrm{O}$ ideal of noble virtues, who sustained your husband, guided him, exalted him!" Pompeo has so many things to attend to that he excuses himself from here working out this theme; he begs the marchioness to accept his modest little work, the homage of an ardent and sincere affection.

We are bound to add that women showed themselves duly grateful ; this kind of literature was not love's labour lost, and many insignificant men found in it the road to success. A Bohemian, half magian and wizard (common enough in those days), a soldier as well as a "doctor in both faculties," Cornelius Agrippa, was elected professor of Cabala at the University of Dole. Not long afterwards he dedicated to his sovereign, Margaret the regent of the Netherlands, a bulky book on the Preëminence of the Feminine Sex, a learned and convincing work, though in places somewhat gross. The chaste Margaret was no more shocked than Vittoria Colonna appeared to be angered at some indecorous details in the work of cardinal Pompeo. She obtained a good appointment for Agrippa, and later on, though a good deal had happened in the interim, she gave him the title of imperial historiographer to Charles V.

Apart from these special productions, which in date 
almost all belong to the early days of the decadence, the influence women exercised on intellectual productivity ran through two very different channels.

The primitive Frenchwomen, who loved breadth and vigour, the women of passion, mistrusted works of mere imagination; they sought for truth. Philosophy and history were their intellectual pabulum, owing to their taste for the clear light of truth, however solidly, even heavily expressed. To become wrapped up, entangled, lost in art and mawkish sentiment appeared to them the proof of inferior minds; to them the supreme art was to be without art; they loved the beautiful simplicity and impressiveness natural to minds that have mastered the subjects with which they are dealing, and are masters of themselves.

But these women were not numerous, and are soon lost sight of. Nor were there many men capable of meeting their views.

History and philosophy had their charlatans who brought discredit on them sooner or later-pedants, perpetrators of futile and vapid euphuisms, not to speak of fantastics and high genealogists like Féron, who carefully describes the armorial bearings of Adam.

Lemaire de Belges, who worked constantly under the eye of grave women and dedicated to them all his writings of whatever description, even a Treatise on Ancient and Modern Funeral Ceremonies, is one of those who carried erudition too far: He has a superb equipment of learning, which he displayed with a magnificent and conscientious tediousness: how could Margaret of Austria, Anne of Brittany, and Claude of France distrust a person of so excellent an appearance! Lemaire loses no opportunity of rendering homage to the sex; if none occurs naturally, he invents one. He cites only women of beauty and intelligence. In the service of Anne of France he extols honour and virtue: with Anne of Brittany he sings the past history of her realm; ${ }^{1}$ and when all is said and done he was nothing but a dull courtier. And yet he made his mark.

Philosophy comes better out of the ordeal. It was not divorced from literature, and, like the literature, it wore a pleasing and cheerful aspect. Laughter was then the

${ }^{1} \mathrm{He}$ undertook to write for her the Annals of Britlany, and had an idea of a history of the Greeks and Turks for the same princess. 
fashion, even in the most serious clubs. The Florentine academy flourished under the title of the "Academy of the Damp," each of its members bearing the name of some fish; and when, as pretty generally happens, its founder, Lasca, was expelled, he established another academy, under quite as facetious a name, the "Academy of Bran," the Dellacrusca."

We have shown what an unrivalled position philosophy obtained in the society of that epoch; many people preferred it to history because they fancied they were more certain of finding truth in it. They found it also of very practical utility; thanks to some familiarity with the ideal, more than one philosophical husband could say, "All is lost, save honour." From the moment when the women began to subsist on philosophy, there was a run upon theoretical wisdom. Happy the man whose academic discourses suggested a comparison with Plato, or merely with Pythagoras! Philosophy bore everywhere the torch of happiness; it gave props to faith, and represented Paradise as the sum and crown of aesthetic joy; the noble bishop Guevara exclaims witi enthusiasm, "God was the first lover in the world; it is from him that we have learnt to love"; and grave professors on formal occasions waxed eloquent on the mystery of love. Cornelius Agrippa opened a course of lectures on Plato's Symposium with this declamation: "I come to expound to you the doctrine set forth by the divine Plato in his Symposium, on love. My discourse has Love for its author and cause; I myself, inflamed by the beams of love, preach Love to you. Far from here, far from this respectable lecture-room, let others, stuck fast in the miry paths of the world, creatures of Bacchus or of the god of gardens, trample this divine gift, love, in the mud, like dogs or swine. You, my pure men, votaries of Diana and Pallas, hail to you! Come and lend attentive ears to this divine mystery."

Filippo Beroaldo goes farther; he undertakes "without false shame "to expound to his young pupils the philosophy of Propertius: "Yes," he exclaims with fervour, "we shall give praise to love, the one god laudable above all things, pre-eminently laudable; we shall show you that the poetry and the poets of love consort with the gravest professors,

${ }^{1}$ [So called because their aim was to purify the Italian tongue by sifting the wheat from the chaff.] 
and that this sort of poem is worthy to serve as subject for a public and complete course in a university of letters." And forthwith we see him occupied for a whole year in drawing a distinction between the work and the writer, conformably to the aphorism of Catullus, that a poet may perfectly well pass for a decent, chaste, and pious man, though his works may not have the same reputation, provided they have salt and wit. Ovid also had said: "My pen is lascivious, but my life is not." Beroaldo insists very strongly on this tutelary principle, and to add force to his demonstration he casually reads the broadest passages in Plato and the Scriptures: "Yet," he adds proudly, "everybody reads the Bible."

In addition to disseminating thus the doctrine of Love, the religion of the Beautiful naturally delighted in beauty of form, and gave a very decided lead on this point also.

In the first place, it brought into high favour a kind of literature which, for brevity's sake, we shall call the literature of conversation. There is nothing surprising in this, since conversation served at once as a means and an end, and appeared to be the realisation of Platonic happiness. Those who had the misfortune to be writers took at least all possible precautions not to show it, and certainly many authors of the dialogues, novels, and various narratives of the time committed them to paper only to keep a permanent record of actual conversations, or at any rate because, in temporary distress for want of someone to talk to, they found themselves reduced to taking up their pens to keep themselves in practice. The critics of our day, who prefer to say their say by themselves, in the form of lectures or articles, are disposed to see in this dialogical method a trick of rhetoric; they regard the dialogues of Plato in the same light, and we see very learned platonists quoting indifferently the thoughts of the various speakers as the thoughts of Plato himself, without remarking that in the same dialogue the different speakers give sincere expression to different ideas. The majority of 16 th century dialogues are real conversations, ${ }^{1}$ and claim to be more or less accurate notes of both sides, with the perfect liberty of movement impossible in didactic exposition. Bembo, in his capacity as an eminent talker, has accepted the responsibility for more than one written

${ }^{1}$ Castiglione got Bembo to revise the speeches he attributed to him. 


\section{THE WOMEN OF THE RENAISSANCE}

dialogue, And thus, the practice was quite the reverse of that which obtains in our drawing-rooms to-day, where, if the conversation happens to rise above the commonplace, we borrow our ideas from the morning's leading article or the last successful play; in those days the drawing-room made the book-a system extremely favourable to the influence of women.

The masterpiece of this literature of conversation is unquestionably the Courtier of Castiglione, of which more than eighty editions or translations are known, and which retained almost undiminished popularity for more than a century.

In proportion, however, as women fell into mere fashionable sensibility, the literature they inspired became an art of form rather than of thought, and soon there was no longer room for anything but poetry. Poetry flooded everything. We are not speaking here, of course, of the high heroic poetry intended for robust appetites: people revelled in the luxury of a beautiful musical phrase which soothed without awakening emotion, in a sort of splendid unreality, in glittering frivolities calculated to give a fillip to conversation.

There was high honour for the improvisatore who, in the decorated hall of the chatteau, whilst in the streets there arose a vague hubbub of music, song, or passing feet, could on the spur of the moment chisel or crystallise a happy thought, and shoot out his little verse, light as an arrow, brilliant as a sky-rocket. Such a man was fêted everywhere, and saw a welcome smiling in every eye. Into a goblet of rare crystal he poured, as it were, but one drop of elixir, but it was an elixir that exhilarated; he was master of his world. With a tender or witty ver'se a man could do anything. A phrase of Bembo's is very typical. When Vittoria Colonna had just lost her husband, he told her that the flood of sonnets on that occasion had reconciled him to the age! Vittoria Colonna herself, whose ideas were of quite a different order in theological matters, wrote to a prelate: "I received your letter this morning, and in your madrigals I saw the force of truth." "Poetry was so much a maid of all work that a luckless ambassador, at his wit's end for a new way of asking for his arrears of salary, ended by addressing 
a dispatch in verse to his sovereign, Margaret of Austria. Another dropped into poetry in his dispatches with the simple object of paying court to his princess. A business agent, instructed to send some information to Vittoria Colonna, declares that, writing to so illustrious a lady, he hardly knows what he is about, and that he cannot refrain from writing in verse : litherto, he says, his higher faculties have been dormant, and the name of the marehioness has roused them to aetivity. Admirable effect of feminine influence, galvanising even auctioneers' clerks! Ladies wrote in verse to their children, sent their friends verses-sometimes, it must be confessed, borrowed. ${ }^{1}$

In all this wealth of poetical production the sonnet ranked as the most profitable, beeause, thanks to its terse and sparkling form, it did well in a glass case among a woman's little love trophies. It admirably hit the tastes of the ladies; it was short and concise, it centred on one idea, and allowed the most diverse and fugitive sentiments to find expression.

In these days we cannot really understand the success which certain oceasional verses met with, for example, the rhapsodies of Molinet ${ }^{2}$ whenever Margaret of Austria took her walks abroad. These gems of other days have the same effect on us as pearls removed from their settings, lying robbed of all their lustre on a dealer's counter. For that matter, they never had the glow of passion; all that was asked of them was to show a certain uniformity of sparkle, and they were strung one after another in the belief that so many languidly gleaming brilliants would in the long run form a pretty set. What charming and unexceptionable ornaments were the waggeries of Saint-Gelais or of Michel d'Amboise, or the "Hui.ured and Five Love Rondeaux" published by M. Tross, or the Hecatomphile (i.e. the hundred loves), and so many more $!^{3}$ Such writers

${ }^{1}$ The Spanish canzone, inserted by Lueretia Borgia in her letters to Bembo, are perhaps not her own.

2 [Her librarian.]

${ }^{3}$ Castiglione, that arbiter of taste, devotes six pages of excellent Latin distiches to dissuade his lady from going to the sea-baths. He gives a charming description of the sea monsters which advance towards the girls, not only to fling them as food to the fishes, but to get them into their embrace, and so on. "Let us go rather," he sighs, "towards the gentle river, in the thick shade, among the flowers. Perfumed, crowned with our favourite colours, we will let the water lave thy snowy fcet, ... the zephyr will lay bare thy marble flanks. . . O, dear soul of mine, the 
had ringing in their ears an air from Ovid ${ }^{1}$ or Petrarch, a mawkish air, with all the sublimity of commonplace, already utilised a thousand times; and they continued to grind out the song of the "exquisite" bard of Laura, to steal from it, comment on it, torture it, raising their eyes to heaven like Greuze's girls; and so they thought themselves deities. "I hope," cries Aretino, with a burst of laughter, "that the soul of Petrarch is not tormented in the other world as it is in this!" They were a long way from the vigorous inspirations craved by Pompeo Colonna. Some repining souls made secret reservations against the seductive force of this sensibility. Vittoria Colonna and Isabella d'Este kept a corner of their heart for Dante; but what could they do to stem the tide? They tried, very clumsily. In France a league of terrible pedants was formed,"skimmers of Latin," who, to separate themselves from the vulgar, employed a sort of pretentious and intolerable jargon. In Italy, Spagnuoli shouted himself hoarse in thundering against the Franco-Italian alliance, and all in vain. Capilupi, ${ }^{2}$ still less adroit, committed the unpardonable folly of finding fault with the women. At bottom he was right.

It was women's duty to warn the world off so disastrous a reef. Unhappily, in consequence of that eternal timidity and that want of energy which were to kill their influence, chey allowed themselves to be utterly bewitched. It was written that they should be able to conquer, but not to profit by victory: that, once mistresses of the world, feebleness would regain the upper hand; that being no longer under the spur of passion, they would come to a stand before a sweetstuff shop.

The masterpiece of these pretentious confectioneries was a monument of verse erected to the glory of some particular lady.

woodland gods will feel the sting of my love, the very water of the river will boil with my flame : let no one know whither we bend our steps! The crowd strips rocks and woods of their charm. . . . Let young scatterbrains go to the sea. We will be silent about the place whereto we are bound. And if on the billows thou hearest a murmur, alı! my love, at once bury thy head in my breast !"

'Virgil was much out of faslion, though translations are occasionally to be met with.

${ }^{2}$ [A poet of Mantua (1498-1560), writer of extremely free verse on monks and women.] 
Joan of Aragon was during her lifetime the object of a deification of this sort, in which the Academy de' Dubbiosi ${ }^{1}$ at Venice proceeded according to the forms employed at Rome in the ceremony of canonisation. There was first a preliminary decree, then a discussion on the proposal made by some member to share the apotheosis between the exquisite Joan and her sister the Marchesa dal Vasto; then a decree, based with great parade of learning on the opposition of Roman pontiffs in bygone days to Marce!lus' project of dedicating a temple to Glory and to Virtue in conjunction, and enacting that the honour was to be reserved for Joan alone, and that it would be enough to offer incense to the Marchesa dal Vasto in sundry allusions.

The temple was erected. It was in the purest Renaissance style ; cosmopolitan, artistic, feminist. Its contents were pretty enough: Ruscelli celebrated the charming, adorable and divine Joan in respectable verse. But that only shows how the finest things suffer most when reality is replaced by sham. Miscellaneous heaps of poems in all languages known or unknown, Hungarian, Hebrew, Syriac, Slavonic-what was it but sham?" In reality, the truly artistic idea was absent.

There was also, especially in France, a whole literature dealing with poodles and little birds, which was not lacking in charm, and above all in sensibility, for it was generally elegiac. Saint-Gelais, Eustorg de Beaulieu and Marot, like Catullus, mourned sparrows, such as that of the unfeeling Maupas:

Las, il est mort (pleurez-le, damoyselles),

Le passereau de la jeune Maupas;

Ung aultre oiseau, qui n'a plume qu'aux aisles,

L'a dévoré : le congnoissez-vous pas?

C'est ce fascheux amour...

...Par despit, tua le passeron,

Quand il ne sçent rien faire à la maistresse. ${ }^{2}$

' [I.e. the Doubtful.]

2 Young Maupas' sparrow-he is dead, alack !

Fair maids, lament him.

A thing unfeathered save upon his baek

Hath slain and rent him.

Ye know the rogue-that froward wight

Called Love hath done it out of spite,

For when the mistress 'seaped his arrow,

He turned about and slew the sparrow. 
Vert-Vert, ${ }^{1}$ whose misfortunes touch us to this day, was a direct descendant of the parrot of Margaret of Austria, which, having been allowed to die during the absence of its mistress, was consequently regarded as having died of despair. Du Bellay has devoted some of his most exquisite verses to the memory of a little $\operatorname{dog}^{2}$ In short, as we see, all these writings were inspired by a sentiment of tenderness, in the manner of Berquin ${ }^{3}$ or Florian. The Cardinal de' Medici loved to style himself "the knight errant." Under the dainty hand leading them, men seemed like meek and gentle sheep, somewhat emasculate perhaps, incapable of a strong diet, but polished, sweet, gracious! Twit them with losing their claws, they reassure you! If their interests or their pride are ever so little touched, they are still masters of a pungent rhetoric! Listen, behind the

${ }^{1}$ [Lemaire de Belges wrote an elegiac poem on L'amant rert, Margaret's parrot. A charming poem with the title Vert-l'ert was written by Gresset, a contemporary of Voltaire, recounting the burlesque story of a parrot which had been the pet of a convent.]

\footnotetext{
${ }^{2}$ Mon Dieri, quel plaisir c'estoit,

Quand Peloton se grattoit,

Faisant tinter sa sonnette,

Avec sa teste folette!

Quel plaisir, quand Peloton

Cheminoit sur un baston,

Ou, coifé d'un petit linge,

Assis comme un petit singe,

Se tenoit, mignardelet,

D'un maintien damoiselet!

Ou, sur les pieds de derrière,

Portant la pique guerrière,

Marchoit d'un front asseuré

Avec un pas mesuré.

[Gad, how pleasant 'twas to see

Flnity scratching prettily,

Making with his silky pate

Toy-bells tintimnabulate!

And what fun to see lim ride

On a hobby-horse astride,

Or, bedight in tiny cape,

Squatting like a little ape,

Posing like a proper squire,

Spruce and dainty in attire;

On hind legs erect, perchance,

Shouldering a martial lance,

Marching at a measured pace,

Full assurance in his face.]
}

${ }^{3}$ [The French adapter of Sandford and Merton, etc.; known as the Friend of Children.] 
scenes (or even before), to Politian, that charming angel, calling an obscure antagonist named Mabillius, "scurvy knave, carcase, lousy dog," and so on.

But let us finish our portrait of women from the intellectual point of view.

They did more than rub their faithful friends to a fine polish: they were gradually drawn on and impelled to take up the pen themselves, cherishing the secret idea of enabling the public to profit by the treasures of their sensibility.

To write a book, even in verse, is not a crime. But how was it that the women did not understand that in coming like professionals before the public they were precisely breaking away from their own system?

They could, it is true, invoke the example of Spain, where women displayed their learning openly and unahashed. But the position of Spain was altogether different; there the women in question were ladies of lofty imagination, who threw themselves with extraordinary energy into regions of pure erudition; brilliant and famous women of high rank- the marchioness of Nonteagudo, Doña Maria Pacheco de Mendoza, the pretty Isabel of Cordova, far richer in Latin, Greek, and Hebrew than in worldly possessions; Catherine Ribera, the bard of love and faith ; the two "professors" of rhetoric at the Universities of Salamanca and Alcala; Beatrice of Galindo, who taught the queen Latin; Isabella Rosera, who preached in Toledo cathedral and went to Rome to convert the Jews and to comment on Scotus Erigena before an array of dumbfounded cardinals; Loysa Sygea, again, the most illustrious of them all, an infant prodigy to begin with, then a Father of the Church, who could speak the most outlandish tongues. These were women full of sap and energy, whom no one was astonished to see taking by main force the first rank in the spheres of literature, philosophy and theology; but were they really and truly women? or rather, did they bring any new thing to humanity? Were they apostles of happiness? No, they advocated the claims of reason as men did, perhaps better, perhaps worse-that is all. The ideal of France and Italy was different: it demanded more discretion. Women might be quite as accomplished; the knowledge of Latin was so widely diffused among them, even in the depth of the

${ }^{1}$ [Alluding to his forename Angelc.] 
country, as to be quite a matter of course; many grappled with Hebrew ; some people went so far as to say that rhetoric was a virtue as necessary to them as chastity, if not more so. Only, everybody was steadily faithful to the maxim that women ought to rule by charm rather than intellectual accomplishment; and if it was necessary to arm them for the strife, their supreme skill would always lie in appearing unarmed, in keeping their minds free and winsome, preserving unsoiled all the bloom of their excellent education, remaining great ladies and "amateurs."

Ought the women, at the time when the ultra-refined shrank from appearing in print as a lapse from taste, as what Montaigne called an "idle business," to have descended in to the arena and addressed themselves to the heart of the commonplace and heedless man in the street? Ought they to have done violence to their thought by printing it? You may address the public in regard to the stern things of life, draw your logical deductions from truth, hammer out your arguments, discuss history, philosophy, theology, everything that is of iron and rock. But sentiment has graces which only flourish well under glass; the true women of the Renaissance were like orchids, choice and rare and delicately perfumed, which close their petals at the first breath of air. The same modesty which defended the purity of their bodies against every indiscreet eye, and which smiled only on friends, seemed to envelop their souls. They were not displeased to hear themselves called the depositaries of "good doctrine," or even to see jestingly attributed to them some pretty work which obviously they had not written: Aretino was a very clever and amusing flatterer when he made the actor in the prologue of one of his most spicy comedies ask if the author of the piece were not Vittoria Colonna or Veronica Gambara. But the most accomplished and instructed woman of the world, Margaret of Savoy for example, never tired of boasting of her "divine goodness." Noble ladies did not take up the pen, any more than a good housewife needs to handle a broom; they readily dictated even private letters, with the splendid indifference of Talleyrand, who, we may say in passing, knew his busi-

${ }^{1}$ In 1500 , in the village of Anvilliers in Normandy, a girl of fourteen named Jeanne la Fournette, as skilled in Latin as the parish parson, sang the 'Tenebrae in church. 
ness very well. If they are ever caught writing, it was for mere amusement, when they were tired of painting, carving, working tapestry, playing the harp, singing, maybe of dancing and riding; then they thought of their souls, if they had time; they would read a psalm or a story; or to "escape idleness," to banish an idea that oppressed and persecuted them, they would artistically chisel their idea in the form of a sonnet. Thus understood, poetry is the divine art, and very few women have been able to resist it from the moment when it appears to them the same thing as painting a fan!

Margaret of Austria delighted in etching in little poems her recollections of the trials of her life, and (in absolute privacy) did not even disdain to address some epistles in verse to her devoted friends or her functionaries. The amiable Graville, the fair Chateaubriand, so dear to Francis I., excelled in this pastime, and when we see Suzanne de Bourbon herself contributing her share, we may well believe that the fashion was general. But between that and proclaiming oneself a poet there was a wide gulf, and when this was crossed, it was the beginning of decadence, because the exquisite freshness and simplicity of the art soon gave place to affectation. To women of simple artless charm succeeded blue-stockings like Madame de Morel and her three daughters, or NIadame des Roches. Women writers arose, and the Academy of the Valois found it quite natural to admit them.

Lyons was the capital of feminine poetry, and certainly it is there that we can best appreciate how and why the women fell into the unfortunate mistake of becoming professional writers. It was not wholly their fault: they only succumbed to the temptation when they could no longer exert their influence otherwise.

Lyons was the city of wealth and pleasure and elegance, the rival of Paris in fashion, the "Florence of France." It was often the headquarters of the court.

Anne of France, as sovereign of the surrounding country, had at first exercised there a very direct influence; and afterwards Mlargaret of France went there more than once, and gladly, as into a friendly land.

The ladies of Lyons, envious of the "great and immortal praise" their neighbours of Italy had acquired, were desirous 


\section{THE WOMEN OF THE RENAISSANCE}

of making their influence also felt on men, and of doing honour to France in the present and the future. It was nothing but music and poetry, poetry and music. ${ }^{1}$ Margaret of France smiled broadly at the universal babblement. Up to a certain point, save for the somewhat excessive development of sensibility, nothing was more legitimate or natural: the husbands acted as archivists, piously classifying their wives' papers and cultivating their reputations. But a time came when it appeared calamitous to leave to husbands alone the care of so many treasures. Du Moulin, Margaret's secretary, ventured to aim a blow at feminine modesty: at the express request of her husband he published the works of Madame Pernette du Guillet, recently deceased, taking good care to indicate his intention of thus paying collective homage to "so many fair and virtuous ladies of Lyons." He encouraged others to make similar confidences.

The somewhat tame and sublunary verses of Pernette du Guillet were not particularly flattering to th? husband who had so well preserved them. Pernette avows in all sincerity that she had never known happiness; how could she have known it? She divided her abilities among so many things. She spoke all languages, played every instrument, and was beautiful in addition. The sentiments she expressed oscillate between a tender sensuousness and bitterness of soul.

Louise Labé, the glory of Lyons, did better service for her cause. The list of her virtues would fill several pages. Fair, rich, and well-bred, a singer, a dancer, a horsewoman, and an Italianist, she drew in her train such a flock of admirers, commentators, panegyrists, biographers, and glossarists that lier death did not quench the enthusiasm, but occasioned a perfect mausoleum of poetry.

There has been endless discussion in regard to this fascinating woman. Nany a lance has been broken in regard to her virtue, of which the late M. de Ruolz was formerly the self-constituted guarantor and paladin, but against which, since his time, two erudite writers, themselves natives of Lyons, Messieurs Gaullieur and Gonon, have brought heavy batteries to bear. But that little concerns us, for we do not claim Louise Labé, even theoretically, as 1 "Verse is the clarion, prose the sword." (L. Veuillot.) 
one of the glories of pure platonism; she is too selfconfident and cock-a-hoop, has such airs of swagger and mock languor; she smacks of decadence. And yet, though she did not, like Pernette du Guillet, make the slight effort needed to defer publication till she was dead, she does affect a modesty which is itself unpleasing. It was not her husband who impelled her to appear before the world, it was her friends; they insisted, swore to "drink the half of the shame"; and then, "not to take the plunge alone," she dedicated her book to another lady, Clémence of Bourges.

These simpering affectations apart, Louise was sincerely convinced of the benefits of feminine domination, and one feels that in boldly facing publieity she was obeying a sentiment of duty. She resolutely encounters the enemy, like a brave eaptain who dashes out of cover to rally his disordered troops. She conjures women not to allow themselves to be despoiled of the "honest liberty" so painfully aequiredliberty to know, to think, to work, to shine. Happiness! - she no longer deludes herself with the idea that she can promise it with certainty, or at least she has awakened from the dream of attaining the absolute; but she tells herself that "one ean at least sweeten the long voyage." She does not lose sight of the fact that it is women's funetion to diffuse sweetness and poetry, to mitigate unsociabilities, to inspire men with energy. The experience already gained does not strike her as discouraging; quite the reverse; the intellectual life takes from day to day a more splendid amplitude, and this amplitude results from the action of women. The moments of all great intellectual vitality are marked by love. So said Louise Labé.

Tullia d'Aragona, who sustained the same theory in other terms, was one of the few Italian women who did not fear to be reputed authors, probably because her place was already only on the fringe of society. In general she employs few circumlocutions, but goes straight to the point with a vigorous eloquence. Her poems, almost all addressed to men, deal with subjects of the gravest kind, particularly with religion. Tullia had the inestimable advantage of knowing humanity from top to bottom. Beside her, Calvin and Ochino are as innocent as babes, and she taunts them, not unfairly, with dealing their blows blindly with- 


\section{THE WOMEN OF THE RENAISSANCE}

out distinguishing between what is serious and what is harmless. Her own wisdom is wonderful! The poet Arrighi cannot help exclaiming, "Vittoria Colonna is a moon, Tullia a sun." She celebrates pure love in the true lyrical and forceful strain, as "the magnificent, the admirable madness which alone produces great enterprises." Whilst immaculate women like Vittoria Colonna and Veronica Gambara too often stifle us with languorous sensibility ("When I was a happy lover, I exhaled the harmonies of my heart in calm and pious accents"), Tullia, who has long ago lost this tranquillity and these religious illusions, knows that will and action are needed; she does not ask for the impossible, but on the other hand she valiantly excommunicates Boceaccio with his "villanous novels," before whom the coy ladies of fashion bow their faces to the earth. In a dialogue with two gentlemen, she discourses on love in quite a platonist key; she investigates its casuistry: "Is the end of love its limit? Is it better to love or to be loved?" She prefers to be loved, this fair artist, because in loving we are acted on by the motive force, while in being loved we exert it. Women who have really loved will perhaps be of a different opinion; nevertheless there in one line we have stated the great contention of the time. The art of women ought to have been to make themselves loved and to constrain men to love; they were often caught in their own toils; they loved, and consequently instead of receiving they gave. "The heart has reasons reason never knows."

These few notes on the literary work of women suffice to show that, on the whole, feminine literature, except in Spain, sprang from love, to return to love again. No great influence in the intellectual crisis of the Renaissance can be attributed to these various writings; they scarcely did more than develop more or less intuitively the platonist philosophy.

On the other hand, women exercised an enormous intellectual influence through their individual and personal action, especially in Italy. They carried their charm into quarters which the mediaeval theologians, so ready to style themselves the "doctors of the poor," never penetrated,-namely, among the poverties of the heart. They overlaid iife with that varnish of wonderful, singular sweetness 
which has never been wholly rubbed off; they intellectualised society, and, in a country essentially marked out as a prey for gold and luxury, they delayed the moment when men were to be estimated merely by the gilding of their ceilings or the thickness of their carpets.

The effects of their work north of the Alps are not very easily measured. Resistance there was too strong; the masculine world was not easily won over; men growled, for it seemed to them that women were plucking their souls out, or wishing to degrade them, in proposing that they should submit to - what? a sort of intellectual goodness. They refused to hear women and intellect spoken of together. The Germans recognised no intelligence in them apart from their domestic duties. What the Italians called intelligence a German would call tittle-tattle, trickery, the spirit of contradiction. They rejected such gratifications, and had no intention of allowing Delilah to shear them. They would readily have declared, like an arrogant character of II. de Curel, that there is nothing in the world but egotism, and that the egotism which creates life is of more worth than that which employs itself in providing life with consolations. As to poetry, forsooth, they were tempted to receive love serenades with a bucket of water. And if the Italians sneered at them as barbarians, "brainless people," they would answer them on the day of battle by demonstrating how far mere brains and sensibility served a nation. Erasmus dubbed "any man who was honest and learned" an Italian; precisely, but what had the Italians come to with their beautiful ideas? They wrangled, but they no longer fought.1 "Don't talk to me of the Venetians," said Louis XII.; " they don't know how to die." To know how to die-that is life.

Virile, stern, frugal, poor, rustic often to boorishness, Germany in this way kept up against the intellectual paradox the old disdainful warfare of the empire against the priesthood, and once more the gulf was dug out between body and mind, between matter and spirit, force and liberty. From the banks of the Rhine a furious hail of missiles was directed against the fragile aspirations of

I "Gli Italiani, col lor saper lettere, haver mostrato poco valer nell" arme, da un tempo in qua." (Castiglione.) [The Italians, with their knowledge of letters, have shown little worth in arms at any time.] 


\section{THE WOMEN OF THE RENAISSANCE}

Italianism. Brandt published his famous Ship of Fools, ${ }^{1}$ reissued seventeen times between 1494 and 1520, a work as much translated, copied and imitated in the Germanic world as Petrarch was in the Latin world; a pungent and unjust work in which defile, as in a booth at the fair, all the little grotesques which bring joy to mind and heart-not merely, needless to say, old 'Turk's heads like the physician or the astrologer, but new types-the spectacled scholar, busy nursing his own reputation under colour of Plato or Menander; the man of the world, oiled and curled indeed, but a wit, a lover, a gidldy-pate, and a fir'm believer in the black art; no one is missing, not even the explorer, at a period when the world was dreaming of free exchanges and the demolition of frontiers, the age of Columbus and Vasco da Gama. In the greater part of these adventurers the old German sees only arm-chair travellers or tap-room oracles, and among the genuine travellers he anticipates Sterne in distinguishing idle loungers, . curiosity hunters, liars, braggarts, conceited puppies, windbags, travellers in their own despite, travellers tleeing from justice, felons, the innocent and unfortunate traveller, the traveller for his own amusement. Hardly any is forgotten but the sentimental traveller.

As to the poets, needless to say whether a genuine German scoffs's at these "gentlemen in -us," a sort of intellectual Tartarins, who in actual life lead old and even wealthy women to the altar.'

And thereupon heads grew hot, and men pointed to the decadence of morals, the desertion of the country, the flocking of people into the towns, and they laid the blame on Rome, the head of the movement-Rome without a rudder, without a compass, drawn helplessly along by the new spirit through which she was to perish.

Some years later, when in spite of everything the rising tide at last made its force felt, the opposition changed front. People began to twit Italian learning with superficial ostentation. A love for books was laughed at. Ptolemy

${ }^{1}$ [The popularity of the Ship of Fools was partly due to its admirable woodcuts, which are of quite extraordinary excellence, and much more amusing than the text.]

${ }^{2}$ Hiitten. Though he is joking, Hiitten pretty faithfully represents the opinions of a part of Germany, which did not perceive his sarcasm. 
Philadelphus was a wonderful man, to be sure, to collect forty thousand volumes at Alexandria! An ass might just as well load himself with guitars and set up for a musician! That may be admitted; but they did not stop there; and, notwithstanding all we know of the violences of party spirit, we eannot help feeling somewhat astonished when we hear a man like Marot contemptuously flinging the epithet of "ignoramus" at the Rome of Leo X., or Melanchthon talking of Italy as "Egyptian darkness, a prey to the worst enemies of literature and study." That seems the very last accusation that night have been expected.

These German ideas were half French too, and consequently, in the hot give-and-take of battle, imperial Germany and papal Italy, in spite of some shrewd blows, maintained their positions well enough, whilst France, caught between two fires, was shattered. At the very gates of Lyons, the sweet city of feminism, the Germanists and Huguenots brutally replied to all the poetry of the women with the jest of I'Aubigné: "When the eggs are hatched, the nightingale stints his song."

In addition to many earnest men and almost all politicians, believers in authority and even in force, Italian dilettantism found other ardent adversaries in Franee in the champions of the old gauloiserie, who continued to dote on uaturalism naked and unadorned, the syntheses or analyses of the Hesh. They felt insulted that anyone should wish to impose on them a strained and uncomfortable Petrarchism with the idea of toning them down. However, Petrarehism did not effect very much, and it was assuredly not guilty of softening certain erudities and of replacing by its mawkishness the twaddle of illustrious nobodies like Jean Picart, Etienne Clavier and others.

Hence, in so disturbed an atmosphere as France then was, we should be led to conclude that the influence of women was negative, in the scientific sense of the word. Their work was like Ml. Pasteur's. The soul of man was stirred, agitated, overwhelmed by a host of imperceptible microbes; the women did not furnish an infallible specific for preserving the health, but sought to sterilise the noxious germs, to make the air pure and the water elear.

Even after the squalls of the 16th century it cannot be $2 \mathrm{D}$ 
said that no vestige of their effort remained. For it is the characteristic of France to be a complex and accommodating country, where nothing triumphs, but everything succeeds, where nothing abides, but nothing is lost. To this very day, an hour's carriage drive through Paris takes you through the last four or tive centuries of our history. The feminism of the 16th century brought down and deposited a new stratum of traditions: nothing more could be expected.

The violence of the opposition prompts us also to find some excuses for the timidity we have pointed out in highplaced women. Women genuinely frank and fearless could only be found in humbler life. We have seen how much difficulty Margaret of France, called to live in a circumscribed and select society, had in determining her precise whereabouts, since she met with nothing but contradiction around her. When her scared platonism came at last, about 1540 , to formulate as in Italy definite principles of guidance through the pen of Héroët de la Maisonneuve, and a heated contention was the result, Margaret prudently tacked about, and smiled, now upon Héroët, now upon his adversary La Borderie. $^{1}$ And yet the rein was feit, ${ }^{2}$ and in her circle it became necessary to sing of love in a more philosophic key. The fierce Des Périers himself, type of the man who loves to bite, saw himself reduced to translating the Lysis of Plato, under the insipid title, "The Quest of Friendship."

The victor'y thus remained a moderate and indecisive one, somewhat out of proportion to the great enthusiasm displayed. The fine triumphant treatises on the excellence and transcendent merit of women, those sacred stones, relics of a forgotten worship, deserted dolmens, were almost all Italian. Margaret showed some displeasure when shc heard women ill-spoken of; but she did not inspire glorious rhapsodies,

\footnotetext{
' Terses by Héroët and La Borderie appeared in Opuscules d'amour, Lyons, 1547. Héroët's Parfaite Amie is a lady who, having lost her lover, is content to await a spiritual union in a better world. La Borderie's Amie de $C_{m}^{\prime \prime} u r$ is a lady of quite contrary proclivities.]

${ }^{2}$ In 1546 Delahaye, sometime printer of Alençon, now blossomed into 'Silvius,' conld praise Margaret for the service she had jnst rendered to the firench mind: A coarse Cupid, he said, was reigning when true Love descenled from heaven to chase him away, found hostelry with the princess, and "untly settled upon a hedge." According to him, Margaret had sncecerled in ruling the appetites, and in practically introducing philosophic love into poetry.
} 
like Vittoria Colonna and many others. In France free discussion on the merits and demerits of women continned rife.

such wrangling was indeed an old French social pastime: everyone said his say, with perfect liberty to change his mind, and a host of well-worn sentiments more or less amusing were bandied about: "Eve was a woman, God made himself man! There are no women among priests. It is very seemly to slecp alone. I have never been in love or married, thank God!" In the 15th century people succeeded for a moment in believing that the intellectual level of their little pastime might be raised till it at last attained the Italian perfection; a Norman named Martin Le Franc, whom his duties as secretary to Felix V. had made half a pontiff, at one moment threw out the grand phrase which was to set Italy on fire: "Women are the apostles of happiness, because they are the apostles of universal and necessary love." A few little academies or puys d'amour, ${ }^{1}$ scattered here and there in Picardy and Flanders, caught eagerly at the idea, but without deriving from it anything better than an encouragement to the flowery verbosities of dead-and-gone chivalry, which they plumed themselves on continuing. Then came the wild outbreaks in Germany to give the finishing stroke, and when Brandt and Geyler ${ }^{2}$ became the idols of public opinion the French ferminists blushed and turned tail. No more monuments were erected to the glory of women, and even a masterpiece of our art of engraving, an absolutely charming Ship ${ }^{3}$ that appeared about 1500 , was devoted to their disparagement. It is a series of little pictures, representing, to begin with, the inevitable Eve, and then coquetry, music, dinners, perfumes, love. The author does not go so far as to say that all these things are unutterably wearisome to him, but he insinuates that in his opinion it is useless to look for any serious idea among such frivolities.

The French were quite ready to admit that women had ccrtain moral qualities, like goodness and devotion; a

${ }^{1}$ [The puy was properly a mound or other elevated place on which competitions in poetry and song were held-eisteddfoddi.]

${ }^{2}$ [A racy preacher whose sermons on Brandt's Ship of Fools were very popular. He preached on "subjects of the day."]

${ }^{3}$ Stultifere naves. 
woman who had only one shift would give it away, they knew. A writer puts into Eve's mouth a cry of sublime self-sacrifice at the moment of her expulsion from the garden: "Slay me," she cries to Adam: "perhaps God will restore you to Paradise!" And yet it was to her that he owed his expulsion. But the great majority of Frenchmen very unjustly believed frivolity, inconstancy, lack of originality to be defects inherent in the sex, and not merely the result of an unfortunate education. If accomplished women quoted Plato or St. Thomas they were laughed at, no one would believe that they had an opinion of their own, but declared that they had got some one to coach them, that 'the doctrine was no deeper than their lips, that they had no naturalness, that they disappeared under art." A woman was believed to be afflicted with the radical incapacity to acquire an individual idea. Montaigne, who nevertheless boasts of being platonic and anti-epicurean, ${ }^{1}$ sums up all these old prejudices in flatly refusing to regard woman as anything but a pretty animal. Virtue (the woman's, that is ; Montaigne has different ideas) is corporeal fidelity : his ideal is Anne of Brittany weaving tapestry in the conjugal bedroom. Montaigne reluctantly admits that feminine coquetry may end in ennobling love, but without changing its destination: "You can do something without the graces of the mind, but nothing without bodily graces." Thus, when Roman and papal society claimed for women the absolute right to have done with paint and powder, it fell foul of a host of preconceived ideas.

Frenchwomen did not firmly enough assert themselves. Their services were accepted for domestic tasks, often delicate and difficult, which necessitated much intelligence, but were considered servile or at least inferior. Further, when they endeavoured to rise above this state of bondage, they were checked, sent back to their idleness and frivolity, persuacled that it was no duty of theirs to defend the great causes men too often deserted; and they believed it. Here is a mass of useless men, says the world: go to, let us match them with useless women! But was it not a mistake thus to bury them alive, so as to prevent their being too much in evidence? Was it right to inflict on the half of the human species a malaise the more terrible because

${ }^{1}$ Bk. i. cap. li. ; bk. iii. cap. v. 
for the most part the victim was unable to account for it? A woman who had all that is apparently necessary for perfect happiness, and who nevertheless was sick and unhappy by reason of the emptiness of her life, exclaimed: "I feel I lack something. In my soul there are faculties stifled and useless, too many things that are undeveloped and of no service to anyone." How many like her have there been at all times-women of deep, vacant, ever virgin souls, who suffer through not giving themselves, and live in maiden meditation, fancy free! And why? For the sole profit of the selfishness of men! "No, this ought not to be," warmly rejoined a convinced spiritualist: "if men complain of seeing themselves equalled or surpassed, more's the pity: they have only themselves to blame. 'Tis that they are unworthy of their women!" This was not the speech of a Frenchman, but of a Roman prelate, Giovanni Monti, secretary to the pope. 


\section{CHAPTER V}

\section{RELIGIOUS INFLUENCE}

THE great effort that we have sought to portray resulted finally in a profound religious revolution; starting from a crisis in belief, it led to a transformation of Christianity through the ministry of women.

In reality, feminism exalted the soul rather than the woman. Woman is born to cling to somebody; if man fails her she seeks s stay in God. It was thus inevitable that her religion of beauty should end in a mystic marriage, in a great dramatic act of religious sensibility, in a development of charity and hope on the basis of definite dogma, in the skilful interpretation of impressions of the unseen by means of external sigus.

That women would fling themselves passionately into religious sensibility was only to be expected. This is their way. ${ }^{1}$ Leaving out of account those who are never happy out of church, women love to fancy themselves queens by the grace of God. The incomprehensible, which irritates men, fascinates them, and they experience a singular joy in rummaging the mysteries. As we have already said, at the moment of the religious crisis a courtesan proffered the most judicious advice on the direction of ecclesiastical affairs.

In the Church, to mistrust the intrusion of women was a peremptory tradition, and indeed the ecclesiastical world may well be considered the citadel of anti-feminism. Religion had taken a logical and theological bent; it recognised only one morality, applying to noble ladies and eminent intelligences the rules taught to plainer folk. Eras-

${ }^{1}$ One of the peculiarities of the Albigensian heresy was that it developed through the apostleship of women. 
mus repeats approvingly the maxim of St. Paul: "Christ is the head of man, man the head of woman; man is the innge and glory of God; woman the glory of man." With the Church Fathers it had been a long-established custom (groing back to the wisest of the wise, Solomon) to compare women, and even the Virgin, to the moon. From sacred literature this comparison passed into profane literature, which employed it in season and out. Rabelais declares that women play hide and seek with their husbands, as the moon with the sun; Boceaccio and Brantôme revive the old proverb about the virtue of women needing to renew itself every month like the moon. One poet decries the moon, pale like woman's love; another adores her, pure like his well-beloved.

The platonists were well content with this phantasmagoric comparison, which represented to them in all likelihood a whole world of freshness and domestic joys.

Dolce himself deems that the moon is feminice. "At night," he says, "she streams through every chink and cranny, spite of blinds and shutters; she inspires the imagination of husbands." In France, during the period of the fair Diana's ascendency, the moon quite eclipsed the sun; the king sported a device of interlaced crescents. ${ }^{1}$ But the Church did not go so far. It excluded women from the priesthood; its tradition granted them nothing except personal piety, or at most heroism like that of St. Catherine of Sienna of unfading memory. In order, therefore, to secure a place in an absolutely new order of ideas, women had to wash their hands once for all of eminent dogmaticians and subtle molalists, and to effect a complete change.

Many enlightened minds in the Church itself called for this renovation.

The weariness and disgust generally felt in regard to certain trivialities in religious observance, to the apologetics and the frigid ethics of the time, had caused the spirit

1 With this motto :

Donnez puissance soliveraine

Au croissant de France, tel cours

Qu'il vienne jusqu'à lume plaine

Sans jamais entrer en décours.

[All sovereign might do ye bestow

On France's crescent; let it grow

Till a full moon in heaven it reigns

And never from that glory wanes.] 


\section{THE WOMEN OF THE RENAISSANCE}

of faith and faith itself almost entirely to lisappear; and thus the Beautiful easily became the guiding principle of theology. Only, some people sought their theology in abstractions, others in the joys of art. The fall of Savonarola precipitated the movement in the direction of art. His friends were downhearted. Michelangelo clave to the Man of sorrows, the crucified Christ, "as a skiff to the harbour"; his faith became confidence, and dogmatic theology had no further interest for him.

So far from feeling itself harmed by this breath of philosophy, Rome, ancient and eternal, regarded itself as invigorated thereby. "I am a Christian platonist," had been the saying of the early platonists. Too proud to have any love for the petty arguments and the material extravagances of every-day religion, these philosophical prelates wished to establish the authority of the Church on the liberty, not the anæmia, of the conscience.

The new philosophy declared itself to be more Christian than that of Aristotle, and bowed before the official dogmas, like the priest before the altar, declaring itself "unworthy" -before dogmas of almost insolent authority, stern, inexorable, but modified by tenderness. The new religion was the philosophy of the Lord's Prayer. It sufficed to recite the Paternoster in the spirit of love harmonising with it ; regarding God as the good Father, who gives life because $\mathrm{He}$ is life,-God, the celestial and ideal, whose will should be done because it is the very essence of love to seek its motives in the will of the beloved one. We love, not the idols of the world, silver and gold, but love and mercy; our daily bread is sufficient for us, love has loosened in us the springs of ambition; filled with tenderness and dignity, foes to intrigue, we have to spread abroad in the world this same tenderness and the tolerance it implies; may God in like manner pardon the evil we may do. We beseech Providence not to put temptation in our way, so that we may be saved from falling!

God is all love and all life. It is not His will to betray us by laying snares for us; His religion can be only the perfect manifestation of natural law. Goodness and piety do not mean pessimism and self-abdication.

The positive side of religion, namely, the creed, may well be left to reasoners and theologians, for it gives rise to 
insoluble problems. But religion also includes principles of practical morality, which have for object the happiness of nian.

In regard to the second point, the Gospel leaves us great liberty. It lays down no dogmas in regard to beauty; it confines itself to bequeathing us love, not a love more or less alloyed with selfishness, vanity or interest, but a general love for God and our neighbours, resulting from an inward spirit of devotion.

That being so, what is the good of quirks and quiddities? What is the good of tight fetters? Love, and go straight on your way - that is the new formula,-a very effective one, since it converts dogmas into sentiments, and consequently gives them a direct bearing upon life; a very philosophical one, for nothing is so personal, so individual as sentiment. And, as Montaigne says, "It is a most excellent and commendable enterprise properly to accommodate and fit to the service of our faith the natural helps and human implements which God hath bestowed upon us. .. Had we fast hold on God by the interposition of a lively faith; had we fast hold on God by Himself, and not by us; the love of novelty, the constraint of princes, the good success of one party, the rash and casual changing of our opinions, should not then have the power to shake and alter our belief."1

Faith is the best and almost the only guarantee of liberty of thought.

That explains why, in the official apartments of the pope, the School of Athens, an eclectic homage to the philosophic spirit, is a companion picture to the Controversy on the Holy Sacrament, the synthesis of the spirit of faith, and why the Parnassus appears to unite them. No one found any thing to object to in this alliance. Erasmus insists on the fact that Christianity and Plato are in wonderful accord in regard to happiness; Cornelius Agrippa himself, who ventured to call Plato a "master of errors," ${ }^{2}$ attributes to Socrates inspiration from on high.

Leo X. acted as pope in countenancing Plato.

Mitigating circumstances have been urged in his favour; as the Roman tradition excels in accommodating itself to

${ }^{1}$ Bk. ii. cap. xii.

2 "Platonis, ceterorumque philosophoru , quos omnes errorum magistros ostendimus." 
the needs of each successive age, some Catholic writers have thought that the alliance between Roman prelates and the new aesthetic cult was a prudent concession to circumstances. Our opinion, on the contrary, is that Rome, under the influence of a century and a half of ardent study, deliberately placed herself at the head of the movement. Rightly or wrongly, she believed that religion is the art of living freely and in peace. "The soul is far above the intellect."

In virtue of this maxim there appeared, closely leagued with the prelates for the purpose of reforming the Christian practice and restoring to it its primitive motive force, the women, whether platonist or not, who have been called bibliennes, but whom we would rather call Mothers of the Church. In these days we stick pretty closely to the external and picturesque features of the Bible; we read it as a story that has come true, and love a realistic illustration. The bibliennes, too, after their fashion, sought impressions, rather than a doctrine; for what they called "my religion" was the dostrine of others, on which they drew their own patterns, like figure-skaters. What concerned them in the Gospel was its philosophy. ${ }^{1}$ They wished to profit by it on their own system, that is, by intuition, by inspiration from on high. Faith in witcheraft flourished more than ever, and it seemed quite natural to regard women as the special interpreters of the unseen. ${ }^{2}$ The bloody persecutions of the 16th century did not succeed in uprooting the belief in witches, who sometimes indulged in horrid midnight abominations, but who were the more habitually consulted by people who wanted to have their

1 "Nevertheless it must not be thought, when we make mention of philosophy, that we speak only of that which is learnt in the writings of Plato and other philosophers, for we get also from the philosophy of the Gospel, which is the word of God, the holy and salutary precepts with which Margaret was so well indoctrinated and instructed by her teachers" (Sainte-Marthe's Funeral Oration).

2 People still went to witches and "Egyptians" to get antidotes for love, or love philtres, or simply potions for securing good luck. These potions were mischievously used, as morphine is to-day : it was what they called selling the devil in bottles. Rabelais shows us his Pantagruelion: Porta, Cardan, and other grave occultists or physicians have handed down several of the prescriptions then current: opium was generally used to produce delightful dreams; nightshade produced smiling illusions. The principle of love philtres was derived from remote antiquity, and apparently $M$. Brown-Sequard has borrowed something from them. 
fortunes told, to have their ailments treated, ${ }^{1}$ to obtain good weather, etc. ${ }^{2}$ The boundless ambition of Julius II. sprang, it was said, from the prediction of a sorceress, who had tolil him to be of good cheer, for he would obtain the tiara and world-wide sway. The witches loosed or bound the devil at pleasure. Their power was evil, but supernatural. People said "witch"; in some parts the word "wizard" did not even exist. If the witch was to credulous people the incarnation of women's special aptitude for medicine and religion, there was a good deal of truth in the idea, and women might well be supposed capable of exercising supernatural power. It was fashionable to extol the ancient sibyls in the same terms as the prophets. These celebrated beings formed the connecting link between antiquity and Christianity; instead of doing as Julius II. wished, and painting the twelve apostles, in other words, the active ministers of

"For instance, a lady of Blois, attacked with a decline, "bewitched," it was said, had a mass said at Notre Dame des Aides; then a witch lay full length upon the patient, mumbling her wicked charnis. The sick lady was at once cured; it is true that, two months afterwards, she had a relapse and died, but the witch attributed that accident to her own unruiy tongue.

2 Witches were the happy possessors of a number of talents : they cured diseases by amulets or charms; they brought hail and rain; their maligr. power played with the secrets of kings as well as of families. Two young peasants of Nivernais, stalwart striplings and much in love, one day married two sisters. On the evening of the wedding day, strange to say, the newly-married couples, instead of making love, fell to lolows. All at once someone remembered that on the previous Palm Sunday one of the young fellows had refused to give a piece of consecrated boxwood to an old witch in that neighbourhood, and that she had simply said: "You will repent this." Off they went to the hag, brought her back with them, gave her a warm welcome and a good meal; she relented and allowed one of the men to drink from her glass; he recovered immediately and his wife was satisfied. The other, on the contrary, who had not drunk of the same cup, fell ill; soon he seemed in imminent danger; the witch, when summoned, refused to inconvenience herself a second time: all offers and threats were alike unavailing. The family was in despair, the whole village at its wit's end. The witch locked herself in; a hole was made in the roof, she was dragged out with her husband and carried off. Arrived at the bedside of the sick man, the husband said: "You are not going to die" ; but the woman refused to utter a syllable. Then the rage of the bystanders knew no bounds: men who had been in hiding flung themselves on the malevolent hag as soon as she withdrew, seized her, and flung her into the fire. Others, more merciful or more appreliensive, managed to pull her out, her legs horribly burned, carried her home, and tended her. But the wretched woman, stoically wrapping herself in her pain, shut her door, refused to send to Nevers for a doctor, and after three months of agony died in her obstinate solitude. 
faith, Michelangelo boldly and triumphantly displayed on the vaulted arches of the Sistine chapel seven prophets and five sibyls, that is, the ministers of intuition.

Thus women substituted themselves for priests as they did for doctors, from a horror of materialism and professionalism, from a sense of duty, an idea of liberty, a spirit of charity, making no professions of profound study, but with the wholesome aim of protecting the youthfulness and beauty of their souls. Apostles of the religion of love and joy, they addressed themselves to the miseries that befall especially those whom the world calls happy; the unfortunate doubtless have no time to think of their woes; it has always been much more difficult to convert the rich, the healthy, and the young.

The idea of the feminine priesthood very easily made headway in Italy: "God is only seen through women." Women addressed themselves to chosen spirits-philosophers, writers, preachers, men of action-who wished to see God, but were too short-sighted. In the religious as in the other arts, every prelate of importance had one woman, if not several, behind him. Bembo was the friend of Olympia Morata ${ }^{1}$ - what could be more natural ? A fiery, proud, austere monk like Ochino, with his large, bloodless face and long, shaggy white beard, hardly seemed likely to prove a grand master in the feminine freemasonry; yet he came in the end to lean upon a bevy of ardent women, with Caterina Cibo, one of the pope's ladies, as their brilliant head. The pope himself came to terms with the ladies: Paul III. displayed his deference for them on various occasions, and especially by a visit to Ferrara, the notable seat of a feminist council.

Vittoria Colonna shines in the front rank of these Mothers of the Church; she is the classical woman par excellence. She got up lectures at Naples and Rome. She sustained and consoled prelates of the highest eminence. "Since the hatred of others, the price I pay for my devotion, has not bereft me of your Excellency's good-will," wrote Giberto from the chancellery at Rome, "every other loss seems to me but a trifle. Your Excellency can do me no more singular favour than to command me."

${ }^{I}$ [An accomplished lady of the court of Ferrara, who wrote dialogues and Greek verses, married a German physician, and died at twenty-nine.] 
Bishop Selva wrote to Cardinal Pole: "Thanks for the copy of your letter to the marchioness of Pescara on recent events ; it is worthy of that Christian lady." And the good Sadoleto, writing also to Pole, said: "I have read the letter addressed to you by the very saintly and prudent lady the marchioness of Pescara, in which she speaks of me and appears to approve of our staying here; it is an indescribable pleasure to me to see my counsels approved by so much virtue and wisdom."

The holy passion of the marchioness for Cardinal Pole burned with a highly mystical glow. Vittoria wrote to this beloved prelate "as the intimate friend of the Bridegroom, who will speak to me through you, and who calls me to Him, and whose will it is that I should converse on this subject for my own encouragement and consolation."

Religious feminism acclimatised itself in France with considerable difficulty, through the fault of the women themselves. They were habituated to tread unswervingly the authorised paths to Paradise-fasts and abstinences, indulgences and pardons, relics, vows and pilgrimages. To follow in the procession of Corpus Christi among their lackeys bearing torches emblazoned with their arms, to wash the feet of the poor on Good Friday and hand the poor a basket of provisions, never to miss a sermon, to have a mass said every morning at a private altar, to purchase indulgences-that was the religion of the great ladies of France. This religion was accused of proceeding from a somewhat mechanical severity, and of proving nothing; and indeed there were among those old-style ladies some who were virtuous without purity, and some who were devout without piety. Among the middle classes it was still worse: "angels at church, devils at home, apes in bed!" How many husbands lost their tempers at finding dinner not ready, and learning that Madame was at her prayers or "slobbering over images"! An old writer declares that there is no mean with religious women; they are eitler sour-tempered, peevish or disagreeable, or adulteresses. And yet the same preachers whom we have already scen obstinately bent on preserving the dead level of morality vaunted equally the dead level of religion; they were desperately afraid of getting above it. They liked women 
to remain little girls, incessantly tormented by infinitesimal scruples; their narrowness of thought, their passive and minute obedience were precisely what the preachers praised, such were the traits they pretended to admire in the Clotildes and Theodelindes. ${ }^{1}$ And if the Saviour after His resurrection went first of all to knock at the gate of the Mlagdalene's garden, that boon, according to them, was motived solely by the purely passive and docile spirit of women. At Paris, where women were said to be deficient in high philosophy, "there were more works of charity done and more masses said than were done or said between Paris and Rome." However, certain flatterers saw virtue everywhere, and went so far as to cite Charles VIII. as an angel, and the boulevards of Paris as a sanctuary. Such reasonings naturally ended in statu quo.

At Rome the exact contrary was the case; liberty was especially rife among the mob of functionaries, and their contempt for the easy-going government they served was unmistakeable. Far back in the 15th century Lorenzo Valla, to histen his advancement, declared publicly that this government rested on a usurpation and a lie. It was all so peaceful and happy! More than one man, like Burckhardt, would kiss the pope's toe in the morning, and in the evening utter blasphemies. The dogma of infallibility served as a shelter and defence. Just as Titian sent to the Emperor a Trinity and a Venus together; or Sigismundo Malatesta had a portrait painted showing him on his knees before madonnas; or the irreverent Poggio destined his sons to the priesthood: so Aretino, speaking of Saints and Venuses, lumped them all as "these ladies," and confessed before he died.

Far from being disturbed by theological attacks or stale criticisms, Rome thought of nothing but displaying her Atticism and rescuing antiquity from its submergence by medievalism, as she had already saved it from its submergence by the barbarians.

The Spirit of God bloweth where it listeth $!^{2}$

${ }^{1}$ [Medieval types of the perfect wife. Clotilde was wife of Clovis I., King of the Franks (475-545); Theodelinde, Queen of the Lombards (died (625). Both converted their husbands to the Christian faith.]

${ }^{2}$ Le nom de foy et de bonté

A tant mon esprit mesconté,

Que je croy qu'il est en nature

Moins de bons hommes qu'en peinture. 
As said the father of one of the cardinals, no man was a gentleman unless he hazarded some heresy or other. The sceptic represented by Raphael in the Miracle of Bolsena is a man of high distinction. Ideas, men, nothing was safe from ridicule. Two cardinals were chaffing Raphael for having, as they said, given S. Peter and S. Paul rather too ruddy a complexion. "Bah!" retorted the painter, "they are blushing to see you ruling the Church." Castiglione one day asked 'Phaedra' Inghirami, with a smile, why on Good Friday, when heathens and Jews, heretics and bishops are prayed for, there is no prayer for the cardinals. "Because," replied Inghirami with great readiness - " because they are included in the prayer for heretics and schismatics." The same Castiglione found the Duke of Urbino's chaplain to be rather long over mass, and begged for a more expeditious celebrant. "Impossible," replied the chaplain, and stooping to the ear of his critic added: "Why, man, I don't say a third part of the secretae."

The Lateran council in 1512 had, indeed, prescribed canon law and theology as part of the course of study for priests. It recommended them also to believe in the immortality of the soul. But these were only very light fetters on liberty of thought. When Pomponazzi denied in set terms the immortality of the soul, the Venetians, who had the logical minds of the northern peoples, condemned his book to the flames; but Leo $\mathrm{X}$. did not even reply to the demand for his excommunication. Were there not many like him at the Vatican? Were ceremonial and dogma spoken of much otherwise there? The judgment we can pass on Rome is that of Talleyrand: the man who does not know Rome does not know the sweetness of life.

At one time Adrian VI. was anxious to restore severer modes of thought, but his aim did not please the prelates, and Clement VI. hastened to bring back the spirit of the Medici, a "sentimental deism," to adopt the apt phrase of M. d'Haussonville, and to send "the imbeciles, the ninnies,"

(Melin de Saint-Gelais, in allusion to the order of St. Francis de Paul, known as bonhommes.)

\footnotetext{
[" Goodness" and "faith" and all such cant

With me find sympathy but scant;

Nature doth fewer good men breed

Than live in pictures: that's my creeci.]
} 


\section{THE WOMEN OF THE RENAISSANCE}

as Bembo called them, about their business. The pope supported the Protestants against Charles V. He was quite willing to hear Firenzuola, in his Benedictine's gown, read him fragments of his dissertations on love. Paul III. plumed himself on continuing this charming system. Bembo became a sort of patriarch; his Asolani served as well for a religious breviary as for a philosophic formulary.

Delightful age, in which nothing was hopelessly stranded in mediocrity! in which the religion of beauty seemed to sum up all aspirations human and divine, all the sanctities!

The cardinals displayed a reasonable magnificence because princes and lords were essential to the kingdom of God on earth.

These were Christian prelates, charged with the duty of guiding a somewhat pagan world. Among them we necessarily meet again the learned doctors of love and witBibbiena, for instance, his Plautus in his pocket, always smiling, always amusing, and philosophising with gusto on the oddities of the moment. "What folly!" is his incessant exclamation. A priest, but one of the fashionable variety! Steeped to the lips in mythology, and so refined, so delicate, that the naive emotions of a primitive Madonna leave him untouched! Wishing with his exquisite politeness to offer a royal present to Francis I., he ordered, not a Madonna, but a portrait of the beautiful Joan of Aragon. That is the man who in the portrait of Leo X. stands near the pope's chair as the heart of his heart.

And Bembo, who invokes Olympus and speaks of the supreme Beauty, how does he regard the sacrel hierarchy? He writes to Isabella d'Est that he "desires to serve her and please her as if she were the pope." .. . "Far better to speak like Cicero than to the pope." And he adds this postseript: "Isabella, my dear, my dear, my dear, I kiss thee with all my heart and soul, and beg thee to remember me, as my big, big love for thee merits." That was his interpretation of eharity! But people were not particularly scandalised at these youthful sallies, any more than it occurred to them to be shocked at finding a bishop's palace peopled with mythological personages, ${ }^{1}$ or the Corso, on a carnival day, gay with masked cardinals.

1 Thus Paul Jove describes the villa on the Lake of Como, in which he wrote his Elogia: a villa fanned by gentle breezes, hung on a hillside 
This intellectual indifference would have had graver consequences if, knowing theology so badly as they did, the clergy had attempted to expound it; but as a matter of fact they only seratched the surface of dogmas; they were far too sensible to speak of things they knew nothing about. The watchword was to render religion lovable. In what respect was Sadoleto, for example-that Fénelon of the 16th century - a worse priest because he was so passionately devoted to the humanities and the arts? Take liberty away, and the degeneracy of Catholic countries was assured.

To-day everything is changed; if Leo $\mathrm{X}$. or Bembo returned to the world, they would be utterly nonplussed by the complete alteration that has taken place. It is in Germany, among their whilom adversaries, that they would recognise the doctrine dear to them, and a freedom of mind that allows a man to call himself a Christian though rejecting the divinity of Jesus Christ. To many presentday Germans, the kingdom of God stands for the whole community of those who believe in the principle of love. God is love: the kingdom of God-that is, a state in which everyone's actions would be prompted by love-is the final end of God, and at the same time the most universal moral ideal, the sum and crown of morality and religion. Singularly enough, people are apt to imagine-not, of course, that the founders of the Reformation professed this doctrine (the mistake would be too glaring), but-that they opened the door, cut the first notch in the tree, by starting the private reading of the Scriptures. Thus Protestant orthodoxy, which holds by a priestly and quasi-infallible tradition, would appear as a pseudo-eatholicism, whilst liberal Protestantism, which pushes forward with open mind in a boundless field of thought, would represent the logical outcome of the work of Luther and Calvin.

On the other hand, it is believed by some that the armour of authority, the spirit of narrowness and officialism

dominating the lake, so rich in classic memories, so pure, so blue; in the episcopal dining-room, Apollo and the Muses presided; the drawing-room, dedicated to Minerva, contained busts of several great writers of antiquity; thence one passed to the library, then into the Hall of the Sirens, then the Hall of the Three Graces. Large windows opened upon green flowerbedecked mountains, luxuriant valleys, rugged granite peaks, a majestic horizon of eternal snow, and indestructible glaciers, above which hung the beautiful transparent blue sky. 


\section{THE WOMEN OF THE RENAISSANCE}

sometimes adopted by Catholicism since the struggles of the 16 th and 18th centuries, are indispensable to it, and that the Reformation was calculated to rid it of that spirit.

On the contrary, it was at Rome that liberal ideas with the utmost audacity secured a footing. They were vanquished, it is true, and disappeared; but if Luther and Calvin had the glory of defeating them, time in its turn has brought in its revenges, and, of Luther as of Calvin, there is very little now remaining.

The liberal Protestantism of the present day is the antithesis of the primitive spirit of the Reformation.

The Reformation had political and social sides, of which this is not the place to speak; in matters religious, the reformers felt a need of disciplinary reorganisation, very natural, but not peculiar to them; but their essential aim was to create a reaction against free thought, to return as far as possible towards the Middle Ages, to rescue the world from the Roman idealism, which was the work of prelates and women, and had sunk into an intellectual dilettantism. Old Germany desired matter-of-fact, or at any rate well-advertised virtues, a quasi-military pietism, and theological reasoning. It revolted against life in the sunlight.

Frenchwomen were not thwarted by their husbands in regard to their patronage of the aesthetic cult, as they were in matters of morality. The majority of men professed a benevolent scepticism, which made them what we call "moderates," that is, not warm partisans of moderate ideas, but moderate or even negative partisans of any idea whatever; and consequently they were open to any sort of impulsion, even from women. Montaigne wanted but one thing to make him a mystic-namely, mysticism: and the Montaignes are legion; only we do not come across them; in their characters of moderates they keep in the shade.

In this case the obstructors were the clergy, the mass of whom in France, as in England or Germany, made common cause with the nation, instead of the nation making common cause with them, as at Rome. They possessed about a fifth part of the land, and found themselves tied to it. The village parson, sprung from the soil, and presented to a benefice on leaving school, did his duty there without hope of advancement, in the same spirit that the lord performed 
his feudal duties-rather like a superior farm-hand, much less accomplished in theology or in platonism than in mixing a sauce for a choice carp, or in roasting to a turn the pullet he brought home under his arm on his return from administering the last rites to a dying parishioner; a jolly good fellow, and a capital gossip, but as far from a mystic movement or a crusade on behalf of the ideal as the poles. If there was to be a Reformation, the only one that would have struck lim as useful would have been to authorise him to marry; and French statesmen, although very good Catholics, were very much of the same opinion. Obviously it was still more impossible to depend, for upholders of the ideal, on a mob of artisans, tradesmen, peasants even, highly practical people, who had got their poles shaven in order to come under the jurisdiction of the church courts, and who, though clerks only in name, still helped to root the Church among the people.

To meddle with this obscure and doltish mass with the idea of implanting in it the germ of the beautiful was the last thing women would have thought of.

There remained the world of distinguished abbés, the higher clergy, the court prelates; but, as benefices served to reward merit of the most various kinds rather than to encourage a philosophic system, the upper ranks of the French clergy showed a curious mixture-eminent priests, venerable monks, younger sons or merrybegots of great nobles, professors, judges, men of letters. No one who did not know would ever have suspected that Melin de SaintGelais was an abbé.

Fausto Andrelini was not at all ashamed to publish a letter to his mistress side by side with an address to the Cardinal of Amboise, in which he solicited ecclesiastical preferment.

The bibliennes put themselves at the head of this motley crew of great churchmen; they were "clergywomen," as someone satirically said, and formed the new priesthood, the Salvation Army of that time. Their simple ambition was to raise these men, these priests, by one stroke of their pinions, into the empyrean, as in Italy. Convinced doubtless that-to adopt the phrase of a distinguished lady - "the law of sex and its pious mysteries lead to great sanctity," they saw shining in the supreme light varions 
groups united by sympathy and tenderness-old St. Jerome sustained by young Paula, Francis of Assisi by sweet Clara; following their example, Francis de Sales and Jeanne de Chantal, Vincent de Paul and Louise de Marillac were going to lend each other mutual support, obedient to the eternal law-to say nothing of innumerable holy maidens who were lovers of Christ "in His sacred humanity," like St. Theresa, or who encircled their finger with the ring of a mystic marriage, as Jeanne de France did when founding the Annunciade. ${ }^{1}$ Faith must needs become love and diffuse a thrilling charm: ${ }^{2}$ the priest must cease to fancy himself a policeman. How many poor souls, athirst for love, have fallen very low simply from want of an ideal! There are sick ones who might become artists in sensibility! Women stretch out beseeching hands to God, that $\mathrm{He}$ may help them to regard life with confidence, with joy, with love.

Margaret of France was, in the highest degree, one of these French bibliennes, no debater and indeed sceptical as to the existence of absolute truth sund goodness in this world, but a woman of quick intuitions and contemplative mind. She had faith; she believed in the sacraments, ${ }^{3}$ and did not deny purgatory; she in no manner sought with the ladders of reasoning to scale the verities that tower far above our reach; she preferred to take to herself wings and fly aloft. Men appeared to her so petty, so feeble, such ants, that a few merits more or less on their part were but insignificant stages in the long road between them and perfect goodness; she represented God to herself as pure kindliness, indulgence and love, wherefore it was necessary to fly towards him on wings of love. She clung to St. Catherine of Sienna, not as a theologian, but because "nothing but love was her argument."

This simple explanation of their principles will clearly show in which species of clergy the women would seek their allies; they loved those who loved them. They did not appreciate the courtier bishop who played the hunter or the

${ }^{1}$ [A conventual order for ladies of rank founded by the repudiated queen of Louis XII.]

2 "With a cable of love and fidelity welded together, I fasten my barque to a never-yielding rock, to Jesus Christ the living stone, whereby I may at any time return to port." (Vittoria Colonna.)

${ }^{3} \mathrm{All}$ the speakers in the Heptamer on begin by taking the communion. 
warrior. Their friends were the scholarly prelates; they knew well that platonic love had little hold, alas! on the brilliant youth of France, and that divine love would not easily subdue them; yet by dint of tenderness they did not despair of success. The protonotary D'Anthe fell sick, and Margaret at once sent him the following prescription-a decoction of "pleasant recollections and sure hope of love," a little "powder of laughter," a drop of "true felicity," an extract of "apple of love," in short, remedies not in the least heroic. The gay Bandello's cure was effected with a rich bishopric, that of Agen.

Grave charges have often been brought against this combination of piety and love, and naturally, anyone who does not understand platonism will see a multitude of more or less deplorable arrière-pensées in these "spiritual gallantries." In the 17th century indeed the grave Nicolle ${ }^{1}$ found a happy phrase to describe ecclesiastics who dangled about the petticoats; he calls them "half-married priests." "Marriage" would be an inept name for the unions of which we speak. It is very natural, surely, that women of feeling should seek their friends and fellow-workers among feeling souls! Besides, experience proves that you can do nothing with reasoners except by force; only the sensitive are converted; only St. Augustines have capabilities for good.

The practical programme of the women consisted first of all in their attaching an extreme value to the developrnent of the sensuous elements in worship; the severity of the Reformers, crudeness and bareness of ceremonial, could never attract them; they loved pomp and decorum. Religion to them was the very essence of art; art in becoming elevated shaded off into religion; only the inexplicable thrill of the awakening aesthetic sense can waft the soul from the expressed to the unexpressed. Pleasure is not the end of art; it is only its vehicle. The end of art is God.

\footnotetext{
Eglises viz, s'écrie Marguerite, belles, riches, anticques,

Tables d'autelz fort couvertes d'ymaiges

D'or et d'argent...

Je prins plaisir d'ouyr ces chants nouveaulx,

De veoir ardiuns cierges et flambeaulx,
}

${ }^{1}$ [The moralist who translated Pascal's Lettres provinciales into Latin. and to some extent coutinued his influence.] 
D'ouyr le son des cloches hault sonnantes

Et par leur bruyt oreilles estonnantes :

C'est paradis icy, me dis-je alors ... ${ }^{1}$

One Good Friday, at Brionne, a Norman châtelaine was highly scandalised at the fantastic manner in which the parson rendered the Litany of the Passion; and on leaving the church, she sent for him and the following dialogue ensued: "My dear sir, I don't know where you learnt to officiate on such a day as this, when people should be in the depths of humility; but to hear you render the service, all our devotional thoughts have been put to flight." "What do you mean, Madam?" said the parson. "Mean! you have sung the Passion all the wrong way. When our Lord speaks, you bawl as if you were in a market; and when 'tis Caiaphas speaking, or Pilate, or the Jews, you speak as gently as any blushing bride. A fine sort of parson! If you had your deserts, you'd be unfrocked!" The parson wriggled out of the difficulty like a true Norman, with a gibe at the Jews: "My dear lady, I wanted to show that with me Christ is master and the Jews are subject to Him." 2

A sort of external sensuousness in worship, therefore, formed an integral part of the feminist religion. As to the substance of that religion, it varied according to the women, and even according to the days, for it was a matter of impressions.

It was fed principally by the reading of the Scriptures.

It is a cominon error to believe that Luther's great reform consisted in inculcating the direct and free reading of the Scriptures. The study of the Bible was, one may say, carried to excess among Catholic women. Vivès went so far as to make it one of his principal rules for the education of young girls. ${ }^{3}$ And some people even vigorously pro-

I [Churches I saw (cries Margaret), rich, beautiful, and old, And altars deck'd with images of silver and of gold;

My heart was fill'd with pleasure as I heard new strains of song, And saw the gleaming tapers and the torches pass along, And heard the merry clash and clang of bells high overhead, To mortal ears astounding: oh, 'tis heaven below, I said.]

2 Bonaventure des Périers, Tale 35.

${ }^{3}$ The Bible was much in request. Editions in the vulgar tongue had long been popular in Germany and Italy. Lefèvre d'Etaples, who produced his translation in 1523 , had passed his life in expounding the sacred books. In 1514, Charles de Saint-Gelais dedicated to Francis I., while still only a prince, a translation of the Book of Maccabees. 
tested against the abuse of such reading. Before Luther's time, about 1504, the French satirist Gringoire, as well as certain preachers, denounced it as a positive scourge. ${ }^{1}$ Later, Brantôme waxed indignant at seeing the Bible in the hands of children, and Montaigne at finding it discussed at street corners or in back-shops.

But the women in their turn were irritated at the attempts to curb their zeal. These criticisms of men recalled to them that contemptible sneak Adam, who marle excuses for himself and shuftled on to his wife the responsibilities of their common thirst for knowledge.

Was their imagination distrusted? they asked. Were they thought incapable of distinguishing between " ancient rubbish and modern trash"? They found in the Old Testament rare beauties, to be sure, but they were very far from admiring everything blindly - the exploits of some of the patriarchs-the inconsistencies even of the Deity himself, who forbids slaughter and yet slew! No, no, the Bible is not the book of love; it is the first of books, but one mustn't go there to find the secret of " changing all strifes into sovereign charity."

The Old Testament pleased the friends of the religion of terror-Savonarola, and some French ladies of the old style, devout and mystical at certain moments, but in reality highly materialistic in their tastes and their practical ideas.

Others criticised the Bible as they did everything else. In the Bible, as in other things, what struck them most was the light it threw on life. An artist stops before a landscape, not to analyse the chemical action of the trees, or to discourse on the species of grasses, but to seize the charm of an effect of light, of a picturesque undulation of the ether; at another time, when the light falls differently,

Les aucunes sont bibliennes

Et le texte très mal exposent:

Jeunes bigottes, anciennes,

Dessus les Evaugiles glosent,

Et tout au contraire proposent

De ce qui est à proposer.

[Some are bible-women bold,

(Gringoire, Les folles Entreprises.)

And very ill the text expound :

Bigots young and bigots old

Gloss the Gospels round and round,

Preaching doctrine far from sound.] 
the very same landscape would not even attract his attention, because its garb would be less striking. We do not well understand the synthetic religion of these women, we men of "fluid and curt speech," habituated to analyse every thing with mathematical precision-and not to look for grand opera at St. Paul's. The practised eye of a Renaissance princess allowed itself to be caressed by tints, while our own seeks geometrical outlines. For the Italians and their friends to love was to pray $:^{1}$ so that in the Heptameron conversations half philosophic, half ribald, come naturally between mass and vespers, and Louise of Savoy mingles with them a feeling homily, or reads a passage from st. John, "meat so tender . . . full of love." 2

The reader will understand how difficult it is to state with any exactitude the developments of such a doctrine; they were different with different people, and are to be felt rather than explained. We have not to do here with students shut up in a smoke-filled hall to construct their theses; it is a question of ladies, very great ladies, habituated to the most perfect liberty of action, and permitted by their rank and intelligence to hold direct communion with God, by vision, by intuition of love. They are recognisable by this characteristic. In her work the Adoration of the Magi (a subject well worthy of her pen) Marcaret of France gives us her formula: "To initiate oneself into the divine verities, first by philosophy, then by intuition, then by inspiration" Do not mistake, this is not illuminism or pride: it is simply caudour. These noble ladies do not grudge their pity to human misery, though the sight of wretchedness is shocking to their nerves; but they set themselves high above these miseries, just as they do above discussion. Their religion is distinguished. They live on sovereign heights, where they have no trouble from

1 M. Gebhardt has well characterised this spirit of Italy : "The astonishing intellectual freedom with which Italy treated dogma and discipline; the serenity she was able to preserve in face of the great mystery of life and death; the art she devoted to the reconciliation of faith with rationalism; her dallyings with formal heresy, and the audacities of her mystic imagination: the enthusiasm of love which often carried her up to the loftiest Christian ideal - such was the original religion of Italy "- that of the Renaissance as of the Midlle Ages. Alexander II. and Julius II. scandalised everybody beyond the borders of Italy : in Italy, no one.

2 Tale 34. 
men and are in touch with their goal. God is the first link in a chain, and man the last. As Gerbert said: "In matters of action, mankind holds the first place: in pure speculation, God comes first." It is meet to follow God rather than man. And those who are able to mount high are compelled by conscience to go to the fount and origin of things, and look ideas square in the fnce. In this respect the truly primitive women of the 16th century are sharply distinguished from their daughters of the 18 th, whom it is natural to compare to them. The exquisite and delightful woman of the 18th century was very superficial: she loved life and the world for their own sake. A few hours before she died Madame Geoffrin, ${ }^{1}$ hearing at her bedside a discussion on the best means of securing general happiness, roused herself once more to exclaim: "Add the diligent quest of pleasure, a thing not sufficiently attended to." A profound and true saying, remarks D'Alembert, and one that Plato himself might have envied. The 16th-century women had a less sparkîng wit, but a much more strongly marked temperament. They were concerned only with brotherly love, and instinctively recoiled from intolerance in any form; they wished to fuse the church with the ideal; to them every idealist was religious; but they also carried into the world the pursuit of this high aim of their aesthetic religion-to live for the soul, for God, to live a secret inward life along with the actual life. We may justly praise their piety, their charity towards the poor; and yet they were a mixture: external observances were repugnant to them as being material and obligatory; they loved the large philosophical faith, God and $\mathrm{His}$ works.

Here there is more than ever reason to speak of a "storklove." What platonism had attempted, religious idealism effected-the superposition of two different worlds. It was vain to expect these great ladies to throw any ardour into terrestrial controversies: Renée of France made her protégé Richardot a Calvinist or a Catholic bishop, indifferently. The material mechanism of divine grace appeared to them to have been devised for the vulgar, and to be of a quite relative truth. They did not see why the delicate ray of grace, the impalpable word of consolation, before it could

${ }^{1}$ [A wealthy bourgeoise who held a literary salon frequented by the Fincyclopaedists-Diderot, D'Alembert, and the rest.] 


\section{THE WOMEN OF THE RENAISSANCE}

penetrate into the dark haunts of wretchedness, should necessarily have to borrow the form of a bearded monk or an unkempt parson splashed to the chin. They would rather hear with their own ears that still small voice which said to St. Theresa: "I will not henceforth that ye commune with men, but only with angels."

Priests were men appointed to the service of the Church, and not demi-gods. Some were pleasant and cultured, just as there were excellent abbesses ; but to spend one's life in the vestries, or not to be able to move a finger without referring to one's clergyman, struck Margaret as sheer insanity. For herself, she would rather talk with a sceptic or a clever atheist than with a vulgar parson, because after all the atheist would aid her to accomplish her end, namely, to draw near to God through the Beautiful. Nothing was more natural than to love God and abase oneself in deed and in truth before Him, God being intelligence and King of kings; but what was the good of intermediaries, often so gross? Clément Marot, who saw through Margaret with wonderful acumen, defines her as "woman in body, man in heart, angel in head." The friends of the princess declare that "from the age of fifteen she seemed directly inspired by the spirit of God, in eyes and features, in gait and speech, in all her actions."

The Bishop of Meaux assures her that by reading a translation of the Gospels he offers her she will be as a holy apostle and will receive directly the Spirit of God, just as well, he adds, "as when we" (that is, the common herd) "receive Him in the Eucharist."

Thus the women aimed at being angels and the word of God. In this lofty mysticism, they exhibited a striking contrast to the ensygoing and lukewarm Catholicism of the mob.

Some of their writings permit us to recognise how, little by little, this great religious work was accomplished in their emotional life.

Vittoria Colonna has left us the type of the final prayer of the Renaissance: a petition for peace and happiness in this world and the next. ${ }^{1}$ It is an aspiration, a strain of sweet

I"Grant, I beseech thee, Lori, that by the humility that becomes the creature and by the pride thy greatness demands, I mav adore thee always, and that, in the fear thy justice imposes, as in the hope thy 
and tender music, a melody of Gounod, rather than a doctrine: it is the result of the co-operation of souls in one common striving toward the most perfect joys.

We have under our eyes the works of three Frenchwomen who, though contemporaries, show us the progressive stages of this co-operation.

The first, Gabrielle de Bourbon, Dame de la Trémoille, still preserves in her Château, "a feminine work," as she says, a character of morality rather than art. The spirit which will renew everything, chisel everything, which is gaily to open doors and windows, has not yet come by. Within, no doubt, there are ravishing delights-apostolic visions, prophets and sibyls on the vaulted arches as at the Sistine; angel's food distributed amidst a floating radiance of light! But all is regular, inflexible, and severe; the contemplative heart has begun by employing the besom of discipline.

And externally this castle of the Christian soul, somewhat resembling the Alhambra, shows a rugged and bristling front. Love fires the cannon on the ramparts, whilst Inspiration surveys the country round, and in the tiny garden of Felicity where flows the stream of Pity, good souls gather exquisite white flowers, luscious fruits, and leafy brauches.

In another work, the Spiritual Journey, a story of the adventures of a soul wandering upon the earth, Gabrielle undisguisedly raises her standard against the new divinities - Presumption who loves flowery paths; Self-love, hostile to terrible dogmas; Vain-glory, uncommonly like Margaret of France. Poverty and Virginity are still her friends, and she gives a naïve, heart-breaking, monstrous description of the world-a giant with innumerable hands, each quivering tentacle of which, at odds with the rest, brandishes some weapon, a book or a sword. Charity defeats this monster, Faith triumphs. Gabrielle de Bourbon, as she herself said, wrote for the simple; she did not plume herself on "understanding Holy Writ."

clemency justifies, I may live eternally and submit to thee as the Almighty, follow thee as the All-wise, and turn towards thee as towarls Perfection and Goodness. I beseech thee, most tender Father, that thy living fire may purify me, thy radiant light illumine me; that this sincere love for thee may protit me in sueh wise that, never finding let or hindrance in things of this world, I may return to thee in happiness and safety." 


\section{THE WOMEN OF THE RENAISSANCE}

But ere long comes a genuine noblewoman, Catherine d'Amboise, lady of Beaujeu, who in her Devout Epistles utters this loyal cry:

J'ay transgressé tous les commandemens ...

Pour abréger, aucun je n'en excepte. ${ }^{1}$

She has only one noble thing left to her-her heart; and that she offers to God. Then follow effusions in a lofty strain, full of antiquity, biblical allusions, "sibyl songs," a plea for mercy and love; and Christ puts on her finger the ring of peace, benediction, and remission of sins; He becomes her spouse and lover, and for guardian gives her an angel. With Catherine d'Amboise we win to a wondrous pleasant and aristocratic paradise, composed of "fair manors and castles." To the 15th-century woman has succeeded the biblienne.

Margaret gives the last upward impulse above the anonymous and often ill-thought-out work of the crowd: to prove her independence, she adopts an abstract and lofty aim.

Not that everything is admirable or even comprehensible in her mystical works. Her correspondence with Briçonnet, where, in interminable letters of eighty or a hundred pagres, she twaddles about "confection of tribulations," "old skins" of the spirit; various writings of hers-The Mirror of the Sinful Soul, the Strife between Flesh and Spirit, the Orison to Jesus Christ, the Orison of the Faithful Soulthese are very curious, precisely as types of incomprehensibility and the despair of reason. They do not evidence a very placid psychology: "Worse than dead, worse than sick" - such is the author, according to her mottoes; there were days when she hated doctrine of any kind, the Bible, the Gospels included. ${ }^{2}$

${ }^{1}$ I have transgresséd all God's Holy laws;

'To stint ny story, I except not one.

2 Las, tous ces motz ne voulois escouter,

Mais encore je venois à douter

Si c'estoit vous, ou si par adventure

Ce n'estoit rien qu'une simple escripture.

[I would not hear those words, but still

A doubt my wearied soul would fill,

Whether 'twere very you indeed,

Or chance had given me trash to read.] 
She learnt the death of her brother intuitively, in a dream. From that time the world crushed her; mystics know that thus "the incorporate soul makes her course for the port of salvation." Margaret's mysticism became a blind infatuation, ${ }^{1}$ a drunkenness of love, in which divine and human elements were commingled, ${ }^{2}$ and which manifestly had for object to banish from sight many of the miseries of life.

It is in the book entitled The Triumph of the Lamb that we see best delineated the Christ of her heart, her divine Saviour and emancipator, shedding a radiance above the grimy factory of life. Death itself becomes lovely, and, like a "courteous friend," opens the gates of heaven to wellnigh all mankind. ${ }^{3}$

Mankind has a right to clemency, unstinted, immeasurable; in fashioning us of a somewhat coarse clay, Heaven did not mean to make us all unhappy. Margaret has a horror of death." But Love reassures her, helps her to pierce the mystery. Not as an avenger, but as a lamb will Christ render justice at the Judgment Day. Men were

I In her Comédie sur le trespas du Roy the shepherdess Amarissima (that is, she herself) mourns the death of the god Pan; she no longer believes in anything-either human virtue, or human consolations, or even the old-time constauey. She has lost her philosophy! In the end, the Paraelete comes to restore our serenity by the assurance that Pan is tasting Elysian joys in the eternal meallows. At the earuival of Mont-de-Marsan in 1547, the princess, shaking off mournful preoceupations, put another comedy on the stage, in which she brought into opposition a beautiful larly of fashion, a superstitious laty who speaks of death and paradise, and a wise woman who advocates equilibrium of soul and body; then the "Queen of God" (we may guess who she is) upsets it all-the world, superstition, and wisdomwith a philosophic panacea of divine and human love commingled. We shall not be expected, however, to follow Margaret in the meanderings of her thought, nor even in her prayers " of the faithful soul," or "to Jesus Christ"-earnest appeals to the love and favour and mercy of the Most High, who ean save us only by love.

2 See the close of the Navire, a poem devoted to the praise of love and to the glorification of the beauty and virtues of the late king Francis $I$.

8 "Souvienne toy qu'ilz sont nés imparfaitz,

Et que de ehair fragile tous sont fait $z$."

[Remember that imperfect were they born,

And of frail flesh God's creatures all are made.]

" "Priez Dieu pour les trespassez,

Dont le retour est incongneu."

[Pray God for sinners whose return

From Death's far bourn is all unknown.]

Very few have returned, "the way is long!" 
complaining of the facility of indulgences; Margaret settles the question off-hand; she proposes a general pardon.

Of mysticism, as well as of love, there were already innumerable varieties known. Perugino, Averulino, the preachers of the royalty of Christ, St. Bernardin of Sienna, Savonarola, and many another, carried on the great traditions of Italy. France too, though more stubborn, had her mystics, especially at Rouen and in Picardy, where the palinodists, ${ }^{2}$ elects souls, magistrates, municipal counsellors, had long been singing praise to the Virgin and reviling the body:

La chair, quoy? nourriture mortelle!

L'esprit d'amour nourrit le cueur fidèle $!^{3}$

These palinodists were men of intelligence and ardour. Asking nothing of tne clergy, whom they riddled with pungent epigrams, they had recourse to worldly means to spread their ideas, such as competitions and dramatic performances. They resembled the women in their excessive cult of the intellect, their unceasing itch for writing and speaking, their taste for mystery and incognito. It was the same in regard to their inpressions: they desired to bring into relief the true life of Christ, that is, the mystic and inward life which they held the rude apostles to have overmuch neglected. Assuredly theirs was a noble aim. Margaret was on excellent terms with the palinodists. Yet the mysticism of platonism was different, implying a much more general abstraction: it mistrusted the senses, the material form, desirous of seeing the reality of things, the essence of God. Among the prelates it gave rise to that exquisite academy of devotion and prayer, the Oratory of the Divine Love, which met at Rome in the church of SS. Silvester and Dorothea Transtevera during the pontificate of Leo X., and which numbered among its members sixty priests and prelates, Sadoleto being one of the chief. They

2[The architect and sculptor (1400-1469) known as Philaretes, who mingled pagan mythology and Christian legend in his designs for the bronze gates of St. Peter's, and in his Treatise on Architecture taught that a true architect should possess all the virtues.]

${ }^{2}[$ The palinod was properly a poem in honour of the Immaculate Conception. Several such poems were recited on a set day, and a prize was awarded to the best.]

3 The flesh! 'Tis mortal, fed with mortal food!

Love's spirit nourishcs true hearts and good. 
gave all their thoughts to the reformation of morals, and among them prayer rose delicately to Heaven, like those wreaths of fire the Bible shows us on altars pleasing to the Lord.

Feminine mysticism was broader: its ain was to develop happiness, in other words, to lead us to the summit of an ideal world, full of love and purity. Love, having lost the egotistic and licentious character without which the French mind refused to understand it, having become an aspiration for the French as well as for the idealist races, represented the very substance of the world; it was divine and eternal; it gathered up all things, even men, into the heart of God. The Gospel was only the practical expression of this high natural law, of which the pagans long ago had caught glimpses, and to which Seneca ventured darkly to allude when he wrote, "When, tell me, will you love one another?" The Gospel was the sum and crown of hmman wisdom. Hence Erasmus wished to canonise Virgil, and to add to the Litany a new response- "St. Socrates, pray for us." Plato was quoted in the pulpit; Anne of France, who was orthodoxy itself, took pains to mingle the philosophers with the Fathers. Trajan was regarded as a model; Louis XII. and Guevara, ihe tutor of Charles V., lived on the maxims of Marcus Aurelius.

They aimed at a sort of natural mysticism, the object of which would be to express the essence of mundane things. "It is God," said Rivio," "who giveth to the sky its splendours, to the trees their shade, to the cheering vines their clusters and fruit. It is $\mathrm{He}$ who clotheth the earth with fruitful crops, who causeth the trees to bud and the crystal streams to gush forth, who covereth the meadows with a carpet. Wherefore to hunt and fish and reap, to fulfil all the conditions of life,- this is to be a Christian."

No one had any bent towards naturalism, or imagined that everything that is natural should be regarded as good or beautiful; on the contrary, men wished to elevate and improve Nature, even to excess. Your vineyard, say, always yields bad wine; M. Zola wonld tell you to drink it, Rousseau to drink water: but these folk of the Renaissance would tell you to distil it into brandy. From Nature they wished to borrow certain quasi-mystical powers which exist in her in force. Hence this mysticism did not, like that of St.

' [Author of De perpetuo in terris gaudio piorum. Basle, 1558.] 


\section{THE WOMEN OF THE RENAISSANCE}

Theresa, lead to the deliberate rejection of all earthly satisfactions, to the adoration of death, suffering and humiliation. Carpe diem was their motto, as it was of Horace and Lorenzo de' Medici. They left to Albert Dürer and other Germanic artists the monopoly of dances of death and maidens carried off in the arms of skeletons.

"For loss of servitors we need not despair, for many others are to be had": so spoke the fair ladies, not out of indifference, but out of fear lest the mournful idea should trouble their hearts: for "there is none of us, if she regards her loss, but has occasion for deep sorrow." "When we ask history or romance or the drama to carry us for a time out of ourselves, do not we too seek, in reality, the satisfaction of forgetting death-perchance, of forgetting life?

That was the very human root of this mysticism. In turning back to the page of love, no one wished to feel under the fingers the page of death. Far from forcetting life, they aflirmed it: the secret of life was life itself. They mocked at death. A skelfton at the feast, a spectre at the ball, were subjects for laughter. Like Boccaccio, Machiavelli sets his gayest stories in a horrible framework of pestilence; rich folk laugh and make love under cool leafy shades; and their excuse is that, but a few paces off, death is grinning at them. Such is the key to this novel mysticism. It is a tragic dance of fragilities; but the dancers see nothing fragile. They forge for themselves an artificial weapon, they prefer bcauty to truth.

It followed from the same ideas that they held direct communion with God. The tender worship of the Virgin, fallen a little out of use, no longer throve except stealthily in a corner, like the beautiful plant which the Flemish painters loved to represent in a crystal vase. ${ }^{2}$ Communication with

\section{${ }^{1}$ Heptameron, Prologue.}

2 This was before Luther, or independently of him. Erasmus pleasantly scoffs at prayers to the Virgin or to St. Christopher, and is convinced that the vows of sailors during a tempest are to be traced simply to paganism, the ancient worship of Venus, "Star of the Seas." He has glorified the Virgin in cold but elegantly rhetorical verses, in which the Styx, Phlegethon, Helicon, and the Castalian fount proclaim the new spirit. While in former days Louis XI., for the slightest tribulation, struck a medal to the Virgin or went on a pilgrimage, neither Louis XII. nor Francis I., who will not be regarded as Lutherans, had any such idea; in an extreme case, Louis XII. pays his rows direct in the Holy Eucharist. Sannazaro, who remained fuithful to the Virgin, declared himself of Spanish descent. 
heaven was opened by means of conspicuous semaphores, though these unhappily were irregular and far apart. St. Theresa, like a genuine freelance, might speak of storming heaven, and carrying its successive redoubts one by one; but the philosophic idea was different-a simple canter in a friendly country. On some beautiful day in May, when Nature, overflowing with love, scatters her gifts in careless profusion, a certain Knight, Beau-Doulx by name, sets off among the flowery meadows to conquer this "noble and delectable castle of Love," all sapphires and emeralds from base to turret. He bears with him no canncn, no scaling ladders. Arrived beneath the walls, he sinks on his knees and declares his love. That is all. That is "the realm of Paradise, wherein is love divine."

Nature hails God in us, and reveals God to us. 'The song that rises from the sea soars even to the stars; the luxuriant warmth of the air is a symbol of mercy. Such a temple was better loved than the frantic mysticism of certain northern cathedrals. As for the rites of this worship, they were those of platonism. Salvatorio wrote a Treasury of Holy Scripture after the Pcems of Petrarch: Fra Feliciano Umbruno offered to the ladies of Rome a Dialogue on the sweet death of Jesus Christ, this too inspired by Petrarch. Fra Malipiero presented the famous Spivitual Petrarch, which appeared at Venice in 1536 and ran into the tenth edition. The spiritualisation of sonnets was effected easily enough : but anyone who wished to amend the canzoni and miscellaneous poems had a troublesome task.

The religion of love found an incomparable interpreter in Corregcio. Correggio is the painter of women. How wonderfully he translates their dream of love and confidence, in harmony with the code of aesthetic Christianity! In his Saint Jerome, the Virgin is beautiful to look upon, of a human. piquant, smiling beauty; but the whole effect of the picture is darived from the face of the Magdalene, and her intensely caressing attitude: it is the apotheosis of the caress! Never, perhaps, has love all-embracing, soft as velvet, been so warmly expressed: prayer, passion, all is cast into the sliade by this contemplation of pure love, this coritact, enchanting, radiant, of two beings united by a magnetic tenderness. The child Jesus has behind Him an angel representing heaven; before Iim St. Jerome holds an 
open book; but $\mathrm{He}$ turns about, bestowing His gracious smile upon the Magdalene, whom He prefers to all human learning because she is Love.

At the Louvre, too, the Mystic Marriage fills one's heart with a golden, sunny vision. "It is impossible," says Vasari, "to see more beautiful hair, lovelier hands, a more natural and charming colouring." In this ardent "conversation" life seems to be suspended: "The will is changed to love, the memory appears to have vanished, and the understanding has ceased to act."

Devotion is often accused of being tiresome. It is true that God has no revelation to make to Himself; He is the immortality of the known. The women who lived on such lofty ideas readily assumed a profound and pensive air, an expression of intelligence and trenchancy rather than tenderness. Like the wounded soldier at Austerlitz of whom Tolstoi speaks, they awoke in the vast silence of the night, alone with the clear bright stars.

Where men would have brought their pride, women brought their sweetness. Their language was a little involved and "precious."

Yet we can see from the correspondence of Margaret of France and Vittoria Colonna, how sincerely they thought themselves happy. These two ladies never saw each other. Vittoria writes that while awaiting the infinite happiness of a meeting, she ventures to reply to the "high and religious" words of the princess, so as to act as balance-weight to that celestial timepiece. "In our day, the long and difficult journey of life compels us to have a guide; it seems to me that everyone can find in his own sex the most appropriate models. . . . I turned towards the illustrious ladies of Italy to find examples for imitation, and though I saw many virtuous among them ... yet one woman alone, and she not in Italy, seemed to me to unite the perfections of the will with those of the intellect; but she was so high placed and so far away that my heart was filled with the gloom and fear of the Hebrews when they perceived the fire and glory of God on the mountain-top, and durst not draw near because of their imperfection."

In this first letter the marchioness contents herself with glorifying the humility and charitableness of her noble correspondent, whose duughter she humbly calls herself, or 
better, her John Baptist, her Forerunner: these personal compliments always play an important part in feminine diplomacy, full of splendid courtesy. She speaks of her group of friends; she often enjoys, she adds, the conversation of Pole, who "is always in the heavens, and only descends to earth to do service to others," and that of Bembo, one of the labourers of the eleventh hour, perhaps, but eminently worthy, by reason of his ardour, of the wages of the first; and all these friends of hers unite in contemplating from afar this queen of gems, so rich in radiance that she enriches others.

In another letter Vittoria grapples more closely with the burning questions of the day. She affirms her respect for reason, but she prefers religion, "the supreme perfection of our soul," the perfect beauty. For the better unfolding of her theme she encloses a copy of her sonnets.

This copy, though addressed to the sister of the king, was intercepted in the post by order of the Constable de Montmorency. Whether he read the sonnets or not is very doubtful ; in any case he judged them to be pernicious stuff, and seized the opportunity of indulging in the luxury of an explosion. $\mathrm{He}$ only gave up the book after a stormy scene at the king's table.

Vergerio, ${ }^{1}$ the amiable prelate who was the pope's nuncio in France, had great difficulty also in meeting Margaret. How ample was his reward when he succeeded! His first audience, which lasted not less than four hours, seemed to him far too short to satisfy his "spiritual enthusiasm." $\mathrm{He}$ lost not a moment in committing to paper all that had been said, in order to show to what altitudes of Grace and divine Love "mounts the spirit of the queen." But how was it possible to transfer to paper so much spontaneous eloquence, so much fervour, so potent a charm ? . . . It was not a very comfortable conversation. Margaret could speak no language but French, and as Vergerio was hardly at home in it, she spelt out her words, so to speak, mingling with them as much Latin and Italian as she could. For all this, when Vergerio took his leave, in his ravishment he fancied he saw the glaciers of the human heart melting under the hot

\footnotetext{
${ }^{1}$ [Disappointed of a cardinalate, he undertook a polemic against the Reformers, but was led to adopt their views. He had met Luther at Wittenberg.]
} 
beams of faith, and breathed the wonderful breath of God. Whonce came this miracle? "Praise be to Jesus Christ, who in our troublous times hath raised up such intelligences -here the queen of Navarre, of whom I speak; at Ferrara the lady Renée of France; at Urbino the lady Leonora Gonzaga, ${ }^{1}$ both of whom I have seen here, with whom I conversed for several hours, and who seemed to me endowed with eminently lofty minds, filled with charity, all on fire with Christ; at Rome the lady Vittoria Colonna-to speak of none but your own sex." And he repeats that the thorns in the Saviour's vine are fast disappearing; thanks to women, he sees the radiance of light and peace.

Vergerio continued to converse with the queen of Navarre with ever-renewed joy. One is almost ashamed to transcribe with a cold pen phrases so ardently trustful and palpitating: "I have in sooth no greater wealth, no greater consolation than this queen; she has words of infinite warmth, and marvellous means for uplifting to the service of God hearts that are cold and dead. It happens that for eighteen days $\bar{i}$ did not appear at court, but dwelt in sweet retirement, busy cultivating; my soul and sowing within myself the word of God. Then went I where the queen's glow:ng charity was found, and I felt that she caused the seed to spring up and wax strong and bring forth fruit, in other words the knowledge of God and the fervent desire to serve Him, and Him alone."

Such were these lofty spirits, so enthusiastic for the beautiful. They lived on poetry in a sphere apart, cheering one another, mutually calmed and comforted; it was after her interviews with Vergerio that Margaret declared herself a platonist and shook off the yoke of the court. No one hoped, of course, that the whole world would chime in tune; they well knew that when these abstractions filtered down to the mob they would become materialised, and love itself would ofttimes become tainted. But was it not a beautiful thing to sow love broadcast with no hope of reaping, and to go forth like angels of God to pour a little dew on the parched ground?

This was not destined to prevent the wars and massacres of the 16th century; but a glance at the map will show that Catholicism triumphed in the countries

${ }^{1}$ Heroine of Bandello's love-poem. 
where women triumphed; fog and beer and men turned Protestant.

Further, these ideas, crushed as people fancied them, reappeared by degrees everywhere, as from the effect of a resistless germination. From them sprang the 18th century; with them our own age also, for all its matter-of-fact bent, is still entirely impregnated.

And Sadoleto the friend of Melanchthon, the liberalminded Contarini, the amiable Reginald Pole so much influenced by Vittoria Colonna, Flaminio, ${ }^{1}$ Vergerio, would all smile at certain reconciliatory schemes of to-day.

${ }^{1}$ [One of the best modern Latin poets (1498-1550). He was nominated by the pope as secretary to the Council of Trent.] 


\section{CHAPTER VI}

\section{RELIGIOUS INFLUENCE (Continued)}

"I would a thousand times rather believe in and pursue an ideal, even though too high, than miss or betray it," said Montalembert. Many persons in the 16 th century were of a different opinion. They deemed aesthetic religion too frivolous or too worldly a thing, above all, too chimerical. The adversaries of the religion of beauty split up into two categories: some opposed it from reasoned conviction, others from social jealousy and incompatibility of temper.

The first, of whom Alberto Pio ${ }^{1}$ and Budé, ${ }^{2}$ eminent and estimable men, may serve as specimens, scouted the very idea of any connection between philosophy and religion, between aesthetics and morals; in their opinion religion did not tend to satisfy the reason, nor beauty to purify the conduct. The suggested reconciliation was to them an illdisguised reversion to paganism, and in practice led to

1 "Who then has supported these men?" cries Alberto Pio: "the dignitaries of the church, and the highest of them! They have maintained at their voluptuous court these men with their half pagan leanings, who pour contempt on all that is dear to the people, and strive only to overturn existing things."

[Pio was prince da Carpi, and a nephew of Pico della Mirandola.]

2 "We," he says, "nourished and moulded by Christianity, no longer approach the thought of divine and eternal things except with a heart full of vanity, a mind deadened and filled with the love of material things. To the instruction of Scripture, to the responses and prophecies of the Son of God, it is necessary to find (I am ashamed to say it) an academic counterpart. We have gone back to the old state of polytheism or atheism, to the maxims of antiquity. . . In this paradise of study it is necessary for every lover of letters that his philosophic mind, leaving behind the pastures of philology (very pleasant, but in themselves futile and of no account for what concerns the present object), should strive to fill itself with the nutri. ment of sacred philosophy, the feast of heavenly wisdom descended among mortals." 
scandals like the representation of Machiavelli's Mandragora ${ }^{1}$ at the Vatican.

As we have seen, persons of this same opinion had already demonstrated the irrationality and inadequacy of reasoning; they had thereby relieved the world of a serious embarrassment; sensibility was henceforth to be the sole guide of life. But now we find others wishing to destroy this sensibility also, and to strip us of everything. At the idea that love is born of beauty such people veil their faces, and beg us to take away this thing they cannot bear to look upon, that is neither moral nor religious!

Assuredly it is impossible to commend everything in the Roman movement. Far from it! There is only too large a scope for criticism. Aestheticism was carried too far : it was, for example, a singularly wild notion to consider the building of St. Peter's at Rome a social necessity of the first importance, and to sacrifice a part of the Catholic world to the desire of completing the Vatican. Antiquity, to be sure, evoked a quite exclusive enthusiasm, and it was singular to see the headquarters of Christianity going crazy about Pomponius Laetus, calling him "the glory of the age," "Caesar," because he was unearthing pagan catacombs. Not that mythology, as then cultivated, aimed at bringing back a real, lively faith in the Olympian deities! Isis, Apollo, Venus, on the walls of the Vatican or the churches, stood only foi symbols and types of philosophy: Jean Bouchet very happily styled them "the aristocracy of the world." Men thought, with Plato, that the beauty of things can only be gauged by comparing them with an eternal type; as Margaret of France said: "The Beautiful is seen in all forms of beauty." Further, morality, without divorcing itself officially from Christianity, sometimes was pretty completely disjoined from it ; to many people virtue consisted in wearing a good coat and keeping up a good style. Montaigne, Aretino, and Benvenuto Cellini, for example, passed for virtuous men.

To protest against this paganism was a right and proper thing. But was it necessary to forbid Christianity to secure a rational appreciation, and even to win our love by working upon our emotions? An ineradicable instinct prompted the Latin races to believe through love; "Italy will be un-

${ }^{1}$ [A brief criticism of this excellent comedy is given in Macaulay's essay on Machiavelli.] 
christianised, not Calvinised," as Azeglio admirably said. To invest worship with mundane pomp and circumstance is as profoundly human an idea as it is to keep the clock at a railway station a few minutes behind time.

The Middle Ages, however, kept strict time : materialistic as they were, they erected cathedrals, the baser instincts avenging themselves by affixing to the cornices, or even to the porches, in full view, ornamental details cynically human. The Penaissance, for all its mysticism, was not partial to the dim religious light, or the mysteries shadowed in lofty arches far out of eyeshot; it loved clearness, daylight, illumination. It built only châteaux, even to the glory of God. St. Peter's at Rome is a château; the eye detects nothing abnormal in it; and there man feels himself at home.

It was thus with the religion of prelates and women. It was lofty, sometimes loftier than Gothic arches, but so broad, so clear, so full of unity, of so human a hospitality that no one felt he had to do with the unknown, the unfathomable. It was a reflection of life itself, but with added brilliance and decoration; it aimed at attracting man, when he had performed his material functions in eating, drinking, loving his wife, to a banquet of spiritual fare and spiritual love. We look to women to quicken our perception. In spiritual concerns the parts are reversed.

Now, men spent their lives in an atmosphere of materialism and unbridled sensuality. Melin de Saint-Gelais declared nudities "heavenly objects, worthy of altars." 1 Coyness was unknown. "Happy the people who have only God to deal with," cries a young lady: "with men it is enough to save appearances." 2 In the view of many, morality found only an insufficient sanction in religion; the third Margaret of France wrote, with a modesty unhappily too well justified: "Some consider that God holds the great in his special protection." And on the other hand, the laws of society did not always oppose a very solid barrier: it was easy to a noble lady to override them. Renée of France

${ }^{1}$ La foy sans amour est morte et endormye, Aussi l'amour sans effect vient à rien.

[A loveless faith is slumberous and dead, And love inactive naught accomplishes.]

${ }^{2}$ Heptameron, Tale 42. 
took a manifest pleasure in running atilt against popular conventions; Marot had only to set the mob against him as "a lascivious pagan," to merit her indulgence. Apparently she was even tempted to believe a daughter of France so superior to humanity at large that she could have only lovers.

However, it was sincerely believed that, for people of refinement and distinction, good style and good taste rendered many artistic things inoffensive. So (to select one example among a thousand) no one was shocked when the Abbé de Maupas gave his approval to some neat verses in which Gilles d'Aurigny boasted his conquest of a "sweet pale Margaret." The gentle spotless Vergerio very gaily accepted the title of " bishop of Aretino." IIargaret compliments her brother on retaining his faith through all his sin. Does she praise the sin? Not at all : but she praises the king for what is praiseworthy, the remaining a Christian. Vergerio would have shrunk with horror from certain of Aretino's books, but he considered the man as a force, of as much importance as any diocese, while many of the episcopal boroughs contained as many vices with less wit. And he tries to coax some good thing out of this diocese. On the same principle Margaret set Vauzelles to translate some of Aretino's devotional works. Indulgence thus shown in practice had no modifying effect on principles, and besides, men were particularly careful not to extend it to the masses. Among them, as everybody knows, there is no such thing as sentiment, but only sensations, and with them, consequently, the fetters of a material morality were still found serviceable. The same Caterina Cibo who highly approved Firenzuola's book on love, severely reproached the bishop of Camerino for his slackness in reforming the morals of his clergy, and succeeded in obtaining from the pope a rigorous brief on the subject.

In society it happened that pagan sensation and Christian sentiment all but touched; it seemed prudent, advantageous, and politic not to accentuate the difference between them. Many people, like true gourmets, let themselves swing gently between mysticism and materialism; perhaps it was just as well not to compel them to decide one way or the other. It has been well said that "faith has this peculiarity, that when it has vanished, it influences still : grace 
survives by force of habit from a once living sentiment." 1 The logical Germans proceeded to deduce from this spiritual condition the system of "faith without works." But folk remained satisfied with " confidence without works." It was in these practical considerations that an answer was found to Budé's objections.

However, Budé was a friend, and sought only to point out abuses. The real and invincible adversaries of the religion of beauty, those who hoped to destroy it, came from below. They were such as society scouted-the vulgar, the superstitious, the material-minded, the street as against the salon : in short, the men. When Vergerio went to Germany to discourse of love, he was answered in a strain that disconcerted him : the Germans talked politics to him. "I am tortured," he cries, "to see the cause of Jesus Christ treated with so much indignity; it appears to me that to-day this is not the real explanation of the immense trouble taken with so many people: it is assuredly only a pretext. The main thing considered under the cloak of zeal for Christ is, I believe, nothing but the private interests of a few individuals."

The clergy did not follow the religious lead of the prelates. The whole of the middle or lower orders among them, the country parsons, the monks, made common cause, some in a materialist direction, ${ }^{2}$ others as visionaries, against the philosophic group, the higher prelacy, and the priesthood of women.

The monk was a man of different stamp. Margaret petting Rabelais resembles, if we may be allowed the expression, a hen mothering a duck. Look at the man of

\section{${ }^{1}$ Renan.}

2 The art of evoling the spirits which hover about us, and of entering by their aid into relations with the absent or the dead-an art largely practised in France and Germany - was quite as pagan as the Italian mythology. Trithemius, the famous abbot of Spanheim, laid down dogmatic rules for it. Many spirits came without being summoned. There were amiable spirits among them, simple domestic goblins who made themselves useful. At the moment of death Agrippa was thus attended. There were also troublesome fiends, like those tricksy sprites who visited women in the darkness of the night. Jean Mansel relates the story of an unhappy woman tormented every night by a sort of unconscionable husband, who was no other than a jovial demon. At last, worn out, she consults a hermit, who directs her to raise her arms at the critical moment towards a sacred picture; with the result that the demon takes flight, not without cursing the hermit. 
fustian, whom one pious author liked to call "God's nightingale," there in his pulpit, fist on hip, vulgar, impassioned, ranting, preaching terrible doctrines with sonorous voice. The antagonism between him and the platonist women is easily realised. He did not bother his head about beauty or love; instead of an amiable liberality which would suit a sceptical audience, it seemed as though with his wild declamations he had no other aim than to quench the embers still smouldering. It was more than a treason, it was a folly. He did not mince matters; he reviled the bishops and great ones of the earth; talk to him of love, he replied with retribution, toil, eternal torments, the glories of poverty, the agonies of the animal man. Savonarola himself, so warm and passionate, so much loved and worthy of love, brandished with scriptural fervour the great popular weapons, the prophecies and the wrath to come. In France, Oliver Maillard, Ménot, Rabelais himself (though misguided) possessed a breezy eloquence, rugged, turbid, picturesque, censorious, verbose, nowhit metaphysical, the opposite of the official Ciceronianism :

Il presche en théologien;

Mais pour boire de belle eau claire,

Faites.la boire à vostre chien,

Frère Lubin ne le peult faire. ${ }^{1}$

Maillard went so far as to sing songs of his own in the pulpit! Others indulged in wearisome or tasteless jests, in the most aristocratic of churches, ${ }^{2}$ and before a queen.

\footnotetext{
1 Theology he will expound;

But as for drinking water pure,

You'd better give it to your hound,

For brother Lubin can't-be sure.]
}

20liver Maillard declaims at St. Jean de Grêve, Paris : "O women, 0 flaunting wenches, bethink ye well. Why fill your time with amusements and vanities? You will have to answer, not for the conceptions of Aristotle, nor the learning of idealists or realists, of legists or physicians, but for your good or evil life... Lift up your hearts, ladies; are you good theologians?" That is what he finds to say to women who patronise and cultivate learning, to platonists penetrated with the idea of the indulgent mercy of God, and convinced of the great number of the Elect. (Sermones de adventu). A preacher is describing the Virgin at the moment of the Annunciation: "What was she doing, ladies? Think you she was occupied in painting and powdering her face? No, at the foot of the Cross she was reading the Hours of Our Lady" ! 
Ignorant of the world and its refinements, the monks and parsons applied to distinguished consciences the casuistry of the suburbs: their morality smacked of the natural man. It proscribed refined joys: a man should be "an ox or an ass," as Savonarola said. Not that the monks were illnatured: they were hospitable; they would console an unhappy wife; they would assist a widow to find a gem of a son-in-law. But there their understanding of the feminine nature stopped. For the rest they saw in women only Satanic lures, false chignons, perfumes, all the fripperies of which Savonarola had made so magnificent a holocaust in the great square of Florence! Amiability was quite beyond them. Fra Inigo, in one of the streets of Toledo, happened to be walking behind some ladies whose trains were raising clouds of dust. They good-naturedly stopped to let him pass. Fancying he was the very pink of courtesy he said : "I kiss your hands, ladies; proceed, I beg you : the dust raised by the sheep doesn't annoy the wolf." In the pulpit it was the same; if they spoke of social necessities, it was like the peasants they were; they preached poverty and chastity without qualification; they had no eye for fine shades, but bedaubed the most delicate façades with their garish colours. "Are you in fit state to die? You women who display your beautiful bosoms, your necks, your throats, would you wish to die in your present condition? And you priests, would you like to die with your conscience burdened with the masses you have said? Not four out of a thousand, I believe, would be found ready. If the last trump here assailed our ears, we should then see who would respond to its appeal!"1

The monastic spirit was indestructible; Spagnuoli ${ }^{2}$ and Du Four carried it into the courts. Adrian VI., coming between two Medicean popes, cherished this spirit at the

${ }^{1}$ Maillard.

2 “ Nec formæ contenta suæ, splendore decorem Auget mille modis mulier ; frontem ligat auro,

Purpurat arte genas et collocat arte capillos, Arte regit gressus, et lumina temperat arte.

Currit ut in latebras Iudens perducat amantem." (Egloga, 4.)

[Not content with her natural beauty, woman enhances the brilliance of her charms in a thousand ways. She binds her brow with gold, artfully colours her cheeks and knots her hair and rules her gait and manages her eyes. She runs that sportive she may lure her lover into her secret nook.] 
Vatican. ${ }^{I}$ During three reigns Francis de Paul remained faithful to it at the court of France. Once before, as he passed through Rome, St. Francis had ventured to upbraid a cardinal lolling in a sumptuous equipage, and the prelate, bending forward over the door, had replied with a fine and courtly smile that it was very necessary to inspire the

\author{
1 Dueil, jalousie, \\ Puis frénésie, \\ Puis souspessons, \\ Mélancolie, \\ Tours de follie, \\ Regretz, tensons, \\ Pleurs et chansous, \\ Sont les façons \\ D'amoureuse chevalerie.
}

Mieulx vauldroit servir les nıassons

Que d'avoir au cœur telz glassons.

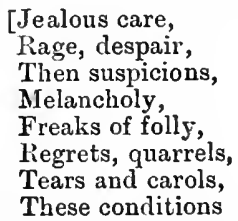

Do our love-lorn knighthood bear.

Better to fill a hodman's part

Than have such icicles chilling the heart.]

That is how the good prior of Liré, Guillaume Alexis, expresses himself as he rides with a nobleman along the road from Rome to Verueuil. (Le grant Blason des faulces amours.) He continues in the same vigorous and cutting style. What, replies his companion, disagreeably surprised, you ask them only to work

Et de nul plaisir n'avez cure !

Tous pageaulx

Sont-ils égaulx?...

... Quant on est jeune,

Force est qu'on tienne

Le train des autres jouvenceaulx.

[And never to have a pleasure in life !

Varlets in hall,

Are they equal all?

When one is young

One needs must along

With other younkers rolling the ball.]

Nature speaks ; Gawain, Arthur, Lancelot

Qui ne craignoyent ne froit ne chault

... Toujours estoyent amoureux.

Nous aymerons

Et chanterons

En noz jouvences : 
children of that generation with respect. How much St. Francis was idolised by the ladies it is beyond us to tell: in all circumstances of gravity they claimed his intercession, and yet he did not flatter them. He would never give audience to them. Women and wealth, said he, are the two scourges of the Church-and especially devout women: them he called "vipers."

How the world flung back these invectives! Ladies and prelates vied with one another in mocking at the lower monastic orders-those shaven scurvy bald-pates who stood in the way of all spiritual regeneration; ill-bred, materialminded fellows, uneducated, coarse, fat, full-blooded, brimming over with a hot, carnal vitality, gay to the core and therefore prompt to sin, much "more attentive to the life active than to the life contemplative "- those easy-going vagabonds who, awaiting eternity, "do not weary their minds overmuch by perusal of a heap of books," for fear lest the lore they might imbibe from them should puff them out with pride, like Lucifer, and "make them decline from monastic learning." The pallid platonists, "crushed under their trappings," called them fanatics, hypocrites, misers, gluttons, and above all filthy and disgusting wretches. It was a singular idea the Prince da Carpi had-to be buried in a monk's fustian frock, and thus "turn monk beyond the tomb." That was clean contrary to the mode!

Quant vieulx serons,

Nous penserons

Des consciences,

Menues offenses,

Et négligences.

Quelque jour récompenseront

Force pardons, prou indulgences.

[Who feared nor heat nor cold a whit,

There ever in love.

Blithe and gay

With love and lay

Youth we will speed:

When old and gray

'Twill be time to pray,

Conscience to heed,

Follies to shun,

To rue good undone.

And some day indulgences, pardons galore,

Will help pay the piper and settle the score.]

The monk replies with a long discourse, flagellating the vices of women and resulting disasters. 
Margaret lampooned the monks. Alexander VI. called them tyrants, and declared he would much rather offend the greatest of kings than the least of these mendicants. At a carnival at Rome, Bibbiena, galloping along under his mask, caught sight of a monk, and swooped down on him like a hawk upon its prey. "I know you," he cries tragically: "the provost is after you to arrest you, but I will save you; I will carry you off to the chancellor's"; and thereupon he grabs the unlucky monk, hoists him on to the crupper all shivering and shaking, and off they go amid the hoots and yells and gibes of the mob, under a shower of eggs! Soon Bibbiena was yolk of egg from head to heel,--and was privately accusing the people of uncommonly bad marksmanship. At last, when the city had had its fill of laughter, he deigned to yield to the supplications of his victim and set him down. Then the other broke a few more eggs over him, flung, off his frock, and with a low bow said, "I am your groom." Bibbiena galloped on.

We need not, of course, take literally the jests of that period against the monks. There were good and bad monks; the good were those least in evidence. But Guy Juvenal, who was an active and honest worker for monastic reform, winds up his enquiry ${ }^{1}$ with a phrase as old as St. Augustine: "You find in the convents the best and the worst."

However, the adversaries of the monks do them justice themselves, unintentionally. The company in the Heptameron, for instance, are much amused at the idea that some monks may possibly have overheard their ribald talk. One of the Urbino coterie traces a portrait of the monks from the outside which leaves us musing. Gross and plump, he says, they were hypocrites: little mortification of the flesh there! Emaciated and unkempt, they were false hounds who distinguished between sins secret and sins open. Elegant, well-trimmed, scented-these were everything that was vilest and most antagonistic to platonism! But what then ought their style to have been?

Trithemius, however, defined the monastic life in a highly platonist phrase: "To love is to know." How came, then, the idea that monks could not actively mingle in the life of the world, since St. Ignatius proved the contrary when he

${ }^{1}$ Reformationis monastica vindicice, 1503. 


\section{THE WOMEN OF THE RENAISSANCE}

founded an order in harmony with the new spirit? The convents of old were peopled with distinguished intellects; Luther, Calvin, Erasmus, Jean Thenaud, André Thevet, ${ }^{1}$ and a thousand others sprang from these decried lower clergy. How can we believe that the monks were by their tenets at odds with aestheticism, when the Italian Dominicans monopolised the charming art of mosaic in wood and almost monopolised also that of painting on glass-when St. Mark's at Florence, impregnated with the fragrant inspirations of the Fra Angelicos and the Fra Bartolomeos, stands forth to this day, in the profound simplicity of neglect, one of the most delightful refuges of human thought?

Certain of the more cultured orders had a lent for learning. And these were expelled; the Jacobins were harried away by the cardinal of Amboise because they lived outside their convent walls in order to dance attendance at court, and neglected the offices of the church. There was a striking repetition of this quarrel in the 17 th century, between Dom Mabillon, who advocated a learned monkhood, and the fiery abbé of Rancé, who wished to maintain the monasteries in the simple practice of piety; and in this contest also a woman (the duchess of Guise) took part.

Yet many of the monks, from a godly desire for success, strove earnestly to suit themselves to the fashinn; they freely cited the Olympian deities and quoted Ovid and Virgil ; in spite of the counsels of Savonarola, they exerted themselves to please, even though at the expense of "the divine." One preacher draws an ingenious parallel between the Virgin and Isis. Others discourse on beauty or coquetry, its benefits and perils. Some maintain that the Virgin was not pretty, because she was lowly and not in society; others, on the contrary, nourished on the Song of Songs and other aesthetic authorities, depict her as "clothed with the sun" according to the phrase in the Apocalypsedark-skinned perhaps, being a Jewess, but a woman to be admired nevertheless!

But the monks, do what they might, seatter a thousand flowers of mythology and rhetoric as they pleased, never acquired the lightness of touch the least of the sonneteers possessed.

${ }^{1}$ [Thenaud and Thevet were both Franciscans who travelled in the East and published accounts of their adventures.] 
Rabelais opens with a polemic on the merit of women, a stale subject, but impossible to avoid. He loves the world and mocks at the "molish monk"; he extols, on the other hand, the monk "young, gallant, dexterous, bold, adventurous, resolute, tall, lean, voluminous in chaps, well-favoured in nose, who smartly patters his prayers and polishes off his masses ... moreover, a clerk to the finger-tips in point of the breviary." He admits both sexes to his abbey of Thelema, on proof of perfect beauty. It is laved and perfumed, this modern abbey-full of gold and jewels, of beauteous garments, of music, of things sumptuous and comfortable, of books: nothing is wanting there: it has nine thousand three hundred and thirty-two chapels, and a single swimming bath under the watchful eye of a statue of the Three Graces. No one there is irked by theology!

And yet Rabelais was absolutely at sea in regard to the platonist spirit, to these mystic abstractions: "To have a woman is to have her for the use wherefor Nature created her .. . for the delectation of man." If anyone speaks to him of the "devotion of love" he laughs and sets himselt down at the table: "Drink," cries the Sibyl in his ear, "drink!" Drunkenness-that is mysticism enough for him! He leaves the convent to become a physician. He commends none but the natural sciences, and the only one he cannot away with is the only one that women acceptprophetic astrology. He was bound to end as a parson!

Even in Italy, the monk always smacked of his convent. Folengo ${ }^{1}$ spent his life in going in and out of it. His works also are nothing but one everlasting buffoonery. In his Moscheid, he appears to depict the conspiracy of monks against fine ladies-an epic complot of all creeping thingsants, bugs, spiders-against the winged race of bees and butterflies. The royal head of the chancellery, Spingard, sets off on a lean-ribbed mare, bearing splendid letters under the great seal of the Senate (an image of Liberty and Justice), in order to entice men into a spider's web.

But the Italian monks accepted their rout; they derided the antiquated "subtleties of St. Thomas," as well as visions

${ }^{1}$ [He eloped with a woman, lived a Bohemian life for ten years, and then returned to the hair-shirt and piety, wandering from convent to convent. He was onc of the earlicst and most successful writers of macaronic verse (Upus Merlini Cocaii macaronicorum).] 


\section{THE WOMEN OF THE RENAISSANCE}

of God without intermediaries, and hatred of indulgences. Their solace was a splendid ignorance, Neapolitan, epicurean.

In Germany, on the contrary, they triumphed. Despite the recommendations of Leo $\mathrm{X}$. and the passionate objurgations of Erasmus, the Germans refused to admire the works of the hour, the Epistles of Eoban, ${ }^{1}$ for instance, in which the holy women of the New Testament are represented as writing in the style of Ovid. They waged implacable war against aestheticism and dilettantism, and the bitterness of the struggle was only accentuated every time they came in contact with Rome. Burckhardt, writing his memoirs day by day about a splendid epoch, is incessantly bemoaning its corruption: does he perceive the existence of a spiritual movement at Rome? He sees nothing of liberty but the scandals; he does his duty like a painstaking but muddleheaded corporal. Erasmus himself is blind to all but the humanities, while Luther finds only horrors. They spoke with different tongues. When Hoogstratten, a German monk, impeached Reuchlin, who had ventured to defend certain Jewish books on scientific grounds, Rome was utterly unable to make out the bearings of this trumpery dispute: she procrastinated, and let the matter drop.

Ulrich von Huitten tried to Italianise himself at the little court of the archbishop of Mayence, which claimed to be a copy of Urbino, but all they did there was to play billiards and abuse the monks behind their backs. He returned to Rome in 1516, one of the years of triumph; and there, son of a sturdy and poor country where the lord ruled and even robbed people at his pleasure, and where woman was emphatically the weaker vessel, he, the old and unknown student, found himself excluded from that superb court, ${ }^{2}$ from those "false gods" as he called them, and

] [Noted for an excellent Latin verse translation of the Iliad. He was a German.]

${ }^{2}$ Maitre Berthold, he relates, who had gone to Rome to seek his fortune, had only succeeded after two months in finding a place as groom to an auditor of the rota, to look after his mule. "But," said I to him, "that's not the sort of thing for me, a master of arts of Cologne; I can't do things like that." "Very well, if you won't, I can't help it." "I think I shall return to my own country. . . . Am I to currycomb the mule and scrub the stable? Sooth, everything may go to the devil, for me!" Again, Conrad Struldriot writes: "Tis the devil who brought me here, and I can't go back; there is no good fellowship here as in Germany; 
relegated to the society of a German financier of low degree; he had no recommendation but his birth; and he could barely succeed in finishing his studies in law. He took his revenge in abuse. "I have human feelings," he wrote to Luther.

With lofty eloquence and burning zeal he preached the necessary war. The apostles of love had called war a brigandage. Hütten denounced as brigands the noncombatants-merchants, advocates, and priests. His motto was: a beautiful woman, gold, and indolence. In 1522 he took up arms, and with a magnificent gesture pointed out the splendid churches to the mob.

Luther, too, protests against the philosophic spirit. $\mathrm{He}$ checks liberty at a certain point, forbidding the mind to emancipate itself further. From a thinker he becomes a man of action, and joins hands with the great lords.

There was an explosion of anti-feminist and anti-liberal sentiments-war to the knife. It took place, like all great moral outbursts, under the banner of religion, because religion possessed organised battalions, a force ready at call, and, above all, excellent pretexts with which to veil struggles entered into on behalf of selfish interests.

"Talk of household concerns is women's affair," said Luther: "they are mistresses and queens there, and more than a match for Cicero and the finest orators. . . . But take them from their housewifery and they are good for nothing. . . Woman is born to manage a household : 'tis her lot, her law of nature : man is born for war and polity, to administer and govern states." As a model for the sculptor woman delighted Luther; but that was all; he denied her physical and moral vigour; the less her moral strength, the more he congratulates her. Evidently the intellectual pretensions of feminism constituted in his eyes an absurdity and a peril. Calvin went still farther. Whatever was pleasing to women he proscribed, even aesthetic emotions however inoffensive, however religious in character. He would hardly deign to believe that

people aren't sociable; if a man gets drunk once a day, they take offence and call him a pig. What is one to do? The courtesans are very dear, and not at all pretty. I tell you in all truth, in Italy the women are uncommonly ill made, spite of all their fine furbelows of silk and camlet. . They stoop, and eat garlic and are swarthy-hued. . . What colour they have is paint." (Epistola obscurorum virorum.) 
women are really good hands at puddings! Some ladies, in their noble devotion to his cause, had found a common prison in the Châtelet; he sent them somewhat grim felicitations. "If men are frail and easily shaken, the frailty of your sex is still greater. . . . God hath chosen the foolish things of the world to confound the wise, and the weak things of the world to confound the things which are mighty, and base things of the world, and things which are despised, to bring to nought those that are great and of high worth."

There was nothing for Luther to invent. Everyone desired a reformation, like himself. The cardinal of Amboise and the traditional school wished to try back and restore discipline; the philosophic women and the Roman world were for pushing ahead, and saw salvation in the rejuvenescence of faith through liberty. ${ }^{1}$ But neither party was eager for a schism, above all the Liberals of Rome, who not only stood for unity, which was their breath of life, but also gladly washed their hands of pure theology.

Luther invented nothing. All that he said, and even more, had been said at Fome for fifty years before him. He caught certain floating ideas, and fixed those which had passed into current morality. This was to attack dilettantism. The gentle feminist and Latinist prelates, with their tolerance, their openness of mind and intellectual freedom-Sadoleto, the friend of Melanchthon, Contarini, Pole, the kindly scholar ruled by Vittoria Colonna, Flaminio, Vergerio-all deplored the degradation of their handiwork: they felt as a Raphaelite painter would feel if he found his dreams copied in a trumpery chromograph. Yet, while lamenting this use made of liberty, they respected it; at bottom they considered Zwingle and Melanchthon as two of themselves, and they did not despair of achieving the triumph of freedom by freedom itself. Such was, as we know, the policy of Pole at Ratisbon, and of Vergerio at Worms; but despite the support of Vittoria Colonna, Margaret of France, and a whole band of enthusiastic and ardent women, they did not succeed; they were caught between two fires.

Women threw themselves into the fray with enthusiasm.

We might fancy ourselves looking at the Sabine women

1 “Post tenebras ego spero lucem," wrote Jean Marot in 1415. 
of David's famous picture: daughters of the Roman Church, very devoted, very judicious (at least in their own opinion), and yet ready in the name of freedom to defend and love their adversaries.

Vittoria Colonna always believed herself as orthodox as the Holy See itself, and more clever, even when in the heat of the battle she put forth opinions somewhat questionable.

She sang the barque of Peter triumphing over all the billows of the world's vileness and ill-will, and she received the papal benediction. But yet, in the great religious struggle of the 16th century, she could never realise that genuine difficulties of doctrine were involved; she saw nothing but a medley of personal intrigues, rivalries, jealousies, offended susceptibilities, good intentions bungled; excellent judges have shared her impressions. Entirely new circumstances had to arise, the fiercest moment of the battle had to come, before the court of Rome at last repudiated retrospectively all fellowship with Vittoria. And yet events seemed to justify the thesis of love-a thesis neither Protestant nnr strictly Catholic.

Attached to a religion of intuition and sentiment, the women aimed at saving the guilty by the love of the innocent; they put into practice a doctrine rather divine than religious; their scheme was that of Henri IV.: "Those who unswervingly follow their conscience are of my religion, and I am of the religion of all who are brave and good."

Vittoria Colonna took a very special interest in a celebrated Capuchin, the ardent and eloquent Ochino, who had formed at Naples a sort of liberal triumvirate. Somewhat intoxicated with his popularity and the warm sympathies of the feminist group, Ochino bitterly attacked Paul III. about certain measures of reform directed against the Capuchins. The marchioness hastened to prevent a rupture; she issued a great liberal manifesto addressed to Contarini, and at the same time urged Ochino to come to Rome. Paul smiled at the manifesto, and sent the author a pilgrim's passport, for herself and a Capuchin. Ochino, however, made a rancorous reply. Women put forth indescribable efforts to bring back to the fold this sheep who was threatening to wander away! Thanks to the feminine freemasonry, Ochino, though openly at odds with the pope, still occupied with brilliance the principal pulpits of 
Verona, Venice, Bologna and Mantua, until at last he took to flight. Vittoria uever lost sight of him; at Venice, she got secret information as to his welfare from Bembo, who had just been raised to the cardinalate. ${ }^{1}$ Later, by means of anonymous letters in which she told her old protégé that she was buying his books and getting insight into his views, flattering him, calling herself his "very obedient daughter and disciple," she did her utmost to bring him to reason. Vain illusion! Ochino was a monk, Vittoria a noble lady; they belonged to two jarring worlds.

Margaret of France wished to play the same part, but she found herself in a more embarrassing situation, and understood still less, if possible, the real bearing of the struggle. She dreamed of reforming humanity, not dogmas; she left to God the task of winning the victory and causing the "word of truth" to shine forth. Why limit the range of these dreams? "The Church is a living and active voice, which is its own explanation, and can always express itself anew and more abundantly." Why this procreation of rigorous dogmas, to the rvin of the feminine apostleship? Margaret pressed towards synthesis; she wished to know, to co-ordinate, to succeed. Briçonnet wrote to her smilingly: "If there were at the end of the earth a learned doctor who, by means of a single compendium, could teach the whole art of grammar, besides rhetoric, philosophy and the seven liberal arts, you would rush to him as a cold man rushes to the fire."

Where then was she to seek the illumination of love and faith if not in that religious philosophy towards which she had always inclined? In regard to faith, still more than in social matters, she felt how good it was to soar into the heights of abstraction, to go direct to the verities without troubling about men. How cramping it would have seemed to her to embody all theology and all faith, both Paradise and Hell, in one man, in one priest! She smiled on men, provided they were men of good-will, even if they burnt others, as Francis I. did, but still more if they were burnt or in danger of burning, like "that poor Berquin," or the

1 "You cannot imagine anyone more useful or holy," her friend Bembo wrote; "I understand why your ladyship is so fond of him !" Again : "Our brother Bernardino is adored here : men, women, everybody lauds him to the skies. - . I I hope some day to converse with your ladyship about him." 
chaplain Michel, or the canons of Bourges, or Farel, Vatable, Gerard Roussel. ${ }^{1}$ A man might translate the Thomist work the Mirror of Ladies; might call himself Lefèvre d'Etaples, faber ingeniorum, or Dolet; might be a witty libertine like Pocques or Duval-no matter, he had claims on her affection, if he was well disposed. She delighted in hearing Erasmus and Luther discuss the question of freewill. She looked on at these passages at arms with the same satisfaction as others witnessed a tourney. In concert with a lady of infiuence, she dragged the king to St. Eustace, to hear a sermon by a whirlwind of a parson who preached peace and sursum corda. She was anxious to arrange at Paris a controversial meeting with Melanchthon, but the Faculty of Theology was not agreeable. The theologian really after her own heart was the amiable prèlate Nicolas Dangu, who followed her everywhere like a perfect lover.

There was yet another man able to please her; a sort of magian, remarkable in spite of his wild notions, who carried feminine theology to the pitch of absurdity. This was Guillaume Postel, a workhouse foundling, a nobody, a village brat and then a lackey, half oriental, half Italian, though a Frenchman: a man of eminent learning and enlightened mind, the fine essence of eclecticism. He wrote in twelve languages on the most various subjects, in

${ }^{1}$ Lavardin also touched the chords of feeling, and was thereupon congratulated by Ronsard in a sonnet: he translated for the princess a dialogue by Mark Antony Natta, on the Nature of God. He acknowledges that in reality the subject seems to him inaccessible, whether one takes the wings of an eagle or descends into the depths : in the end he thinks that the incomprehensible had better be left to faith. But he dedicates this work to Margaret in excellent verse :

A quel plus propre autel pourrions-nous présenter

Le sujet immortel de ce précieux livre?

... O perle, o Marguerite,

O beau fleuron royal, vostre sang très chrestien,

Et toutes les vertus dont vostre grâce hérite ...

Nous font foy ...

Que des enfans de Dieu vous serez le soutien.

[To what more seemly altar could we bring

The immortal subject of this precious book?

$O$ pearl, $O$ Margaret,

Fair queenly gem, thy purest Christian ray

And all the virtues by thy grace possest

To us attest

God's children all will find in thee their stay.] 


\section{THE WOMEN OF THE RENAISSANCE}

support of the most diversified theses. He advocated a universal monarchy which he offered to Francis I., and a universal religion, genuinely catholic and Roman, the papacy of which he reserved for himself. He based it upon the doctrine of infinite love (if need be, a somewhat sensual love), and upon an aesthetic philosophy which should solve all mysteries by applying the formula of the Beautiful. According to this religion, it was for women to regenerate the world; wherefore he salutes with ardent sympathy the Mothers of the Church whom he sees budding forth almost everywhere-More's daughters in England; Isabella Rosera in Spain; in Portugal Loysa Sygea who at the age of twenty-two honoured Pope Paul III. with her advice in five little-known languages. Paul replied in Latin, Greek and Hebrew, but excused himself in regard to Chaldean and Arabic, and instructed Postel to take the pen.

Postel's strange work ${ }^{1}$ appeared after the death of Margaret of France, under the auspices of Margaret of Savoy. Postel announced the discovery of a new Eve, whom he extolled above all other women, even above Vittoria Colonna. She was an aged sorceress of Venice, endowed with second sight, who read through paper as if she had the Röntgen rays at her disposal. Unhappily the Venetians sent her about her business.

To sum up, the women believed and maintained that, in dealing with the people, the only language they understood must be employed-that of force; but that for the elect there was only one real weapon-the matchless one, liberty. The first of liberties is that of talking nonsense. It was needful, then, to be able to tolerate freedom in others, one's own friends included.

The practical result of women's intervention was in France insignificant enough.

The long-standing hostility of the French clergy to the court of Rome had burst out so glaringly in the reign of Louis XII., it displayed itself so vigorously in the more or less official dithyrambs of Andrelini, Villebresme, De Mailly, Gringoire, Jean d'Auton, Seyssel, against the "Roman profligacy," that Leo X. became alarmed and very prudently abandoned in 1515 the real bone of contention, the right to dispose of benefices. From that moment the Church,

${ }^{1}$ Les très merveilleuses Victoires. 
fused with the State, became a national machine, and no philosophic argument could in future shake an organisation so solid. Luther gave wide application to the same system in secularising the property of the clergy. The ruck of men left the business of dealing with these religious questions to the higher powers; they held to their creed either out of a taste for ignorance or from scepticism; the learned were quite content to smile and call theology a "poesy"-like vine-growers who sell a certain doctored wine, but keep the genuine locked up in their cellars-the wine they alone are sure of because they cut the grapes.

Liberalism was supported, then, by only a few timid and affectionate voices, like that of Longueil, the friend of Bembo and Pole, who said in his Letter to the Lutherans: "I take no side in the struggle: a simple citizen of the Christian republic, neither gratitude, nor hate, nor ambition impels me to one side or the other." Unhappily, it is not with lofty language like this that you can rouse a mob!

Is it necessary to recall what followed? It was at all points the reverse of what the feminists had hoped. "Our adversaries say of us," wrote Calvin, "that we have begun a sort of Trojan war, on account of women, mulierum causa." And in truth, as in the wars of the past, women had again become to a certain extent the gage of battle. Religion declared war on platonism, just as platonism had declared war on religious virginity; instead of draping women in inaccessibility, people contented themselves with making matrimony easier. That was a simple solution of the difficulty. And yet it took longer than might be supposed to get back to this solid ground of matter-of-fact. The first woman espoused by an Archbishop of Canterbury was obliged, it appears, to travel like an animal in a chest pierced with holes, so as to escape the buffooneries of the mob; the second went to court; but when Queen Elizabeth saw her she bit her lips: "What am I to call you? Madam I cannot, and Mistress I dare not."

Catholicism, roused to action, henceforth asked for nothing except to condemn. It was a sudden drop from the ideal back again to earth, a dreadful battle of personalities, a life and death struggle with mythical or literal methods of exegesis for weapons. Erasmus was already writing: "These interpreters of the language of Heaven go off like gunpowder, 


\section{THE WOMEN OF THE RENAISSANCE}

they frown most terribly. What is Hütten to me? Shall I prefer the authority of Luther to that of the pope? If we had not received a pope from Christ, we should have to invent one." "They scream and scuffle and insult one another," sneers Des Périers, who no longer believed even in the existence of God. Blessed are the poor in spirit, concludes Agrippa; blessed are illiterate people like the apostles; blessed is the ass! 


\section{CONCLUSION}

Nothing now remains but to relate the conclusion of the dream.

A dream indeed-all these schemes of happiness which had flashed across the gloomy background of realities like dissolving views on the wall of a lecture-room: the blue sea, the blazing sun, appearing but for a moment, left the blackness deeper still.

Margaret, the great organiser of happiness, never found the secret of happiness for herself. Her last days were vexed with the most poignant sorrows : the court, Calvin, the people, well-nigh the whole world,cast her off and treated her as a Utopian dreamer: her husband went the length of striking her, her daughter was torn from her, and Henri II. sent her into exile; several of her friends, such as Ramus and Dolet, were persecuted, alas! from motives far from sincere: it was, in truth, what she called "the suburbs of death." By divine mercy her heart, incessantly a prey to anxieties, at length parted company with a life that was anything but love. She perished, poor duchess, at her post as charitable vendor of love-perished in flames, like the salamander! No man came to her aid, none even paused to mourn her. Three young English maidens named Seymour erected to her a frail monument of verse under the auspices of her niece; but save for one devoted friend, Sainte-Marthe, whose enthusiastic funeral oration nevertheless provoked the liveliest criticisms, men maintained a remarkable silence. The princess had greatly erred in scattering her affections and seeking to create a sociology of the heart. Men do not care for love, they wish to fear and obey! There is no true love but the love of an individual. 
The Saint-Gelais, the Héroëts, the Salels, all those exquisite hearts bubbling over with sentiment when a smile from Margaret could lead them to fortune, now remained mute; the drum had to be set a-beating, and then at length there appeared a volume of elegies, a subtle fantasia in many tongues, which would have been cold as ice but for the vigorous beam Ronsard shot into the midst of the medley - a tiny volume, brilliant, ingenious, perverse, like the princess's soul, full of pretty verses all alike-alike in expression, with the same silvery veneer of tenderness-the very image of the somewhat phantasmagoric and unreal moonshine in which some mystic women delighted: brightness, but no warmth or light. Yes, Margaret was too fond of these intense lights and shades. A thousand causeless murmurings woke echoes in her soul. She sustained herself upon the subtle aroma wafted on certain nights upon the breath of the quickening world. She never heard the full, resounding roar of the sea in the darkness, but was content to see the fringe of foam.

At the moment when Margaret disappeared, the power of women in France seemed at its apogee; in reality, it was on the wane. It was attacked more especially on the moral side. According to so-called Puritans like Agrippa, the influence of women resulted in the declension of morals; and what a declension! Everything converged towards the joys of the senses; painters could no longer paint anything but bower scenes, architects could only open doors or pierce balconies, husbands only speculate on the exploits of their wives, Luther only recommend the reading of stories (sometimes astonishing) from the Bible.

Unquestionably, feminine influences, even the purest, seemed soft and enervating. The energetic spirit of old France, of the time before Francis I., sprang suddenly to life again. A country gentleman, Du Bellay, sounded the charge against Roman cosmopolitanism by claiming France for the French. At one stroke, as J. M. de Heredia has said, his clear and picturesque style clean obliterated Marot, Saint-Gelais, and the whole of Margaret's school. Du Bellay would have loved Savonarola: he speaks the same tongue as the friends of Anne of France; he has sworn implacable hatred against platonism with its cloying sweetness, against the languors of petrarchism: " $\mathrm{He}$ has 
not breathed in the ardour that sets Italy in flame." Though he has seen Rome, decadent Rome, he has not caught her infection; it is she that he blames, and yet the "bashful squires," the "exiles from joyance," and other vulgar "fantasticals," whom he flagellates and sends packing along with the Round Table, were very often French. He has in his veins the proud and lusty blood of a soldier. Like Anne of France he worships truth, and candour, and lucidity.

Ronsard too, of like blood and ancestry, advocates truth : "I love not the false, I love the true." He overwhelms with his vigorous eloquence all sham loves, "Cupids with curled love-locks, but broken arrow"; all the platonic cant, so virtuous in show and so little virtuous in fact: and all these refinements, and hypocrisies, and conceits on twofold incorporeal love!

Aimer l'esprit, Madame, c'est aimer la sottise. ${ }^{1}$

The voices of these two men stirred up no little commotion arnong a large number of the lesser nobility or quasi-nobility, men of middling station, less sensible to high-falutin' than to the spirit of frankness and independence- " gaillards," as they styled themselves, who loved women as they loved "daylight and the sun," but as men, by no means with an idea of "playing lackey to a mistress," particularly one who was wrinkled, painted, or terribly accomplished.

De Juuon sont vos bras, des grâces vostre sein,

Vous avez de l'aurore et le front et la main,

Mais vous avez le cœur d'une fière lionne. ${ }^{2}$

That was their type. And they laughed at the Vadiuses and Trissotins ${ }^{3}$ of their day, at all the fine carollings that Du Bellay amused himself by imitating, forgotten tunes of long ago, the faded frippery of the ballroom. What merriment there is when a belated poet returns from Italy with

${ }^{1}$ To love the mind, Madam, is loving folly.

2 Your arms are Juno's, and your breast

The Graces have with beauty drest;

Your hand and brow Aurora sent,

A liouess proud your heart has lent.

${ }^{3}$ [Trissotin is the affected coxcomb and Vadius the pedant of Moliere's famous comedy, Les Femmes savantes (Act iii. scene v.).] 


\section{THE WOMEN OF THE RENAISSANCE}

another Amadis! Neither Olivier de Magny nor Baïf will take the moon for the sun, or love for a mere ornamentation.

The men of the Pléiade had no love for patronage or the Medici species. They hated and abhorred the Jews. Ronsard would have liked to see a fine St. Bartholomew butchery of them, and could not forgive Titus for wasting his chances: his gorge rises at the thought of a Leo the Hebrew ${ }^{1}$ figuring among the sages of platonism. Good decent fellows, they drape themselves in their somewhat rustic free-and-easiness. From their modest snuggeries they proudly tell the king "Nature has made us of the same flesh and blood as you"; 2 they do not hesitate to write to a Medici lady that the finest royalty is to be "king of oneself." 3 They vie with one another in launching their epigrams against the court, the salons, the ruling women ; they sing of woods and dales, even of the wild untrammelled life-

$\mathrm{O}$ bienheurenx le siècle où le peuple sauvage

Vivoit, par les forêts, de gland et de fruitage. ${ }^{5}$

-Ronsard.

${ }^{1}$ [A Jewish physician whose Dialogues on Love were printed at Venice in 1549.]

2 Ronsard to Henri III.

${ }^{3}$ Baif to Catherine de' Medici.

${ }^{4}$ L'homme à la femme y rend obéissance...

L'esprit bon s'y fait lourd, la femme s'y diffame,

La fille y perd sa honte, la veuve y acquiert blasme.

Tous y sont desguisez: la fille y va sans mère,

La femme sans mary, le prestre sans bréviaire.

[At court the woman rules the man ...

The brightest wit grows sluggish, and women smirch their fame,

The maid loses her modesty, the widow her good name.

All there is masquerade: the girl without her mother fares,

IVife without husband; and the priest no breviary bears.]

All they think of there is

mendier le goust d'une vaine fumée

(Qui s'acquiert à grand'peine, et tost est consumée),

Piaffer, se friser, à faire l'amoureux.

(Jean de la Taille, Satires).

[to beg a spark of empty praise

(That's very hard to kindle, and too quickly burns away),

To cut a dash, and dandify, a lover's part to play.]

${ }^{5}$ [Happy the age when wild in woods

The naked savage ran,

When nuts and apples were his foods, And man was yet a man.] 
They sing praise to Nature their mother, not an abstraction, an infinity, but immeasurable $:^{1}$ the lines of the horizon, it would seem, spring from their hearts, and like an outspread fan gather up the whole immensity of life. How remote this from the gardens of philosophy ordered so delicately, with their shimmering fountains, their shivering Venuses ! ${ }^{2}$

When under a clear Roman sky Du Bellay is sauntering in pleasant indolence amid all the pomp and luxury of cultured prelates, enjoying the serene life of country villas; when, as a background to the picture, behind carriages and laurels, fashionable women and noble statues, he sees flushed in a golden haze the forest of towers, and pediments, and obelisks, and St. Peter's in all its majesty, the glory of the world, what does his heart say to him?

Quand reverray-je, hélas! de mon petit village Fumer la cheminée ? ${ }^{3}$

Such was the sentiment of the Pleiade.

Social philosophy had changed all at once. People were weary of the idea of the beautiful, and henceforth the wind was to set towards scepticism: no longer an airy, Ciceronian, superficial scepticism, the scepticism of Cardan, or of Erasmus, the jabberer of Latin, the flouter of monks, often madder than the madmen he derides, but a masculine aggressive scepticism, which believes in nothing in this world, not even in love, and is incredulous about the other world and the immortality of the soul. Yet it feels an "impression" of the unseen: deprived of an ideal for this life, it must willy-nilly suppose another apart from mortal

\footnotetext{
1 Mnlta tegit sacro involucro Natura ; neque ullis

Fas est scire quidem mortalibus omnia; multa

Admirare modo, necnon venerare, neque illa

Inquires quae sunt arcanis proxima.
}

[Nature conceals many things within her sacred shrine; nor may any mortal presume to know all things; many things indeed thou mayst admire, aye, reverence, without prying into those that lie closest to the mysteries.]

${ }^{2}$ Yet Ronsard and his friends made the mistake of believing that the language should be aristocratic, and that it was for writers, not for the people, to form or reform it.

${ }^{3}$ [Alas ! when shall I see again

The smoking chimneys of my village home?] 


\section{THE WOMEN OF THE RENAISSANCE}

men, and thus yearningly, gropingly, unawares, it takes a step towards Christ.

And then those who are still reasoning in this untoward generation laugh or weep. What a harsh harrowing laugh is that of Boistuau, ${ }^{1}$ who had nevertheless been a friend of Margaret! Boistuau speaks to us of love, and tells us that it is a distressing malady of the mind, characterised by symptoms of agitation and disorder, and exhausting all its energies, physical and moral. You hear those attacked by it groaning and dropping words like "coral, alabaster, roses, lilies"; they have lost all individuality; they sob and abase themselves and are a continual supplication. The cause of the malady is obscure; some speak of magnetism, others of microbes, others of the influence of the stars.

It was this kind of scepticism which was destined to lead us to the morality of Charles IX.'s court.

Then it was seen how fatal had been the disease of sensibility, and the profound soul-weariness which resulted from imaginative pleasures, from the mirage which overlay the things of life since women had undertaken to interpret everything through the affections. It had been a woful error to create an art of sensibility! Sensibility serves to attract men, but cannot hold or guide them. Women believe in sensibility because they always consider the heart of a man as a reservoir of moral strength. It is the other way about; men for the most part err through weakness; it is that which renders them inconstant and vicious. They would gain in steadfastness and goodness if women, less timid and more active, had strength rather than tenacity, and a real energy under an appearance of tenderness.

An attempt was made, hut too late, to show that the feminist spirit could display energy as well as tenderness.

A certain Almanque Papillon ${ }^{2}$ proposed a new formula of love, more robust than platonism, and bound, as he thought, to render men truly "virtuous and not effeminate." François

' [A popular French writer (died in 1566). He translated Bandello into French, and his Thétrte du Monde, in which he discussed "the woes of humanity and the dignity and excellence of man," ran into twenty editions.]

${ }^{2}$ [His Nouvel Amour appeared along with Héroët's Opuscules d'Amour.] 
Billon, one of the royal secretaries, wandering one evening amid the ruins of home, felt the tonch of grace within himself. He dreamed of witing a book entitled The Impregnable Fortress of the Female Sex. He descried and saluted anong the shadows a number of vigorons wonenCatherine de' Hediei and Jeanne d'Albret, more valorous than any man; Mestames de Berry and de Nevers, surpassingly witty; Anme d'Este, duchess of Guise, the eloquence of fleshly beanty. Billon made his book, but not his fortune. Under the Talois, many women were not anxious to be too well defended.

Ronsard and Du Bellay triumphed, then: and yet, to all appearance, their triumph tronbled them; they hankered after ideas they had gone about to destroy; they mistrusted themselves, their friends, their principles. Rousard had an admirable genius, but he hesitated between an attempt to satisfy the popular naturalism with the crudities so much in request, and an instinctive thirst for an aristocratic spiritualism. He followed rather than led the morement; both he and Du Dellay, in spite of their robust breezy energies, remained more sensitive than they cared to acknowledge to the charm of classical art and the graciousness of the salons.

Further, an eminent woman kept a tight rein on the Pléialle, and showed them that gracionsness was not necessarily tameness, that there were women's liearts at once ardent and strong, that it is possible to retain practical views of life while "rising wholly towards spiritual things." This woman was the niece and goddaughter of Mirgaret of France, her spiritual daughter and the faithful guardian of her fame-the second Hargaret of France, duchess of Berry and afterwards duchess of Savoy.

Slie pursued a totally different method from her aunt. She abimloned philosophy, intuitions, mystic profussions of faith: instead of wearing black she dressed fashionably, tricking herself out with jewels and brightly-coloured materials: thus (pardon the detail) she used handkerchiefs of crimson silk: that formed part of her psychology. Her household was maintained on a very princely scale, and directed by the solemn Madame de Brissac, who never shifted her quarters without taking with her a huge pile of dresses and especially a terribly big bed, which alone requiren 
several mules to carry it; the moment the destination was reached, Madame de Brissac's bed had to be set up with infinite precautions, as though it were a shrine. One can guess how the treasurer, among many other people, grumbled; but the princess was so kind!

With this system of simplified morals and external complexity, Margaret of Savoy exercised extraordinary fascination over men's affections. She had adopted as emblem an olive branch guarded by serpents, with the motto, "Sagesse, gardienne des choses!" She resembled, as a poet tells us, "a rose-bud, nourished on celestial dew," and received the nickname of Pallas. She was just the woman to govern vigorous men: a woman of taste and intelligence, who had a passion for winning love, but with much breadth and dignity, and without recourse to the spiritual and material experiments of her aunt. Her secret she had not gone far to seek, but had found simply in her woman's heart; her Machiavelism consisted in a kindliness carried to perfection, intelligent, antive, ingenious - a refined goodheartedness, which embraced both rich and poor. Des Périers himself could not refrain from spealing of it in a tone of respect and sympathy quite unusual in him; Brantôme has painted the princess in one magnificent phrase: "She was the goodness of the world."

And we must not forget that life had not spared her hard lessons. The poor woman's greatest ambition was to root and ground herself in the family affections, and these affections had been torn from her one by one with her heart's blood. Her father Francis I. had as little to do with her as possible, indeed, but scantily appreciated her. She lost her brother Charles miserably enough; at that period it was not the custom to care for life's halt and maimed, yet Margaret sedulously watched over servants who were out of employment. Her heart was wrapped up in her sister Madeleine. Madeleine coveted a crown; she went to Scotland, and six months afterwards came news of her death. Margaret was so grievously stricken that she remained in utter prostration, and it was doubtful for some time whether her health would recover from the shock. Her aunt Margaret had to intervene to insist on her taking care of herself, and going for long morning walks in the pirk of Fontainebleau. 
Thus, instead of "devouring her heart," in the forcible phrase of Pythagoras, this noble princess made existence a song of grave and warm passion, not a song of love.

Her disappointments were no fewer, it is true, since it is a natural law for the heart to be deceived in its hopes, like the reason; but she found less bitterness and more grief; the wholesome contact with real suffering, in bringing out the true power of sympathy, saved her from social and intellectual extravagances, and bred in her that perfection of tenderness which no one could resist; for the world itself loves to be treated seriously.

The passion Du Bellay felt for her in no way resembles either the flowery sentimentalism to which princesses had till then been accustomed, or the coarse freedom of Marot's school: it was a constant, sincere, and lasting passion. On returning from Italy, he exclaims with the same emotion as at his departure:

Alors, je m'aperçus qu'ignorant son mérite,

J'avois, sans la connoistre, admiré Marguerite,

Comme, sans les connoistre, on adwire les cieux. ${ }^{1}$

And these are not mere idle words. Many years afterwards, when it came to Margaret's turn to leave her country, the poor poet, struck, no doubt, with presentiments of an imminent death, shed real tears, "the truest tears that e'er I shed."

The great sense of truth and constancy that Margaret carried into the concerns of the heart she applied also to the concerns of the mind. She showed, like Anne of France, how women were slandered, how they slandered themselves when they fancied they were incapable of a genuine effort; instead of pouring out a stream of conversation and writings like her aunt, and of trusting to her impressionability merely, she applied herself with all the force of a fine intellectual health to the most rigorous tasks involved in the discipline of truth. Many scholars by profession would not have pushed solicitude for the niceties of truth so far. She got her reader, for instance, to buy for her at Paris three different editions of Cicero's Offices; she read Aristotle's

1 [Then I perceived that, ignorant as yet

Of her high worth, I worshipped liargaret, As, all unwitting, we almire the heavens.] 


\section{S4 THE WOMEN OF THE RENAISSANCE}

Ethics simultaneously in Greek and in a Latin translation; she collated six commentaries on Horace.

Although entirely French-she was much more French than her aunt-she set herself to stem the somewhat too violent tide of reaction setting in against Italy. Like Louis XII. before her, she thought there was much in Italy and the classics that was worth adopting; while she read Aristotle she proclaimed Urbino the "school of knowledge," and Du Bellay had to draw in his horns and, under her gentle guidance, acknowledge the charm which he did not feel spontaneously. He not only translated Bembo and Naugerius, ${ }^{1}$ but went so far as to agree that time would never extinguish the fame of Boccaccio, and that the laurels of Petrarch would remain for ever green.

She did more (for the words "art" and "patriotism" cloaked in reality questions infinitely smaller, and largerquestions of personal jealousies); she had the courage to keep by her side an Italian, Baccio del Bene, an enthusiastic worshipper of the "pearl of the West," who declared he had been saved by her bright eyes, "his stars," from the direst of shipwrecks. Ronsard undertook, against wind and tide and his own convictions, to rehabilitate this relic of the past, and to proclaim that Del Bene was the only Italian for two centuries who was worth consideration.

Margaret long remained the tutelary "virgin," the spirited " unbacked colt," running where frolic fancy led her, unfretted by the "spurs of love." Whatever the inevitable malignity of mankind may have said, she was a perfect type of platonism, basking in her many warm friendships with men, and in no hurry to be married. Too much attached to France to go far away, too thoroughly a princess to wed one of her brother's subjects, she fixed her choice on the heir of Savoy. On one occasion she did not hesitate to accompany her aunt to Nice and present herself in person, in defiance of the elementary rules of etiquette; lut as politics, the bane of sentimental prineessises, threw obstacles in the way, she possessed her soul in patience, and waited twenty-one years. She was married in 1559.

The king of France ordered a magnificent trousseau, an exact copy of that of IIadame de Lorraine-gold-embroidered

${ }^{1}$ [Andrea Navagero, commentator on the classics, author of Viaggio.] 
dresses, laces, jewels; he chose for the bridal dress a robe of yellow satin with bodice embroidered in gold, a regal mantle trimmed with lace a foot wide, an evening cloak in silver cloth, lined with lynx fur. He commanded splendid entertainments. Everyone knows what followed-Henri II. mortally wounded in the official tournament; this long-desired marriage consecrated at midnight beside a bed of anguish. Here truly was something to amaze and strike with awo. Anyone with a touch of superstition would have attributed to the princess the evil eye.

They knew better, to be sure.

If she was loved, it was because she had the very uncommon talent of loving her friends.

No sooner was she in Piedmont than she seemed to have thoughts only for them. She wrote to Catherine de' Medici commending Ronsard to her notice, and the poet, much moved, hastened to reply with a noble apostrophe to the royal honse of France, "happy and fruitful ... mother of such a line of kings."

From time immemorial France and Piedmont had played in the world the somewhat ungrateful part of quarrelsome lovers. 'Margaret, like a true woman, patched up this quarrel; while she lived there was no open rupture. Still more, every Frenchman who visited Turin was conscious of being anticipated by a gentle and invisible protecting hand. Presented to the duchess, often lodged and entertained at her cost, he would receive in addition, anonymously, a purse to defray his travelling expenses.

France did not, therefore, lose Margaret altogether; but she planted in Savoy the sweetness of Urbino with the sparkling brilliance of her own land. At the gates of Geneva she caused the most perfect religious peace to flourish; it was there that Francis de Sales was born. Without flinging heart and mind piecemeal to the winds, like her aunt, we see her in a corner of that violent 16th century, a radiant centre of kindliness and spiritual illumination, surrounded by testimonies of gratitude as by a modest and glorious retinue. She often received thanks at that supreme moment when all men speak the truth. In his last hour Du Bellay wept for her; an ambassador of France at Constantinople left her his fortune; L'Hôpital declared in his will that to her he owed his whole career. 
She herself on her deathbed heaved, so to speak, the last breath of the feminist spirit.

Il ne restoit rien d'entier de la France,

De pur, de saint, d'une antique bonté,

Que Marguerite, humaine déité.

And now what more is to be said? The hateful orgies of the 16th century were unchained! Here and there in the turmoil some few feeble shoots of platonism continued to appear $^{2}$ under the form of preciosity or literary feminism, till we come to the hôtel de Pambouillet. ${ }^{3}$ Women of energy and activity were still seen. But fate willed that the 17 th century, magnificent, wholly masculine, ${ }^{4}$ should be ushered in with terrible convulsions. It was a momentous and appalling epoch, and bore out the prediction of the Heptameron: "The best thing are those from which, when abused, result the worst ills." ${ }^{5}$ What a spectacle is the court of the Valois $!^{6}$-all these sly, knowing women, talking in a way to make the shades of their grandmothers blush, running after men who wish them further! How little the third Marsaret of France, the first wife of Henri IV., resembles her earlier namesakes! She was as highly gifted, prettier, as accomplished, as witty, as fascinating; as noble, as thoroughly a princess-so princely indeed that she thought herself quite entitled to love gipsies and let prejudices go hang! Fair as a lily, too, polished, wonderfully polished, bathed and perfumed! All she saw was that platonic love had broken down, and of the other

\footnotetext{
1 [Nothing remained in all the realm of France Holy and pure, of antique charity,

Save Margaret, a human deity.]
}

2The 16th century was the golden age of women's education.

${ }^{3}$ The hotel de Rambouillet was the famous salon helk by the marquise de Rambonillet, where met a crowd of wits, fols, and scholars, to set fashions for society and for literature. This was the headquarters of the Précienses, who were anxions to polish the language, and who introduced, among forms of expression which time has approved, absurd affectations like the Euphuism of the previous century in England.]

"When women were not supposed to be able to do more than "distinguish a doublet from trunk-hose." [A quotation from Molière's Les Femmes savantes, Act ii. sc. vii.]

5 Tale ii., "Corruptio optimi pessima."

6 "Venus has caught the ladies in her toils, and God is tired!" (Montaiglon). Tavannes asks that someone will shut women's mouths. 
love she said: "Nothing could be so sweet, if it were not so short."

Even in Spain platonism perished, or rather it winged its flight towards God with zest and ardour, often worthy of the Song of Songs:" "A love redeemed from all terrestrial things, and having only God for its object," exclaims St. Theresa, "is like an arrow shot by man's will towards his God with all the force of which he is eapable." Or else it was flung out of window. When the cook and the niece of Don Quixote make a bonfire of the Amadis romances and other illustrious annals of pure love and valiant exploits, the good Spanish curate, who assists at the auto-da-fé, momentarily hesitates before a volume bearing the name of Ariosto. He opens it, to burn it if it is a Spanish translation, to kiss it if it is the Italian text. O relic of old Spain! O son of the Cid !

In Italy the crisis could not take a tragic development, as in Germany, but men felt the need of returning to anonymity, to placid affection, to love without any twaddle. "The learned are so mad after love," writes Nelli, "they have so pounded and minced and dissected it, that it is altered out of all knowing." Petrarch was blasphemed : everyone was eager to revile him as a flashy rhetorician, to sneer at his so-called purity. They declared that they preferred to the sighs of love-sick princesses and the sentimental romances, the bold, frank love of a coster-wench.

Farewell to the dream! It dissolved in a religious crisis. Rome herself recovered from her intoxication, and no longer existerl as the nursery of sentimental philosophy and the liberal-minded instructress of mankind.

La paix et le bon temps ne règnent plus icy ;

La nusique et le bal sont contraints de s'y taire. ${ }^{2}$

Attacked, Catholicism had stood to the defence in the armour of authority. It was fighting for life, and was bent only on self-discipline and purification. One good soul devoted himself to the task of spiritualising the writings of Bembo.

I St. Theresa goes to these words from the Song of Songs: "The milk of thy breasts is sweeter than wine, and from them riseth a savour more exeellent than precious ointments"; or to these: "I sat down under his shadow with great delight, and his fruit was sweet to my taste."

2 Peace and joy in living reign no longer here;

Music and the dance to silence are constrained. 
The tender imaginings of art disappeared. The time was coming for art itself to return to scenes of domestic commonplace, as in Holland, or of pure reason, as in France. The sole impression Brantôme received as he viewed the Coliseum was that its ruined condition was most strikingly apparent at the top-as was seen also with women.

The mortification would have been less acute if people had not really expected to find happiness, and if they had begun by looking painful realities square in the face as they did afterwards. The 17th century left philosophy to the philosophers; it believed in suffering as a gift of God: Pascal coldly investigated only the secret of the anxieties which hold us by the throat; and so that admirable time of vigorous action and patient endurance led us to philosophy.

Platonist tenderness resulted in nililism. And then how sad a spectacle was the spiritual Sahara! And how well men understood, as soon as women had disappeared, that they were right in believing them necessary! Our great Moutaigne, who arises at this moment, is a splendid eulogist of the cold and colcurless in life. He is the perfect son of this respectable land of France, where wisdom consists in settling down in a benevolent neutrality, without hating, and without loving: life being such, without restraints, withont illusions, nothing is left, surely, but to die.

Montaigne, in his cool, common-sense way, delights in making mincemeat of everything that has given women faith and enthusiasm and an object in life.

The heart! what a dangerous organ, essentially a thing to keep under restraint! Better forgive a folly than a victory!

Love! After having distilled out its quintessence, after having discovered "three, four, or five degrees of superior things" external to onrselves capable of producing it, is it not found that wisdom lies in looking after one's own interests, in loving as little as possible, in loving one's children perhaps, but even then with sufficient tranguillity "to live comfortably after their loss"?

Goodness!- - that does not exist in the pure state, but contains always some taint of corruption, a savour of mortality, which Plato should have discerned: "Man is but patchwork and motley."

The quest for the Beautiful! How conventional! Let us hear no more of Bembo or Equicola! "When I write 
I do very well without the company the stry of books!"

Fame! A mere bubble, at the mercy of every puff of wind, dissolving under our own eyes, ere we reach the grave! Fame!-for books or ideas which are fated to disappear as everything has clisappeared:- a name which changes and will pass to others!

The charm of original thought! Ah! the ridiculous pretension of wishing to transcend the current opinions, the common sense of one's fellows, and to fancy oneself "capable of all things." It is on this head that we must hear Montaigne; he has no more illusions about the mind than about the heart: he warms up, and celebrates in Shakespearian accents the immensity of the human void. And is he wrong when he tells us that we are our own deceivers? - that we are unwilling to confess our ignorance lest we scare our children? "Overmnch knowledge is harmful, as in virtue. Keep in all points to the common highway : 'tis not good to be so subtle and nice. . . . Shun all novelty and oddity. . . . All extravagant ways vex me. . . . In my time, those who have some rare excellence beyond others, and some extraordinary sprightliness of nind, we see as it were overflowing into license in opinion and morals.... We are right to set upon the human mind the rigidest barriers we can." 1

The traitor! How he laughs at himself and his friends! At bottom he is a son of women ${ }^{2}$ and of love, but he has lost women and love. The shallow epicurism with which his doctrine may be reproacher is also the weak side of feminism, which had alrearly shown us the madness and error of the idea of saddling the few years we have to

1 Cf. the following well-known passage from the Apology of Raymond de Selonde (Essays, ii. cap. xii.): "The sonl, by reason of her trouble and imbecility, as unable to subsist of herself, is ever and in all places questing and searching comforts, hopes, foundations, and foreign circumstances on which she may take hold and settle herself. And how hight and fantastical soever his iuvention cloth frame them unto him, he notwithstanding relieth more surely upon them, and more willingly, than upon himself. . . . It is for the punishment of our temerity, and instruction of our misery and incapacity, that God caused the trouble, downfall, and confusion of Babel's tower. Whatsoever we attempt without his assistance, whatever we see without the lamp of his grace, is but vanity and folly. With our weak. ness we eorrupt and adulterate the very essence of truth (which is uniform and constant) when fortune giveth us the possession of it." [Florio.]

.2 "Nam vere sumus ommes de muliere" (Faceluts). 
spend on earth with fatigue, tribulation, vanities. And yet, while inheriting this need for living the easy impressionist life, Montaigne revolts with characteristic feeling and vigour against women, because he belongs to a disillusioned generation which feels constrained to wreak personal vengeance against those who had been confounding the religion of beauty with the religion of happiness. Religion consists in resignation to unhappiness, while beauty and happiness are in truth somewhat loosely connected. The keeper of a museum who spends his life among masterpieces will acknowledge, if you put it to him, that one can be very unhappy there. Further, perched in his rustic turret, between his few books and a large farmyard, Montaigne is one of those peaceable and self-satisfied country folk who have not succeeded in understanding what all the pother is about, or how women could ever pass for priests or physicians. He considers them as objects serviceable, even necessary, to inew, but socially speaking he chants their De Profuncis.

His bile is moved at the sight of the grand duchess taking the head of the table in the dueal palace at Florence. What a rage he flies into! "She has wheedled the prince"; is it by "her pleasant and commanding features," or her beautiful bosom? Don't talk to him of the ideal. Take a peep into this dressing-room--rouge-pots, false teeth, second-hand lures, perfumes like musk derived from the "discharge of animals," and all the rest: this is the ideal, forsooth, you think of making the axis of life! To him (the phrase will serve, it is homely but exact) platonism is the art of palming off paste for diamonds.

Yet the same scoffer Montaigne has for aide-de-camp a sinple maiden, Mademoiselle de Gomrnay; and, after all, his whole system comes to this-that we should do well to be women, nay children; and that the best thing for us would be to live like the bird on the bough, with no other care than the due round of the seasons.

But no: this is an impossibility! There are no seasons for us, we have no right to expect seasons! or rather, we have only a summer,-life; only a winter,-death! And this winter lies hungrily in wait for us! It comes to thisthat the science of life is the science of death! "The continual work of our life is to build up death." Since there is 
neither beanty nor love, in other words no life, we are but animated eorpses: our life plunges into the stream of death, emerges, and disappears again; we live on death as a tulip lives in its water, or corn in its refuse. Then, like the tulip and the corn, we go through the inverse process: "Your death is part of the order of the universe, a piece of the life of the world." From your disintegrated flesh the vital energy will spring up and pass into the larva, into the sap of plants, to die yet again and nourish afresh the butterfly or the bird or the ox, continuing thus its endless transmigrations. Without hailing death as it passes, like the mysties, Montaigne is continually brooding upon it, and holds it "in particular affection," since that is the only sure conclusion and all the rest is chimera. Wherever he goes, a grinning spectre seems to go before to show him the way. Of what account are the fashionable quintessences beside the clear and insistent spectacle of a bed "surrounded by physicians and parsons, by creatures all mazed and quaking, by pale-faced lackeys ... and the room without daylight, the candles lit!" It is just that! And "the leap to be made with lowered head and dazed brain . . . into a depth of silence and obscurity!" Yes, that is death, as said (merely adding a word of immortality and hope) those humble monks of the early days of the century, so violently excluded from philosophic religion; men had stopped up their ears so as not to hear them, and yet now return soberly to their seheme of morality, which grips one round like a ring of iron! What does Hénot say?"We die all of us, and like water sink into the earth and return no more to the surface. Yea, Lord, we all step on towards death. The water of the Loire ceases not to flow, but is it the water of yestereve that passes under the bridge to-day? The folk who to-day dwell in this town were not here a hundred years ago. Now, I am here; next year you will have another preacher. Where is king Louis, but late so dread a monarch, and king Charles, who in the flower of his youth set Italy aquake? Alas! the earth has already rotted his corpse. Where are all these damsels of whom we have heard so much? Have you not the Romance of the Rose, and Melusina, and many another far-famed beauty? Behold, we all die, and like the water we enter into the earth, to return no more for ever." 


\section{THE WOMEN OF THE RENAISSANCE}

Montaigne is right. Whether we like it or not, we have to live in contact with the enemy, that is, with reality. Only, is it absolutely necessary to look at reality so mistrustfully, and to ask of it but gloomy impressions? All the enemies of faith maintain that faith cannot but be sombre and melancholy; in making itself pleasant and speaking of a God of Love, religion, it seems, would lie and do them wrong, would trench on their domain, would go beyond its part, which consists in expiation and sacrifice. Material joy - that is their creed; and at the same time they believe it is a great mistake to wish to rule the world by love; men are not held by spiritual systems; you buy them, crush them, oppress and coerce them.

Nevertheless, all was not false in the delicious dream of prelates, women, platonists. Pure love is too exquisite a thing erer to exist in this world. But it is the business of women to strive towards it, and to show that we have need of it. The idea of dividing the wrorld, of leaving bodies to men and souls to women, had something to be said in its favour. Mer. are sometimes too philosophical, women never philosophical enough.

The convulsions which broke out every time men wished to turn the tables on women, in the 16th century, and in the 18th, are not sufficient to convince us that the unmitigated employment of frree is the ideal of politics. What luman being is there, even with all the sentiment crushed out of him, who does not feel an unquenchable thirst for happiness! Nations also feel this thirst. No, it cannot be said that the need of happiness is but an empty dream : it is a real need, sincere, imperious, natural, a moral and physical leed which takes entire possession of us, in which all things are summed up-this need in which we live and die.

We live an die in it! We should have to remain always children, or strangely to shut our eyes, not to see falling around us the rictims of life's ironies, felled by Montaigne's philosophy as surely, as clearly, as by a daggerthriest.

A proverb says that one does not die of love: perhaps; but what we know with absolute certainty, what stares us everywhere in the face in letters of fire and blood, is that one dies of the absence of love, one dies of inanition.

Hence it will always be necessary to ascend to the 
source of life, to fix ourselves firmly at the fountainhead: in other words, to nourish ourselves on beauty. Philosophically, "beauty" and "life" are synonymous terms; so we have already said, and we shall not cease to revert to this thought, because it appears to us clear and salutary. All the possible definitions of beauty apply also to life; life and beauty are one and the same thing.

Beauty and life generate love and are themselves born of love, so that love does no more than forge links in the immeasurable chain of life and beauty. And what men call happiness is the perfect joy of life.

Why did they fail in their schemes of love and peacethese timid women of the 16th century, who had all that was necessary for success-a heart, boundless, bottomless ocean of kindliness; an admirable intelligence; and in many cases knowledge, beauty, wealth? They licked the courage to be themselves; they were wanting in passion. Instead of taking their rightful place they fell back into obedience,half-hearted dilettanti, caught in their own snares. Why?

Medieval Christianity was not hostile to the idea of the beautiful, but it had unduly neglected it, for the purely scholastic and traditional reason that, strictly speaking, no theory of the beautiful is to be found in the Gospels.

No, you will not tind a theory of the beautiful there. But the Renaissance unquestionably was right in saying that you find assurances of life. And how many assurances of love? Christianity is of hope and love all compact. Love speaks on every page of its early lessons, and at every moment of its history. The Magdalene, St. Augustine, and many another-have they not marked stages on the road to heaven? St. Francis of Sales, Fénelon-were they not yet to cheer by affection the victims of pure reason?

The Renaissance, then, accomplished a very great advance when, with Plato's ail, it instituted the religion of beauty, and in this respect we certainly cannot reproach the platonists of the 16th century with having followed a wrong bent. They were right to believe that happiness and peace can only be effectually secured if men can be induced to turn their eyes towards the beautiful, to adopt beauty as the beacon of their lives, to believe through love, act through love, live through love. That, in truth, is the common substance underlying both Christianity and platonism. 


\section{THE WOMEN OF THE RENAISSANCE}

But how then are we to explain the phenomenon we have noted?

Plato, so far as theory and literary style are concerned, is admirable; why does his teaching end in negative results whenever it is enforced? Why could he himself deduce from it only a sociology embroidered with Utopian dreams? Why are those who live familiarly with him and upon him tortured by the consciousness of the emptiness of things, as was seen in the 16th century, and as we may see still?

The platonism of the Renaissance had a strange fate. It found a society in the plenitude of vigour, and save for a few elect souls it left it dead. As a philosophy, it resulted in perfect scepticism; as a social panacea, in the wars of religion. It slew art, it slew literature through the idea of seeking beauty in itself, in other words, by academism, by art for art's sake: the aesthetic Utopia alongside of the philosophic Utopia! Still further,-in place of the exquisite, enthusiastic, ardent, adorahle women who were the queens of the world, it gave us, as time went on, women without energy, without activity, case-hardened with the idea of a selfish happiness; it left behind it a progeny of coquettes, précieuses, or else of Delilahs and sensual women. The woman of vigorous and irradiant affection, the woman who used to shed life and happiness around her, has disappeared. And, finally, we observe that at the very moment of Plato's greatest glory, few women steadfastly pursued the path of happiness: with some, goodness had disappeared in feebleness, with others intelligence had evaporated in reasoning. They ought to have saved us from sensualism and metaphysics, and they ran aground on both reefs. How bitterly they have been reproached! We have done them the high honour of throwing upon them and their ideas the blame of all our calamities, as though they were exclusively at fault. A.s if it would not have been allowable, after all, to combine common sense with the spirit of kindliness and love!

If there were, then as always, silly women, profligate vomen, insatiate cormorants, why take platonism to task, why blame women alone?

Certain personages of that time, and some of the most notable, refused to admit any division of responsibility. 
To them, all that had happened was bound to happen; the origin was patent, the year 1515; when women of ligh rank, admitted to court, determined to devote themselves personally to the apostolic mission of love, all France took the cue, so that the idea of love, which issued to legin with from a source insufficiently philosophic, as it flowed downwards gained nothing and became no purer. It is very curious to find this line of argument proceeding from Brantône's pen; he is not generally a preacher of virtue, and has indecd enunciated this eminently courtier-like maxim: "The cast-off's of great kings could not but be excellent." According to Brantôme and his friends, men had undergone an irresistible infatuation for which they were not to be blamed: thus, he says, no one would regard Francis I. as a Heliogabalus or accuse him of having employed violence: he was a victim. All men are victims. It is very true that the frightful demoralisation of the 16th century sprang from the court, which set the example and persistently dragged the nation after it. But we shall be permitted to thiuk that Francis I. and the other victims among his circle, without being Heliogabaluses, were not anchorites either; which is capable of demonstration. In any case, it seems to us very difficult to characterise the doings of the court as platonic: platonism, on the contrary, was a barrier, and the only reproach we can bring against it is that it was often leaped.

But the real question is not to know whether there were women of average or cheap virtue at the court of France, and whether they gave the tone to others. We want to know whether women like Anne of France, Vittoria Colonna, Margaret of France, Margaret of Savoy, and their likes were wrong to strive after high ideals, and whether they did what was necessary to succeed. This question is much more delicate than the first, because it really touches platonism and shows how it came to grief.

Women can be reclaimed from sensualism; their necessarily refined feelings, the passive part they play, the disparity between the advantage and the disadvantage, conduce easily to disgust. But they never revert from mysticism to love. The Gospels mention no Jewesses converted by mysticism, whilst the Magdalene, the Woman of Samaria, the Woman taken in Adulter'y, see Heaven's 
light while in the full flush of sensualism. Men, on the contrary, often get the better of mysticism, because their instincts scarcely lie that way, and moreover the throng and press of realities only too easily brings them down to earth.

Now, Plato, even when rendered practical by the theory of two loves, which sanctioned curious concessions, represented the algebra of the beautiful; but you cannot make algebra your daily bread.

Women of the highest distinction, and especially those we have named, lived with Plato as it were in a balloon: there was no more actual communication with the world, no more really practical energy, no more heat and flame! The rope was cut; they were adrift in the clear and rarefied atmosphere of an altitude of thousands of feet. What an illusion, and how disastrous! Instead of elevating the world, this was the very means of abandoning it to itself. How many strange visions this dizzy height brought before their eyes!

First, the idea of living face to face with the absolute, and of importing the absolute into life-pride of thought of the vainest kind! To adopt St. Augustine's figure, you might as well shut up the ocean in a hole in the sand! As De Musset said: "My glass is small, but from my glass I drink." The realms of space do not furnish a substantial love, and it is vexatious enough to leave that love grovelling on the earth.

Secondly, along with this supramundane mysticism, platonism developed the exclusive contemplation of self, another deplorable mistake. We live in virtue of a continual exchange, as physiological and moral laws equally prove. God alone can rejoice in perfect independence of lite and happiness; the condition of us men is to be happy through give and take; we have to receive everything, but also to give everything. To search for happiness within oneself allows no room for enthusiasm or an enlarged current of life, nor, conseguently, for life itself: one withers up like a tree which should forlid its roots to imbibe moisture from the soil, its branches to breathe.

The poor dear women, once isolated in the boundless tracts of their imagination, became giddy, fell a prey to needless torments, lost the precious gift of simplicity, which was so natural to them in their capacity as great ladies-that 
excellent and wise simplicity of mind which assigns us our place in the vast sequence of things, according to the will of God. They hovered too far out of touch with realities, they generalised, wished to grasp too much, they grew restless and uncasy, which rendered them a prey to intriguers: their sensibility had no ballast. To influence humanity, they had first to influence the human beings they had at hand. So long as their mission remained individual, private, concrete, intimate, it produced satisfactory results. How many men did they carry up with them into the heights! But when they wanted to act upon mankind at large, the game was up. Trying to influence everybody, they ended by influencing nobody. Thus Vittoria Colonna gave to her beloved Michelangelo forces which he turned to admirable account; but in her abstract efforts towards public regeneration she completely failed.

Let us add that Frenchwomen had a much more difficult mission to fulfil than the Italian women. Spell-bound by the example of Italy, they fancied that what had succeeded there was sure to succeed here, and they did not even see (so great was their taste for bliud imitation) that they were behind the fair, that they were importing among us the imitation of a decadent art, the imitation of an imitation, a counterfeit love, a counterfeit curiosity, a counterfeit scheme of life. What they should have done was to inspire robust activities, to cause, no matter whence or how, a gush of ideas beautiful, striking, original, soul-stirring; instead, they refined and subtilised and complicated, they wasted their ingenuity in seeking to discover which was the more aesthetic, poetry or painting; complication seemed to them to be art, and not the apprentice stage of art: they never attained that noble logic which is art itself. Truly strong souls know well that you cannot nourish the world on sweetstuffs merely, that a decided will is needed in life, and that the beautiful becomes one with the true when truth has all its potency. Happy are those who skilfully draw love from truth :- the ploughnan who loves his furrow, the poor man who loves his poverty, the maiden who loves her purity! We find among women many valiant souls of the stamp of Anne of France, able thus to lay hold of life. As to those who allow themselves to be led astray by the obsession of an abstract and too lofty ideal, they die. 
Platonism, then, marked a great advance towards the idea of beauty, but it did not accomplish any striking progress towards the idea of happiness, and Nifo was not far wrong in predicting that the doctrine of two loves, the one celestial, immaterial, good, and desirable, the other terrestrial and carnal, would result in mere negation, by setting men between impossible alternatives-a colloquy of angels, or, as M. France says, a colloquy of chimpanzees. We may regret our condition, but how escape from it? Natural law (that is, divine law) bids us disdain none of the gifts of God, but to obtain from each its particular beauty. Happiness consists really in loving what we have round about us, in appropriating therefrom all that is beautiful and congenial, and in affectionately conforming to Nature without coercing her, so as to nourish ourselves upon her spiritual and physical forces, and to assimilate her warmth and energy and her universal harmony.

In our own day John Ruskin has been one of the apostles of happiness under this aspect, and though his doctrine may be difficult to define, he has unquestionably carried the idea of platonism a stage further, in harmony with the saying of Plato which we have already quoted: "Those who know have impressions."

The impressions on which he lived were often inconsistent, and still more often nebulous, one might almost say musical. He has been taunted with his apparent lack of logic, though the glitter of his thought by its very brilliance often conceals a logic that is sufficiently real. But, after all, he has unduly neglected the spiritual side of Nature, in particular the human soul. While we cannot shut our eyes to the existence of the body and the utility of earthly possessions, it is at the same time good and necessary for happiness to keep the body and material well-being on the lower plane. The body is essentially localised, wealth is limited, and, for both, giving spells exhaustion; only the soul can spend itself unceasingly, and grow the richer thereby. And thus social happiness results, so to speak, from the socialism of souls.

Ruskin belongs to the old Venetian school, materialistic, and pagan; his heart has echoed to physical harmonies, and to him a certain material socialism would not have 
been unpleasing. Yet he has well shown what we ought to feel in our communion with Nature, he has glorified the worship of beauty and happiness, which consists in guessing at God, in seeing Him, in acclaiming Him in the beauty of mountains as in the beauty of a heart overflowing with tenderness and love, in all that is beautiful, and beautiful for us. His essential idea is that everything around us produces an impression upon us, and that we ourselves have a duty to our environment. Gardens are no longer a mere setting of life, they are alive. Ruskin goes so far as to extol the idea of sacrificing ourselves for posterity-to plant forests under whose shade our descendants may live, to build cities in which future nations will be able to dwell.

It is a far cry from these undulatory but noble theories to the egoistic enjoyment of oneself; yet it is very certain that to carry them into practice in reasonable measure is the way to find happiness.

That is essentially the moral system which women ought to teach-women born for impressions, for devotion, generosity, the higher life.

Unhappily, Ruskin, little conversant with love and altogether unacquainted with the domestic affections, never showed in his own life a really high appreciation of women's rôle, nor has he less misconstrued it from the theoretical standpoint. Apart from some sonorous phrases in which he recommends them to be queens, but in submission to their husbands, or to practise good social economy in relation to their dressmakers, it may be said that he did not understand the charm of women, and that he felt no attraction for their particular beauty. When he speaks of beauty, whether in regard to modern painters or to the Greeks, it is always in general terms, without indicating in any way whether the feminine expression of the beautiful has for him a special signification. In his enthusiasm for the aesthetics of the Middle Ages be even admires masculine beauty above all: his type in that case is the beauty of a stalwart knight.

M. Bourget, for example, has more clearly conceived and accurately interpreted the necessity of harmony with Nature; his sensations or sentiments approximate to the philosophy of the Renaissance, and refiect the spirit of penetrating sweetness which women had undertaken to develop. 


\section{THE WOMEN OF THE RENAISSANCE}

"The sincere acceptance of the inevitable," he says, "supposes a love for the inevitable, the consciousness, and not merely the idea, that this obscure universe has a mysterious and kindly signification. In the depths of our sensibility there exists an indestructible craving that this world shall contain something wherewith to satisfy our heart, since this heart is the world's own child; and the pure and guileless men whose ever young and tender spirits speak to us across the ages-Francis of Assisi, Savonarola, those who believed in this bountiful kindness of the universe, as they breathed, as they lived, with the whole of their being-these appear to us in a state of unanswerable protest against the nihilism with which we are stifled. They become the accomplices in us of a faith that is hardly conscious of itself, and sometimes seeks its way with tears. 'Thou wouldst not seek me,' says the Saviour in the beautiful Mystery of Jesus, 'if thou hadst not found me.' Is this phenomenon far from that other mysterious one which trus believers call prayer?"

We can, we must love Nature, because God has placed her all about us, and because happiness consists in living with what we love. We love things that are not ideally perfect, in other words, which are not superlatively beautiful, because happiness presents itself to us under an essentially relative aspect, and because there is no one but lays clain to it. It is not even a question of loving beautiful things, then, but, as we said, of loving what is beautiful in things.

In real life, to be sure, unpleasant things are as common as blackberries, while pleasant things are few and far between. Nevertheless the truth of the system of happiness through love is proved by its efficacy. Just as the pure platonist, penetrated by his glorious ideal, is cold, unprofitable, and unhappy, the man who loves is conscious of being filled with strength and light. To love is to have real and ardent emotions instead of locking oneself in the icy sentimentalism of reasoning or of false mysticism; it is to become a wellspring of sweetness, kindliness, activity, a mainstay of the world: it is to sow life with flowers, to bestow happiness and to possess it. Though placed by birth in a refractory mediun, Ruskin, in spite of his insufficiencies, contradictions, weaknesses, lacunae, has exercised a pro- 
found influence, while the platonism of Ficino and Bembo, in a land of high sensibility, amongst incomparable artists and charming women, stifled everything and throttled itself.

There are, spread over the world, two unequal races which, living continually side by side, yet never understand each other and never blend-the race of pride, and the race of vanity. Pride tends to enthusiasm and advancement; it would be well to have proud women. Unhappily men, no matter who they are, do not love them, but much prefer the feeble and the vain.

Yet the efforts of the Renaissance women have not been wholly wasted. Those noble women sowed for the future, and the germ subsists.

Nor can it be said that their defeat was absolute. To form a sound judgment on the question we should have to be able (failures being invariably more noticeable than successes) to gauge the mysterious, secret operations of their grace; to number the despondent men cheered by a kind word or a glance of pity or affection; to fathom the resources, in truth unfathomable, possessed by the spirit of love ever when pure, and possessed by it alone. Women of great soul, the Vittoria Colonnas of the world, have drawn from it results almost miraculous ; and many others, without turning themselves into a sort of celestial dancingmistresses, or becoming lost in worthless caprices, have given us reason to hope that, what with labour and earnestness and dignity, the end of their usefulness will not be seen for many a long day.

In short, they took the lead in the profoundest revolution we have ever experienced; from Louis XI. they led us to the boudoirs of the 18th century.

We can give their work neither unqualified praise nor condemnation. But we can praise many of these highsouled women-praise them for having seen and followed their star, though they at first sight may not have recognised the more excellent way. With all our reservations, we feel their spell upon us, because they were interesting, sincere, devoted, eminently tender, eminently feminine. We can commend them to the sympathy of those many ladies of our own day who, as we know, are also seeking their path, and even their star. 


\section{THE WOMEN OF THE RENAISSANCE}

Some of my readers may not approve of this conclusion : some will think it optimistic, others pessimistic: in such matters contradiction is easy. Will they allow me to reply in advance that such criticisms would not surprise me? More than onee I myself have recast this book, now in the optimistic direction, now in the pessimistic: a simple historian, in contact with subtle, fleeting, elusive shades, with women I sought to see through; as independent as a man may be, in presence of beauties for three centuries in the grave, when he is grey with years, sated with the two great spectacles which, according to Montaigne, quiet the soulthe sight of government, the sight of death,-I would ever and anon catch myself understanding their witchery, enthralled to their charm, or else hating their charm, unjustly; and then, at the moment when I fancied I could at last write my veni, vidi, vici, the ideas slipped from my book like water through a sieve. It is thus I have acquired the right of loving these dear ghosts.

And now adieu, princesses, cease to tempt us beyond our powers! Oniy continue to live amongst us! Our age is very masculine, your spiritualism pays us but angel visits now! -you have been driven in a thousand ways to learn what a soulless commercialism is like. And yet, in your better, spiritual part, you are with us always. We have lovable and accomplished women, we have women in a true sense aristocratic, whose hearts are capable of enthusiasm and heroic charities; there have been some whose names even live after them as synonyms of intelligence and goodness. We have our Margarets of Savoy, and, in goodly numbers, women whose moral bearing surpasses that of men; we have even women of energy, and also, it is said, of tenderness. The day when they proudly resume the motto Non inferiorcl secutus, and when to their eminent good qualities they add the talent of being themselves, the will to speak in their own true accents rather than a borrowed tongue, they will give us back our illusions, and with them what was not illusion.

Let them renounce public life! But let them take complete possession of the home life. Let mannish women, if they must, turn doctors, and womanish women turn priests! Let all be philosophers, comforters, ministers of love human and divine; let them work through love, and love through love! Let them have what we lack, let them excel 
us, enlighten us, encourage us! And in our hearts we Latins shall bless them, as we bless the sun. Passion is a warrantroyal of life.

The moral of our book is that good women should love the beautiful, and that virtue can be neither tiresome nor torpid.

There is no need to be always a maiden of twelve. True sweetness, true goodness, true love come, not of naïveté or feebleness, but of intelligence and personal force. 


\section{INDEX}

Accolti, Bernardo, itinerant singer, 273.

age of marriage, $27,28,98$.

Agrippa, Cornelius, his view of marriage, 21 ; on Louise of Savoy, $166 n$; book on the Pre-eminence of the Female Sex, 400 ; lectures on Plato, 402.

Alexander VI., pope, on Urbino marriage, 52 ; his hunting, 247 ; on monks, 463 .

Alfonso of Aragon's wedding, 40.

Alfonso of Naples' dinners, 231.

Alione's ballad, $121 n$; anecdote b7, 222.

almsgiving, 66-69.

A madis de Gaule, its popularity, 269.

Amaretta, Costanza, 339, 340.

' amateurs,' 56, 264, 388.

Amboise, cardinal of, 146, 257.

Andrelini, Fausto, 17, 326.

Anet, château of Diana of Poitiers, 387.

animals, platonist attitude towards, 244.

Anne de Graville quoted, $198 n$.

Anne of Brittany, 145, 375.

Anne of France, her first lover, $26 n$; as sick nurse, 54 ; her charity, 68 ; views on education, $85,89-91$; on girls' stories, 100-102; 'school of manners,' 103 ; on maternal selfsacrifice, 105; on mourning, 129, 130,133 ; on valour, 146 ; on lovemaling, 165; her character, 166168; idea of charm, 180,181 ; her platonism, 181; compared with Mar'garet, 197; opinion on 'age of wisdom,' 214 ; on dress, 216,218 ; hunting, 252, 253; books, 265; political career, 313,314 ; love of art, 375 .

Anne of Polignac, 131.
Anne of Vivonne, 385.

architecture, domestic, 224.

Aretino, on tutors, 79, 80; his Marescalco, 80,281 ; on duchess of Urbino, 351; courtesans, 201, 358, 361 ; on nudities, 204 ; his methods, 370 ; relations with Vittoria Colonna, 390, 391; correspondence, $394,395$.

art, 377, 380 .

Asolani, Bembo's, 156, 432.

Baden in Aargau, 259, 260.

balls, 232, 236; Daneau on, 236, 237. baths, 254; Calvinists' view of, 255 , 256; life at, $259,260$.

Battista Spagnuoli, his view of marriage, 21; of baths, 258 ; of monks, 460.

beards, dispute on growing of, 370 .

Beatrice d'Este, see D'Este.

beauty, platonist idea of, 158,159 , 161; Bembo's idea of, 160 ; Michelangelo's, 161 ; distrusted, 196; preservation of, 215.

Bembo, on Latin for girls, 96 ; his Asolani, 156, 432 ; on love, 159161 ; conversation, 294,295 ; handwriting, 304 ; his Morosina, 366-368, 390 ; his talk, 403, 404; idea of poetry, 404 ; relations with Olympia Morata, 428; letter to Isabella d'Este, 432.

Beroaldo, Filippo, on drunkenness, 298 ; on love and Propertius, 402, 403.

Bibbiena on Catherine Sforza, 29; his Calandra, 79, 278, 279 ; decoration of his bath-room, 256; his letters, 307; his liberalism, 432 ; anecdote of, 463 .

Bible, reading of, $155,288,438,439$. bibliennes, the, 426,435 . 
Billon, 481.

Blando, Michelangelo, on hunting, $251,252$.

blasons, 208.

Boccaccio, popularity of, 100, 268, 398.

Bonaventure des Périers, see Des Périers.

Boistuan, 480.

Bonnivet, admiral de, 178, 213.

books, 88, 263.

Botticelli's Venus and Cupid, 318.

Bouchet, Jean, on flirtation, 105, 106 ; remedy for materialism, 147 ; story of ladies of Poitiers, 288; Les Regnars traversant les voies périlleuses, 392.

Bourget, Paul, his naturalism contrasted with Ruskin's, 499, 500 .

boutrimés, 300 .

boys'.education, 75,76 .

Brandiolini, Aurelio, musician, 273.

Brandt's Ship of Fools, 416.

Brantôme on tutors, 99 , on marquis of Pescara's book, 124; on spicy literature, 266; on Mortemart ladies, 286 ; on the court, 495.

Brascha, ambassador, $42,43$.

Briçonnet, bishop of Meaux, 470 .

Budé, Guillaume, Livre de l'Institution $d u$ prince, 250,251 ; on religion, 454 .

burial customs, 129.

Burye, character in Heptameron, 385.

Calvin on women, 84, 467 ; on divorce, 339 ; character of Reformation, 467.

Calvinists, objection to fine weddings, 37 ; to baths, $255,256$.

Cardan on marriage, 32; on gout, 230 ; on talk, 285; life at Venice, $290 n$.

Carnesecchi, 259.

carpet knights, 369 .

Castelli, Cardinal, his hunting ode, $248,249$.

Castiglione, relations with his wife, 51 ; theory of social aesthetics, 144 ; on Raphael, 157; on intellectual occupations for women, 261 ; his Courtier, 265, 395, 404, $405 n$; on music, 274 ; on talk, 292 ; on duke of Urbino, 293; handwriting, 304; letters to Vittoria Colonna, 306, 345 ; letter to Marchesa Scaldasole,
306 ; on viragos, 319 ; on painting, $377,381,431$.

Cataneo, on two lores, 156,159 .

Catherine de' Medici, see De' Medici.

Catholicism and colour, 220; relation to philosophy, etc., $456 \mathrm{ff}$.

Caviceo, his Peregrino, 22, 239.

Célestine, La, 270.

Chailly, Louis XII.'s hound, 249.

Champier on marriage age, 28 ; Livre de vraye amour, 45,46 ; on doctors, 59 ; on love, 114,168 ; on women and men, 301.

charity, 66-69.

charm, theory of, 195-200.

chase, the, 246-253.

Christian socialism, 142.

churches, mundane use of, 237-240.

Church's distrust of women, 422,423 .

Cibo, Caterina, papaline, 428, 457.

cicisbeo, 346, 347.

classics, respect for, $143,156,157$.

clergy, character of, $165,434-438$.

Clichtoue's philosophy of life, 146, 147.

Clouet, Jean, 207.

college education, $75,76,78$.

Collerye, Roger, quoted, $46 n, 115 n$.

Colonna, Ascanio, 312.

Colonna, Pompeo, his Apologia pro mulieribus (us. in M. de Maulde's possession), 399, 400 .

Colonna, Vittoria, age of betrothal, 27 ; widowhood, 131, 316, 317; relations with Michelangelo, 163, $182,183,395$; on painting, 182 ; relations with Carnesecchi, 259; letter to Paulo Giovio, 292 ; handwriting, 304 ; letters, 305-308, 450, 451 ; character, $316,317,328$; relations with Aretino, 390, 391; with Dolce, 394; with Bembo, 394; her poetry, 163, 404, 405; religion, 428,469 ; relations with Pole, 429 ; her prayer, 442 ; relations with Ochino, 469, 470.

colours, 219-221.

complexions, 199.

concubinage, $113,363-366$.

Condivi on Michelangelo, 162, 182 , 183.

Consentana, countess of, anecdote of, 129.

conversation, 284-302, 345, 347.

coquetry, 187.

Coquillart, 105, 325. 
Correggio's St. Jerome, 449; Mystic Marriage, 450.

correspondence, 304-310.

Costa, Lorenzo, picture by, 276.

country life, 242, 243.

country squires, 64, 140.

courtesans, 356-362.

Courtier, Castiglione's, 265, 395, 404.

Cremonini, 152.

Cymbalum, Des Périers', 386, 393.

D'Albret, Charlotte, 131.

D'Albret, Henri, 53, 334, 352.

D'Amboise, Catherine, 444.

D'Amboise, Françoise, 132.

D'Amboise, Michel, 206, 252.

dancing, 233-237.

Daneau on dancing and balls, 236 , 237.

Dangu, Nicolas, 384.

Dante, 406.

D'Aragona, see Tullia.

De Beaulieu, Eustorg, 99.

De Bourbon, Gabrielle, expenditure, 66 ; lack of dowry, 117; death of her son, 126; religious works, 443.

De Clermont, Mlle, 24, 385.

De Longray, Mme, 385.

De' Medici, Catherine, her 'flying squadron,' 103.

De' Medici, Julian, 205.

De Montausé, 384.

Des Périers, Bonaventure, 59, 386, 387; his Cymbalum, 386, 393, 418.

De Pons, 315, 316.

De Soubise, Madame, 315.

Desprez, Josquin, 275.

D'Este, Beatrice, 318.

D'Este, Isabella, setter of fashions, 219 ; on pilgrimage, 240 ; love of art, $374,375$.

D'Etampes, duchess, 364.

dialogues, 156, 403 .

Diana of Poitiers, as widow, 131; her portraits, 207,211 ; statue of, by Goujon, 208; relations with king, 364, 365 ; love of art, 387.

divorce, 127, 338, 339.

doctors, $55-58$.

Dolce on misadventures of husbands, 58 ; on education, 94,95 ; the moon, 423.

domestic letters, $117 n, \mathbf{1 2 6}$, 304-310.

dowries, 117-119.

'dragons,' 330, 331.

drama, 278-283. dress, 216-223.

drinking, 229, 230.

Du Bellay, $169 n, 362,365,408,476$, 477, 479, 483, 484.

Du Four, 165.

Dürer's women, 203.

dwelling house, 223, 224.

eating, customs in, 229-231.

education, 74-78, 86-100.

Egnatius, 31.

Eleanor, wife of Francis I., 53.

Equicola, Di natura d'amore, 161.

Erasmus, on virginity, 32 ; on maternity, 48 ; education, 82,97 ; husbands, 116; women's stupidity, $157 n$; church music, 277; his attitude to reformers, 473 .

Estienne, Heuri, 84.

Eustorg de Beaulieu, 99.

eyes, 199 .

facéties, 266-268.

Feo, lover of Catherine Sforza, 30,321.

Ferrara, music at, 276 ; talk at, 290.

Ficino, Marzilio, on platonic love, 154, 158, 159.

Firenzuola, on beauty, 196; his stories, 299 ; his inspiration, 399.

flirtation, 103-107.

Florentine worship of Plato, 153, 154 ; idea of charm, 198.

flowers, 243 .

Folengo, 465.

Francis I., 62, 125, 169, 170, 240, 251,265 ; his mistresses, 363, 364 .

Francis de Paule, St., story of, 461.

Franco, Veronica, 358.

free love, 327.

Fregoso, detractor of women, 298.

French marriage customs, 37-39; country gentry, 64-66; society, 140-142; worship of rank, 144, 145 ; idea of charm, 198; drama, 282, 283; conversation, 296, 297 ; letters, 308-310.

Gambara, Veronica, 364, 394.

gambling, 237.

Gastius' table talk, 232.

Gazius, Florida Corona, treatise on health, 255.

German girls' education, 89; table talk, 297 ; opposition to Italy, 415 , 416; liberalism, 433 ; narrowress, 434; monks, 466. 
Gioconda, see Monna Lisa.

girls'education, 86-100; tutors, 98,99. Gonzaga, Julia, 52.

Gonzaga, Leonora, 28.

Goujon's statue of Diana, 208.

hair, popular colour of, 199 .

hair-dressing, 216, 217.

handwritings, 303,304 .

Helysenne de Crenne, 39.

Henri II., 364.

Heptameron quoted, $24,25,33,34,49$, $53,84,112 n, 151,173,175,189$, 212, 213, 296, 298, 299, 329, 334, $335,351,353,354$; realist character of, 382-385.

Héroët de la Maisonneuve, 344, 418.

history, 401.

hood, the, 217.

households, constitution of, 66 .

Huguenots on dancing, 236, 237.

hunting, 246-253.

husbands' authority, 109, 110.

Hiitten, Ulrich von, 83, 466, 467.

hydrotherapeutics, 254-258.

illegitimacy, 338.

Imitation of Christ, 139, 150.

Imperia, courtesan, 358,361 .

impromptus, 300 .

incomes, 64, 68, 117.

Inghirami, Tommaso, $280,281,300$; anecdote of, 431.

' innocents,' the, 212.

instrumental music, 276-278.

interviews, 29.

Isabella d'Este, see D'Este.

Isabella of Aragon, 312.

Isabella the Catholic, 323.

Italian marriage customs, 34 ; education, 94-96; drama, 278-281 ; conversation, 285-296; letters, 306 ; monks, 465.

Jews, hatred of, 478

Josn of Aragon, 312, 407

Joanna, wife of Philip the Fair, anecdote of, 114, 115.

Josquin Desprez, 275.

Jove, Paul, 52, 292.

Julius II., anecdote of, 68 ; hunting, 247 ; beard, 370 .

kissing, 233-235.

Labé, Louise, poetess, on dress, 218; accomplishments, 245 ; on music, 274 ; poetry, $412,413$.

La Bruyère quoted, 115, 210, 296, 372.

ladies' letters, 305.

Lancelot du Lak, 269.

lapdogs, 244.

La Rochefoucauld quoted, 111, 184, $214,314$.

La Salle, Antoine de, 79.

La Trémoille, Louis de, 29, 117 ; see Gabrielle de Bourbon.

Lefèvre d'Etaples, 250, 264.

Lemaire de Belges, 79, 327, 401.

Leo X., 247, 280, 300, 362, 425, 431.

Leonardo's Monna Lisa, 191 ; ideal of beauty, 200 .

letters, domestic, 126, $127 n$.

letter-writing, 303.

liberalism at Rome, 430, 431, 433, $434,473$.

life at spas, $259,260$.

Limosin, Leonard, 207.

literature, licentious character of, 391-393.

Longueil, 473.

Louis XI., 118.

Louis XII., 64, 67, 118, 129, 234, 249.

Louise of Savoy, her views on educa. tion, 77, 85, 96 ; her sphere, 170 , 311 ; her reading and books, 262, 265,267 ; her politics, 311 ; on mystic love, 335 ; her principles, 354.

Luther on celibacy, 32 ; divorce, 338 ; on women, 467 ; his true relation to Reformation, 468 .

Lyons, headquarters of feminine poetry, 411.

Madeleine, sister of Francis I., 309.

Maillard, Oliver, on bathing, 255; his preaching, 459, 460.

Marescalco, Aretino's, 281.

Margaret of Austria, her collections, 226; career, 313; parrot, 408; poetry, 411.

Margaret of France (sister of Francis I.), on marriage, 49 ; relations with her husband, 53 ; on doctors, 53 , 58; influence of stars, 61 ; charity, 69; education, 96-98; authority of husband, 123 ; widow, 131 ; remarriage, 134 ; defects of women, 137 ; remedy for materialism, 147-149; names and character, 


\section{INDEX}

170-172, 245, 418; her portraits, 170,210 ; theory of love, 173-175; motto, 176 ; platonic love, 189, 352,353 ; compared with Anne of France, 197; petit lever, 213; on physical decay, 214; on wearing black, 221 ; books, 263, 266, 267; poetry, 274; drama, 282, 283; as a talker, 285; her failure, 287, 475; handwriting, 304; moral scheme, 334 ; toleration, 355,475 ; relations with Francis' mistresses, 364 ; intellectual influence, 378-383; lovers, 384,385 ; writings, 386, 387; vacillation, 418 ; religion, 436 , $437,442-445,457,470$.

Margaret of France (wife of Henry of Navarre), 486.

Margaret of Lorraine, 133.

Margaret of Savoy, 172, 481-486.

Marone, Andrea, 273.

Marot, Clement, 29, $165 n, 198 n$, 212 , 287, 315, 317, 353, 407, 457.

marriage customs, 37.42 ; presents, 72.

Mary of Cleves, 67.

Mary of England, 129, 217, 274.

Mary Stuart, 92, 376.

materialism, 456 .

matrimony, test questions for, 33 .

Maupas' sparrow, 407.

medicine, 54-58.

men of letters, 392.

Menot on death, 491.

Michelangelo, his nephew's marriage, 35,$36 ;$ on love, 162 ; relations with Vittoria Colonna, 162, 182, 183, 213, 214, 395, 396; his Eve, 202 ; Last Judgment, 204, 324; Virgin of Casa Buonarotti, 323; Pieta, 323, 324; ideal of woman, $324 ;$ sonnets to courtesans, 3อ̃9; frescoes, 428 .

Mirror of the Sinful Soul, 92, 386. mistresses of Francis I., 363.

money, importance of, 117-121; worship of, 145, 146, 148, 149.

monks, 458-466.

Monna Lisa, Leonardo's, 191.

Montaigne on marriage, 46 ; on capricious treatment of women, 52 ; on business, 65 ; on peasant nurture, $73 n$; on college education, 76,78 ; on women's 'policy,' 86 ; on his daughter, 88 ; 95 ; on moneyed wives, 121; on tears of mourning, 130; his scepticism, $191,479,488.490$; on coquetry, $362 n$; on women's virtue, 420 ; on faith, 425 ; on death, 491 .

moon, woman compared to the, 423 . Morosina, Bembo's mistress, 366, 367. Mortemart, ladies of, 286.

motherhood, 7I-74, 77.

mother-in-law, the, 110.

mourning, 128.

Muguet, falcon of Louis XII., 250 .

music, 83, 88, 270-278.

Mysteries, 282, 283.

mysticism, varieties of, 446-448, 465 . mythology, use of, 156, 455 .

Naples, love of art at, 225.

Nature and man, 138, 139, 254, 449 ; platonist attitude towards, 241-243, $253,254$.

naturalism, Ruskin's, 498, 499; contrasted with Bourget's, 499, 500 .

needlework, 88.

Nifo, -his changeableness, 152,331 ; catalogue of love-motives, 191,192 ; pen portrait of Jeanne of Aragon, 208,209 ; anecdote of, 327,328 ; platonism, 332, 333 ; Phausina Rhea, 348, 399; feminism, 369.

Nourelles, 259, 266, 267.

nudities, 202-209.

nurses, 73.

Ochino, 339, 428, 469, 470.

Ockeghem, John of, 275.

Olympia Morata, $94 n, 428$.

Ordelaffi, husband of Catherine Sforza, 321.

Orleans, duchess of, her charity, 66 ; love of music, 273.

Ovid, popularity of, 265,266 .

painting, 396, 377.

palinods, the, 446.

Papillon, Almanque, 149, 480.

patronage, 393-396, 398.

Paul II., 247.

Paul III., 432, 469.

Paul IV., the 'breeches-maker,' 204. pen portraits, 208-210.

Peregrino, Caviceo's romance, 22.

Pernette du Guillet, 412.

Perugino, 375.

Petrarch, 234, 265, 272, 406, 487.

'Phaedra,' see Inghirami.

Phausina Rhea, 210, 348. 
Philippa of Gueldres, 133.

philosophy, love of, 401, 402.

physical exercise, 244.

Pia, Emilia, 288, 305.

Piccoli, Gabriele, 322.

Pico della Mirandola, 154.

pilgrimages, 240 .

Pio, Alberto, 277, 454, 462.

plate, family, 229.

Plato, theory of love, 151-153; vogue of, $154,402,448$; theory of beauty, 158, 161; Nature, 241 ; relation to Christianity, 425 ; negative results of doctrine, 494.496 .

platonic love, $213,339 \cdot 344,348$.

platonism, 154, 157, 164, 177-193, $197,260,297,334,336$; causes of its failure, 487,$488 ; 495-498$.

Pléiade, the, 172, 478-481.

poetry, 262, 271, 404-40s ; and hunting. 248-250.

Poggio, his facetiae, $100, .154$; on Baden, 259, 260.

Poirier, son-in-law of Monsieur, 117.

Poitiers, three maids of, 102 ; ladies of, 288.

Pole, Cardinal, 429.

Politian, 154, 265, 409.

polygamy, 339 .

Pomponius Laetus, 154, 278.

Pontanus, 88, 104, 144, 240.

poodles, 244, 407, 408.

portraits of ladies as Venus, 205. 207.

Postel, Guillaume, 471, 472.

priesthood of women, 428 .

princesses' love, 187, 188.

publicity, writers' objection to, 376 .

Puritans and music, 277.

puys d'amour, 419.

Rabelais, pedigrees, 145 ; on colours, 221 ; antiplatonist, 325,336 ; his abbey of Thelema, 465 ; his mysticism, 465 .

Raphael on marriage, 36, 37; Vision of a Knight, 330; anecdote of, 431.

Raulin, Jean, his sernon, 108.

reading, 88, 262.

religion and aesthetics, 423, 424; relations to philosophy and Plato, $425,426,479 \mathrm{ff}$.

Rence of France, on influence of stars, 61 ; letters, 308 ; career and character, 314-316, 456.

Romances, 100, 268-270.
Roman aristocracy, 143; idea of beauty, 143 ; liberalism, 430-434.

Ronsard, $60,198,215,235,343,365$, $376,477,478$.

Rosera, Isabella, 409.

Ruskin, 111; on nature, 137, 138 ; his naturalism compared with Bourget's, 498-500.

Sadoleto, 429 .

'Saffredent' (character in Heptameron), 385 .

Saint-Gelais, Melin de, 235, 327, 431.

Saint-Gelais, Octovien de, 167, 266, $300,326$.

Saint-Simon on Mortemart ladies, 286.

Salel, Hugues, 382.

Savonarola, 163, 164, 278, 297, 322, 459.

Scaldasole, Marchesa, 184.

scepticism, 479.

Semblançay, 141.

serving maids, 106, 112.

Sforza, Ascanio, 248, 249.

Sforza, Bianca, 42, 43.

Sforza, Catherine, widowhood, 29 ; her wedding presents, $40 n$; alchemy, 61, 62; character and career, 245, 246, 320-322.

Ship of Fools, 416 .

slave girls as concubines, 113 .

small families, 71 .

sonnet, popularity of, 405 .

Spagnuoli, Battista, on nıarriage, 21; on baths, 258 ; on monks, 460 .

Spain, education of girls in, 91-94; idea of charm, 198.

spas, 257, 258.

Spinola, Thomasina, 190.

stick, the, 110, 111.

'stork-love,' $355,441$.

story-telling, 299.

subsidiary marriage, 339.

Sygea, Loysa, 409.

table-talk, 231, 232.

Theresa, St., 92, 197.

Tiraqueau, 27, 35.

titles, love of, 143.

topics of conversation, 294.

tournaments, $245,246$.

Triboulet, 34 .

Trithemius, $458 n, 463$.

Tullia d'Aragona, her book on the Infinity of Perfect Love, 164; her 
influence, 357, 360; a poetess, | virtue represented in painting as 413.

tutors, 78-81.

Urbino, court of, $159,290,303,381 n$. Urbino, duke of, $52,145,293$; duchess of, $41,43,52,129 n, 309$.

Valois, court of, 369,486 .

Vegio on tutors, 79.

Venice, marriages at, 41 ; education at, 96 ; idea of charm, 198; music at, 277 ; courtesans at, 361 .

Venus, passion for painting, 201-205.

Virard, publisher, 392.

Vergerio, 451, 452, 457, 458.

Vert-vert, 408.

Villamarina,Isabella, anecdote of, 320 .

Virgil, unpopularity of, 265. repellent, $329,330$.

Vittoria Colonna, see Colonna.

Vivès, on education of girls, 92, 98, 100 ; on husbands, 111; on daneing and kissing, 233, 234. vocal music, $270-273$.

Voiture, 187.

volta, the, 236, 237.

war, 317-319.

wealth, worship of, $222,2 \varepsilon 6$.

widows, 128-134.

witcheraft, $426,427$.

women as professional writers, 409 , 410 .

Zwingle on education, 82.

Printed by Cowan de Co., Limited, Perth. 

